UNIVERSIDADE DE SÃO PAULO

FACULDADE DE FILOSOFIA, LETRAS E CIÊNCIAS HUMANAS

DEPARTAMENTO DE LINGUÍSTICA

PROGRAMA DE PÓS-GRADUAÇÃO EM SEMIÓTICA E LINGUÍSTICA GERAL

JOSÉ BENTO CARDOSO VIDAL NETO

A formação do pensamento linguístico brasileiro: entre a gramática e novas possibilidades de tratamento da língua (1900-1940)

Versão corrigida

São Paulo 


\title{
A formação do pensamento linguístico brasileiro: entre a gramática e novas possibilidades de tratamento da língua (1900-1940)
}

\author{
Versão corrigida
}

Tese de Doutorado apresentada ao Programa de Pós-Graduação em Semiótica e Linguística Geral da Faculdade de Filosofia, Letras e Ciências Humanas da Universidade de São Paulo, para a obtenção do título de Doutor em Letras.

Orientadora: Profa. Dra. Olga Ferreira Coelho Sansone

São Paulo 
Autorizo a reprodução e divulgação total ou parcial deste trabalho, por qualquer meio convencional ou eletrônico, para fins de estudo e pesquisa, desde que citada a fonte.

Faculdade de Filosofia, Letras e Ciências Humanas da Universidade de São Paulo

\begin{tabular}{|c|c|}
\hline \multirow[t]{3}{*}{ V649 f } & $\begin{array}{l}\text { Vidal Neto, José Bento Cardoso } \\
\text { A formação do pensamento linguístico brasileiro: } \\
\text { entre a gramática e novas possibilidades de } \\
\text { tratamento da lingua (1900-1940)/ José Bento Cardoso } \\
\text { Vidal Neto; orientadora Olga Ferreira Coelho Sansone } \\
\text { - São Paulo, } 2021 . \\
547 \text { f. }\end{array}$ \\
\hline & $\begin{array}{l}\text { Tese (Doutorado) - Faculdade de Filosofia, Letras e } \\
\text { Ciências Humanas da Universidade de São Paulo. } \\
\text { Departamento de Linguistica. Área de concentraça: } \\
\text { Semiótica e Lingǘstica Geral. }\end{array}$ \\
\hline & $\begin{array}{l}\text { 1. Gramaticografia brasileira. 2. Historiografia } \\
\text { linguistica. 3. Século XX. } 4 \text {. Dialetologia. } 5 \text {. } \\
\text { Filologia. I. Sansone, Olga Ferreira Coelho, orient. } \\
\text { II. Título. }\end{array}$ \\
\hline
\end{tabular}




\section{ENTREGA DO EXEMPLAR CORRIGIDO DA DISSERTAÇÃO/TESE} Termo de Ciência e Concordância da Orientadora

Nome do aluno: José Bento Cardoso Vidal Neto

Data da defesa: 18/5/2020

Nome da orientadora: Profa. Dra. Olga Ferreira Coelho Sansone

Nos termos da legislação vigente, declaro ESTAR CIENTE do conteúdo deste EXEMPLAR CORRIGIDO elaborado em atenção às sugestões dos membros da comissão Julgadora na sessão de defesa do trabalho, manifestando-me plenamente favorável ao seu encaminhamento e publicação no Portal Digital de Teses da USP.

São Paulo, 31/7/2021.

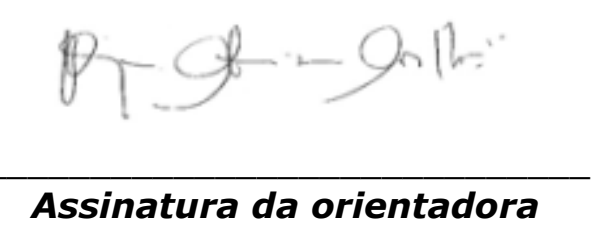


VIDAL NETO, José Bento Cardoso. A formação do pensamento linguístico brasileiro: entre a gramática e novas possibilidades de tratamento da língua (1900-1940). Tese apresentada à Faculdade de Filosofia, Letras e Ciências Humanas da Universidade de São Paulo, para a obtenção do título de Doutor em Letras.

Aprovado em: 18/5/2020.

Banca Examinadora

Profa. Dra. Olga Ferreira Coelho Sansone

Instituição: USP/DL

Julgamento:

Assinatura:

Profa. Dra. Maria Cristina Fernandes Salles Altman

Instituição: USP/DL

Julgamento:

Assinatura:

Profa. Dra. Marli Quadros Leite

Instituição: USP/DLCV

Julgamento:

Assinatura:

Prof. Dr. José Borges Neto

Instituição: UFPR

Julgamento:

Assinatura: 
Para a Ju e o Gabi, amores da minha vida, dedico o que há de melhor neste trabalho... 


\section{AGRADECIMENTOS}

Gostaria de iniciar meus agradecimentos prestando uma sincera homenagem a todos os funcionários públicos brasileiros, docentes e não-docentes. Estamos em um momento histórico no qual os ataques às instituições públicas são intensos e frequentes, todos com o claro objetivo de aprofundar um desmonte que não é recente, mas que há tempos não via tamanha virulência. Esse processo de sucateamento, claro, não tem como objetivo beneficiar a população e a democratização dos serviços públicos, mas favorecer o capital privado e sua sanha privatista. Assim, não haveria universidade pública, de qualidade e gratuita e, consequentemente, não haveria a Pós-Graduação a qual esta tese está vinculada, sem a luta incessante e muitas vezes ingrata de um sem-número de funcionários públicos que se dedicam na defesa de um patrimônio que é de todo o povo brasileiro.

Ainda no campo das instituições, gostaria de agradecer:

À Capes, pela bolsa concedida ao longo dos quatro anos de doutoramento;

Ao Departamento de Linguística da FFLCH-USP, pelo apoio financeiro, o que fez com que eu pudesse ir a vários congressos nacionais e um internacional.

Dentro dessas instituições, há pessoas que muito me ajudaram, as quais preciso render meus mais sinceros agradecimentos:

Primeiro, à minha orientadora, Olga Coelho, por quem nutro grande admiração. A Olga, sempre com muita leveza e competência, consegue apontar para os caminhos da pesquisa de uma forma estimulante e respeitosa com as opções de seus alunos. É consenso entre nós que, depois de uma reunião de orientação, saímos com aquele "índice de angústia da pesquisa" reduzido. Admiro também a pesquisadora competente e arguta que é, além de excelente professora, sempre dedicada e preocupada com seus alunos, de graduação e de Pós.

À Cristina Altman, por várias razões: primeiro, pelas inúmeras vezes em que me acolheu como aluno ouvinte em seus cursos; também pela enorme disponibilidade em comentar e ajudar no desenvolvimento de minha pesquisa, primeiro na banca de seleção para ingresso na Pós-Graduação, depois na qualificação e finalmente na defesa. Além desses momentos, agradeço por todos os comentários à minha pesquisa, ainda em fase de desenvolvimento, feitos ao longos de várias edições do MiniEnapol de Historiografia Linguística, promovidas anualmente pelo CEDOCH. 
À professora Marli Quadros (USP), por ter me introduzido nos estudos historiográficos lá pelos idos de 2005. Também por aceitar participar da banca de defesa e pelos importantes comentários feitos nessa ocasião.

Ao professor Borges Neto (UFPR), por sua participação em minha defesa e por suas observações sempre pertinentes e instigantes. Também por sua disposição em contribuir com minha pesquisa ao longo de seu desenvolvimento, tanto em algumas edições do MiniEnapol quanto em alguns congressos que participamos.

Ao professor Francisco Eduardo Vieira (UFPB), por ter aceitado fazer parte da banca, embora por questões pessoais não tenha podido participar.

Ao professor Carlos Faraco (UFPR), pela gentileza com que, mesmo na condição de suplente, leu atentamente a tese e enviou preciosas observações. Também pelas interações sempre muito instigantes.

Ainda aos professores Carlos Faraco e Francisco Eduardo Vieira, pelo minicurso sobre gramática ministrado durante o XII MiniEnapol de Historiografia Linguística e também e pela frutífera interação ocorrida ao longo desse evento.

Ao professor Mário Viaro (USP), pela participação em meu exame de qualificação e por suas preciosas observações. Também pelos conhecimentos adquiridos nos vários cursos de graduação e pós-graduação que fiz com ele desde 2003.

Ao Pasta, pela amizade e pelo exemplo que é de intelectual e professor.

À biblioteca do IEB-USP, em especial aos funcionários Daniela, Silvana e Flávio, pela ajuda com a pesquisa documental.

Aos funcionários da biblioteca Florestan Fernandes (FFLCH), também pela ajuda com a pesquisa documental.

Aos funcionários do DL, Érica, Robson e Denise, pela ajuda com as questões burocráticas.

A todos os amigos e colegas do CEDOCH-USP, pela amizade e por bacana que é fazermos parte de um grupo de pesquisa, infelizmente não tão frequente na Pós-Graduação.

Agora, gostaria de agradecer pessoas do meu círculo familiar e de amizades que também foram decisivas para que eu pudesse realizar esta tese:

À Ju, minha mulher, sem ela teria sido impossível realizar esta empreitada. Sem as tantas vezes que ela me "cobriu" nas tarefas de casa e nos cuidados com nosso filho, seria impraticável me dedicar a esta tese. A você, meu amor, meu muito muito obrigado! 
Ao Gabriel, meu filho amado, por ser tão compreensivo com as ausências "do papai" e por torcer para que tudo desse certo. Agora, a gente "vai brincar muito", tá?

À minha amada mãe (in memoriam) por ter sido uma mãe maravilhosa! A ela tudo devo...

Aos meus amados avós maternos, Susana (in memoriam) e Roland (in memoriam), também a quem tudo devo, sublinho a minha mais profunda gratidão...

À equipe do Colégio Ítaca, em especial aos meus colegas do Ensino Médio e à minha diretora Mercedes, também professora de Português, pelo clima de trabalho animado e sadio!

$\mathrm{E}$, finalmente, registro meu agradecimento a todos os alunos que tive ao longo destes 26 anos de profissão, que me mostraram, cada qual de uma forma diferente, que, apesar das dificuldades, ser professor ainda vale muito a pena!

Quero, por fim, destacar que, a despeito da ajuda de todas as pessoas aqui mencionadas, os erros e as incompletudes desta Tese correm por minha total e exclusiva culpa. 
Quem construiu a Tebas de sete portas?

Nos livros estão nomes de reis.

Arrastaram eles os blocos de pedra?

E a Babilônia várias vezes destruída -

Quem a reconstruiu tantas vezes? Em que casas

Da Lima dourada moravam os construtores?

Para onde foram os pedreiros, na noite em que a Muralha da China ficou pronta?

A grande Roma está cheia de arcos do triunfo.

Quem os ergueu? Sobre quem

Triunfaram os Césares? A decantada Bizâncio

Tinha somente palácios para seus habitantes? Mesmo na lendária

Atlântida

Os que se afogavam gritaram por seus escravos Na noite em que o mar a tragou.

O jovem Alexandre conquistou a Índia.

Sozinho?

César bateu os gauleses.

Não levava sequer um cozinheiro?

Filipe da Espanha chorou, quando sua Armada

Naufragou. Ninguém mais chorou?

Frederico II venceu a Guerra dos Sete Anos.

Quem venceu além dele?

Cada página uma vitória. Quem cozinhava o banquete?

A cada dez anos um grande homem.

Quem pagava a conta?

Tantas histórias.

Tantas questões.

(Bertolt Brecht, Perguntas de um trabalhador que lê) 


\section{RESUMO}

VIDAL NETO, José Bento Cardoso. A formação do pensamento linguístico brasileiro: entre a gramática e novas possibilidades de tratamento da língua (1900-1940). Tese apresentada à Faculdade de Filosofia, Letras e Ciências Humanas da Universidade de São Paulo, para a obtenção do título de Doutor em Letras.

A presente tese teve como objetivo central compreender como se organizou, no Brasil, a reflexão sobre o Português nas quatro primeiras décadas do século XX. Estudar o papel desempenhado pelos diferentes gêneros textuais e pelas diferentes práticas de tratamento da língua na formação do pensamento linguístico brasileiro. Identificamos que tais reflexões foram desenvolvidas no interior de três programas de investigação (Swiggers, 1981, 1987, 2004): o gramatical, o filológico e o dialetológico. Nossa hipótese, ao propor a investigação que ensejou a presente tese, era a de que o aumento de publicações, dentro dos programas filológico e dialetológico, alterou o cenário gramaticográfico brasileiro, acarretando a perda da centralidade que a gramática tinha até o século XIX. Para investigar a validade dessa hipótese, realizamos, inicialmente, um levantamento bibliográfico de pretensão exaustiva de todas as publicações brasileiras sobre o Português entre 1900-1940. Chegamos ao número total de 581 obras, sendo 400 gramaticais, 89 filológicas e 92 dialetológicas. Metodologicamente, para melhor compreendermos as relações do programa gramatical frente aos outros dois, utilizamo-nos das camadas do conhecimento linguístico (Swiggers, 2004). Quanto ao programa gramatical, nossas análises mostraram que ele, no início do século XX, se manteve bastante ativo e profícuo em duas frentes: (i) obras escolares (em suas três configurações, gramáticas completas, obras com temas gramaticais específicos e livros didáticos de Português), processo que classificamos como didatização da gramática brasileira e (ii) obras que discutem questões em torno da norma culta, principalmente mostrando "o que se deve dizer" e "o que deve ser evitado" no uso da língua. Um dado da camada contextual que nos ajudou a explicar o aumento das produções gramaticais escolares foi a estruturação e ampliação do Secundário, o que gerou grande demanda por materiais específicos, promovendo, assim, maior especialização na produção destinada a esse nível de ensino. Quanto aos programas filológico e dialetológico, nosso levantamento e as análises que pudemos fazer a partir das obras mostraram que o tipo de discussão que se fazia nas gramáticas do século XIX, notadamente as sob orientação da Linguística HistóricoComparativista, passaram a ser feitas, no século XX, em obras monográficas, recebendo, nesses espaços, maior desenvolvimento e aprofundamento, o que demonstra que esses dois programas também sofreram maior especialização no início dos novecentos.

Palavras-chave: Gramaticografia brasileira; Historiografia linguística; Século XX; Dialetologia; Filologia. 


\begin{abstract}
VIDAL NETO, José Bento Cardoso. The formation of Brazilian linguistic thought: between grammar and new possibilities of language treatment (1900-1940). Tese apresentada à Faculdade de Filosofia, Letras e Ciências Humanas da Universidade de São Paulo, para a obtenção do título de Doutor em Letras.
\end{abstract}

The main objective of this thesis was to understand how, in Brazil, reflection on Portuguese was organized in the first four decades of the 20th century. To study the role played by different textual genres and different language treatment practices in the formation of Brazilian linguistic thought. We found that such reflections were developed within three programs (Swiggers, 1981, 1987, 2004): grammatical, philological and dialectological. Our hypothesis, when proposing the investigation that gave rise to the present thesis, was that the increase in publications, within the philological and dialectological programs, altered the Brazilian grammatical scenario, causing the loss of centrality that the grammar had until the 19th century. To investigate the validity of this hypothesis, we carried out, initially, a bibliographic research of exhaustive intention of all Brazilian publications on Portuguese between 1900-1940. We reached the total number of 581 works, 400 grammatical, 89 philological and 92 dialectological. Methodologically, to better understand the relations of the grammatical program vis-à-vis the other two, we use the layers of linguistic knowledge (Swiggers, 2004). As for the grammatical program, our analyzes showed that, at the beginning of the 20th century, it remained quite active and fruitful on two fronts: (i) school works (in its three configurations, complete grammars, works with specific grammatical themes and textbooks of Portuguese), process that we classify as didatization of Brazilian grammar and (ii) works that discuss issues around the cultured norm, mainly showing "what should be said" and "what should be avoided" in the use of the language. A data from the contextual layer that helped us explain the increase in school grammatical productions was the structuring and expansion of the Secondary School, which generated great demand for specific materials, promoting, thereby, greater specialization in the production for this level of education. As for the philological and dialectological programs, our survey and the analyzes we were able to make from the works showed that the type of discussion that took place in 19th century grammars, notably those under the guidance of Historical-Comparative Linguistics, started to be made, in the century, in monographic works, receiving, in these spaces, greater development and deepening, which demonstrates that these two programs also underwent greater specialization in the early 1900s.

Keywords: Brazilian grammarography; Linguistic historiography; 20th century; Dialectology; Philology. 


\section{LISTA DE QUADROS}

Quadro 1 - Os cinco perfis de historiografia segundo Swiggers .28

Quadro 2 - Quadro comparativo entre parte do Programa de Português, de 1942 e o sumário da Gramática brasileira do português contemporâneo, de Cândido Jucá (filho) (1943)

Quadro 3 - Instruções metodológicas para o ensino de Português - $1^{\text {a }}$ série do Secundário

- Portaria n' 172, de 1942 . .63

Quadro 4 - Lista de exercícios de fixação: "adjetivos qualitativos" 65

Quadro 5 - Gramáticas secundárias vindas de coleções didáticas .68

Quadro 6 - Relação de literatos usados na Grammatica expositiva, de Eduardo Carlos Pereira. . .76

Quadro 7 - Objetivos do curso secundário (1890-1925) .93

Quadro 8 - Programas de ensino de 1931 e 1942 quanto ao tópico análise léxica e lógica

Quadro 9 - Estrutura do ensino secundário pela Reforma Francisco Campos (1931) 103

Quadro 10 - Estrutura do ensino secundário pela Reforma Gustavo Capanema (1942)

Quadro 11 - Gramáticas de referência completas: século XX

Quadro 12 - Teses acadêmicas com viés gramatical.

Quadro 13 - Definições de gramática histórica - Quadro-síntese. 148

Quadro 14 - Definições sobre as técnicas de análise da gramática histórica - Quadrosíntese 152

Quadro 15 - Tratamento (edição) de texto 184

Quadro 16 - Definições de filologia presentes nas gramáticas históricas 186

Quadro 17 - Síntese das ideias sobre o processo de dialetação presente nas obras

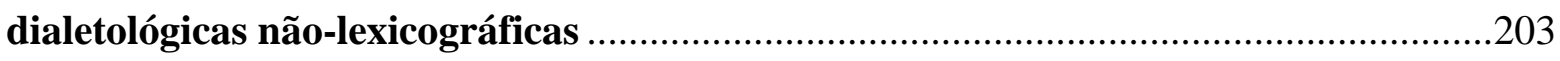

Quadro 18 - Estudo dos dialetos: apenas Gramática Histórico-Comparada ..............208

Quadro 19 - Estudo dos dialetos via folclore

Quadro 20 - Estudo dos dialetos: apenas Gramática Histórico-Comparada ou outro modelo teórico.

Quadro 21 - Estudo dos dialetos via folclore, história, geografia, etc

Quadro 22 - Obras de dialetologia com viés teórico, ensaístico 


\section{LISTA DE TABELAS}

Tabela 1 - Quantitativo geral da produção linguística sobre o Português: 1900 -1940.40

Tabela 2- Quantitativo da produção gramatical escolar e de referência

Tabela 3 - Gramáticas escolares: destinação quanto ao segmento escolar . .66

Tabela 4 - Quantidade de classes de palavras nas gramáticas escolares .83

Tabela 5 - A alfabetização brasileira entre 1872 e 1950.

Tabela 6 - Conteúdo tratado nas obras escolares de temas gramaticais específicos .95

Tabela 7 - Escolas, docentes e matrículas no Secundário (1907) . .99

Tabela 8 - Escolas, docentes e matrículas no Secundário (1932-1938) . .99

Tabela 9 - Quantitativo da produção gramatical de referência 108

Tabela 10 - Gramáticas escolares e de referência: comparação entre os séculos XIX e XX

Tabela 11 - Divisão das gramáticas por segmento escolar - Séculos XIX e XX

Tabela 12 - Gramáticas do século XIX que avançaram até o século XX

Tabela 13 - Longevidade das gramáticas do século XIX durante o século XX

Tabela 14 - Gramáticas mais longevas do século XIX com edição também no século XX

Tabela 15 - Gramáticas de referência do século XIX mais longevas: edições póstumas

Tabela 16 - Quantitativo da produção filológica sobre o Português

Tabela 17 - Principais temas das obras de temas filológicos específicos

Tabela 18 - Quantitativo da produção dialetológica sobre o Português 


\section{LISTA DE FIGURAS}

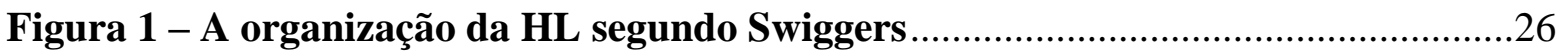

Figura 2 - Classificação das obras dentro de cada programa de investigação ..............41

Figura 3 - Estruturação da Grammatica portugueza, de Julio Pires Ferreira .................81

Figura 4 - Estruturação das Breves noções de grammatica portugueza, de Achilles Alves

Figura 5 - Estruturação da Gramática ginasial, de José Mesquita de Carvalho. . .82

Figura 6 - Estruturação das Lições elementares de Lingua Portugueza, de Maximino Maciel

Figura 7 - Os fonemas segundo a prosódia brasileira na visão de José de Oiticica .....135 


\section{SUMÁRIO}

INTRODUÇÃ

$1 \quad$ Fundamentação teórico-metodológica..........................................................................25

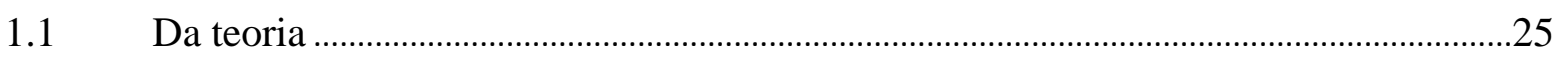

1.1.1 Da Historiografia Linguística e seus propósitos.................................................25

1.1.2 Dos conceitos da Historiografia Linguística utilizados nesta tese .........................29

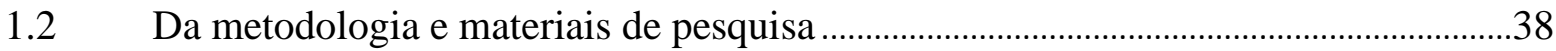

1.2.1 Da periodização e da construção do levantamento .................................................38

1.2.2 Critérios e procedimentos de análise .............................................................42

2 O programa de investigação gramatical: as obras gramaticais escolares sobre o

Português ......................................................................................................................................................44

2.1 Considerações gerais sobre o programa de investigação gramatical ............................45

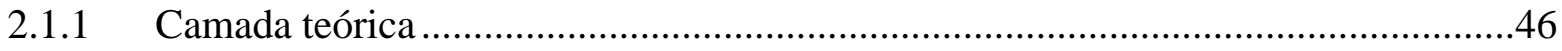

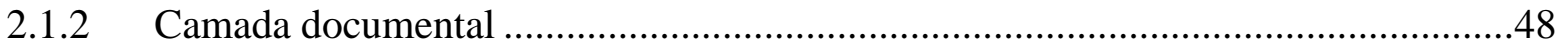

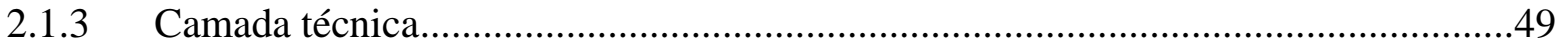

2.2 A respeito da normatividade em obras metalinguísticas ..................................................52

2.3 O programa de investigação gramatical entre 1900 e 1940: os textos escolares......57

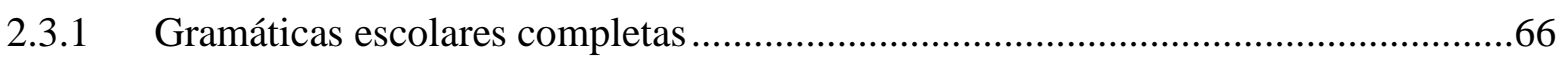

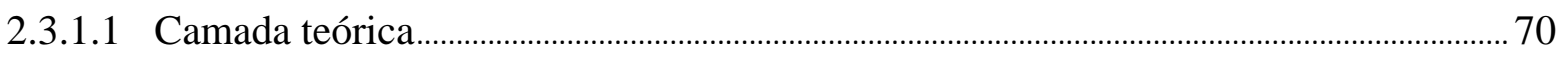

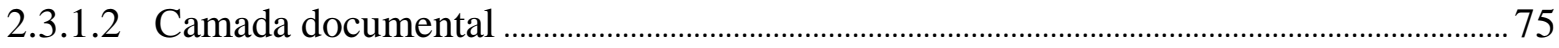

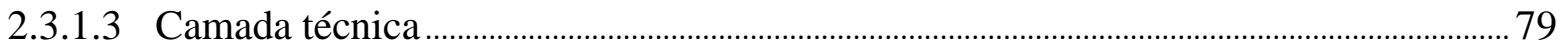

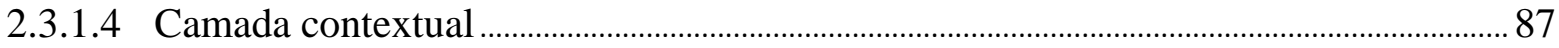

2.3.1.4.1 O Colégio Pedro II e a disciplina "Português" ....................................................................... 87

2.3.1.4.2 As gramáticas sob impacto do Programa de Fausto Barreto ............................................ 90

2.3.1.4.3 As reformas educacionais e os programas de ensino entre 1900 e 1942 ..................92

2.3.2 Obras escolares de temas gramaticais específicos .............................................95

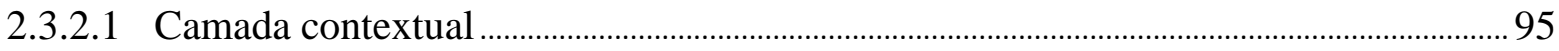

2.3.2.2 Camadas teórica, documental e técnica......................................................................................98

2.3.3 Livros didáticos de Português ...............................................................................99

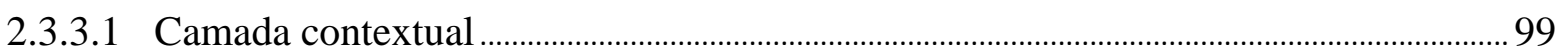


$3 \quad$ O programa de investigação gramatical: as obras gramaticais de referência sobre o Português

3.1 Gramáticas de referência completas .................................................................................... 109

3.2 Obras de referência de temas gramaticais específicos .................................................... 122

$4 \quad$ O programa de investigação filológico: as obras históricas sobre o Português137

4.1 Considerações gerais sobre o programa de investigação filológico............................. 138

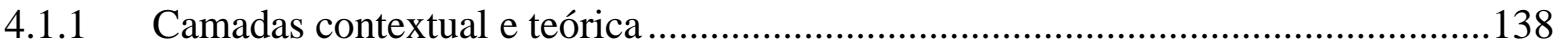

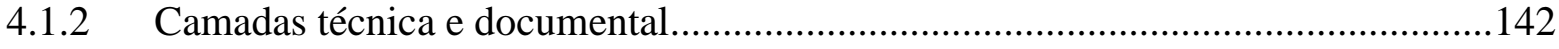

4.2 Gramáticas históricas do Português.................................................................................... 144

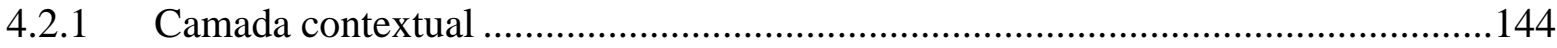

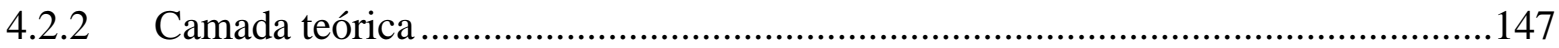

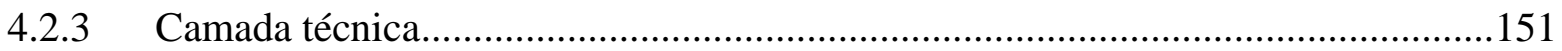

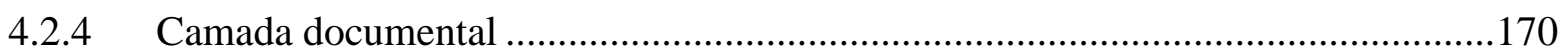

4.3 Obras de temas filológicos específicos......................................................................... 172

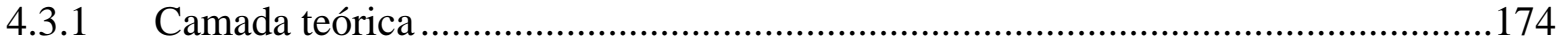

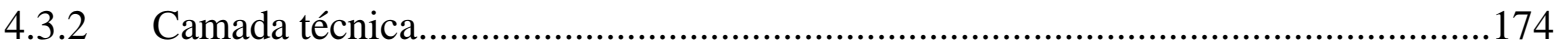

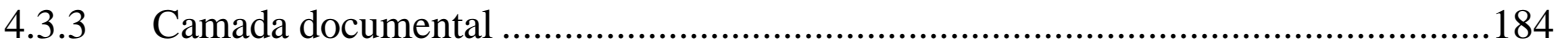

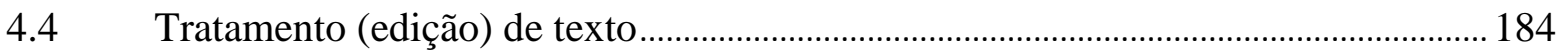

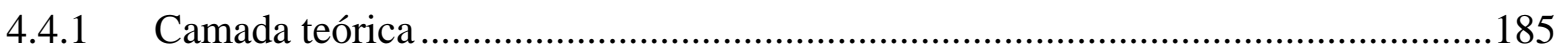

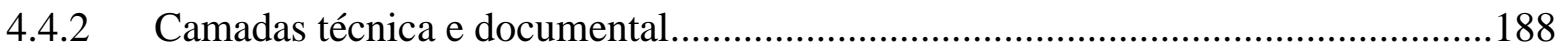

$5 \quad$ O programa de investigação dialetológico: a variedade brasileira do Português

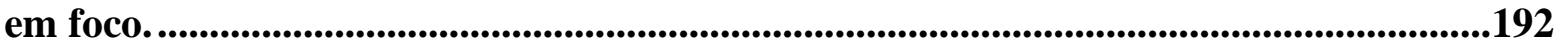

5.1 Considerações gerais sobre o programa de investigação dialetológico ...................... 192

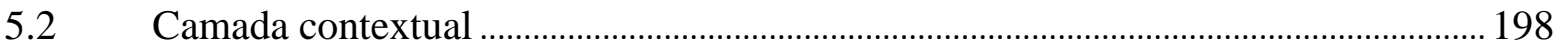

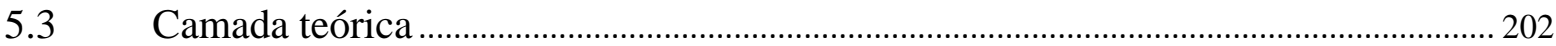

5.4 Descrição de dialetos regionais e sociais ............................................................................... 207

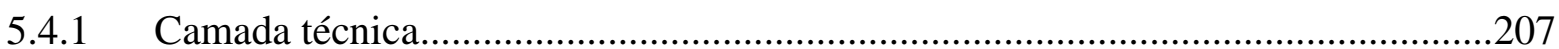

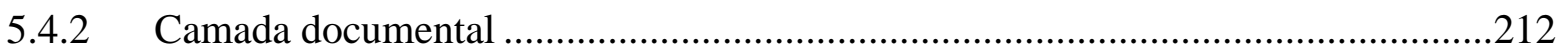

5.5 Descrição dialetológica do Português do Brasil .............................................................. 218

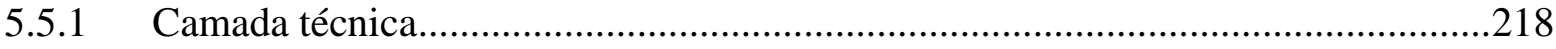




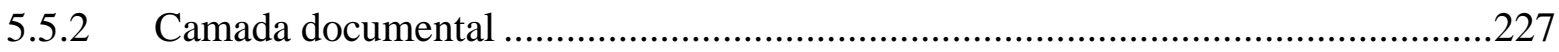

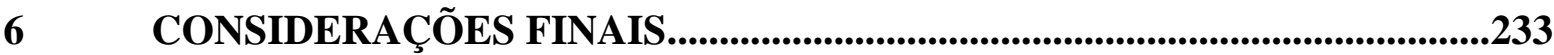

REFERÊNCIAS BIBLIOGRÁFICAS ....................................................................240

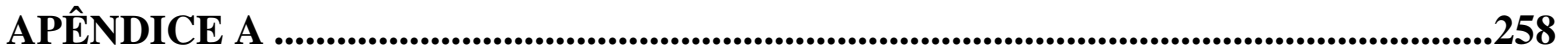

QUADRO 1A - Produção linguística brasileira (1900-1940): programa de investigação gramatical

QUADRO 2A - Produção linguística brasileira (1900-1940): programa de investigação filológico

QUADRO 3A - Produção linguística brasileira (1900-1940): programa de investigação dialetológico

QUADRO 1B - Gramáticas escolares completas

QUADRO 2B - Definições de gramática: grupo das gramáticas escolares completas 363

QUADRO 3B - O estudo da gramática e suas divisões

QUADRO 4B - Obras escolares de temas gramaticais específicos

QUADRO 5B - Livros didáticos de Português 406

QUADRO 6B - Obras de temas gramaticais específicos

Quadro 7B - Obras que abordam vários temas gramaticais.

Quadro 8B - Obras em que se estudam as ideias gramaticais (ou a linguagem) de um determinado autor/ Polêmicas gramaticais entre autores

QUADRO 9B - Obras de temas filológicos específicos.

QUADRO 10B - Temas de gramática histórica presentes no currículo de Português entre 1887 e 1961

QUADRO 11B - Gramáticas históricas do Português

QUADRO 12B - Definições de gramática histórica, filologia, glotologia, linguística e demais conceitos correlatos presentes nas Gramáticas Históricas do Português 
QUADRO 13B - Definições de dialeto presentes nas gramáticas históricas do

Português

QUADRO 14B - Definições e considerações sobre dialeto presentes nas obras dialetológicas do Português

QUADRO 15B - Posições nacionalistas nas obras dialetológicas lexicográficas

QUADRO 16B - Obras dialetológicas lexicográficas: descrição de dialetos regionais e sociais.....

QUADRO 17B - Obras dialetológicas não-lexicográficas: descrição de dialetos

regionais e sociais

QUADRO 18B - Obras dialetológicas lexicográficas: descrição dialetológica do

Português do Brasil.

QUADRO 19B - Obras dialetológicas não-lexicográficas: descrição dialetológica do Português do Brasil.

ANEXO A

ANEXO A1 - PROGRAMA DE FAUSTO BARRETO - 1887

ANEXO A2 - Programa de ensino do Colégio Pedro II - Português - 1898

ANEXO A3 - Programa de ensino do Colégio Pedro II - Português - 1912

ANEXO A4 - Programa de ensino do Colégio Pedro II - Português - 1915 e 1916...

ANEXO A5 - Programa de ensino do Colégio Pedro II - Português - 1917 ................508

ANEXO A6 - Programa de ensino do Colégio Pedro II - Português - 1926.

ANEXO A7 - Programas de ensino do Colégio Pedro II - Português - 1928, 1929 e 1930.

ANEXO A8 - Programa de ensino do Ministério da Educação e Saúde Pública -

Português - 1931

ANEXO A9 - Programa de ensino do Ministério da Educação e Saúde - Português 1942 
ANEXO A10 - Instruções metodológicas para execução do programa de Português 1942

ANEXO B .534

ANEXO B1 - Gramáticas presumidas como de referência: não acessíveis à análise física e/ou sem pistas no título/subtítulo que são escolares - Século XIX (1853 - 1900) .....535 ANEXO B2 - Gramáticas presumidas como escolares: principalmente pelo não acesso físico às obras - Século XIX (1853 - 1900) .540 


\section{INTRODUÇÃO}

O trabalho que ora propomos tem como objetivo central compreender como se organizou, no Brasil, a reflexão sobre o Português nas quatro primeiras décadas do século XX. Objetivamos estudar o papel desempenhado pelos diferentes gêneros textuais e pelas diferentes práticas de tratamento da língua na formação do pensamento linguístico brasileiro.

Podemos dizer que, no século XIX, as gramáticas da Língua Portuguesa - de algum modo inseridas, conceptual e terminologicamente, na longa tradição de origem greco-latina desfrutavam de um duplo papel no contexto dos estudos da linguagem no Brasil: de um lado, inseriam-se no rol das obras em circulação no ambiente escolar (cada vez mais publicadas a partir da segunda metade do século, em vista de projetos educacionais ${ }^{1}$ do Segundo Império), assumindo a função de manuais de ensino; de outro lado, constituíam-se em espaço para o registro e a discussão de reflexões (novas ou antigas) sobre língua, sobre gramática e suas bases teóricas (no mais das vezes, no contexto dos prefácios, ou no contexto da discussão de fenômenos linguísticos específicos), sobre o Português. Tais reflexões e discussões eram dirigidas não ao alunado, mas a outros estudiosos do Português, que, sobre elas, em alguns casos, se manifestavam em resenhas, colunas de jornais, artigos e outros textos, às vezes reproduzidos (sobretudo quando carregavam elogios) em edições posteriores das gramáticas. Podemos, assim, tomar as gramáticas como locais privilegiados, naquele período, para o desenvolvimento da reflexão linguística e, sobretudo, para a reflexão acerca da Língua Portuguesa.

Apesar do duplo papel acima destacado, ao chegarmos nos anos 1900, nos parece que a jovem gramaticografia ${ }^{2}$ brasileira - iniciada no começo do século XIX, com orientação (ao menos no nível retórico) preponderantemente filosófica e redimensionada (igualmente, ao menos no nível retórico), a partir do texto inaugural de Ribeiro (1881), para uma perspectiva mais atenta às contribuições histórico-comparativas - começa a perder o seu segundo papel, tornando-se, cada vez mais, um tipo de texto mais especializado, de circulação e impacto preponderantemente no ambiente escolar. Assim, se verifica que, paulatinamente, a gramática começa a perder (ou ao menos disputar) seu destaque no cenário de discussão sobre a Língua Portuguesa com outros tipos de produção, como as teses elaboradas para concursos de cátedra nos colégios mais

\footnotetext{
${ }^{1}$ Como, por exemplo, o Programa de Fausto Barreto, em 1887. (cf. Anexo A1)

2 Conceito aqui entendido como referência ao compêndio gramatical propriamente dito ou a trabalhos com tratamento de viés gramatical, em que há, por exemplo, referências específicas a partes ou seções tradicionais da gramática, como a fonologia, a morfologia e a sintaxe.
} 
prestigiados das grandes cidades, livros ou opúsculos de caráter monográfico, ensaios sobre questões pontuais da língua, colunas e artigos em jornais e revistas, coleções desses textos de periódicos em formato de livros, entre outros.

A leitura de obras de cunho histórico e historiográfico ${ }^{3}$ a respeito dos estudos linguísticos no Brasil voltados para a Língua Portuguesa - seja para a gramática, a filologia ou a linguística - indica para a hipótese que adotamos inicialmente como ponto de partida: a partir do início do século XX, parece ter havido a paulatina perda da primazia da gramática como local privilegiado para as discussões a respeito da língua para outros gêneros editoriais, associados, por sua vez, à requisição de algum nível de inovação no tratamento da linguagem, supostamente não mais sustentável nas "gramáticas".

Neste amplo horizonte, enxergamos ao menos três processos: (i) o de distinção mais clara entre textos gramaticais de referência e textos gramaticais escolares; (ii) o fortalecimento de produções voltadas para o estudo de variedades do Português; (iii) o estabelecimento da "filologia" e da "dialetologia" como disciplinas distintas da gramática.

Ao analisarmos o primeiro processo, notamos, por exemplo, que a crescente estruturação do ensino secundário ocorrida no início do século XX impulsionou a produção de materiais didáticos com vistas a atender aos alunos desse nível de ensino. Nesse sentido, foi necessário lidar - no presente trabalho - com a distinção entre as gramáticas que em sua origem não se destinavam ao uso escolar - aqui denominadas de gramáticas de referência - e as gramáticas escritas para fins pedagógicos, que serão aqui chamadas de gramáticas pedagógicas.

Atentamo-nos para as questões envolvidas no segundo processo, isto é, o fortalecimento de produções voltadas para o estudo de variedades do Português, ao lidarmos com o levantamento bibliográfico que realizamos para esta tese. $\mathrm{Na}$ análise desse material, pudemos notar que os trabalhos de orientação dialetológica podem ser divididos esquematicamente em dois grupos: (i) primeiro, os que voltaram seus interesses ao contraste entre o Português utilizado no Brasil e em Portugal, investigando, então, se haveria ou não diferenças suficientes entre essas duas "línguas" a ponto de serem consideradas línguas diferentes. Trabalhos como Português da Europa e Português da América: aspectos da evolução do nosso idioma, de Clóvis Monteiro (1931), Língua nacional: as diferenciações entre o português de Portugal e o do Brasil autorizam a existência de um ramo dialetal do português peninsular?, de Cândido Jucá (filho) (1937), são representativos desse primeiro grupo. Por outro lado, (ii) um outro grupo descreveu ou

\footnotetext{
${ }^{3}$ Cf. Nascentes (1939), Figueiredo (1957), Elia (1975), Morel Pinto (1976), Câmara Jr. (1972; 1976), Guimarães (1996), Coelho (1998), Azevedo Filho (2002), Cavaliere (2002), Altman (2004), Polachini (2013; 2017).
} 
caracterizou os diferentes falares regionais presentes no Brasil. Dessa safra, aparecem trabalhos como o O dialeto caipira, de Amadeu Amaral (1920), O linguajar carioca em 1922, de Antenor Nascentes (1922), A lingua do nordeste (Alagôas e Pernambuco), de Mário Marroquim (1934), O falar mineiro, de José Aparecida Teixeira (1938), dentre muitos outros títulos que serão mencionados nesta tese.

Outra preocupação entre os dialetólogos foi no sentido de estudar as influências que o Português utilizado no Brasil sofreu, principalmente em relação às línguas africanas ${ }^{4}$ e indígenas. Trabalhos como A influência africana no Português do Brasil, de Renato Mendonça (1933), O elemento afro-negro na Lingua Portuguesa, de Jacques Raimundo (1933), também dentre vários outros trabalhos, provam tal interesse.

Com efeito, os estudos dialetológicos trarão para os estudos sobre a Língua Portuguesa no Brasil um novo programa de investigação ${ }^{5}$ (Swiggers, 1981). Curiosamente, como assinalou Altman (2004, p. 74):

Mesmo inaugurando um programa de investigação diferente, Amaral - e seus continuadores - não sustentaram uma retórica de ruptura com o programa da Filologia. Pelo contrário, o estudo da variação dialetal residual, rural, contribuiria ainda mais para fundamentar interpretações histórico-filológicas divergentes sobre os substratos da "língua brasileira".

Compreender o surgimento desse novo programa de investigação e sua relação de "ruptura-permanência" com o programa da filologia é algo que precisa ser realizado no trabalho que aqui propomos, para que assim compreendamos adequadamente os estudos relativos ao Português realizados no início do século XX.

Finalmente, quanto ao terceiro processo, isto é, o estabelecimento da "filologia" e da "dialetologia" como disciplinas distintas da gramática, destacamos que também pôde ser nós observado através do levantamento bibliográfico realizado para esta tese. Com efeito, pudemos notar a existência de uma quantidade significativa de obras de viés histórico e não normativo, características que nos levaram a separá-las dos trabalhos gramaticais tradicionais, ou seja, os de viés normativo, caudatários do modelo gramatical greco-latino. No presente trabalho, é a esse tipo de publicação que estaremos nos referindo quando falarmos da filologia, ou ainda, em programa de investigação filológico.

Nossos objetivos, nesta tese, foram:

\footnotetext{
${ }^{4}$ Cf. Borges (2014) sobre a produção dedicada ao estudo sobre a influência das línguas africanas no Português do Brasil.

${ }^{5}$ Abordaremos o conceito de programa de investigação no próximo capítulo, o teórico-metodológico.
} 
1. Analisar produção linguístico-gramatical brasileira voltada para a Língua Portuguesa entre os anos 1900 e 1940, nas suas relações de continuidade e descontinuidade com a produção dos anos 1800 (esta última produção foi estudada a partir de pesquisas anteriores, tanto elaboradas por nós quanto por outros autores). Tal análise teve como objetivo levantar quais e que tipos de textos foram decisivos para a formação do pensamento linguístico brasileiro do início do século;

2. Avaliar a constituição, os contextos de circulação e o impacto dos novos textos organizadores de novos conhecimentos e de novas formas de se estudar o Português - com o programa gramatical, no sentido de dimensionar a suposta perda da primazia da gramática como local privilegiado para as discussões a respeito do Português para outros gêneros editoriais;

3. Sistematizar e interpretar aspectos contextuais de relevância para a condução dos objetivos anteriores, tais como os aspectos relativos à "instrução pública" na virada dos séculos; os primeiros movimentos de profissionalização e especialização da área de Letras; as novas esferas de influência intelectual e os distintos climas de opinião (cf. Koerner, 2014) a agir sobre os estudiosos do Português no início do século XX.

Para atingirmos tais objetivos, inicialmente, realizamos um levantamento bibliográfico de pretensão exaustiva acerca da produção brasileira sobre o Português. Localizamos 581 obras, das quais 366 foram examinadas fisicamente, para, então, serem divididas em três programas de investigação: gramatical, filológico e dialetológico.

No próximo capítulo, apresentaremos como, metodologicamente, analisamos as obras acima mencionadas.

Os estudos realizados nesta tese foram assim estruturados:

- No capítulo 1, Fundamentação teórico-metodológica, apresentamos aspectos gerais da Historiografia Linguística, bem como as bases teóricas/autores dessa disciplina que utilizamos para analisar dos dados. Também apresentamos como foi feita a periodização e a construção de nosso levantamento, além de justificar os critérios e os procedimentos de análise dos dados que utilizamos;

- No capítulo 2, "O programa de investigação gramatical: as obras gramaticais escolares sobre o Português", tivemos alguns objetivos: (i) apresentar características gerais do programa gramatical, fazendo, nesse primeiro momento, um balanço histórico quanto às suas características constitutivas; (ii) analisar a normatividade em obras metalinguísticas e (iii) estudar as obras escolares gramaticais quanto às camadas do conhecimento linguístico (Swiggers, 2004); 
- No capítulo 3, "O programa de investigação gramatical: as obras gramaticais de referência sobre o Português", não analisamos aspectos ligados às camadas do programa gramatical, já que tal tarefa foi realizada no capítulo 2, mas sim procuramos analisar questões contextuais que explicassem o sucesso editorial de obras como os consultórios gramaticais, as polêmicas linguísticas e outros tipos de publicações monográficas, além de investigar a baixa quantidade de gramáticas de referência publicada no início dos novecentos;

- No capítulo 4 e 5, respectivamente, "O programa de investigação filológico: as obras históricas sobre o Português" e "O programa de investigação dialetológico: a variedade brasileira do Português em foco", estudamos as obras desses programas quanto às camadas do conhecimento linguístico (Swiggers, 2004), tal como fizemos, no capítulo 2, com as obras gramaticais;

- Nas Considerações finais, retomamos nossa hipótese de trabalho e ali verificamos se ela se mostrou verdadeira sob dois aspectos: (i) um mais ligado ao levantamento quantitativo e aos aspectos contextuais que ajudaram a explicar a divisão da produção linguística sobre o Português do início dos 1900 em diferentes gêneros textuais e não mais concentrada apenas na gramática e (ii) outro, relacionado às questões de ordem linguística, que, nesta tese, foram analisadas por meio das camadas do conhecimento linguístico (Swiggers, 2004), o que nos possibilitou dimensionar como esses outros gêneros estudavam o Português e suas diferenças ou não frente às gramáticas. 


\section{Fundamentação teórico-metodológica}

\subsection{Da teoria}

\subsubsection{Da Historiografia Linguística e seus propósitos}

De maneira sintética, podemos dizer que a Historiografia Linguística (doravante HL) é uma disciplina científica que tem como objetivo descrever e interpretar o conhecimento linguístico gerado a partir do primeiro documento escrito. Ou seja, é uma área que visa a trazer para o linguista contemporâneo uma narrativa que ofereça elementos para compreensão de como se deu a produção e a circulação de reflexões e práticas com as línguas e a linguagem em um determinado período histórico. Dessa forma, é importante que se diga que a HL é uma disciplina que alia, essencialmente, dois gestos: o descritivo e o interpretativo.

Nas considerações sobre a HL que faremos aqui, privilegiaremos os pressupostos teóricos e metodológicos definidos por Pierre Swiggers, autor a cujos estudos têm se alinhado, desde o início dos anos 1990, as pesquisas desenvolvidas no Centro de Documentação em Historiografia Linguística $(\mathrm{CEDOCH})$ do Departamento de Linguística da USP. Vejamos abaixo como Swiggers (2009, p.68, itálicos do autor) a define:

(...) historiografía (se tratará de la historiografía de uma disciplina) y lingüística. Por lingüística entiendo el corpus global de conocimientos y reflexiones en relación con el fenómeno (antropológico) del lenguaje y el hecho (histórico) de las lenguas. Por historiografía (de una disciplina) entiendo el proceso de descripción y de comprensión de los productos así como del quehacer que constituyen y caracterizan la (historia de la) disciplina en cuestión.

Swiggers (2010, p.4-5, itálicos do autor) também aponta como a HL deve se organizar, apresentando, para isso, o seguinte organograma: 


\section{Figura 1 - A organização da HL segundo Swiggers}

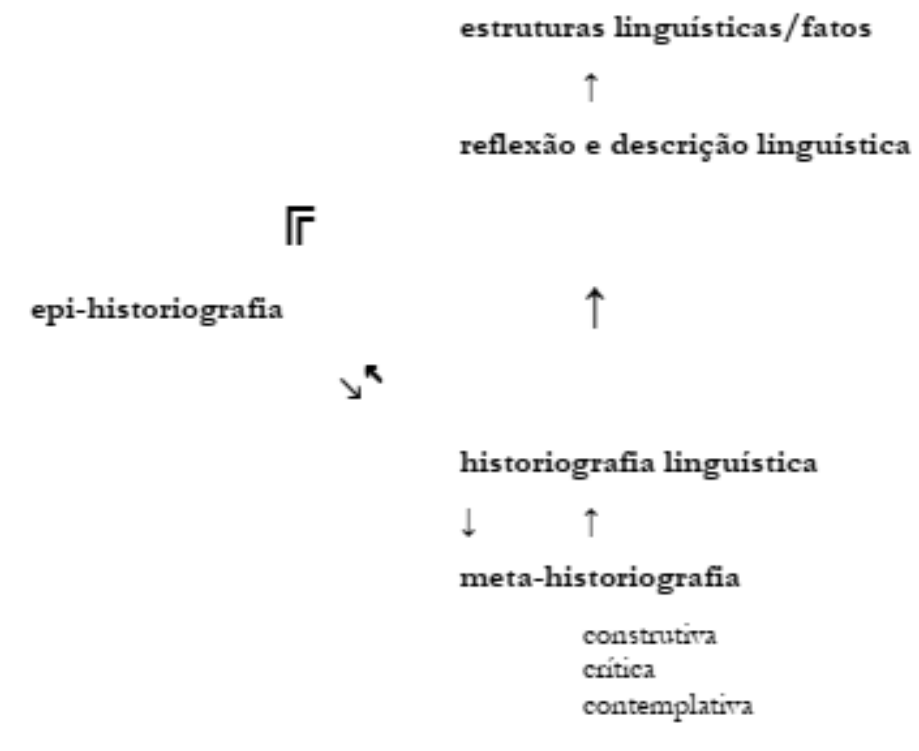

\footnotetext{
I斤 simboliza uma relaçào de 'integraçào material' (informaçào factual)

$\uparrow$ simboliza a relação entre descrição e objeto (de descrição)

$\downarrow \uparrow$ simboliza alimentação cruzada e enriquecimento mútuo
}

Fonte: Swiggers (2010, p.4)

A seguir, no mesmo texto, Swiggers passa a definir os cinco componentes que formam o organograma, ou seja, (i) estruturas linguísticas/fatos; (ii) reflexão e descrição linguísticas; (iii) historiografia linguística; (iv) epi-historiografia e (v) meta-historiografia.

Estruturas linguísticas/fatos são definidas por Swiggers (2010, p.4) como “os fatos (selecionados), ou conjuntos de fatos relacionados às estruturas linguísticas e às situações linguísticas que (no passado) foram objeto de reflexão linguística, ou de descrição”. Como destacou o autor, a matéria linguística pode ensejar reflexão e descrição linguísticas, que são por ele assim definidas:

Este nível inclui todos os tipos de práticas e de conceptualizações que tratam (mesmo fragmentariamente) de análise, regulação, comparação (histórica/geográfica/tipológica), classificação, avaliação (estética) de línguas. O rótulo "reflexão e descrição linguísticas" inclui, pois, uma ampla gama de "operações" (mais ou menos) linguisticamente relevantes sobre estruturas linguísticas; estas vão desde o nível da linguística folclórica [folk-linguistics] (folketimologia; trocadilhos e jogos de palavras) e o desenvolvimento desde apontamentos técnicos até modelos sofisticados de análise linguística e metodologias de comparação linguística em escala mundial. O curso histórico da "reflexão e descrição linguísticas" constitui a história da linguística (a ser interpretada no seu sentido "ontológico"). 
Com efeito, é explorando esses dois "componentes" que o historiógrafo produzirá seu texto, que é, como já mencionamos anteriormente, "uma narrativa descritivo-explicativa da reflexão e descrição linguística no passado ("passado" que se estende até o presente do historiógrafo)." (SWIGGERS, 2010, p.4)

Finalmente, encerrando seu organograma, o autor apresenta seus últimos componentes: a epi-historiografia e a meta-historiografia.

Trata-se de duas dimensões de trabalho adjacentes ao que se poderia chamar de historiografia linguística, isto é, àquela de marcantes características descritivas e interpretativas. São dimensões que oferecem apoio ao fazer historiográfico. Tal apoio pode se dar no campo da obtenção, tratamento e disponibilização de materiais que possam se converter em fontes de pesquisa, tanto a concernente à natureza do conhecimento linguístico produzido ao longo do tempo por determinados agentes, quanto a concernente aos contextos (de surgimento, difusão, desdobramento, apagamento, recuperação, etc.) desses saberes. O trabalho epi-historiográfico é assim definido por Swiggers (2010, p. 5):

Este ramo "lateral" da historiografia concerne à história dos "agentes"
(pesquisadores individuais, ou grupos de pesquisadores de uma língua), e
"materiais produzidos" (papiros, manuscritos, livros, artigos, textos eletrônicos,
etc.), esses últimos constituem o depósito do conhecimento linguístico. Em
acréscimo, o componente epi-historiográfico também integra o material documental
produzido por historiógrafos, como meio de apoio e reforço à pesquisa meta-
historiográfica.

A outra forma de subsidiar o trabalho do historiógrafo é atuando no campo da reflexão teórica a respeito das práticas da própria HL, constituindo, portanto, uma atividade metahistoriográfica. Swiggers (2010, p.5) a define da seguinte forma: "o campo das atividades reflexivas que tomam por objeto as práticas e os produtos historiográficos".

Outro aspecto importante analisado por Swiggers é quanto à pesquisa documental (sejam textos do presente ou do passado) que deve ser realizada em três fases: a heurística, a hermenêutica e a executiva.

A atividade heurística é, basicamente, a de levantamento e trabalho com as fontes que serão utilizadas na historiografia a ser construída. Swiggers (2013, p. 44) diz que essa atividade "compreende as seguintes tarefas: informar-se sobre as fontes e sua disponibilidade; ler os textosfontes; 'catalogar' ideias, os pontos de vista e a terminologia; contextualizar as ideias, os termos". Cumprida essa etapa - que na descrição do autor parece singela, mas que impõe desafios diversos ao pesquisador -, o historiógrafo deve passar ao trabalho hermenêutico, ou seja, uma vez que já realizado a trabalho de estabelecimento e aproximação inicial das fontes primárias da pesquisa, 
o pesquisador pode passar ao trabalho interpretativo do material por ele levantado. Para Swiggers (2013, p. 44, sublinhados nossos):

Uma fase hermenêutica, que consiste em uma interpretação, que sempre se fundamenta no uso de categorias interpretativas. Aqui se pode fazer a distinção entre categorias gerais (os conceitos que fazem parte da metodologia geral) e categorias específicas (os conceitos que constituem a metodologia específica). Há de destacar-se o fato de que a interpretação implica uma dimensão comparativa, porque (quase sempre) se trata de relacionar conceitos/autores/modelos.

A última fase, a executiva, segundo o autor, relaciona-se "à demonstração dos resultados da investigação". Para Swiggers (2013, p. 45, sublinhamos), "nessa fase, intervêm, como parâmetros fundamentais, três dimensões: (i) a do formato de exposição; (ii) a dimensão da intencionalidade do historiógrafo e (iii) a dimensão do programa cognitivo". Vejamos como o autor concebe tais parâmetros:

1) a do formato de exposição: a execução historiográfica pode tomar uma forma sequencial (basicamente narrativa), uma forma "tópica" (focalizada na análise de um tema ou em um tipo de problema) ou uma forma "combinatória" (centrada entre o contexto e o conjunto de pontos de vista em determinada época da história da linguística). 2) a dimensão da intencionalidade do historiógrafo: aqui se apresenta a possibilidade de optar por uma historiografia (meramente) taxonômica ou classificadora, polêmica ou apologética, teleológica, exegético-crítica: em cada uma das opções, influem considerações (e pressuposições) sobre o que é (ou seria) mais ou menos científico/válido/adequado/relevante no campo da linguística e, em plano mais geral, das ciências humanas. 3) a dimensão do programa cognitivo: esta é uma dimensão essencial, que, estando determinada, em parte, pelo objeto de estudo e pela documentação disponível e, em parte, pelos interesses e aspirações do historiador, define o perfil intelectual dos produtos historiográficos. Com referência a esse parâmetro, podem-se distinguir cinco perfis distintos de historiografia (...).

Swiggers (2004, p.120) destaca que, na prática, frequentemente encontra-se combinação entre esses perfis a depender dos aspectos estudados pelo historiógrafo. Vejamos, no quadro abaixo, os perfis mencionados.

\section{Quadro 1 - Os cinco perfis de historiografia segundo Swiggers}

\begin{tabular}{|c|l|}
\hline Atomística & $\begin{array}{l}\text { É feita sob forma de uma apresentação analítica de } \\
\text { acontecimentos e fatos da história da linguística. }\end{array}$ \\
\hline Narrativa & $\begin{array}{l}\text { Relata, na sua sucessão cronológica, os "acontecimentos" na } \\
\text { história da linguística. }\end{array}$ \\
\hline Nocional-estrutural & $\begin{array}{l}\text { Análise estrutural de conjuntos de ideias, de tipos de } \\
\text { abordagens na história da linguística. }\end{array}$ \\
\hline
\end{tabular}




\begin{tabular}{|c|l|}
\hline Arquitetônico-axiomática & $\begin{array}{l}\text { Descrição e análise da estrutura lógica de teorias e modelos } \\
\text { como sistemas de axiomas e enunciados. }\end{array}$ \\
\hline Correlativa & $\begin{array}{l}\text { Estudo das relações entre teorias e das correlações entre } \\
\text { pontos de vista, no âmbito da linguística, e o contexto } \\
\text { sociocultural, político, institucional. }\end{array}$ \\
\hline
\end{tabular}

Fonte: Swiggers (2013, p.44-45)

\subsubsection{Dos conceitos da Historiografia Linguística utilizados nesta tese}

Feitas as considerações mais gerais quanto à HL, vejamos agora quais conceitos operatórios dessa disciplina foram por nós utilizados para levar a cabo os estudos propostos nessa tese. No entanto, para que se realize tal tarefa, é necessário que antes apresentemos nossa proposta de investigação, para que assim se compreenda melhor o motivo de requisitarmos os conceitos que aqui foram utilizados.

Em nossa pesquisa de mestrado (Vidal Neto, 2010), estudamos a Grammatica portugueza, de Júlio Ribeiro (1845-1890), publicada em 1881, quanto a dois aspectos: (i) os registros do Português do Brasil e (ii) as mudanças de ordem epistemológica promovidas na gramaticografia brasileira pelo autor. Para além dos objetivos da dissertação, a aproximação que tivemos com a produção gramaticográfica do final do século XIX e início do século XX, nos fez perceber algumas questões que ensejaram os estudos que ora realizamos.

Com efeito, ao analisar as gramáticas oitocentistas do final do século, nos parecia que uma de suas características formativas era a presença de reflexões teóricas mais aprofundadas, mais voltadas aos pares, aos especialistas. No entanto, ao olharmos para as gramáticas do início do século XX, não víamos tal aprofundamento. Víamos, sim, uma gramática que mais se aproximava dos manuais meramente escolares. Baseados nessa percepção intuitiva, propusemos o presente estudo, no qual objetivamos compreender para onde se deslocou a discussão linguística mais aprofundada que antes enxergávamos na gramática do final do século XIX.

Para que a HL possa lidar adequadamente com o tema da mudança, alguns modelos teóricos são utilizados para realizar as análises e fornecer as devidas explicações quanto a esse processo. Essencialmente, todos eles se dedicaram a compreender como, ao longo da história, há mudanças no processo de produção do conhecimento. 
Kuhn (1962) estuda o tema da mudança de modelos teóricos nas ciências físicas e naturais. Outros autores, como Koerner (1989) e Swiggers (2004), refletem sobre a mudança tendo como interesse principal os modelos teóricos que foram utilizados ao longo da história para se estudar a linguagem e as línguas.

O ponto de partida para compreender a proposta de Kuhn (1962) é o conceito que o autor desenvolve de paradigma: “Considero 'paradigmas' as realizações científicas universalmente reconhecidas que, durante algum tempo, fornecem problemas e soluções modelares para uma comunidade de praticantes de uma ciência” (KUHN, 1975[1962], p. 13).

Em sua obra, o autor propõe que as mudanças na história da ciência podem ser vistas a partir de quatro estágios, por ele assim classificados: pré-paradigmático, ciência normal, ciência extraordinária e revolução científica.

Quanto ao primeiro estágio, o pré-paradigmático, pode ser entendido como um período "regularmente marcado por debates frequentes e profundos a respeito de métodos, problemas e padrões de solução legítimos - embora esses debates sirvam mais para definir escolas do que para definir um acordo" (KUHN, 1975[1962], p.73). Dessa forma, tais debates entre propostas científicas conflitantes entre si ocorreriam até que uma delas fosse considerada, pelos membros de uma determinada área, como mais eficiente. Talvez a principal característica desse estágio seja justamente a disputa em torno da hegemonia dentro de um determinado campo.

Quando essa disputa é vencida por um determinado grupo, passamos ao segundo estágio, o de ciência normal ou paradigmático.

(...) "ciência normal" significa a pesquisa firmemente baseada em uma ou mais realizações científicas passadas. Essas realizações são reconhecidas durante algum tempo por alguma comunidade científica específica como proporcionando os fundamentos para sua prática posterior. (KUHN, 1975[1962], p.29)

Segundo Kuhn, os livros - "manuais científicos elementares e avançados" - exercem um importante papel nesse estágio de ciência normal. Eles representam uma espécie de repositório das práticas teórico-metodológicas exitosas de um determinado campo, servindo como referência tanto para pesquisadores que atuam em uma determinada época quanto a novos quadros que virão futuramente.

Embora raramente na sua forma original, hoje em dia essas realizações são relatadas pelos manuais científicos elementares e avançados. Tais livros expõem o corpo da teoria aceita, ilustram muitas (ou todas) as suas aplicações bem sucedidas e comparam essas aplicações com observações e experiências exemplares. Uma vez que tais livros se tornaram populares no começo do século XIX (e mesmo mais recentemente, como no caso das ciências amadurecidas há pouco), muitos dos 
clássicos famosos ${ }^{6}$ da ciência desempenham uma função similar. (KUHN, 1975[1962], p.29-30)

Outra característica importante desse período de ciência normal é o fato de que é nele que os pesquisadores resolvem problemas ou "quebra-cabeças" já previstos dentro do paradigma, seguindo às coerções por ele impostas. Nesse sentido, a resolução de "quebra-cabeças" serve para mostrar o quão eficiente determinado paradigma é, embora ele sempre esteja limitado às suas regras internas de atuação. Tal processo, apesar de restritivo ao cientista, permite que um determinado paradigma acumule uma quantidade de conhecimentos científicos bastante significativa dentro de seu campo de atuação. É, portanto, um processo de aperfeiçoamento e legitimação.

Em função desse caráter restritivo, o paradigma, durante o estágio de ciência normal, pode se ver diante de novos tipos de fenômenos aos quais ele não tem como oferecer solução. São vistos, então, como anômalos. Frente a essa anomalia, o paradigma pode se comportar de formas diferentes: (i) ou tenta solucioná-la por meio de adaptações de suas práticas, o que resultaria na alteração de status de anomalia para um problema que passa a ser considerado relevante para o paradigma. (ii) ou é possível também que o paradigma enxergue tal anomalia com algo irrelevante, não merecendo, assim, nenhuma ação interna. (iii) finalmente, se a anomalia não é vista como irrelevante e se o paradigma não consegue resolver esse "problema" - visto agora como relevante - com suas próprias práticas, isso pode gerar uma crise paradigmática ou uma fase de ciência extraordinária, nas palavras de Kuhn.

Esse terceiro estágio é, essencialmente, um momento de crise, de esgotamento dos valores e práticas adotados por um paradigma. O reconhecimento da anomalia como relevante e a impossibilidade de resolvê-la fragiliza o paradigma, sendo um sinal claro da passagem da ciência normal para a ciência extraordinária. Em outros termos, a solução de "quebra-cabeças", que antes era eficaz, passa a não ser mais possível. A partir desse cenário, os pesquisadores, que antes eram fiéis às práticas paradigmáticas, começam a buscar soluções diferentes daquelas que seriam adotadas no estágio de ciência normal. Esse processo, naturalmente, enfraquece o paradigma e o leva ao quarto estágio, que é a revolução científica.

6 "A Física de Aristóteles, o Almagesto de Ptolomeu, os Principia e a Óptica de Newton, a Eletricidade de Franklin, a Química de Lavoisier e a Geologia de Lyell - esses e muitos outros trabalhos serviram, por algum tempo, para definir implicitamente os problemas e métodos legítimos de um campo de pesquisa para as gerações posteriores de praticantes da ciência." (KUHN, 1975[1962], p.29-30) 
Esse último estágio é apresentado por Kuhn (1975[1962], p. 25, sublinhados nossos) da seguinte forma: "As revoluções científicas são os complementos desintegradores da tradição à qual a atividade normal está ligada".

A referida desintegração, iniciada na fase de ciência extraordinária, conta com um outro fator importante para produzir uma revolução científica: o convencimento de novas gerações de cientistas.

Quando, pela primeira vez no desenvolvimento de uma ciência da natureza, um indivíduo ou grupo produz uma síntese capaz de atrair a maioria dos praticantes de ciência da geração seguinte, as escolas mais antigas começam a desaparecer gradualmente. Seu desaparecimento é em parte causado pela conversão de seus adeptos ao novo paradigma. Mas sempre existem alguns que se aferram a uma ou outra das concepções mais antigas; são simplesmente excluídos da profissão e seus trabalhos são ignorados. (KUHN, 1975[1962], p.39, sublinhados nossos)

A revolução científica, portanto, alça à condição de paradigma esse novo modelo, que está, naturalmente, exposto ao mesmo processo que o levou a essa condição. A possibilidade de sucessivos paradigmas é que, segundo Kuhn, garantiria o desenvolvimento progressivo do conhecimento científico. É importante destacar aqui a visão do autor quanto a esses paradigmas sucessivos: para ele, são incomensuráveis, ou seja, não podem ser comparados e não há diálogo possível entre eles, já que o novo só se instaurou pela superação do outro. Nesse sentido, para Kuhn, o paradigma vigente de uma determinada ciência representa o que há de mais avançado e eficaz em relação aos seus conceitos e métodos.

Naturalmente, por esses estudos terem sido realizados no âmbito das ciências físicas e naturais, o modelo kuhninano encontra limitações explicativas quando aplicado às ciências humanas, incluindo, as ciências da linguagem. O principal óbice apresentado diz respeito à incomensurabilidade dos paradigmas, já que em tais ciências há sempre algum nível de aproveitamento entre diferentes paradigmas (cf., por exemplo, Percival (1976), a esse respeito).

Hymes (1983), dentre outros autores, é um dos que se dedicaram a apontar os problemas de se aplicar integralmente a proposta de Kuhn à história da linguística. Hymes (1983, p.362) critica o conceito kuhniano de paradigma, já que o uso desse termo, para ele, pressupõe afirmar que a ciência progrida linear e monodirecionalmente.

Muito em função dos problemas acima expostos, historiógrafos da linguística vêm propondo modelos que possam analisar a relação entre os diferentes modelos teóricos pelos quais a disciplina passou, sem, no entanto, cair nas limitações que a morfologia kuhniana apresenta para se analisar a história da linguística. Swiggers (2004) propõe que essa história possa ser estudada através de "programas de investigação", modelo que o autor traz Lakatos (1979), 
adaptando-o à HL. O autor destaca que pelas características que possuem os modelos teóricos, chamá-los apenas por seus nomes - modelo gerativo, por exemplo - seria algo um tanto restritivo. Segundo Swiggers (2004), é possível encontrar, na história da linguística, em diferentes teorias, aspectos em comum, como "concepção de língua e forma como ela se estrutura, unidades descritivas, técnicas de análise, etc”. Assim, modelos teóricos que compartilham tais concepções em comum formam os "programas de investigação". É importante destacar que esse imbricamento entre modelos diferentes - podendo ser, inclusive, de épocas diferentes - relativiza fortemente o conceito de "revolução científica", de Kuhn, já que dentro de um mesmo programa de investigação podem ser agrupados paradigmas diferentes, o que para Kuhn, como já dissemos, seria impossível, dada a incomensurabilidade entre os paradigmas.

(...) haciendo hincapié en las aproximaciones conceptuales que se pueden distinguir en la historia de la lingüística e insistiendo sobre el hecho que los modelos teóricos son cada uno una sistematización de ideas sobre el lenguaje, su estructura, las unidades descriptivas, las técnicas de análisis, etc., tenemos que preguntarnos cómo se pueden clasificar las diferentes aproximaciones más allá de los agrupamientos conocidos bajo el título "modelo X", "escuela Y". Me parece que para lograr una clasificación de mayor impacto teórico se puede hacer uso de la noción de "programa" en el sentido de "programa canalizador". (...) programa como un sistema conceptual que encauza aproximaciones que comparten la misma visión, la misma focalización, la misma "técnica" con respecto al objeto de estudio (en nuestro caso, el lenguaje). (SWIGGERS, 2004, p.129-130, sublinhados nossos)

Com efeito, tal proposta nos parece ser a mais adequada aos objetivos desta tese, uma vez que assim será possível captar as características dos três programas de investigação que, segundo nossa proposta de sistematização, formam a produção linguística brasileira sobre o Português no início do século XX: o gramatical, o filológico e o dialetológico.

Swiggers (1981, p.12, tradução e sublinhados nossos) assim define o que é um programa de investigação:

Um programa é um sistema cognitivo complexo que possibilita algumas operações e resultados particulares, excluindo outras possibilidades. Um programa inclui várias teorias que, apesar das diferenças técnicas e terminológicas, têm o mesmo conceito de como o objeto da disciplina deve ser investigado. Objeto e método são definidos intra-teoricamente; mas a unidade de um programa reside nas concepções semelhantes de como um determinado método deve "lidar" com o objeto de uma determinada disciplina.

Um programa, segundo o autor, pode ser caracterizado a partir de três parâmetros: “visão: ponto de vista global [sobre a língua]; incidência: contexto específico de inserção dos dados, ou ainda, qual nível a análise linguística privilegia? e técnica: a 'sintaxe' descritiva do programa, ou seja, os dados linguísticos são analisados de que forma?”. Swiggers (1987, p.2714, tradução nossa) 
Assim, a partir de parâmetros específicos, como os acima mencionados, é possível captar as mudanças dentro da história da linguística.

Com tal abordagem, foi possível compreender melhor a mudança de perfil que percebemos nas gramáticas publicadas entre o final do século XIX e início do XX. Assim, obtivemos melhores respostas às seguintes perguntas: $\mathrm{O}$ tipo de discussão mais aprofundada, mais especializada e potencialmente dirigida aos pares deslocou-se para outros tipos de produção sobre o Português? Caso positivo, para qual tipo/gênero de obra houve tal deslocamento? Ocorreram mudanças nas técnicas de análise linguística? E no tipo de dado linguístico a ser analisado, houve mudança quando desse pretenso deslocamento? Ainda, há mudança no conceito de língua quando essa discussão "sai” da gramática?

Ainda em relação aos programas de investigação, Swiggers (1987) propõe que a história dos estudos sobre a linguagem tenha se desdobrado essencialmente em torno de quatro programas, tendo como critério de classificação os três parâmetros acima apontados. Os programas são: o de correspondência, o descritivo, o sociocultural e o de projeção. Vejamos cada um deles:

1) Programa de correspondência: Swiggers (1987, p. 2714) diz que o objetivo desse programa é estabelecer uma correlação de língua-pensamento-realidade. Afirma que esse modelo tem uma concepção principalmente instrumentalista sobre a língua, ou seja, a língua é considerada como o instrumento do pensamento. O autor afirma que um refinamento e uma reinterpretação subversiva dessa concepção ocorreram no século XVII, momento em que se percebeu o papel crucial da língua na articulação do pensamento e na formação de ideias. Dadas suas características, esse programa não se limita à descrição da estrutura gramatical, mas também se volta aos processos estilísticos e retóricos. Swiggers, por fim, aponta as limitações do programa de correspondência: o pouco interesse na diversidade social e na dimensão histórica das línguas. Para o autor, os principais representantes desse programa são Platão, Aristóteles, os modistas, os gramáticos-filósofos dos séculos XVII e XVIII, Gustave Guillaume, Noam Chomsky (e seus discípulos).

Quanto aos parâmetros, Swiggers (1987, p. 2714) faz a seguinte esquematização: visão: correlação entre língua - pensamento - realidade; incidência: relações entre estruturas morfossintáticas e conteúdos ou processos mentais; técnica: semanticização de estruturas gramaticais (estabelecimento de classes lógico-semânticas: estabelecimento de correlações entre processos mentais e regras gramaticais). 
2) Programa descrivista ${ }^{7}$ : Swiggers (1987, p. 2714) diz que as línguas, nesse grupo, são consideradas conjuntos de dados formais que podem ser ordenados de forma sistemática. Destaca que a ideia básica do programa é que as formas linguísticas constituem um campo autônomo de pesquisa, baseado em um princípio de auto-operação e autossuficiência: o todo explica as partes e vice-versa. O autor aponta que, nesse programa, podem ser vistas duas orientações fundamentais: a "formalista" (voltada ao inventário e à estruturação de formas) e a "funcionalista" (que relaciona a estruturação formal às funções comunicativas). Swiggers destaca a longa tradição que tem esse programa na história da linguística, dando como exemplo Panini, gramáticos alexandrinos (e seus comentadores), gramáticos romanos e carolíngios e os do Renascimento, comparativistas do século XIX e do século XX, os estruturalistas (especialmente as teorias do tipo distributivo). Também faz parte desse programa a tradição secular das gramáticas escolares.

Quanto aos parâmetros, Swiggers (1987, p. 2715) faz a seguinte esquematização: visão: descrição das línguas como objetos; incidência: análise (segmentação/ oposição/combinação de formas observadas: comparação de formas de várias línguas (para fins contrastantes/para fins comparativos: reconstrução), função das formas; técnica: determinação de contextos; segmentação; comutação; estudo das relações de proporcionalidade entre elementos; estabelecimento de relações entre formas linguísticas e funções comunicativas.

3) Programa de sociocultural: Swiggers (1987, p. 2715) afirma que esse programa tem como objetivo estudar a língua como um fato social ou cultural. Dessa forma, destaca que estudiosos ligados a esse programa partem da ideia de que a língua é principalmente caracterizada por variação ou variabilidade (o que supõe uma competência "múltipla", sendo então a língua um sistema de sistemas). O autor aponta que essa variabilidade é mais frequentemente relacionada a fatores externos, daí uma descrição em termos de "variação diastrática", "variação diafásica" e "variação diasituacional" (vinculado a situações discursivas). Swiggers aponta como exemplos desse programa as tentativas de "planejamento linguístico", as discussões sobre o uso e as reflexões linguístico-filosóficas sobre a diversidade (social) das línguas (nos séculos XV, XVII e XVIII), a linguística (neo-) humboldtiana e a sociolinguística moderna.

Quanto aos parâmetros, Swiggers (1987, p. 2715) faz a seguinte esquematização: visão: a língua como fato social ou cultural; incidência: determinação de usos linguísticos; competência comunicativa; variação sociolinguística; a expressão de uma cultura através da língua; técnica:

\footnotetext{
${ }^{7}$ Não se relaciona ao descritivismo norte-americano. Agradeço à professora Cristina Altman por essa observação.
} 
integrativa ou sintética (inserção de fatos linguísticos em uma análise de sociedades ou culturas; inserção de análises linguísticas em uma teoria da estratificação social ou da evolução social e cultural).

4) Programa de projeção: Swiggers (1987, p. 2715) afirma que esse programa resulta de uma modelagem secundária, ou seja, é o resultado da transferência de um modelo desenvolvido pela lógica formal para a descrição de línguas naturais. O autor destaca ainda que esse programa de projeção analisa certas estruturas das línguas naturais considerando-as como estruturas lógicas, abarcando áreas que se prestam à descrição em termos de semântica intensional ou extensional. Swiggers aponta que esse programa negligencia a história e a diversidade social das línguas naturais e privilegia certos subsistemas gramaticais: tempos e modos verbais, procedimentos de determinação (nominais) e o estabelecimento de uma referência. Finalmente, diz que os trabalhos de Montague, Hintikka, Cresswell, Dowty e Partee são exemplos de alguns autores que podem ser enquadrados nesse programa.

Quanto aos parâmetros, Swiggers (1987, p. 2715) faz a seguinte esquematização: visão: línguas como conjuntos de estruturas lógicas (proposições); incidência: expressão de tempo, modalidade, determinação; técnica: tradução de estruturas linguísticas em linguagem formalizada.

É preciso ainda destacar uma questão importante quanto ao enquadramento de uma determinada teoria a um dos quatro programas. Segundo Altman (2004, p. 42), "uma teoria específica, ou um conjunto de trabalhos realizados no quadro de uma teoria específica, pode não esgotar, na sua totalidade, ou com igual intensidade, todas as propriedades preditivas de um programa”. A seguir apresenta um exemplo bastante elucidativo.

A teoria chomskiana, a título de exemplo, embora defenda o princípio da autonomia no estudo do sistema semântico-formal das línguas naturais, característica do programa classificado como descritivista, se enquadra melhor, quanto à visão global, incidência e técnica no programa de correspondência. Ou autores da tradição dialetológica que, embora se valham de critérios sociais e culturais para estratificar os sujeitos informantes das formas linguísticas que buscam mapear, tratam-nas como objetos autônomos de descrição, o que os enquadraria em um programa descritivista de investigação de forma mais adequada do que no programa sociocultural. (ALTMAN, 2004, p. 42)

Swiggers (1981, 1987, 2004), ao dizer que um programa de investigação é estruturado em torno de três parâmetros - visão, incidência e técnica - acaba por enfatizar sob quais aspectos pode ser analisada a história "interna" da linguística: (i) visão de língua e de linguística, (ii) 
natureza dos dados linguísticos e (iii) as técnicas utilizadas para esse trabalho. Respectivamente, tais aspectos são os parâmetros acima mencionados.

Apesar de Swiggers (1981, 1987, 2004), como apresentado anteriormente, dividir os programas de investigação em quatro tipos, nesta tese, faremos um uso ligeiramente diferente, porém mantendo a essência do conceito estabelecido pelo autor, ou seja, o fato de um programa ser um aglutinador de teorias que têm o mesmo conceito de como a linguagem deve ser estudada.

Dada as especificidades dos materiais presentes em nosso levantamento, enxergamos, tal como Altman (2004), a existência de três diferentes programas de investigação relacionados aos estudos linguísticos do Português nas primeiras décadas do século XX, no Brasil: o gramatical, o filológico e o dialetológico.

Optamos por tal distinção, pois há, nesses três programas, distinções bastante significativas quanto ao "conceito de como o objeto da disciplina deve ser investigado" (SWIGGERS, 1981, p.12) e nas concepções dissemelhantes "de como um determinado método deve 'lidar' com o objeto de uma determinada disciplina" (SWIGGERS, 1981, p.12), diferenças tais que serão apresentadas e desenvolvidas ao longos dos capítulo 2, 4 e 5.

Swiggers, no texto de 2004, além de retomar a discussão em torno dos programas, apresenta um modelo operatório para também captar mudanças específicas ocorridas ao longo da história da linguística. De modo análogo ao que propôs quanto aos programas, Swiggers (2004) sustenta - nesse modelo por ele classificado como de camadas do conhecimento linguístico - que a sucessão de modelos teóricos pelos quais a linguística passou se dá em função da discrepância entre os diferentes domínios (camadas) que constituem essas diferentes teorias.

Essas camadas também são definidas de forma semelhante aos parâmetros visão, incidência e técnica, ou seja, estão pautadas, respectivamente, pelo conceito de língua, pelo tipo de dados linguísticos e pelas técnicas utilizadas para esse trabalho.

La capa ${ }^{8}$ teórica corresponde a la visión global del lenguaje, a la concepción de las tareas y del estatutos de la lingüística; la capa técnica incluye las técnicas de análisis (lingǘstico/gramatical) y los métodos de presentación de los datos; la capa documental corresponde a la documentación lingüística y filológica (número de lenguas, tipos de fuentes y de datos) sobre la cual se basa el estudio lingüístico; la capa contextual e institucional (esta última se hace más importante a medida que nos acercamos a la época moderna) de la reflexión y de la práctica lingüísticas. (SWIGGERS, 2004, p.134, sublinhados nossos)

\footnotetext{
${ }^{8}$ Após discussões internas entre os membros do CEDOCH-USP e consulta ao professor Pierre Swiggers, chegou-se à conclusão de que o termo "camada" era a melhor tradução, em Português, para a palavra utilizada no original, em Espanhol.
} 
Metodologicamente, procedemos da seguinte forma: utilizamos o modelo das camadas do conhecimento linguístico para a análise das obras, buscando mudanças quanto (i) ao conceito de língua; (ii) ao trabalho com os dados linguísticos e (iii) às técnicas utilizadas na análise linguística. A partir desse trabalho, foi possível enquadrar as 581 obras de nosso levantamento nos três programas de investigação que anteriormente mencionamos, ou seja, o gramatical, o filológico e o dialetológico.

\subsection{Da metodologia e materiais de pesquisa}

\subsubsection{Da periodização e da construção do levantamento}

Com efeito, na seção anterior, expusemos a hipótese sobre a qual orientamos nossa pesquisa. Naquele momento, dissemos que ao analisar as gramáticas oitocentistas do final do século, nos parecia que uma de suas características formativas era a existência de reflexões teóricas mais aprofundadas, mais voltadas aos pares, aos especialistas. No entanto, ao olharmos para as gramáticas do início do século XX, não víamos tal aprofundamento. Víamos, sim, uma gramática que mais se aproximava dos manuais meramente escolares. Dado esse cenário, nosso questionamento foi no sentido de compreender para onde se deslocou a discussão linguística mais aprofundada que antes enxergávamos na gramática do final do século XIX.

Dessa forma, para poder analisar a relação entre a gramática e os demais tipos de produção sobre o Português, realizamos um levantamento bibliográfico de pretensão exaustiva que nos mostrou quais são essas outras publicações. A partir daí, foi possível estudar como estavam estabelecidas as relações (de força) entre os diferentes tipos de obras que se dedicaram a estudar o Português no início do século XX.

Blikstein (1976, p. 4, itálicos do autor), em texto comemorativo dos cem anos de Linguística no Brasil, ao historiá-la, aponta para um cenário e para autores que nos ajudaram na definição do recorte temporal proposto para nossa pesquisa: "Estas datas ${ }^{9}$ dividem a linguística

\footnotetext{
${ }^{9}$ Criação da Faculdade de Filosofia, Ciências e Letras da USP, em 1934, e da Faculdade de Filosofia e Letras da Universidade do Distrito Federal, em 1935 (RJ).
} 
brasileira em dois períodos, grosso modo: $1^{\circ}$ ) período de autodidatismo, da segunda metade do século XIX até $1934 ; 2^{\circ}$ ) período de estudos superiores sistematizados, de 1934 em diante.”

\begin{abstract}
Estes períodos admitem subdivisões; assim, o período de autodidatismo apresenta uma $1^{\text {a }}$ etapa em que os estudiosos elaboravam gramáticas do português, inspirados na leitura de romanistas e indo-europeístas (Diez, Bréal, Whitney, Max Muller), como é o caso de Júlio Ribeiro ao publicar sua Gramática Portuguesa, em 1881. (...) numa $2^{\mathrm{a}}$ etapa, essa linguística embrionária dá lugar a uma teorização mais independente e original de uma geração de filólogos que se destacam pelo espírito antinormativo que imprimiram aos estudos de língua portuguesa, já agora sob influência direta dos comparatistas e indo-europeístas; mas, todos eles graças a um esforço de orientação pessoal: João Ribeiro, Said Ali, Sousa da Silveira, Antenor Nascentes, Augusto Magne, Otoniel Mota, Américo de Moura, Sílvio de Almeida e outros. Esta $2^{\mathrm{a}}$ etapa vai, nas suas grandes linhas, de 1900 até 1934-39 (data da criação das faculdades de Filosofia). (BLIKSTEIN, 1976, p. 4, sublinhados nossos)
\end{abstract}

É justamente essa segunda etapa do primeiro período, ou seja, de 1900 a 1940, que utilizamos como balizamento temporal. Além desse critério, a seleção de obras foi feita seguindo mais três parâmetros:

- Tratarem especificamente do Português;

- Escritas por brasileiros;

- Só livros, não periódicos ou demais tipos de publicação.

Quanto ao último aspecto, justifica-se na medida em que julgamos necessário estudar e comparar obras que tiveram tratamento editorial semelhante ao dispensado às gramáticas.

A realização desse levantamento bibliográfico de pretensão exaustiva realizou-se da seguinte forma:

$1^{a}$ etapa: nesse primeiro momento, o levantamento de autores e obras foi feito a partir das menções a eles em trabalhos de cunho histórico e historiográfico. Recorremos aos estudos de Nascentes (1939), Figueiredo (1957), Hampejs (1961), Elia (1975), Morel Pinto (1976), Câmara Jr. (1972; 1976), Guimarães (1996), Coelho (1998), Azevedo Filho (2002), Cavaliere (2002), Penha (2002); Polachini (2013; 2017) e ao Dicionário biobibliográfico da Academia Brasileira de Filologia ${ }^{10}$ (2012).

$2^{\mathbf{a}}$ etapa: Feitos os registros de autores e obras presentes nos trabalhos acima, criamos outras estratégias com vistas à necessária ampliação das fontes. A primeira, que se mostrou

\footnotetext{
${ }^{10}$ Apesar deste dicionário ainda se encontrar, como nos informa seu frontispício, em "versão preliminar, sem revisão dos autores", julgamos ser este um material importante, principalmente em função da escassez de informações sobre boa parte dos filólogos brasileiros. A obra, editada pela Academia Brasileira de Filologia (ABL), enfeixa 174 verbetes de filólogos de diferentes épocas e perfis.
} 
bastante efetiva, foi a pesquisa em acervos on-line de bibliotecas públicas e universitárias e também a consulta a acervos de sites de venda de livros ${ }^{11}$. Quando o acesso físico às obras foi possível, pudemos adotar uma outra medida para a ampliação dos dados, que foi a consulta à relação de obras que muitos livros apresentam na quarta capa ou no próprio interior do volume. Normalmente, essas relações registram publicações do catálogo da editora - sendo, nesse caso, uma ótima maneira de conhecer autores "novos" - ou mesmo uma lista completa com as "obras do autor".

As obras foram classificadas e divididas em função de seus programas de investigação, ou seja, no caso desta tese, o gramatical, o filológico e o dialetológico. Chegamos aos seguintes números:

Tabela 1 - Quantitativo geral da produção linguística sobre o Português: 1900 -1940

\begin{tabular}{|c|c|c|}
\hline Obras gramaticais & Obras filológicas & Obras dialetológicas \\
\hline 400 & 89 & 62 \\
\hline 173 autores & 56 autores & 63 autores \\
\hline \multicolumn{3}{r}{ Total geral de autores: $\mathbf{2 9 2}$} \\
\hline \multicolumn{3}{c}{ Total geral de obras: $\mathbf{5 8 1}$} \\
\hline
\end{tabular}

Para que pudéssemos identificar, nessas obras, características específicas de cada programa de investigação, foi necessária a consulta física a uma parte considerável dos livros encontrados nos bancos de dados. Utilizamos os seguintes critérios para a classificação das obras:

1) Obras gramaticais: presença de viés normativo (cf. seção 2.2);

2) Obras filológicas: ausência de normatividade e o apelo ao trabalho histórico com a língua;

3) Obras dialetológicas: obras que estudam (i) a dialetação interna do Português do Brasil, tanto abordando a variação geográfica quanto a social e (ii) a diversificação do Português do Brasil em relação ao de Portugal.

\footnotetext{
${ }^{11}$ Quanto às bibliotecas, consultamos principalmente os acervos de universidades com USP, Unicamp, Unesp e UnB. Também pesquisamos em instituições como a Biblioteca Nacional e na rede de bibliotecas da Prefeitura de São Paulo. No que diz respeito aos sites de venda de livros, consultamos portais como o Estante Virtual e Mercado Livre, por exemplo. Quando necessário, fizemos pesquisas complementares em outros sites e plataformas congêneres.
} 
Assim, das 581 obras presentes em nosso levantamento, consultamos e analisamos 366 obras. Incluímos as 215 não consultadas, pois, mesmo sem o contato físico, pudemos nos assegurar que atendiam aos critérios acima apontados. Esse processo foi possível apenas nas situações em que, apenas pelo título, a classificação se tornava óbvia. Por exemplo, não localizamos Lições de grammatica historica: de acordo com o Programma do Collegio Pedro II, de A. de Lara Resende (?-?) em nenhuma biblioteca ou sebo, porém, em função de seu título e subtítulo, não restam dúvidas a respeito de seu enquadramento, a saber, "obras filológicas" > "gramáticas históricas".

No entanto, uma das principais características investigadas, o viés normativo, só pôde ser verificado com a obra em mãos. Dessa forma, tivemos que deixar de fora do levantamento alguns livros que encontramos em catálogos, porém não localizamos em nenhuma biblioteca ou sebo.

O conjunto de obras pertencentes a cada programa de investigação foi por nós subdividido segundo suas especificidades, para que assim chegássemos a categorias que pudessem melhor captar as diferentes nuances da produção linguística brasileira do início dos novecentos. Todos esses dados foram organizados em tabelas com a estrutura que abaixo reproduzimos e estão integralmente reproduzidas no final desta tese, no Anexo 1.

Figura 2 - Classificação das obras dentro de cada programa de investigação

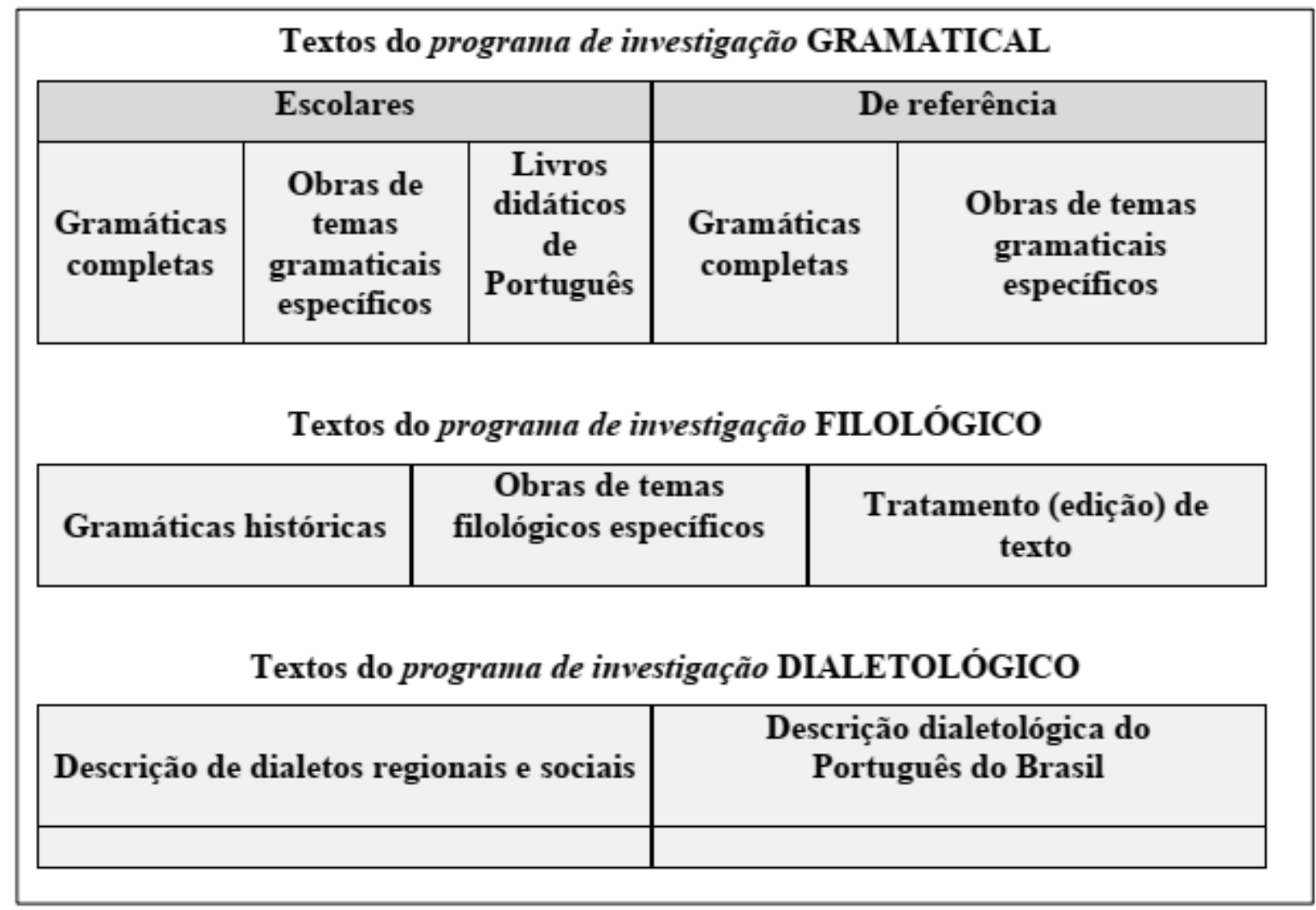


Os critérios específicos que utilizamos para a formação de cada subgrupo estão apresentados no início de cada seção, ao longo dos capítulos da tese.

\subsubsection{Critérios e procedimentos de análise}

Novamente, para que pudéssemos analisar a relação entre a gramática e os demais tipos de produção sobre o Português, verificando assim a validade de nossa hipótese a respeito do deslocamento da discussão especializada da gramática para outros gêneros de textos, estruturamos a análise dos dados em dois movimentos: (i) dentro de cada programa de investigação, o de sistematização e análise do conjunto das obras quanto às suas principais características, como: temas privilegiados, técnicas de análise linguística, tipo de dado de língua estudado, entre outros aspectos que se mostraram relevantes e (ii) análise de como cada programa de investigação pode ser caracterizado quanto às camadas do conhecimento linguístico (Swiggers, 2004). É importante destacar que nos interessou uma análise relativamente ao programa como um todo, para que assim conseguíssemos chegar às características principais de cada programa quanto às camadas. Dito de outra forma, optamos por essa metodologia para que pudéssemos assim responder a perguntas como: "Qual técnica de análise linguística predomina entre as obras dialetológicas?”; “Qual conceito de língua predomina entre as obras gramaticais?”; “Qual tipo de dado linguístico predomina entre as obras filológicas?”, entre outras perguntas congêneres.

A busca dos eixos estruturantes de cada programa de investigação quanto às camadas, justifica o fato de não termos selecionado obras em específico (ou mesmo um conjunto de obras) para uma análise verticalizada. Se assim fizéssemos, chegaríamos a resultados mais restritos e específicos da produção linguística brasileira realizada dentro daquele programa, o que para nós seria limitado, já que nos interessou um retrato mais amplo da atuação dos programas frente aos outros.

Nessa análise que faremos das camadas, observamos aspectos como:

- Camada teórica: verificamos quais são os conceitos predominantes nas obras que formam cada programa quanto à visão de linguagem sustentada pelas teorias e práticas linguísticas. Também à concepção relativa a quais tarefas as "disciplinas que estudam a língua (gramática, filologia, dialetologia)" devem se dedicar. 
- Camada técnica: verificamos como os três programas de investigação se comportam quanto à forma de análise e à condução do trabalho com os dados linguísticos.

- Camada documental: analisamos o tipo de documentação linguística que serve de base para os diferentes programas. Assim, verificamos, por exemplo, se as obras se utilizam de corpus literário, dados da oralidade, etc.

- Camada contextual: estudamos aspectos do contexto intelectual e histórico do início do século XX, período de publicação das obras analisadas. Notadamente, nos debruçamos nos aspectos relativos à educação brasileira (legislação, programas de ensino, reformas educacionais, etc) que impactaram, de alguma forma, as publicações sobre o Português. 


\section{O programa de investigação gramatical: as obras gramaticais escolares sobre o Português}

Ao analisarmos os resultados a que chegamos em nosso levantamento ${ }^{12}$, pudemos perceber algumas especificidades presentes nas 400 obras incluídas no programa gramatical. A característica mais evidente é quanto à destinação desses materiais, ou seja, se eles são de uso escolar ou não. Conseguimos localizar 239 obras de viés escolar e 161 de cunho não escolar. Dessa forma, esse aspecto quantitativo já aponta para uma importante característica do programa gramatical nas décadas iniciais do século XX: a divisão entre as obras escolares e as que não tinham como destino a escola, que, nesta tese, chamaremos de obras de referência.

Apesar dessa divisão, é importante dizer que todas elas são caudatárias ao que se convencionou chamar de gramática tradicional ou gramática greco-latina. Tal vínculo faz com que uma série de características em comum apareçam em todas as obras do programa de investigação gramatical, sejam elas escolares ou não.

Em função do cenário acima apresentado, antes de iniciarmos uma análise das características específicas dos textos do início do século XX, faremos algumas considerações a respeito dessa longa tradição gramatical, que teve sua origem na Antiguidade Clássica e, ainda hoje, se mostra bastante presente em textos de cunho gramatical. Na sequência, analisaremos os materiais específicos desta tese, primeiro os de viés escolar, neste capítulo 2, e depois, no capítulo seguinte, aqueles que classificamos como de referência.

12 Nesta tese, objetivando maior concisão, iremos utilizar apenas o termo (nosso) levantamento sempre que nos referirmos à pesquisa bibliográfica, de pretensão exaustiva, que realizamos acerca da produção linguística brasileira dos anos de 1900 a 1940 sobre o Português. Tal levantamento pode ser consultado no apêndice A. 


\subsection{Considerações gerais sobre o programa de investigação gramatical}

Borges Neto (2018, p.17, sublinhados nossos), em sua História da gramática, nos apresenta um panorama bastante claro e sintético do que se pode entender quando se faz referência à gramática tradicional. Segundo o autor

Chama-se de gramática tradicional um tipo de estudo que tem origem nas reflexões
filosóficas dirigidas às manifestações linguísticas pelos filósofos gregos. Por meio
dessas reflexões filosóficas, foi se desenvolvendo ao longo do tempo um conjunto
de noções e de uma terminologia correspondente que, por volta do início do século
I a.C., resultou numa forma de "manual técnico" - a Téchnē grammatiké - que
tratava de aspectos das manifestações linguísticas e que se destinava, basicamente,
a um uso escolar. Essas Téchnai foram reproduzidas pelos romanos - com o nome
de artes grammaticae - e posteriormente, já na Idade Média, passaram a ser
chamadas simplesmente de gramáticas.

Alguns aspectos mencionados por Borges Neto ao se referir à gramática tradicional, como "conjunto de noções e de uma terminologia correspondente", " "manual técnico" e "uso escolar" são pontos importantes para compreendermos o programa de investigação gramatical e sua perenidade, característica que apontamos anteriormente. Dessa forma, retomaremos tais aspectos quando analisarmos as obras de nosso levantamento, mostrando assim a conexão dessas obras com a tradição gramatical, o que sublinha sua relação de continuidade. Por outro lado, buscaremos destacar aspectos de descontinuidade com a tradição, o que nos levaria, portanto, a características específicas da produção gramatical das décadas iniciais do século XX.

Ainda destacando a permanência do modelo greco-latino no decorrer dos séculos, Borges Neto (2018, p.18, itálicos do autor) diz que

As artes grammaticae latinas foram a base das gramáticas das línguas vernáculas,
que as seguiram - tanto quanto possível - tanto na forma e no conteúdo, quanto na
destinação pedagógica. Esse modelo de gramática, que vem dos gregos e dos latinos
e que se espalha por toda a Europa a partir do século XVI, é seguido ainda hoje por
nossas gramáticas escolares. É a esse modelo de gramática que vamos designar de
gramática tradicional (ou, às vezes, de gramática greco-latina).

É necessário ainda fazer algumas considerações a respeito da gramática tradicional, principalmente no sentido de sublinhar seus laços de continuidade, isto é, sua permanência da Antiguidade Clássica até as décadas iniciais do século XX, período ora em exame nesta tese. Como já mencionamos na seção de metodologia, para realizar as análises das obras presentes nos três programa de investigação (gramatical, filológico e dialetológico), utilizaremos a proposta das camadas do conhecimento linguístico (SWIGGERS, 2004). 
Neste momento, mesmo não realizando análises de nenhuma obra especificamente, as considerações que faremos a seguir serão estruturadas seguindo esse modelo de Swiggers (2004), já que isso possibilita a comparação do que falaremos a respeito da tradição gramatical clássica com as análises que serão feitas, nos próximos capítulos, sobre as obras do início do século XX.

\subsubsection{Camada teórica}

O estudo e a devida compreensão da camada teórica de uma obra são de fundamental importância, já que é através dela que se pode saber qual é a visão de língua/linguagem que tal obra sustenta. Como veremos mais à frente, tal visão, muitas vezes, acaba por orientar quais serão as opções do autor quanto às demais camadas, a saber, a técnica e a documental.

Recorrer à Téchnē grammatiké, de Dionísio Trácio, como texto fundante do que hoje chamamos de gramática tradicional parece ser consenso entre vários pesquisadores que se dedicaram a esse assunto, como Neves (2005), Leite (2007), Chapanski (2003), Borges Neto (2018), entre outros.

Com efeito, uma forma de se iniciar uma investigação a respeito da camada teórica de uma determinada gramática é verificar como o autor a define. Embora muitos gramáticos não explicitem tal definição em seus textos ou mesmo não sendo essa a única maneira de se estudar a camada teórica, recorrer às definições é extremamente útil, pois elas servem como verdadeiras "cartas de intenção" - nem que seja no campo da retórica do autor (MURRAY, 1994) fornecendo, assim, importantes pistas de como esse autor pensa a disciplina gramatical.

Parece-nos relevante, portanto, verificar como o texto fundamente da tradição gramatical definiu gramática. Em sua dissertação de mestrado, Chapanski (2003, p.21) realizou a tradução para o Português da Téchnē grammatiké, bem como estudos e comentários ao texto. É dessa tradução que extraímos a definição de gramática dada por Dionísio Trácio, que assim a enuncia: "o conhecimento empírico do comumente dito <nas obras> dos poetas e prosadores". Ainda Chapanski (2003, p.68, sublinhados nossos), ao comentar essa definição, diz que

Quanto ao conteúdo dessa definição, cabe notar que ela não trata do manual de gramática, nem do exercício de organização de que, em muito, ele consiste. É a "grande" gramática que está em questão, aquela que é o conhecimento das obras mais importantes na Literatura, dos artifícios de linguagem nelas empregados e também dos conteúdos que expressam. 
Ao analisarmos essa que é a mais antiga definição de gramática (ROBIN ${ }^{13}$, 1966, p.5 apud CHAPANSKI, 1996, p.68), não podemos deixar de notar a referência feita à Literatura. Como mostraremos ao longo desta tese, o uso de textos literários, na camada documental, como índice abonador do bom uso é algo muito frequente nos três programas, principalmente nas obras do programa gramatical. Dessa forma, é correto afirmar que tal relação representa, para a gramática tradicional, uma marca identitária, já que presente em sua gênese. Dito de outra forma, a imbricação entre gramática e textos literários que se observa nos textos gramaticais presentes em nosso levantamento marca uma forte relação desse material novecentista com a tradição gramatical clássica. Ainda nos comentários à Téchnē grammatiké, Chapanski (2003, p.69, sublinhados nossos) explica como devemos entender, modernamente, o conteúdo da definição presente nessa gramática.

Trata-se de uma definição que, a princípio pode suscitar algum estranhamento se confrontada com os assuntos encontrados na obra de Dionísio Trácio: enquanto a abordagem da leitura, por exemplo, soa condizente com o propósito dessa definição, a observação das partes da frase pode parecer alheia a ele. Nesse sentido, vale lembrar que, na gramática antiga, os dados que hoje seriam comumente considerados tipicamente gramaticais convivem com aqueles que a atualidade remeteria à crítica textual ou mesmo à literatura. Nada tão estranho, se se pensar que uma tradução imediata do termo grammatikê 'gramática' seria algo próximo de 'estudo das letras'. E claramente se entendem, de modo geral, como âmbitos de atuação das atuais Letras a literatura, como a linguagem de modo geral $(\mathrm{O}$ paralelo aí proposto não é, obviamente, absoluto e preciso, e não visa a sobrepor ideias pertencentes a épocas radicalmente distintas, mas talvez seja válido para a compreensão do conceito de gramática na Antiguidade.)

Com efeito, apontar a forte relação entre a gramática tradicional e a literatura desde a Antiguidade Clássica é importante, pois releva qual é a visão de língua que está subjacente a esse programa de investigação, ou seja, como pode ser caracterizada sua camada teórica. Neves (2002, p. 49, sublinhados nossos), ao falar sobre a gênese da gramática entre os gregos, explicita qual era a função que os textos literários ali desempenhavam.

A disciplina gramatical aparece na época helenística, que se diferencia da época helênica tanto na organização política e social, como no modo de vida e na cultura. Nessa época o que se procura é, acima de tudo, transmitir o patrimônio literário grego, privilegiando-se, como atividade cultural, o exame das grandes obras do passado. O objetivo de tal atividade é oferecer os padrões da linguagem dessas obras consideradas excelentes, padrões que contrastam com os da linguagem corrente, contaminada de barbarismos. Tal esforço de divulgação do helenismo impulsiona o desenvolvimento dos conhecimentos linguísticos, já que implica o levantamento de fatos que, nos textos não corrompidos, caracterizam a língua modelar que deve ser preservada. É, pois, para servir à interpretação e à crítica que se compõe o que se vai qualificar como gramática. Trata-se de um estudo que, pelas condições de

\footnotetext{
${ }^{13}$ ROBIN, R. H. The development of the word class system of the european grammatical tradition. Foudation of language. V.2, 1966.
} 
seu surgimento, se limita à língua escrita, especialmente a do passado, mais especificamente à língua literária e, mais especificamente, ainda, à grega. O próprio termo grammatiké - a arte de ler e escrever -, usado para dar nome ao estudo da língua, tem sido invocado para evidenciar a atenção precípua dada à forma escrita da língua.

Como pode ser visto nas considerações de Neves, o papel da literatura na gênese da gramática tradicional era justamente o de transmitir e assim preservar as características de uma determinada variedade da língua, aquela considerada "excelente", "não corrompida", encontrada no "patrimônio literário grego do passado". Dessa forma, a gramática desempenhava um papel de proteção desse patrimônio linguístico considerado modelar, pois era responsável por servir de "remédio" à linguagem corrente, contaminada de barbarismos". Tais valores e procedimentos apontam de maneira inequívoca qual era a visão de língua ali presente - ou, em outros termos, a camada teórica.

É correto dizer que essa visão de língua permanecerá ativa durante muitos séculos, uma vez que a encontramos nas obras gramaticais presentes em nosso levantamento. Mais à frente, analisaremos com mais vagar essa questão.

\subsubsection{Camada documental}

Como pudemos ver no item anterior, a gramática tradicional, desde sua origem, utilizouse fundamentalmente de textos literários antigos para apontar qual era o modelo de língua a ser seguido por aqueles que desejassem se expressar "corretamente". Em muitas gramáticas, os exemplos utilizados não vinham com a indicação da fonte, processo ao qual se convencionou chamar de "exemplos forjados". Nesses casos, era o gramático quem elaborava as frases ou os trechos que serviam de comprovação para o que a teoria gramatical prescrevia. Ou seja, em vez de o gramático procurar em obras literárias canônicas exemplos que abonassem aquilo que ele estava prescrevendo como correto na parte teórica de seu texto, ele mesmo se encarregava de elaborar seu exemplário.

Dessa forma, podemos dizer que a opção pelos textos literários canônicos constitui, fundamentalmente, a camada documental do programa de investigação gramatical. 


\subsubsection{Camada técnica}

Entendida por Swiggers (2004, p.134) como "as técnicas de análise (linguístico/gramatical) e os métodos de apresentação dos dados”, vejamos agora as principais características da Téchnē grammatiké quanto à camada técnica. É importante lembrar novamente que a opção por utilizar a gramática de Dionísio Trácio (170 a.C. - 90 a.C.), como forma de caracterizar, em termos gerais, o programa gramatical, deve-se ao fato de ele representar o texto fundante dessa tradição, bem como apresentar características que permaneceram ativas até o século XX. A ausência da sintaxe na obra de Dionísio fez com que usássemos também como referência os estudos de Apolônio Díscolo (viveu na primeira metade do século II d.C.), já que ele é considerado o responsável por introduzir a sintaxe nos estudos gramaticais.

Investigar a camada técnica de uma gramática tradicional significa olhar para aspectos que evidenciem as técnicas por ela aplicadas para realizar as análises a que se propõe. Nesse sentido, podemos dizer que a forma utilizada pela gramática para segmentar e então analisar a língua é um aspecto a ser considerado na camada técnica. Em termos práticos, vemos tal processo, por exemplo, na divisão do estudo gramatical em fonologia, morfologia e sintaxe (ou termos congêneres). Ainda nesse contexto, nos estudos da palavra, isto é, da morfologia, o fato de a análise ser estruturada em classes de palavras, antes de ser algo naturalizado (Borges Neto, 2013; 2018), é, com efeito, uma técnica vinda da tradição gramatical grega ${ }^{14}$, como pode ser visto no texto de Dionísio Trácio.

[antes vem a definição de gramática já apresentada nesta tese] Suas partes são seis: 1. a primeira é a leitura treinada, que respeite a prosódia; 2 . a segunda é a exegese dos tropos poéticos existentes; 3 . a terceira é a pronta restituição do sentido das palavras estranhas e das estórias; 4. a quarta é a descoberta da etimologia; 5. a quinta, o cálculo da analogia; 6 . a sexta é a crítica dos poemas, que é a mais bela das partes da arte. (CHAPANSKI, 2003, p.21)

Como é possível observar, Dionísio - ao falar em "prosódia”, “exegese dos tropos", "sentido das palavras estranhas", "descoberta de etimologia" e o "o cálculo da analogia15" -

\footnotetext{
${ }^{14}$ Considerarmos que há adjetivos, pronomes e artigos nas línguas é resultado inequívoco de uma determinada visada sobre os fenômenos. Essas “decisões” não são necessárias e a adoção de uma ou de outra proposta está ligada a modos particulares de conceber, teoricamente, o funcionamento do objeto. Naturalizar uma teoria é abrir mão de possibilidades outras de construir o objeto teórico. (BORGES NETO, 2013, p.6)

15 “[...] o trabalho aí sugerido pela expressão analogias eklogismos implica, ainda que metaforicamente a noção de cálculo: não se trata simplesmente de um exercício de encaixe de palavras em paradigmas pré-estabelecidos ou de elaboração de conjuntos através de critérios determinados, cabe também à gramática o processo de elaboração desses paradigmas." (CHAPANSKI, 2003, p.43)
} 
mostra o quanto a unidade palavra é central em sua gramática, tanto nos aspectos fônicos quanto nos morfológicos. Ainda Chapanski (2003, p.74), em seus comentários ao texto gramatical, reforça justamente esse aspecto.

De maneira geral, as partes da gramática dionisianas denotarão um claro centramento na palavra. Esta é a unidade sobre a qual trabalham exclusivamente etimologia, a exegese das palavras estranhas, a analogia e mesmo a descoberta dos tropos poéticos. A própria leitura funda-se em grande parte sobre a boa pronúncia dos acentos da palavra e da própria palavra. Só a crítica dos poemas e o resgate das histórias conseguem escapar totalmente à regra.

Outra importante estudiosa da gramática grega, Neves (2013, p.53, sublinhados nossos) também destaca a prevalência da palavra no texto dionisiano e acrescenta que

A classificação de Dionísio o Trácio das partes do discurso representa a tradição da escola de Aristarco, a escola de Alexandria. É um esquema bastante semelhante ao das nossas gramáticas, separando, porém, o particípio da classe dos verbos, o que não ocorria na classificação dos estoicos. Ainda em contraposição aos estoicos, a classe das conjunções vem desdobrada em conjunções e preposições, e a classe dos artigos e pronomes, embora os pronomes relativos se mantenham na classe dos artigos. São apontados como partes do discurso: 1 . o nome; 2 . o verbo; 3 . o particípio; 4. o artigo; 5. o pronome; 6. a preposição; 7. o advérbio; 8. a conjunção.

Com efeito, é necessário sublinhar a perenidade da divisão das partes do discurso utilizada por Dionísio. O fato de ainda encontrarmos essa divisão nas gramáticas tradicionais dos séculos XX e XXI, mostra que o modelo greco-latino de gramática não permanece ativo somente nos aspectos ligados às camadas teórica e documental, mas também naquilo relacionado à camada técnica.

Outra característica relativa à camada técnica do programa gramatical é o estudo da morfologia segundo o modelo "palavra-e-paradigma", classificação proposta por Charles Hockett, em 1954. Relativamente a esse modelo, nos valeremos de uma sintética explicação feita por Borges Neto (2013, p.3).

Tradicionalmente (desde Dionísio de Trácia, no séc. I a.C.), são reconhecidas "marcas" de gênero e de número nos elementos nominais (substantivos e adjetivos, pronomes e artigos) e "marcas" de tempo/modo, número e pessoa nos elementos verbais. Palavras que pertencem às classes dos advérbios, preposições e conjunções são ditas invariáveis porque seu paradigma apresenta um único elemento. As demais classes contêm palavras variáveis, isto é, palavras cujo paradigma apresenta ao menos dois elementos. As noções de flexão e derivação [por exemplo] surgem naturalmente no contexto do modelo morfológico "palavra-e-paradigma". A flexão é interna ao paradigma e a derivação é externa. A flexão indica as modificações secundárias (acidentes) sofridas pela ideia veiculada pela palavra e a derivação é o processo de obter palavras novas a partir de outras palavras ("ideias" novas a partir de outras "ideias").

Como já dissemos, não há sintaxe na Téchnē grammatiké. É com Apolônio Díscolo que esse tipo de estudo começará a ser considerado no interior da disciplina gramatical. 
Apolônio Díscolo merece um lugar especial na história das ideias gramaticais. Dentro do quadro da instituição da disciplina gramatical no Ocidente, ele representa o marco da consideração da sintaxe como ponto central da análise linguística, consideração que se baseia na "afirmação constante da regularidade existente na união dos elementos (Neves, 1987, p. 129 ${ }^{16}$ ). (NEVES, 1993, p.69)

É justamente quanto à “regularidade existente na união dos elementos" acima mencionada por Neves que parece residir a principal inovação dos trabalhos de Apolônio. "Não mais se empreende o isolamento dos elementos ("das partes da oração") como fizera Dionísio o Trácio (Uhlig, $1883^{17}$ ), mas o que se busca é a sintaxe, o relacionamento dos elementos". (NEVES, 1993, p.69)

Ao não mais considerar os elementos da oração isoladamente, Apolônio irá analisar as funções que cada elemento isolado exerce sobre os demais.

Pelas próprias necessidades que condicionaram sua tarefa, ela [a gramática alexandrina incipiente] se preocupou basicamente com a classificação e a sistematização das formas, não com a análise das funções. E onde está a sintaxe para Apolônio Díscolo? Ele abre o seu livro Da sintaxe afirmando que a exposição compreenderá a construção (sýntaxis) das palavras, feita em vistas à congruência (katallelótes) da oração perfeita (I, 1). A sintaxe, na verdade, abarca todos os níveis, constituindo o conjunto de regras que regem a síntese dos elementos, sob o princípio básico de que a língua é uma série de elementos relacionados. Entretanto, é a oração completa (o autotelès lógos), que é o domínio da sintaxe, porque nela existe a congruência ou coerência, obtida apenas quando nome e verbo se juntam. (NEVES, 1993, p.69-70, sublinhados nossos)

Devemos destacar também o que diz Beccari (2007, p. 20) sobre Apolônio: “(...) [ele] postula um mesmo processo combinatório em todos os níveis de organização de uma língua (letras que se combinam e formam sílabas, sílabas que formam palavras, palavras que formam frases)". Esses níveis seriam o da "letra-fonema", o "morfológico" e o "sintático", que devem estar regidos pela mesma lógica, pelo mesmo processo combinatório, para que uma frase tenha a congruência (katallelótes) da oração perfeita. ${ }^{18}$

Com efeito, mesmo depois da ampliação dos estudos sintáticos, ocorrida a partir da obra de Apolônio Díscolo, a preponderância do estudo da palavra na gramática tradicional não será eliminada, já que a sintaxe, nesse modelo, é concebida como uma expansão da palavra. Vejamos como Borges Neto (2012, p.89) apresenta essa ideia.

A GT [gramática tradicional] assume que a palavra é a unidade de análise (nada há abaixo da palavra) e que a oração (sentença, proposição, frase, a depender do autor) é uma construção de palavras. Na oração, as palavras recebem certa ordenação (sintaxe) para que a oração consiga exprimir um pensamento completo e cada

\footnotetext{
${ }^{16}$ NEVES, Maria Helena de Moura. A vertente grega da gramática tradicional. 1. ed., São Paulo: Hucitec/ Editora da UnB/Fapesp, 1987.

${ }^{17}$ UHLIG, G. Dyonisii Thracis Ars Grammatica. Leipzig: Teubner, 1883.

${ }^{18}$ Agradeço ao Alessandro Beccari pela conversa bastante elucidativa sobre Apolônio Díscolo.
} 
palavra - na medida em que representa uma ideia - contribui, na oração, para que esse pensamento seja obtido. Cabe à sintaxe, então, mostrar como as ideias contidas nas palavras devem ser ordenadas para que se chegue ao pensamento veiculado pela oração.

Feitas as considerações mais gerais a respeito do programa de investigação gramatical, apresentaremos, na próxima seção, uma discussão a respeito da normatividade, principal critério que adotamos, nesta tese, para a inclusão das obras neste programa de investigação.

\subsection{A respeito da normatividade em obras metalinguísticas}

Eugênio Coseriu (1921-2002) é um dos precursores dos estudos relacionados à norma linguística ${ }^{19}$. Tal conceito surge, em sua obra, com o objetivo de ampliar a discussão em torno da dicotomia saussuriana língua e fala. Para o autor, a norma é uma espécie de "filtro social" mediando o uso individual ( fala) frente ao sistema (língua), o que resulta em um sistema tripartite língua, norma e fala. Vejamos como Coseriu (1979, p. 69, sublinhados nossos) concebe a norma linguística:

Esclarecemos, ademais, que não se trata da norma no sentido corrente, estabelecida ou imposta segundo critérios de correção e de valoração subjetiva do expressado, mas sim da norma objetivamente comprovável numa língua, a norma que seguimos necessariamente por sermos membros duma comunidade linguística, e não daquela segundo a qual se reconhece que "falamos bem" ou de maneira exemplar, na mesma comunidade. Ao comprovar a norma a que nos referimos, comprova-se como se diz e não se indica como se deve dizer: os conceitos que, com respeito a ela, se opõem são normal e anormal, e não correto e incorreto. O fato de que as duas normas possam coincidir não nos interessa aqui; cabe, porém, assinalar que muitas vezes não coincidem, dado que a "norma normal" se adianta à "norma correta", é sempre anterior à sua própria codificação.

Com efeito, é importante sublinhar que Coseriu aponta para a existência de dois tipos de norma: uma objetiva e outra subjetiva. A primeira é fruto da observação, da verificação dos usos linguísticos de uma determinada comunidade linguística. Por outro lado, a norma subjetiva implica na observância de um conjunto de valores que irá, de forma subjetiva, apontar para usos linguísticos “adequados' ou "não adequados”, o que implicará dizer se um determinado usuário

\footnotetext{
${ }^{19}$ Louis Hjemslev (1899-1965) também tem grande relevância nos estudos sobre a norma. Coseriu (1979, p. 13) inicia seu texto "Sistema, norma e fala" mencionando o fato de Hjemslev ter apresentado, em 1951, um trabalho em que discutia "a distinção em três aspectos da linguagem: esquema, norma estabelecida e parole (fala)".
} 
"fala bem ou não". Ainda sobre a distinção dessas duas normas, Coseriu diz que a norma objetiva opera com a oposição normal versus anormal, enquanto a norma subjetiva traz a oposição entre correto e incorreto.

Do exposto a respeito do conceito coseriano de norma linguística, podemos depreender que é inerente à língua regulações de ordem normativa, embora elas sejam, como demostrado, de vieses bastante diferentes. $\mathrm{O}$ mesmo ocorre com as obras metalinguísticas, que podem estar mais ou menos ligadas ao estabelecimento e divulgação da norma subjetiva, isto é, com aquilo que consideram correto ou incorreto na língua. Metodologicamente, são exatamente essas as obras que incluímos no programa de investigação gramatical.

Trabalhos metalinguísticos em que essa não é a preocupação central foram agrupados nos programas de investigação filológico e dialetológico. Esse procedimento é importante, pois ajuda a compreender, sob o ponto de vista normativo, algo que está em investigação no presente trabalho e assim foi enunciado no subtítulo desta tese: A formação do pensamento linguístico brasileiro: entre a gramática e novas formas de tratamento da língua (1900-1940). Assim, é possível verificar se essas "novas formas de tratamento da língua" diferem das gramáticas sob o viés normativo. Dito de outra forma, ao apresentarmos nossa hipótese, destacando que no início do século XX a gramática deixa de ser o centro das discussões sobre a língua e divide esse papel com outros tipos de produção metalinguística, podemos verificar se essas "novas produções" diferem ou não da gramática quanto ao viés normativo que adotam.

Vejamos, então, exemplos em que verificamos esse diferente engajamento normativo nas obras que compõem nosso levantamento. A fim de tornar nossa comparação mais efetiva, analisamos o mesmo tópico linguístico: a flexão de número do substantivo.

Do programa gramatical, usaremos a Grammatica expositiva: curso superior, de Eduardo Carlos Pereira (1855-1923), de 1929. Para o programa filológico, a Grammatica historica, do mesmo autor, de 1916. Finalmente, para o programa dialetológico, O dialeto caipira, de Amadeu Amaral (1875-1929), de 1955 [1920].

Em sua Grammatica expositiva, Pereira (1929, p.69) assim se manifesta a respeito da flexão dos substantivos:

Numero é a propriedade que teem os substantivos de indicar, pela sua terminação ou flexão, a UNIDADE ou SINGULARIDADE e a PLURALIDADE dos seres, como livro e livros. Dois são os numeros grammaticaes: o SINGULAR, que indica um só objecto, como - livro; o PLURAL, que indica mais de um objecto - como livros. O $\mathbf{s}$ accrescentado ao singular dos substantivos fórma o seu plural, porém este accrescimo subordina-se ás regras seguintes: (PEREIRA, 1929, p.69) 
Após essas breves definições, sob o título de "regras para a formação do plural", o autor apresenta nove regras para a formação dos substantivos simples e quatro para os compostos.

$1^{\text {a }}$ REGRA.- Aos nomes terminados em vogal pura ou nasal juncta-se simplesmente um s. Exs.: banco e bancos [e segue uma lista de exemplos que iremos aqui suprimir]. $\mathbf{2}^{\mathbf{a}}$ REGRA. - Aos nomes terminados em ão correspondem respectivamente tres fórmas pluraes - ãos, ões, ães: 1. - ãos: mão e mãos [...]; 2. ões: botão e botões [...]; 3. - ães: pão e pães [...] Ha em muitos substantivos oscillação na formação do plural; dahi os pluraes DUPLOS E TRIPLOS dos seguintes: DUPLOS: cortezão - cortezãos e cortezões [...]; TRIPLOS: aldeão aldeãos, aldeões e aldeães [...]. $\mathbf{3}^{\text {a }}$ REGRA. - Os nomes terminados em al, ol e ul perdem o 1, e recebem es: canal - canaes, sol - soes, paul-paues. Excs.: cal (cano de escorrer a agua do telhado), mal, real (moeda), consul, fazem o plural -cales, males, réis e reales (moeda hespanhola), consules. (PEREIRA, 1929, p.70-71, negritos do autor)

$\mathrm{O}$ autor, seguindo essa mesma estrutura e tipologia analítica, segue apresentando as demais regras de formação dos substantivos. Com efeito, podemos perceber que sua preocupação se limita a prescrever as regras que o consulente da gramática deve seguir para realizar a flexão de número do substantivo de forma correta. Em algumas situações, quando o autor sente que algo em sua prescrição possa soar contraditório ou incorreto, se vale de breves esclarecimentos históricos. "Obs.- No portuguez antigo o plural desses nomes retinha o $\mathbf{l}$, que lhe vinha da fórma latina, como: annales, soles e paules. As excepções representam os casos em que, por algum motivo, não se operou a syncope do l.” (PEREIRA, 1929, p.71, sublinhamos)

Como veremos a seguir, recorrer de forma subsidiária à história da língua não se confunde com a perspectiva histórica que vai caracterizar programa de investigação filológico, pois nesse, diferentemente do que ocorre no gramatical, o objetivo é descrever e explicar a evolução histórica de uma determinada língua vernácula, nesse caso especificamente, do Português.

Em sua Grammatica historica, Eduardo Carlos Pereira (1855-1923), de forma bastante diferente do que ocorre na Grammatica expositiva, analisa assim a flexão de número do substantivo.

224. Numero. Ha em latim dois numeros - o singular e o plural. Cedo perdeu o latim o dual, que subsiste em grego e hebraico, e que se extendeu largamente no dominio aryano. Parece ter sido o dual, no sentir de alguns glottologos, a concepção primitiva e rudimentar da pluralidade. Do dual só conservou o latim ambo e duo, que forneceram os unicos vestigios desse numero em portuguez - ambos e dois. (PEREIRA, 1916, p.145, itálicos do autor)

Após essas considerações iniciais, o autor desenvolve, ao longo de três páginas e meia, uma detalhada explicação histórica a respeito da flexão de número dos substantivos. Com efeito, é possível notar em tais explicações a intenção de explicar esse processo linguístico desde o Latim, passando por fases antigas do Português, até chegar à sincronia do autor. 
225. Origem do s como expoente do plural em portuguez: - O plural de um substantivo em latim era multiplo: cada caso tinha sua fórma especial de pluralidade. Obliterados os casos pelo ensurdecimento da syllaba final, sobreviveu, entretanto, o accusativo, como o caso etymologico, que nos deu o typo da fórma plural, a flexão do plural dos nomes. Esta flexão é o s da desinencia, que caracterizava os accusativos pluraes das cinco declinações latinas: $1^{\mathrm{a}}$ decl. - horas; $2^{\mathrm{a}}$ decl. - servos; $3^{\mathrm{a}}$ decl. - consules; $4^{\mathrm{a}} \mathrm{decl}$.-manus; $5^{\mathrm{a}} \mathrm{decl}$ - - dies. Deste facto historico veio-nos o s como expoente do plural em portuguez. (PEREIRA, 1916, p.145-146, itálicos do autor e sublinhado nosso)

O título do próximo tópico (226) é "Historia do plural em portuguez", assunto que é analisado em nove itens. No primeiro, vemos uma discussão que também aparece na Grammatica expositiva e que já foi por nós aqui apresentada: a síncope do $l$ intervocálico. Mais uma vez, é importante notar a diferença com que esse mesmo item entra em cada uma das gramáticas.

226. Historia do plural em portuguez. Na evolução do accusativo plural dos nomes para o portuguez soffreram os vocabulos alterações morphologicas que convem examinar. $\underline{1}^{\circ}$ Os nomes que actualmente terminam em -al, -ol , - $u l$, faziam o plural no v. port. de accordo com a tradição latina, em -ales, - oles, -ules: capital capitales, sol - soles, paul — paules. Do sec. XVI em diante, pela quéda do $l$ intervocalico, fixaram-se os pluraes - capitaes, soes, paues. O 1, entretanto, resistiu nas seguintes palavras, que constituem actualmente excepções: males, reales (moeda hespanhola), cales (cano), consules. (PEREIRA, 1916, p.146, itálicos do autor, sublinhados nossos)

Ao longo dos nove itens, não há a menção a regras, como ocorre na Grammatica expositiva, mas sim uma clara preocupação do gramático em explicar historicamente a língua de sua sincronia. Além das explicações históricas em si, podemos perceber isso no nível discursivo, uma vez que o autor constantemente se utiliza de frases como "Os nomes que hoje terminam em -ão, tinham no v. port, até o sec. XVI [...]" (PEREIRA, 1916, p.146), o que mostra o recuo à história da língua para explicar sua forma presente.

Evidentemente, há injunções normativas também na Grammatica historica, pois a fixação da língua do presente está sujeita a critérios estabelecidos pelo gramático, os quais, muitas vezes, coincidem com aqueles adotados pela gramática tradicional, como optar por textos literários como modelo de língua a ser seguido. No entanto, é importante destacar que o fato de cada gramática ter objetivos analíticos diferentes produz diferentes intensidades normativas.

Outro nível de normatividade, menos intenso, pode ser visto no programa de investigação dialetológico. Como já apontamos, os objetivos de cada programa parecem apontar para um maior ou menor engajamento normativo. Com efeito, o programa de investigação dialetológico tem como objetivo central descrever as variedades dialetais brasileiras ou o próprio Português do Brasil. A construção de um corpus para tal tarefa (camada documental) passa, essencialmente, 
pela coleta de falas vindas a língua oral do presente e também de literatura regional, técnica ou não canônica. Como é perceptível, não é possível considerar que tal programa tenha o mesmo rigor normativo daquele encontrado nas gramáticas caudatárias da tradição greco-latina, isto é, nas gramáticas tradicionais.

Ainda no mesmo tópico, a flexão de número dos substantivos, vejamos como n'O dialeto caipira, de Amadeu Amaral (1875-1929), esse tema é tratado.

[sobre o] s - Cai, quando final de palavra parò ou proparoxítona: arfére (alferes), pire (pires), bamo (vamos), imo (imos). Desaparece também nos oxítonos, quando é sinal de pluralidade: mau, bambu, avô. Conserva-se nos adjetivos determinativos e nos pronomes, ainda que graves, o que se explica, em parte, pela posição proclítica habitual: duas casa, minhas fiia, arguas pessoa, aquêles minino, êles, elas. A prova é que, quando não está em próclise, frequentemente se submete à regra: aquelas são as minha, estas são sua. Em parte, porém, essa conservação se deve à necessidade de manter um sinal de pluralidade. Voltaremos oportunamente a este ponto, que é, talvez, mais do domínio dos fenômenos psicológicos na morfologia, do que de ordem fonética. (AMARAL, 1955 [1920], p.53, itálicos e negritos do autor)

O trecho acima está no capítulo de fonética, o que justifica sua última frase. No capítulo de morfologia, como prometido, o autor retoma esse tópico do -s final e faz interessante observação a respeito da pronúncia da palavra mas, apontando sua ditongação em mais: "Nos VOCÁBULOS ÁTONOS, conserva-se: os, as, nos (contração e pronome), nas. Aliás, ha pronunciada tendência para tornar tônicos esses vocábulos, pela ditongação: ois, ais, etc. $\underline{\mathrm{A}}$ conjunção mas tornou-se mais." (AMARAL, 1955 [1920], p.70, sublinhado nosso)

Com efeito, podemos observar, nesses trechos, em frases como "ha pronunciada tendência" e "o mas tornou-se mais", "cai o $s$ ", "desaparece o $s$ ", "conserva-se o $s$ ", que o autor preocupa-se, fundamentalmente, em descrever aquilo que observou nos dados linguísticos a que teve acesso. Não se encontram neste trabalho, bem como em outros de orientação dialetológica, instruções normativas do tipo "deve-se dizer assim" e "não se deve dizer assado" ou "é vicioso este uso" e "é bom Português este uso".

Baseado no cenário que aqui apresentamos, nos parece adequado dizer que em relação ao engajamento normativo da produção linguística das quatro primeiras décadas do século XX, há uma gradação crescente de intensidade, sendo o programa gramatical o mais normativo e o dialetológico o menos. 


\subsection{O programa de investigação gramatical entre 1900 e 1940: os textos escolares}

Nosso primeiro gesto no sentido de compreender a produção linguística brasileira das quatro primeiras décadas do século XX foi feito a partir do contato que tivemos com as 400 obras gramaticais que conseguimos levantar. As categorias que criamos no sentido de captar as especificidades dessas obras já foram explicadas no capítulo de metodologia, mas aqui reforçaremos alguns pontos, na medida em que forem necessários para as análises que desenvolveremos nesta e em outras seções.

O primeiro aspecto a ser novamente sublinhado é o fato de nosso levantamento ter mostrado de maneira muito destacada o predomínio das obras gramaticais escolares sobre as não escolares, isto é, as de referência ${ }^{20}$. Tal prevalência pode ser verificada na tabela abaixo:

Tabela 2- Quantitativo da produção gramatical escolar e de referência

\begin{tabular}{|c|c|c|c|c|}
\hline \multicolumn{3}{|c|}{ Escolares } & \multicolumn{2}{c|}{ De referência } \\
\hline $\begin{array}{c}\text { Gramáticas } \\
\text { completas }\end{array}$ & $\begin{array}{c}\text { Obras de } \\
\text { temas } \\
\text { gramaticais } \\
\text { específicos }\end{array}$ & $\begin{array}{c}\text { Livros } \\
\text { didáticos } \\
\text { de } \\
\text { Português }\end{array}$ & $\begin{array}{c}\text { Gramáticas } \\
\text { completas }\end{array}$ & $\begin{array}{c}\text { Obras de temas } \\
\text { gramaticais } \\
\text { específicos }\end{array}$ \\
\hline 51 obras & 101 obras & 87 obras & 4 obras & 157 obras \\
\hline Total de obras escolares: 239 & Total de obras de referência: 161 \\
\hline \multicolumn{3}{|c|}{ Total de obras do programa gramatical: 400 } \\
\hline
\end{tabular}

Com efeito, é necessário que aqui estabeleçamos os critérios metodológicos que nos levaram a propor essa divisão bipartite do programa gramatical, especialmente, nesta seção, o que enxergamos e classificamos como escolar ${ }^{21}$.

Explicar tal divisão torna-se ainda mais necessário, pois, em termos gerais, podemos dizer que a gramática ocidental, desde sua origem, tem, como característica, a produção de reflexões

\footnotetext{
${ }^{20}$ Relativamente ao Espanhol, Danna (2019) também aborda esta dicotomia. Em sua tese, a autora estuda o que chamou de o "Espanhol nos materiais para fins escolares" e o "Espanhol nos materiais filológicos", porém valendose de um recorte temporal ligeiramente diferente do nosso, 1919 a 1961.

${ }^{21}$ No capítulo 3, falaremos a respeito das obras de referência.
} 
a respeito de uma norma de determinada língua e sua consequente transmissão àqueles que não possuíam tais conhecimentos, incluindo nesse grupo, além dos já letrados, os mais jovens ou os que estavam se iniciando nesse universo. Essa característica tem conferido à gramática, por si só, um viés didático, independentemente dos diferentes matizes epistemológicos pelos quais passou ao longo dos séculos e de sua maior ou menor inserção em ambientes explicitamente caracterizados como de ensino. No entanto, isso não nos autoriza a dizer que todas as gramáticas são escolares, uma vez que para assim classificá-la é necessário haver vínculo com o ambiente específico da escola, o que certamente não constituiu seu único lugar de uso ao longo da história.

Considerando essa distinção entre didático e escolar, é razoável dizer que à medida que um país vai estruturando e ampliando sua rede de ensino, criando tanto escolas primárias quanto secundárias, também começam a ser produzidos materiais escolares que atendam as especificidades de cada um desses segmentos, o que inclui, evidentemente, as gramáticas escolares e demais materiais de apoio.

No caso brasileiro, em especial, a relação entre a gramática e o universo da escola principalmente a não relacionada ao universo da alfabetização - aparecerá com alguma relevância no final do século XIX e ganhará volume ao longo do século XX. Esse processo pode ser justificado pela tardia criação do ensino secundário no Brasil, que ocorreu apenas em 1837, e também pela pouca relevância que tinha a disciplina Português no currículo deste período, o que começa a ser alterado só “depois de 1869, quando o exame de Português foi incluído entre os Preparatórios de muitos cursos superiores (faculdades de Direito, faculdades de Medicina, Escola Politécnica, Escola de Minas, etc.)”. (RAZZINI, 2000, p. 238)

Dado esse cenário de crescente ampliação do ensino secundário brasileiro e do consequente aumento de materiais a ele relacionado, foi necessário definir critérios metodológicos que balizassem a divisão das 400 obras gramaticais, separando as que estão conectadas com o universo escolar daquelas em que esse vínculo não está marcado. Para tal tarefa, foram de grande valia os apontamentos metodológicos feitos por Swiggers (2012) visando uma historiografia da gramaticografia didática ${ }^{22}$.

Por gramaticografía didáctica entiendo la redacción de obras gramaticales con vistas al aprendizaje/enseñanza de una (o de varias) lengua (s). [...] Bastará aquí hacer referencia a lo que se conoce (o reconoce) como un 'manual de gramática'. El término didáctico, que los lexicógrafos definen como "relativo a la enseñanza" tiene que tomarse en un sentido muy amplio, cuando se refiere a la historia de la gramática. Muy a menudo, las gramáticas que se utilizaban no lo fueron en un contexto explícito de enseñanza: en general, las gramáticas "didácticas" de los siglos pasados eran gramáticas de "aprendizaje" - manuales "auto-didácticos" - o

\footnotetext{
${ }^{22}$ Neste artigo, Swiggers utiliza o termo didática com sentido equivalente ao que, nesta tese, chamamos de escolar.
} 
gramáticas para la lectura y la memorización (o, por lo menos, un estudio muy cuidadoso). (SWIGGERS, 2012, p. 17-18)

Em seguida, o autor destaca que "no resulta fácil caracterizar más nítidamente el concepto de "gramática didáctica'” (Swiggers, 2012, p. 18) e apresenta alguns aspectos utilizados por Leonardo Gómez Torrego para justificar a inclusão do adjetivo "didática" no título de sua Gramática didáctica del español, de 1997.

Apesar do exemplo utilizado por Swiggers estar fora do recorte temporal desta tese, as características apontadas por Torrego podem ser encontradas nas obras gramaticais presentes em nosso levantamento, o que, associado à análise específica que fizemos dessas obras, fez com que encontrássemos nossos próprios critérios para classificarmos como escolar uma determinada publicação.

Las características que invoca Leonardo Gómez Torrego para justificar la denominación Gramática didáctica del español de su gramática de 1997 - a saber (i) la exposición sencilla y clara, (ii) la presentación tipográfica muy nítida, (iii) la referencia a la norma, (iv) la atención prestada a la terminología, (v) la presencia de remisiones, (vi) la inclusión de ejercicios. (SWIGGERS, 2012, p. 18, numerações nossas)

Nesta tese, os critérios que utilizamos para classificar uma obra como escolar são os seguintes: (i) menção explícita no título, subtítulo, folha de rosto ou prefácio ao universo escolar; (ii) presença de referências aos programas de ensino oficiais e (iii) presença de exercícios de fixação. Vejamos, agora, algumas considerações acerca de cada um deles:

1) Menção explícita no título, subtítulo, folha de rosto ou prefácio ao universo escolar, como vemos, por exemplo, em Língua Portuguesa: gramática e exercícios para as quarto séries ginasiais, de Aníbal Bruno (1890-1976) ou Gramática intuitiva da Língua Portuguesa: para os dois primeiros anos do curso ginasial e normal, de Brant Horta (1876-1959).

Já os "prefácios", "advertências" ou demais textos introdutórios acabavam funcionando como verdadeiras "cartas de intenções" dos gramáticos, servindo de palco para diferentes manifestações. No caso das gramáticas escolares, esses registros poderiam ter algumas especificidades, como marcar a: (i) indicação das séries para as quais se destinava a obra, (ii) a adesão a um determinado programa de ensino, (iii) a aceitação que o material teve por parte de outros professores e/ou alunos, (iv) as críticas à estruturação/conteúdo dos programas, mas sublinhando que, apesar disso, o professor e o aluno poderiam encontrar, naquela gramática, os tópicos definidos pelo poder público. Vejamos alguns exemplos desse processo:

Tem o presente compendio por objecto expôr as doutrinas e regras grammaticaes relativas á nossa lingua, attendendo ás necessidades e conveniencias do ensino 
secundario. É dever de todo o autor de grammatica aplanar tanto quanto possivel a estrada ao estudante e ajudal-o a vencer as difficuldades technicas proprias do idioma, e não crear-lhe novos embaraços collocando no caminho pedras de tropeço. (ALI, 1923, prólogo, sublinhado nosso)

Nesse excerto, além de indicar o nível escolar para o qual se destina a obra, fica clara a intenção do autor de destacar as adaptações feitas na gramática para que o aluno encontre uma obra acessível ao universo escolar e não um abstruso material de compreensão reservada apenas aos especialistas.

Comquanto esta grammatica se destine aos cinco annos gymnasiaes, todos os seus leitores verão que o programma do $4 .^{\circ}$ anno não se encontra desenvolvido e completo como o dos outros annos, por julgarmos que o genero de estudo grammatical proprio desse anno (grammatica historica), deve ter um livro á parte e que em breve será tambem por nós collocado na praça. Além disso augmentar-seia muito este volume com semelhante estudo. Convem notar tambem que estamos em completo desaccordo com a maneira de se escreverem certas palavras. A nossa opinião é: ou tudo etymologico ou nada; ou tudo phonetico ou nada. (RODRIGUES, 1935, prefacio, sublinhado nosso)

$\mathrm{Na}$ gramática de J. Rodrigues (?-?), podemos ver novamente a menção ao nível educacional, mas com uma crítica à ortografia adotada pelo governo nos programas. Também é possível ver uma explicação de ordem editorial: nesta obra, tratarei, fundamentalmente, da gramática expositiva (sincrônica) e deixarei a gramática histórica para um volume à parte. Aliás, esse é o conteúdo do $4^{\circ}$ ano ginasial e a referência aos programas de ensino, já nos leva ao ponto 2 de nossa exposição.

2) Presença de referências aos programas oficiais de ensino. Nas quatro primeiras décadas do século XX, foram três os programas vigentes: o primeiro, conhecido como Programa de Fausto Barreto, vigente de 1887 a 1931, quando é publicado novo programa, que, por sua vez, permanece vigente até 1942, quando passa a valer o último programa de ensino da década. Um outro programa só será expedido em 1951, portanto fora dos limites temporais desta tese.

Tais referências podem ser vistas, por exemplo, na Gramática brasileira do português contemporâneo, de Cândido Jucá (filho) (1900-1982), publicada em 1943, cuja folha de rosto diz: "Aplicação: do $1^{\mathrm{o}}$ ao $4^{\mathrm{o}}$ anos ginasiais de acordo, rigorosamente, com os programas exarados no Portaria ministerial, de 11 de Julho de 1942”. Outro exemplo desse registro é o Programa de Português: gramática (1948_7ed.), de Julio Nogueira (1873 - ?), que tanto na capa cartonada quanto na folha de rosto diz: "Organizada inteiramente de acordo com o programa expedido pela portaria ministerial n ${ }^{\circ} 172$, de 15 de Julho de 1942”. 
Para melhor compreendermos essa relação entre programas de ensino e gramáticas escolares faremos um quadro comparativo da gramática de Cândido Jucá (filho) e com o programa de 1942.

Quadro 2 - Quadro comparativo entre parte do Programa de Português, de 1942 e o sumário da Gramática brasileira do português contemporâneo, de Cândido Jucá (filho) (1943) Fontes: BRASIL (1942) e Jucá (filho) (1943, p. 7).

\begin{tabular}{|c|c|}
\hline $\begin{array}{c}\text { Programa de Português } \\
\text { (Portaria Ministerial no } 170, \text { de } 11 \text { de julho } \\
\text { de 1942) }\end{array}$ & $\begin{array}{c}\text { Sumário da Gramática brasileira do } \\
\text { português contemporâneo, de Cândido } \\
\text { Jucá (filho) (1943) }\end{array}$ \\
\hline $\begin{array}{l}\text { PRIMEIRA SÉRIE } \\
\text { Unidade I } \\
\text { 1. Oração. Sujeito e predicado. Oração sem } \\
\text { sujeito, oração sem verbo. } \\
\text { 2. Substantivo, artigos, adjetivo, numerais. } \\
\text { 3. Gênero e número. Idéia de concordância } \\
\text { nominal. } \\
\text { 4. Exercícios para o bom emprego dos artigos } \\
\text { e dos numerais. }\end{array}$ & $\begin{array}{l}\text { PRIMEIRA SÉRIE } \\
\text { UNIDADE I } \\
\text { 1. Oração. Sujeito e predicado. Oração sem } \\
\text { sujeito, oração sem verbo. } \\
\text { 2. Substantivo, artigos, adjetivo, numerais. } \\
\text { 3. Gênero e número. Idéia de concordância } \\
\text { nominal. Exercícios de concordância } \\
\text { nominal. } \\
\text { 4. Exercícios para o bom emprêgo dos artigos } \\
\text { e dos numerais ............................. PÁGS. } 11\end{array}$ \\
\hline $\begin{array}{l}\text { Unidade II } \\
\text { 1. Verbo: números, pessoas, tempos e modos. } \\
\text { Vozes. } \\
\text { 2. Verbos regulares e irregulares. Exercícios } \\
\text { de conjugação, feitos por meio de frases. } \\
\text { 3. Exercícios de concordância do verbo com } \\
\text { o sujeito. }\end{array}$ & $\begin{array}{l}\text { UNIDADE II } \\
\text { 5. Verbo; números, pessoas, tempos e modos. } \\
\text { Vozes. } \\
\text { 6. Verbos regulares e irregulares. Exercícios } \\
\text { de conjugação, feitos por meio de frases. } \\
\text { 7. Exercícios de concordância do verbo com } \\
\text { o sujeito......................................... PÁGS. } 41\end{array}$ \\
\hline $\begin{array}{l}\text { Unidade III } \\
\text { 1. Pronomes, advérbios. } \\
\text { 2. Coordenação. Noção de conjunção } \\
\text { coordenativa. } \\
\text { 3. Estudo simultâneo e moderado da análise } \\
\text { léxica e da sintática, não indo esta além do } \\
\text { periodo composto por coordenação. } \\
\text { 4. Exercícios para o bom emprego dos } \\
\text { pronomes, sobretudo do relativo cujo e dos } \\
\text { demonstrativos. } \\
\text { (...) }\end{array}$ & $\begin{array}{l}\text { UNIDADE III } \\
\text { 8. Pronomes; advérbios. } \\
\text { 9. Coordenação. Noções de conjunção } \\
\text { coordenativa. } \\
\text { 10. Estudo simultâneo e moderado da análise } \\
\text { léxica e da sintática, não indo além do } \\
\text { período composto por coordenação. } \\
\text { 11. Exercícios para o bom emprego dos } \\
\text { pronomes, sobretudo do relativo cujo e dos } \\
\text { demonstrativos ............................ PÁGS. } 71 \\
\text { (...) }\end{array}$ \\
\hline
\end{tabular}


Como pode ser observado, há um total espelhamento entre o programa e o conteúdo da gramática. Na verdade, é preciso dizer que apresentamos apenas um recorte do programa, pois esse documento, em sua integralidade ${ }^{23}$, apresenta o conteúdo a ser dado nas quatro séries ginasiais (primeira parte do Secundário), divididos em três eixos: (i) leitura, (ii) gramática e (iii) outros exercícios. Sendo a obra de Jucá (filho) uma gramática, evidentemente que ela apresenta apenas os tópicos do item dois (ii) do programa, ou seja, de gramática. Aspectos ligados à leitura (i) eram abordados nas seletas literárias, muito frequentes à época, já que serviam para atender às exigências dos programas quanto à literatura. Com efeito, gramática e seleta constituíam os principais materiais didáticos do estudante secundarista na disciplina Português. Voltaremos a esse tópico mais à frente, quando formos falar dos livros didáticos de Português. Quanto ao demais anos, a gramática de Jucá (filho) apresenta a mesma equivalência temática que ilustramos acima com os tópicos do primeiro ano.

Com algumas diferenças na organização do texto, a mesma observância aos programas de ensino pode ser verificada em outras gramáticas escolares do período. Não seguir o que estabeleciam as diretrizes curriculares oficiais não parecia ser uma boa estratégia, principalmente no aspecto comercial, já que isso implicaria na impossibilidade de adoção desses materiais no Secundário. Ficar fora desse mercado seguramente não era algo que os gramáticos da época consideravam, pois isso significaria perder prestígio entre os pares, além de perda financeira, dada a demanda crescente por materiais ligados a esse nível de ensino. Mais uma vez, trazemos as palavras de Bittencourt (2004, p.479), muito esclarecedoras quanto ao processo que aqui nos referimos: "O autor de uma obra didática deve ser, em princípio, um seguidor dos programas oficiais propostos pela política educacional”.

Um outro aspecto importante a ser destacado quanto à crescente influência do poder público no ensino de Português é a publicação de instruções metodológicas (Portaria $\mathrm{n}^{\circ}$ 172, de 15 de julho de 1942), que eram documentos que estabeleciam como deveriam ser ensinados os temas presentes no programa (Portaria $\mathrm{n}^{\circ}$ 170, de 11 de julho de 1942), além de apresentarem também reflexões mais gerais a respeito dos objetivos do ensino de Português na escola, do papel da leitura na formação do aluno, entre outras questões congêneres. O programa de 1931 foi o primeiro em que tais instruções vieram à lume, porém de forma menos detalhada e no mesmo documento em que os tópicos de ensino são apresentados. Em 1942, durante o Estado Novo, é publicado um novo programa de ensino e, pela primeira vez, as instruções metodológicas são

\footnotetext{
${ }^{23}$ Todos os programas de ensino $(1887,1931$ e 1942) podem ser consultados integralmente no anexo A.
} 
publicadas em portaria ministerial à parte do programa. Também, pela primeira vez, tais instruções são apresentadas de forma extremamente detalhada, indo além das instruções metodológicas relativas ao ensino de Português em si, avançando em aspectos de postura do professor em sala de aula, como no tópico "VIII - Observações gerais", em que o texto legal diz: “[...] 6. Fale-se e escreva-se sem afetação. Haja com naturalidade ao falar e com naturalidade ao escrever [...]." BRASIL (1942).

Tal controle pode ser atribuído, em um primeiro plano, às políticas de controle típicas do Estado Novo, como foi o caso da criação da Comissão Nacional do Livro Didático (CNLD), mas também não podemos deixar de atribuir esse maior detalhamento ou, em outros termos, uma maior especialização, a uma crescente estruturação do ensino secundário no Brasil, fruto das políticas públicas educacionais criadas a partir do início do século XX. Vejamos um trecho da Portaria Ministerial $\mathrm{n}^{\mathrm{o}}$ 172. O documento completo pode ser encontrado no anexo A.

\section{Quadro 3 - Instruções metodológicas para o ensino de Português - $1^{\text {a }}$ série do Secundário - Portaria no 172, de 1942}

\section{IV - O ensino na primeira série}

1. O professor dará as primeiras noções gramaticais partindo da oração, concebida como "a menor unidade do discurso dotada do sentido completo".

2. Assim, tomará um objeto que tenha ao seu alcance, e perguntará a vários alunos o que pensam, o que querem dizer ou saber, a respeito dêsse objeto. Obterá resposta diferentes. Destas, escolherá as mais simples e que melhor se prestem ao seu fito didático em relação a alunos que mal deixaram a escola primária. Por exemplo:

O giz é branco.

O giz quebra-se facilmente.

Como se fabrica o giz?

3. Dirá então aos alunos que as palavras, com que declaramos ou perguntamos alguma coisa, formam uma "oração". É, pois, uma oração: "O giz é branco"; é outra oração: "Como se fabrica o giz?".

4. Depois, fará que os alunos, com a colaboração dêle, vão apontando as orações curtas e simples, que o texto de leitura contiver.

5. Realizando durante algumas lições esse exercício, passará o professor a mostrar que também formam oração as palavras com que exprimimos um desejo, como quando dizemos, no Padre-Nosso: "Venha a nós o vosso reino".

6. Dirá que ainda há oração quando se faz um pedido, se dá uma ordem ou uma incumbência:

Entregue este livro à sua irmã.

Faça direito o seu trabalho. 
7. Durante alguns dias auxiliará os alunos a descobrirem, nos textos, todos esses tipos de oração; e quando vir que eles já têm adquirido certa prática de tais pesquisas, entrará a ministrar as noções de sujeito e de predicado, porém, de modo muito simples e adequado à tenra mentalidade de crianças de onze anos.

(...)

As instruções, da $1^{\text {a }}$ série, seguem até a número 13.

Fonte: BRASIL (1942).

Como é possível notar nos trechos selecionados, essa portaria deixa transparecer que a preocupação dos órgãos oficiais ia além da reflexão teórico-metodológica a respeito do ensino de Português, extravasando para aspectos que podem ser classificados como de tutela do professor, indicando detalhes de como ele deveria agir na sala de aula, como pode ser visto em: “[o professor] tomará um objeto que tenha ao seu alcance, e perguntará a vários alunos o que pensam, o que querem dizer ou saber, a respeito dêsse objeto”. BRASIL (1942). Apesar das ações de maior controle pedagógico adotado durante o Estado novo, neste momento, nos interessa sublinhar o quanto a ação do Estado brasileiro no sentido de ampliar e estruturar o ensino secundário gerou uma maior produção de materiais escolares (gramáticas escolares, materiais complementares, livros didáticos de Português, etc) para atender esse segmento escolar. É importante sublinhar ainda que essas ações regulatórias do poder público diminuem a liberdade criativa e autoral do gramático quanto à sua produção, já que, se quisesse ter seu livro vendido e adotado em escolas, teria de se submeter aos referidos textos oficiais.

Com o mercado editorial de materiais ligados ao Secundário em franco crescimento, produzir gramáticas escolares, bem como os outros materiais de apoio pedagógico, era algo que parecia despertar bastante interesse na época, tanto de autores pouco conhecidos e de menor relevância na gramaticografia brasileira quanto de nomes de grande projeção na época, como Said Ali (1861-1953), Mattoso Câmara (1904-1970), Maximino Maciel (1866 - 1923) e o já mencionado Cândido Jucá (filho) (1900-1982).

3) Outro aspecto relevante que utilizamos como critério para incluir uma gramática no rol das obras escolares foi a presença de exercícios de fixação. Tal estratégia representa exatamente o processo de didatização pelo qual passou a produção gramaticográfica do início do século XX, momento em que muitas obras ligadas ao programa gramatical eram preparadas para servir ao uso escolar, no contexto de ensino-aprendizagem de gramática.

Podemos verificar um exemplo de tal processo no Manual de gramática portuguesa, de Carlos de Brito Pereira (?-?), de 1942. No capítulo sobre os "adjetivos qualitativos", depois da exposição teórica sobre as "particularidades do superlativo absoluto sintético", o autor oferece 
ao estudante uma sequência de exercícios de fixação relativa ao tema do capítulo. A gramática, como um todo, apresenta 58 exercícios aos estudantes.

\section{Quadro 4 - Lista de exercícios de fixação: "adjetivos qualitativos"}

EXERCÍCIO 51 - Dar o feminino dos seguintes qualificativos:

Perfeito. Bom. Mau. Plebeu. Espanhol. Inglês. Judeu. Trabalhador. Facil. Multicor. Motor. Cru. Ilhéu. Anterior. Beirão. São. Bissector. Justo. Feliz. Pecador. Valentão. EXERCÍCIO 52 - Formar o plural dos adjetivos seguintes:

Facil. Negro. Fatal. Cruel. Vil. Afavel. Poderoso. Penoso. Médico-cirúrgico. Angloamericano. Surdo-mudo.

EXERCÍCIO 53 - Formar uma comparação (de igualdade, superioridade e inferioridade) entre:

Duas flores. Duas casas. Dois relógios. Dois homens. Dois animais. Dois alunos. Dois paises. Dois livros.

EXERCÍCIO 54 - Dar o superlativo absoluto sintético dos seguintes adjetivos:

Fragil. Afavel. Voraz. Fertil. Rico. Pobre. Áspero. Facil. Humilde. Util. Salubre. Bom. Louvavel. Comum. Veloz. Célebre. Amigo. Cruel. Grande. Exemplar.

EXERCÍCIO 55 - Formar frases com os adjetivos do exercício anterior, empregados no superlativo absoluto analítico.

Fonte: Pereira (1942, p. 126-127).

Quanto aos critérios que utilizamos para classificar as obras de nosso levantamento como escolares, há uma última observação importante a ser feita. Não foram incluídas nesse grupo as obras que apenas apresentam a exposição do conteúdo gramatical de forma simplificada. Para que houvesse tal inclusão, era necessário atender a pelo menos um dos três critérios que apresentamos nesta seção. Julgamos que somente a exposição simplificada não é suficiente para garantir que uma determinada obra é um material escolar, já que é possível encontrar gramáticas de referência, portanto para uso não escolar, em que o autor resolve desenvolver o conteúdo de forma mais acessível, simplificada, visando com isso atender ao público em geral.

No caso das obras que atendem a um dos três critérios de "escolaridade", encontramos também a exposição feita de forma simples, porém essa característica, por si só, pode ser vista como uma consequência das adaptações necessárias para o uso escolar, não como a causa. 


\subsubsection{Gramáticas escolares completas}

Feitas as considerações mais gerais a respeito dos textos gramaticais escolares, passaremos agora à análise de suas especificidades. Como já dissemos, a análise das 239 obras de viés escolar nos levou a separá-las em três subgrupos: as gramáticas completas, as obras de temas gramaticais específicos e os livros didáticos de Português. Nesta seção, trataremos do primeiro subgrupo e depois, sequencialmente, dos outros dois.

Classificamos como gramática completa os trabalhos que remetem, com maior ou menor aderência, à tradição das gramáticas greco-latinas, que incluíam estudos de fonologia, morfologia e sintaxe. Obras em que apenas um ou dois desses níveis são tratados foram incluídas no subgrupo obras de temas gramaticais específicos.

Nosso levantamento bibliográfico localizou 51 gramáticas escolares completas. A relação completa dessas obras pode ser consultada no apêndice B (Quadro 1B). Nesta tese, adotaremos essa estratégia com aquelas tabelas que forem muito extensas, deixando, nos capítulos, apenas as análises relativas a esses dados ou mesmo pequenos quadros-síntese, quando for o caso. Agimos assim em favor de uma maior fluidez do texto.

A partir deste momento, analisaremos todos os subgrupos a partir do modelo das camadas do conhecimento linguístico, de Swiggers (2004). No entanto, antes disso, faremos aqui algumas considerações de caráter mais geral a respeito destas 51 gramáticas.

O primeiro aspecto a ser considerado é a destinação dessas gramáticas em dois níveis de ensino distintos: primário ou secundário. Fazendo essa separação, chegamos ao seguinte cenário:

Tabela 3 - Gramáticas escolares: destinação quanto ao segmento escolar

\begin{tabular}{|c|c|}
\hline Gramáticas primárias & 10 obras \\
\hline Gramáticas secundárias & 31 obras \\
\hline $\begin{array}{c}\text { Gramáticas em que não há informações explícitas sobre o nível de ensino } \\
\text { para o qual se destina. }\end{array}$ & 10 obras \\
\hline
\end{tabular}

Esta primeira análise quantitativa já nos mostra algo que nos parece ser uma grande característica da gramaticografia brasileira do início do século XX: um viés fundamentalmente escolar. Com efeito, o crescimento e a estruturação do ensino secundário e o consequente aumento de demanda por materiais didáticos que atendessem a esse nível constituem fatores 
decisivos para embasar a afirmação que acima fizemos. São 31 gramáticas destinadas explicitamente para o Secundário, frente a 10 preparadas para uso no Primário. Quanto às outras 10 gramáticas, não há nelas nenhuma indicação específica a um determinado nível de ensino. Algumas apresentam, no título, qualificantes que remetem a um texto mais introdutório, como as Primeiras noções de grammatica ou Breves noções de grammatica portuguesa, ou mais avançado, como A grammatica do professor. Há ainda gramáticas com o título bem genérico quanto ao seu aprofundamento, como Grammatica portugueza, Elementos de gramática ou Licções de grammatica portugueza.

Outra característica perceptível no grupo dessas 10 gramáticas é a marcação do nível de aprofundamento por um critério individual do gramático e não por pautar-se em fatores externos, como a série ou segmento escolar. Isso pode ser visto na Gramática portuguesa: curso elementar, de Alfredo Alvares de Macedo de Coutinho (?-?) ou nas duas obras de Alfredo Clemente Pinto (1854-1938), Primeiras noções de grammatica: $1^{\circ}$ curso e Primeiro anno de grammatica por meio de exercicios praticos: $2^{\circ}$ curso, trabalhos em que as expressões especificadoras “curso elementar", "1 ${ }^{\circ}$ curso" e " $2^{\circ}$ curso" não estão relacionadas a nenhum nível escolar específico, mas sim a uma escala definida pelo próprio autor. É como se o gramático dissesse: "esse meu trabalho é para quem está começando a estudar gramática, por isso é elementar", ou "comece estudando esse primeiro volume, depois que tiver dominado os conceitos ali presentes, passe para o segundo".

A educação brasileira, sobretudo a secundária, no início do século $\mathrm{XX}$, estava em processo de estruturação. Nesse contexto, não vincular uma gramática a um determinado ano/segmento parecia ser uma estratégia comercial interessante, já que abria a possibilidade do material ser adotado em diferentes séries ou até mesmo em contextos mais informais de ensino.

Vejamos, a título de exemplo, a utilização do termo "elementar". Ele aparece nos três grupos das gramáticas escolares: primárias, secundárias e nas em que não há indicação explícita de nível de ensino. Essas três destinações podem ser verificadas, por exemplo, na Grammatica elementar da Lingua Portugueza, de Said Ali (1861-1953) e Noções elementares de grammatica portugueza: de acordo com o programma das escolas primarias, de Osório DuqueEstrada (1870-1927), ambas para uso no Primário; nas Lições elementares de lingua portugueza, de Maximino Maciel (1866-1923) e na Grammatica elementar da Lingua Portugueza: destinada ao primeiro anno dos gymnasios, de João Motta (?-?), destinadas para o Secundário e na Gramática portuguesa: curso elementar, de Alfredo Alvares de Macedo Coutinho (?-?), obra sem indicação de nível de ensino. 
Examinamos as gramáticas de Said Ali, Maximino Maciel e Alfredo Alvares de Macedo Coutinho, uma obra de cada grupo, e não encontramos nenhuma diferença significativa quanto ao aprofundamento entre essas três obras. Todas são produções com o conteúdo gramatical bastante simplificado, fazendo jus ao qualificante "elementar", independentemente da indicação de série/nível que elas estampam - ou não estampam - em suas folhas de rosto.

Com efeito, nos parece válido afirmar que essas oscilações podem ser justificadas por uma rede de ensino que estava em pleno processo de ampliação e estruturação, principalmente se considerarmos o Secundário. Nesse sentido, é compreensível a presença de gramáticas em que a distinção principal era feita apenas por dois níveis de dificuldade: o elementar, que era a gramática "mais fácil", e o superior, que era a gramática em que estavam presentes os assuntos "mais difíceis". No entanto, podemos dizer que à medida em que uma determinada rede de ensino se estrutura, tudo a ela relacionado também se torna mais específico e direcionado. Um exemplo desse processo pode ser visto em outra característica relevante das 51 gramáticas escolares presentes em nosso levantamento: a produção de gramáticas dentro das coleções didáticas que, nesta tese, categorizamos como livros didáticos de Português. Falaremos dessas obras na seção 2.3.3, mas podemos antecipadamente dizer que esses livros eram produções que reuniam, em volumes seriados, todos os tópicos dos programas de ensino: gramática, seleta literária (coletânea), estudo crítico da literatura e redação.

Identificamos esse tipo de coleção didática apenas no Secundário e das 31 gramáticas ligadas a esse nível de ensino, 10 fazem parte de coleções de livros didáticos de Português. São elas:

\section{Quadro 5 - Gramáticas secundárias vindas de coleções didáticas}

\begin{tabular}{|c|l|}
\hline $\begin{array}{c}\text { BACHELET, Mário; NUNES, } \\
\text { José de Sá }\end{array}$ & $\begin{array}{l}\text { - Novo manual da Língua Portuguêsa: gramática: para } \\
\text { as } 4 \text { séries do ciclo ginasial (1943) } \boldsymbol{\Omega}\end{array}$ \\
\hline BRUNO, Aníbal & $\begin{array}{l}\text { - Língua Portuguesa: gramática e exercícios para as } \\
\text { quarto séries ginasiais }\left(1944 \_19^{a} \text { ed.) } \boldsymbol{\beta}\right.\end{array}$ \\
\hline CRUZ, José Marques da & $\begin{array}{l}\text { - Português prático: gramática para as } 4 \text { séries do curso } \\
\text { ginasial (1944_15ed.) } \boldsymbol{\beta}\end{array}$ \\
\hline $\begin{array}{c}\text { CARVALHO, José Mesquita } \\
\text { de }\end{array}$ & $\begin{array}{l}\text { - Gramática ginasial: para as quatro séries de acordo } \\
\text { com a nova programação de ensino, e com o novo } \\
\text { vocabulário ortográfico oficial (1945) } \boldsymbol{\beta}\end{array}$ \\
\hline
\end{tabular}




\begin{tabular}{|c|c|}
\hline $\begin{array}{c}\text { FONSECA, Alcides da; } \\
\text { ARAGÃO, Jarbas Cavalcante } \\
\text { de }\end{array}$ & $\begin{array}{l}\text { - A Língua Portuguesa: gramática para as quatro séries } \\
\text { ginasiais (1943) } \boldsymbol{\Omega}\end{array}$ \\
\hline MORAIS, Bento Bueno de & $\begin{array}{l}\text { - A nossa língua: Português para as } 1^{\mathrm{a}} \text { e } 2^{\mathrm{a}} \text { séries }^{24} \\
\text { (1944_2 } 2^{\mathrm{a} e d .)} \boldsymbol{\beta}\end{array}$ \\
\hline NASCENTES, Antenor. & $\begin{array}{l}\text { - O idioma nacional: gramática para as quatro séries } \\
\text { ginasiais (1944) } \boldsymbol{\beta}\end{array}$ \\
\hline NOGUEIRA, Julio & - Programa de Português: gramática (1948_7ed.) $\boldsymbol{\beta}$ \\
\hline TORRES, Arthur de Almeida & $\begin{array}{l}\text { - Compêndio de língua portuguesa: gramática: para o } \\
\text { Curso Ginasial (1943) } \boldsymbol{\beta}\end{array}$ \\
\hline ABREU, Modesto de & $\begin{array}{l}\text { - Idioma pátrio: volume 3: gramática expositiva }{ }^{25} \text { e } \\
\text { histórica; noções de estilística e literatura (1944) } \boldsymbol{\beta}\end{array}$ \\
\hline TOTAL & 10 obras \\
\hline
\end{tabular}

Como já dissemos, a produção de materiais didáticos com uma destinação tão específica representa, de maneira inequívoca, o quanto a produção escolar sobre o Português vai se especializado, atendendo assim às necessidades de ampliação e estruturação do ensino secundário e do mercado por ele gerado. Devemos destacar ainda que a presença desses materiais junto àqueles mais inespecíficos, antes de caracterizar uma contradição, representa, na verdade, uma das marcas formativas da gramaticografia escolar brasileira.

Feitas as observações mais gerais a respeito das 51 gramáticas escolares completas presentes em nosso levantamento, passaremos agora à análise desse grupo quanto às suas camadas teórica, técnica e documental (Swiggers, 2004).

\footnotetext{
${ }^{24}$ Essa obra é uma gramática escolar, organizada em lições, e composta por 2 volumes: o primeiro, para as $1^{\mathrm{a}}$ e $2^{\mathrm{a}}$ séries ginasiais e o segundo volume para as $3^{\mathrm{a}} \mathrm{e} 4^{\mathrm{a}}$ séries. No exemplar que possuímos, $1^{\circ}$ volume, $7^{\mathrm{a}}$ edição de 1953 , há indicação da publicação do $2^{\circ}$ volume, mas não localizamos demais informações sobre o autor/obra em nenhum arquivo. Como nosso exemplar é da década de 50, não temos como garantir que o $2^{\circ}$ tenha sido publicado dentro do nosso recorte temporal, motivo que fez com que não o incluíssemos no presente levantamento.

${ }^{25}$ Esta obra é uma gramática ao estilo "dois em um". Na primeira parte, é uma gramática expositiva tradicional e, na segunda, uma gramática histórica. Já que temos duas obras autônomas, que estão reunidas apenas fisicamente, consideramos, nesta tese, essas duas gramáticas isoladamente. Quando formos falar das gramáticas históricas, no capítulo 4, retornaremos a ela. Parece-nos que tal junção é justificada por questões comerciais. Antes composta por 5 volumes, a coleção Idioma pátrio passou a ser formada por 3 tomos. Nesse novo formato, os volumes 1 e 2 têm como conteúdo apenas seletas literárias. Assim, o terceiro e último volume apresenta os tópicos faltantes exigidos pelos programas de ensino do Secundário, ou seja, a gramática expositiva, a gramática histórica e as noções de estilística e literatura. Eliminar 2 volumes da coleção parece ser uma estratégia comercial mais atrativa, uma vez que tal supressão torna a coleção mais compacta e barata, estimulando, assim, sua adoção nas escolas secundárias da época.
} 


\subsubsection{Camada teórica}

Como já dissemos, a camada teórica representa a concepção de língua/linguagem que uma determinada obra sustenta. Também dissemos que, no caso das gramáticas, um primeiro gesto no sentido de descrever essa camada é verificar como o autor define o que é gramática. Tal procedimento não deve ser o único utilizado, pois nem sempre o que o gramático declara que fará, ele acaba efetivamente fazendo. Em muitas situações, há grande distância entre a retórica do autor (MURRAY, 1994) e o texto gramatical por ele efetivamente produzido. Dessa forma, além de analisarmos as definições, também nos debruçamos no próprio texto gramatical, para assim compreender qual visão de língua está nele materializada.

Dada a secular tradição da gramática tradicional, já analisada neste capítulo, é importante verificarmos se as gramáticas do início do século XX mantêm-se ligadas a essa tradição ou não. Também, em caso de rupturas, quais mudanças teriam ocorrido. De forma geral, podemos afirmar que a visão de língua herdada dessa tradição é a da gramática como guardiã de uma variedade considerada como correta, modelar. Vimos no início deste capítulo que o que disse Neves (2002, p. 49) a esse respeito. Reproduziremos novamente um trecho da citação original, dada sua importância para as análises que faremos nesta seção.

A disciplina gramatical aparece na época helenística [...]. Nessa época o que se
procura é, acima de tudo, transmitir patrimônio literário grego, privilegiando-se,
como atividade cultural, o exame das grandes obras do passado. O objetivo de tal
atividade é oferecer os padrões da linguagem dessas obras consideradas excelentes,
padrões que contrastam com os da linguagem corrente, contaminada de
barbarismos.

Com efeito, parece-nos adequado dizer que a palavra que melhor sintetiza os objetivos originais da gramática tradicional é "correção", já que tinha como função transmitir às futuras gerações o que era "considerado excelente" em termos de língua e assim preservá-la dos "barbarismos da língua corrente".

Das 51 gramáticas escolares, conseguimos compilar 27 definições de gramática. Essa diferença se explica por não termos tido acesso a todas as obras e também pelo fato de alguns autores não incluírem tais definições em seus trabalhos. A tabela completa com todas as definições pode ser consultada no apêndice B (Quadro 2B). 
Desse universo de 27 conceituações a respeito do que vem a ser gramática, 19 contêm termos como "regras" e/ou "falar e escrever corretamente". Todas elas, a despeito de variações individuais, reproduzem o que podemos ver na definição de Carreiro (1918, p.23, sublinhamos): "A Grammatica portugueza é o conjunto das regras que se devem seguir para bem falar e escrever a lingua portugueza". Vejamos outras ocorrências: "A lingua está sujeita a uma disciplina ou norma. Essa disciplina ou norma chama-se "Grammatica”. Portanto: Grammatica é a norma para falar ou escrever bem uma lingua. (GÓES, 1929, p.6, sublinhamos) e ainda "Gramática (do grego gramma: letra) é a arte que ensina a ler, escrever e falar corretamente uma língua, isto é, é a sistematização dos fatos de uma linguagem comum a um povo. (CARVALHO, 1948, p.17, sublinhamos)

Tomando apenas as definições, há bastante aderência das gramáticas escolares completas do início do século XX com a tradição greco-latina. Resta-nos, agora, verificar se essa opção pelo trabalho com as regras e com ofalar e escrever corretamente são, de fato, postos em prática nos textos gramaticais dessas 51 gramáticas.

$\mathrm{O}$ exame que realizamos nos mostra que sim, mas vejamos algumas passagens que comprovam tal relação. Analisando as funções da palavra que, Carvalho (1948) diz que essa palavra pode assumir o papel de substantivo, adjetivo, pronome ou conjunção. Ao analisar as possibilidades do que quando ele é um pronome, o autor diz que:

[...] c) pronome indefinido, quando de um modo vago substitui um substantivo: Tenho que fazer, tens que escrever. Advertência - Em tais formas de conjugação perifrástica, quando o complemento exigido pela predicação do verbo infinitivo, vem claro, é correto o emprego da preposição de parte integrante da expressão verbal:

Tenho de escrever uma carta, tenho de esclarecer tudo, etc.

Daí ainda se concebe que só se deve empregar que, com os verbos transitivos; de que, com os relativos ou bitransitivos; quando os complementos exigidos pela predicação do verbo estiverem ocultos:

Tenho que escrever, tenho de que depender, tenho de que me lembrar, etc.

Com os verbos que exprimem movimento e exigem complementos terminativos de procedência ou de direção, só se há de empregar $d e$, e não que:

Tenho ou hei $d e$ ir, tenho $d e$ ir à cidade, tem $d e$ vir do campo, etc. (CARVALHO, 1948 , p. 286-287, itálicos do autor)

Feita a devida prescrição da norma, isto é, qual deve ser o uso correto do que nessas circunstâncias, o autor apresenta alguns óbices ao uso do que no lugar do de. 
Eis o que diz L. Vasconcelos, lente na U. de Lisboa:

"Deve dizer-se: tenho de ir lá, tenho de escrever uma carta, e não: tenho que ir lá, tenho que escrever uma carta. O êrro provém da analogia com - tenho que fazer, tenho que escrever, mas aquí o que é pronome e serve de objeto direto ao infinitivo".

Não obstante isso, encontramos em bons autores, exemplos que nos obrigam a analisar o que como preposição:

"Falando do Tejo, como temos que lhe chamar rio".

(Cândido de Figueiredo. L. P. P., I Volume, pg. 49).

"Tenho que ousar aquí uma apologia ..."

(A. F. Castilho, Colóquios Aldeões).

"Temos porém que prevenir tudo".

(R. Barbosa, Queda do Império, I tomo, pg. 69).

Tais construções acidentais, usadas por estes e outros mestres, não deixam de ir de encontro às boas regras de análise, e têm dado margem a que alguns mestres, por admiração, respeito ou acanhamento, se esquivem de dá-las por erradas: criam convenções. (CARVALHO, 1948, p. 287, itálicos do autor)

Na sequência, após criticar o uso da partícula que que fazem, inclusive os "bons mestres", Carvalho continua em suas críticas e no reforço à norma gramatical.

Não se escuda, em lei alguma, o emprêgo do que para substituir a preposição de em tais formas verbais. O que encontramos na gramática, é:

tenho ou hei de fazer,

tens ou hás de fazer,

tem ou há de escrever, etc.

Observa-se claramente que é o de e não o que, a parte integrante da composição verbal. Abstenhamo-nos por isso, do emprêgo do que; tôdas as vezes em que êle não figurar como complemento do infinitivo. (CARVALHO, 1948, p. 287, itálicos do autor)

Nesses excertos, fica clara a força da tradição gramatical no texto de Carvalho, além de ser perceptível qual é a visão de língua presente nesta obra. Com efeito, podemos dizer que tal visão é aquela que enxerga na gramática um instrumento para a transmissão do "falar e escrever corretamente", tal como consta na definição de gramática que reproduzimos anteriormente. Esta preocupação com aquilo que considera correto, isto é, com a norma linguística subjetiva 
(COSERIU, 1979), é bastante intensa, inclusive pela censura que o gramático faz a respeito do uso da partícula que em alguns bons autores, segundo suas próprias palavras.

Vejamos essa questão do "falar e escrever corretamente" em outra gramática, a de Cruz (1947). Também analisando as funções da partícula que, o autor apresenta 21 possibilidades. Na décima segunda, local em que fala do que como conjunção consecutiva, o gramático apresenta a seguinte prescrição:

12) Conjunção consecutiva. Ex.: É de tal maneira idiota que todos se riem dêle. Na expressão de Eça de Queirós, que se encontra em "A Cidade e as Serras", na pág. 75 , rijas que nem cerdas, o que é conjunção consecutiva. A expressão é igual a: (tão) rijas que nem cerdas são tão rijas. São muito comuns expressões, como esta, em português. A expressão: êle é que nem eu não é vernácula. (CRUZ, 1947, p.125126, itálicos do autor e sublinhado nosso)

Ao destacar a não vernaculidade da expressão "êle é que nem eu", porém tendo o cuidado de salvaguardar um uso que ao consulente da gramática poderia soar igual e que fora utilizado por Eça de Queirós, “rijas que nem cerdas”, Cruz explicita a visão de língua que está presente em sua obra, que é, efetivamente, a de prescrever uma norma linguística subjetiva (COSERIU, 1979) com o fito de ensinar "falar e escrever corretamente".

Tanto estas obras e seus respectivos trechos quanto outras que poderíamos aqui reproduzir confirmam e destacam a força da tradição gramatical greco-latina quanto ao seu papel de registrar e transmitir uma norma linguística considerada correta. Tal ligação com a tradição é perceptível nas 27 gramáticas escolares que reunimos neste grupo e constituem, portanto, a principal característica de sua camada teórica.

Por fim, vejamos um caso em que a retórica do autor (MURRAY, 1994), manifestada na definição que ele dá para gramática, não encontra eco naquilo que ele acaba, de fato, realizando em seu trabalho, ou seja, um caso em que a intenção do autor não se coaduna com a sua prática. Casos como este que mostraremos a seguir evidenciam a força e a presença da tradição greco-latina na gramaticografia escolar novecentista, pois mesmo quando o autor tem críticas à gramática tradicional e as manifesta no início de seu trabalho, como nos prefácios, advertências e demais textos introdutórios, ele não consegue se desvencilhar da tradição ao escrever sua obra, caindo, assim, em contradição.

Já lá se foram os ominosos tempos em que a Grammatica era considerada $a$ arte de ensinar a falar e escrever correctamente; hoje tal definição seria o maior dos absurdos ou illogismo. Grammatica, em sentido lato, é o codice da linguagem natural de um ou mais povos, presos ao mesmo idioma. Grammatica, em sentido estricto, não tem por fim ensinar a falar e a escrever correctamente, não; apenas reune umas tantas regras que servem de base ao grande edificio da linguagem, a 
qual se inicia na familia, se desenvolve no convivio social e se consolida na acurada leitura dos classicos. (ANDRADE, 1935, p.I-II, itálicos do autor)

O autor, apesar de rejeitar peremptoriamente a ligação da gramática com o ensino do "falar e escrever corretamente", acabou elaborando uma gramática que pouco difere da tradição, portanto das demais obras analisadas neste grupo. Ao falar de concordância nominal, há um tópico específico para o "adjectivo attributivo", que é assim analisado pelo autor:

$\mathrm{O}$ adjectivo atributivo, referindo-se a dois ou mais substantivos do mesmo genero, e do mesmo numero, vae para o plural, ex..: A dhalia e a rosa brancas. $\mathrm{O}$ adjectivo, referindo-se a dois ou mais substantivos, ambos do singular, mas de generos differentes, vae para o plural, masculino: O cravo e a rosa brancos. Neste caso, deve-se collocar o substantivo do genero masculino, em ultimo lugar: A rosa e o cravo brancos. $\mathrm{O}$ adjectivo, referindo-se a dois ou mais substantivos do plural, mas de generos differentes, vae para o plural, concordando com o ultimo substantivo: Os cravos e as rosas brancas ou As rosas e os cravos brancos. O adjectivo, referindo-se a dois ou mais substantivos synonymos, concorda com o ultimo: A alegria e o contentamento manifesto ou $\mathrm{O}$ contentamento e alegria manifesta. Dois ou mais adjectivos, modificando a um substantivo, para com este formar locuções, o primeiro fica invariavel, concordando apenas o ultimo: Alliança-luzo-brasileira. (ANDRADE, 1935, p.130-131, itálicos do autor)

Podemos notar que o autor, nesse excerto, realiza a prescrição justamente ensinando o que é certo e o que é errado, segundo a tradição gramatical. As regras por ele apresentadas, diferentemente do que enuncia no Prólogo de sua gramática, nada têm de naturais, não são o registro das regras naturais de funcionamento do Português. Representam, sim, convenções normativas da tradição gramatical. Tal artificialismo pode ser especialmente notado na regra que estabelece que a concordância nominal de dois ou mais nomes de gêneros diferentes deve ser feita seguindo o gênero masculino. $\mathrm{O}$ autor exemplifica com a seguinte frase: "O cravo e a rosa brancos". Evidentemente que não há nada na estrutura gramatical no Português que impeça construções como "A rosa e o cravo brancas" ou "O cravo e a rosa brancas". Tais sentenças não são agramaticais e só não são ditas quando se consideram as restrições de ordem normativa. Ao definir gramática, Andrade (1935) parece colocá-la próxima daquilo que hoje chamamos de gramática descritiva, rechaçando vinculá-la à gramática normativa, segundo a nomenclatura contemporânea. No entanto, apesar do autor ter uma retórica que pregava a renovação dos objetivos gramática, o que a análise de seu texto revela é que ele não conseguiu colocar em prática aquilo que anunciara.

Outras passagens da gramática também comprovam essa nossa afirmação, como o capítulo de "vicios de linguagem", no qual o autor condena sentenças como: "Elle descasca 
melão p'ra comer" (cacophato), "A mascara fingida do rosto" (perissologia), "Eu lhe esperei hontem" e "Houveram muitas descargas" (solecismo). (ANDRADE, 1935, p.156, itálicos do autor)

\subsubsection{Camada documental}

Feitas as análises relativas à camada teórica do programa gramatical, vejamos agora quais são as principais características ligadas à camada documental. Swiggers (2004, p.134) define essa camada como a que investiga os aspectos relativos à "documentación lingüística y filológica (número de lenguas, tipos de fuentes y de datos) sobre la cual se basa el estudio lingüístico".

No caso das gramáticas escolares completas analisadas nesta seção, podemos afirmar que, ao estudar essa camada, estamos investigando qual foi o tipo de corpus linguístico recrutado pelo gramático para realizar seu trabalho.

Dissemos no início deste capítulo, que a gramática tradicional, desde sua origem, utilizou-se de textos literários antigos para apontar qual era o modelo de língua a ser seguido por aqueles que desejassem se expressar "corretamente". Vejamos, agora, em que medida encontramos ou não esse perfil nas gramáticas escolares do início do século XX.

\section{Plural de adjetivos, que indicam côr}

1) adjetivos compostos de 2 adjetivos:

Em geral, o $1 .^{\circ}$ adjetivo fica invariável, no masculino do singular; o $2 .^{\circ}$ concorda com o substantivo.

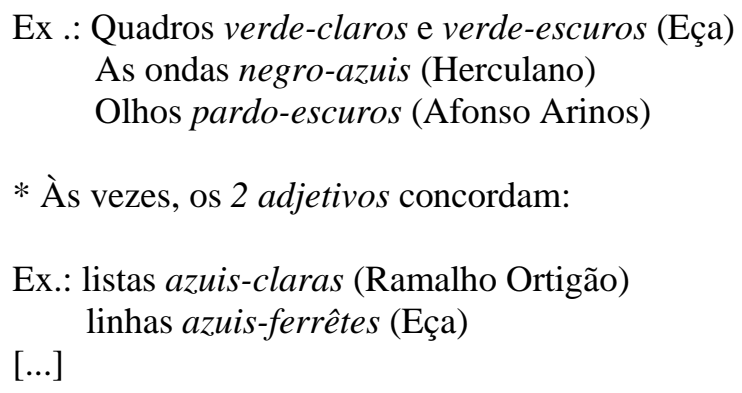

2) expressões adjetivas compostas (1 adjetivo, que indica côr e 1 substantivo, que lhe restringe a significação). Ficam invariáveis.

Ex.: ramagens verde-garrafa (Eça) um par de luvas verde-gaio (Camilo) 
NOTA: Encontram-se exceções a estas regras nos escritores. O que é comum, porém, na nossa língua é usar-se a preposição de; ou as locuções de côr, da côr de, côr de:

Ex.: $\left\{\begin{array}{l}\text { ramagens da côr verde de garrafa } \\ \text { um par de luvas da côr verde de gaio } \\ \text { Olhos de verde-mar (Gonçalves Dias) } \\ \text { Olhos côr de esperança (Gonçalves Dias) } \\ \text { Olhos verdes da côr do prado (Gonçalves Dias) }\end{array}\right.$

(Exemplos colhidos em "Trechos seletos", de um ponto de Sousa da Silveira). (CRUZ 1947, p.47, itálicos do autor e sublinhado nosso)

O trecho que reproduzimos acima é representativo de algo que frequentemente encontramos nas gramáticas deste grupo, isto é, depois de feita a prescrição da norma linguística, é apresentado um exemplo extraído de alguma obra literária de prestígio. É evidente que tal estratégia confere maior credibilidade ao texto gramatical, uma vez que a formulação de uma determinada norma, por exemplo, não seria fruto da inventividade ou capricho do gramático (como no caso dos "exemplos forjados"), mas referendada por autores já consagrados por bem manusear o Português. Com efeito, tal expediente funciona como um eficiente discurso de autoridade em favor da prescrição gramatical.

Muitas gramáticas apresentam quadros em que listam os autores que serviram para a composição de seu exemplário, acompanhadas ou não de suas respectivas obras. Vejamos um exemplo desse procedimento.

Quadro 6 - Relação de literatos usados na Grammatica expositiva, de Eduardo Carlos Pereira

\section{Auctoridades classicas que amplamente auctorizam as theorias desta GRAMMATICA}

\begin{tabular}{|lr|}
\hline A. H. - Alexandre Herculano. & $*$ [século XIX, Portugal] \\
\hline A. C. - Antonio Feliciano de Castilho. & [século XIX, Portugal] \\
\hline L. C. - José Maria Latino Coelho. & [século XIX, Portugal] \\
\hline G. - João Baptista da Silva Leitão d'Almeida Garret. & [século XIX, Portugal] \\
\hline G. D. - A. Gonçalves Dias. & [século XIX, Brasil] \\
\hline O. M. - M. Odorico Mendes. & [século XIX, Brasil] \\
\hline F. Lisboa - João Francisco Lisboa. & [século XIX, Brasil] \\
\hline R. S. - Luiz Augusto Rabello da Silva. & [século XIX, Portugal] \\
\hline
\end{tabular}


C. C. B. - Camillo Castello Branco.

[século XIX, Portugal]

F. E. - Filinto Elysio, Francisco Manoel do Nascimento. [séculos XVIII- XIX, Portugal]

A. P. - Padre Antonio Pereira. [século XIX, Brasil]

A. V. - Padre Antonio Vieira. [século XVII, Portugal]

A. de F. - Arte de Furtar, attribuida a A. V. [século XVII, Portugal]

M. B. - Padre Manoel Bernardes. [séculos XVII-XVIII, Portugal]

L. S. - Fr. Luiz de Souza. [séculos XVI-XVII, Portugal]

J. Freire - Jacintho Freire de Andrade. [séculos XVI-XVII, Portugal]

F. M. - D. Francisco Manoel de Mello. [século XVII, Portugal]

S. de Menezes - Sá de Menezes. [século XVII, Portugal]

F. R. L. - Francisco Rodrigues Lobo. [séculos XVI-XVII, Portugal]

C. - Luiz de Camões. [século XVI, Portugal]

G. V. - Gil Vicente. [séculos XV-XVI, Portugal]

Nota. - M. M. quer dizer Marquez de Maricá.

*[ ] = As informações referentes ao século e à nacionalidade dos autores foram por nós inseridas. Fonte: Pereira (1913, p.VII).

Ao analisarmos a composição do exemplário da gramática de Eduardo Carlos Pereira, algumas características saltam aos olhos. A primeira é que $81 \%$ dos autores utilizados são portugueses. Quanto à antiguidade dessas obras, a preponderância é de autores do século XIX. Fazendo uma separação mais pormenorizada, chegamos ao seguinte cenário: 11 autores do século XIX (52\%), 7 do século XVII (33\%), 4 do século XVI (19\%), 2 do século XVIII (9,5\%) e 1 do século XV (4,8\%). Casos como o de Francisco Rodrigues Lobo, que viveu entre os séculos XVIXVII, foram registrados nos dois séculos correspondentes.

Com tais características apontadas acima, podemos dizer que o corpus dessa gramática é essencialmente formado a partir de textos literários portugueses antigos, considerando que predominam os textos escritos nos séculos XVII e XIX.

Analisando as conjunções subordinativas, Eduardo Carlos Pereira destaca que são de oito tipos diferentes. Vejamos alguns exemplos de abonação literária em sua gramática a partir de dois tipos de conjunção:

$3^{\text {a }}$ Causaes, que ligam exprimindo circumstancia de causa ou motivo: porque, que (= porque), pois que, porquanto, visto que, visto como, uma vez que, como, já que, de modo que. Exs.: 
A flor encanta, porque é bella - Elle foi absolvido, porquanto se justificou - Não mais, ó Musa, não mais, que a lyra tenho destemperada, e a voz enrouquecida (C.) - Ella existe, visto que eu existia (A.C.) - Exijo-o, uma vez que assim o quer Como temos opportunidade, examinemos o caso - Já que assim o querem, assim o tenham - Elle guardou, de modo que não lhe viesse a faltar.

$4^{\mathrm{a}}$ Finaes, que ligam exprimindo uma circumstancia de fim: para que, que (= para que), afim de que. Exs.:

Agora tracta de dispor as coisas, para que não seja um dia inutil o dia de amanhã (A.H.) - Tu que as gentes da terra tudo enfreias, que (= para que) não passem o termo limitado (C.). (Pereira, 1913, p.151, itálicos do autor e negritos nossos)

Como já dissemos, além das referências literárias, outra estratégia bastante frequente nas gramáticas tradicionais é a utilização dos exemplos forjados, isto é, aqueles que são formulados pelo próprio gramático a fim de exemplificar aquilo que antes havia prescrito na teoria. Esses casos podem ser assim classificados sempre que não há alguma referência a autor e/ou obra depois de um exemplo dado pelo gramático. Nos trechos acima, as frases que foram retiradas de obras literárias vêm com a sigla de seu autor entre parênteses, já as que foram inventadas pelo autor da gramática estão sem nenhuma referência. Isso pode ser visto também no item das conjunções condicionais, que, diferentemente das causais e finais, foram exemplificadas apenas com exemplos forjados.

$2^{\mathrm{a}}$ Condicionaes, que ligam exprimindo uma condição; se, salvo se, excepto se, com tanto que, sem que, a não ser que, a menos que. Exs.:

Irei, se puder - Não farei, salvo se elle ordenar - La estarei, excepto se for impedido - Farei, com tanto que elle não se opponha. - Não começarei, sem que elle esteja presente -Vou, a não ser que seja impedido - Não sahirei, a menos que elle chegue. (Pereira, 1913, p.151, itálicos do autor)

Com efeito, as características que aqui apresentamos a respeito da camada documental das gramáticas escolares completas parecem confirmar aquilo que já mencionamos a respeito dos objetivos da gramática tradicional desde sua origem, ou seja, a prescrição de uma norma linguística considerada correta, que era assim classificada por estar de acordo com os registros que eram encontrados em uma determinada tradição literária. Mais uma vez, transcreveremos as palavras de Neves (2002, p. 49), pois elas servem para confirmar a destacada influência da tradição gramatical clássica na gramaticografia brasileira do início do século XX. 
A disciplina gramatical aparece na época helenística [...]. Nessa época o que se procura é, acima de tudo, transmitir patrimônio literário grego, privilegiando-se, como atividade cultural, o exame das grandes obras do passado. O objetivo de tal atividade é oferecer os padrões da linguagem dessas obras consideradas excelentes, padrões que contrastam com os da linguagem corrente, contaminada de barbarismos.

Feitas as considerações a respeito da camada documental, é necessário que façamos agora a análise da camada técnica. Faremos um levantamento das características dessa camada, além de verificar se as técnicas utilizadas pelas gramáticas do início do século XX também estão bastante ligadas à tradição gramatical.

\subsubsection{Camada técnica}

Como já dissemos algumas vezes, a camada técnica é definida por Swiggers (2004, p.134) como "as técnicas de análise (linguístico/gramatical) e os métodos de apresentação dos dados".

O primeiro aspecto da camada técnica que analisaremos é o relativo às partes da gramática, ou seja, de que forma, no início do século XX, a língua era segmentada no âmbito dos estudos gramaticais. Das 51 gramáticas que formam o grupo das gramáticas escolares completas, conseguimos coletar informações de 23 obras, cuja reprodução integral pode ser consultada, no apêndice B (Quadro 3B), sob o título "O estudo da gramática e suas divisões". Outras 8 gramáticas espelham-se na estruturação dos programas de ensino, o que faz com que elas sejam exatamente iguais quanto à forma de organizar e apresentar o conteúdo gramatical.

No primeiro grupo, isto é, o das 23 gramáticas, constatamos que a divisão bipartite em lexeologia e sintaxe é a mais adotada, já que a encontramos em 16 obras. Uma divisão tripartite em fonologia, morfologia e sintaxe é vista em apenas 4 gramáticas. Encontramos também 2 autores que se valeram de uma estruturação quadripartite, em que além da fonologia, morfologia e sintaxe incluem a semiologia, no caso de um gramático, e a lexiologia à parte da morfologia, no caso do outro. Finalmente, 1 gramática não registra tais informações em seu texto. 
Com efeito, apesar de termos indicado que as gramáticas da época tinham preferência por dividir os estudos gramaticais em lexiologia e syntaxe ${ }^{26}$, ao analisarmos as outras 6 formas variantes, vimos que não há grandes diferenças teórico-metodológicas entre elas, já que todas assumem que os estudos gramaticais devem ser divididos em duas partes: a palavra e a frase. A ligeira divergência está justamente na abrangência da lexiologia. Para os 16 gramáticos que adotam a divisão bipartite, a lexiologia deve estudar a palavra sob dois enfoques: o som e a forma. Alguns autores incluem também o sentido. Já para os 4 gramáticos que adotam a divisão tripartite, a phonologia/phonetica tem autonomia frente à lexiologia, devendo assim constituir uma parte autônoma da gramática.

É importante lembrarmos que todas as gramáticas estudadas nesta tese foram publicadas antes da Nomenclatura Gramatical Brasileira ${ }^{27}$ (doravante, NGB), o que pode explicar essas pequenas variações entre os autores. Foi a NGB que, em 1959, padronizou a classificação e a estruturação que as gramáticas brasileiras deveriam seguir. A divisão tripartite, por exemplo, foi adotada pela NGB e, a partir de então, utilizada por todas as gramáticas e demais materiais que tratavam desse assunto, como aqueles usados nas escolas, por exemplo.

Também encontramos diferenças entre autores quanto à classificação e à estruturação no interior das partes da gramática, ou seja, da lexiologia e da syntaxe. Para Pereira (1933), por exemplo, a morfologia subdivide-se em três partes: taxinomia, camptologia (ou campenomia ou flexismo) e tematologia. Para o autor, essas áreas estudam, respectivamente, "a classificação das palavras", "a flexão das palavras" e "os processos vernáculos de derivação e composição". Andrade (1911), por sua vez, divide a morphologia em duas partes: a taxinomia e a campenomia, classificando-as da mesma forma que Pereira, mas nada fala a respeito da tematologia. Também dividindo a lexeologia em duas partes, Carvalho (1945) propõe a divisão em taxeonomia e etimologia, sendo a primeira o "estudo da palavra de acordo com a categoria gramatical a que pertence" e a segunda o "estudo da origem e construção das palavras". Há ainda outras variações entre os autores, mas nenhuma delas representa uma mudança significativa na forma de se estudar a gramática, ou, em outros termos, algo que aponte para diferentes camadas técnicas. Isso pode ser comprovado, inclusive, ao se verificar as definições que os autores dão para a lexiologia/morfologia: todos apontam que essa é a parte da gramática responsável por estudar as palavras isoladamente. Como já dissemos, as variações se dão, basicamente, nas subdivisões, ou

\footnotetext{
${ }^{26}$ Alguns autores grafam "sintaxe".

${ }^{27}$ A NGB foi instituída pela portaria do MEC no 36, de 28 de janeiro de 1959.
} 
seja, na forma como cada autor enxerga que a palavra deve ser estudada, considerando seus aspectos sonoros, formais e de sentido.

Vejamos alguns exemplos de divisão das partes da gramática. Lembramos novamente que os dados completos podem ser consultados no apêndice B (Quadro 3B).

Figura 3 - Estruturação da Grammatica portugueza, de Julio Pires Ferreira

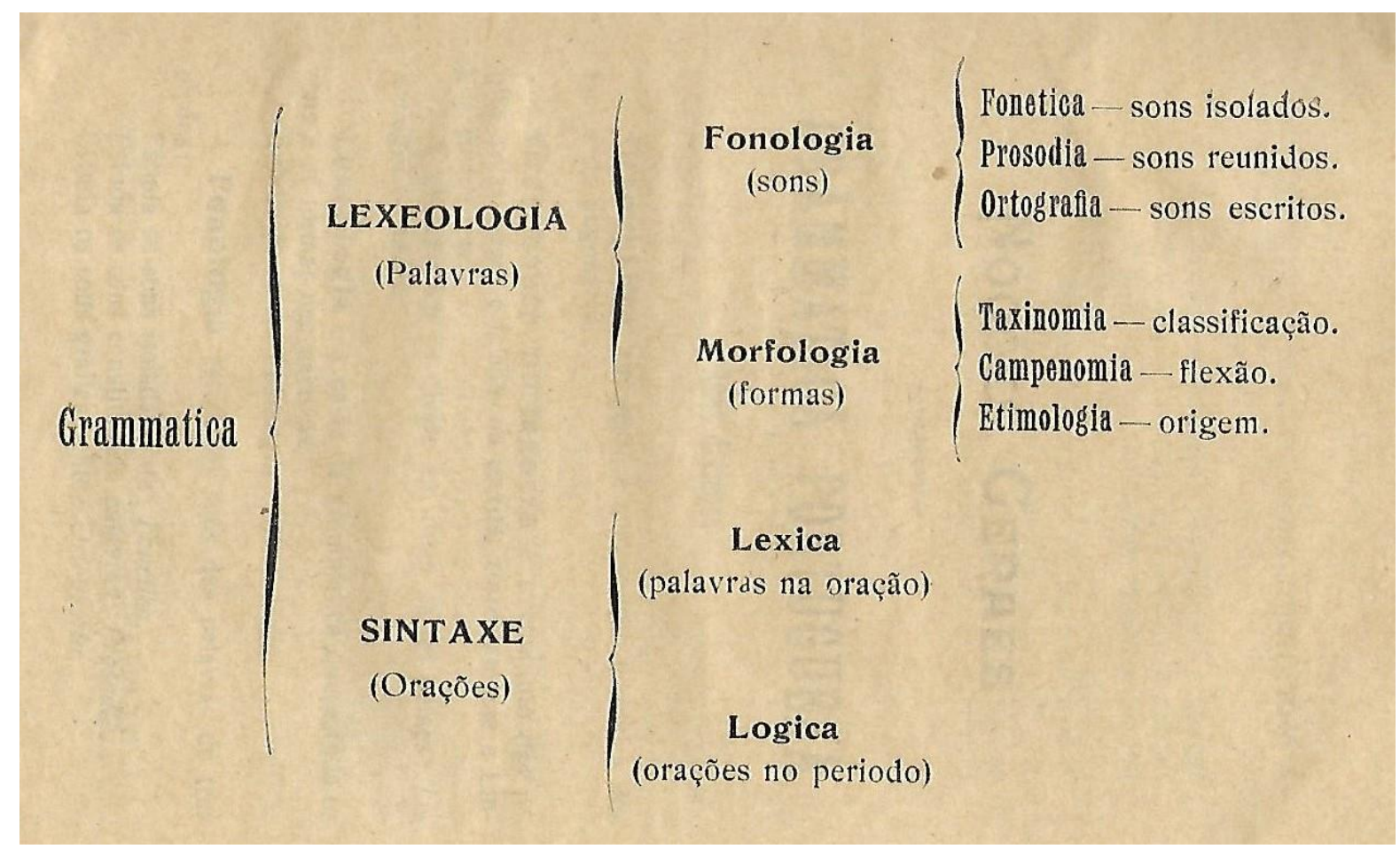

Fonte: Ferreira (1921, p.3). 
Figura 4 - Estruturação das Breves noções de Grammatica portugueza, de Achilles Alves

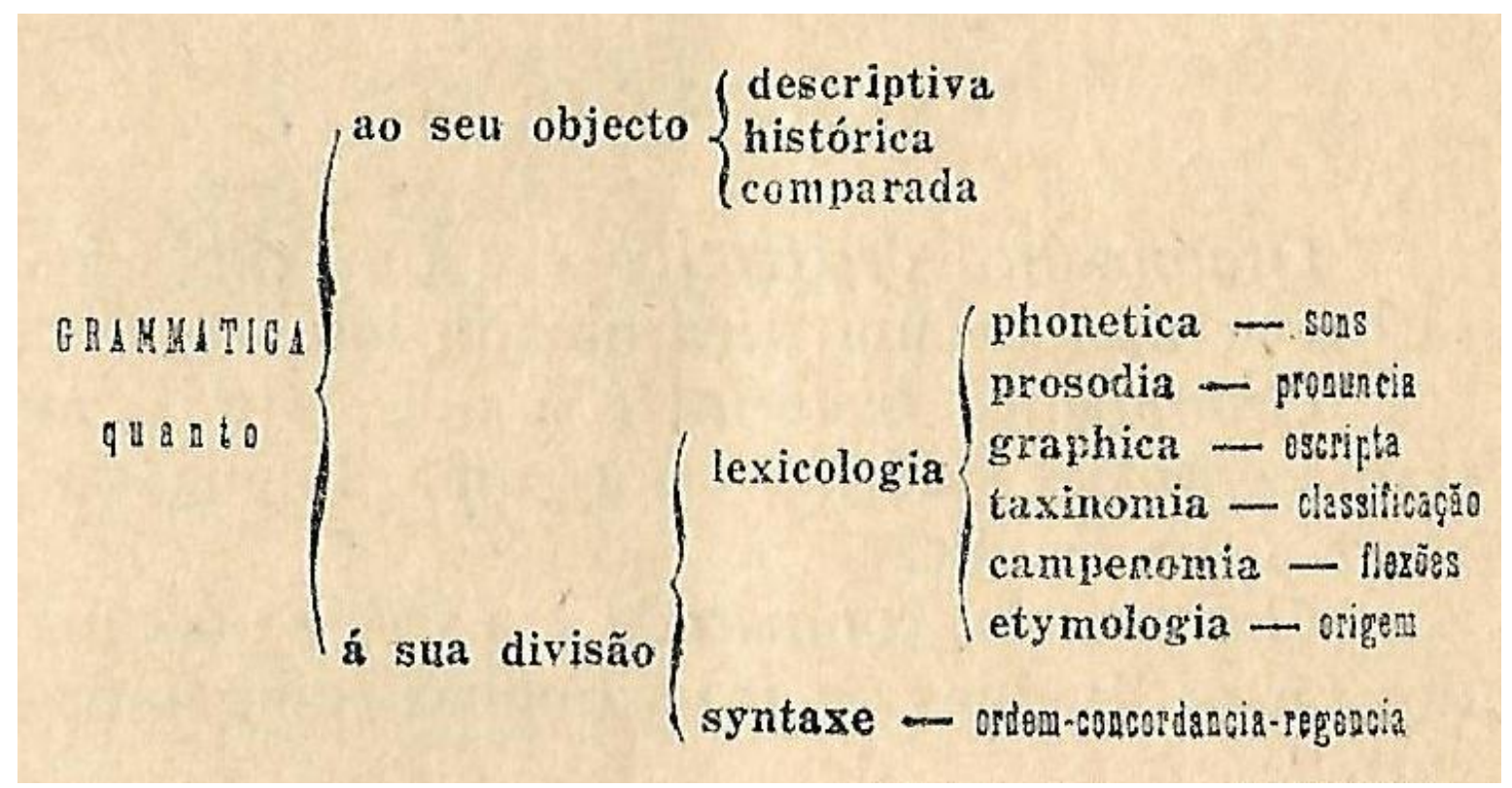

Fonte: Alves (1936, p.13).

Figura 5 - Estruturação da Gramática ginasial, de José Mesquita de Carvalho

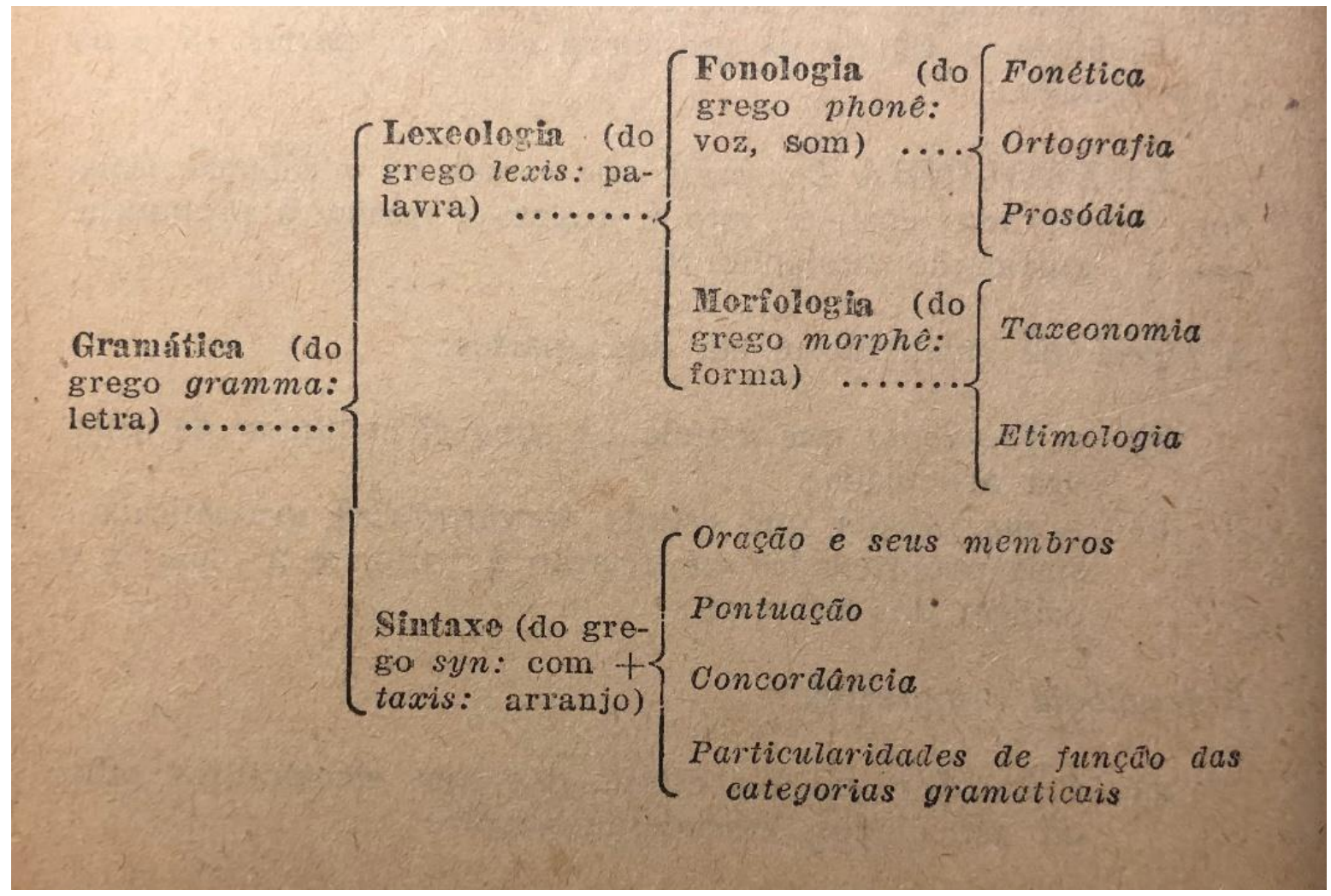

Fonte: Carvalho (1945, p.18). 
Figura 6 - Estruturação das Lições elementares de Lingua Portugueza, de Maximino Maciel

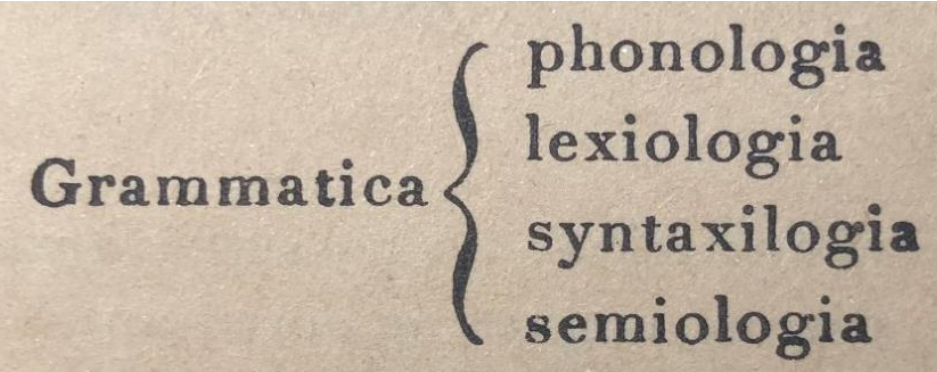

Fonte: Maciel (1938, p.11).

Feitas as considerações mais gerais a respeito da camada técnica, vejamos agora como eram desenvolvidos os estudos gramaticais no interior de cada parte da gramática. Dito de outra forma, veremos o que significava, na época, fazer lexiologia, phonologia, syntaxe, etc.

No nível da palavra, que a depender do autor era chamado de lexiologia ou de morphologia, o levantamento que fizemos (cf. apêndice B - Quadro 3B) mostrou que tais estudos eram predominantemente divididos em três partes: um dedicado ao processo de classificação (também chamada de taxeonomia), outro destinado ao estudo da flexão nominal e verbal (campenomia, camptologia ou flexismo) e outro dedicado aos estudos históricos e formativos do Português (etymologia ou tematologia).

Na classificação, as gramáticas traziam as análises referentes às classes de palavras, cuja quantidade variava segundo o autor.

Tabela 4 - Quantidade de classes de palavras nas gramáticas escolares

\begin{tabular}{|c|c|}
\hline 10 classes & $\begin{array}{l}\text { Nomes substantivos e adjectivos, pronomes, verbos, adverbios, preposições, } \\
\text { conjunções, interjeições, numeraes e artigos. (ALI, 1923, grifamos) }\end{array}$ \\
\hline 9 classes & $\begin{array}{l}\text { Nomes substantivos e adjectivos, pronomes, verbos, adverbios, preposições, } \\
\text { conjunções, interjeições e numeraes. (RODRIGUES, 1935, grifamos) }\end{array}$ \\
\hline 9 classes & $\begin{array}{l}\text { o substantivo, o adjectivo, o pronome, o verbo, adverbio, a preposição, a } \\
\text { conjuncção, interjeição e o artigo. (VIEIRA, 1922, grifamos) }\end{array}$ \\
\hline 8 classes & $\begin{array}{l}\text { substantivo, adjectivo, pronome, verbo, adverbio, preposição, conjuncção e } \\
\text { interjeição. (CARREIRO, 1918); (FREITAS COUTINHO, 1909); } \\
\text { (FREITAS, 1952 [1927]); (MORAIS, 1944_2 }{ }^{\mathrm{a} e d .) ;} \text { (BRITO PEREIRA, } \\
\text { 1933); (PINTO, 1907); (ALVES, 1936_5aed.); (MACIEL, 1903); } \\
\text { (MACEDO COUTINHO, 1939_8 }{ }^{\mathrm{a} e d .) ; ~(P E R E I R A, ~ 1908) ; ~(C A R V A L H O, ~} \\
\text { 1945); (ABREU, 1944); (SAMPAIO, 1932); (FERREIRA, s/d); (GÓES, } \\
\text { 1928). }\end{array}$ \\
\hline
\end{tabular}




\begin{tabular}{|l|l|}
\hline 7 classes & $\begin{array}{l}\text { substantivo, adjetivo, pronome, verbo, advérbio, preposição, conjunção. } \\
\text { (RÉVEILLEAU, 1938) }\end{array}$ \\
\hline 6 classes & $\begin{array}{l}\text { substantivo, adjectivo, verbo, adverbio, connectivo e contraccão, sendo esta } \\
\text { ultima apenas uma combinação de palavras. (COSTA, 1920) }\end{array}$ \\
\hline TOTAIS & $\begin{array}{l}10 \text { classes }=1 \text { autor } \\
9 \text { classes }=2 \text { autores } \\
\mathbf{8} \text { classes }=\mathbf{1 5} \text { autores } \\
7 \text { classes }=1 \text { autor } \\
6 \text { classes }=1 \text { autor }\end{array}$ \\
\hline
\end{tabular}

Como pode ser visto no quadro, a quase totalidade dos gramáticos considerava que as classes de palavras são oito: substantivo, adjectivo, pronome, verbo, adverbio, preposição, conjuncção e interjeição. Essa composição nos mostra que poucos autores da época consideravam o artigo e o numeral como classes de palavras. Essas pequenas variações existentes, como já dissemos, pode ser explicada pela ausência de padronização na descrição gramatical, o que ocorrerá apenas com a NGB, em 1959.

Quanto à campenomia, camptologia ou flexismo, as gramáticas, no caso das categorias nominais, apresentam estudos das flexões de gênero, número e grau (alguns autores não consideravam o grau) e, no caso dos verbos, das flexões de pessoa, número, modo e tempo.

Já na etymologia ou tematologia, o que encontramos, basicamente, foi o estudo dos processos de formação das palavras. Tal estudo é desenvolvido em tópicos como: radical (tema), raiz, prefixo, sufixo, palavras primitivas e derivadas, processos de derivação e composição, parassíntese, listas com afixos e radicais grecos e latinos.

Há ainda outra dimensão da palavra que precisa ser analisada, que é aquela relativa ao seu som, chamada de fonologia ou fonética, a depender do gramático. Como já apontamos aqui, a maioria dos autores adota da divisão bipartite da gramática, o que significa dizer que a fonologia/fonética não é vista como um nível autônomo, mas sim como uma parte da lexeologia. Independentemente de como cada autor enxerga essa questão, o levantamento que fizemos (cf. apêndice B - Quadro 3B) mostrou que a visão predominante, neste grupo de gramáticas escolares, é o de dividir os estudos relativos ao som, que a maioria chama de fonologia, da seguinte forma: fonética, prosódia e ortografia. Nessa separação, a fonética é a responsável pelos

\footnotetext{
${ }^{28}$ No caso de autores que têm mais de uma gramática, como as de nível elementar e secundário, por exemplo, consideramos apenas uma delas, já que os autores repetem o mesmo posicionamento em ambos os volumes.
} 
estudos dos sons considerados por si só, isto é, isoladamente. Já a prosódia se ocupa do estudo da pronúncia correta das palavras e a ortografia estabelece como elas devem ser corretamente grafadas.

Feitas as considerações a respeito da lexeologia, passemos à análise de como a sintaxe era concebida e estudada nas gramáticas escolares da época. Falamos algumas vezes aqui da multiplicidade de nomenclaturas e de divisões do estudo da gramática no período pré-NGB e no caso da sintaxe ocorreu o mesmo. Em função disso, em um primeiro momento, pode parecer que essas gramáticas realizam suas análises de forma totalmente distinta umas das outras. No entanto, independentemente dessas variações, pretendemos aqui apontar concepções e práticas sintáticas preponderantes neste grupo de gramáticas.

Quanto à atuação da sintaxe, a visão preponderante é a de que a sintaxe estuda dois processos: (i) a relação das palavras entre si, o que forma as orações (ou proposições, ou frases) e (ii) a relação das orações entre si, o que forma o período. A esse primeiro processo, algumas gramáticas atribuem o nome de análise léxica (ou syntaxe relacional) e, ao segundo, análise lógica ou freseológica (ou syntaxe phraseologica).

Com efeito, podemos dizer que há aí uma visão que estrutura o processo sintático a partir do nível de complexidade envolvido. Assim, as gramáticas iniciam seus estudos de sintaxe a partir da oração, que é definida, basicamente, como a unidade em que se afirma, nega ou interroga algo ou como a combinação de palavras para se expressar um pensamento, a depender da obra consultada. A oração é estruturada a partir de duas partes: o sujeito e o predicado (algumas gramáticas incluem o complemento).

Ao olharmos para as seções de sintaxe das gramáticas escolares completas, veremos que, a despeito das diferentes classificações, os estudos são estruturados considerando os dois processos já mencionados, ou seja, (i) análise das relações no interior da oração apenas e (ii) estudo as relações no período, isto é, quando se tem duas ou mais orações. É justamente nesse universo oração/período que os seguintes tópicos são estudados: sintaxe de regência, sintaxe de construção (ou colocação), sintaxe de concordância (nominal e verbal), sintaxe relacional, sintaxe fraseológica, pontuação, as relações de coordenação e subordinação.

É importante sublinharmos que todas as gramáticas estudadas destacam que é a sintaxe a responsável por interconectar todos os elementos da oração, lembrando que se antes, na lexeologia, as palavras eram estudadas isoladamente, agora, na sintaxe, elas são estudadas a partir da sua função dentro da oração. Essa ideia pode ser vista em Carreiro (1918, p. 34, itálicos do 
autor) da seguinte forma: "O estudo da Syntaxe não pode ser feito em separado do estudo das outras partes: depende do da Morphologia e tem estreita relação com o da Lexicologia".

No início desta seção, dissemos que há 8 gramáticas que organizam os tópicos gramaticais utilizando a mesma sequência proposta pelos programas de ensino ${ }^{29}$. Assim, não encontraremos a sequência que normalmente as gramáticas seguem, ou seja, primeiro os estudos relativos ao som, depois à palavra e, finalmente, à frase. O primeiro ano de Secundário, por exemplo, começa os estudos gramaticais com os tópicos “oração; sujeito e predicado; oração sem sujeito, oração sem verbo", que são assuntos de natureza sintática. Dessa forma, essas 8 gramáticas começam, logo no capítulo 1, o estudo dos referidos temas. A sequência e o conteúdo completo de todos os programas de ensino podem ser vistos no anexo A.

Destacamos, por fim, que tirante o aspecto organizacional acima apontado, as análises gramaticais dessas 8 obras em nada diferem das outras 23, ou seja, seguem o mesmo modelo teórico, o da gramática tradicional, adotando apenas uma organização diferente dos tópicos gramaticais. Tal opção parece ter sido adotada para atender as demandas de ordem exclusivamente pedagógica, pois fornecia, ao aluno e ao professor, os assuntos do programa exatamente na ordem em que deveriam ser ensinados, eliminado, assim, a necessidade de o aluno ficar "pinçando" a matéria de cada ano ao longo da gramática completa. Nesses casos, tais gramáticas escolares, em função de sua estruturação, acabam funcionando como verdadeiros livros didáticos de gramática. Na seção 2.3.3, falaremos dos livros didáticos de Português, que só não são iguais a essas gramáticas, pois trazem também outros tópicos do programa, como leitura, literatura e redação.

Com efeito, a existência de gramáticas que seguem ipsis litteris os programas de ensino é mais uma prova do quanto a gramaticografia brasileira do início do século XX vai assimilando características de ordem escolar, dando origem a uma gramaticografia de contornos verdadeiramente didáticos, que irá, nas décadas seguintes, crescer e se especializar cada vez mais. No final deste capítulo, desenvolveremos melhor essa ideia, pois então já teremos analisado os outros grupos de obras gramaticais escolares: as obras de temas gramaticais específicos (seção 2.3.2) e os livros didáticos de Português (seção 2.3.3)

\footnotetext{
${ }^{29}$ No caso dessas 8 gramáticas, todas estão ligadas ao programa de 1942.
} 


\subsubsection{Camada contextual}

Neste capítulo, já falamos que, no início do século XX, houve um acentuado crescimento e estruturação do ensino secundário brasileiro. Destacamos também a importância que tiveram os programas oficiais de ensino no conteúdo e até mesmo na forma como as obras gramaticais escolares eram organizadas editorialmente. Para melhor compreendermos esses dois aspectos mencionados, é necessário recuarmos ao século XIX, verificando alguns aspectos de ordem contextual que impactaram na produção e constituição das 239 obras gramaticais de viés escolar aqui analisadas.

\subsection{O Colégio Pedro II e a disciplina "Português"}

O recuo ao século XIX precisa ser feito não só para olharmos aspectos diretamente ligados ao Secundário, mas também para alguns dados mais amplos sobre a educação brasileira nos meados do XIX e XX. A verificação das taxas de alfabetização do país, por exemplo, nos fornece um aspecto relevante sobre o contexto de circulação das produções editadas no Brasil, uma vez que não havendo uma população alfabetizada, consequentemente, todo o universo em torno da produção de livros e demais materiais impressos fica reduzido a uma pequena elite cultural. Quando um país decide expandir seu sistema de ensino, de maneira que atenda números cada vez maiores da população, obviamente que se cria uma demanda por materiais de ensino que possam atender às especificidades pedagógicas de cada nível de ensino. Vejamos, então, dados relativos à alfabetização brasileira entre 1872 e 1950.

Tabela 5 - A alfabetização brasileira entre 1872 e 1950

\begin{tabular}{|c|c|c|c|c|c|c|}
\hline População brasileira & 1872 & 1890 & 1900 & 1920 & 1940 & 1950 \\
\hline $\begin{array}{l}\text { Sabem ler e escrever } \\
\% \text { sobre o total de hab. } \\
\text { considerados }\end{array}$ & $\begin{array}{c}1.564 .481 \\
16 \%\end{array}$ & $\begin{array}{c}2.120 .559 \\
15 \% \\
\end{array}$ & $\begin{array}{c}4.448 .681 \\
25 \%\end{array}$ & $\begin{array}{c}7.493 .357 \\
24 \% \\
\end{array}$ & $\begin{array}{c}10.379 .990 \\
44 \% \\
\end{array}$ & $\begin{array}{c}14.916 .779 \\
49 \% \\
\end{array}$ \\
\hline $\begin{array}{l}\text { Não sabem ler e } \\
\text { escrever }\end{array}$ & 8.365 .997 & 12.213 .356 & 12.989 .753 & 23.142 .248 & 13.269 .381 & 15.272 .632 \\
\hline $\begin{array}{l}\text { Total de habitantes de } \\
15 \text { anos e mais }\end{array}$ & - & - & - & - & 23.649.371 & 30.189 .411 \\
\hline
\end{tabular}




\begin{tabular}{|l|c|c|c|c|c|c|}
\hline $\begin{array}{l}\text { Total de habitantes de } \\
\text { todas as idades }\end{array}$ & 9.930 .478 & 14.333 .915 & 17.438 .434 & 30.635 .605 & 41.236 .315 & 51.944 .397 \\
\hline
\end{tabular}

Fonte: Razzini (2000, p. 20) ${ }^{30}$.

O início de expansão do ensino secundário brasileiro não foi uma ação isolada, mas parte de um processo maior de "modernização cultural burguesa" pelo qual passava a sociedade brasileira. Razzini (2000, p. 22, sublinhados nossos) se refere a esse processo de modernização, dizendo que

\begin{abstract}
Ao longo do século XIX, nossa pequena classe dominante passou a apreciar cada vez mais as formas modernas de civilização burguesa. Porém, ao mesmo tempo, a aclimatação do modelo europeu de civilização tinha que conviver numa sociedade de estrutura colonial, assentada sobre a escravidão, cuja permanência sustentava a elite local e reproduzia o alheamento da maioria da população. Dentre as importações culturais europeias, destaca-se o modelo francês, que sempre exerceu entre nós grande fascínio durante o século XIX, prolongando-se até a metade do século XX. A França se fez presente desde o financiamento, por D. João VI, da "missão artística francesa", no início do século XIX, passando pela fundação de instituições nela inspiradas, como o Colégio Pedro II (1837) ${ }^{31}$, o Instituto Histórico e Geográfico Brasileiro (1838), a Academia Brasileira de Letras (1897), além de salões, clubes, teatros, associações, até a disseminação do consumo de bens importados, tais como, arquitetura, decoração, companhias teatrais (e cocotes), moda, culinária, além, é claro, de muito material impresso (folhetins, romances, compêndios, etc.).
\end{abstract}

Ainda Razzini (2000, p. 24, sublinhados nossos), ao analisar as condições de surgimento do ensino secundário no Brasil, destaca sobretudo sua vocação original.

No século XIX, inicialmente "anexa" às faculdades de Direito e a outros cursos superiores, a escola secundária cresceu com o aumento da demanda dos cursos superiores, justificando o aparecimento de vários colégios, liceus, ginásios, ateneus, etc., e o desenvolvimento significativo de seu respectivo aparato (corpo docente, currículos e livros didáticos), logo controlado pelo estado. É neste contexto que surge e se destaca o Imperial Colégio de Pedro II.

Não é exagero dizer que o Colégio Pedro II passa, então, a exercer um papel nuclear no tocante à educação secundária no Brasil. A importância da instituição e de seus professores começa a balizar os rumos da escola secundária no Império e início da República. Vejamos o que Razzini (2000, p. 240, sublinhados nossos) diz a respeito dessa influência:

Para pôr em prática o projeto nacionalista republicano, o ensino secundário e os Exames Preparatórios sofreram uma centralização efetiva, através da oficialização

\footnotetext{
${ }^{30}$ Razzini (2000, p. 20) informa ter elaborado esta tabela com os dados extraídos das seguintes fontes: Sinopse do Recenseamento Realizado em 1 de Setembro de 1920, População do Brasil, "Coeficientes da população dos Estados do Brasil em 1872, 1890 e 1920 segundo o grau de instrução e a idade”, p. 26-27, e A população do Brasil: dados censitários - 1872/1950, 1958, p. 3.

${ }^{31}$ Neste momento, ainda chamado de Imperial Colégio Pedro II.
} 
do currículo do Colégio Pedro II (então Ginásio Nacional), cujos programas e compêndios passaram a servir de base para os outros estabelecimentos de ensino secundário (públicos e privados) e para os Preparatórios que, apesar de combatidos, sobreviveram até o início da década de 1930.

Dado tal cenário, é evidente que o poder dos professores do Colégio Pedro II era muito grande, já que eram eles que "decidiam, cada um na sua cátedra, o programa curricular e os compêndios adotados no Pedro II e, por conseguinte, nos exames preparatórios." (RAZZINI, 2000, p. 27, itálicos nossos)

É nesse contexto que se cria um cenário profícuo para o surgimento de compêndios didáticos que atendessem primeiro ao próprio ensino secundário, depois também aos exames preparatórios.

Relativamente aos mencionados programas de ensino e exames preparatórios é necessário aclarar alguns pontos. Como destacou Razzini (2000), o currículo desenvolvido no curso secundário do Colégio Pedro II passa a ser referência para todo o país, já que foi oficializado pelo Governo Federal. Já os exames preparatórios eram as provas que habilitavam os alunos ao curso superior. Tais exames eram de responsabilidade do ensino secundário e é o sistema que antecedeu o vestibular, esse já de responsabilidade das próprias faculdades. É exatamente nessa relação entre os ensinos secundário e superior que há um aspecto de interesse a ser destacado: até 1931, o Secundário era de frequência não obrigatória e o que contava, de fato, era a aprovação nos exames preparatórios. Assim, os alunos estudavam em cursos avulsos ou mesmo contratavam professores para aulas particulares ou em pequenos grupos, visando o devido preparo para ser aprovado nos referidos exames. Somente a Reforma Francisco de Campos, em 1931, que põe fim a esse modelo e institui definitivamente a seriação e a frequência obrigatória. Voltaremos a essa discussão mais à frente, na seção 2.3.3.1.

Não obstante ao cenário acima apresentado, de acordo com Razzini (2000), a disciplina "Português" não gozava inicialmente de muito prestígio no currículo do Pedro II, em função da importância que o ensino clássico ainda possuía. Nele preponderava o ensino de Latim e de disciplinas como a Retórica e a Poética. É somente em 1869, no âmbito da Reforma do Ministro Paulino de Souza, com o decreto $\mathrm{n}^{\circ} 4430$, de 30 de outubro, que institui a obrigatoriedade da prova de Português para os exames preparatórios, que a disciplina passa a ter maior importância no contexto do Secundário. Cumpre destacar que esse decreto entra em vigor apenas em 1871.

Além do referido decreto, podemos assinalar que a disciplina "Português" receberá outros dois grandes incentivos vindos inicialmente do decreto $\mathrm{n}^{\circ} 9649$, de 2 de outubro de 1886 e depois 
do aviso $n^{\circ}$ 974, de 17 de março de 1887, que institui o Programa de Fausto Barreto ${ }^{32}$. Quanto ao primeiro, destacamos que é esse decreto que institui a precedência do exame de Português sobre todos os outros, ou seja, o torna eliminatório. O segundo, o aviso $\mathrm{n}^{\circ} 974$, determina qual o conteúdo de Português que deve ser cobrado nos exames preparatórios em todo o Império. Assim, em conjunto, essas duas determinações legais colocam o conhecimento dos pontos exarados no Programa de Fausto Barreto (doravante chamado de PFB) (cf. anexo A) como condição sine qua non a todos os alunos que desejassem ingressar nos cursos superiores, já que presentes no exame de acesso a todos os cursos desse nível de ensino.

Além do PFB, que era programa para um exame, o Secundário brasileiro também estava sob influência dos programas de ensino definidos para cada uma das séries do Colégio Pedro II. Para o período em análise nesta tese, houve oito programas: 1898, 1912, 1915, 1916, 1917, 1926, 1929 e 1930 (cf. anexo A). Em 1931, o recém-criado Ministério da Educação e Saúde Pública publica o primeiro programa sob sua responsabilidade. Tal ação ocorreu no âmbito da Reforma Francisco de Campos, encerrando assim a influência direta do Pedro II no currículo do ensino secundário.

Com efeito, é desnecessário dizer o quanto tais documentos impactaram a produção gramatical, já que a partir da publicação do PFB, em 1887, não se mostrava prudente ignorar os pontos apresentados por tais programas. Haverá, portanto, a partir desse momento, uma adaptação dos compêndios já existentes ao próprio PFB e aos demais programas de ensino ou mesmo a produção de novas gramáticas a eles atreladas.

\subsection{As gramáticas sob impacto do Programa de Fausto Barreto}

Podemos dizer que antes da publicação do PFB predominavam as gramáticas que categorizamos como de referência e as gramáticas primárias (cf. POLACHINI, 2018 33), já que o ainda incipiente ensino secundário não demandava produções escolares que pudessem atendêlo em suas especificidades. A partir de então, deixar de atender tal programa não era algo que se

\footnotetext{
${ }^{32}$ Fausto Barreto era professor do Colégio Pedro II.

${ }^{33}$ No capítulo 3, nos valemos dos dados da pesquisa de Polachini (2018) sobre a produção gramaticográfica oitocentista para estabelecermos um quadro comparativo com a produção novecentista. O levantamento bibliográfico feito pela autora, adaptado aos interesses desta tese, pode ser consultado no Anexo B.
} 
mostrava prudente. Vejamos como Silva Júnior e Andrade (1887, p.3, sublinhados nossos), no prefácio das Noções de grammatica portugueza, se manifestam a respeito.

Tínhamos emprehendido escrever uma grammatica completa da língua portugueza, rompendo em lucta a tradição, e fazíamos fundamento de entregal-a em breve á publicidade. $\underline{\mathrm{O} \text { novo programma para os exames geraes de preparatórios, porem, }}$ veio fazer-nos mudar do propósito. É que muitos dos pontos nelle exigidos para os exames de portuguez não se encontrando nas grammaticas que por ahi correm impressas, e os alumnos não tendo fontes onde possam haurir a instrucção de que carecem, resolvemos vir ainda uma vez em auxilio da mocidade estudiosa.

Cientes que não estavam entregando uma gramática de referência como desejavam fazer, mas sim uma gramática escolar, Silva Júnior e Andrade (1887, p.3) asseveram: "Não apresentamos este trabalho como merecedor de gabos de excellente, nem no intuito de nos revelarmos professores de sciencia jubilada. O tempo urgia; bosquejamos apenas o assumpto".

Essa mudança de planos não parece ter agradado aos autores, que continuam o registro dessa contrariedade no prefácio. Vejamos: "Nem sempre o nosso parecer coincidiu com a indicação do programma official; seguimos todavia, para maior segurança dos viajantes noveis, o roteiro apresentado pelo governo". Os gramáticos parecem ter clareza daquilo que observa Bittencourt (2004, p.479): “O autor de uma obra didática deve ser, em princípio, um seguidor dos programas oficiais propostos pela política educacional”.

Passado um ano da publicação de sua gramática, Pacheco da Silva Júnior ${ }^{34}$ (1842 - 1899) - só que agora em coautoria com José Ventura Boscoli (1855 - 1919) - publica um livreto complementar à sua gramática para então deixar estss dois materiais adaptados o máximo possível à realidade escolar da época. Vejamos o que dizem, no prefácio, os autores sobre o motivo de tal publicação.

Escrevemos este livrinho porque se nos afigurou de grande utilidade para os estudantes de preparatorios, obrigados tambem, na prova oral, a uma analyse syntaxica, phonetica e etymologica. [...] Só nos reportámos, no correr da primeira parte deste livrinho, ás Noções de Grammatica Portugueza por ser esse trabalho incontestavelmente o mais completo sobre os pontos oraes, tanto assim que foi premiado pelo Conselho pedagogico, e acaba de ser adoptado no Imperial Collegio de Pedro II, para o $5^{\circ}$ anno (exame final). Para organização da segunda parte, porém, compulsámos diversas producções grammaticaes e philologicas, entre as quaes avultam as de Julio Ribeiro, Fausto Barreto, G. F. Holms, A. Grivet, A. Bain. (SILVA JUNIOR; BOSCOLI, 1888, prefação)

Mesmo gramáticos das chamadas gramáticas de referência, como Júlio Ribeiro (18451890), que não produziu sua Grammatica portugueza com fins explicitamente escolares, ao ver

\footnotetext{
${ }^{34}$ Pacheco da Silva Junior foi catedrático do Colégio Pedro II e sua gramática foi nele adotada entre 1893 e 1898).
} 
publicado, em 1887, o PFB, portanto seis anos depois da $1^{\text {a }}$ edição de sua obra, reivindica o título de ser o seu compêndio o único a atender a doutrina e os pontos do programa.

Si foramos vaidoso, era esta a hora de rejubilar: o programma de Portuguez, bem
como os de todas as outras linguas que se ensinam oficialmente no Brasil, está de
accordo exacto, perfeito com os principios da grammatica scientifica, que, em 1881,
tivemos a ousadia de arrojar á publicidade. Hoje abundam em Portuguez
monografias linguisticas valiosissimas; temos a primeira parte da monumental
grammatica historica de Pacheco Junior; Adolpho Coelho, Leite de Vasconcellos,
João Ribeiro, Fausto Barreto, Lameira de Andrade brilham como astros de primeira
grandeza no céo da nossa filologia: mas, ainda assim, é a nossa Grammatica a unica
grammatica por onde se possa preparar um alumno para enfrentar com o actual
programma de exames. (RIBEIRO, [1935?], p. 93, itálico do autor)

Ribeiro $^{36}$ não era professor do Colégio Pedro II, mas teve lá sua gramática adotada por breve período, apenas em 1882. Como destacou Razzini (2000), os compêndios adotados nesse prestigioso colégio foram, em sua grande maioria, os escritos por seus catedráticos como foi o caso de João Ribeiro (1860 - 1934), Fausto Barreto ${ }^{37}(1852$ - 1915) e Antenor Nascentes (1886 $-1972)$.

Além de atenderem ao que estabeleciam os programas de ensino, as gramáticas escolares e os demais materiais de viés gramatical passam a se moldar a esse ambiente, que vai se tornando cada vez mais especializado. O contraste com as gramáticas de referência aponta para suas especificidades, como: questionário/exercícios sobre a teoria explanada, indicação expressa, em prefácios, por exemplo, de que se trata de material destinado ao aluno, indicação de série, segmento da escolarização a que se destina o material, ausência de citações de rodapé em que se traziam teóricos que fundamentavam e vinculavam doutrinariamente a gramática em questão.

\subsection{As reformas educacionais e os programas de ensino entre 1900 e 1942}

Com efeito, não eram apenas os programas de ensino que agiam normativamente sobre o ensino secundário. Também havia, a partir da Primeira República, as sucessivas reformas do ensino, que definiam as diretrizes, estruturação e demais aspectos relativamente aos ensinos primário, secundário e superior. Não estava sob a alçada das reformas a definição do que

\footnotetext{
${ }^{35}$ Ribeiro publica seus textos no jornal A Procellaria, em 1887. O livro homônimo, no entanto, sai cerca de 50 anos depois, reunindo todos os textos publicados pelo autor nos referidos jornal e ano.

${ }^{36}$ Ribeiro foi professor, entre outros lugares, do Colégio "Culto à Ciência", em Campinas, SP.

${ }^{37}$ No caso de Fausto Barreto, a adoção não foi de uma gramática, mas sim da Anthologia nacional ou coleção de excerptos, escrito em parceria com Carlos de Laet (1847-1927).
} 
exatamente ensinar em cada componente curricular dos diferentes níveis de ensino, o que era, sim, responsabilidade dos programas.

No período estudado na presente tese, a educação brasileira passou por sete reformas educacionais diferentes: Benjamim Constant (1890); Epitácio Pessoa (1901); Rivadávia Correia (1911); Carlos Maximiliano (1915); João Luís Alves [ou Rocha Vaz, como ficou conhecida] (1925); Francisco Campos (1931) e Gustavo Capanema (1942). Vejamos, então, algumas informações sobre os objetivos do Secundário nessas diferentes reformas.

Quadro 7 - Objetivos do curso secundário (1890-1925)

\begin{tabular}{|c|c|c|}
\hline Reforma & Objetivos & $\begin{array}{l}\text { Duração do } \\
\text { curso } \\
\text { secundário }\end{array}$ \\
\hline $\begin{array}{l}1 \text { - Benjamin } \\
\text { Constant } \\
(1890)\end{array}$ & $\begin{array}{l}\text { "Proporcionar à mocidade brasileira a instrução secundária e } \\
\text { fundamental, necessária e suficiente, assim para a matrícula nos } \\
\text { cursos superiores da República, como em geral para o bom } \\
\text { desempenho dos deveres do cidadão na vida social." (Art. } 1^{\circ} \text { do } \\
\text { Decreto n }{ }^{\circ} 1075 \text {, de 22-11-1890.) }\end{array}$ & 7 anos \\
\hline $\begin{array}{l}2 \text { - Epitácio } \\
\text { Pessoa } \\
\text { (1901) }\end{array}$ & $\begin{array}{l}\text { "Proporcionar a cultura intelectual necessária para a matrícula } \\
\text { nos cursos de ensino superior e para a obtenção do grau de } \\
\text { bacharel em ciências e letras." (Decreto n } \text { n }^{\circ} \text { 914, de 26-01- } \\
\text { 1901.) }\end{array}$ & 6 anos \\
\hline $\begin{array}{l}3 \text { - Rivadávia } \\
\text { Correia } \\
\text { (1911) }\end{array}$ & $\begin{array}{l}\text { "Proporcionar uma cultura geral de caráter essencialmente } \\
\text { prático, aplicável a todas as exigências da vida, e difundir o } \\
\text { ensino das ciências e das letras, libertando-o da preocupação } \\
\text { subalterna de curso preparatório." (Art. } 1^{\circ} \text { do Decreto n. }{ }^{\text {o }} 8.660 \text {, } \\
\text { de 05-04-1911.) }\end{array}$ & $\begin{array}{l}\text { - Externato: } 6 \\
\text { anos; } \\
\text { - Internato: } 4 \\
\text { anos }\end{array}$ \\
\hline $\begin{array}{l}4 \text { - Carlos } \\
\text { Maximiliano } \\
\quad(1915)\end{array}$ & $\begin{array}{l}\text { "Ministrar aos estudantes sólida instrução fundamental, } \\
\text { habilitando-os a prestar, em qualquer academia, rigoroso } \\
\text { exame vestibular." (Art. } 158 \text { do Decreto } \mathrm{n}^{\circ} 11 \text { 530, de 18-03- } \\
\text { 1915.) }\end{array}$ & 5 anos \\
\hline $\begin{array}{l}5 \text { - João Luís } \\
\text { Alves (ou } \\
\text { Rocha Vaz) } \\
\quad(1925)\end{array}$ & $\begin{array}{l}\text { "Base indispensável para a matrícula nos cursos superiores"; } \\
\text { "Preparo fundamental e geral para a vida" (Exposição de } \\
\text { Motivos). "Fornecer a cultura média geral do país." (Art, } 47 \text { do } \\
\text { Decreto n } 16782-A \text {, de 13-01-1925.) }\end{array}$ & $\begin{array}{l}-5 \text { anos: } \\
\text { certificado de } \\
\text { aprovação; } \\
\text { - } 6 \text { anos: } \\
\text { bacharelado } \\
\text { em Ciências e } \\
\text { Letras. }\end{array}$ \\
\hline
\end{tabular}


Fonte: Piletti (2000, p. 60-61).

Relativamente às reformas Francisco Campos (1931) e Gustavo Capanema (1942), seus principais objetivos podem ser assim apresentados.

A reforma do ensino secundário foi proposta, primeiramente, através do Decreto 19.890, de 18 de abril de 1931, e depois consolidada pelo Decreto $\mathrm{n}^{\circ} 21.241$, de 4 de abril de 1932. Na exposição de motivos que acompanhou este último, Francisco Campos escreveu: "A finalidade exclusiva do ensino secundário não há de ser a matrícula nos cursos superiores; o seu fim, pelo contrário, deve ser a formação do homem para todos os grandes setores da atividade nacional (grifo da autora), constituindo no seu espírito todo um sistema de hábitos, atitudes e comportamento que o habilitem a viver por si e tomar, em qualquer situação, as decisões mais convenientes e mais seguras". Tais finalidades denunciavam uma concepção completamente distorcida das funções da escola secundária, como se pode prontamente observar. $\mathrm{O}$ resultado disso foi o currículo enciclopédico implantado por essa reforma. (ROMANELLI, 1990, p.134-135, sublinhados nossos)

Quanto à Reforma Gustavo Capanema, essa já durante o Estado Novo, podemos notar a preocupação nacionalista, explicitamente manifestada na "exposição dos motivos", parte introdutória da lei que instituía a referida reforma.

A 9 de abril de 1942 era promulgada a chamada Lei Orgânica do Ensino Secundário, mediante o decreto-lei $\mathrm{n}^{\circ} 4244$. Na exposição de motivos pelos quais o Governo a promulgava, Gustavo Capanema assim se pronunciava, segundo citação de Maria Tetis Nunes: "o que constitui o caráter específico do ensino secundário é a sua função de formar nos adolescentes uma sólida cultura geral e, bem assim, de neles acentuar e elevar a consciência patriótica e a consciência humanística. O ensino secundário deve ser, por isto, um ensino patriótico por excelência, e patriótico no sentido mais alto da palavra, isto é, um ensino capaz de dar ao adolescente a compreensão dos problemas e das necessidades, da missão, e dos ideais da nação, e bem assim dos perigos que a acompanhem, cerquem ou ameacem, um ensino capaz, além disso, de criar, no espírito das gerações novas a consciência da responsabilidade diante dos valores maiores da pátria, a sua independência, a sua ordem, e seu destino (apud Maria Tetis Nunes. Ensino secundário e sociedade brasileira)". (ROMANELLI, 1990, p.156-157, sublinhados nossos)

Não realizaremos aqui maiores análises a respeito das reformas, pois assim o faremos na seção 2.3.3, a dos livros didáticos de Português, momento em que mostraremos a influência dessas reformas na organização e composição dos materiais didáticos de Português. 


\subsubsection{Obras escolares de temas gramaticais específicos}

\subsubsection{Camada contextual}

Durante o processo de pesquisa para compor nosso levantamento, fomos encontrando em número bastante significativo de materiais que não eram gramáticas escolares completas, mas que abordam um ou mais tópicos gramaticais específicos, como análise sintática, análise morfológica, conjunção, verbos, acentuação, entre outros assuntos. Dessa forma, tais obras podem ser vistas como verdadeiras separatas de uma gramática completa, pois ali são desenvolvidos tópicos gramaticais que foram selecionados para receber maior aprofundamento teórico ou mesmo prático, já que várias obras ofereciam uma quantidade farta de exercícios de fixação ou ainda de nível de dificuldade maior. É evidente, então, que as obras incluídas neste grupo funcionavam como ferramenta auxiliar às gramáticas escolares completas. $\mathrm{O}$ levantamento que realizamos corrobora essa afirmação, já que no grupo das obras escolares de temas gramaticais específicos estão listadas 101 obras, ante 51 gramáticas completas.

Além do papel auxiliar acima mencionado, outros três critérios foram utilizados para incluirmos as obras neste grupo: (i) menção explícita no título, subtítulo, folha de rosto ou prefácio ao universo escolar, (ii) presença de referências aos programas de ensino ou a demais documentos oficiais de ensino e (iii) presença de exercícios de fixação. Destacamos serem os mesmos critérios utilizados para caracterizar uma gramática completa como escolar e não como de referência.

Quanto aos conteúdos dessas obras, nossa análise ${ }^{38}$ aponta para o seguinte cenário:

\section{Tabela 6 - Conteúdo tratado nas obras escolares de temas gramaticais específicos}

\begin{tabular}{|l|l|}
\hline Análise léxica e/ou lógica. (32 obras) & \multirow{2}{*}{$\mathbf{7 1 \%}$} \\
\hline Obras destinadas a preparar alunos para o Exame de Admissão. (22) & \\
\hline $\begin{array}{l}\text { Obras destinadas a preparar candidatos para concursos e provas em geral. } \\
\text { (11) }\end{array}$ & \\
\hline Exercícios gerais de gramática. (7) & \\
\hline
\end{tabular}

\footnotetext{
${ }^{38} \mathrm{O}$ quadro em que constam apenas essas obras pode ser consultado no Apêndice B (Quadro 4B).
} 
Demais temas, como: acentuação/crase; pontuação; colocação pronominal; verbos; vícios de linguagem; conjunção; concordância; palavra quê; infinito pessoal; entre outros tópicos.

Como pode ser visto na tabela acima, dois são os eixos que, basicamente, estruturam os 71\% das obras presentes neste grupo: (i) livros sobre análise léxica e/ou lógica (32) e (ii) obras destinadas ao preparo de alunos a exames, concursos etc (32).

Quanto ao primeiro eixo, são obras que tratam da análise morfológica e sintática, respectivamente. É importante lembrar, nesse caso, daquilo que dissemos, na seção anterior, em relação à variedade terminológica no período pré-NGB, época que eram os próprios gramáticos que escolhiam quais termos iriam usar em suas obras. Assim, nessas 32 obras que localizamos, vimos a análise léxica ser chamada também de análise gramatical, morfológica ou lexicológica. Já a análise lógica era também chamada de sintática ou oracional. Não vimos diferenças teóricas que justificassem a diferença terminológica, nos parecendo que tal oscilação pode ser justificada pela ausência de padronização vigente no período pré-NGB.

Uma explicação para a grande quantidade de obras destinadas às análises léxica e lógica pode ser encontrada ao analisarmos os programas de ensino de 1931 e 1942. Em ambos, esses dois tópicos gramaticais aparecem explicitamente.

\section{Quadro 8 - Programas de ensino de 1931 e 1942 quanto ao tópico análise léxica e lógica}

\begin{tabular}{|l|l|}
\hline \multicolumn{2}{|c|}{ Programa de 1931 } \\
\hline $\begin{array}{l}1^{\mathrm{a}} \text { e } \\
\text { séries }\end{array}$ & - Estudo simultâneo e moderado da análise lexicológica e da sintática. \\
\hline $3^{\mathrm{a}}$ série & - Resumo sistemático das observações feitas nos anos precedentes. \\
\hline $4^{\mathrm{a}}$ série & - Apenas estudo da gramática histórica. \\
\hline $5^{\mathrm{a}}$ série & - Apenas estudo de literatura. \\
\hline & $\begin{array}{l}\text { Programa de } \mathbf{1 9 4 2} \\
\text { - (3) Estudo simultâneo e moderado da análise léxica e da sintática, não indo esta }\end{array}$ \\
\hline $1^{\mathrm{a}}$ série & $\begin{array}{l}\text { - (4) Estudo de análise léxica e sintática, um tanto mais desenvolvido que na } \\
\text { primeira série. }\end{array}$ \\
\hline $2^{\mathrm{a}}$ série
\end{tabular}




\begin{tabular}{|l|l|}
\hline $3^{\mathrm{a}}$ série & $-(2)$ Exercícios de análise léxica e sintática. \\
\hline $4^{\mathrm{a}}$ série & - Apenas estudo da gramática histórica. \\
\hline $5^{\mathrm{a}}$ série & - Apenas estudo de literatura. \\
\hline
\end{tabular}

Como pôde ser visto, o estudo das análises léxica e lógica está presente em todos os anos em que se estudava a gramática expositiva, uma vez que o $4^{\circ}$ ano era dedicado apenas ao estudo da gramática histórica e o $5^{\circ}$ ano à literatura. Assim, produzir materiais que atendessem a esses tópicos parece ser útil em termos pedagógicos e atrativo em termos comerciais.

Relativamente ao segundo eixo, podemos notar a grande quantidade de obras dedicadas a preparar os alunos do último ano do Primário para o exame de admissão, que era uma prova que todos os alunos desse segmento deveriam realizar para ter acesso à $1^{\text {a }}$ série do Secundário. Tal obrigatoriedade foi instituída pela Reforma Francisco Campos (decreto $\mathrm{n}^{\circ}$ 19.890, de 1931) e vigou no país até 1971, quando foi extinta pela lei n $5.692\left(\mathrm{LDB}^{39}\right)$. Além de Português, o exame de admissão era composto pelas seguintes disciplinas: Matemática, Geografia, História do Brasil e Ciências Naturais (até 1942, quando é excluída do exame).

A presença de uma grande quantidade de obras destinadas aos exames de admissão pode ser explicada pela importância que tinha essa prova, já que o aluno não aprovado era impedido de prosseguir seus estudos. Com efeito, tais exames representavam um significativo entrave para a democratização do ensino no Brasil, pois a preparação para essas provas demandava, muitas vezes, a realização de cursos extras, contratação de aulas particulares ou mesmo a compra de livros específicos, como os aqui analisados, ações que eram inacessíveis às parcelas mais pobres da população. Ao analisarmos os títulos dos livros destinados ao exame de admissão, encontramos duas obras que podem servir para ilustrar o quanto a questão financeira era impeditiva à época. Antônio Gonçalves (? - ?), Geraldo Rodrigues (? - ?) e Marcelo Mesquita (? - ?), professores do Liceu Rio Branco ${ }^{40}$, tinham duas versões de livros preparatórios ao Secundário: a primeira, chamada Exames de admissão aos cursos ginasiais e outra, uma versão econômica dessa primeira, que tem o sugestivo título Preparatórios ao alcance de todos: edição popular do livro "Exames de admissão ao Ginásio".

De 1931 a 1940, o exame de admissão tinha como conteúdo, em Português, um ditado e uma redação (DECRETO N. ${ }^{\circ}$ 19.890, de 18 de abril, de 1931, Art. 22). Já a partir de 1940, o exame se tornou mais elaborado, com a inclusão de prova teórica. Tal processo foi regulamentado

\footnotetext{
${ }^{39}$ Lei de Diretrizes e Bases da Educação Nacional (LDB).

${ }^{40}$ Atual Colégio Rio Branco, tradicional escola de elite de São Paulo.
} 
pela Portaria Ministerial $n^{\circ} 479 / 1940$, que estabeleceu quais seriam os tópicos cobrados no exame, o que acabou consequentemente definindo o conteúdo dos livros usados pelos alunoscandidatos ao Secundário:

II -PORTUGUÊS - Leitura e interpretação de um trecho de 25 a 30 linhas de escritor nacional contemporâneo. Argüição sobre o alfabeto, vogais e consoantes, grupos vocálicos e grupos consonantais, sílaba, vocábulo, notações léxicas e acento tônico. Conhecimentos das categorias gramaticais (excluídas as classificações das conjunções de 1a e 2a classe): análise léxica. Exercícios sobre as flexões de gênero, número e grau. Conjunção completa dos verbos auxiliares e dos regulares. Exercícios de sinônimo antônimos. Exercícios de redação. (BRASIL, 1940)

\subsubsection{Camadas teórica, documental e técnica}

Já dissemos aqui que as obras escolares de temas gramaticais específicos funcionavam como extensões das gramáticas completas. Dessa forma, não há, nessas obras, orientação teórica ou prática metodológica que difiram daquelas adotadas pelo modelo gramatical greco-latino ou, em outros termos, da gramática tradicional. Com efeito, tais materiais são fragmentos da gramática tradicional, já que abordam temas específicos dessa mesma gramática tradicional.

Apresentamos, no item anterior, algumas explicações para a grande quantidade de obras publicadas neste grupo (101 obras), mas todas são de cunho extralinguístico, tais como a presença acentuada de um tópico em um programa oficial de ensino e a consequente necessidade de os alunos estudarem com mais vagar e/ou profundidade esse assunto específico ou ainda o preparo para concursos e provas em geral.

Dessa forma, todas as observações linguísticas que fizemos quanto às camadas teórica, documental e técnica na seção anterior, a das gramáticas escolares completas, são aplicáveis às obras dessa seção, ou seja, das obras escolares de temas gramaticais específicos. Em benefício da fluidez do texto, não as repetiremos aqui, já que isso envolveria repisar análises que já foram feitas na seção 2.3.1. 


\subsubsection{Livros didáticos de Português}

\subsubsection{Camada contextual}

Nesta seção, analisaremos um tipo de publicação que até no início do século XX praticamente inexistia no contexto educacional brasileiro, isto é, o livro didático para uso no Secundário. Com efeito, o Brasil inicia o século XX com uma parca estrutura de ensino destinada a esse segmento escolar. Em 1907, havia, em todo o país, apenas 31 escolas que ofereciam o Secundário, que eram frequentadas por 3937 alunos. As próximas décadas, no entanto, serão de forte expansão dessa rede, gerando, 31 anos depois, números bem mais significativos: 2149 escolas e 237833 alunos secundaristas. Quanto aos docentes dedicados a esse nível, eram 432, em 1907, passando para 20 864, em 1938.

Tabela 7 - Escolas, docentes e matrículas no Secundário (1907)

\begin{tabular}{|c|c|c|}
\hline ESCOLAS & DOCENTES & MATRÍCULA \\
\hline $31^{*}$ & 432 & 3937 \\
\hline
\end{tabular}

* Números absolutos referentes às escolas públicas dos três níveis: federal, estadual e municipal. Fonte: Ministerio da Agricultura, Industria e Commercio (1927, p.1 038-1 053).

Tabela 8 - Escolas, docentes e matrículas no Secundário (1932-1938)

\begin{tabular}{|c|c|c|c|}
\hline ANOS & ESCOLAS & DOCENTES & MATRÍCULAS \\
\hline 1932 & $1314^{*}$ & 13205 & 120412 \\
\hline 1933 & 1514 & 14936 & 145644 \\
\hline 1934 & 1703 & 16330 & 160345 \\
\hline 1935 & 1806 & 17243 & 173981 \\
\hline 1936 & 1886 & 18393 & 193896 \\
\hline 1937 & 2001 & 19572 & 211236 \\
\hline $\mathbf{1 9 3 8}$ & $\mathbf{2} \mathbf{1 4 9}$ & $\mathbf{2 0 ~ 8 6 4}$ & $\mathbf{2 3 7 8 3 3}$ \\
\hline
\end{tabular}

* Números absolutos referentes às escolas federais, estaduais, municipais e particulares.

Fonte: Instituto Brasileiro de Geografia e Estatística (1941, p.712). 
Os números acima nos mostram que, entre 1907 e 1938, o crescimento do ensino secundário brasileiro foi de $6000 \%$ nas matrículas, de $6800 \%$ em unidades escolares e de $4700 \%$ no corpo docente. Percentuais de crescimento tão grandes podem ser explicados por alterações estruturais na sociedade brasileira, a qual passava por um processo de mudança de seu sistema econômico, de um "modelo econômico agrário-exportador para industrial-urbano" (BITTAR; BITTAR, 2012, p.158). Evidentemente que para realizar tal empreendimento seria necessário formar mão de obra mais qualificada, o que passava pela estruturação e ampliação de uma rede de ensino que não fosse apenas a primária. Apenar do aumento de alunos matriculados no Secundário, devemos destacar que havia ainda uma cobertura muito baixa em relação ao públicoalvo desse segmento escolar (jovens de 11 a 17 anos), cerca de 7,2 \%, em 1935, e 18,2\%, em 1945. (SANTOS RIBEIRO, 1995, p.143)

Nas décadas compreendidas entre 1930 e 1960 , o Brasil passou por mudanças
estruturais que incidiram diretamente sobre a construção de um sistema nacional de
educação pública. No plano estrutural, o país passava por uma transição
caracterizada pela aceleração do modo capitalista de produção, o que ocasionou
transformações superestruturais, notadamente no aparelho escolar. Em termos
políticos, o período está compreendido entre dois processos vinculados à transição
de um modelo econômico agrário-exportador para industrial-urbano: a Revolução
de 1930 e o golpe de Estado de 1964. (BITTAR; BITTAR, 2012, p.158,
sublinhamos).

Para uma rede secundária de ensino que se estruturava e crescia a passos largos, é necessário que se produzam materiais didáticos adequados a esse segmento, criando, assim, tipos de materiais até então inexistentes. Com efeito, esse é o caso dos livros didáticos de Português, publicações que assim categorizamos em função da presença de três tipos de conteúdo: (i) gramática; (ii) seleta literária com ou sem comentários críticos e (iii) redação.

Os livros didáticos de Português receberam essa organização e esse conteúdo, pois assim estabeleciam os programas oficiais de ensino (cf, anexo A). Nas seções anteriores, já analisamos o quanto o conteúdo e as orientações presentes nos programas foram importantes ou mesmo determinantes para a composição das gramáticas completas escolares e para obras escolares de temas gramaticais específicos. Com efeito, não é exagero dizer que as quatro primeiras décadas do século XX, principalmente a partir da década de 30, foram as que presenciaram uma verdadeira didatização da gramática brasileira, já que foi exatamente neste período que o país vivenciou uma explosão de publicações didáticas em que o objetivo não era mais apresentar apenas os tópicos gramaticais da tradição greco-latina, mas sim fazer isso associado a uma preocupação didática, ou seja, considerando aspectos como: Em que série esse tema vai ser estudado? Está adequado a idade dos alunos? Esse tema está presente nos programas oficiais? 
Com qual relevância? Se muita, é necessário um capítulo mais longo, com mais explicações e exercícios? Ou seja, essas e muitas outras perguntas representam a preocupação e a necessidade de se atender editorialmente uma demanda escolar que estava surgindo, ou seja, a produção de materiais didáticos que pudessem ser adequadamente utilizados nas aulas de Português do ensino secundário.

Nas obras do final do século XIX e início do XX, não era incomum encontrar observações críticas a respeito da inadequação da gramática de referência para uso escolar. Vejamos três exemplos retirados de obras com perfis diferentes: uma gramática de referência do final do século XIX, uma gramática de referência do início do século XX e uma obra gramatical também do início do século XX.

DEVE SER BANIDO O COMPENDIO DO ENSINO DA GRAMMATICA? Tem se proposto muitas vezes leccionar grammatica sem compendio, e na realidade ha quem siga este systema. Dizem que as difficuldades não proveem da materia, mas da forma que lhe dão, ou do livro que adoptam. Nisto deve haver sophisma. Nos compendios, só se exara o que convem dizer de viva voz; e, si mais claramente que o melhor delles se exprime o professor, importa que, redigindo o que diz, componha outro, e o dê a estampa, para servir de norma. Assim se conseguirão compendios mais perfeitos, e se reduzirá a reforma que suggere a sua completa suppressão, á producção de novos livros. ALEX. BAIN.- A Sciencia da Educação, Vol. XXXI da Bibl. Scient. Intern., 3.a ediç., Cap. VII, II, pag. 255. (FREIRE DA SILVA, 1886, n.p, maiúsculas do autor)

Augusto Freire da Silva (1836-1917) abre seu Compendio de grammatica portugueza com o texto chamado "Deve ser banido o compendio do ensino da grammatica?", do qual extraímos a citação anteriormente reproduzida. Embora não seja um texto de sua lavra, a reprodução do excerto de Alex Bain, retirado da obra A sciencia da educação, demostra que o questionamento exarado no título do texto era algo que ocupava as mentes de gramáticos e educadores da época. O texto de Bain é, com efeito, uma defesa do papel do compendio, do livro de gramática nas aulas de Português, mas, como já apontamos, demonstra que havia, naquele momento, uma discussão razoavelmente intensa a ponto de justificar a inclusão do referido texto logo após a folha de rosto, servindo praticamente como uma defesa prévia da validade e da relevância da gramática no ambiente escolar. Devemos destacar que Augusto Freire era professor catedrático de Língua Portuguesa no "Curso Preparatório", anexo à Faculdade de Direito de São Paulo e que tal curso era, na verdade, um curso pré-universitário, vinculado à própria Faculdade de Direito de São Paulo, frequentado por pessoas que ali desejavam ingressar.

Agora, em uma gramática de referência do início do século XX, vejamos como aparece essa discussão. 
Não se deve confundir a grammatica de ensino escolar com a de consulta, philologica ou historica, destinada aos que pretendem conhecer a fundo a nossa lingua. $\mathrm{O}$ ensino mediano e regular de uma lingua, requer uma grammatica resumida, clara, facil, num compendio unico, como tentei fazer, sem attingir o ponto almejado, eu sei. (ABREU, 1923, p. V-VI, grifamos)

No trecho, A.E. Abreu (?-?) reproduz claramente a oposição entre as gramáticas escolares e as que, nesta tese, categorizamos como gramáticas de referência. Por fim, embora mais ligado ao universo do ensino primário do que do secundário, usaremos o excerto abaixo, pois ele também representa o incômodo que havia na época quanto à inadequação de se usar, nas escolas, materiais que a elas não eram destinados originalmente ou ainda materiais que eram destinados a alunos mais velhos. No trecho abaixo, Otoniel Mota aponta sua tristeza e indignação ao saber que sua própria filha usaria, no grupo escolar ${ }^{41}$, a gramática de Júlio Ribeiro (18451890).

Era de esperar que eu chamasse a este pequeno trabalho [o seu livro Chave da língua] Gramática infantil. Não o fiz, porque quasi voto horror a certas gramáticas infantís de que tenho conhecimento, mostrengos que principiam com as mais abstrusas noções, as quais poderão ser decoradas, mas jamais compreendidas pelas inteligências incipientes. A mania de dar à inteligência infantil, violentamente, com se enfia o alimento pela goela de um ganso, as mais áridas e indigestas noções de gramática, tem produzido verdadeira tragédia: um esfôrço nulo, seguido de invencível aversão ao estudo da nossa lingua. Neste livrinho tive por intuito evitar aos filhos dos outros o que não pude evitar aos meus, pois passei pela desventura de ver uma filhinha entrar, por assim dizer, para um grupo escolar, sobraçando por ordem da professora a gramática de Júlio Ribeiro! Parece incrível. Não dei ao livrinho o nome de gramática, porque, a bem dizer, é êle uma reação contra as gramáticas: são antes palestras com os pequenos, e, quanto possível, na língua dos pequeninos. (Tarefa quasi sobrehumana!). (MOTA, 1939, p.15)

No caso específico das obras que fazem parte do nosso levantamento, localizamos 87 livros didáticos de Português, escritos por 33 autores diferentes ${ }^{42}$ (cf. apêndice B - Quadro 5B). Nas seções anteriores, falamos a respeito da influência dos programas oficiais de ensino no conteúdo e estruturação das gramáticas escolares completas e nas obras escolares de temas gramaticais específicos e, no caso dos livros didáticos, não ocorreu de forma diferente. Além da influência no conteúdo, os livros didáticos apresentam outra característica que é derivada dos programas e que representa uma novidade no universo de materiais escolares destinados ao Secundário: volumes separados e específicos para uso em cada série desse segmento escolar.

41 Eram assim denominadas algumas escolas primárias.

42 Para evitar distorções na relação livros/autores, as obras escritas em coautoria foram contabilizadas como escritas por 1 autor. 
A estruturação do Secundário sofreu, ao longo das quatro primeiras décadas do século $\mathrm{XX}$, algumas alterações que influenciaram na apresentação editorial das referidas coleções didáticas de Português. São três os períodos relevantes para a nossa análise, vejamos:

1) Do início do século $X X$ até o final da década de 20, o Secundário funcionava como "antessala" do ensino superior, servindo quase que exclusivamente de curso preparatório para os alunos passassem nas provas de ingresso na faculdade. Assim, predominava o ensino avulso, de frequência não obrigatória, ou seja, não havia seriação e, dessa forma, não havia reflexos na organização dos livros didáticos de Português.

Até o final da década de 1920, como já o dissemos antes, imperava o sistema de "preparatórios" e de exames parcelados para ingresso no ensino superior, sendo o currículo seriado, quando existente, pouco procurado. Nem sequer o Colégio Pedro II, modelo de educação secundária para todo o país, pôde fugir à regra e teve de submeter-se ao regime de exames parcelados que eliminavam a seriação dos cursos secundários. A Reforma Rocha Vaz, de 1925, tentou eliminar os preparatórios, mas, ao que parece, em vão, já que a própria Reforma Francisco Campos faz menção à existência deles ainda em 1929 (Decreto 19.890, de 18 de abril de 1931, art. 80). (ROMANELLI, 1990, p.135, sublinhamos)

2) Em 1931, a Reforma Francisco de Campos consegue eliminar o ensino avulso e não obrigatório, instituindo, definitivamente, a seriação e a obrigatoriedade. Assim,

\begin{abstract}
pela reforma, o curso secundário ficou dividido em dois ciclos: um fundamental, de

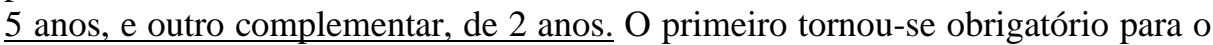
ingresso em qualquer escola superior e o segundo, em determinadas escolas. Além disso, para esse ciclo complementar, foi estabelecida uma subdivisão que compreendia um certo grau de especialização, conforme se tratasse de curso preparatório para ingresso nas Faculdades de Direito, Ciências Médicas e Engenharia. (ROMANELLI, 1990, p.135, sublinhamos)
\end{abstract}

A seguir, a autora apresenta a divisão das disciplinas ao longo dos 7 anos de Secundário. Com efeito, é justamente a partir dessa reforma e da seriação por ela definida que surgem os livros didáticos de Português, pois assim era possível oferecer aos alunos um material com o conteúdo já definido pelos programas oficiais para cada ano do ensino secundário que possuía Português na grade curricular.

Quadro 9 - Estrutura do ensino secundário pela Reforma Francisco Campos (1931)

a) Ciclo fundamental, com 5 séries:

\begin{tabular}{|l|l|}
\hline Disciplinas & Séries \\
\hline Português & I, II, III, IV, V \\
\hline
\end{tabular}




\begin{tabular}{|l|l|}
\hline [demais disciplinas] & {$[\ldots]$} \\
\hline \multicolumn{1}{|c|}{ b) Ciclo complementar, com 2 séries: } \\
\hline $\begin{array}{l}\text { Português não entra na grade de nenhum dos cursos preparatórios (Direito, Ciências } \\
\text { Médicas e Engenharia. }\end{array}$ \\
$\begin{array}{l}\text { Literatura entra na grade apenas no curso destinado aos candidatos ao curso de Direito, nas } \\
1^{\mathrm{a}} \text { e } 2^{\mathrm{a}} \text { séries. }\end{array}$
\end{tabular}

Fonte: Romanelli, 1990, p.135-136.

3) Em 1942, instituídas pela Reforma Gustavo Capanema, ocorrem mudanças na estrutura do Secundário, porém mantendo-se a duração em 7 anos.

$\mathrm{O}$ artigo 22 reestruturava o ensino da seguinte forma: um primeiro ciclo, que se chamava ginasial, e um segundo ciclo, subdividido em clássico e científico. Assim, pois, este último ciclo, que na reforma Francisco Campos, estivera subdividido em três, passava agora a constituir-se de dois cursos apenas, os quais não apresentavam pelo currículo nenhum caráter de especialização. (ROMANELLI, 1990, p.157, sublinhamos)

Quadro 10 - Estrutura do ensino secundário pela Reforma Gustavo Capanema (1942)

\begin{tabular}{|l|l|}
\hline \multicolumn{2}{|c|}{ Ensino secundário pela Reforma Gustavo Capanema (1942) } \\
\hline \multicolumn{2}{|c|}{$1^{\mathbf{0}}$ ciclo - Ginasial, com 4 séries: } \\
\hline Disciplinas & Séries \\
\hline Português & I, II, III, IV \\
\hline [demais disciplinas] & {$[\ldots]$} \\
\hline \multicolumn{2}{|c|}{$\mathbf{2}^{\mathbf{0}}$ ciclo - Curso Clássico, com 3 séries: } \\
\hline Português & I, II, III \\
\hline [demais disciplinas] & {$[\ldots]$} \\
\hline & $\mathbf{2}^{\mathbf{0}}$ ciclo - Curso Científico, com 3 séries: \\
\hline Português & I, II, III \\
\hline [demais disciplinas] & {$[\ldots]$} \\
\hline
\end{tabular}

Fonte: Romanelli, 1990, p.157-158.

Quanto ao conteúdo abordado em cada livro didático de Português, vejamos como eram organizados em cada um dos três períodos acima mencionados: 
1) Do início do século XX até o final da década de 20: Como os cursos não eram seriados, os conteúdos dos livros didáticos eram estruturados apenas para atender ao que estava previsto nos programas de ensino (cf. anexo A).

2) Obras publicadas sob vigência da Reforma Francisco de Campos (1931): da $1^{\mathrm{a}}$ a $4^{\mathrm{a}}$ série, o programa de ensino apresentava três eixos comuns: (i) leitura de trechos de prosadores e poetas; (ii) estudo gramatical e (iii) composição. A $5^{\text {a }}$ série era inteira dedicada à literatura (análise literária, teoria literária e história da literatura) e à composição, ou seja, não havia estudo gramatical, o que fez com que excluíssemos, de nosso levantamento, os volumes 5 das coleções didáticas. Da $1^{\mathrm{a}}$ a $3^{\mathrm{a}}$ série, estudava-se gramática expositiva/tradicional, mas, na $4^{\mathrm{a}}$ série, o programa estabelecia gramática histórica, o que fez com que deslocássemos esses volumes para o levantamento de obras do programa de investigação filológico.

3) Obras publicadas sob vigência da Reforma Gustavo Capanema (1942): da $1^{\mathrm{a}}$ a $4^{\mathrm{a}}$ série, o programa de ensino apresentava três eixos comuns: (i) leitura; (ii) gramática e (iii) outros exercícios. Esse último, de caráter complementar, é apresentado nos programas da seguinte forma: "além da leitura e dos exercícios próprios de cada unidade de gramática, haverá [aparece a lista de tópicos]" (BRASIL, Portaria n 170 de 11 de julho de 1942) Nessa lista, aparecem temas ligados à redação, à ortografia, à pontuação, entre outros.

Relativamente aos programas dos cursos clássico e científico, na $1^{\mathrm{a}}$ e $2^{\mathrm{a}}$ séries, há a mesma estrutura do ginásio, mais a introdução do estudo sistematizado da literatura. $\mathrm{Na} 1^{\mathrm{a}}$ série, há um quarto eixo chamado noções gerais de literatura e, na $2^{\mathrm{a}}$ série, esse eixo literário recebe o nome de noções de história da literatura portuguesa. Na $3^{\mathrm{a}}$ série, há apenas três eixos: (i) noções de história da literatura brasileira; (ii) leitura e (iii) outros exercícios, não havendo, nessa série, tópicos de gramática. Dessa forma, não incluímos, em nosso levantamento, os volumes da $3^{\mathrm{a}}$ série dos cursos clássico ou científico.

Apesar de muitos autores seguirem, em suas coleções, exatamente a organização curricular que aqui expusemos, ao analisarmos os 87 livros didáticos presentes em nosso levantamento (cf. apêndice B - Quadro 5B) é possível verificar algumas organizações diferentes. Uma apresentação de coleção didática bastante frequente é aquela em que há um volume de antologia literária para os $1^{\circ}$ e $2^{\circ}$ anos e outro para os $3^{\circ}$ e $4^{\circ}$ anos, além do volume de gramática escolar completa para os quatro anos, o que faz a obra didática, para o ginasial, ter três volumes. Essa estruturação atende a uma sugestão contida na Portaria n ${ }^{\circ} 172$, de 15 de julho de 1942, chamada "Instruções metodológicas para a execução do programa de Português" que diz 
1. Para a realização do curso, além dos livros da biblioteca escolar, de que os alunos se devem utilizar para leituras e consultas, deverão eles ter consigo os seguintes compêndios:

a) livro de leitura, num volume para a primeira e segunda séries e noutro volume para a terceira e quarta;

b) gramática, em um volume para as quatro séries;

c) dicionário portátil, em um volume, também para as quatro séries.

No entanto, percebemos que alguns autores, muito provavelmente por razões comerciais, adotaram outras disposições quanto à organização de suas coleções. Um exemplo disso pode ser visto na "Explicação necessária", introdução a um dos volumes do Compêndio de língua portuguêsa, de Artur de Almeida Tôrres.

Para maior conveniência do estudante, resolvemos, na presente edição, reunir a antologia à gramática, fundindo assim em dois, os três volumes destinados ao curso ginasial. Essa orientação, além de ser mais pedagógica, tem ainda a vantagem de facilitar a aquisição do livro, tornando-o mais acessível à bolsa do estudante. (TÔRRES, 1953, p.7, sublinhamos)

Ainda sobre a Portaria 172, seu item $b$ fala em publicação de "gramática, em um volume para as quatro séries". Quanto a isso, devemos lembrar que, por serem gramáticas escolares completas, tais obras já foram por nós analisadas na seção 2.3.1. Como já dissemos, as antologias literárias, por não terem conteúdo gramatical, não foram, nesta tese, consideradas.

\subsubsection{Camadas teórica, documental e técnica}

Quanto aos aspectos relativos às camadas teórica, documental e técnica, os livros didáticos de Português não apresentam diferenças do que já apresentamos na seção 2.3.1, a das gramáticas escolares completas, ou seja, também seguem as práticas linguísticas herdadas da gramática tradicional. Já havíamos feito essa mesma afirmação em relação ao grupo das obras escolares de temas gramaticais específicos (cf. seção 2.3.2), o que reforça o fato de que todas as obras analisadas, neste capítulo, seguem, em relação às camadas teórica, documental e técnica, o modelo da gramática tradicional. A diferença entre os três tipos de publicações que aqui estudamos está em elementos não gramaticais, como a inclusão, na obra, de antologia literária ou a publicação de um livro com um tema de gramática apenas, por ser ele muito cobrado em um determinado exame e/ou programa de ensino. Com efeito, podemos dizer que são aspectos 
ligados à camada contextual que diferenciam as obras aqui analisadas, ou seja, as gramáticas escolares completas, as obras escolares de temas gramaticais específicos e os livros didáticos de Português. 


\section{O programa de investigação gramatical: as obras gramaticais de referência sobre o} Português

No capítulo anterior, por várias vezes dissemos que não foram critérios linguísticos, ou seja, relativos às camadas teórica, técnica e documental, que justificaram a separação das obras gramaticais escolares em três grupos: gramáticas completas, obras de temas gramaticais específicos e livros didáticos de Português. Com efeito, quanto a essas camadas, todas as 239 obras ali presentes seguem as práticas linguísticas da gramática tradicional, por nós analisadas ao longo do capítulo 2. Ali afirmamos que fundamentalmente foram questões de ordem educacional, ou seja, contextuais (cf. seções 2.3.1.4; 2.3.2.1 e 2.3.3.1), as responsáveis por tal divisão.

No caso das obras que classificamos como de referência ocorre o mesmo, ou seja, a divisão entre gramáticas completas e obras de temas gramaticais específicos não foi por nós realizada em função de diferenças quanto às três camadas acima mencionadas. Como demonstraremos ao longo do capítulo, são fatores de ordem contextual os responsáveis por essa dupla categorização. Com efeito, a divisão das obras em escolar (capítulo 2) e de referência (capítulo 3) também pode ser justificada por aspectos contextuais, notadamente pelas demandas surgidas a partir da ampliação da escola secundária no Brasil.

Dessa forma, as análises já realizadas do programa gramatical quanto às camadas teórica, técnica e documental são plenamente aplicáveis e válidas para as 161 obras de referência, o que nos fez não retomar aqui as análises linguísticas feitas no capítulo 2. Assim, nos dedicaremos, no presente capítulo, a entender quais foram os aspectos contextuais que influenciaram na produção das obras de referência.

Aplicando a dicotomia escolar ou de referência às obras de nosso levantamento, chegamos aos seguintes números.

Tabela 9 - Quantitativo da produção gramatical de referência

\begin{tabular}{|c|c|}
\hline Gramáticas completas & Obras de temas gramaticais específicos \\
\hline 4 obras & 157 obras \\
\hline \multicolumn{2}{|c|}{ Total de obras gramaticais de referência: 161} \\
\hline
\end{tabular}




\subsection{Gramáticas de referência completas}

Como destacamos no capítulo 2, é no início do século XX que a ocorre o processo de didatização da gramática brasileira. Tal processo ocorre em função da significativa expansão pela qual passou o ensino secundário: entre 1907 e 1938, por exemplo, o crescimento foi de $6000 \%$ nas matrículas, de $6800 \%$ em unidades escolares e de $4700 \%$ no corpo docente (INSTITUTO BRASILEIRO DE GEOGRAFIA E ESTATÍSTICA, 1941, p.712). Esse crescimento gerou um constante processo de especialização nos materiais destinados a atender um número cada vez maior de crianças e adolescentes que passaram a frequentar as escolas brasileiras. Dadas essas especificidades, progressivamente os materiais gramaticais de uso escolar começaram a ficar significativamente diferentes daqueles que não tinham a escola como destino final.

Quanto às gramáticas completas presentes em nosso levantamento, a presença dessas especificidades possibilitou que facilmente separássemos tais obras em escolares e não-escolares ou de referência, como aqui as categorizamos. Especificamente, os critérios que utilizamos para atestar o vínculo com a escola foram os seguintes: (i) menção explícita no título, subtítulo, folha de rosto ou prefácio ao universo escolar; (ii) presença de referências aos programas de ensino oficiais e (iii) presença de exercícios de fixação (cf. seção 2.3).

Assim, o critério que utilizamos para classificar uma gramática do início dos novecentos como de referência é a inexistência dessas três variáveis, o que nos levou, no conjunto total de 55 gramáticas presentes em nosso levantamento, ao seguinte quadro:

Quadro 11 - Gramáticas de referência completas: século XX

\begin{tabular}{|c|l|}
\hline ABREU, A. E. & - Grammatica popular da Lingua Portugueza (1923) $\boldsymbol{\beta}$ \\
\hline ANDRADE, Gustavo de & $\begin{array}{l}\text { - Grammatica ecletica da Lingua Portugueza: curso } \\
\text { superior (1917) } \boldsymbol{\beta}\end{array}$ \\
\hline BARBUDA, Pedro Julio & - Grammatica (1926) $\boldsymbol{\beta}$ \\
\hline $\begin{array}{c}\text { PEREIRA JUNIOR, } \\
\text { Francisco Augusto }\end{array}$ & $\begin{array}{l}\text { - Gramatica pratica: unica do curso superior completo } \\
\text { (1924) } \boldsymbol{\Sigma}\end{array}$ \\
\hline
\end{tabular}


Com efeito, a análise dessas 4 gramáticas de referência publicadas no início dos novecentos nos mostrou características diferentes daquelas que identificamos nas gramáticas de referência oitocentistas. Nestas, vimos um maior aprofundamento na discussão teórica e na própria análise linguística, características ausentes nas gramáticas de referência do século $\mathrm{XX}$, com exceção da gramática de Barbuda (1926), que se mostra mais densa. Tal constatação nos levou a perceber que esse tipo de gramática possui características distintivas importantes a depender do século de publicação, se o XIX ou o XX. Assim, esquematicamente, temos o seguinte cenário:

- Gramática de referência do século XIX: aprofundamento na discussão teórica e na análise linguística. Ausência de processos de didatização mais explícitos, como exercícios e mensagens de orientação ao professor ao longo do texto;

- Gramática de referência do século XX: ausência de aprofundamento teórico e na análise linguística. Ausência de vínculo com a escola, aferíveis pelas três variáveis apresentadas anteriormente.

Para ampliarmos os parâmetros de comparação entre as gramáticas de referência dos séculos $X I X$ e $X X$, especificamos um pouco mais aquilo que chamamos de maior aprofundamento teórico-analítico das gramáticas oitocentistas:

- Desenvolvimento de discussão teórica, com o objetivo de enquadrar a obra frente às teorias gramaticais existentes. Esse processo se dá normalmente com o autor declarando a qual teoria sua gramática está vinculada - Gramática Tradicional, Gramática HistóricoComparada, Gramática Filosófica -, mas, também, há autores que incluem, ao longo da obra, críticas relativamente aos modelos teóricos que ele julga inadequados;

- Presença de referências a outras obras teóricas, de autores nacionais ou estrangeiros, incluídas com o objetivo de ampliar e aprofundar a reflexão a respeito de um determinado ponto ou também a fim de estabelecer um diálogo teórico-metodológico com os pares. Dessa forma, em tais gramáticas, o objetivo não é apenas prescrever a norma linguística, mas também refletir sobre ela, muitas vezes discordando de outros gramáticos a respeito de algum ponto. Essas discordâncias muitas vezes já aparecem no prefácio, se estendendo, depois, ao próprio texto gramatical.

Dado o que apresentamos até aqui, cremos que uma questão se impõe: se as gramáticas de referência do início do século XX já não tinham mais as características de aprofundamento 
que acima descrevemos, para onde essa discussão mais densa e técnica se deslocou? Em outros termos, em que tipo de obra, se não mais na gramática, os estudiosos do Português publicavam seus estudos, suas ideias? Onde publicavam suas ideias, para que seus pares as conhecessem?

Tal cenário parece apontar para a validade de nossa hipótese, ou seja, para o fato de a gramática, até o final do século XIX, acumular tanto a função da discussão especializada quanto a de instrumento escolar e, a partir do início do século XX, passar a ser um material de viés predominantemente escolar, enfraquecendo, assim, sua outra função.

Com efeito, a despeito das questões que acima levantamos sobre o aprofundamento das gramáticas e sobre sua relação com a escola, é importante sublinhar que a gramática ocidental tem, desde sua origem, uma função didática (cf. seção 2.3, discussão sobre as diferenças entre didático e escolar). Isso equivale a dizer que mesmo com as diferenças que identificamos entre as gramáticas de referência dos séculos XIX e XX, ambas permaneceram desempenhando um papel didático, ou seja, continuaram servindo de fonte de consulta para a população em geral, notadamente àqueles que já tinham saído da escola e ali buscavam solução para suas dúvidas linguísticas e/ou para melhor escrever. Auroux (1992, p.69, itálico do autor e sublinhado nosso) destaca esse papel instrumental da gramática quando a categoriza como um instrumento linguístico.

A gramática não é uma simples descrição da linguagem natural, é preciso concebêla também como instrumento lingüístico: do mesmo modo que um martelo prolonga o gesto da mão, transformando-o, uma gramática prolonga a fala natural e dá acesso a um corpo de regras e de formas que não figuram juntas na competência de um mesmo locutor.

Para respondermos às questões acima e verificarmos a validade de nossa hipótese, é necessário analisar a produção gramaticográfica do século XIX, mesmo que façamos isso de maneira panorâmica e utilizando-nos, em grande medida, de material historiográfico sobre o período. Polachini (2018), em sua tese Uma história serial e conceitual da gramática brasileira oitocentista de Língua Portuguesa, fez um amplo estudo sobre a gramaticografia brasileira do século XIX e também um levantamento de pretensão exaustiva das gramáticas brasileiras do século XIX. Ali, a autora chegou ao número de 216 gramáticas produzidas entre o começo e o final dos anos 1800 no Brasil, sendo que 12 delas não apresentavam data registrada, fato que resultou na não consideração desses materiais na análise.

Em seu trabalho, Polachini (2018) utilizou alguns critérios diferentes dos nossos, como a contagem das reedições, o que faria com que a comparação entre os séculos XIX e XX ficasse distorcida. Para nossa análise, em especial nesse momento, nos interessa saber a quantidade de 
gramáticas e demais obras publicadas no período e não sua permanência no tempo e/ou sucesso editorial (e acadêmico) aferível através de sucessivas reedições. Em nosso trabalho, considerar as reedições poderia fazer, por exemplo, que disséssemos que um determinado período do século XIX foi marcado pela publicação de muitas gramáticas, sendo que o que houve, na verdade, foram as sucessivas reedições de 3 ou 4 obras.

Aplicando os mesmos critérios que utilizamos em nosso levantamento (cf. Apêndice A), temos 127 gramáticas publicadas do século XIX, sendo que seriam 204 se considerássemos as reedições. Da mesma forma que Polachini (2018), não incluímos aqui as obras que, apesar de serem oitocentistas, não possuem data de publicação. Também no que se refere a datas, é necessário apontar para outro critério de seleção e análise por nós utilizado. Em seu trabalho sobre a gramaticografia dos 1800, a autora analisou todo esse século, ao passo que nós, ao estudarmos os 1900, nos circunscrevemos aos 45 primeiros anos. Novamente, outra ação para colocar os dados em condição de comparação se fez necessária e, para tal, retrocedemos, no século XIX, os mesmos 45 anos que estudamos no XX. A rigor, 47 anos, já que em nosso levantamento temos obras registradas que vão até 1947.

Dessa forma, consideramos as publicações a partir de 1853, o que fez o número de gramáticas cair para 108. Esses números mostram algo que Polachini (2018, p.99) apontou, ou seja, a grande quantidade de publicações a partir de 1860. Em seu levantamento, considerando o total de 204 gramáticas, entre 1800 e 1850 vieram a lume 30 obras, enquanto de 1851 a 1899 foram 174 .

Ainda no intuito de compararmos nossos dados com os de Polachini (2018) e assim dimensionarmos melhor a amplitude de nossa hipótese, tivemos de separar as gramáticas encontradas pela autora tal qual fizemos na presente tese, ou seja, em dois grupos, as gramáticas escolares e as de referência (cf. Anexo B).

Diferentemente do que ocorreu com os materiais que compõem nosso levantamento, não tivemos contato físico com a quase totalidade das gramáticas localizadas pela autora, exceção feita, claro, às obras de maior prestígio e disponíveis em bibliotecas, sebos, além daquelas pertencentes ao acervo pessoal do pesquisador. Dessa forma, a checagem da ligação de uma determinada gramática com a escola não pôde ser feita da mesma maneira que ocorreu com as publicações do século XX, às quais tivemos acesso físico. Separamos, portanto, no grupo das gramáticas escolares do século XIX, apenas aquelas em que no título ou subtítulo havia clara referência ao ambiente escolar. Termos mais amplos no que diz respeito ser a obra um material didático ou não e que exigisse, para dirimir essa dúvida, um exame físico, nos fez optar pela não 
inclusão da obra nesse grupo. Assim, a simples presença nos títulos de palavras como compêndio, elementar, postilas, princípios, elementos não foi suficiente para categorizarmos estas gramáticas como escolares, pois, em alguns casos, tais termos foram colocados em seus títulos não com o objetivo de designar um material didático, mas apenas para indicar o grau de aprofundamento daquela obra, dizendo, com isso, que ela se destinava ao consulente pouco experimentado ou estudado. Ao analisarmos, por exemplo, o Compendio da grammatica portugueza, de Augusto Freire da Silva (1836-1917), publicado em 1875, percebemos que não há nele vinculação direta com o ambiente escolar.

Com esses critérios, chegamos ao seguinte quadro comparativo:

Tabela 10 - Gramáticas escolares e de referência: comparação entre os séculos XIX e XX

\begin{tabular}{|c|c|c|}
\hline \multicolumn{2}{|c|}{ Século XIX (1853-1899) } & $\begin{array}{c}\text { Total de } \\
\text { cada } \\
\text { século }\end{array}$ \\
\hline $\begin{array}{c}\text { Gramáticas presumidas como } \\
\text { escolares }\end{array}$ & $\begin{array}{c}\text { Gramáticas presumidas como de } \\
\text { referência }\end{array}$ & \\
\hline 62 obras & 44 obras & 106 \\
\hline \multicolumn{2}{|c|}{ Século XX (1900-1947) } & \\
\hline Gramáticas escolares & Gramáticas de referência & $\mathbf{5 5}$ \\
\hline 51 obras & 4 obras & \\
\hline
\end{tabular}

Para entendermos melhor o cenário gramaticográfico do século XIX, fomos verificar, no grupo das gramáticas escolares, a quais níveis de ensino elas se destinavam. Ao analisarmos fisicamente 12 gramáticas e apenas os títulos e subtítulos das outras 50 que não tivemos acesso, chegamos ao seguinte resultado:

Tabela 11 - Divisão das gramáticas por segmento escolar - Séculos XIX e XX

\begin{tabular}{|l|c|}
\hline \multicolumn{2}{|c|}{ Século XIX (1853-1899) } \\
\hline - Gramáticas primárias & 33 \\
\hline - Gramáticas secundárias & 8 \\
\hline
\end{tabular}

\footnotetext{
${ }^{43}$ Presumidas, pois não tivemos acesso físico a boa parte das obras. Realizamos esta categorização a partir dos títulos e subtítulos das gramáticas ou de informações obtidas em fontes secundárias.
} 


\begin{tabular}{|l|c|}
\hline - Gramática primária e secundária & 1 \\
\hline - Gramáticas em que não foi possível identificar a destinação específica & 20 \\
\hline Total parcial & $\mathbf{6 2}$ \\
\hline \multicolumn{2}{|c|}{ Século XX (1900 - 1947) } \\
\hline - Gramáticas primárias & 10 \\
\hline - Gramáticas secundárias & $\mathbf{3 1}$ \\
\hline - Gramáticas em que não foi possível identificar a destinação específica & 10 \\
\hline Total parcial & $\mathbf{5 1}$ \\
\hline
\end{tabular}

Quanto ao século XIX, é nítida a prevalência das gramáticas primárias frente às secundárias. Na seção 2.3.1.4.1, apontamos a importância que teve o Colégio Pedro II quanto à estruturação e consolidação do ensino secundário no Brasil. O colégio foi fundado em 1837 e passou a funcionar apenas em $1838^{44}$, mas foi somente a partir de 1869 que a disciplina "Português" passou a ter relevância no currículo, no âmbito da Reforma do Ministro Paulino de Souza. Esse cenário parece explicar a distribuição de gramáticas secundárias no período de 1853 a 1889: das 8 obras localizadas, 5 foram publicadas após o Programa de Fausto Barreto, de 1887 (cf. Anexo A1). Quanto às demais, foram publicadas em 1875, 1876, 1879. É natural, portanto, que antes de 1837, as gramáticas escolares fossem apenas as primárias. Também é natural que, a partir de 1869, com a progressiva estruturação e crescimento do Secundário, houvesse o respectivo crescimento de materiais didáticos que pudessem servir a esse novo nível de ensino.

Esquematicamente, podemos dizer que a segunda metade do século XIX foi um período profícuo para as gramáticas escolares primárias, enquanto a primeira metade do século XX o foi para as secundárias.

Ainda comparando a produção gramaticográfica dos períodos acima mencionados, passemos ao universo das gramáticas de referência. É exatamente nesse grupo que os números mais impressionam, já que temos 44 gramáticas produzidas no século XIX, ao passo que no século XX são apenas 4 obras. Tal disparidade numérica nos fez enxergar esse ponto como algo a ser melhor investigado, principalmente porque esses números parecem apontar, mais uma vez, para a validade de nossa hipótese, ou seja, para o fato de a gramática, até o final do século XIX, acumular tanto a função da discussão especializada quanto a de instrumento escolar e, a partir do

\footnotetext{
${ }^{44}$ Agradecemos ao professor José Borges Neto por esta informação.
} 
início do século XX, passar a ser um material de viés predominantemente escolar, diminuindo, assim, sua outra função.

Com efeito, para os autores do começo do século $\mathrm{XX}$, a gramática não pareceu ser o melhor espaço para a reflexão mais especializada, mais profunda sobre a Língua Portuguesa. Esse processo, porém, não fez cessar o prestígio de que gozavam importantes gramáticas editadas no século XIX. Este levantamento que realizamos comprova tal permanência:

Tabela 12 - Gramáticas do século XIX que avançaram até o século XX

\begin{tabular}{|c|c|c|c|c|c|c|c|}
\hline Autor & Gramática & 焉 & : & 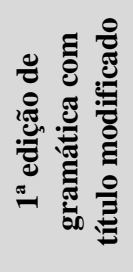 & 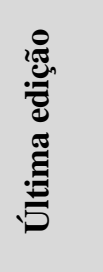 & 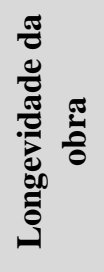 & 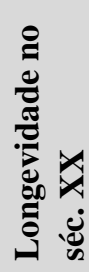 \\
\hline $\begin{array}{l}\text { ALMEIDA, } \\
\text { Bibiano } \\
\text { Francisco } \\
(1838-1892)\end{array}$ & $\begin{array}{l}\text { - Compêndio de grammatica } \\
\text { portugueza: dedicado ao } \\
\text { estudantes rio-grandenses }\end{array}$ & $\underset{45}{\text { Esc. }}$ & 1880 & & $\begin{array}{l}\mathrm{s} / \mathrm{d} \\
\left(12^{\mathrm{a} e}\right. \\
\text { d. })^{46}\end{array}$ & $?$ & $?$ \\
\hline $\begin{array}{l}\text { BANDEIRA, } \\
\text { Adelia Ennes } \\
\text { (?- 1923) }\end{array}$ & $\begin{array}{l}\text { - Grammatica portugueza } \\
\text { pratica }\end{array}$ & $\begin{array}{l}\text { Esc. } \\
\text { Prim } \\
\text {. }\end{array}$ & 1897 & & $\begin{array}{l}1937 \\
\left(23^{\mathrm{a} e}\right. \\
\text { d. })^{*}\end{array}$ & $\begin{array}{c}40 \\
\text { anos }\end{array}$ & $\begin{array}{c}37 \\
\text { anos }\end{array}$ \\
\hline \multirow[t]{2}{*}{$\begin{array}{l}\text { BORGES, } \\
\text { Abilio } \\
\text { Cesar }^{47} \\
(1824-1891)\end{array}$} & $\begin{array}{l}\text { - Epitome da grammatica } \\
\text { portugueza }^{48} \\
\text { (com este título até a } 5^{\text {a }} \text { edição, ano ?) }\end{array}$ & $\begin{array}{c}\text { Esc. } \\
?\end{array}$ & 1860 & & & & \\
\hline & $\begin{array}{l}\text { - Resumo da grammatica } \\
\text { portugueza: para uso nas } \\
\text { escolas } \\
\text { (com este título a partir da } 7^{\mathrm{a}} \text { edição, } \\
\text { 1877) }\end{array}$ & & & & $\begin{array}{l}1907 \\
\left(12^{\mathrm{a} e}\right. \\
\text { d. })^{*}\end{array}$ & $\begin{array}{c}47 \\
\text { anos }\end{array}$ & $\begin{array}{c}7 \\
\text { anos }\end{array}$ \\
\hline $\begin{array}{l}\text { BOSCOLI, } \\
\text { José Ventura } \\
(1855-1919)\end{array}$ & - Grammatica da puericia & $\begin{array}{l}\text { Esc. } \\
\text { Prim } \\
\text {. }\end{array}$ & 1895 & & $\begin{array}{l}1900 \\
\left(2^{\mathrm{a} e d .}\right. \\
)^{*}\end{array}$ & $\begin{array}{c}5 \\
\text { anos }\end{array}$ & $\begin{array}{c}0 \\
\text { ano }\end{array}$ \\
\hline
\end{tabular}

\footnotetext{
${ }^{45}$ Examinamos a obra e não há informações que a liguem a algum segmento de ensino. A gramática possui exercícios e pelo seu nível de aprofundamento, parece ser destinada ao ensino primário.

${ }^{46}$ Temos um exemplar da $9^{a}$ edição, que é de 1906. Não foi possível obter o ano de publicação da $12^{a}$ edição.

${ }^{47}$ O autor também assina como: "Abilio Cezar Borges, barão de Macahubas” ou “Abilio Cezar Borges".

${ }^{48}$ As informações sobre esta gramática são lacunares. Não sabemos, por exemplo, a respeito da $6^{a}$ edição.
} 


\begin{tabular}{|c|c|c|c|c|c|c|c|}
\hline Autor & Gramática & 选 & 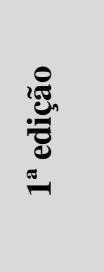 & 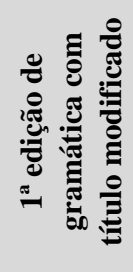 & 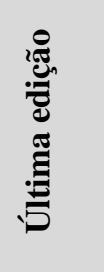 & 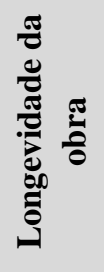 & 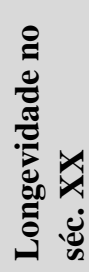 \\
\hline \multirow[t]{3}{*}{$\begin{array}{c}\text { FREIRE DA } \\
\text { SILVA, } \\
\text { Augusto } \\
\text { (1836-1917) }\end{array}$} & $\begin{array}{l}\text { - Compendio da grammatica } \\
\text { portugueza }\end{array}$ & Ref. & $\begin{array}{l}1875 \\
\left(2^{\mathrm{a}}\right. \\
\text { ed. }) \\
49\end{array}$ & & & & \\
\hline & - Grammatica portugueza & & & $\begin{array}{l}1906 \\
\left(9^{\mathrm{a}} \mathrm{ed} .\right)\end{array}$ & $\begin{array}{c}1906 \\
\left(9^{\mathrm{a} e d .}\right. \\
)\end{array}$ & $\begin{array}{c}31 \\
\text { anos }\end{array}$ & $\begin{array}{c}6 \\
\text { anos }\end{array}$ \\
\hline & $\begin{array}{l}\text { - Rudimentos da grammatica } \\
\text { portugueza para uso dos } \\
\text { alumnos de primeiras lettras }\end{array}$ & $\begin{array}{l}\text { Esc. } \\
\text { Prim }\end{array}$ & 1879 & & $\begin{array}{c}1903 \\
\left(6^{\mathrm{a} e d .}\right. \\
)\end{array}$ & $\begin{array}{c}24 \\
\text { anos }\end{array}$ & $\begin{array}{c}3 \\
\text { anos }\end{array}$ \\
\hline $\begin{array}{l}\text { GOMES,Alfr } \\
\text { edo } \\
(1859-1924)\end{array}$ & - Grammatica portugueza & $\begin{array}{l}\text { Esc. } \\
\text { Sec. }\end{array}$ & 1887 & & $\begin{array}{l}1930 \\
\left(20^{\mathrm{a} e}\right. \\
\text { d. })^{*}\end{array}$ & $\begin{array}{c}43 \\
\text { anos }\end{array}$ & $\begin{array}{c}30 \\
\text { anos }\end{array}$ \\
\hline \multirow{2}{*}{$\begin{array}{l}\text { MACIEL,Ma } \\
\text { ximino } \\
\text { (1866-1923) }\end{array}$} & - Grammatica analytica & Ref. & 1887 & & & & \\
\hline & - Grammatica descriptiva & & & $\begin{array}{l}1894 \\
\left(2^{\mathrm{a}} \mathrm{ed} .\right)\end{array}$ & $\begin{array}{l}1931 \\
\left(12^{\mathrm{a} e}\right. \\
\text { d. })^{*}\end{array}$ & $\begin{array}{c}44 \\
\text { anos }\end{array}$ & $\begin{array}{c}31 \\
\text { anos }\end{array}$ \\
\hline $\begin{array}{c}\text { MAIA, Zillah } \\
\text { do Paço } \\
\text { Mattoso } \\
\text { (?-?) }\end{array}$ & $\begin{array}{l}\text { - Grammatica da Lingua } \\
\text { Portugueza }\end{array}$ & $?$ & 1899 & & $\begin{array}{c}1914 \\
\left(3^{\mathrm{a} e d} .\right. \\
)\end{array}$ & $\begin{array}{c}15 \\
\text { anos }\end{array}$ & $\begin{array}{c}14 \\
\text { anos }\end{array}$ \\
\hline $\begin{array}{c}\text { P.S } \\
\text { (Pedro } \\
\text { Schneider) } \\
(1866-1931)\end{array}$ & $\begin{array}{l}\text { - Livro de exercicios para } \\
\text { apprender os elementos da } \\
\text { Grammatica portugueza }\end{array}$ & $\begin{array}{l}\text { Esc. } \\
\text { Prim } \\
. / \mathrm{Sec} \\
.\end{array}$ & $\begin{array}{l}1897 \\
\left(3^{\mathrm{a}} \mathrm{e}\right. \\
\text { d. })^{50}\end{array}$ & & $\begin{array}{c}\mathrm{s} / \mathrm{d} \\
\left(9^{\mathrm{a} e d}\right. \\
\quad)\end{array}$ & $?$ & $?$ \\
\hline $\begin{array}{l}\text { RIBEIRO, } \\
\text { Ernesto } \\
\text { Carneiro }\end{array}$ & $\begin{array}{l}\text { - Serões grammaticaes ou } \\
\text { nova grammatica portugueza }\end{array}$ & Ref. & 1890 & & $\begin{array}{l}1956 \\
\left(6^{\mathrm{a} e d}\right. \\
) *\end{array}$ & $\begin{array}{c}66 \\
\text { anos }\end{array}$ & $\begin{array}{c}56 \\
\text { anos }\end{array}$ \\
\hline
\end{tabular}

\footnotetext{
${ }^{49}$ Não encontramos referência à data da $1^{\mathrm{a}}$ edição em nenhum arquivo.

${ }^{50}$ Não conseguimos acesso à data de publicação da $1^{a}$ edição. Temos um exemplar da $9^{a}$ edição e não há nele nenhuma marcação de data. Encontramos registros que apontam a $5^{\text {a }}$ edição como sendo de 1905 .
} 


\begin{tabular}{|c|c|c|c|c|c|c|c|}
\hline Autor & Gramática & 赵 & 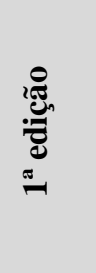 & 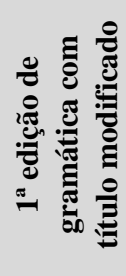 & 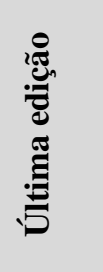 & 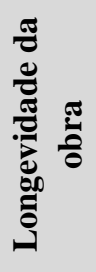 & 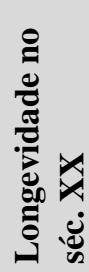 \\
\hline$(1839-1920)$ & $\begin{array}{l}\text { - Elementos de grammatica } \\
\text { portugueza }\end{array}$ & Ref. & 1885 & & $\begin{array}{l}1932 \\
\left(7^{\mathrm{a}} \mathrm{ed} .\right. \\
)^{51 *}\end{array}$ & $\begin{array}{c}47 \\
\text { anos }\end{array}$ & $\begin{array}{c}32 \\
\text { anos }\end{array}$ \\
\hline \multirow[t]{3}{*}{$\begin{array}{l}\text { RIBEIRO, } \\
\text { João } \\
(1860-1934)\end{array}$} & $\begin{array}{l}\text { - Grammatica portugueza: } 1^{\circ} \\
\text { anno }\end{array}$ & $\begin{array}{l}\text { Esc. } \\
\text { Prim }\end{array}$ & 1890 & & $\begin{array}{l}1951 \\
\left(101^{\mathrm{a}}\right. \\
\text { ed. })^{*}\end{array}$ & $\begin{array}{c}61 \\
\text { anos }\end{array}$ & $\begin{array}{c}51 \\
\text { anos }\end{array}$ \\
\hline & $\begin{array}{l}\text { - Grammatica portugueza: } \\
\left.\text { curso médio ( } 2^{\circ} \text { anno }\right)\end{array}$ & $\begin{array}{l}\text { Esc. } \\
\text { Prim } \\
.\end{array}$ & 1887 & & $\begin{array}{l}1930 \\
\left(39^{\mathrm{a} e}\right. \\
\text { d. })\end{array}$ & $\begin{array}{c}43 \\
\text { anos }\end{array}$ & $\begin{array}{c}30 \\
\text { anos }\end{array}$ \\
\hline & $\begin{array}{l}\text { - Grammatica portugueza: } \\
\left.\text { curso superior ( } 3^{\circ} \text { anno }\right)\end{array}$ & $\begin{array}{c}\text { Ref. } \\
52\end{array}$ & 1887 & & $\begin{array}{l}1933 \\
\left(22^{\mathrm{a} e}\right. \\
\text { d. })\end{array}$ & $\begin{array}{c}46 \\
\text { anos }\end{array}$ & $\begin{array}{c}33 \\
\text { anos }\end{array}$ \\
\hline \multirow{2}{*}{$\begin{array}{l}\text { RIBEIRO, } \\
\text { Júlio } \\
\text { (1845-1890) }\end{array}$} & $\begin{array}{l}\text { - Holmes brasileiro ou } \\
\text { grammatica da puericia }\end{array}$ & $\begin{array}{l}\text { Esc. } \\
\text { Prim }\end{array}$ & 1886 & & $\begin{array}{l}1903 \\
\left(4^{\mathrm{a} e d .}\right.\end{array}$ & $\begin{array}{c}17 \\
\text { anos }\end{array}$ & $\begin{array}{c}3 \\
\text { anos }\end{array}$ \\
\hline & - Grammatica portugueza & Ref. & 1881 & & $\begin{array}{l}1914 \\
\left(12^{\mathrm{a} e}\right. \\
\text { d. })^{*}\end{array}$ & $\begin{array}{c}33 \\
\text { anos }\end{array}$ & $\begin{array}{c}14 \\
\text { anos }\end{array}$ \\
\hline \multirow{2}{*}{$\begin{array}{l}\text { SANTOS, } \\
\text { Hemetério } \\
\text { José dos } \\
\text { (1858-1939) }\end{array}$} & $\begin{array}{l}\text { - Grammatica elementar da } \\
\text { lingua portugueza extrahida } \\
\text { dos melhores auctores e.. }\end{array}$ & $\begin{array}{l}\text { Esc. } \\
\text { Sec. }\end{array}$ & 1897 & & & & \\
\hline & - Grammatica portugueza & & & $\begin{array}{l}1913 \\
\left(3^{\mathrm{a} e d} .\right)\end{array}$ & $\begin{array}{l}1913 \\
\left(3^{\mathrm{a} e d} .\right. \\
\quad)\end{array}$ & $\begin{array}{c}16 \\
\text { anos }\end{array}$ & $\begin{array}{c}13 \\
\text { anos }\end{array}$ \\
\hline
\end{tabular}

\footnotetext{
${ }^{51}$ Em 1957, Deraldo Inácio de Sousa publica Estudos gramaticais e filológicos, volume que reúne cinco obras de Ernesto Carneiro Ribeiro, entre elas Elementos de gramática portuguêsa, em sua $8^{a}$ edição, já que contou com intervenções do organizador. Optamos por não considerá-la em nosso quadro, pois julgamos mais adequado registrar a última edição em que houve a publicação da obra como uma gramática avulsa e não em um volume em que se compilou outros textos. O volume preparado por Sousa, em 1957, nos parece muito mais um registro histórico ou mesmo o resgate de obras pouco acessíveis de Carneiro Ribeiro, do que uma gramática para uso regular.

${ }^{52} \mathrm{Se}$ consideramos o plano da obra estabelecido pelo autor, esta gramática foi elaborada para ser usada no curso secundário. No entanto, ao examinarmos a obra, percebemos que ela se encaixa nos critérios que estabelecemos para as gramáticas de referência do século XIX, notadamente no que se refere ao aprofundamento da discussão linguística.
} 


\begin{tabular}{|c|c|c|c|c|c|c|c|}
\hline Autor & Gramática & 退 & 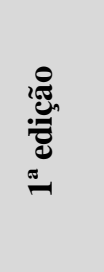 & 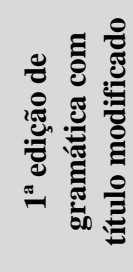 & 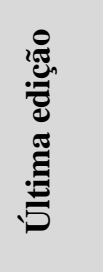 & 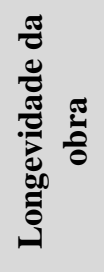 & 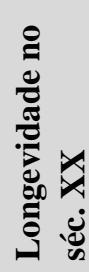 \\
\hline \multirow{2}{*}{$\begin{array}{c}\text { SILVA } \\
\text { JUNIOR, } \\
\text { Pacheco da } \\
(1842-1899) \\
\text { e } \\
\text { ANDRADE, } \\
\text { Lameira de } \\
(?-?)\end{array}$} & $\begin{array}{l}\text { - Noções de grammatica } \\
\text { portugueza: de accordo com o } \\
\text { programma oficial }\end{array}$ & Ref. & 1887 & & & & \\
\hline & $\begin{array}{l}\text { - Grammatica da lingua } \\
\text { portugueza: para uso dos } \\
\text { gymnasios, lyceus e escolas } \\
\text { normaes }\end{array}$ & & & $\begin{array}{c}1894 \\
\left(2^{\mathrm{a}} \mathrm{ed} .\right)\end{array}$ & $\begin{array}{l}1907 \\
\left(3^{\mathrm{a} e d} .\right. \\
\quad)\end{array}$ & $\begin{array}{c}20 \\
\text { anos }\end{array}$ & $\begin{array}{c}7 \\
\text { anos }\end{array}$ \\
\hline $\begin{array}{l}\text { VIEIRA, } \\
\text { Verissimo } \\
(1855-?)\end{array}$ & $\begin{array}{l}\text { - Grammatica portugueza: } \\
\text { curso elementar (Obra } \\
\text { adoptada ao curso medio dos } \\
\text { estabelecimentos de Instrucção } \\
\text { Primaria) }\end{array}$ & $\begin{array}{l}\text { Esc. } \\
\text { Prim }\end{array}$ & 1898 & & $\begin{array}{l}1937 \\
\left(43^{\mathrm{a} e}\right. \\
\text { d. })\end{array}$ & $\begin{array}{c}39 \\
\text { anos }\end{array}$ & $\begin{array}{c}37 \\
\text { anos }\end{array}$ \\
\hline TOTAL & \multicolumn{7}{|c|}{20 gramáticas } \\
\hline
\end{tabular}

Legenda: *: Edições póstumas.

Ref.: Gramática de referência

Esc. Prim.: Gramática escolar primária

Esc. Sec.: Gramática escolar secundária

Com efeito, a longevidade de várias gramáticas do século XIX, muitas delas em edições póstumas, nos chamou bastante atenção. Não se trata de casos isolados, de uma ou outra obra que fez sucesso e se manteve ativa/reeditada por muito tempo, mas de 20 gramáticas, o que a nosso ver parece representar um número bastante significativo. Além da quantidade, há outros aspectos que saltam aos olhos quando analisamos as gramáticas presentes o quadro acima, como: (i) a grande quantidade de edições existentes para uma mesma obra e (ii) as muitas décadas em que determinadas obras se mantiveram ativas no mercado. É natural que tais características não se apresentem de maneira homogênea nessas 20 gramáticas, o que nos motivou a fazer considerações mais específicas sobre esse universo, a fim de melhor entendê-lo.

Quanto ao primeiro aspecto que levantamos, a quantidade de edições, sabemos que ele por si só não é suficiente para revelar algumas informações, como o sucesso editorial de uma gramática. Podemos ver isso se compararmos duas gramáticas bastante longevas de dois autores bastante influentes no século XIX, João Ribeiro (1860-1934) e Ernesto Carneiro Ribeiro (18391920), que, respectivamente, publicaram Grammatica portuguesa: $1^{\circ}$ anno e Serões 
grammaticaes ou nova grammatica portugueza. Ambas foram editadas ao longo de 60 anos aproximadamente, porém a primeira teve 101 edições e a segunda apenas 6. Há, possivelmente, nessa discrepância, explicações de ordem editorial, como a tiragem de cada edição, o que pode fazer uma obra com poucas edições, mas com tiragens muito grandes e feitas com um certo espaçamento de tempo, apresentar grande capilaridade e longevidade no mercado, comparativamente a outra, com mais edições, porém com baixa tiragem em cada uma delas. Em relação às duas gramáticas acima citadas, não estamos afirmando que elas necessariamente se enquadram nessa questão editorial, mesmo porque não encontramos dados que fundamentassem esse caso em especial.

Em função desses aspectos, optamos por dar, em nossa análise, centralidade ao segundo aspecto, ou seja, à quantidade de anos em que determinada gramática permaneceu sendo editada, ativa. Como nosso objetivo é compreender, de uma forma mais ampla, como estava estruturado o cenário gramaticográfico do início do século XX, a variável longevidade nos pareceu a mais adequada aos nossos propósitos. Vejamos, então, um quadro onde esquematizamos os dados a ela relacionados.

Tabela 13 - Longevidade das gramáticas do século XIX durante o século XX

\begin{tabular}{|l|c|}
\hline \multicolumn{1}{|c|}{ Longevidade } & Quantidade de gramáticas \\
\hline $50-59$ anos & 2 \\
\hline $40-49$ anos & 7 \\
\hline $30-39$ anos & 0 \\
\hline $20-29$ anos & 3 \\
\hline $10-19$ anos & 6 \\
\hline $1-9$ anos & 2 \\
\hline Indeterminado/Prejudicada a análise & $\mathbf{2 0}$ \\
\hline Total de gramáticas & \\
\hline
\end{tabular}

Estas faixas de longevidade foram calculadas considerando-se a quantidade de anos, a partir de 1900, que uma gramática do século XIX seguiu sendo editada até a data da última edição por nós encontrada. Peguemos, por exemplo, o caso da gramática mais longeva de nossa tabela, os Serões grammaticaes, de Ernesto Carneiro Ribeiro (1839-1920). Sua $1^{\text {a }}$ edição data de 1890 
e a última de 1956. Essa obra foi, portanto, editada por 66 anos, sendo que 56 anos se referem ao século XX.

Como pode ser visto acima, há 9 gramáticas que consideramos significativamente longevas, ou seja, com períodos de permanência no século XX acima de 30 anos. São elas:

Tabela 14 - Gramáticas mais longevas do século XIX com edição também no século XX

\begin{tabular}{|c|c|c|c|}
\hline Autor & Título & Longevidade $^{53}$ & Enq. \\
\hline $\begin{array}{l}\text { BANDEIRA, Adelia } \\
\text { E. }\end{array}$ & - Grammatica portugueza pratica & 37 anos & EP \\
\hline GOMES, Alfredo & - Grammatica portugueza & 30 anos & ES \\
\hline \multirow[t]{2}{*}{$\begin{array}{l}\text { RIBEIRO, Ernesto } \\
\text { Carneiro }\end{array}$} & $\begin{array}{l}\text { - Serões grammaticaes ou nova } \\
\text { grammatica portugueza }\end{array}$ & 56 anos & $\mathrm{R}$ \\
\hline & - Elementos de grammatica portugueza & 32 anos & $\mathrm{R}$ \\
\hline \multirow[t]{3}{*}{ RIBEIRO, João } & - Grammatica portugueza: $1^{\circ}$ anno & 51 anos & EP \\
\hline & $\begin{array}{l}\text { - Grammatica portugueza: curso médio } \\
\left(2^{\circ} \text { anno }\right)\end{array}$ & 30 anos & $\mathrm{EP}$ \\
\hline & $\begin{array}{l}\text { - Grammatica portugueza: curso superior } \\
\left(3^{\circ} \text { anno }\right)\end{array}$ & 33 anos & $\mathrm{R}$ \\
\hline MACIEL, Maximino & - Grammatica descriptiva & 31 anos & $\mathrm{R}$ \\
\hline VIEIRA, Verissimo & $\begin{array}{l}\text { - Grammatica portugueza: curso } \\
\text { elementar }\end{array}$ & 37 anos & EP \\
\hline TOTAL & \multicolumn{3}{|l|}{9 gramáticas } \\
\hline
\end{tabular}

Legenda: R: Gramática de referência

EP: Gramática escolar primária

ES: Gramática escolar secundária

Enq.: Enquadramento

${ }^{53}$ Corresponde ao período total em que a gramática foi editada, considerando o intervalo entre a $1^{\mathrm{a}}$ edição (no século XIX) e a última (no século XX). 
Desta tabela, cabe destacar que 4 gramáticas são de referência e 5 escolares. Também é importante mencionar que nela encontramos autores apontados por vários historiógrafos ou historiadores da gramaticografia brasileira - seja em periodizações, seja em textos críticos - como destacados gramáticos do século XIX (cf. Nascentes (1939), Elia, (1975), Cavaliere (2002), Guimarães (1996), Azevedo Filho (2002), Polachini (2013; 2018), entre outros).

Relativamente às gramáticas de referência, que é o que nos interessa mais de perto nesta seção, temos, nos autores acima, a presença de Ernesto Carneiro Ribeiro (1839-1920), João Ribeiro (1860-1934) e Maximino Maciel (1866-1923), autores de grande projeção no século XIX, como atestam os trabalhos históricos e historiográficos que acima mencionamos.

Quanto a essas 4 gramáticas de referência, além do tempo total em que se mantiveram ativas editorialmente, nos interessa também outro dado: a quantidade de anos em que elas permaneceram sendo editadas postumamente.

Obras técnicas, como é o caso das gramáticas, quando editadas depois da morte de seu autor, evidentemente perdem a possibilidade de serem atualizadas em suas bases teóricas, o que faz com que elas possam ficar defasadas frente às teorias mais modernas. Ciente desse fato, é possível que o público olhasse para esses trabalhos como ultrapassados, datados, pertencentes ao passado daquela disciplina. Uma gramática que continua ativa por 10 anos ou mais depois da morte de seu autor, demostra uma vitalidade, um sucesso editorial que merece ser visto mais de perto. Vamos, então, à lista.

Tabela 15 - Gramáticas de referência do século XIX mais longevas: edições póstumas

\begin{tabular}{|c|l|c|c|}
\hline \multirow{2}{*}{ Autor } & \multicolumn{1}{|c|}{ Gramática } & $\begin{array}{c}\text { Data } \\
\text { da } \\
\text { última } \\
\text { edição }\end{array}$ & $\begin{array}{c}\text { Anos de } \\
\text { publicação } \\
\text { após a morte } \\
\text { do autor }\end{array}$ \\
\hline $\begin{array}{c}\text { RIBEIRO, Ernesto } \\
\text { Carneiro } \\
(1839-1920)\end{array}$ & $\begin{array}{l}\text { - Serões grammaticaes ou nova } \\
\text { grammatica portugueza }\end{array}$ & 1956 & 36 anos \\
\cline { 2 - 4 } & - Elementos de grammatica portugueza & 1932 & 12 anos \\
\hline $\begin{array}{c}\text { MACIEL, } \\
\text { Maximino }\end{array}$ & - Grammatica descriptiva & 1931 & 8 anos \\
\hline $\begin{array}{c}\text { RIBEIRO, João } \\
(1860-1934)\end{array}$ & $\begin{array}{l}\text { - Grammatica portugueza: curso superior } \\
\left(3^{\circ} \text { anno }\right)\end{array}$ & 1933 & 1 ano \\
\hline
\end{tabular}


Com efeito, julgamos ser possível, agora, com as variáveis apresentadas a respeito do século XIX, voltarmos para o fato de termos editadas, nas quatro primeiras décadas do século XX, apenas 4 gramáticas de referência. Se considerarmos que no período de 1853 a 1899 houve a publicação de 44 gramáticas de referência, nos parece bastante evidente que a edição de novas gramáticas de referência deixa de ser prioritária no contexto gramaticográfico brasileiro do início do século XX, o que pode ser comprovado tanto pela expressiva redução numérica quanto pela mudança de perfil das gramáticas de referência entre o século XIX e começo do XX, por nós destacada no início desta seção.

No entanto, o fato de 4 gramáticas de referência do século XIX (cf. Tabela 14) permanecerem sendo editadas no século XX por longos períodos (acima de 30 anos), mostra que havia demanda por esse tipo de material no início dos novecentos. Dentre os autores dessas gramáticas, estão importantes nomes da gramaticografia brasileira oitocentista - Ernesto Carneiro Ribeiro (1839-1920), João Ribeiro (1860-1934), Maximino Maciel (1866-1923) -, ou seja, são autores cujas obras mantiveram, no começo do século XX, o prestígio que gozavam no século XIX.

Já quanto aos autores que produziram no início do século XX, permanece a questão que elaboramos no início desta seção, ou seja, se as gramáticas de referência escritas nesse período não tinham mais o aprofundamento teórico e analítico característico dos oitocentos, para onde essa discussão mais densa e técnica se deslocou? Onde os estudiosos do Português publicavam suas ideias, para que seus os pares as conhecessem?

Com efeito, a resposta para essas perguntas nos parece ser a seguinte: a produção gramaticográfica novecentista de maior profundidade migrou para as obras monográficas, que, pelo seu caráter verticalizado, tinham condições de discutir mais detidamente e de forma mais aprofundada os poucos temas ali tratados. A esse tipo de publicação e às suas especificidades, nos dedicaremos a estudar na próxima seção.

\subsection{Obras de referência de temas gramaticais específicos}

No capítulo 2, dissemos que durante o processo de pesquisa para compor nosso levantamento, fomos encontrando em número bastante significativo de materiais que não são 
gramáticas escolares completas, mas que abordam um ou mais tópicos gramaticais específicos, como análise sintática, análise morfológica, conjunção, verbos, acentuação, entre outros assuntos (cf. 2.3.2). Esse tipo de obras foi por nós categorizado como obras escolares de temas gramaticais específicos.

Ainda no capítulo 2, dissemos que elas podem ser vistas como verdadeiras separatas de uma gramática escolar completa, pois ali são desenvolvidos tópicos gramaticais que foram selecionados para receber maior aprofundamento teórico ou mesmo prático, já que várias obras ofereciam uma quantidade farta de exercícios de fixação ou ainda de nível de dificuldade maior. Afirmamos, com efeito, que tais materiais funcionavam como ferramenta auxiliar às gramáticas escolares completas.

Excluindo as especificidades ligadas ao universo escolar, podemos dizer que o mesmo cenário se aplica às obras de referência, o que nos fez categorizá-las como obras de referência de temas gramaticais específicos. A volumosa produção nesse grupo, 157 obras, que é a maior entre as cinco categorizações que propusemos para o programa gramatical, parece compensar e justificar as apenas 4 gramáticas de referência escritas no início dos novecentos. Mais importante do que o número reduzido em si, é o fato de que tais gramáticas tiveram baixo impacto no cenário gramaticográfico brasileiro, considerando que são raramente mencionadas entre autores do período e em obras de cunho histórico ou historiográfico, como as aqui já citadas.

Assim, quanto ao início do século $\mathrm{XX}$, nos parece que a produção gramatical de referência de maior relevância ocorre nas obras que incluímos na presente seção. Tais publicações se dedicam, basicamente, a quatro tipos de tarefas:

- Obras que reúnem temas gramaticais variados, normalmente sob títulos como Questões de linguagem, Questões vernáculas, Estudos/Lições/Questões de Português, entre outros títulos assemelhados. Boa parte dessas obras são consultórios gramaticais ou tratam de questões gramaticais que o autor julgava difíceis ou controversas (78);

- Obras em que se estudam as ideias gramaticais (ou a linguagem) de um determinado autor e as que trazem as polêmicas gramaticais entre autores (crítica, réplica e tréplica) (25);

- Teses elaboradas para os concursos de ingresso à docência secundária ou superior (8);

- Obras que abordam poucos temas gramaticais (geralmente, entre um e três). Encontramos neste grupo obras com os seguintes títulos: Collocação dos pronomes, Verbos portugueses, $O$ problema da crase, Gallicismos, Tres questões de grammatica: topologia pronominal, crase, impessoalidade e pessoalidade do infinito, entre outros (42). 
$\mathrm{Na}$ seção anterior, dissemos que as gramáticas de referência do século XIX eram utilizadas tanto pelos especialistas, que se valiam desse espaço para reflexões e análises mais profundas sobre o Português, quanto pelo cidadão letrado comum, que consultava a gramática com o objetivo de sanar as dúvidas que surgiam em seu dia a dia de usuário da língua ou mesmo para escrever melhor. Devemos destacar que esse grupo que chamamos de cidadão letrado comum representava, no século XIX, uma pequena parcela da população brasileira, uma vez que em 1872, por exemplo, apenas $16 \%$ da população brasileira era alfabetizada (cf. tabela 6 - seção 2.3.1.4.1). Assim, nessa época, a gramática de referência circulava em diminutas parcelas da sociedade, mesmo considerando esses dois perfis de público-alvo.

No entanto, no começo dos novecentos, esse cenário parece se alterar. A análise das 157 obras de temas gramaticais específicos sugere que elas passaram a atender a esses dois perfis de público em tipos de publicação diferentes. As 78 obras de tipo consultório gramatical têm como destino o cidadão letrado comum, principalmente se considerarmos o aumento de demanda por esclarecimento de dúvidas e usos corretos do Português gerado pelo aumento significativo da alfabetização no Brasil, ocorrido na primeira metade do século XX. Se, em 1872, o percentual dos que sabiam ler escrever era de 16\%, em 1940, já era de 44\%, atingindo, em 1950, a marca de metade da população brasileira alfabetizada. Os números completos são, para efeito de comparação, os seguintes: 1872 (16\%), 1890 (15\%), 1900 (25\%), 1920 (24\%), 1940 (44\%) e 1950 (49\%) (cf. tabela 6 - seção 2.3.1.4.1).

Já o debate mais denso e técnico, realizado pelos professores e demais estudiosos do Português era realizado, predominantemente, nas obras que agrupamos nos grupos 2 e 3 que acima mencionamos: (i) nas publicações que estudam as ideias gramaticais (ou a linguagem) de um determinado autor e nas que trazem as polemicas gramaticais entre autores e (ii) nas teses de concurso à docência.

Quanto às 42 obras relacionadas ao quatro grupo, julgamos que elas atendiam tanto ao cidadão letrado comum quanto aos especialistas.

Como já dissemos, do ponto de vista das camadas teórica, técnica e documental, não há diferenças significativas entre as obras reunidas neste capítulo 3 e as já analisadas no capítulo 2 . Assim, nosso objetivo será o de contextualizar essas obras no cenário gramaticográfico brasileiro do início do século XX.

Começaremos com o grupo que contém as obras de tipo consultório gramatical, que são, segundo nosso levantamento, a maioria nesta seção (78 entre 157) (cf. Quadro 7B - Apêndice 
B). Nos exemplos selecionados, é possível dimensionar o tipo de dúvida que incomodava a população que procurava e consumia essas obras.

\begin{abstract}
Mílton Flaquer Arouca - S. Paulo
Quer o snr. saber se é certo dizer meio-dia e meio no masculino, em lugar de meiodia e meia como ensinam alguns. É muito certo, muito correto. Dá-se na concordância do adjetivo meia a atração sintática exercida pela palavra principal da expressão dia ainda mais que já precede o mesmo adjetivo meio, no masculino: meio-dia e meio. Todos sabem que aí está oculta a palavra hora: meio-dia e meia hora, mas, como está oculta deixa de influenciar na concordância do adjetivo meio que, em vez de concordar no feminino com hora, passa a concordar com o substantivo masculino dia, bem claro e expresso na frase. Para maiores esclarecimentos consulte o nosso último livro Páginas Floridas, II série e lá o snr. encontrará o assunto longamente explicado. (BUENO, 1938, p.112, itálicos do autor e sublinhado nosso)
\end{abstract}

Temos nesse caso, uma dúvida envolvendo concordância nominal. O consulente deseja saber se o correto é meio-dia e meia ou meio-dia e meio. Neste caso, Bueno apresenta em formato de livro as dúvidas que ele respondia em um programa de rádio. A obra tem o sugestivo nome Português pelo rádio. Devemos considerar que esta era uma época de grande prestígio do rádio, o que, mais uma vez, denota o interesse da população pelos consultórios gramaticais, independentemente do veículo de comunicação utilizado (jornal, revista, rádio ou livro).

Vejamos outro exemplo, novamente envolvendo concordância, só que agora verbal.

ACABEM-SE COM AS REGALIAS - Por influência do substantivo regido pela preposição com, é comum o emprego do verbo no plural. Advirta-se, porem, que o sujeito de acabar é indeterminado, e não a palavra regalias, que só exerceria essa função se não estivesse regida. É certo dizer de um dos dois modos seguintes: Acabe-se com as regalias (sujeito indeterminado) ou acabem-se as regalias (sujeito - as regalias, paciente). (BERGO, 1942, p. 9, itálicos do autor e sublinhado nosso)

Ao analisarmos as 78 obras presentes neste grupo (cf. Quadro 7B - Apêndice B), nos chamou atenção o fato de vários títulos destacarem a percepção dos autores quanto à existência de deformações, erros, distorções, problemas na língua e que caberia ao gramático, então, alertar a esse respeito e proceder o devido conserto, "remédio" para esses "males" 54 . Outros autores são mais sutis em seus títulos, embora, muitas vezes, tenham a mesma postura crítica quanto às “deformações" e "erros da língua".

\footnotetext{
${ }^{54}$ Nestes títulos, abundam termos como dúvidas, consultas, erros, impurezas, problemas, falar certo, correto, consultório, emendas, reparos, todos eles, obviamente, acompanhados dos complementos linguagem, linguístico, Português, língua nacional, escrever, falar, entre outros.
} 
Faraco (2002, p. 52), ao falar sobre as colunas gramaticais publicadas na imprensa, aponta qual teria sido sua gênese no Brasil.

Seu criador [do modelo que se cristalizou entre nós] parece ter sido o gramático português Cândido de Figueiredo ${ }^{55}$ que, no fim do século XIX e começo do XX, dispunha de espaço em jornais de Lisboa e do Rio de Janeiro para tratar de questões de língua. Em sua coluna, se dedicava ele, no melhor espírito inquisitorial, a caçar "erros" de língua em toda parte e a condenar furiosamente os falantes por sua suposta ignorância linguística e pelo descuido e descaso das questões vernáculas.

Assim, todos estes materiais deixam bastante evidenciada a preocupação que existia na época com o bom uso ou bon usage, conceito assim definido por Rey (2001, p. 136): “o uso das classes dirigentes ou, melhor, o que elas apreciam mais, e que não é obrigatoriamente o delas, torna-se o bon usage".

Ainda Faraco (2002, p. 42-43, itálico do autor), ao analisar as características constitutivas e as diferenças entre a norma-padrão e a norma culta, faz as seguintes considerações sobre o processo de fixação da norma-padrão brasileira.

Embora o padrão não se confunda com a norma culta, está mais próximo dela do que das demais normas, porque os codificadores e os que assumem o papel de seus guardiões e cultores saem dos extratos sociais usuários da norma culta. (...) O caso brasileiro é particularmente exemplar nesse sentido, em especial porque o padrão foi construído, na origem, de forma excessivamente artificial. A codificação que se fez aqui, na segunda metade do século XIX, não tomou a norma culta brasileira de então como referência. Bem ao contrário: a elite letrada conservadora se empenhou em fixar como nosso padrão um certo modelo lusitano de escrita, praticado por alguns escritores portugueses do Romantismo. O modelo não foi, portanto, $a$ língua de Portugal, como muitos pensam, imaginando uma homogeneidade que, de fato, não existe, já que o português de lá é, como qualquer língua, um emaranhado de variedades.

Com efeito, tanto Rey (2001) quanto Faraco (2002) apontam uma característica que parece explicar o grande interesse pelos consultórios gramaticais e demais obras de consulta sobre certo e errado: a distância entre o falar culto e o padrão. Em um país que começava a se alfabetizar, mesmo que lentamente, julgamos que as questões envolvendo a mencionada distância passou a ser algo que realmente deixava incomodava a parcela letrada da sociedade brasileira, deixando-a insegura, com dúvidas ao usar a língua, expondo o fosso existente entre o uso culto que faziam da língua e o que era prescrito pela norma-padrão.

\footnotetext{
${ }^{55}$ Candido de Figueiredo (1846-1925) é autor de uma obra cujo título é bastante significativo: Combates sem sangue em favor da Língua Portuguesa, publicada em 1925.
} 
Marcondes (2008, p. 13), em um trabalho sobre os consultórios gramaticais, assim os define:

\begin{abstract}
Os consultórios gramaticais surgiram no final do século XIX e foram muito populares nesta época e no início do século XX. Podemos dizer que esse tipo de trabalho linguístico, que preza o uso "correto" da língua, juntamente com outras formas textuais, fez parte da reação conservadora que enfrentou as inovações linguísticas pregadas pelos escritores do romantismo brasileiro. Alguns dos principais consultores gramaticais daquela época, conforme já mencionamos, são: Cândido de Figueiredo, Napoleão Mendes de Almeida e Mário Barreto.
\end{abstract}

Por fim, dentro do universo das 78 obras que aqui estamos analisando, devemos dizer que havia espaço não só para obras que propunham rápidas respostas às dúvidas de seus consulentes, mas também para algumas que se dedicavam a elas com maior profundidade e vagar. Nesse grupo, por exemplo, estão os trabalhos de Mário Barreto (1879-1931), autor bastante reconhecido à época pelos seus pares e pelo público não-especializado, já que também atuava na escrita de textos em respostas aos seus consulentes, que geraram, inclusive, a publicação de três livros que reuniram tais esclarecimentos gramaticais (cf. Quadro 7B - Apêndice B).

Vejamos um exemplo extraído dos Novos estudos da Lingua Portuguesa, publicados em 1911. O trecho está no capítulo que tem o seguinte título: "Proposições relativas e conjuncionais. Omissão de que. Pleonasmo de que. - Outros factos sintácticos”.

Vamos tratar no presente capítulo de uma forma complecsa da proposição relativa,
e de outros assuntos mais, se fôr necessário. Os pronomes relativos introduzem ás
vezes duas orações, uma subordinada á outra, relativa a primeira, e substantiva de
forma conjuncional ou infinitiva a segunda, a qual faz o ofício de sujeito ou
complemento directo: Aqui tens os livros que eu disse que tinha em casa, recebi a
encomenda que eu supunha que se tinha extraviado, sairam do pôrto os navios que
os jornais anunciaram que saíam hoje, perdeu-se na má vida que ora diziam que
tinha, homens há que parece que celebram esta festa todo o ano, há ali figuras que
parece que estão falando, é vício êste de que fôra louvável que se reprimissem
alguns senhores, etc. (BARRETO, 1911, p. 161)

$\mathrm{O}$ autor segue o desenvolvimento desse trecho e dos demais tópicos presentes no título ao longo de 22 páginas, até abrir novo capítulo de temática diversa: "A concordáncia gramatical”, que será tratada em 46 páginas.

Como destacamos anteriormente, entre as 157 obras agrupadas nesta seção, consideramos haver dois grupos que tinham como destinatário não a população em geral, como apontamos no caso dos consultórios, mas sim os especialistas em Português, estabelecendo assim um diálogo técnicos entre pares (cf. Quadro 8B - Apêndice B). Nessa situação, estão os livros em que se 
estudam as ideias gramaticais ou a linguagem de um determinado autor, o que, em alguns casos, pode derivar para aquilo que se convencionou chamar de polêmicas gramaticais. O motivo de assinalarmos esse caráter potencial é o fato de haver, muitas vezes, a publicação de um determinado livro em que o autor aborda, analisa ou mesmo critica as ideias gramaticais ou a linguagem de um outro autor e, a partir dessa publicação, poderia ocorrer de o autor citado se sentir ofendido e preparar uma resposta, uma réplica, também em formato de livro, refutando os pontos a ele imputados e tidos como injustos. Em alguns casos, essa resposta seguia sendo contestada em formato de uma tréplica.

Embora fossem comuns na época estas discussões públicas, muitos autores citados em tais obras "iniciais" não respondiam às críticas/comentários feitos, pelo menos não em formato de livro, o que naturalmente impedia a instauração das polêmicas. Em muitos casos, as respostas vinham em colunas de jornais ou revistas, mas nesta tese não analisaremos esse tipo de publicação.

Como nos lembram Leite (1999), Faraco (2001), Pagotto (1998), além de outros autores, entre o final do século XIX e o começo do XX, houve no Brasil duas importantes polêmicas linguísticas: primeiro, a envolvendo o escritor José de Alencar (1829-1877) e Joaquim Nabuco (1849-1910) e depois outra, entre Ernesto Carneiro Ribeiro (1839-1920) e Rui Barbosa (18491923), em torno da redação do Código Civil brasileiro. Relativamente à polêmica alencarina, Leite (1999, p. 26) diz que "no Brasil do século XIX, as polêmicas que giraram em torno da linguagem de José de Alencar ilustram bem esse espírito da época. Alencar foi acusado de praticar uma linguagem descuidada, cheia de neologismos e galicismos”.

Quanto à segunda polêmica mencionada, Leite (1999, p.76, sublinhado nosso), em obra em que discute a configuração do purismo brasileiro, assim se manifesta:

O maior símbolo do purismo linguístico do português do Brasil é, sem dúvida, o conjunto de documentos fruto das discussões sobre a redação do Projeto do Código Civil, elaborado pelo jurista Clóvis Beviláqua. (...) Em todas as épocas há purismo, como preocupação com a manutenção do status quo da língua. O que muda de época para época é a concepção de língua e com ela o modo como a preocupação com aquele status se manifesta. Tal mudança escamoteia o sentimento, a atitude, que as pessoas de cada geração têm em relação à língua. Assim, em todas as épocas há escritores que têm a sensação de não serem puristas, mas o são, e, bem ao contrário, imaginam-se renovadores em relação à língua do seu tempo. É o que se pode inferir das atitudes de Rui Barbosa e Carneiro Ribeiro, quando cada um, por seu turno, nega o fato de serem efetivamente puristas. 
Se a contenda entre Carneiro Ribeiro e Rui Barbosa teve início fora dos domínios gramaticais, já que foi a redação do novo Código Civil a responsável por toda a celeuma, ao analisarmos as demais obras presentes neste grupo, verificaremos que há outras em que a crítica, a polêmica, o embate se dá em torno de uma gramática ou de uma obra em que um tema gramatical específico é estudado. Podemos ver isso, por exemplo, em Notas de Raul Soares à Gramática de João Ribeiro, de Mario Casasanta (1898- 1963), de 1941; Questões de Português: reparos aos erros de gramática do professor Silveira Bueno, de Francisco Ribeiro Sampaio (1909-1988), de 1939 ou O pronome "SE": réplica ao professor Said Ali, de Othoniel Motta (1878-1951), de 1916.

Iniciemos com o livro de Francisco Ribeiro Sampaio, obra dedicada a criticar a coleção didática Páginas floridas, de Silveira Bueno (1898-1989). No prefácio, Sampaio (1939, p. 9) assim esclarece os objetivos de sua obra:

Saem enfeixados no voluminho alguns reparos com que minha leitura marginou as notas gramaticais das "Páginas Floridas" do prof. Silveira Bueno, lente na Escola Normal de São Paulo. (...) Não há nêles farfalho de má vontade, nem propósito de escândalo. Com sereno objetivismo procurei corrigir e consertar (ou suscitar dúvidas para que os competentes as destramem) tudo que me pareceu abstruso ou demolidor ou errado na Seleta do professor paulistano.

Na sequência, refere-se a algo comum nas polêmicas gramaticais, o tom agressivo e belicoso com que os contendores travavam seus embates.

\begin{abstract}
Se alguma vez saí da bitola do comedimento que a natureza da obra me impunha, veja-se bem que disso não me cabe a culpa. Às minhas críticas o Prof. de São Paulo se arremangou e me respondeu com destemperadas e tremendas filípicas... pela rádio $^{56}$. Até o nome de Benedito Sampaio, culto professor, estilista e filólogo, - meu digníssimo pai, - foi trazido à balha na falação que o lente da Normal de S. Paulo deitou pelo rádio... vociferando. (SAMPAIO, 1939, p. 10)
\end{abstract}

Dentre os vários temas gramaticais que o livro de Sampaio aborda em suas 180 páginas, vejamos um exemplo em que o autor critica a colocação pronominal utilizada por Silveira.

No volume III, pág. 254, escreve comentando o prof. Silveira Bueno as suas "Páginas Floridas": "Еu o amava muito - a colocação pronominal no Brasil não segue, em absoluto, as regras da gramática portuguesa, por diversas razões. Aquí temos um exemplo em que o advérbio "muito" não atraíu o pronome para junto de sí.' Oponhamos desde já embargos à primeira afirmação. Os escritores do Brasil, verdadeiramente dignos dêste nome, antigos e modernos, arrumam como os portugueses os pronomes átonos na frase. Os que colocaram "à brasileira" os seus pronomes, Alencar e Macedo, por exemplos, só por isto perderam muito da vida, prestígio e duração que eram de esperar de suas obras. Ninguém vê, nem em gramático brasileiro, - e é, no Brasil, casta prolífera a dêstes beneméritos da língua,

56 Silveira Bueno mantinha sua coluna de consultório gramatical na Rádio Difusora Paulista, o que gerou a publicação do livro Português pelo rádio (1938), obra já mencionada neste capítulo. 
- ninguém vê o nome de Alencar arpoado para dirimir com seu prestígio o vernáculo de uma expressão. (SAMPAIO, 1939, p. 87)

Outro exemplo que trazemos à baila é a polêmica travada entre Othoniel Motta (18781951) e Said Ali (1861-1953), em torno da função do pronome SE. Vejamos o contexto em que esse embate ocorreu.

Em 1905 tive a audácia de apresentar ao mundo pensante um opusculo de 52 paginas, intitulado Ensaio linguistico, monographia que versava sobre a tão debatida questão da funç̧ão synctactica do pronome se. Ensaio chamei-lhe, porque eu vinha de largar a casca de bicho para sentar-me na cathedra de mestre. Atirei a bomba a tremer, como succede com os principiantes, com os fracos e, ás vezes, até com os fortes, quando têm de enfrentar, no ardor da refrega, inimigo poderoso e encanecido á poeira dos combates. (MOTTA, 1916, p. 3, itálicos do autor)

E, na sequência, aquilo que era muito comum nas polêmicas: a fundamentação do discurso de autoridade, com a citação de vários autores importantes que também partilhavam das opiniões do autor a respeito do tema em debate.

\begin{abstract}
Ora, qual não foi a minha surpresa quando vi que meu livrinho era acolhido com as mais vivas demonstrações de syrnpathia - ás vezes tão elogiosas que me confundiram - por parte daquelles que mais poderiam comprehendê-lo e criticá-lo? Candido de Figueiredo, João Ribeiro, Alcindo Guanabara, Oscar Nobiling, Freire da Silva, Alexandre Hummel, Eduardo Carlos Pereira, Conego Braga (até o Conego Braga, que pouco antes escrevera uma monographia em que chegava a conclusões contrarias ás minhas), todos esses espiritos cultos e superiores manifestaram-me pela imprensa, ou em cartas particulares, um apreço que me fez exultar. O professor Eduardo Carlos Pereira deu-me a subida honra de subscrever de todo a conclusões a que cheguei, na sua excellente Grammatica Expositiva. A todos agradeço $a b$ imo pectore. (MOTTA, 1916, p. 3-4)
\end{abstract}

Sobre o teor da polêmica em si, Motta (1916, p. 4-5) assevera:

No meu opusculo azorraguei o mais que pude a estapafurdia theoria da subjectividade do pronome se, theoria que é um verdadeiro contrabando linguistico, uma solução que me parece rasteira, offerecida a uma difficuldade de analyse que a grammatica comparada destrinça a contento pela apassivação. Ainda bem que o professor Said Ali, impugnando embora a funcção apassivante do pronome se, não embarcou na canôa do "se sujeito", miserando calhambeque que faz agua por todos os lados. Estudando as diversas funcções do reflexivo no português, salientei-lhe a de particula apassivante. "Compra-se terra", "Compram-se terras", são, evidentemente, phrases de sentido passivo, como veremos.

Após tais considerações, o opúsculo de Othoniel Motta (1878-1951) apresenta, ao longo de 27 páginas e organizadas em oito tópicos, as respostas às objeções feitas a ele por Said Ali (1861-1953). Vejamos, por fim, um exemplo de um dos oito tópicos mencionados. 
1. "A THEORIA DO "SE" APASSIVANTE É UM MYTHO [referência à fala de Said Ali]. Esses homens [Motta novamente usa o discurso de autoridade e cita gramáticos e filólogos estrangeiros que, segundo ele, têm posição igual a sua quanto a essa questão pronominal] nos mostram que até nas linguas escandinavas (Bréal) e eslavas (Brugmann) o verbo activo com o reflexivo faz as vezes de passiva: só aqui, no português, é mytho! Essas tiradas e outras semelhantes parecem-se com certos livros em que os auctores se esgotam, estadeando erudição, para provar que Shakespeare é um mytho e que os Annaes de Tacito foram escriptos na edade média. Ao discutirmos os outros pontos verá o leitor como a passiva de se é um facto impossivel de negar-se. (MOTTA, 1916, p. 6-7)

Em benefício da concisão do texto, não reproduziremos o texto de Said Ali, pois nosso objetivo aqui não é exatamente analisar o conteúdo linguístico em si da polêmica, mas chamar atenção para a existência desse tipo de embate nas obras monográficas do início do século XX e, assim, contrastar com esse mesmo tipo de prática que também ocorria nas gramáticas de referência do século XIX.

Podemos ver um exemplo disso na Grammatica portugueza, de Júlio Ribeiro (18451890). O autor era adepto de utilizar, na gramática tradicional, também conceitos e métodos da Gramática Histórico-Comparada (cf. Vidal Neto, 2010). Assim, era frequente que desferisse críticas à Gramática Filosófica, bem como aos gramáticos que a ela se alinhavam, como o português Jerônimo Soares Barbosa (1737-1816) e o seu seguidor em solo nacional, o maranhense Sotero dos Reis (1800-1871). Aqui, ao falar sobre o uso do infinito impessoal no Português, cita o romanista Friedrich Diez (1794-1876) e critica às regras denominadas por Ribeiro como “cerebrinas”, por ele associadas à Gramática Filosófica.

\section{Emprega-se o infinito impessoal}

1) quando o verbo no infinito não póde eximir-se da dependencia em que está para com o verbo principal. Acontece isto especialmente com os verbos que exprimem virtualidades, volições do espirito, taes como poder, saber, desejar, intentar, pretender, querer, etc., ex.: "Não podemos emprestar dinheiro-Sabeis fazer as cousas-Desejamos partir cedo-Intentais comprar casas-Os mouros pretendem levar-nos de vencida". (...) Esta é a doutrina de F. Diez (1), deduzida dos factos, positiva, simples, satisfactoria. As regras cerebrinas que na differença de sujeitos baseiam Soares Barbosa, Sotero e cem outros, só servem para gerar incerteza no espirito de quem estuda. Segundo taes regras os escriptos de Camões, de Frei Luiz de Souza, de Vieira, de Herculano, estão inçados de erros!!! (RIBEIRO, 1881, p. 241)

Mais adiante, Ribeiro (1881, p. 256) segue com as críticas a Sotero dos Reis, só que neste caso, estendidas também a Jerônimo Contador de Argote (1676-1749) e a Vergueiro 
(?-?) e Pertence (?-?), todos gramáticos portugueses, sendo o primeiro da virada do século XVII para o XVIII e os demais do século XIX:

É, pois, dislate a doutrina de Argote assim formulada por Vergueiro e Pertence [Compendio da Grammatica Portugueza]: "O verbo haver empregado no sentido de existir usa-se nas terceiras pessôas do singular ainda que o sujeito seja da terceira pessôa do plural" .Tambem não passa de subtileza metaphysica, condemnada pelos factos linguisticos, a explicação que desenvolvidamente dá Sotero dos Reis [Postillas de Grammatica Geral]: "O verbo unipessoal haver, cuja significação é a mesma de existir emprega-se ordinariamente com o sujeito gramatical oculto classe, genero, especie, porção, quantidade, numero, tempo, espaço, etc.- e um complemento expresso desse sujeito precedido da preposição de, tambem occulta. Ex.: 'Dizei-lhe que tambem dos Portuguezes/ Alguns traidores houve algumas vezes' (CAMÕES)".

Dissemos, no início deste capítulo, que a gramática de Barbuda (1926) é, das 4 gramática de referência do século $X X$, a única que apresenta um aprofundamento maior em relação às demais. Lá encontramos uma seção chamada "Critica dos systemas orthographicos", onde o autor expõe suas ideias quanto a essa matéria e critica os outros sistemas ortográficos, como o adotado pela Academia Brasileira de Letras, por exemplo. Considerando a diminuta quantidade de gramáticas de referência publicada no início dos novecentos e o fato de ser essa a única passagem em que encontramos algum tipo de questionamento a ideias de outros autores, julgamos correto dizer que as polêmicas, como as exemplificadas na citação a Ribeiro (1881), foram deslocadas, no início do século XX, para as obras monográficas, como é o caso das 25 publicações presentes neste segundo grupo, que denominamos como o "das polêmicas/das estudam as ideias gramaticais ou a linguagem de um determinado autor".

Por fim, um outro grupo de obras destinadas aos especialistas em Português - e não ao público em geral - são as teses destinadas ao acesso à docência secundária ou superior. Localizamos 8 publicações com esse perfil, das quais tivemos acesso a 7.

\title{
Quadro 12 - Teses acadêmicas com viés gramatical
}

\author{
CASASANTA, \\ Mario

\section{- A palavra MESMO $(1935)^{57} \boldsymbol{\beta}$}

Mario

\footnotetext{
${ }^{57}$ Nesta obra, não há data de publicação, mas em outra obra do autor, Notas de Raul Soares à Gramática de João Ribeiro, na relação de obras por ele publicadas, informa-se 1935 como data de publicação da tese.
} 


\begin{tabular}{|c|l|}
\hline $\begin{array}{c}\text { COUTINHO, Ismael } \\
\text { de Lima }\end{array}$ & - A crase (1928) ${ }^{58} \boldsymbol{\beta}$ \\
\hline $\begin{array}{c}\text { LIMA, Mario } \\
\text { Pereira de Souza }\end{array}$ & - Theoria da construcção grammatical $(1923)^{59} \boldsymbol{\beta}$ \\
\hline MELLO, Pedro de & - Novas teorias grammaticaes: these de concurso (1900) $\boldsymbol{\beta}$ \\
\hline $\begin{array}{c}\text { NUNES, José de } \\
\text { Sá60 }\end{array}$ & - O sinclitismo pronominal no idioma luso-brasileiro (1920) $\boldsymbol{\Omega}$ \\
- Comentários à "Réplica" de Rui Barbosa, visando \\
exclusivamente aos arcaismos (1939) $\boldsymbol{\beta}$
\end{tabular}

Corroborando o que já dissemos quanto ao círculo em que estas teses estavam inseridas, vejamos o que diz Morel Pinto (1976, p. 1):

Na falta de um curso superior de Letras, era o Colégio Pedro II o principal centro de estudos linguísticos. Seus professores catedráticos submetiam-se a concursos com defesa de teses. Mas foi em São Paulo que se publicou a gramática renovadora de Júlio Ribeiro, escrita, ao que tudo indica. na época em que ele era professor do famoso colégio "Culto à Ciência", de Campinas.

No conjunto das 8 teses, constatamos haver diferentes níveis de aprofundamento. Há produções como A crase, de Ismael de Lima Coutinho (1900-1965), em que o tema é tratado pelo autor com menor profundidade, sendo, nesse caso, mais uma sistematização sobre o assunto do que sua visão particular a respeito do tema em análise. Diferentemente, ao analisarmos a tese de José de Oiticica (1882-1957), Estudos de phonologia: $1^{\text {a }}$ série, encontramos um maior aprofundamento teórico. Oiticica tanto sistematiza o assunto, ao resenhar a posição de outros gramáticos a respeito do assunto em análise, quanto apresenta sua visão particular, inserindo-se, portanto, no debate que antes resenhara.

\footnotetext{
58 “These de livre escolha, apresentada á Congregação do Lyceu de Humanidades de Campos, para o concurso á $1^{\text {a }}$ Cadeira de Português".

${ }^{59}$ These para o concurso a cadeira de Portuguez, no Gymnasio Official de S. Paulo.

${ }^{60}$ Professor Catedrático de Português no Ginásio Paranaense, em Curitiba, Paraná. A partir de 1939, passa a ser professor de Filologia Portuguesa, na Faculdade de Filosofia, Ciências e Letras, da Universidade de São Paulo.
} 
Vejamos, então, um exemplo de discussão gramatical realizada em uma tese, considerando aquelas que desenvolvem uma reflexão mais aprofundada, mais autoral, como é o caso da obra de Oiticica, acima mencionada. $\mathrm{Na}$ folha de rosto, o autor informa que a tese foi escrita para o concurso ao Colégio Pedro II, em 1916. Há três capítulos, sendo o primeiro intitulado "Classificações dos fonemas segundo a prosodia brasileira". Nele, logo no início, Oiticica (1916, p. 5) destaca que "as grammaticas portuguêsas são muito discordes neste assumpto, omissas, muitas vezes erroneas", apontando, em seguida, a Grammatica philosophica, de Jerônimo Soares Barbosa (1737-1816), como "o melhor tratado, em lingua portuguêsa, (...) devendo ser ele considerado o fundador do phonologia portuguêsa".

Na sequência, ao longo do capítulo, o autor vai confrontando o posicionamento dos principais gramáticos brasileiros sobre o assunto, fazendo suas críticas ao que foi dito por cada um deles. Entraram nessa lista gramáticos como Júlio Ribeiro (1845-1890), Alfredo Gomes (1859-1924), Maximino Maciel (1866-1923), Eduardo Carlos Pereira (1855-1923). Oiticica também traz para sua análise autores portugueses como Gonçalves Viana (1840-1914), Fernão de Oliveira (1507-1581), Duarte Nunes de Leão (1530-1608), entre outros. As 29 páginas que compõem esta primeira parte da tese servem como uma espécie de estado da arte a respeito do tema estampado no título do capítulo. Tendo apresentado os óbices que tinha aos estudos dos gramáticos e demais estudiosos apontados até então, já no final do capítulo 1, na página 21, Oiticica começa a esboçar como ele próprio enxergava a questão fonológica.

26 - Divido as articulações explosivas em quatro classes do seguinte modo: [tópico] A - articulações feitas pelos dois labios - BILABIAES; são tres: uma surda - P; duas soantes - B (preresonancia bucal) e M (preresonancia nasal). [tópico] B articulações feitas pela ponta da lingua sobre a face interna dos incisivos superiores - LINGUODENTAES; são quatro: uma surda - T; tres soantes: D (preresonancia pharyngea), L prevocalico (preresonancia bucal), $\mathrm{N}$ (preresonancia nasal). (...) (OITICICA, 1916, p.25, itálicos do autor)

O autor segue sua exposição nos tópicos C e D, além de abrir novo item, o de número 27 , sobre as "consonancias fricativas", também desenvolvidas em quatro tópicos: A, B, C e D.

Ao final do capítulo, Oiticica (1916, p.29) encerra com um quadro em que sistematiza e expõe como classifica "os fonemas segundo a prosodia brasileira". 


\section{Figura 7 - Os fonemas segundo a prosódia brasileira na visão de José de Oiticica}

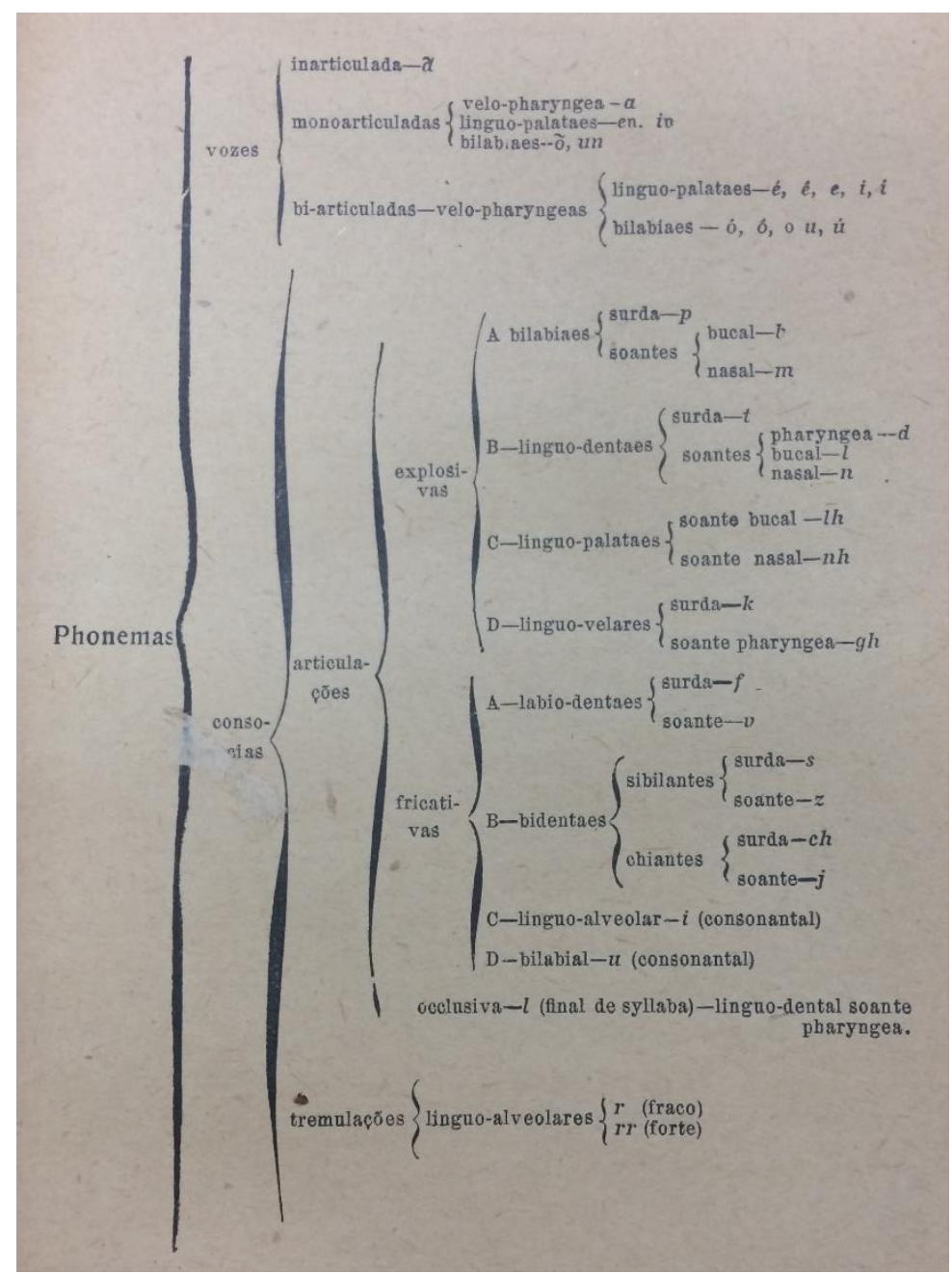

É no segundo capítulo, porém, que o autor parece dar tons mais autorais à sua tese. Sob o título de "Theoria dos encontros vocalicos", Oiticica (1916, p. 31) abre assim essa seção: “A divergencia entre grammaticos sobre o numero dos ditongos, sobre a existencia e numero dos tritongos em português, mostra quão longe estamos do solução scientifica do problema". Novamente, faz comentários sobre como gramáticos e outros autores brasileiros e portugueses trataram do tema, só que agora de forma breve, iniciando um longo exemplário por ele reunido para fundamentar sua argumentação.

Também aqui, em benefício da concisão do texto, não entraremos em detalhes a respeito da discussão linguística em si, pois nosso objetivo, ao falar das teses, foi destacar o crescimento de um espaço de discussão no início dos novecentos, já que até o século XIX esse era um gênero ainda incipiente. 
Com efeito, apresentamos e discutimos o contexto em que se deu, nas quatro primeiras décadas do século XX, a publicação das 4 gramáticas de referência e das 157 obras de temas gramaticais específicos. Julgamos que essa desproporção numérica pode ser explicada por um processo de especialização dos estudos gramaticais do Português, tal como ocorreu com as obras escolares, já que as crescentes necessidades de um país que entrava em um intenso processo de crescimento e urbanização exigiam tipos de obras mais específicas - teses, consultórios gramaticais, monografia de um tema considerado complexo, etc -, necessidades que, naturalmente, não podiam mais ser supridas com os compêndios gramaticais em volume único, tal como eram as gramáticas de referência até o século XIX. 


\section{O programa de investigação filológico: as obras históricas sobre o Português}

Concluída a análise das obras inseridas no programa gramatical, passaremos a analisar, no presente capítulo, as obras do programa filológico, que constituem, segundo o nosso levantamento e a nossa posterior classificação dos textos, a segunda grande tendência da produção sobre o Português no início do século XX.

Os critérios que adotamos para incluir as obras neste grupo foram a ausência de normatividade e a ênfase no trabalho histórico com a língua. Quanto ao primeiro critério, é preciso fazer um destaque. No capítulo 2, item 2.2, falamos a respeito da normatividade nas obras metalinguísticas e lá dissemos que é inerente à língua, como instituição social que é, apresentar regulações de ordem normativa. Retomando o conceito coseriano de norma, apontamos para a distinção que o autor faz entre a norma subjetiva e a objetiva. A primeira opera com a oposição correto versus incorreto, enquanto a segunda trabalha com o eixo normal versus anormal. Por fim, dissemos também que as obras reunidas no programa de investigação gramatical apresentam características normativas ligadas à norma subjetiva. Com efeito, as que foram incluídas no programa filológico são aquelas em que se pode verificar um engajamento normativo do tipo objetivo.

Tal diferença normativa não é fortuita, mas reflexo dos objetivos linguísticos de cada um dos programas mencionados. No caso do presente capítulo, o viés histórico que as obras aqui incluídas têm favorece uma normatividade de tipo objetiva.

Utilizando tais critérios, encontramos 89 publicações, que foram divididas em três grupos, segundo suas especificidades.

Tabela 16 - Quantitativo da produção filológica sobre o Português

\begin{tabular}{|c|c|c|}
\hline Gramáticas históricas & $\begin{array}{c}\text { Obras de temas filológicos } \\
\text { específicos }\end{array}$ & $\begin{array}{c}\text { Tratamento (edição) } \\
\text { de texto }\end{array}$ \\
\hline 30 obras & 51 obras & 8 obras \\
\hline \multicolumn{2}{|r|}{ Total de obras do programa filológico: 89} \\
\hline
\end{tabular}




\subsection{Considerações gerais sobre o programa de investigação filológico}

\subsubsection{Camadas contextual e teórica}

Mostramos, no capítulo 2, que o programa de investigação gramatical tem suas origens na Antiguidade Clássica. Assim fizemos, pois esse movimento retrospectivo melhor contextualiza as obras gramaticais escritas no início do século XX que ali estavam sendo analisadas. Quanto ao programa filológico, é preciso realizar o mesmo processo, compreendendo-o sob dois aspectos: o momento histórico em que ele surge, avaliando com isso o clima de opinião da época (KOERNER, 1989) e o contexto acadêmico-científico em que os autores que produziram dentro desse programa estão inseridos.

Robin (1983), em sua Pequena história da Linguiística, diz que já é um lugar-comum apontar o século XIX como o período de destaque para os estudos comparativos e históricos, principalmente os relacionados às línguas indo-europeias. No entanto, o autor diz que isso

não significa que antes não se tenham feito estudos históricos baseados na comparação de línguas, nem que os demais domínios de investigação lingüística tenham sido esquecidos durante o século XIX. O que acontece é que o século passado assistiu ao desenvolvimento de modernos conceitos, teóricos e metodológicos, no terreno histórico-comparativo e à concentração neste domínio lingüístico da maior parte dos esforços e talento dos lingüistas. (ROBIN, 1983, p.132)

Leroy (1977, p.31), por seu turno, diz que "foi o conceito do parentesco das línguas que racionalizou os estudos linguísticos, [e] o ponto de partida foi a revelação do sânscrito aos sábios ocidentais". O autor destaca que desde o século XVI o Ocidente mantinha contato com a Índia, porém as observações de alguns eruditos a respeito das semelhanças entre o Sânscrito e as línguas da Europa não tiveram repercussão. Leroy cita alguns exemplos, como o de Sassenti, que viveu em Goa de 1583 a 1588 e revelou algumas correspondências entre o Sânscrito e o Italiano (respectivamente, saptá/sete, náva/nova, devá/dio, sarpá/serpe, entre outros exemplos), porém tais constatações permaneceram inéditas até 1855. Há também o caso de Couerdoux, um jesuíta francês estabelecido em Pondichéry ${ }^{61}$, que, em 1767, apontou a semelhança entre o Sânscrito, o

\footnotetext{
${ }^{61}$ Região na Índia sob forte influência da França, iniciada pela Companhia Francesa das Índias Orientais, empresa colonial francesa, criada em 1664 com objetivo de estabelecer comércio com a Índia e demais países do Oriente.
} 
Latim e o Grego (sânsc. dāna $\rightarrow$ lat. dōnum; sânsc. vidhávā $\rightarrow$ lat. vidua; sânsc. ásmi $\rightarrow$ gr. címí), mas, de igual forma, esses apontamentos só foram publicados 40 anos depois e também sem repercussão.

Somente a partir dos estudos de William Jones (1746-1794) que esse cenário de desinteresse na comparação do Sânscrito com as línguas europeias irá mudar. Jones era um juiz inglês que foi designado a atuar em Calcutá, Índia, então colônia inglesa. Era orientalista e poliglota e a partir dessa designação passou a estudar profundamente o Sânscrito, o que o levou a postular que a grande semelhança existente entre essa língua, o Grego e o Latim só poderia ser explicada por uma origem comum. Para ele, tais semelhanças seriam inexplicáveis se essas línguas derivassem umas das outras, o que para Leroy (1977, p.32, sublinhamos) levou à formulação de duas noções: "a do parentesco lingüístico e a do protótipo comum - que lançavam as bases de um estudo científico das famílias de línguas".

Leroy fala ainda do papel de outro importante estudioso na formação de método comparativo: Frederico Schlegel (1772-1828), que, em 1808, publica seu famoso livro Ueber die Sprache und Weisheit der Inder [Sobre a linguagem e a sabedoria dos hindus], onde, segundo Leroy, se ouve pela primeira vez a expressão vergleichende Grammatik [gramática comparada]. É nessa obra que Schlegel afirma que a relação do Sânscrito com as outras línguas será demostrada pela estrutura interna das línguas ou com a vergleichende Grammatik [gramática comparada], já que isso produzirá informações inteiramente novas acerca da genealogia da linguagem.

Depois de dados os primeiros passos, a consolidação dos estudos comparativistas coube a Franz Bopp (1791-1867), ao "reunir as provas indiscutíveis do parentesco de tais línguas e fundar ao mesmo tempo a gramática comparada das línguas indo-européias” (LEROY,1977, p.32).

Ainda considerando a formação do método histórico-comparativo, Faraco (2005, p. 134135) apresenta um panorama bastante elucidativo a respeito, explicando as diferenças, na origem, entre o método apenas comparativo (mais ligado a Franz Bopp) e o apenas histórico (mais ligado a Jacob Grimm).

O objetivo inicial do empreendimento de Bopp era, ao detectar as correspondências sistemáticas entre as línguas, estabelecer o parentesco entre elas, mas não o percurso histórico de um estágio anterior para outro(s) posterior (es). Costuma-se dizer que o estudo propriamente histórico foi estabelecido por Jacob Grimm (1785-1863). Em seu livro Deutsche Grammatik [Gramática alemã] — cuja primeira edição é de 1819, mas cujo ponto de referência é a segunda edição publicada, com o texto 
completamente remodelado e ampliado, em 1822 - Grimm interpretou a existência de correspondências fonéticas sistemáticas entre as línguas como resultado de mutações no tempo. Temos aqui uma diferença importante entre Bopp e Grimm.

A seguir, Faraco aponta como Bopp e Grimm realizaram seus estudos, apontando o tipo de técnica e de documentação utilizado para a análise linguística.

O primeiro [Bopp] intencionava fundamentalmente estabelecer o parentesco entre as línguas. Para isso, trabalhou com textos sem pretender seguir nenhuma cronologia entre eles. Assim, utilizou dados do sânscrito anterior a 1000 a.C., do grego dos séculos IX ou VIII a.C., do latim dos séculos V ou IV a.C., do germânico do século IV d.C., do eslavo do século IX d.C., do persa moderno. Grimm, por sua vez, ao estudar o ramo germânico das línguas indo-europeias, tinha dados distribuídos numa sequência de catorze séculos e pôde assim estabelecer a sucessão histórica das formas que estava comparando. Aliou-se, desse modo, ao empreendimento comparativo, o histórico, donde vem a denominação que se costuma dar à linguística do século XIX: gramática ou linguística históricocomparativa. A partir dos estudos de Grimm, ficou mais claro que a sistematicidade das correspondências entre as línguas tinha a ver com o fluxo histórico e, mais especificamente, com a regularidade dos processos de mudança linguística. (FARACO, 2005, p. 135-136, itálicos do autor e sublinhados nossos)

Assim, podemos dizer que o método histórico-comparativo se formou a partir da soma de duas práticas diferentes. Se olharmos pela perspectiva das camadas, Bopp utilizou diferentes línguas (documental), para que assim, pela comparação entre elas (técnica), fosse possível encontrar “correspondências sistemáticas”. Já Grimm, estudava apenas uma língua (documental), já que seu objetivo era estudá-la historicamente. Ao ter em mãos dados de catorze séculos do ramo germânico das línguas indo-europeias, Grimm pôde, por exemplo, "estabelecer a sucessão histórica das formas que estava comparando" (técnica).

Com efeito, a partir das bases conceituais que até aqui sumarizamos, a Linguística Histórico-Comparada, ao longo do século XIX, se desenvolverá com a contribuição de diferentes pesquisadores, seguindo, muitas vezes, perceptivas teórico-metodológicas diferentes. No entanto, não analisaremos todo esse cenário, já que, nesta seção, nosso objetivo é contextualizar as obras que serão estudadas neste capítulo, isto é, aquelas por nós chamadas de filológicas. Para cumprir tal objetivo, precisamos avançar rumo à Linguística Românica, disciplina que se utiliza dos métodos da Linguística Histórico-Comparada, porém com objetivo específico de estudar as línguas derivadas do Latim. Sendo o Português uma língua neolatina, fica clara a maior proximidade das obras presentes em nosso levantamento (as do programa filológico) com a Linguística Românica, disciplina fundada por Friedrich Diez (1794-1876), na segunda metade do século XIX. 
De acordo com Faraco (2005, p. 137), os estudos românicos trouxeram contribuições importantes para o método histórico-comparativo, já que não era mais necessário trabalhar com reconstruções hipotéticas, procedimento adotado quando inexistia documentação escrita de uma determinada língua. A farta documentação de textos em Latim fez com que a Linguística (ou Filologia) Românica pudesse trabalhar com textos reais. Assim, tal disciplina, quanto às camadas técnica e documental, passa a lidar com práticas de pesquisa ligeiramente distintas daquelas utilizadas nos estudos de outras subfamílias das línguas indo-europeias.

A filologia românica teve um papel fundamental no desenvolvimento dos estudos histórico-comparativos. Enquanto em outras subfamílias só se alcançam os estágios mais antigos por reconstrução hipotética em razão da inexistência de registros escritos, na subfamília românica a documentação em latim é extensa, o que permitiu um importante refinamento metodológico dos estudos históricos: com uma situação em que as formas ascendentes são atestadas, foi possível reforçar a confiabilidade nos procedimentos do método nos casos em que isso não ocorria. (FARACO, 2005, p. 137)

Quanto ao cenário brasileiro, é importante dizer que o responsável por introduzir os estudos histórico-comparativos no Brasil foi Pacheco da Silva Júnior (1842 - 1899).

[a Linguística Histórico-Comparada] entrou no Brasil na década de 1870 pelas mãos de Pacheco da Silva Jr., seja com seu livro de Fonologia (1877), seja com sua gramática histórica (1878), a primeira a ter esse título em língua portuguesa ${ }^{62}$, embora não a primeira a se dedicar à história do português pelo olhar da Linguística Histórico-Comparativa, mérito que coube ao livro publicado em 1868 por Adolfo Coelho - A lingua portugueza: phonologia, etymologia, morphologia e syntaxe. Será sob esse paradigma que os estudos linguístico-históricos se desenvolverão no Brasil durante quase um século. (FARACO, 2018, p. 48)

\footnotetext{
${ }^{62}$ Frequentemente, encontramos referências como esta, em que a Grammatica historica da Lingua Portugueza, de M. Pacheco da Silva Junior (1842-1899), de 1878, é considerada como a primeira gramática histórica do Português. No entanto, Penha (1996, p. 521) discorda dessa primazia: "Aprendemos com o filólogo brasileiro Mário Barreto (1879-1931) que a primeira gramática histórica portuguesa foi escrita por Antônio Garcia Ribeiro de Vasconcelos (1860-1941), Professor da Universidade de Coimbra. É a Gramática Histórica da Língua Portuguesa (229 p.), que saiu sem data de edição, mas com Prólogo de 30 de setembro de 1900. Entretanto, Theodoro Henrique Maurer Júnior (1906-1979), que foi Professor Filologia Românica na Universidade de São Paulo, dá outra informação em o Estado de S. Paulo de 25.1.1954. Para ele, a primeira gramática histórica da língua portuguesa é de Manuel Pacheco da Silva Júnior (1842-1899) e foi editada em 1878. Quando Maurer conferiu a Pacheco Júnior a posição de primeiro autor nesse campo, estranhamos a notícia e escrevemos a ele. Em resposta de 3 de abril de 1954, Maurer reafirmou a prioridade do brasileiro Pacheco Júnior”.
} 


\subsubsection{Camadas técnica e documental}

Para encerrarmos a contextualização relativa às obras do programa filológico, vejamos agora quais eram as técnicas de análise, além do tipo de documentação linguística que predominavam nas produções que seguiam o método histórico-comparativo. Como já dissemos, no conjunto de estudos ligados a esse método, nos interessa especificamente a romanística, já que o Português é uma língua neolatina.

Metodologicamente, é correto dizer que os estudos histórico-comparativos, como o próprio nome já indica, utilizaram-se de técnicas linguísticas de comparação entre documentos de duas ou mais línguas produzidos ao longo de suas histórias. Ao assim procederem, objetivaram conseguir, por dedução, informações que, muitas vezes, não podiam ser obtidas e comprovadas através do acesso físico, documental às fontes. Um exemplo desse processo pode ser visto nos trabalhos de Linguística Indo-europeia, que através da comparação, buscava encontrar a protolíngua (o Indo-europeu), que seria justamente a origem das línguas modernas. Para realizar esse estudo retrospectivo, a principal técnica era a da reconstrução, o que era feito pelo uso de leis, que serviam exatamente para dizer, por dedução, como eram os estágios passados de uma determinada língua. Podemos ver tal processo nos estudos de Jacob Grimm (1785-1863), que "en 1822, [...] enunció principios generales sobre las relaciones entre las obstructivas germánicas y las de otras lenguas" (LEHMANN, 1969, p.124). A seguir, o autor passa a apresentar a chamada Lei de Grimm:

Llamando tenues (T) a $p t k$, aspiradas (A) a $b h d h g h$ (y a $f \theta \chi$, etc.), y medias (M) a $b$ $d g$, estableció que $\mathbf{T}$ indoeuropea $>\mathbf{A}$ germánica, $\mathbf{A}$ indoeuropea $>\mathbf{M}$ germánica, $\mathbf{M}$ indoeuropea $>\mathbf{T}$ germánica, produciéndose, en consecuencia, un esquema circular que frecuentemente se ha reproducido así:

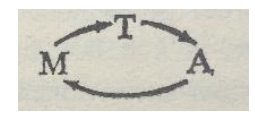

Basándose en los cambios subsiguientes del área del alto alemán, donde la $t$ se transformó más tarde en $t s$, como ocurre en alemán $z u$ en oposición al inglés to, supuso también que este cambio se repetía en las lenguas germánicas y, por consiguiente, lo consideró una ley. De ahí que a la formulación apuntada arriba se le haya llamado ley de Grimm. (LEHMANN, 1969, p.124-125, negritos do autor, sublinhados nossos).

Quanto à romanística, também houve o uso de leis como técnica de pesquisa linguística, porém não mais com o fito dos primeiros comparativistas, ou seja, o de retroceder à protolíngua. 
Essa mudança de objetivo foi proposta a partir dos estudos dos neogramáticos, já que esses julgavam ser muito mais produtivo o trabalho com as "linguas vivas, onde os processos de evolução lingüística poderiam ser vistos em ação, e onde poderia ser captado o papel das forças psicológicas que estão na base do funcionamento e da evolução das línguas.” (ILARI, 1999, p.19). Com efeito, dois grandes nomes da romanística tiveram formação neogramática: Friedrich Diez (1794-1876) e Wilhelm Meyer-Lübke (1861-1936). O primeiro, como já dissemos, foi o fundador da Linguística Românica, e o segundo, de acordo com Ilari (1999), o responsável por aprimorar os estudos de Diez.

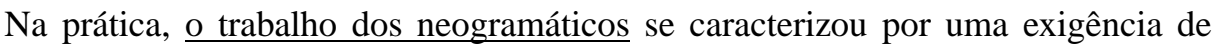
extremo rigor, que se traduziu na crença de que as "leis" da evolução fonética agem de maneira absolutamente regular, admitindo exceções apenas quando sua ação é contrariada pela ação da força psicológica da analogia. Exemplos simples de como a analogia atua no funcionamento das línguas podem ser encontrados na fala das crianças, em erros como fazi ou trazi por fiz ou trouxe: na expressão de Saussure, que retoma o conceito de analogia dos neogramáticos, operaria aí uma espécie de regra de três: se viver, correr etc. fazem o perfeito em $-i$ pode-se esperar que fazer e trazer também o façam. Um exemplo muito simples de como a analogia afeta a evolução das línguas é o verbo português render, e seus correspondentes românicos rendre, rendere etc.: essas formas não poderiam provir do verbo que significa render em latim clássico, ou seja, reddere: nenhuma lei fonética conhecida justificaria o aparecimento de um $-n$ - fechando a primeira sílaba: as formas românicas derivam verossimilmente de * rendere $^{63}$, construído por analogia com o verbo que significa "tomar", isto é, prendere (clássico prehendere). (ILARI, 1999, p.19, sublinhados nossos).

Influenciada pelo movimento neogramático, a Linguística Românica utilizará como técnica de análise linguística o método histórico-comparativo, dentro do qual o uso das leis fonéticas, por exemplo, funcionava como importante instrumento para deduções mais precisas a respeito das formas mais antigas das línguas românicas. Vejamos um exemplo a partir do verbo saber.

Quando se comparam, por exemplo, port. e esp. saber, fr. savoir, it. sapere fica
legitimada a conjectura de que tenham uma origem latina comum, numa palavra (i)
cuja primeira sílaba começa por sibilante e (ii) cuja segunda sílaba é tônica e
comporta uma consoante bilabial ou labiodental $(p, b$ ou $v$ ). Constatando-se além
disso que na evolução do latim para o espanhol e o português é regular a passagem
do $p$ intervocálico a $b$; que o $p$ intervocálico do latim passa regularmente a $b$ e em
seguida a $v$ em francês; que, ainda em francês, o $e$ longo das sílabas tônicas não
travadas passa a $e i$, depois oi, oé, ué e wá (a grafia acompanhou esta evolução
apenas até a forma oi), torna-se legítimo supor que a forma originária comum fosse
*sapére, paroxítona. A identificação de * sapére como a forma de que se originaram
saber e seus correspondentes românicos não deixa de ser surpreendente quando
referida ao vocabulário conhecido do latim clássico: o latim clássico tinha um verbo

${ }^{63}$ A Gramática Histórico-Comparada utiliza-se da notação $\left(^{*}\right)$ para indicar formas hipotéticas que foram reconstruídas através de seus métodos, mas que ainda não puderam ser comprovadas através de documentação física. 
sápere, conjugado como cápere, que significava entre outras coisas "saborear, provar uma comida para sentir-lhe o sabor. Este verbo sápere deve ter sido conjugado em latim vulgar como um verbo da $2^{\text {a }}$ conjugação". (ILARI, 1999, p.21, sublinhados nossos).

No trecho acima, dois aspectos devem ser destacados quanto ao uso do método históricocomparativo. O primeiro, mais ligado à camada documental, é o fato de ser possível estudar uma língua mesmo que o pesquisador não tenha acesso físico à documentação a ela relacionada. No caso acima, o estudo se dá relativamente ao Latim Vulgar, língua que, como se sabe, possui pouquíssimos registros escritos. No entanto, há farta documentação do Latim Clássico e das línguas neolatinas, o que associado, às técnicas de reconstrução utilizadas pela romanística, possibilita tais estudos do Latim Vulgar. Com efeito, foi o que ocorreu para se chegar à forma reconstruída *sapére, que é a "forma originária comum" do verbo português saber, bem como seus correspondentes nas outras línguas românicas.

Como pode ser observado, os exemplos que aqui trouxemos são todos relativos à fonética. Isso não significa que o método histórico-comparativo só trabalhou com esse nível de análise linguística, mas aponta, sim, para o fato de ser a fonética o nível em que tal método conseguiu chegar a resultados mais satisfatórios. A esse respeito, diz Ilari (1999, p. 22) que "o campo em que o método comparativo deu os resultados mais sistemáticos é o da fonética; em morfologia e em sintaxe, sua aplicação exige a manipulação de dados mais complexos, e seus resultados foram menos espetaculares.".

Feitas as considerações mais gerais a respeito da Linguística Histórico-Comparada, vejamos, a forma que ela impactou as obras presentes em nosso levantamento, especificamente quanto ao programa filológico.

\subsection{Gramáticas históricas do Português}

\subsubsection{Camada contextual}


Dedicamos o capítulo 2 às gramáticas escolares e o capítulo 3 às gramáticas de referência. Pela análise conjunta desses dois capítulos, ficou evidenciado o caráter escolar que a produção gramaticográfica brasileira do início do século $\mathrm{XX}$ assumiu. Relativamente às gramáticas históricas, não nos parece haver diferenças quanto a esse aspecto. Questões como a obediência aos programas oficiais de ensino também tiveram grande impacto nesse tipo de gramática. Dessa forma, parece-nos adequado dizer que, em termos contextuais, são as questões de ordem educacional aquelas que mais influenciaram as gramáticas históricas do início do século XX. Tal relação pode ser comprovada quando verificamos que todas as gramáticas históricas que localizamos, isto é, 30 obras, são escolares. Dessa forma, como mostraremos mais à frente, a seleção de conteúdo e como ele é apresentado seguem as orientações estabelecidas pelos órgãos oficiais de educação.

Com efeito, a partir dessas constatações mais o que apresentamos ao longo do capítulo 2, é possível dizer que os estudos escolares de gramática, no início do século XX, notadamente os realizados no Secundário, eram estruturados em dois eixos: tópicos de gramática normativa e de gramática histórica. A presença da primeira não é de se estranhar, dada sua tradição milenar (cf. seção 2.1). Já compreender os motivos de os estudos históricos constarem nos currículos escolares passa por avaliarmos algumas questões do clima de opinião da época (KOERNER, 1989). Como destacamos na seção anterior, o século XIX foi o século dos estudos do tipo histórico e/ou comparativo. O início do XX ainda estava sob essa influência, que só irá diminuir com a ascensão dos estudos linguísticos de orientação sincrônica, desenvolvidos a partir de outro modelo epistemológico, o Estruturalismo, o que vai ocorrer, no Brasil, a partir dos anos 1950, aproximadamente. Dessa forma, não é de se estranhar que os currículos escolares do início do século XX incluíssem a gramática histórica no rol de temas a serem ensinados, procedendo, evidentemente, as adaptações didáticas necessárias em relação ao que se discutia nas obras especializadas, que, nesta tese, convencionamos chamar de obras de referência. Tais adaptações variaram ao longo dos anos, mas giraram em torno de uma carga horária menor em relação àquela dedicada à gramática tradicional (geralmente, apenas um ano dedicado os estudos históricos); redução da quantidade de tópicos de gramática histórica a serem estudados e/ou apresentação simplificada de tais tópicos.

Especificamente quanto às gramáticas históricas que fazem parte de nosso levantamento, é importante destacarmos que elas foram estruturadas a partir de três diferentes diretrizes, a depender do ano de sua publicação. As editadas até 1931 seguiam os programas de ensino do curso secundário do Colégio Pedro II (cf. anexo A - Anexos A2 - A7), que era até então 
referência nacional para esse segmento de ensino. Já as gramáticas que vieram a lume a partir de 1931 seguem os conteúdos estabelecidos pelo recém-criado Ministério da Educação e Saúde Pública $^{64}$, através de duas diferentes reformas educacionais: a primeira, chamada Francisco de Campos, que vigorou entre 1931 e 1942 e a segunda, conhecida como Reforma Gustavo Capanema, vigente entre 1942 e 1961 (cf. anexo A - Anexos A8 - A9/10, respectivamente).

Dado esse cenário, diferentemente do que fizemos com as gramáticas tradicionais, o critério utilizado para classificarmos uma obra como gramática histórica não foi a presença dos três níveis de análise linguística (fonologia, morfologia e sintaxe), mas sim sua autodeterminação como tal. Em função de sua prevalência no ambiente escolar, alguns títulos dessas obras não eram literais, isto é, "gramática histórica", adotando, muitas vezes, o nome da coleção didática, como é o caso do Idioma nacional: volume 4, de Antenor Nascentes (1886-1972), tomo este inteiramente dedicado aos estudos diacrônicos do Português.

Com efeito, uma certa exigência ou mesmo expectativa de a gramática contemplar análises de fonologia, morfologia e sintaxe parece ser algo mais ligado à tradição gramatical greco-latina, ou em outros termos, à gramática tradicional. Os dados mais relevantes que a Gramática Histórico-Comparada produziu para a compreensão histórica do Português estão localizados nos níveis fonético e morfológico. Isso explica o fato de a sintaxe estar ausente em várias gramáticas históricas, como no caso do Compêndio de gramática histórica portuguesa: fonética-morfologia, do português José Joaquim Nunes (1859-1932), publicada em 1919. Outro exemplo é a primeira gramática histórica publicada no Brasil, a Grammatica historica da Lingua Portugueza, de M. Pacheco da Silva Junior (1842-1899), de 1878. Nesse caso, tal título foi atribuído àquilo que o autor chamou de "introdução", mesmo que tal seção tenha consumido 154 páginas e seja encerrada por ele com a seguinte afirmação: "Muito tinhamos ainda a accrescentar, mas paramos aqui para não tomar descommunal esta introducção.” (SILVA JUNIOR, 1878, p. 154). Apesar de assim se manifestar, nunca houve a publicação do restante da obra $^{65}$. Ao analisarmos essa "introdução", pudemos ver que, apesar dessa classificação, ela foi subdividida em seis seções: historia da lingua portugueza, formação da lingua portugueza, elementos historicos, idiotismos, hybridismo e dialectos. Dessa forma, a seleção desses seis tópicos mostra, na verdade, uma gramática histórica que aborda, primeiro, a história externa do

\footnotetext{
${ }^{64}$ O Ministério da Educação e Saúde Pública foi criado pelo decreto n. ${ }^{\circ}$ 19 402, em 14 de novembro de 1930, durante a presidência de Getúlio Vargas.

${ }^{65}$ Penha (2002, p.20) afirma ter encontrado no Dicionário bibliográfico brasileiro, de Sacramento Blake (18271903), menção à existência da " 2 a edição [desta gramática] (1883) com mais um volume que se achava inédito". O autor diz nunca ter encontrado outra menção a essa $2^{\mathrm{a}}$ edição.
} 
Português, para, depois, adentrar, fundamentalmente, nos domínios da morfologia, incluindo também algumas análises fonológicas.

Finalmente, é importante destacarmos que as obras que tratam também de temas da gramática histórica, porém de forma monográfica, ou seja, analisando-os de forma mais detida e aprofundada, foram categorizadas no grupo das obras de temas filológicos específicos, estudadas na próxima seção deste capítulo (cf. 4.3).

\subsubsection{Camada teórica}

Na seção 4.1, apresentamos um panorama a respeito da Linguística Histórico-Comparada, pois é justamente a ela que estão ligadas epistemologicamente as gramáticas históricas presentes em nosso levantamento.

Tal ligação coloca as gramáticas tradicionais e as gramáticas históricas em quadros epistemológicos bastante diferentes em si. Nas primeiras, a principal preocupação é com a correção linguística, com o bom uso, com o bem falar (cf. seção 2.4.1), já no caso das gramáticas históricas, o objetivo principal é o de se estudar "a origem e o desenvolvimento das línguas, através de leis/princípios que expliquem os estágios evolutivos pelos quais passaram as línguas, desde sua origem até o presente".

Como já apontamos na seção anterior, ao longo do século XIX e início do XX, os estudos de orientação histórico e/ou comparada eram aqueles que gozavam de maior prestígio científico entre os estudiosos da linguagem. Ou seja, nessa época, ao se realizar tais estudos, havia o sentimento, inclusive expresso na própria retórica dos autores (MURRAY, 1994), que se estava fazendo ciência linguística. Isso pôde ser por nós constatado quando analisamos as gramáticas históricas presentes em nosso levantamento.

Para o estudo da camada teórica, levantamos como os autores dessas obras definiam seu campo de atuação, ou seja, o que falavam a respeito dos objetivos da gramática histórica e das demais disciplinas correlatas. Também verificamos se o conteúdo presente em tais definições é, de fato, colocado em prática nas análises realizadas no texto gramatical ou se fica limitado apenas ao nível retórico. 
O resultado de tal levantamento consta em um quadro ${ }^{66}$ elaborado especialmente para esse fim, porém, em função de sua extensão (23 páginas), o colocamos no apêndice B (cf. Quadro 12B). No entanto, a seguir apresentaremos um quadro-síntese, onde reunimos as informações mais representativas para a compreensão da camada teórica dessas gramáticas.

\section{Quadro 13 - Definições de gramática histórica - Quadro-síntese}

\begin{tabular}{|l|}
\hline $\begin{array}{l}\text { "Gramática histórica - Estuda a evolução da Língua desde as suas origens." (ABREU, } \\
1944, \text { p. 183) }\end{array}$ \\
$\begin{array}{l}\text { "Grammatica historica é aquella que estuda a evolução dos diversos factos da língua desde } \\
\text { a sua origem até a epoca presente." (ALI, 1923, p.5) }\end{array}$ \\
$\begin{array}{l}\text { "Gramática Histórica - É aquela que estuda a origem e a evolução de uma língua através } \\
\text { das influências das épocas e dos lugares em que se falou essa língua." (BUENO, 1938, p.13) }\end{array}$ \\
$\begin{array}{l}\text { "Gramática Histórica é a ciência que estuda os fatos de uma língua, no seu } \\
\text { desenvolvimento sucessivo, desde a origem até a época atual." (COUTINHO, 1938, p.13) }\end{array}$ \\
"A Gramática Histórica da língua portuguesa estuda a origem e a evolução do idioma \\
português no tempo e no espaço." (COUTINHO, 1938, p.14) \\
\hline $\begin{array}{l}\text { "Gramática histórica é a que estuda origem e o desenvolvimento de uma lingua. A } \\
\text { gramática histórica explica os fatos da gramática expositiva atual em estudando o passado; } \\
\text { remonta ao curso da lingua em observando as mutações que têm sofrido os sons, as palavras } \\
\text { (forma e sentido) e as construções." (GUÉRIOS, 1937, p. 17) }\end{array}$ \\
$\begin{array}{l}\text { "Gramática Histórica é a que estuda a origem e o desenvolvimento de uma lingua. A } \\
\text { gramática histórica explica metòdicamente os fatos da gramática expositiva atual em }\end{array}$ \\
\hline
\end{tabular}

\footnotetext{
${ }^{66}$ Neste quadro, constam as definições e demais registros correlatos de 15 gramáticas históricas. Também tivemos acesso a outras 6, porém nessas o autor não define gramática histórica. Quanto às demais (10 obras), não conseguimos acesso.

${ }^{67}$ Said Ali, na Grammatica historica da Lingua Portugueza, não define o que vem a ser gramática histórica. Isso só acontece em sua Grammatica secundaria da Lingua Portugueza, de onde extraímos esta definição. Em relação à Grammatica historica, ocorre algo curioso e que talvez explique a ausênciade tal definição. Em 1921, o autor publica o livro Lexeologia do Portuguez historico e, em 1923, Formação de palavras e syntaxe do Portuguez historico. Em 1931, muito provavelmente por questões de ordem comercial, a Editora Melhoramentos resolve juntar esses dois livros sob o título de Grammatica historica da Lingua Portugueza. Aqui o uso do termo juntar é exato, pois, com exceção do deslocamento de dois capítulos escritos na Formação de palavras para a $1^{\mathrm{a}}$ parte da gramática (Estudo dos sons e Lexeologia), o restante da Grammatica historica é exatamente a junção sequencial desses dois livros de Said Ali, seguindo as ordens de paginação das publicações originais. Ou seja, a editora simplesmente juntou esses dois livros e colocou na capa o título de gramática histórica, o que, em um contexto de maior demanda por esse tipo de publicação, parece ser muito mais atrativo comercialmente do que as obras monográficas avulsas. Dessa forma, e para não haver duplicidade no registro em nosso levantamento, optamos por não considerar a Grammatica historica como obra avulsa. Nesta tese, consideraremos apenas as duas obras monográficas isoladamente, incluídas no grupo das obras de temas filológicos específicos, a serem analisadas na próxima seção (cf. 4.3).
} 
estudando o passado; remonta ao curso da lingua em observando as mutações que têm sofrido os sons, as palavras e as frases." (GUÉRIOS, 1944, p. 250)

"Gramática Histórica estuda a origem e as leis de formação e evolução de uma língua de sorte que a gramática histórica da língua portuguêsa estuda a origem e as leis de formação e evolução do português.” (HORTA, 1941, p. 13)

"A Gramática histórica ou comparativa abrange precisamente $\underline{0}$ estudo dessas modificações, confrontando-as ou comparando-as nas diversas épocas de uma mesma língua, ou nas diversas línguas de um mesmo grupo, afim de verificar quais as leis que as regem." (MARTINS, 1937, p. 13)

"O estudo de uma lingua no passado pertence à gramática denominada histórica." (NASCENTES, 1942 [1928], p.13)

"A grammatica historica é, por assim dizer, a biographia das linguas, o registro dos factos capitaes, dos differentes aspectos que ellas vão apresentando, nessa evolução perenne a que estão sujeitas." (NOGUEIRA, 1918, p. 8)

"Grammatica historica é a que estuda a origem e evolução de uma lingua no tempo e no espaço.” (PEREIRA, 1916, p. 13)

"A grammatica historica indaga os factos que apresenta a lingua e as leis a que está sujeita, desde a origem até a epoca presente." (P.S., 1909, p. 215)

“(...) o estudo da gramática histórica, a qual se ocupa com a origem e evolução da lingua. Portanto, gramática histórica portuguesa é o estudo da língua desde a origem latina até a fase atual. Ela semelha um filme, ou seja uma série de fotografias que se desenrolam sucessivamente." (SILVA NETO, 1942, p. 11)

Nota: Os sublinhados são nossos.

Com efeito, estas 13 definições corroboram aquilo que já dissemos a respeito dos objetivos da gramática histórica: estudar "a origem e o desenvolvimento das línguas, através de leis/princípios que expliquem os estágios evolutivos pelos quais passaram as línguas, desde sua origem até o presente". Evidentemente que no caso específico das gramáticas históricas do Português, esse estudo é realizado retrocedendo-se à língua que originou o Português, ou seja, o Latim. Como o método de análise utilizado por essas gramáticas é o histórico-comparado, além do Latim, outras línguas românicas, como o Espanhol, o Francês e o Italiano, frequentemente aparecem nas análises que são feitas nesse tipo de gramática.

Nas gramáticas históricas que fazem parte de nosso levantamento, é possível encontrar uma grande quantidade de exemplos que ilustram e comprovam os objetivos que acima 
descrevemos. Selecionamos alguns trechos presentes da gramática de Sousa da Silveira (18831967).

DIA. Em latim clássico dizia-se dies, gen. diei. vimos, porêm, (pág. 39) que havia substantivos da $5^{\text {a }}$ declinação que tinham formas da $1^{\text {a }}$. Por isso, em latim popular deve ter existido dia: desta palavra é que proveio o nosso substantivo dia. O que há de notável é que, sendo breve o $i$ do latim dies $<>$ dĩa, êle está contudo representado em português por $i$ e não por $\hat{e}$. É que o ĭ breve, e mesmo o $e$ de um hiato podem passar a $i$, para distanciar as duas vogais que devem estar cada uma em sua sílaba, facilitando dest'arte a pronúncia: por isso, lat. dǐa $>$ port. dia; lat. mea (adj. posseivo) > port. mia, e, com a nasalação do $i$ provocada pelo $m$, mia > minha. (SILVEIRA, 1921, p. 72, sublinhados nossos)

Nesse trecho, o autor estuda os diferentes estágios evolutivos pelos quais passou a palavra dia, fazendo o percurso desde suas formas latinas até chegar ao Português. Também podemos observar, no excerto, a presença das regras - ou leis - que explicam tal percurso.

Vejamos outro exemplo em que Silveira (1921, p. 73, sublinhados nossos) detalha um pouco mais a aplicação de uma lei de evolução, neste caso, a evolução fonética. A análise a seguir é relativa à palavra ontem.

Constituída a expressão adverbial anoite, que se arrima, como acabamos de ver, na analogia com amanhã, e tem formas paralelas em outras línguas românicas, a evolução fonética subsequente é fácil e natural. $\mathrm{O}$ - $n$ - nasala o ditongo seguinte, $\mathrm{e}$ cai, e disto resulta aõite; a assimilação do $a$ à vogal do ditongo dá lugar à forma arcaica oõite e a queda da semivogal, mui comum, como já vimos, produz a outra forma arcaica, oonte, que, com a contraç̧ão dos dois oo, se reduz à forma popular onte. A repercussão, na desinência, da nasalidade do começo do vocábulo ocasiona o advérbio actual ontem.

Silveira (1921, p. 73, sublinhados nossos), a seguir, demostra preocupação em comprovar que as leis de evolução por ele utilizada são, de fato, válidas. Essa comprovação será feita através de corpus literário, recurso bastante utilizado pelos gramáticos históricos quando precisavam atestar uma fase mais antiga da língua. Falaremos mais a esse respeito na seção 4.2.3, local dedicado à análise da camada documental das gramáticas históricas.

Para convencer da legitimidade desta etimologia importa mostrar que todos êstes factos fonéticos são naturais na língua. A queda do - $n$ - intervocálico já estudamos (pág. 63); a assimilação de uma vogal a outra e posterior fusão de ambas em uma só podemos mostrar agora: portucalense (= natural de Portucale) produziu, pelas leis fonéticas que já nos são familiares, portugaệse e portugaês, e a assimilação do $a$ ao $\hat{e}$ originou a forma portugueêse, com cinco sílabas, que se vê no trecho abaixo:

"El-rei portugueese

barcas mandou fazere"

(Joan Zorro, apud Nunes, Crest. Arc., 339.) 
Por fim, a absorção do $e$ átono no $\hat{e}$ tónico fêz surgir português. A queda frequente da semivogal vimos a pág. 59. No vocábulo mũito ela tambêm caíu, produzindo munto, popular em Portugal e no Brasil. Usou-o A. F. de Castilho:

"De outro qualquer assunto

Só para ociosos bom, cansou-se o povo há MUNTO."

(Geórgicas, 139.)

Em falar brasileiro é bastante comum:

"Num ai munto tempo"

(Cornélio Pires, Conversas ao pé do fogo, S. Paulo, 1921, 181.)

A preocupação do autor em comprovar as leis de evolução fonética é reforçada pelo cuidado em selecionar trechos não só oriundos da literatura portuguesa, mas também da brasileira. Assim, ao se utilizar de tal expediente, o autor reforça seu objetivo quanto a demonstrar que os fatos fonéticos analisados são naturais ao Português, ou seja, não foram criados artificialmente pelo gramático.

\subsubsection{Camada técnica}

Vimos, na seção anterior, qual é o conceito de língua que fundamenta teoricamente o programa filológico. Como já apontamos anteriormente, ao se estudar a camada técnica é possível saber quais são as ferramentas linguísticas utilizadas por um determinado programa de investigação para colocar em prática seus objetivos teóricos.

Com efeito, isso significa dizer que, nesta seção, nosso interesse será o de estudar quais são as técnicas linguísticas utilizadas pelas gramáticas históricas para cumprirem os objetivos por elas enunciados, os quais podem ser sintetizados da seguinte forma: estudar a origem e o desenvolvimento do Português.

Tal como fizemos com as gramáticas tradicionais (cf. seção 2.3.1.3), estruturaremos esta seção a partir da definição de camada técnica dada por Swiggers (2004, p.134), que assim a enuncia: "[são] as técnicas de análise (linguístico/gramatical) e os métodos de apresentação dos dados". 
Como subsídio para o estudo da camada teórica, fizemos um levantamento, já anteriormente mencionado, que localizou e transcreveu uma série de definições a respeito dos objetivos da gramática histórica e das demais disciplinas correlatas (cf. apêndice B - Quadro 12B). Afortunadamente, em algumas definições, os autores vão além do "o que é" a gramática histórica e avançam no "como fazer", ou seja, realizam considerações pertinentes justamente à camada técnica. Dada a extensão desse levantamento, apresentaremos a seguir um quadrosíntese.

\section{Quadro 14 - Definições sobre as técnicas de análise da gramática histórica - Quadro-síntese}

Emprega principalmente o método comparativo (comparação das formas atuais com as antigas, na própria língua e nas línguas estrangeiras). (ABREU, 1944, p. 183)

Método histórico-comparativo - O estudo evolutivo da nossa língua é feito de acórdo com o confronto das formas históricas não só portuguesas, mas também espanholas, italianas, francesas, etc., afim de que as conclusões sejam certas e científicas. Assim, a forma atual do futuro (amarei) dizemos que é criação puramente romana, e a esta conclusão chegamos através das comparações históricas que remontam até o tempo de Cícero. (BUENO, 1938, p.13)

[Apresentação dos dados] 3. Divisão. - Divide-se a Gramática Histórica em Lexiologia e Sintaxe. 4. A Lexiologia estuda a palavra isoladamente. Sob dois aspectos se pode fazer êste estudo: o material e o significativo. Daí a subdivisão da Lexiologia em Fonologia e Morfologia. 5. A Sintaxe ocupa-se das palavras relacionadas umas com as outras, na frase.

[Técnicas de análise] 6. Método Comparativo. - Consiste o Método Comparativo em relacionar os fatos de uma língua com os análogos de outra ou outras da mesma família, para descobrir-lhes a origem ou procedência. O Método Comparativo é um auxiliar poderoso e seguro nas pesquisas etimológicas, fornecendo, de pronto, a chave de muitos problemas que, de outro modo, seriam de difícil solução. Para exemplo, tomemos o verbo ousar. O latim clássico ministra-nos audere, de idêntico sentido, que, entretanto, não pode justificar a origem de ousar.

\section{Apliquemos ao caso o Método Comparativo.}

Em provençal, a palavra correspondente à portuguesa é ausar; em italiano, osare; em espanhol, osar; em francês, oser. Estas formas paralelas, nas línguas românicas, estão a indicar que o verbo originário, em latim, devia ser da primeira conjugação. A permanência do $s$, em todos os exemplos, é também argumento contra audere. Conhecidas as leis fonéticas que presidiram à evolução dos vocábulos nas citadas línguas novi-latinas, só uma palavra há que pode justificar plenamente a existência daquelas várias formas, e esta é *ausare, verbo formado, no latim popular, a exemplo de outros, do particípio ausum, de audere. (COUTINHO, 1938, p. $14-15$, sublinhado nosso)

O método a seguir é o comparativo que consiste em estudar uma língua, comparando as suas formas com as formas gramaticais das línguas afins e também com as transformações 
sucessivas que a própria língua sofreu. As línguas afins são as que se originam de um mesmo tronco comum. As línguas afins do português são as que se originam, como ele, do latim popular. São élas o francês, o italiano, o espanhol, o provençal, o rético, o rumeno, o sardo e o dalmático. (HORTA, 1941, p. 13)

Para suas investigações, a gramática histórica lança mão do método chamado históricocomparativo porque, ao mesmo tempo que estuda o fenômeno em todas as suas transformações no passado, desde a lingua mãe, recorre muitas vezes para corroborar suas afirmações, a linguas oriundas do mesmo tronco. Assim, por exemplo, a palavra portuguesa nau vem certamente do latim nave (de acordo com a praxe moderna as palavras latinas são dadas no acusativo sem a desinencia $m$ : nave $(m)$ ), que deu nave. A presença anormal daquele $u$ só nos pode ser explicada por meio do catalão, lingua em que normalmente desaparece a final vocálica latina, com alterações da consoante precedente ou sem ela: nave>nav > nau. (NASCENTES, 1942 [1928], p. 13-14)

[Técnicas de análise] O seu methodo [da gramática histórica] é sempre o methodo historicocomparativo, versando a comparação das formas grammaticaes, não só com as transformações parallelas das linguas affins, mas ainda com as transformações successivas da mesma lingua. (PEREIRA, 1916, p. 13)

[Apresentação dos dados] O seu estudo divide-se naturalmente em trez partes, chamadas Phonologia, Morphologia e Syntaxe. Estas trez partes da Grammatica encerram os trez aspectos fundamentaes em que a palavra pode ser estudada na expressão completa do pensamento. (PEREIRA, 1916, p. 15)

O methodo a seguir é o historico comparativo i. é estudamos as diversas phases, valendo-nos das analogias ou differenças que nos subministram as outras linguas da mesma familia. Este methodo, primeiramente adoptado pelos fins do seculo 18 no estudo das linguas aryanas, foi no seculo 19 applicado por Diez á investigação dos idiomas que descendem do tronco latino. Modernamente empregam, sobretudo nas indagações phonicas, o subsidio da physiologia dos sons i. é uma divisão mais exacta e a facilidade ou difficuldade, com que em certa lingua se proferem e associam os phonemas. (P.S., 1909, p.215)

Vamos dividi-la em história externa e história interna: a primeira ocupa-se com a origem e a expansão do idioma, enquanto a segunda traça a evolução do material linguístico latino até o português. Por material lingùístico entendemos os fonemas, as palavras e as frases de uma língua. A história interna divide-se, portanto, em fonética histórica, morfologia histórica e sintaxe histórica. (SILVA NETO, 1942, p. 11)

Como é possível verificar acima, as gramáticas históricas do Português do início do século XX afirmam estar metodologicamente ligadas à Linguística Histórico-Comparada, disciplina sobre a qual já falamos no início deste capítulo (cf. seção 4.1). Já dissemos aqui algumas vezes que definições como as que apresentamos no quadro são manifestações retóricas do autor (MURRAY, 1994) e seu conteúdo pode ou não ser colocado em prática ao longo da 
obra. Em outros termos, o autor pode afirmar, no prefácio, que fará uso de uma determinada teoria e/ou prática de análise linguística e, no decorrer da obra, não seguir aquilo que havia anunciado. Assim, a depender do estudo que se está realizando, é necessário verificar esses dois gestos do autor, o retórico e o prático. É exatamente isso que faremos a seguir, verificando como se deu a aplicação do "método histórico-comparado" nas gramáticas históricas presentes em nosso levantamento.

Como já dissemos no item sobre a camada contextual (cf. seção 4.1.1), as gramáticas históricas aqui analisadas têm, todas elas, relação com o ambiente escolar. Assim, são os programas de ensino que definirão o conteúdo desses materiais. Os programas também exercem grande influência na forma como as gramáticas apresentam os dados de análise linguística, já que muitas delas utilizam a mesma estruturação desses documentos. Em tais situações, o sumário da gramática é o próprio programa de ensino.

No anexo A (Quadro 12B), colocamos a relação completa de temas presentes em cada programa, de 1887 a $1961^{68}$. A análise desses oito documentos mostra uma grande oscilação quanto à abordagem que a escola deveria dar à gramática histórica. Enquanto alguns programas são bastante sintéticos, outros são bem mais extensos e com tópicos que possibilitam um maior aprofundamento na matéria. Há, por exemplo, programas que excluem a sintaxe histórica, relacionando apenas temas de fonética e morfologia históricas. Outros, por sua vez, estabelecem o estudo apenas da morfologia histórica. Aqui, no entanto, apresentaremos todas as "técnicas de análise" (SWIGGERS, 2004, p.134) presentes nessas gramáticas, independentemente do ano/programa em que elas aparecem.

Comecemos pela história interna, que nos termos de Silva Neto (1942, p. x) é o estudo da "evolução do material linguístico latino até o português". A história interna se preocupa apenas com a língua em si, sem considerar suas relações com a sociedade, objeto de estudo da história externa. Dessa forma, a análise da língua isoladamente divide-se em três níveis diferentes - o som, a palavra e a frase - o que, no caso da gramática histórica, fica a cargo, respectivamente, da fonética histórica, morfologia histórica e sintaxe histórica.

Quanto à fonética histórica, a análise que fizemos das gramáticas presentes em nosso levantamento indica que elas se dedicam, basicamente, ao estudo de três tópicos: (i) leis fonéticas, (ii) metaplasmos e (iii) vocalismo e consonantismo. A despeito de ligeiras diferenças,

\footnotetext{
${ }^{68}$ O último programa que transcrevemos é o relativo à Reforma Gustavo Capanema, que vigeu entre 1942 e 1961.
} 
consideramos que esses três temas constituem uma boa representação de como a fonética é estudada nessas 30 gramáticas históricas.

São quatro as leis fonéticas apontadas pelos autores: (i) a lei do menor esforço; (ii) o princípio da transição; (iii) a persistência da sílaba ${ }^{69}$ tônica e (iv) o princípio da analogia. Quanto à primeira, Lobo (1936, p.49-50, itálicos do autor) diz que

(...) é a tendencia que todos nós temos para realizar as coisas com o menor dispendio possivel de energia. Esta lei existe na linguagem, como em todas as demais coisas da vida, e assim, os sons difficeis de se pronunciarem, são substituidos por outros mais faceis. É pela lei do menor esforço, tambem, que abreviamos as palavras, dizendo, por exemplo, auto, Pinda, Guará, Rio, em vez de automovel, Pindamonhangaba, Guaratinguetá, Rio de Janeiro.

Pereira (1916, p. 43-44, itálicos do autor, sublinhado nosso) assim apresenta a segunda lei, isto é, o princípio da transição e a relaciona com a lei anterior, a do menor esforço.

O principio da transição indica o modo de operação da lei do menor esforço no enfraquecimento e suppressão dos phonemas incorporados nos vocabulos latinos. Consiste, portanto, este principio, na graduação de successivo enfraquecimento ou abrandamento dos phonemas vocabulares até o limite maximo da suppressão ou quéda. Assim os phonemas se alteram na escala descendente: um som forte passa primeiro para seu homorganico fraco, isto é, abranda-se. Seguindo este principio de transição, as consonancias surdas - $p, f, t, s, k$, abrandam-se respectivamente nas sonoras homorganicas $b, v, d, z, g$. Abrandando-se o phonema ou permanece no vocabulo ou cae, ou, sendo explosiva, póde passar para a contínua proxima, como se vê em seguida:

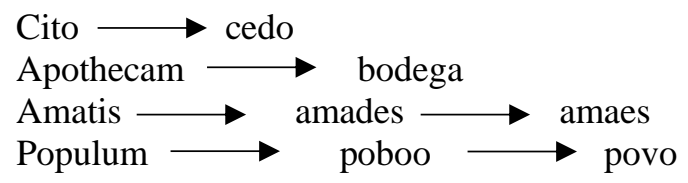

Com efeito, ao analisarmos essa lei, podemos observar a presença de dois importantes aspectos que constituem a essência (camada teórica) da gramática histórica: o estudo das leis que possibilitaram o desenvolvimento (evolução ${ }^{70}$ ) de uma determinada língua, de sua origem até o tempo presente. Nos casos acima, o princípio da transição explica a formação de cedo, bodega, amaes e povos, palavras em Português, que se originaram das formas latinas cito, apothecam, amatis e populum, respectivamente. Como veremos a seguir, os estudos relacionados ao desenvolvimento do Português a partir do Latim não se limitam a essa segunda lei, mas será também a tônica das demais.

\footnotetext{
${ }^{69}$ Alguns autores chamam esta lei de persistência do acento tônico.

${ }^{70}$ Alguns gramáticos utilizam evolução, termo muito utilizado ao longo do século XIX, período em que esteve muito em voga as teorias naturalistas-evolucionistas, inclusive no âmbito das ciências de linguagem.
} 
A terceira lei, persistência da sílaba tônica, diz que "na transformação do latim para o português, as palavras, em geral, conservaram a acentuação tónica do latim: árbore > árvore; rúbiu > rúivo; artíc( $(u) l u>$ artelho; décimu > dízimo; auríc(u)la > orelha; ventu > vento; potione > peçonha; etc." (GUÉRIOS, 1937, p. 63). Na sequência, o autor destaca que as exceções a essa lei devem-se aos casos de analogia, que é a quarta lei fonética a que faremos menção. "Assim amabámus (paroxitónico) que deveria dar amavámos, deu amávamos (proparoxítono), conforme a acentuação de amáva, amávas, amávam. A esta deslocação da tónica dá-se o nome de hiperbibasmo. (GUÉRIOS, 1937, p. 63).

Na explicação de Guérios (1937, p.64, sublinhamos) para o hiperbibasmo, novamente podemos ver destacado o processo de desenvolvimento/evolução do Português a que nos referimos anteriormente. Alguns exemplos a seguir apontam para três diferentes fases, isto é, o latim clássico, o latim popular e o Português. Vejamos: "lat. cláss. pariete > lat. pop. pariéte > [port.] parêde; lat. cláss. lintéolu > lat. pop. lintiólu > lençol; port. orquídea > pop. orquidéa ou orquidéia; port. suplíca (verbo) > port. súplica (subst.); etc.”.

Finalmente, quanto à analogia, é preciso destacarmos que ela atua além do nível fonético, já que nos níveis nominal (morfológico) e sintático também podemos encontrar processos analógicos. Com efeito, esse é o motivo que levou alguns autores a não incluir a analogia no rol das leis fonéticas, estudando-a separadamente. Falaremos aqui da analogia fonética e, mais à frente, da nominal e sintática.

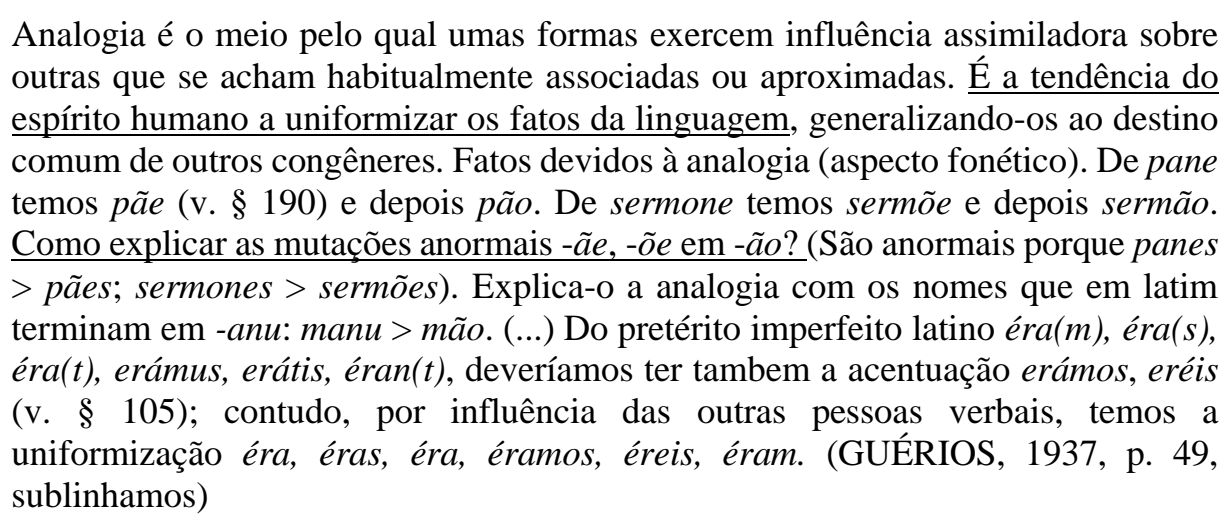

Assim, a analogia acaba por apontar exceções às leis fonéticas, que alguns autores consideravam como regulares e infalíveis. Os exemplos apontados por Guérios são bastante elucidativos. Vejamos um deles: se, no plural, panes > pães, então, no singular, pelas leis fonéticas, deveríamos ter pane > pãe, mas, pela analogia, temos pane > pãe> pão. Ou seja, pela aplicação das leis fonéticas não seria possível explicar a forma final pão, mas a analogia com as formas latinas terminadas em - anu consegue sim explicá-la, já que manu > mão. 
Dissemos que, quanto à fonética histórica, são três os tópicos mais presentes no universo das 30 gramáticas históricas analisadas: (i) leis fonéticas, (ii) metaplasmos e (iii) vocalismo e consonantismo. Feitas as considerações a respeito das leis fonéticas, vejamos agora como os metaplasmos ajudam a compreender o processo de desenvolvimento/evolução do Português estudado nessas gramáticas.

Martins (1937, p.35, itálicos do autor) diz que os "metaplasmos são modificações que sofrem as palavras em sua evolução histórica. Essa evolução obedece aos postulados das leis fonéticas.".

Como já dissemos, a apresentação da matéria nas gramáticas históricas é diferente a depender do ano em que elas foram publicadas, pois alguns programas previam maior aprofundamento dos temas históricos e outros menos. Apesar dessa oscilação, optamos aqui por apresentar os metaplasmos de forma mais ampla, já que, além de ser uma técnica de análise utilizada por obras do programa filológico, também aparecerá em algumas obras do programa dialetológico (cf. cap. 5)

Martins (1937, p.35-36, itálicos do autor, sublinhados nossos) diz ainda que "os metaplasmos são de quatro classes: a) por permuta; b) por adição; c) por subtração; d) por transposição.”. Na sequência, o autor apresenta as oito formas de permuta:

1) Abrandamento. - Dá-se quando um som forte se transforma num fraco: coecum $>$ cego; superbum > soberbo. 2) Vocalização. - É a transformação, em vogal, das consoantes $c, p, l, b, g$, nos grupos: $c t, p t, l t, b s, g n$ ou $g m$, em $i$ ou $u$ : pectum > peito; conceptum > conceito; alterum > outro; absentem > ausente; regnum > reino; flegma > fleuma. 3) Consonantização. - Observa-se na mudança do $i$ inicial em $j \mathrm{e}$ do $u$ em $v$ : iota > jota; Hierusalem > Jerusalém; audire > ouir > ovir > ouvir. 4) Assimilação. - Atração que um fonema exerce sôbre outro, tornando-o igual ou semelhante a si. Tem também êste fenômeno o nome de aliteração. Pode ser vocálica ou consonantal. Ex.: novaculam > navalha; en lo > enno > eno > no. (...) 5) Dissimilação.- É o metaplasmo, em que um fonema se transforma ou cai, desde que haja fonema idêntico na palavra. Pode ser vocálica ou consonantal. Ex.: horoogium > rologio > relogio; Massiliam > Masselha > Marselha; rostrum > rosto. 6) Apofonia. - É a mudança de uma vogal de uma palavra em outra, sob a influência de um prefixo. Ex.: In+aptum > ineptum > inepto; in+barbam > imberbem > imberbe. 7) Crase é a fusão de duas vogais numa: Pedem> pee > pé; colorem > coor > côr. Nos fatos atuais da linguagem, a crase se dá entre os adjetivos determinativos $a$, aquele, etc. e a preposição a. 8) Ditongação, cujas causas, modalidades e número estudaremos no ponto seguinte.

Vejamos agora as demais classes de metaplasmos, começando pela adição e subtração.

POR ADIÇÃO: Pode-se verificar no principio, no meio e no fim do vocábulo. $1^{\circ}$ ) Prótese - acréscimo no principio. Ex.: scribere < escrever. $2^{\circ}$ ) Epêntese - acréscimo 
no meio. Ex.: sinum > seo > seio. Alguns fazem distinção entre o acréscimo medial de letra e o de sílabas na palavra, dando aquele o nome de epêntese e a este o de suarabacti. $3^{\circ}$ ) Paragoge - acréscimo no fim. Ex.: sic > si > sim. POR SUBTRAÇÃO: $1^{\circ}$ ) Aférese - perda inicial. Ex.: eccu-hac > acá >cá. $2^{\circ}$ ) Sincope perda medial. Ex.: aquilam > aguia. Diz-se Haplologia quando a queda é de uma de duas sílabas idênticas. Ex.: idololatram > idólatra. $3^{\circ}$ ) Apócope - perda no fim. Ex.: amat > ama. (MARTINS, 1937, p.36-37, itálicos do autor, sublinhados nossos)

Finalmente, temos a última classe de metaplasmo, a transposição.

POR TRANSPOSIÇÃO: Pode ser de fonema ou de acento. De fonema: $1^{\circ}$ ) Metátese - transposição de um fonema dentro de uma mesma sílaba. Ex.: super > sôbre. $2^{\circ}$ ) $\underline{\text { Hipértese }}$ - transposição de um fonema de uma sílaba para outra. Ex.: capiam > caiba. De todos os fonemas o que mais fàcilmente troca de lugar é o $r$. De acento: Dá-se a êste metaplasmo o nome de hiperbibasmo. Chama-se diástole, quando a transposição do acento tônico se faz da silaba anterior para a posterior. Ex.: ocěănum > oceano. Chama-se sístole, quando a transposição se faz da sílaba posterior para a anterior. Ex.: idōlum > ídolo. (MARTINS, 1937, p.37, itálicos do autor, sublinhados nossos)

Como pôde ser visto, os metaplasmos aqui apresentados representam um amplo conjunto de ferramentas analíticas para o estudo e a melhor compreensão da evolução fonética do Português, desde o Latim até seus estágios contemporâneos. É importante sublinhar, mais uma vez, as diferenças quanto ao programa gramatical. Em função dos valores presentes em sua camada teórica, as técnicas utilizadas pelo programa filológico não buscam estabelecer as bases do bom uso na língua, definindo assim um conjunto de regras que constituem a norma subjetiva. Podemos ver que não há preocupação normativa nessas leis, mas sim um interesse em estudar e explicar historicamente o Português.

Encerrando os tópicos de fonética histórica, vejamos outros dois processos importantes para a compreensão da evolução do Português: o vocalismo e o consonantismo. A esse respeito, Bruno (1941, p. 109, itálicos do autor, sublinhados nossos) esclarece que

a Fonética histórica estuda as alterações sofridas pelas palavras, sob o ponto de vista fonético, na sua evolução do latim para o português. Conforme esse estudo tem por objeto as vogais ou as consoantes, chama-se vocalismo ou consonantismo. Em latim, as vogais distinguem-se segundo a quantidade. Eram longas ou breves, conforme o maior ou menor tempo empregado na sua prolação. A posição da tônica dependia, nas palavras polissilábicas, da quantidade das vogais. No latim popular começou a perder-se a noção da quantidade, que acabou por desaparecer no português, permanecendo apenas o acento tônico.

O estudo do vocalismo é extenso, mas vejamos, como exemplo, a atuação desse processo na formação dos ditongos.

Os quatro ditongos existentes no latim literario - ae, oe, au e eu-manifestam desde o latim popular tendencia para se reduzir a vogais. Ae tônico transforma-se em é: 
saepe > sebe, caecu > cego. Ae pretônico reduz-se a $i$ ou $e$ : aequale > igual, aestiuu $>$ estio. Oe torna-se $\hat{e}:$ oedu > feio, poena > pena. Au transforma-se em ou: auru > ouro, thesauru > tesouro. No latim vulgar, já se encontra au com o valor de $o$ : popere por paupere > pobre. Eu manteve-se em geral. Na linguagem popular, tomou, em certos nomes proprios, a forma $o$ : Eulalia $>$ Olalia. Na derivação do latim para o português, varios ditongos se formaram. Para isso contribuiram: a) A queda da consoante media: patre > pai, malu > mau; b) A transformação de certas consoantes em vogais: actu > auto, lacte > leite; c) A transposição de vogal de uma para outra sílaba: feria > feira, primariu > primeiro; d) A intercalação de vogal eufônica: catena > cadeia, frenu > freio. (BRUNO, 1941, p. 111, sublinhados nossos)

Os trechos sublinhados não deixam dúvidas sobre o papel do vocalismo no processo de evolução do Português. Isso é visto, por exemplo, quando o autor fala da existência, no latim clássico, de ditongos, que depois, no latim popular, são reduzidos a vogais, como em aequale > igual.

Nesse processo evolutivo, além do estudo das vogais, há também aquele destinado às consoantes, chamado, portanto, de consonantismo. "Na historia das transformações que as consoantes sofreram na sua evolução do latim para o português, deve-se estudar sobretudo a posição que ocupavam no corpo do vocábulo. Devemos assim distinguir as consoantes em iniciais, mediais e finais." (BRUNO, 1941, p. 120). O estudo do consonantismo também é extenso, então apresentaremos apenas sua aplicação no caso das consoantes iniciais.

As consoantes iniciais em geral mantêm-se inalteraveis. Só em casos excepcionais,
por influencia da analogia, por assimilação ou por confusão de sons, as consoantes
iniciais se modificam. Podemos, então, encontrar: a) $\mathbf{C}$ transformado em $G:$ cattu $>$
gato, creta $>$ greda. b) $\mathbf{L}$ convertido em $N$ : libellu $>$ livel $>$ nivel. c) $\mathbf{N}$ em $M$ :
nasturciu $>$ mastruço. d) $\mathbf{M}$ em $L:$ memorare $>$ nembrar $>$ lembrar. e) $\mathbf{V}$ em $B$ ou
$G$ : vesica $>$ vessica $>$ bexiga, vastare gastar. (BRUNO, 1941, p. 120, negritos e
itálicos do autor).

Feitas as análises referentes à fonética histórica, passemos agora para a morfologia histórica. Tal como ocorre no programa gramatical, a gramática histórica estrutura seus estudos de morfologia a partir das classes de palavras. Embora use a mesma metalinguagem (substantivo, adjetivo, verbo, advérbio, pronome, ...) as técnicas de análise são outras, já que os objetivos desses dois programas são bem diferentes. Nesta seção, não iremos abordar as especificidades analíticas de cada classe. Como nosso objetivo aqui é mostrar quais são as técnicas utilizadas pelas gramáticas históricas em suas seções de morfologia, julgamos que é possível realizar tal tarefa pela análise de apenas uma dessas classes. Com efeito, estamos assim dizendo que a técnica utilizada na análise de cada classe morfológica é fundamentalmente a mesma, sendo, 
portanto, desnecessário uma análise individualizada. Pautados por essa visão, selecionamos apresentar os estudos relativos o advérbio.

Sob o título de "Etymologia dos adverbios, preposições e conjuncções; formas archaicas", Nogueira (1930, p. 257, sublinhados nossos), antes de falar especificamente do advérbio, faz uma observação a respeito da história dessas três classes, o que no ajuda a compreender o tipo de análise que virá em seguida.

Na passagem das palavras invariaveis para o dominio romanico nem sempre houve perfeita equivalencia morphologica e semantica. No portuguez muitas não tiveram entrada; outras viveram algum tempo e depois cairam em desuso; outras ainda mudaram de categoria grammatical. A nossa lingua, por sua vez, serviu-se de recursos já vernaculos para formar palavras e locuções desse genero. Esses elementos, em ultima analyse, são de origem latina, de modo que a lingua mãe, de uma maneira ou de outra, ministra a materia prima para a formação de novas palavras.

Tal como vimos na fonética histórica, o trecho acima nos mostra, mais uma vez, aquilo que apontamos, na camada teórica, ser o principal objetivo da gramática histórica, ou seja, estudar "a origem e o desenvolvimento das línguas, através de leis/princípios que expliquem os estágios evolutivos pelos quais passaram as línguas, desde sua origem até o presente". O uso desses diferentes estágios na análise feita pelo autor é perceptível quando ele, primeiro, fala do advérbio no latim, para, depois, falar do advérbio no Português.

No latim o adverbio é uma categoria que se desprende de varias outras, principalmente do adjectivo. Esta origem communica ao adverbio uma das propriedades do adjectivo, a saber, a flexão de grau. Assim, do adjectivo doctus, o adverbio docte, o comparativo doctius e o superlativo doctissime; do adjectivo facilis, o adverbio facile, o comparativo facilius e o superlativo facillime. O adverbio não perde essa capacidade de exprimir o grau nem mesmo quando o adjectivo não tem flexão gradativa e, para esse fim, serve-se de palavras differentes. Assim, a bonus, melior, optimus correspondem os adverbios bene, melius, optime; a malus, peior, pessimus, os adverbios male, peius, pessime etc. (NOGUEIRA, 1930, p. 257, sublinhados nossos)

O fato de o advérbio latino ter se originado principalmente dos adjetivos faz com que uma de suas características, a flexão de grau, seja também vista nos advérbios latinos. Do ponto de vista dos "estágios evolutivos", Nogueira diz que o Português preserva, em seus advérbios, tal característica flexional.

Esse facto não podia deixar de reflectir-se no portuguez. Apenas a flexão é que se alterou, em vista de outro phenomeno: a grande expansão que tiveram os adverbios em mente, de cuja estructura trataremos adiante. Dahi os adverbios igualmente, melhormente, optimamente, pessimamente. $\underline{O}$ portuguez não recebeu os adverbios em $e$ e ter (probe, libere; suaviter, acriter) tambem formados de adjectivos nem os que indicam uma ou mais vezes: semel, ter, quater etc. Quanto a bis existe sob a forma de interjeição. Perderam-se os adverbios provenientes de nomes com o 
suffixo itus (humanitus, antiquitus); os em atim (gradatim) e os em im. Destes, passim é usado em forma inalterada na linguagem erudita. (NOGUEIRA, 1930, p. 258, sublinhados nossos)

Vejamos agora como a formação do advérbio é tratada em outra gramática histórica, a de Eduardo Carlos Pereira (1855-1923). Novamente, há a explicação de como eram formados os advérbios em Latim, para depois falar dessa formação no Português. Nesta obra, o autor é mais detalhista em sua exposição, apontando que os advérbios latinos se formaram a partir de dois processos.

O latim formava adverbios de adjectivos dando a estes, conforme a sua classe, as desinencias -e, $-e r$, iter $=$ misere, misserrime, prudenter, fortiter, pariter. Além deste processo, possuia o latim outro, que consistia em dar valor adverbial a certos adjectivos no accusativo e ablativo: multum = muito, paucum $=$ pouco, manifesto $=$ manifestamente, raro $=$ raramente, fortuito $=$ casualmente, súbito $=$ subitamente . Conservou o portuguez este processo: fallar alto, não raro, trabalhar pouco. (PEREIRA, 1916, p. 179, sublinhados nossos)

Na sequência, o autor mostra que o Português desenvolveu um novo processo de formação adverbial: a aglutinação do substantivo feminino mente $(\leftarrow$ mentem).

Um processo novo, porém, desenvolveu-se em portuguez e nas outras linguas romanicas do Occidente, na formação do adv. de modo, qual consiste em agglutinar-se o subst. feminino mente $(\leftarrow$ mentem $)=$ maneira, intenção, aos adj. qualificativos, que assumem por concordancia flexão feminina - justamente, honradamente, agradavelmente, cruamente. Serviu de typo a esta formação a locução adverbial latina: bona mente $=$ de boa mente, intrepida mente respondeo (Hier.) No v. port., como nestas expressões latinas, guardava o subst. mente a sua plena autonomia, escrevendo-se separadamente de seu respectivo adject. - fera mente. Ainda hoje guarda essa attitude na locuç. adverbial de boa mente: fazer alguma coisa de boa mente. Pouco a pouco o habito foi englobando na pronuncia os dois elementos desse grupo nominal e o subst. agglutinado ao adject., ou, melhor, este áquelle, deu ao subst. mente o caracter de um mero suffixo adverbial, não obstante a concordancia do adject. Entretanto, dizemos, sem esta concordancia portuguezmente, francezmente, hespanholmente, por terem sido invariaveis estes adjectivos em -ez e -ol, na época dessa formação. (PEREIRA, 1916, p. 180, sublinhados nossos)

Depois de explicações mais gerais a respeito dessa classe morfológica, as gramáticas históricas costumam apresentar, em formato de listas, o estudo histórico de cada advérbio. Vejamos alguns exemplos.

abaixo - de $a$ e baixo. Este adjectivo, de bassu, talvez por uma forma popular que contivesse uma semi-vogal postonica *basseu, o que explicaria o $i$.

acima - de a e cima, lat. pop. O classico é cyma.

(...)

$\boldsymbol{a h i}$ - A forma antiga é $i$, contracção de $i b i$, pela queda do $b$ intervocalico. O $a$ da forma actual ahi apparece em muitas outras palavras invariaveis: até, após etc. Tem 
sido proposto para o adverbio archaico $i$ o etymo hic, de que resultariam outras alterações. A forma $i$ deve ser comparada à franceza, arbitrariamente representada por $y$, da qual a intermediaria $i v$, encontrada no "serment de Strasb", attesta a verdadeira origem. (NOGUEIRA, 1930, p. 258, sublinhados nossos)

Os sublinhados que fizemos no trecho acima mostram aquilo que já destacamos nesta seção, que é a marcação das diferentes fases históricas (a evolução, nos termos de alguns gramáticos) pelas quais passou determinada palavra.

Alguns autores apresentam essas listas de advérbios de maneira mais sintética, como o que pode ser visto em Pereira (1916, p. 180-181): “Ahi $\leftarrow$ a $+\mathrm{i}(\mathrm{i} \leftarrow \mathrm{ibi})$; (...) Acima $\leftarrow$ ad + cimam; (...) Embora $\leftarrow$ em + boa + hora".

Com efeito, além das classes de palavras, há outro tópico de morfologia histórica bastante presente nas 30 gramáticas aqui em análise. Trata-se do estudo da "constituição do léxico português", título abrangente que inclui desde questões essencialmente morfológicas, como os processos de formação das palavras, até temas de natureza mais lexical, como o estudo dos neologismos, arcaísmos, gírias, entre outros.

Guérios (1937, p.27, itálicos do autor e sublinhados nossos) diz que "o léxico português é constituído de vocáculos oriundos de 3 fontes históricas". São elas:

$1^{\circ}$ ) Origem latina. O latim é a origem primária do nosso vocabulário, e a mais importante. $2^{\circ}$ ) Origem estrangeira. Em todos os tempos, as línguas estrangeiras, quer diretamente, quer por meio do latim e de outros idiomas, contribuíram para o aumento do nosso dicionário. $3^{\circ}$ ) Origem vernácula. A própria língua portuguesa fornece, por meio de processos internos de derivação e composição, novos vocábulos, que aumentam constantemente o léxico.

Quanto à origem latina, o autor destaca o papel que teve o latim popular ou vulgar na formação do vocabulário português. Destaca que além do léxico, o Português recebeu também do Latim as formas gramaticais, os pronomes, as partículas e quase todos os prefixos e sufixos. Guérios diz ainda que tais características entraram no Português via Latim Vulgar, mas que também houve contribuições lexicais vindas do Latim Clássico, os chamados latinismos, como ocorre nos casos de album, deficit, inclusive, por exemplo.

Em relação à origem estrangeira, Guérios mostra que além dos povos que invadiram a Península Ibérica, como os árabes, outras nações também deixaram marcas vocabulares no Português. A seguir reproduzimos tais nações, além de alguns exemplos.

[Vindos] Do hebraico (aleluia, sábado, [...]); Do germânico (abandonar, canivete, $[\ldots])$; Do inglês (bife, futebol, $[\ldots]$ ); Do francês (avenida, constatar, $[\ldots])$; Do espanhol (frente, trecho, [...]); Do italiano (aquarela, bússola, [...]); Do tupí- 
guarani (capim, caipira, [...]); De línguas africanas (carimbo, moleque, [...]); Do grego (anjo, ateu, [...]). Modernamente, por via erudita, palavras como fotografia, quilómetro, [...]. Os sufixos - ismo, -ista, -ía, -izar são [também] de origem helênica. (GUÉRIOS, 1937, p.28-30, negritos nossos)

Finalmente, quanto à origem vernácula, os estudos, nessa seara, se dão, basicamente, pela investigação das seguintes questões: (i) questões mais estruturais das palavras, ao se estudar os afixos (prefixos e sufixos), desinências, tema ou radical, raiz e (ii) aspectos mais ligados à formação das palavras, com a análise dos processos de derivação e composição. Tais tópicos são bastante conhecidos do leitor contemporâneo, pois eles estão presentes nas atuais gramáticas tradicionais (escolares ou não). Tal presença indica a incorporação, pela gramaticografia brasileira, de temas caros à gramática histórica. Destarte, faremos uma breve apresentação da forma como esses tópicos são estudados nas gramáticas que aqui estamos analisando.

A respeito do significado de tema, radical e raiz, bem como alguns exemplos, recorremos ao que disse Guérios (1937, p.33-34, negritos do autor).

Tema ou radical é a parte principal da palavra, que não sofre variação. Exs.: AMor, des-AM-or, LIVR-O, MENT-e, MENT-ir, etc. Incluido no tema está núcleo que se chama raiz. Raiz é o elemento irredutível da palavra, obtido por eliminação de todos os elementos de formação. A raiz exprime a idéia vaga e fundamental do vocábulo. Muitas vezes a RAIZ se confunde com o TEMA, e esta com a PALAVRA tôda. Ex.: am-or, ment-e, etc. Am- e ment- - são raízes e ao mesmo tempo temas. Marinho tem por tema e raiz a palavra mar. Porêm outras vezes sòmente a análise fonética ou etimológica faz sobressair a raiz. Assim, chuva tem o latim pluvia por origem, e cuja raiz será então $p l u v$-. Dai se verá que qualquer raiz pode aparecer em palavras sob formas diferentes. Outros exemplos: MENT-ir, MEMÓR-ia, LEM-BRar (v.§ 96 memorare), etc.

Quanto ao afixo, "é o elemento que se acha ou se coloca antes ou depois do tema para variar-lhe o sentido. Assim, são afixos: des-am-or, re-dobr-ar, ab-jura-mento, gost- oso, filh-o, filh-a, livr-o-s, sabor-osa-mente, etc. (Guérios, 1937, p.34). Caso o elemento esteja na frente do tema, dá-se o nome de prefixo, e, se vem depois, deve ser chamado de sufixo.

Com efeito, tanto as gramáticas históricas quanto algumas obras que analisaremos na próxima seção, a das obras de temas filológicos específicos (cf. 4.3), ao estudarem os prefixos, sufixos e radicais, o fazem buscando suas origens históricas (normalmente latinas ou gregas) e apresentando o resultado em longas listas, separadas segundo o tipo de elemento mórfico e sua origem. Vejamos alguns exemplos de palavras extraídas de tais listas:

[prefixo de origem latina] $=$ "mult- de multum: multímodo. [...] tre $(s)-\leftarrow$ tres: tresfôlho, ter.zentos. Outra forma, por analogia com “bis”.: trisavô, tridente." [...] 
[sufixo de origem grega] $=\mathrm{I}$, de origem grega/ $-i a \leftarrow-i a:$ Geografia, fidalguia . Farmácia, polícia. Mantêve no latim popular a prosódia original -ia, por confusão com -ía procedente de -éia. Profecia $\leftarrow$ lat. prophecia $\leftarrow$ gr. prophetéia. (JUCÁ (filho), 1945, p.132; 140, negritos do autor)

O processo de formação das palavras ainda é estudado, nas gramáticas, através de outros dois mecanismos: a derivação e a composição. O primeiro pode ser assim entendido:

Derivação é o processo de formar palavras novas de outras já existentes. A derivação pode ser própria, imprópria e regressiva. Derivação própria ou afixação é o processo de formar palavras novas por meio de afixos. Há, portanto, duas derivações próprias - prefixação ou derivação prefixal e sufixação ou derivação sufixal ou ainda flexionismo. Exs. de prefixação: re-tocar; in-justo, desleal, a-laranjado, en-velhecer, pre-meditar, a-católico, anti-católico, antediluviano, contra-regra, entre- ver, etc. Exs. de sufixação: goiab-ada, espiritu-al, sabor-oso, livr-aria, homi-cida, envelh-ecer, am-ar, amo-ou, moral-izar, livro-s, mulher-es, espôs- $o$, espôs- $a$, sàbia-mente, etc. (GUÉRIOS, 1937, p.35, negritos e itálicos do autor).

Tanto a derivação quanto a composição são importantes ferramentas na criação de novas palavras no Português, já que em ambos os processos há o aproveitamento de termos já existentes na língua. Vejamos mais dois casos de derivação, a imprópria e a regressiva.

Derivação imprópria é o processo de formar palavras novas pela simples mudança de categoria gramatical. Assim [...] Pôrto > pôrto (vinho); o falar; [...] os porquês; [...] moço guerreiro [de substantivo formou-se um adjetivo]. Derivação regressiva ou retrógrada é o processo de formar palavras novas pela supressão de desinência ou terminação. Exs.: sarampão > sarampo; [...] bênção > bença (pop.); port. arcaico: aceiro > aço. (GUÉRIOS, 1937, p.38-39, negritos do autor).

Já a composição "é o processo de formar palavras novas com a reunião de dois ou mais vocábulos. [exs.] papel-moeda, couve-flor, [...] ourives ou, melhor, ourívez < lat. auri + fice; vinagre < lat. vinu + acre". (GUÉRIOS, 1937, p.40-41)

Finalmente, para encerrarmos as considerações a respeito da morfologia histórica, vejamos novamente o fenômeno da analogia. Anteriormente, dissemos que tal processo ocorre em três níveis da língua: fonético, morfológico e sintático. Da analogia fonética, já falamos, passemos, então, à analogia morfológica.

A forma meridional faz supor a existência de *meridião de que aquela se derivou, porêm meridional foi formado por analogia de setentrional, que é um derivado de setentrião, de fato existente. A terminação - avo da palavra oitavo foi base suficiente para as creações analógicas doze-avos, quinz'avos, etc. O feminino de freire é sôror; contudo, fez-se o novo feminino freira. (GUÉRIOS, 1937, p.49-50, sublinhado nosso) 
Nos exemplos aqui reproduzidos, é importante notar o já mencionado efeito assimilador e uniformizador que a analogia exerce na língua. A criação da forma feminina freira para ser utilizada no lugar de sôror evidencia aquilo que Guérios (1937, p. 49) chamou de "tendência do espírito humano a uniformizar os fatos da linguagem", uma vez que é muito mais fácil e lógico utilizar o mesmo radical da palavra no masculino (freir-), fazendo apenas a flexão do feminino em $-a$.

Como destacado no trecho abaixo, as formas populares da língua também se valem da analogia.

As formas populares duzentão, trezentão, quatrocentão, quinhentão, etc., são analógicas de tostão (do italiano testone). Da expressão latina vade retro, Satanas! fêz-se com acentuação portuguesa vá de retro, salta atrás! O advérbio adúnia (universal, abundantemente), de origem arábica, transformou-se em à unha e depois à cunha: --- "Estava o teatro à cunha" = repleto. Cogote passou a cangote por influxo de canga. $\mathrm{O}$ povo, para dar mais expressão ao superlativo grandíssimo, forjou grandissíssimo (cp. lat. pop. pessimissimus). Até o substantivo é passível de grau: - "Não fêz coisíssima nenhuma". Fenómeno igual ao latim *abissimus ou *abississimus, superlativo de abyssus, abismo. Oculissimus (de oculus), dominissimus (de dominus). (GUÉRIOS, 1937, p.49-50, sublinhados nossos)

Encerrando as considerações sobre as técnicas de análise da história interna da língua, passemos à sintaxe histórica. Como já dissemos, as 30 gramáticas aqui analisadas estão ligadas ao universo escolar e aos programas de ensino. A leitura atenta desses documentos nos mostra que o nível sintático não foi muito privilegiado. Exceção a essa situação ocorreu apenas nos programas de 1912, 1915 e $1916^{71}$ (cf. apêndice B - Quadro 10B). Das 19 gramáticas que consultamos, 9 não apresentam capítulo de sintaxe. Das que abordam esse nível, 6 o fazem de forma bastante sintética, restando apenas 4 que analisam a sintaxe histórica de forma mais aprofundada.

O tópico sintático que recebeu mais atenção nessas gramáticas é a comparação da sintaxe do Português com a do Latim. Vejamos como Horta (s/d, p. 191, negrito do autor e sublinhados nossos) apresenta esse cenário comparativo.

A sintaxe trata, pois, da órdem, da regência, da concordância e das funções das palavras na frase. Sintaxe histórica é a que estuda, em todas as suas modalidades, a evolução da frase, nas diferentes épocas e fases de uma lingua. Pelo estudo de sintaxe histórica da lingua portuguesa, depreende-se que esta tem, mais ou menos, a mesma estructura fraseológica da lingua latina, os mesmos processos de coordenação e subordinação, de regência e concordância, divergindo, no entanto dela, apenas na ordem das palavras, em virtude do desaparecimento dos casos.

\footnotetext{
${ }^{71}$ Os programas destes três anos são idênticos entre si.
} 
Seguindo em sua exposição, Horta compara a importância que a ordem tem para o Latim e o Português. No caso da língua latina, o fato de as desinências determinarem a função sintática das palavras faz como que a ordem não seja algo relevante. Situação diferente ocorre com o Português, pois com o desaparecimento dos casos nas línguas neolatinas, não é mais possível, apenas pela análise isolada da palavra, saber qual papel ela desempenha na frase. Para comprovar essa questão, o autor apresenta o seguinte exemplo.

Para vêr-se, pois, como a ordem dos termos não influía na sintaxe latina, basta o seguinte exemplo: - O homem deu o cão a seu filho - que em português oferece as seguintes modalidades: [i] $O$ homem deu o cão a seu filho; [ii] $O$ homem deu a seu filho o cão; [iii] A seu filho o homem deu o cão; [iv] $O$ homem a seu filho deu o cão. E em latim pode dizer-se de vinte quatro maneiras diferentes na colocação tais como: [i] Homo filio canem dedit; [ii] Homo canem filio dedit; [iii] Filio homo canem dedit; [iv] Filio canem homo dedit; [seguem as outras 20 formas possíveis]. (HORTA, s/d, p.192)

Em seguida, conclui, dizendo que em tais frases latinas não haverá ambiguidade "porque as desinências casuais inerentes ao nominativo, acusativo e dativo, indicam claramente a função lógica de cada uma delas." (HORTA, s/d, p. 192).

Com efeito, o autor destaca que, para as línguas neolatinas, a consequência dessa perda desinencial é a preferência pela ordem direta, ou seja, sujeito/verbo/complementos. Essa mesma consideração pode ser vista em um trecho de Júlio Ribeiro (1845 - 1890) citado por Horta (s/d, p. 193): “A tendência que atualmente apresentam todas as linguas para tornarem-se analíticas é a causa da preferência que cada vez mais tem a construção direita sobre a inversa".

Vejamos mais um tópico de comparação entre a sintaxe latina e a portuguesa, desta vez relativo à regência. Horta (s/d, p. 211, sublinhados nossos) diz que a "regência é a relação de dependência que tem as palavras, umas com as outras. No latim a regência era feita por meio das desinências casuais. Com a obliteração dos casos nas linguas novi-latinas, a regência passou a ser exercida pelas preposições". Na sequência, o autor mostra como se deu esse processo nos casos dativo, genitivo, ablativo e acusativo. Para que dimensionemos a técnica envolvida nessas análises, falaremos apenas do dativo e do genitivo.

O dativo latino foi substituido ou pela preposição a ou pela preposição para, antiga pera, conservando-se excepcionalmente nos pronomes oblíquos átonos me, te, se, lhe, nos, vos, lhes, sem preposição ou nas formas tônicas, mim, ti, si, êle, êles, éla, élas, nós, vós precedidos de preposição. No português antigo, empregava-se representando nome plural, ex.: "Deixam dos sete céus o regimento que do poder mais alto LHE foi dado, por lhes foi dado (Camões). O genitivo foi geralmente substituido pela preposição de." (HORTA, s/d, p.211, sublinhados nossos) 
Quanto ao ablativo e ao acusativo, a análise é feita da mesma forma, ou seja, dizendo como era no Latim e como é atualmente no Português (no caso do acusativo, o autor também analisa esse processo em outros períodos do Português, como o quinhentista, por exemplo). Com efeito, ao analisarmos como outros temas sintáticos eram analisados, nos parece que a principal técnica envolvida era a da simples comparação do antes (Latim) e do agora (Português). Isso pode ser verificado no capítulo subsequente ao de regência, que é o de concordância verbal e nominal. Também encontramos o mesmo procedimento no estudo da "sintaxe histórica das palavras variáveis e invariáveis", outro tópico presente nos já mencionados programas de ensino de 1912, 1915 e 1916. Vamos utilizar, como exemplo, o estudo de uma das classes, o substantivo.

O SUBSTANTIVO desempenha, na phrase portugueza, o mesmo papel que no

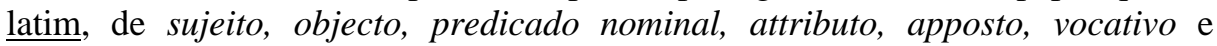
complemento. Porém, em relação á ultima funcção, foi o seu emprego ampliado em portuguez. Certas ideas que o latim preferia expressar por adjectivos derivados de substantivos, o portuguez prefere expressá-las por substantivos regidos de preposição, p. ex.: Dies festus = dia de festa, - pugna cannens $=$ batalha de Cannes.lac asininum = leite de jumenta. $\mathrm{O}$ papel ou a funç̧ão syntactica do substantivo era, na phrase latina, indicado pelas desinencias casuaes; com a perda, porém, dos casos, teve o portuguez de recorrer, para esse fim a outros processos, entre os quaes avulta a posição e a preposição. (PEREIRA, 1916, p. 359, itálicos do autor e sublinhados nossos)

Diferentemente do que ocorre no estudo da fonética histórica, no caso da sintaxe, o rigor analítico parece ser bem menor. No trecho selecionado, isso pode ser visto, inclusive, pela escolha lexical, quando o autor diz que "certas ideias o Latim preferia expressar por adjetivos". O que significa, em termos linguísticos, a preferência de uma língua? É possível perceber que a opção por esse termo vem justamente da técnica de análise utilizada para se estudar a sintaxe histórica, que é estruturada mais na comparação entre as formas latinas e as portuguesas, realizando, na sequência, uma espécie de "antes e depois", do que na obtenção de um modelo explicativo para as mudanças percebidas. Por outro lado, a fonética histórica, ao estabelecer as leis fonéticas, consegue chegar a explicações para a mudança histórica que vão além do "antes se pronunciava assim" e "agora a pronúncia é essa". Ilari $(1999$, p. 22) lembra que a eficácia do método comparativo não é homogênea, já que "o campo em que o método comparativo deu os resultados mais sistemáticos é o da fonética; em morfologia e em sintaxe, sua aplicação exige a manipulação de dados mais complexos, e seus resultados foram menos espetaculares”.

Relativamente aos estudos de sintaxe, temos ainda a analogia. É importante lembrar que muitos autores apresentam os processos analógicos relativos à fonética, morfologia e sintaxe em capítulo à parte, porém julgamos mais adequado aos nossos objetivos realizar a apresentação das 
técnicas linguísticas separando-as nesses três níveis de análise da língua. Vejamos, portanto, a última que nos falta analisar, a sintática.

\begin{abstract}
Embora na sintaxe os efeitos da analogia se sintam menos, contudo êles existem em regular número. Foi a analogia que, visando à clareza, submeteu o discurso a uma ordem mais analítica, multiplicou o uso das preposições, formulou regras para o emprêgo dos advérbios, etc. A leitura de obras estrangeiras, sobretudo francesas, a que se entregam quasi exclusivamente alguns de nossos literatos, é causa freqüente das expressões ou construções viciosas, que se encontram em seus escritos, o que é ainda um resultado da analogia. É na regência que ocorrem os casos mais comuns de analogia sintática. Os verbos transitivos diretos são, em quantidade muito maior, que os indiretos. Isso justifica a tendência que manifesta o povo para considerar transitivos diretos muitos verbos que o não são. Nêste rol, estão presidir, assistir, perdoar, responder, mirar, etc. (COUTINHO, 1938, p. 270, sublinhados nossos)
\end{abstract}

O menor rigor nas análises de sintaxe histórica a que nos referimos anteriormente parece se repetir no exemplo acima. $\mathrm{Na}$ ausência de ferramentas mais refinadas para explicar os casos de analogia, Coutinho recorre a argumentos normativos, bastante frequentes nas gramáticas tradicionais. Para o autor, a leitura de obras literárias francesas pelos autores brasileiros fez com esses adotassem galicismos sintáticos, que são por ele classificados como construções viciosas. A ausência de explicações históricas e um viés mais normativo nas análises também pode ser visto na gramática histórica de outro autor.

Fatos devidos à analogia (aspecto sintático). - Porque se diz ao passo que e outras locuções conjuntivas acompanhadas de que, é comum a expressão analógica em quanto que, em vez de em quanto (ou enquanto). Vejo-lhe, cumprimento-lhe, conheço-lhe, etc., expressões tôdas erradas e condenadas, estão baseadas nas corretas falo-lhe, agradeço-lhe, etc. Apoiado numa expressão, como - "Apesar do tempo mau ela veio" - formou-se erradamente - "Apesar do tempo ser mau, ela veio," - em vez de "apesar de o tempo ser mau,..." porque a locução prepositiva está regendo o infinito e não o substantivo, como no primeiro caso. O segundo exemplo é o mesmo que - "apesar de ser o tempo mau, ela veio." (GUERIOS, 1937, p. 50, sublinhados nossos)

Com esse tópico, encerramos as análises relativas à história interna de língua, passando, então, à verificação de como era estudada a história externa. Presente em praticamente todos os programas de ensino, tal estudo aparece nas gramáticas sob os títulos de "origem da Língua Portuguesa" ou "História do Português".

Na história externa, basicamente são estudados elementos da história social e política significativos na constituição de uma determinada língua. Assim, fatos históricos como invasões territoriais e o consequente domínio de um povo frente a outro são questões relevantes a serem investigadas. Um exemplo bastante eloquente desse processo foi a influência do Latim nas várias línguas da Europa Ocidental em função da grande expansão militar-territorial realizada pelo Império Romano. Tal expansão produziu também impactos de ordem linguística, já que as 
línguas faladas nos territórios invadidos eram influenciadas pela língua do invasor, isto é, o Latim.

Sabemos que as línguas neolatinas surgiram desse contato, mas para estudá-las de forma mais ampla é necessário ir além da história interna, investigando também aspectos históricossociais desses povos, já que eles influenciam diretamente na língua. Vejamos um exemplo desse impacto:

O território ocupado pelos Romanos, chamava-se România e compunha-se de várias províncias: Hispânia, Gália, Dácia, Italia, etc. Até o V. ${ }^{\circ}$ século depois de Cristo houve unidade no mundo romano, pois Roma era o centro donde se irradiava a cultura e donde emanavam as ordens. Roma era o coração do Império. [...] $\underline{A}$ partir, porém, daquela data, esmagados os Romanos pelas invasões dos Bárbaros, perdida a unidade nacional, cada província passou a ter evolução à parte. Por essa razão a língua foi-se a pouco e pouco diversificando, a ponto de revestir hoje as várias formas a que chamamos línguas românicas. Assim o francês é a continuação do latim outrora falado no norte da Gália, o romeno é a continuação do latim outrora falado na Dácia, o português o é do latim falado antigamente na Lusitânia, região a oeste da Península Ibérica. Com muita razão podemos dizer, portanto, que as línguas neo-latinas são fases atuais do latim. (SILVA NETO, 1942, p.18, sublinhados nossos)

Como pôde ser visto no trecho acima, o surgimento das línguas românicas tem explicação a partir de um evento histórico: a derrocada do Império Romano pelos bárbaros. Com isso, a forte coesão e unidade existente no mundo romano desaparece, abrindo espaço para a diversificação linguística na România, denominação dada ao conjunto de regiões comandado por Roma. Como destacou Silva Neto, o Latim que se falava na região da Lusitânia originou o Português, bem como o Francês foi originado pelo Latim falado na Gália e assim sucessivamente para outras regiões do antigo império.

Por fim, vejamos mais um exemplo a respeito da importância de se estudar aspectos históricos e sociais para a melhor compreensão de uma determinada língua. Em boa parte das 30 gramáticas históricas aqui analisadas, há uma seção dedicada a se estudar o dialeto brasileiro. Para que tal ação seja realizada a contento, não é possível deixar de se considerar dois capítulos da história brasileira: o processo de colonização, especificamente quanto ao contato dos portugueses com os povos indígenas e a escravidão. Recorremos a eles para compreender algumas diferenças existentes entre o Português falado em Portugal e o falado no Brasil ou, nos termos dessas gramáticas, do dialeto brasileiro. Assim, algumas diferenças entres essas duas variedades do Português podem ser explicadas em função desses países possuírem processos históricos distintos entre si. 


\subsubsection{Camada documental}

Já dissemos algumas vezes, o objetivo principal das gramáticas históricas é estudar "a origem e o desenvolvimento das línguas, através de leis/princípios que expliquem os estágios evolutivos pelos quais passaram as línguas, desde sua origem até o presente”. Para cumprir tais objetivos, a Gramática Histórico-Comparada necessita do maior número possível de documentação linguística, já que só assim ela consegue colocar em prática suas principais ferramentas analíticas, isto é, comparação entre textos de diferentes línguas e o estabelecimento de uma cronologia entre textos de uma mesma língua.

Dessa forma, nenhum tipo de texto pode ser desprezado pela Gramática HistóricoComparada, já que todos são documentos responsáveis por comprovar um determinado estágio da língua. No entanto, muitas vezes o pesquisador é forçado a trabalhar com menos textos do que gostaria dada a inacessibilidade às fontes documentais. De épocas mais antigas, o gênero textual que mais se preservou ao longo do tempo parece ser o literário, o que explica a frequente presença desses textos nas gramáticas históricas.

Nas seções 2.1.2 e 2.3.1.2, vimos a grande relevância que têm os textos literários para as obras inseridas no programa gramatical, dado que eles servem de referencial para se estabelecer o bom uso da língua, aspecto central desse programa. Como já dissemos, esse não é o objetivo das obras ligadas ao programa filológico, embora se valham, muitas vezes, do mesmo tipo de texto.

Um exemplo do uso do texto literário em uma gramática histórica pode ser visto quando Silveira (1934, p.105-106, itálicos do autor e grifos nossos) analisa a "filiação latina do Português", mostrando as semelhanças em diferentes níveis.

Do comércio constante com as letras clássicas, sob a idéia da filiação latina da nossa língua, deveria resultar, como resultou, o aparecimento nela de inúmeros latinismos: gráficos, complicando a escrita mais singela dos primeiros tempos; fonéticos, aproximando formas populares, muito alteradas, das formas clássicas conhecidas; morfológicos, com a adoção de sufixos, prefixos e radicais da língua mãe; sintáticos, com a transplantação para vernáculo de construções latinas não usadas em português, e, finalmente, léxicos, constituídos pela introdução de muitos dos vocábulos denominados eruditos ou literários. Não será fácil, com os estudos até hoje feitos, discriminar com segurança os latinismos, e mesmo alguns grecismos, apadrinhados naquela época, dos que, por ventura, já o tinham sido antes. Contudo, parecem devidas à influência clássica reinante naquele tempo estas, e outras semelhantes, expressões e dizeres: 
Na sequência, Silveira (1934, p.106, itálicos do autor e grifos nossos) exemplifica essa ligação do Português ao Latim com trechos extraídos de Virgílio, Camões e Antônio Ferreira. Vejamos inicialmente exemplos nos níveis lexical e morfológico.

a) coroado as frontes paralela à maneira latina, imitada do grego, nuda genu (VERGÍLIO, Eneida, I, 324) (= com os joelhos nus, ou nus os joelhos):

"Vem Maio de mil ervas, de mil flores

As frontes coroado, e riso, e canto,

Com Vênus, com Cupido, cos Amores."

(ANTONIO FERREIRA, Poemas Lus., I, 153).

b) $\underline{\mathrm{O} \text { imperfeito do subjuntivo usado como condicional: }}$

"O' ditosa cigarra, se tu amasses,

Eu sei que nem dormisses nem cantasses."

285).

(ANTONIO FERREIRA, Obras, ed. Fernandes Pinheiro, 1895, I,

"S'esta minh'alma triste perguntasses,

Sampaio, de que vive, ou em que espera?

Sei que de seus desejos só chorasses."

(IDEM, ibid., II, 72).

É possível observar que o uso desses textos não tem como objetivo prescrever uma determinada norma subjetiva, procedimento caro à gramática tradicional, mas sim comprovar, através de textos de diferentes épocas, a conexão entre o Latim e o Português. Para tal tarefa, o autor recorre à Eneida, do poeta romano Virgílio (70 a.C - 19 a.C) e a três poemas do português Antonio Ferreira (1528- 1569).

$\mathrm{O}$ contraste entre esses diferentes textos serve para mostrar o paralelo existente entre a expressão portuguesa coroado as frontes e a latina nuda genu, além de identificar a influência latina no Português quando se utiliza o imperfeito do subjuntivo com valor de condicional. Quanto ao nível sintático, a influência entre essas duas línguas é exemplificada da seguinte forma:

d) "espingardas de aço puras" (Lus., I, 67) por "espingardas de aço puro", "reino Melinde" (Lus., II, 73) em vez de "reino de Melinde", "lusitânicas fadigas, que eu favoreço", (Lus., IX, 38) equivalente a "fadigas dos lusitanos, os quais eu favoreço", expressões todas que se explicam pela imitação de construções latinas semelhantes (v. os comentários de Epifânio aos lugares indicados dos Lusíadas, e Sousa da Silveira, Trechos Seletos, pág. 325). (SILVEIRA, 1934, p.106, itálicos do autor e grifos nossos) 
Além dos textos em Latim Clássico e dos escritos nas línguas neolatinas, a Gramática Histórico-Comparada também se utiliza dos escassos registros do Latim Vulgar, que vêm de três diferentes fontes: "as inscrições, o Appendix Probi e a Peregrinatio ad loca sancta." (SILVA NETO, 1942, p.18). Segundo o autor,

as inscrições são frases gravadas em vários lugares por pessoas incultas que deixavam resvalar particularidades da fala corrente. O Appendix Probi é uma espécie de Dicionário do latim usual, pois consiste numa lista de 227 palavras da fala quotidiana, tendo ao lado as formas literárias:

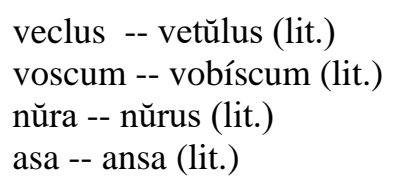

A Peregrinatio ad loca sancta [Peregrinação aos lugares santos] é a relação que ũa monja inculta faz de sua viajem à Terra Santa. Nela ressumbram muitos fatos da língua corrente.

\subsection{Obras de temas filológicos específicos}

Nos capítulos 2 e 3, separamos, em grupos diferentes, as gramáticas completas e as obras de temas gramaticais específicos (cf. 2.3 .2 e 3.2), que são, com efeito, publicações responsáveis por abordar um ou mais tópicos gramaticais específicos. Lá dissemos, que essas obras podem ser vistas como verdadeiras separatas de uma gramática completa, pois ali são desenvolvidos tópicos gramaticais que foram selecionados para receber maior aprofundamento teórico e/ou prático.

É exatamente esse mesmo processo de complementariedade e aprofundamento que ocorre entre as gramáticas históricas e as obras de temas filológicos específicos. Tanto no programa gramatical quanto no filológico, a abundância de obras com esse viés monográfico parece indicar uma maior especialização dos estudos linguísticos no Brasil, já que em um livro dedicado a um ou dois temas é possível alcançar um nível de aprofundamento muito difícil de se realizar em uma gramática completa, dada a limitação de espaço que esse tipo de compêndio tem.

Quantitativamente, é possível dimensionar a relevância desses materiais para os estudos do Português, no início do século XX: são 51 obras de temas específicos (cf. apêndice B - Quadro 
9B), frente a 30 gramáticas históricas. Em relação a esses dois grupos, é importante dizer que ao passo que todas as gramáticas históricas são ligadas ao universo escolar, nenhuma das 51 obras específicas têm esse vínculo. Todas elas são obras destinadas aos especialistas da área, aos pares. Dissemos, na seção anterior, que a Gramática Histórico-Comparada era considerada, entre meados do século XIX e início do XX, uma disciplina científica, área em que se desenvolviam estudos avançados na área linguística. Assim, parece haver aqui uma divisão de trabalho: as obras específicas ficaram reservadas aos estudos e discussões destinados aos especialistas, aos pares, e as gramáticas históricas tiveram a incumbência de suprir o ensino secundário com aquilo que havia de moderno, avançado nos estudos sobre as línguas, no caso em análise, sobre o Português. Dissemos também que os estudos de viés histórico apareciam nos programas de ensino, entre 1900 e 1940, de forma distinta em quantidade de tópicos abordados e em profundidade. A despeito dessa variação, nos parece que a presença da gramática histórica nos currículos do Secundário, onde predominava o estudo da gramática tradicional, era uma forma de garantir que os alunos secundaristas tivessem acesso, mesmo que facilitado, ao que havia de mais moderno em ciência linguística.

Finalmente, investigamos os temas mais frequentes nestas 51 obras específicas e o resultado apresentamos na tabela a seguir. Tal levantamento é importante, uma vez que nos mostra quais eram os temas filológicos do Português que os estudiosos do início do século XX julgavam merecedores de maior aprofundamento.

Tabela 17 - Principais temas das obras de temas filológicos específicos

\begin{tabular}{|l|l|}
\hline Etimologia das palavras & $\begin{array}{l}22 \text { obras, dentre as quais 7 são de estudos } \\
\text { antroponímicos (1) e toponímicos (6). }\end{array}$ \\
\hline $\begin{array}{l}\text { Coletâneas de temas históricos: obras que } \\
\text { reúnem vários temas de gramática } \\
\text { histórica. Essas obras, geralmente, } \\
\text { apresentam títulos genéricos, como: } \\
\begin{array}{l}\text { Estudos de filologia portuguêsa, } \\
\text { Palestras philologicas, Horas } \\
\text { philologicas, etc. }\end{array}\end{array}$ & \\
\hline $\begin{array}{l}\text { "Evolução do Português"/ Formação das } \\
\text { palavras }\end{array}$ & 10 obras \\
\hline
\end{tabular}




\begin{tabular}{|l|l|}
\hline $\begin{array}{l}\text { Demais temas (aqui entram os temas que } \\
\text { tiveram apenas } 1 \text { obra dedicada à sua } \\
\text { análise). }\end{array}$ & \\
\hline TOTAL: & $\mathbf{5 1}$ obras \\
\hline
\end{tabular}

\subsubsection{Camada teórica}

Dada a ligação dessas obras específicas com a Gramática Histórico-Comparada, não há diferenças teóricas relevantes entre tais obras e as gramáticas históricas analisadas na seção anterior (cf. 4.2). Dessa forma, as considerações que fizemos relativamente à camada teórica, no item 4.2.1, são também aplicáveis às 51 obras presentes nesta seção. Não as repetiremos em benefício do espaço.

\subsubsection{Camada técnica}

Quanto à camada técnica, podemos dizer que há a mesma equivalência apontada na camada teórica. No item 4.2.1, fizemos uma ampla exposição das técnicas utilizadas pelas gramáticas históricas e, com efeito, as obras de temas filológicos específicos também lançam mão dessas mesmas técnicas. Assim, uma obra que estuda a etimologia do Português ou outra que analisa a evolução fonética do Português farão uso, basicamente, das mesmas ferramentas que apresentamos na seção destinada às gramáticas históricas, já que todas estão submetidas ao mesmo modelo teórico, ou seja, à Gramática Histórico-Comparada.

Em função dessa ligação, não repetiremos aqui todas as exposições e análises já feitas na referida seção. Optamos, no entanto, por apresentar uma pequena amostra destas 51 obras específicas, seguindo os seguintes objetivos: (i) antecipar as análises relativas à camada documental (próximo item), investigando a diversidade de línguas requisitada pelos filólogos 
para mostrar as influências que tiveram na formação do Português e (ii) comprovar a referida semelhança dessas obras com as gramáticas históricas.

Começaremos pelo tema mais frequente, ou seja, a etimologia. Nas 22 obras que tratam desse tema, a formação histórica das palavras do Português é estudada a partir das influências das seguintes línguas: Greco; Latim; Tupi (e outras línguas indígenas, como o Quéchua, por exemplo); Árabe; Persa e o Turco. Quanto às línguas indígenas, a investigação é feita, principalmente, através de estudos toponímicos. Vejamos, então, exemplos de análises relacionando a influência de cada uma dessas línguas, começando pelo Grego.

O Dicionário etimológico da Língua Portuguêsa, de Antenor Nascentes (1886-1972), faz um amplo estudo etimológico do Português. É dessa obra que extraímos um verbete em que a origem da palavra em análise é grega.

IDOLO - Do gr. eidolon, imagem, simulacro, pelo lat. idolu. Sôbre a alteração da acentuação latina, v. Diez, Gram. I, 468, M. Lübke, Gram., I, 36, Lindsay, The Latin Language, 150, Seelmann, Aussprache des Latein, 48, Macé, La prononciation du latin, 26, Sommer, Handbuch der lateinischen Laut-und Formenlehre, 143. A forma idolum se encontra em Prudêncio. Trata-se de um vocábulo erudito que, ou pôde conservar a prosódia grega, ou sofreu influência das palavras que têm o sufixo ulu. (NASCENTES, 1955[1932], p.271)

É possível notar que o autor traça o percurso histórico da palavra portuguesa ídolo, de sua origem até chegar ao Português. Indica que sua origem é o termo grego eidolon, que em Latim clássico evoluiu para idolum, mantendo, nesse caso, a mesma acentuação da palavra em Grego. Ídolo, no entanto, vem da forma latina idolu, que possuía outra acentuação, era proparoxítona e não paroxítona como na forma clássica. Ramiz Galvão (1846 - 1938), publica um dicionário específico de palavras portuguesas de origem grega, chamado Vocabulario etymologico orthographico e prosodico das palavras portuguesas derivadas da língua grega. Nele, embora de maneira mais sintética, ele faz a descrição do mesmo processo relativamente à palavra ídolo.

Idolo, s.m. figura, imagem representativa de alguma divindade e que é objecto de culto. // De $\varepsilon i ̈ \delta \omega \lambda o v$.

N. O uso sanccionou a accentuação na syll. antepenultima, posto que a quantidade etymologica exigisse o accento tonico na penultima. (GALVÃO, 1909, p. 347)

Considerando o fato de o Português ser uma língua neolatina, é natural que uma grande quantidade de obras deste grupo analise historicamente o processo de formação lexical dessa língua a partir das influências do Latim. 
Já dissemos aqui que as obras de temas filológicos específicos constituíram espaços mais amplos para que houvesse um maior aprofundamento dos temas que ali estavam sendo estudados. Para ilustrar essa característica e também apresentar uma análise relativa à influência do Latim no Português, selecionamos Filologia jurídica, de João Henrique dos Santos (1884 -1952). Nessa obra, são estudados 20 termos jurídicos, sendo cada termo um capítulo do livro. Com essa estruturação, foi possível ao autor realizar um estudo bastante detido e extenso de cada palavra. Quanto ao termo selecionado, após apresentar as primeiras informações, o autor segue, ao longo de seis páginas e meia, estudando um a um os elementos mórficos constitutivos da palavra (tri, tribu, tribun e $a l)$.

TRIBUNAL: A lingua latina, tão rica e harmoniosa em seu vocabulário, tinha o substantivo tribunal, pertencente á classe dos nomes imparissilábicos, neutros (temas consonantais). De aí proveio diretamente a palavra portuguêsa tribunal. Etimologicamente este vocábulo é constituido de varios elementos morfológicos: tres que originou o termo tribus; deste formou-se tribunus e de tribunos, com acrescimo do sufixo al, apareceu tribunal. (SANTOS, 1934, p.33)

Este início do capítulo, mais sintético, poderia facilmente ser encontrado em uma gramática histórica, mas, depois desta introdução, o autor analisa a palavra tribunal ao longo de seis páginas e meia, o que dificilmente ocorreria em uma gramática, dada a limitação de espaço que esses materiais têm. Com efeito, a obra toda tem 114 páginas, utilizadas para o estudo de apenas 20 palavras.

Para que melhor se dimensione o estudo desenvolvido pelo autor, reproduzimos abaixo pequenos trechos, em que cada elemento mórfico da palavra é estudado.

TRI: O sanscrito, donde procedem as linguas indo-europeias de que a nossa é um ramo, tinha o numero tri. De lá passou para o grego tria (neutro) e dali para o latim, tambem com a mesma forma e genero tria. O radical deste cardinal é tri que se mantém nos casos neutros e nos vocábulos dêle compostos: tri-angulo, tri-dente, tri-partido, tri-forme, tri-tono, etc. (...)

TRIBU: Nos prístinos tempos de Roma toda a sua população estava dividida em três partes chamadas por esse motivo tribus, ager romanus primum dicere in parteis tris, como diz Varrão. A propria etimologia da palavra tribu (conf. tribuere) dá a idea de divisão tri partida. Os nomes dessas três primeiras tribus ou circuscrições eram, como já dissemos, Tacienses, Ramnenses e Luceros, nomes esses tirados repectivamente de seus troncos geneológicos: Tacio, Rómulo e Lucumon. (...)

TRIBUN: Na primitiva Roma a principal autoridade da tribu, com poder quasi igual ao do "pater familias," tinha o nome de tribuno. Nem outra significação etimológica tem este vocábulo (tribus, unus), "um" que está á frente da "tribu". Daí, para manter-se a tradição primeva, é que aos chefes ou magistrados maiores da plebe se deu o nome de tribunos. (...) 
AL: O sufixo al que passou para o português em al é sufixo nominal latino e servia para formar substantivos geralmente neutros (animal), designando também lugar onde ha reunião (pinhal, laranjal, cafezal... tribunal). (...) (SANTOS, 1934, p.3336)

É possível notar o uso do método histórico-comparativo logo no início do estudo do elemento tri, momento em que o autor aponta a existência desse elemento em Sânscrito (tri, usado como numeral), sublinhando ser essa uma língua indo-europeia, tal como o Português o é. Depois, marcando a historicidade dessa partícula, destaca que é da forma sânscrita que o Grego forma a sua tria (neutro), passando para o Latim também como tria (mesmo gênero também).

Encontramos ainda trabalhos com o mesmo viés do feito por Santos, mas aplicado a outras áreas do conhecimento. Para a área da saúde, principalmente para a Medicina, há o livro Vocábulos médicos e de outra natureza, de P. A. Pinto (1882-1971), de 1944. Já para a Biologia, encontramos a obra Biologia e linguística, de Afrânio do Amaral (1882-1971), publicado em 1945.

Além do papel que teve o Latim e o Grego na formação do Português, há obras que mostram as influências vindas de línguas orientais, como o Árabe, Persa e Turco. Para esses casos, tomemos como exemplo o livro Influências orientais na Língua Portuguesa: os vocábulos árabes, arabizados, persas e turcos - tomo I / etimologia aplicações analíticas - primeira parte, de Miguel Nimer (1895 - ?), publicada em 1943. Nessa obra, o autor organiza os verbetes da seguinte forma: inicialmente, apresenta o vocábulo de entrada e seus cognatos, sempre abonados por dicionários, vocabulários ou glossários do Português, para, depois, introduzir a explicação etimológica. Vejamos um exemplo de verbete organizado dessa forma.

\section{N. ${ }^{\circ}$ 6. - ALMAZEM - ARMAZEM}

ALMAZEM. m. "(Forma popular) e mais exata que armazem ... Cf. Etiópia Or., II 323; Carta de Guia dos Casados, 21; Peregrinação, LXXXVIII; Livro das Monções, n. ${ }^{\circ}$ 13. (Cp. cast. almacen)" $\mathrm{CDF}^{72}$ - ARMAZEM. m. "Depósito de mercadorias. Depósito de fornecimentos para a guerra. Taberna. Mercearia. $\mathrm{Pl}$. ARMAZENS GERAIS, serviços dos caminhos de ferro, que se reduzem a comprar, conservar e distribuir pelos outros serviços os materiais e outros objetos necessários". CDF; -- ARMAZENAR, v. t. "Pôr em armazem. Depositar. Conservar. Reunir". CDF; - ARMAZENAGEM, f. "Ação de armazenar. Aquilo que se paga pelo depósito de mercadorias em alfândegas, e noutras estações de despacho". CDF; ARMAZENÁRIO, m. bras. de Pernambuco. "Negociante que toma de arrendamento grandes armazens, onde deposita açucar que compra para revender ou exportar". CDF'; - ARMAZENISTA, m. bras. "Fiel de armazem. Encarregado de armazem" CDF. (NIMER, 1943, p. 4-5)

\footnotetext{
${ }^{72}$ CDF: Novo dicionário de Língua Portuguesa, de Cândido de Figueiredo.
} 
Em um primeiro momento, o autor contextualiza o uso termo no Português, indicando obras em que ele aparece (Carta de Guia dos Casados, por exemplo), usos específicos da palavra no Brasil (armazenista) e também em regiões específicas, como em Pernambuco (armazenário). Há ainda referências ao termo em Espanhol (almacen) e a observação de que a forma preferencial é almazem e não armazem. O autor não apresenta o motivo de tal preferência, mas julgamos que possa ser em função da formação da palavra almazem, que é a junção do artigo árabe al mais o radical makzan. Isso pode ser visto na parte etimológica do verbete, que vem logo na sequência:

Cp. [compare] árabe clássico. 'almakzan, composto de 'al- art., e de -makzan: "Lugar onde se conservam, depositam objetos, donde makzan de mercadorias entre os comerciantes" < kàzàna, v.t. "Guardar com cuidado, entesourar; acumular (dinheiro) num cofre, kazana o segredo, v. t. Guardar, ocultar" <* kzn. $\mathrm{ODO}^{73}$. subst. (deriv.), masc. sing.- semantema - kz-n; - morf, 'alma -a-; - tipo maftal, com 'al-. -Sobrevivência. (NIMER, 1943, p. 4-5)

Quanto às notações utilizadas pelo autor, é necessário fazer algumas observações. O asterisco (*), diferentemente do que ocorre na maioria das obras ligadas ao programa filológico, não representa forma hipotética reconstruída, mas "quer dizer raiz: elemento irredutivel, que se obtem pela eliminação de todas as formas secundárias e serve para orientar as buscas nos léxicos árabes, ou nas outras línguas, ditas semíticas. (NIMER, 1943, p. LV)”. Os demais símbolos indicam derivações tendo a raiz como ponto de chegada ou de saída. Tal procedimento também aponta para um estudo de tipo histórico.

< - Indica o étimo do étimo. No caso dos substantivos derivados, marca as sucessivas fases do processo de derivação até chegar à raiz. Interpreta-se por: derivado de.

$>$ - Aponta o vocábulo derivado e, no caso de processo de derivação, marca as sucessivas fases, tendo a raiz como ponto de partida. Interpreta-se por: de que se deriva. (NIMER, 1943, p. LV)

Quantos aos verbetes que analisam a influência do Turco e do Persa no Português, todos seguem a mesma estrutura e técnica que apresentamos quanto ao Árabe. Em função disso e em benefício do espaço, optamos por não reproduzir os verbetes envolvendo tais línguas. Passaremos, assim, para um outro conjunto de obras, que é aquele que reúne as toponímias. Nelas, o foco está nas relações entre o Tupi ou outras línguas indígenas e o Português. Em tais obras, ou há um tratamento geral dessa influência, ou há estudos toponímicos de alguns estados, como Rio de Janeiro ou Pernambuco.

\footnotetext{
${ }^{73}$ ODO: Léxico árabe, de Bustáni.
} 
Selecionamos um exemplo para ilustrar o processo que aqui mencionamos. Theodoro Sampaio (1855-1937) publicou, em 1901, O Tupi na geographia nacional, obra de destaque no início do século XX. Apresentaremos, inicialmente, um trecho em que o autor destaca como o assunto da obra permanece relevante, porém ressalta que ele, diferentemente do que já se fez, imprimirá um inédito rigor linguístico à matéria que será estudada.

Não é novo, antes, pelo contrario muito frequentemente debatido é o objecto do presente estudo. Sobra-lhe, porém, interesse historico, exalça-o notavelmente o valor, que assume na geographia nacional e, sobretudo, o recommenda a attenção sympathica que sempre logrou despertar no nosso meio litterario. Encarando-o agóra por uma face nova, outro não é o nosso intuito, aliás despretencioso e modesto, que não o de methodisar, ou submetter a regras esse estudo linguistico que por ahi anda ao belprazer das phantasias de uns e ao desazo dos que menos familiarisados com a lingua dos primitivos habitadores desta terra a deturpam e desfeiam, attribuindo-lhe aos vocabulos sentido e significados absurdos ou procurando interpretar aquelles já adulterados ou assimilados pela dicção vulgar por processos extranhos ás leis gottologicas (sic) que regem a materia. (SAMPAIO, 1901, p.3, sublinhados nossos)

Como pode ser visto, Sampaio critica a forma como os estudos toponímicos eram feitos até então e se coloca como um estudioso que segue as leis glóticas. Com efeito, é importante entendermos o era a Glotologia (ou a Linguística, nomenclatura preferida por alguns autores ${ }^{74}$ ). Tais termos eram utilizados para classificar a disciplina surgida, no século XIX, a partir dos estudos do indo-europeu, que, como já dissemos no início deste capítulo (cf. seção 4.1), utilizava o método histórico-comparativo. Assim se manifestando, Sampaio faz questão de destacar que é um seguidor das novas doutrinas linguísticas. Esse vínculo com a Linguística HistóricoComparada fica evidente no trecho a seguir, quando Sampaio (1901, p.88-89, sublinhados nossos) diz que seus estudos não são de orientação lexicológica, mas sim de viés histórico.

O estudo etymologico dos nomes tupis com applicação na geographia ou na historia nacional é, a meu vér, um trabalho mais de investigação historica do que propriamente de lexicologia. Sendo o tupi, como é, uma lingua agglutinante, com os elementos componentes quasi integraes, ou mui raramente contractos, a palavra, nesse idioma, com facilidade se analysa; e ainda quando mettida numa como que ente capsulação em que os varios elementos se envolvem uns aos outros, as linhas de separação destes não desapparecem totalmente, e a desaggregação desses

\footnotetext{
74 “Glotologia é a ciência que estuda a origem e o de desenvolvimento da linguagem. Esta denominação é italiana. Os franceses preferem o têrmo Lingüística. Glótica é criação alemã. Acha Adolfo Coelho que todos estes têrmos estão suficientemente consagrados. Estudando a linguagem, a Glotologia a encara sob o aspecto fisiológico e psicológico. Assim, é privativo desta ciência o estudo dos sons da voz humana, da origem da linguagem, do seu desenvolvimento sucessivo, dos fenômenos gerais que as línguas apresentam, da classificação das línguas, etc. A Glotologia estuda uma ou mais línguas, sem outra finalidade que não seja o seu conhecimento. Para ela, tanto monta aplicar-se a um idioma bárbaro, sem monumentos literários, como a outro que tenha rica literatura. São auxiliares da ciência da linguagem a Arqueologia, a Mitologia, a História, a Etnologia, etc.” (COUTINHO, 1938, p.16, itálicos do autor e sublinhados nossos) (Cf. também Apêndice B - Quadro12B)
} 
elementos habilita o interpretador a traduzir. O problema mais importante, o estudo mais serio, e a meu ver essencial, é o da identificação historica do vocabulo ou a restauração da sua graphia primitiva, tal como ella symbolicamente representou em outro tempo a palavra falada. [...] Conseguida a restauração historica do vocabulo, facil será explicar como elle se alterou ou como evoluio até nós, porque invariaveis e positivas são as leis phylologicas que regem a especie.

Vejamos agora, em alguns verbetes, como o autor coloca em prática os métodos a que fez referência.

Morumbi. merú-õby, a mosca verde, a varejeira; marã-mbi, lucta ou peleja oculta, guerra de emboscada, cilada; 127. Paçoca. corrupção de pó-çoca, esmigalhar á mão, desfiar, pilar ou machucar com a mão, 119. Pampa. vocabulo kechua que se traduz - campo, planice limpa; corresponde a nhû do tupi; alt. bamba. Pacaembú. corrupção de Paca-embú. arroio das pacas; S. Paulo; 102. S. Paulo. V. yembó. (SAMPAIO, 1901, sublinhado nosso, p.141;143)

No verbete da palavra pampa, é possível verificar a influência, no Português, de outras línguas indígenas além do Tupi. Esse termo é de origem quéchua, sendo utilizado no lugar do equivalente tupi $n h \hat{u}$. Os números no final do verbete indicam uma característica da obra de Sampaio: a divisão em duas partes, cada uma responsável por diferentes abordagens linguísticas. $\mathrm{Na}$ primeira, encontramos os seguintes tipos de estudos: (i) história externa, fornecendo informações mais amplas a respeito dos termos em análise, correlacionando-os a questões históricas, folclóricas, antropológicas, geográficas etc e (ii) discussões teórico-metodológicas a respeito das opções feitas pelo autor na elaboração da obra. Com efeito, nos verbetes, é mais frequente o primeiro tipo de discussão (i).

A segunda parte da obra é o dicionário propriamente dito, ou seja, é o espaço dedicado à história interna dos vocábulos. Voltando aos números, são eles os responsáveis por estabelecer a conexão entre essas duas partes, já que estão presentes tanto nos verbetes do dicionário quanto nos textos relativos à primeira parte do livro.

Mais do que uma simples descrição de como Theodoro Sampaio (1855-1937) organizou seu trabalho, apontar para tais características é importante, pois muito nos fala a respeito da forma de se analisar os dados linguísticos, ou seja, da camada técnica, utilizada também em obras toponímicas de outros autores.

Vejamos, então, um exemplo do tipo de texto presente na primeira parte da obra de Sampaio (1901, p.55), em que o número 102 é a conexão com o verbete Pacaembú.

102. - Aos regatos, arroios, ou riachos se dava o nome ycanga e tambem yembó que se traduzem litteralmente: cabeça de agua ou principio de rio, e fio de agua. $\mathrm{O}$ segundo vocabulo apparece muitas vezes alterado em yembú, quando entra na composição de outros nomes, como, por exemplo: Pacaembú, por Paca-yembó, 
arroio das pacas. Os nomes Taquarembó, Acarembó não são senão corruptellas de Taquara-yembó, arroio das taquaras, Acará-yembó, arroio dos acarás. O nome Ibó, tão commum no valle de S. Francisco, tambem é alteração de yembó e significa riacho, regato.

Depois das obras que estudam a etimologia, o segundo grupo com mais publicações é aquele que chamamos de coletâneas de temas históricos, composto por 13 livros. Em tais publicações, diferentemente das obras que se dedicam a estudar um ou dois temas filológicos específicos, há a análise de vários temas, o que ajuda a compreender o fato de seus títulos serem mais genéricos, como: Estudos de filologia portuguêsa, Palestras philologicas, Horas philologicas, etc. Com efeito, normalmente são temas ligados à Gramática Histórico-Comparada e a respeito deles já falamos na seção 4.2. No entanto, para comprovarmos essa ligação, selecionamos dois trechos presentes na obra Rusgas filológicas: réplica a Jucá inestudioso, implicante e roncador, de Serafim da Silva Neto (1917-1960). Realizamos essa escolha, pois além de trazer a discussão de um tema histórico em si, essa obra é a reunião de textos de uma polêmica travada entre o autor e Cândido Jucá (filho) (1900-1982) levada a cabo no jornal O Estado, de Niterói, na revista literária Dom Casmurro e na Revista de Cultura, discussão depois enfeixada no mencionado livro.

As polêmicas linguísticas, até o século XIX, normalmente ocorriam no interior das gramáticas completas, no entanto o caso que aqui analisaremos parece ser representativo da já mencionada reconfiguração do papel da gramática no século XX. A crítica realizada por Jucá (filho) foi ao Manual de gramática histórica portuguesa: de acordo com o Programa Oficial do $4^{\circ}$ ano, de Silva Neto, mas a réplica do autor não veio na próxima edição da gramática, como ocorria nas gramáticas do XIX, mas sim na imprensa e em revistas de cultura. Sendo essa gramática do tipo escolar, travar ali uma discussão teórica com outro autor fugiria totalmente dos propósitos de um material destinado aos alunos do Secundário. Em função de ambos serem filólogos, a discussão deveria ser feita nas obras de temas filológicos específicos, já que a gramática se tornou, no século XX, um instrumento, predominantemente, escolar, como já demonstramos no capítulo 2.

No capítulo chamado "Bombardeio... de falsidades", Silva Neto (1942, p.21) reproduz trecho de Jucá para depois expor sua resposta. Vejamos inicialmente o trecho de Jucá:

Quanto ao Sr. Serafim, esse mesmo que de si afirma ter escrito um livro "incomparavelmente simples" ( $O$ Estado, 11 de Junho de 1942), o que é o maior encômio que algum autor se possa fazer a si mesmo -- quanto ao Sr. Serafim, esse mesmo que recusa o nome de "latinista" (porque lhe convem) a Darmesteter, a Dauzat, a Gonçalves Viana, e que à opinião dêsses antepõe (porque lhe convem) o 
parecer de filólogos nacionais entre os quais ... - quanto ao "incomparável" Sr. Serafim, este é latinista das dúzias, que classifica vinum (êle escreve vinus) entre os vocábulos masculinos da segunda... (Quem duvidar leia a pg. 18 do citado livro incomparável, que se intitula Manual de Gramática Histórica Portuguesa). É o mesmo latinista que diz haver no latim só três ditongos: $a e, a u, o e$, e observa que o ditongo oe é "muito raro" (pg. 55)...

Excluindo as grosserias e as ofensas mútuas, a questão filológica em si gira em torno do uso da forma vinus entre os vocábulos masculinos de segunda declinação no lugar de vinum, além de uma discussão sobre a quantidade de ditongos em Latim. Em benefício do espaço, analisaremos apenas a resposta de Silva Neto (1942, p.23) quanto à questão dos ditongos.

Creio que o Dr. Jucá ficou desatinado com um artigo em que o Prof. Ernesto Faria
provava que ele, o Dr. Jucá, é hospede em latim... Só tal insânia explica o fato de o
Sr. Cândido andar escrevendo tantas leviandades. Desfaçamos as falsidades do
alucinado Sr. Jucá: [o autor apresenta suas respostas em 5 tópicos. Selecionamos,
no entanto, apenas uma, a de número 4] 4) à pg. 55 do meu Manual, livro elementar
feito para alunos da $4^{a}$. série, escreví, com relação aos ditongos latinos: "Em latim
somente havia três: ae, oe, au. Assim competia expôr num livro didático. Em obra
de outra natureza (Fontes do latim vulgar, pgs. $108-109$ e 187 ) estudei mais o
ditongo eu. De certo oe é muito raro em latim. Se o Sr. Jucá não fosse tão jejuno
em fonética latina saberia por que. Enquanto o ditongo arcaico ai evolvia para ae,
o ditongo oi evolvia para $u$ : oinom > unum.

Aqui, novamente vem à tona a questão dos espaços para se estabelecer a discussão filológica. Silva Neto rebate a acusação de Jucá (filho) de não ter incluído, na sua gramática, o ditongo $e u$ dizendo que não houve esquecimento, mas sim adequação da matéria ao fim para o qual sua obra foi escrita, isto é, subsidiar o estudo dos alunos quartanistas do Secundário. Assim, aquilo que é básico, os alunos devem saber - ditongos $a e, o e, a u$ - e casos mais específicos, de maior complexidade, como o caso do ditongo eu, devem migrar para as obras de temas filológicos específicos, como é o caso da mencionada por Silva Neto: Fontes do latim vulgar, publicada em 1938.

Finalmente, para encerrarmos as discussões acerca da camada técnica das obras específicas, passaremos à análise de exemplos relativos a outro tema também frequente no conjunto de 51 obras deste grupo: "evolução do Português"/ formação das palavras, com 10 publicações. Com efeito, esse tema é muito frequente nas gramáticas históricas, porém, como já destacamos, com um nível de profundidade menor, já que em tais materiais o espaço físico é limitado, possibilitando assim que vários temas possam ser estudados em um só volume. Selecionamos um exemplo extraído da obra Formação de palavras e sintaxe do Português histórico, de Said Ali (1861-1953), de onde retiramos um trecho em que o autor fala sobre a derivação sufixal, especificamente do sufixo -aria (-eira). 


\section{DERIVAÇÃO SUFFIXAL}

\section{a) Substantivo e adjectivo}

-aria (-eria) -- Ao elemento formativo -aria do port. ant. correspondem castelh. eria, ital. -eria, franc. -erie. O seu historico é commum a estas diversas linguas. Para evitar prolixidade, deixaremos de parte o estudo comparativo; explicaremos a proveniencia do suffixo á luz de alguns exemplos do nosso idioma. Palavras do genero de cavallaria, rouparia, feitiçaria devem a sua origem a junção do suffixo -ia aos derivantes cavalleiro, roupeiro, feiticeiro, do mesmo modo que frontaria, romaria, padaria procederam de fronteiro, romeiro, padeiro; mas por um erro de analyse veio a imaginar-se que aquelles vocabulos se filiariam directamente a cavallo, roupa, feitiço, e deste erro resultou o novo suffixo -aria, com o auxilio do qual se crearam, por analogia de sentido, innumeras outras palavras. (...) (ALI, 1923, p.5, sublinhados nossos)

Neste trecho, é possível ver claramente a utilização das técnicas da Gramática HistóricoComparada. Em um primeiro momento, vemos a referência ao comparativismo, mostrando os sufixos equivalentes em outras línguas românicas, mas é ao historicismo que o autor dedica atenção, provavelmente em função de o objetivo da obra ser analisar questões históricas do Português. Isso pode ser visto pelo estudo de fases antigas do Português (port. ant.) e também com o uso do conceito de analogia (cf. 4.2.3.). O autor segue com sua exposição, tentando explicar o porquê da preferência do sufixo -aria e detrimento de -eria, no Português antigo.

Porque preferiu o port. ant. -aria a -eria, forma mais proxima de -eiro? Que assim o exigisse a pronuncia, é possivel; mas seria caso particular, pois que exemplos como fantesia permittem pôr em duvida que $a$ não accentuado soasse realmente como a vogal pura quando tonica. Concorreu talvez para fixar-se a escripta, senão a pronuncia, a reminiscencia da terminação latina -aria, embora esta tivesse accentuação differente. Como quer que seja, certo é que em port. ant. occorre geralmente cavallaria, frontaria, montaria, etc. (ALI, 1923, p.5, sublinhados nossos)

A despeito de uma possível justificativa pela pronúncia, é no Latim que Said Ali encontra maior plausibilidade para justificar a preferência pelo sufixo - aria, já que na língua latina também havia esse mesmo sufixo. Comprovando o maior aprofundamento que estas obras específicas dão aos temas por elas tratados, o autor segue seu estudo, comentando e exemplificando o uso desses sufixos (-aria ou -eria) ao longo dos séculos XV, XVI, XVIII e XIX. Quanto ao uso no início do século XX, Ali (1923, p.6, sublinhados nossos) diz que

$\underline{\text { Recentemente, }}$ vai-se reagindo contra semelhante dualismo, procurando-se restabelecer a antiga terminação -aria. Resistem a este tentamen, entre outras palavras, principalmente galeria (cf. Vieira, Serm. 2. 445: salas e galarias douradas), parceria, loteria, vocabulo importado do italiano, e bateria, do francez, com sentido differente do termo bataria, usado por quinhentistas e seiscentistas, e que denotava a acção de bater. 


\subsubsection{Camada documental}

Dada a relação entre as obras de temas filológicos específicos e as gramáticas históricas por nós já analisada, não há diferenças substanciais entre as obras desses dois grupos relativamente à camada documental. Destarte, podemos considerar totalmente pertinentes e aplicáveis à presente seção, aquelas que realizamos para as gramáticas históricas (cf. 4.2.3).

Há, no entanto, um aspecto que merece ser sublinhado, que é o relativo ao "número de lenguas" (Swiggers, 2004, p. 134) utilizado para o estudo linguístico. O significativo número de estudos etimológicos presente nas obras deste grupo, sobretudo das toponímias, amplia o uso de documentação de outras línguas para assim comprovar suas influências no Português. Como já demonstramos, nas gramáticas históricas, os estudos etimológicos eram realizados fundamentalmente no sentido de mostrar a influência do Grego e do Latim na formação do Português. Estudos utilizando línguas indígenas como o Tupi eram de menor monta, restritos geralmente às seções dedicadas às especificidades do Português do Brasil, chamadas geralmente de "Brasileirismos", "Dialetos", "Português do ou no Brasil", entre outros títulos. Com efeito, tais estudos estavam previstos nos programas de ensino oficiais (cf. Apêndice B - Quadro 10B).

É exatamente nas obras de temas filológicos específicos que houve a realização de estudos mais detidos a respeito do quanto as seguintes línguas influenciaram na formação do Português: Tupi e outras línguas indígenas, Árabe, Turco, Persa, além, obviamente, do Grego e do Latim.

\subsection{Tratamento (edição) de texto}

Dividimos em três grupos as obras do programa de investigação filológico: (i) gramáticas históricas, (ii) obras de temas filológicos específicos e (iii) tratamento (edição) de texto. Dos dois primeiros grupos já cuidamos, passemos, então, ao terceiro e último grupo, que é formado pelas seguintes obras:

\section{Quadro 15 - Tratamento (edição) de texto}




\begin{tabular}{|c|l|}
\hline $\begin{array}{c}\text { BUENO, } \\
\text { Silveira }\end{array}$ & $\begin{array}{l}\text { - O auto das regateiras de Lisboa: composto por hum frade loyo, filho } \\
\text { de hua dellas (1939) (T) } \boldsymbol{\beta}\end{array}$ \\
\hline $\begin{array}{c}\text { CUNHA, } \\
\text { Celso } \\
\text { Ferreira da }\end{array}$ & $\begin{array}{l}\text { - O cancioneiro de Paay Gómez Charinho, trovador do século XIII: } \\
\text { aspectos literários; texto crítico (1945) } \boldsymbol{\Omega}\end{array}$ \\
\hline $\begin{array}{c}\text { MAGNE, } \\
\text { Augusto }\end{array}$ & $\begin{array}{l}\text { - A demanda do Santo Graal: reprodução fac-similar e transcrição crítica } \\
\text { do códice 2594 da Biblioteca Nacional de Viena: volume 1 (1944) } \boldsymbol{\Sigma}\end{array}$ \\
& $\begin{array}{l}\text { - A demanda do Santo Graal: reprodução fac-similar e transcrição crítica } \\
\text { do códice 2594 da Biblioteca Nacional de Viena: volume 2 (1944) } \boldsymbol{\Sigma}\end{array}$ \\
& $\begin{array}{l}\text { - A demanda do Santo Graal: reprodução fac-similar e transcrição crítica } \\
\text { do códice 2594 da Biblioteca Nacional de Viena: volume 3 (1944) } \boldsymbol{\Sigma}\end{array}$ \\
\hline $\begin{array}{c}\text { SILVA } \\
\text { NETO, }\end{array}$ & $\begin{array}{l}\text { Edição facsimile do único exemplar conhecido, acompanhada de } \\
\text { introdução e notas (1947) } \boldsymbol{\Omega}\end{array}$ \\
\hline $\begin{array}{c}\text { Serafim da } \\
\text { SILVEIRA, }\end{array}$ & $\begin{array}{l}\text { - Poesias de Casimiro de Abreu (1940) } \mathbf{\Omega} \\
\text { Sousa da }\end{array}$ \\
\hline $\begin{array}{c}\text { TOTAL } \\
\text { - Textos Quinhentistas (1945) } \boldsymbol{\beta}\end{array}$ \\
\hline
\end{tabular}

\subsubsection{Camada teórica}

Do já mencionado arquivo que preparamos, chamado "Definições de gramática histórica, filologia, glotologia, linguística e demais conceitos correlatos presentes nas Gramáticas Históricas do Português" (cf. Apêndice B - Quadro 10B), foi possível extrair uma série de definições e/ou reflexões a respeito do se entendia por filologia, no início do século XX. Mesmo que tais definições estejam nas gramáticas históricas, ou seja, em obras diferentes das analisadas neste grupo, há autores que produziram tanto gramáticas quanto obras que classificamos como de filologia. Essa coincidência ocorre com Silveira Bueno (1898-1989), Serafim da Silva Neto

\footnotetext{
${ }^{75}$ Augusto Magne (1887-1966) nasceu na França, mas emigrou para o Brasil em 1907 e já no ano seguinte se naturalizou brasileiro, fato que nos fez incluí-lo em nosso levantamento.
} 
(1917-1960) e Sousa da Silveira (1883-1967), embora apenas o primeiro tenha incluído, em sua gramática, definição de filologia. Independentemente dessa dupla produção, é importante saber como os autores que estavam envolvidos com o estudo histórico do Português, no início do século $\mathrm{XX}$, enxergavam suas disciplinas e outras conexas.

Depois de verificadas essas definições, em fontes secundárias, verificaremos, nas próprias obras de tratamento (edição) de texto (que, na época, eram chamadas de obras de filologia) a que tivemos acesso, se as concepções colhidas nas gramáticas históricas se mantêm ou se são distintas.

\section{Quadro 16 - Definições de filologia presentes nas gramáticas históricas}

Filologia. - Estudo comparativo e crítico das diversas línguas através de suas literaturas. (ABREU, 1944, p. 183)

Filologia - É a ciência que estuda a linguagem fixada em documentos de um povo, numa determinada época. O estudo dos documentos deixados pelos gregos e latinos chama-se Filologia Clássica. O estudo dos documentos (poesias, contos, romances, teatro, sermões, discursos), portugueses forma a Filologia Portuguesa. (BUENO, 1938, p.11)

Filologia é a ciência que estuda a literatura de um povo ou de uma época, e a língua que lhe serviu de instrumento. (...) É uma ciência muito velha. Nasceu da necessidade, que sentiram os antigos povos, de explicar os textos arcaicos dos seus monumentos literários ou religiosos. $\mathrm{Na}$ Índia, ela aparece com os trabalhos destinados a interpretar os Vedas, que são os mais antigos poemas bramânicos. Entre os gregos, no século III antes da Era Cristã, já são notáveis, os estudos dos autores alexandrinos sôbre as obras de Homero e dos velhos poetas líricos. Aristarco é o grande vulto que domina toda essa época. Qualquer estudo feito no sentido de reconstituir textos antigos de uma lingua, corrigí-los quando errados, restituí-los sua genuinidade quando interpolados, constitue trabalho de Filologia. Rollin denomina filólogos "os que trabalham sôbre os autores antigos, corrigindo-os, explicando-os e editando-lhes as obras". (COUTINHO, 1938, p. 20)

Filologia é a ciência dos fatos literários e eruditos que se referem sòmente a uma determinada língua. "É o estudo científico, histórico e comparado da lingua nacional em toda a sua amplitude, não só quanto à gramática (fonética, morfologia e sintaxe) e quanto à etimologia, semasiologia, etc., mas também como órgão da literatura e como manifestação do espírito nacional”. (Carolina M. de Vasconcelos) (GUÉRIOS, 1937, p. 15)

Filologia é a ciência que estuda as linguas não só sob o aspeto glotológico, como também literário e métrico. (HORTA,1941, p.13)

A Filologia é o estudo da literatura de um povo ou de uma época e da língua que lhe serviu de veículo. É, portanto, o estudo da arte da linguagem, da sua parte estética. Do meado do século XIX, parte a distinção que hoje estabelecemos entre a Glotologia e a Filologia. Pela definição 
de ambas, observamos que qualquer língua, ainda bárbara, será objeto da Glotologia; ao passo que tão só das línguas que apresentam documentos literários se pode ocupar a Filologia. Sendo a linguagem uma criação social, o estudo da Filologia e da Glotologia são históricos. A Literatura, por sua vez, é o conjunto de documentos, que determinam o valor artístico de uma língua. (MARTINS, 1937, p.13-14)

OBS.: Os sublinhados são nossos.

Pelo que se pode notar, há unanimidade em se apontar como tarefa central da filologia o trabalho com texto literário. Mais especificamente ainda, não se trata de qualquer trabalho, mas sim o de fornecer uma série de subsídios, como apoios do tipo linguístico, histórico, sociológico, antropológico, de história da literatura ou demais suportes para que um determinado texto literário, sobretudo os mais antigos, possa ser contextualizado e mais bem compreendido pelo leitor contemporâneo.

É em função desse estudo crítico, isto é, de se tomar um determinado texto literário e realizar um profundo estudo de todas as suas dimensões, apondo-lhe várias notas explicativas, é que optamos por classificar as obras deste grupo como tratamento (edição) de texto. Destacamos, portanto, que, quando optamos por chamar o programa de investigação que aqui estamos analisando de filológico, o fizemos considerando um sentido mais amplo de filologia, que não é, como demostramos, o utilizado pelos autores do início do século XX.

Passemos agora para análise específica das obras que compõem este grupo. Do conjunto total de 8 publicações, tivemos acesso a 2 obras: $\mathbf{O}$ auto das regateiras de Lisboa: composto por hum frade loyo, filho de hua dellas, tese ${ }^{76}$ de Silveira Bueno (1898-1989), publicada em 1939, e Textos Quinhentistas, de Sousa da Silveira (1883-1967), publicado em 1945. Na primeira, há uma clara definição a respeito das tarefas os objetivos da filologia.

Mas, não é só a linguagem que interessa ao filólogo: são os costumes, os hábitos, as crenças, as superstições, os vestígios de outras influências que se faziam sentir nessa época; são os vocábulos que ainda conservam formas em evolução, as indecisões da grafia, os gêneros que estão incertos, a atuação, numa palavra, das leis fonéticas, das leis semânticas na transformação do velho latim na língua portuguesa até dar de si o tipo atual. Tudo isto, pouco ou muito, vamos encontrando nos versos do auto, verdadeiro manancial de observações filológicas e linguísticas para os estudiosos. Eis porque o escolhemos como assunto da cadeira de filologia portuguesa, ora em concurso na Faculdade de Filosofia, Ciencias e Letras de S. Paulo. (BUENO, 1939, p.31, sublinhado nosso)

\footnotetext{
${ }^{76}$ Esta tese foi apresentada ao concurso de Filologia Portuguesa, na Universidade de São Paulo.
} 
O autor, ao justificar a escolha do texto literário que será analisado em sua tese, aponta para o tipo de abordagem que um filólogo deve realizar em seus estudos. Segundo o autor, o tratamento estritamente linguístico do texto não é suficiente, pois deve incluir também análises de ordem cultural, como as relativas aos "costumes, [a]os hábitos, [às] crenças, [às] superstições, [a]os vestígios de outras influências que se faziam sentir nessa época [de escrita do texto] (BUENO, 1939, p.31)”.

O segundo livro, Textos Quinhentistas, é dedicado à edição de quatro poemas: (i) "Sôbolos Rios", de Camões ([ca.1524] - 1580); (ii) "Crisfal”, de Cristóvão Falcão ([entre 1512 e 1515] - 1557); (iii) "Castro", de Antônio Ferreira (1528-1569) e "Auto da Alma", de Gil Vicente (1465-1536). No prefácio, o autor fala sobre a "utilidade do [seu] livro como instrumento de estudo da língua e da nossa literatura (SILVEIRA, 1945, p.10)”.

\subsubsection{Camadas técnica e documental}

Com efeito, do ponto de vista documental, todas as 7 obras deste grupo trabalham com textos literários. Em relação às técnicas de análise aplicadas nesses textos, vejamos como os autores realizam seus estudos nas duas dimensões mencionadas anteriormente: a de ordem interna ao texto (e à língua) e a de ordem externa (histórica, cultural etc).

Inicialmente, Bueno (1939, p. 100) reproduz o texto original, escrito, segundo o autor, entre 1580 e 1640, para depois apresentar a modernização do texto preparada para sua tese. Os números colocados entre os versos referem-se às notas, aos comentários feitos por Bueno ao auto. Vejamos primeiro um fragmento do texto original.

\section{“AUTO (1) DAS REGATEIRAS (2) DE LISBOA,} composto por hum (3) frade (4) Loyo (5) filho (6) de hũa (7) delas

Entram as pessoas seguintes:

Brázia (8) Antunes (9), Domingas Nunes, Natália do Valle sua criada, Juis aa Casinha (10), (11) Meirinho (12), Beleguim. 
Sahe Domingas Nunes com hũa teiga (13) de castanhas (14) à cabeça, e diz ao sahir da porta:

D. N. Acompanheme (15) a Virgem May (16) de Deos,

e a Corte celeste la dos ceos:

o meu Anjo da guarda me defenda,

porque (17) não encontre quem me offenda:

os Fieis de Deos, e as almas santas

encaminhem com bem (18) as minhas prantas.

$(\ldots) "$

Na sequência, Bueno (1939, p. 123) apresenta o texto modernizado:

\section{“AUTO DAS REGATEIRAS DE LISBOA,}

composto por um frade loio, filho de uma delas.

\section{Personagens:}

Brázia Antunes,

Domingas Nunes, $\} \quad$ Regateiras.

Natália do Vale.

Juiz à Casinha - Miguel Saraiva.

Meirinho.

Beleguim.

I Ato.

Cena I.

Sai Domingas Nunes com uma teiga de castanhas à cabeça e diz ao sair da porta:

D. N. Acompanhe-me a Virgem Mãe de Deus

e a côrte celeste lá dos céus;

o meu anjo da guarda me defenda,

porque não encontre quem me ofenda;

os fieis de Deus e as almas santas 
encaminhem com bem as minhas plantas.

$(\ldots) "$

Finalmente, depois de apresentadas as duas versões do auto, o autor inicia seus comentários ao texto, que são desenvolvidos em 120 notas ao longo de 118 páginas. Em tais notas é que encontramos os mencionados estudos de história interna e externa ao texto e à língua. Vejamos um trecho de um estudo linguístico feito pelo autor a respeito de uma palavra presente no subtítulo do auto: hũa.

[nota] 7. Hũa (uma) - Sem tocarmos na desnecessidade do $h$ nesta forma antiga e da inutilidade da moderna tilada $\tilde{u} a$ desde que a palavra seguinte não seja iniciada por $m$, queremos discutir o modo geral pelo qual costumam os mestres explicar a origem deste feminino uma. $\mathrm{O}$ artigo indefinido um, uma, procede do numeral latino unum, unam. Esta opinião não admite contradição, todos a aceitam. Do numeral masculino unum pela queda da consoante final $m$ (ипи) e pela substituição do $n$ intervocálico por til, tivemos a forma $\tilde{u} u$ que por crase se reduziu a $\tilde{u}$-um. Esta derivação não apresenta dificuldade alguma de explicação porque as leis fonéticas são facilmente aplicadas. Mas, o feminino uma, derivado de unam, já apresenta algum escolho. Leite de Vasconcellos repetido por J. J. Nunes assim explica a transformação (...) [o autor segue em uma longa nota, que optamos em não reproduzir integralmente] (BUENO, 1939, p. 155, sublinhados nossos)

Neste excerto, em função de tudo o que já apresentamos e analisamos quanto às técnicas de análise da Gramática Histórico-Comparada (cf. 4.2.3), fica evidente o uso de tais técnicas por Bueno, ao recorrer, por exemplo, às leis fonéticas para explicar a formação do artigo masculino um $($ ипит $>$ ипи $>\tilde{u} u>\tilde{u}$-um) e problematizar a formação do artigo feminino (uma) a partir da mesma lei.

Se as mesmas técnicas de análise, ligadas ao mesmo modelo epistemológico, são utilizadas nas obras que classificamos como de tratamento (edição) de textos, o que as diferenciariam das obras presentes nos demais grupos, ou seja, das gramáticas históricas e das obras de temas filológicos específicos? A este respeito, Coutinho (1938, p.21, itálicos e negritos do autor) apresenta uma distinção bastante didática.

É freqüente encontrar-se empregada a palavra Filologia por Glotologia, e viceversa. Esta confusão desaparece, quando se considera que o objeto e fim destas duas ciências são diferentes. 18. Distinção entre a Filologia e a Glotologia. - A Filologia visa à parte artística da linguagem; esta preocupação escapa ao domínio da Glotologia. Com efeito, a primeira tem por objeto a literatura de um povo ou de uma época; o objeto da segunda é constituído pela língua. Aquela, se estuda um idioma, é para conhecer-lhe a literatura; esta encontra a sua finalidade no próprio estudo do idioma. Schleicher, numa feliz comparação, deixou bem patente a diferença que vai do filólogo ao glotólogo. Aquele, estudando com exclusividade as línguas que possuem literatura, é o jardineiro, cuja atenção se volta sòmente para 
as espécies belas; êste, aplicando-se ao conhecimento de qualquer língua, tenha ou não monumentos literários, é o naturalista, que analisa a flor, pouco se lhe dando da sua beleza.

Ou seja, da explicação de Coutinho, podemos depreender que o uso das técnicas da Gramática Histórico-Comparada pela filologia serve como meio para se conhecer o texto literário, que é, com efeito, seu objeto de estudo. No caso das obras presentes nos outros dois grupos, ocorre o inverso, ou seja, sendo a língua o objeto de estudo, o texto literário é um dos meios para se realizar essa tarefa, mas não o único. Como já apontamos algumas vezes ao longo desta tese, o uso de textos literários é bastante frequente nos três programas de investigação, porém com diferentes estatutos. Mesmo no interior dos programas podem ocorrer diferentes usos, como no caso que aqui analisamos.

Finalmente, para encerrarmos as análises referentes às obras de tratamento (edição) de textos, vejamos uma outra nota ao auto, só que, neste caso, de cunho histórico, subsidiando, assim, a compreensão do texto para além dos aspectos puramente linguísticos.

[nota] 2) Regateiras - Eram e ainda são vendedoras de pescado, de gulodices, das ruas e praças de Portugal. Correspondem, em parte, às nossas quitandeiras. Foi um dos tipos mais singulares daqueles tempos, servindo de assunto a vários escritores pela vivacidade da linguagem e dos costumes, pela desenvoltura dos modos, caracterizando muito bem uma cidade, um bairro, uma época. Inspirou a Gil Vicente em dois autos, no Auto da Barca do Purgatório e na Romagem dos Agravados; a António Chiado no Auto das Regateiras e ainda a Alexandre de Lima nos Encantos de Amor e muito antes foi assunto de certa passagem da Crónica del Rei D. Afonso Henriques, de Duarte Galvão. (BUENO, 1939, p. 147, itálicos do autor) 


\section{O programa de investigação dialetológico: a variedade brasileira do Português em foco}

Concluída a análise das obras inseridas na tradição filológica, passaremos a analisar, no presente capítulo, as obras da tradição dialetológica, que constituem, segundo o nosso levantamento e a nossa posterior classificação dos textos, a terceira grande tendência da produção sobre o Português no início do século XX.

Foram incluídas, nesse grupo, as obras que estudam: (i) a dialetação interna do Português do Brasil, tanto abordando a variação geográfica quanto a social e (ii) a diversificação do Português do Brasil em relação ao de Portugal. Não localizamos trabalhos que comparem o PB a outras variedades, que não a europeia.

Encontramos 92 publicações, que foram subdivididas em dois grupos, segundo as especificidades acima apontadas.

Tabela 18 - Quantitativo da produção dialetológica sobre o Português

\begin{tabular}{|c|c|}
\hline Descrição de dialetos regionais e sociais & $\begin{array}{c}\text { Descrição dialetológica do } \\
\text { Português do Brasil }\end{array}$ \\
\hline 42 obras & 50 obras \\
\hline \multicolumn{2}{|c|}{ Total de obras do programa dialetológico: 92} \\
\hline
\end{tabular}

\subsection{Considerações gerais sobre o programa de investigação dialetológico}

No capítulo 4, destacamos que durante o século XIX e início do XX a Gramática Histórico-Comparada desempenhou papel central nos estudos linguísticos, notadamente naqueles considerados científicos à época. No caso das obras analisadas nesta tese, pudemos ver que as 87 publicações relativas ao programa de investigação filológico estão ligadas às concepções e metodologias do histórico-comparativismo.

Assim, a referida influência não está limitada às obras que analisamos no capítulo anterior, mas está também presente em parte das obras dialetológicas. Como afirma Ilari (1999, 
p. 25, sublinhados nossos), os estudos dialetológicos vão se estruturar justamente a partir da percepção de que os métodos da Gramática Histórico-Comparada apresentavam certa limitação na análise, principalmente no que se refere ao estudo dos dialetos neolatinos.

No final do século XIX e nas primeiras décadas do século XX, várias tendências
reagem contra o método histórico-comparativo e contra a maneira como ele levava
a representar a formação das línguas românicas: algumas dessas orientações
"novas" resultam de uma reflexão fillosófica ou teórica sobre linguagem, como é o
caso do chamado "idealismo lingüístico" ou da escola lingüística de Saussure;
outras surgem no próprio campo de estudo das línguas românicas, como resultado
de um contacto mais direto com os dialetos neolatinos. Estão neste último caso as
orientações que se costuma reunir sob o título genérico de "geografia lingüística".
Como orientações da "geografia lingüística", serão mencionados aqui (i) as
investigações sobre os dialetos galo-românicos de Jules Gilliéron; (ii) o movimento
"Wörter und Sachen" de Schuchardt; e (iii) a proliferação, inspirada pelas duas
orientações anteriores, de atlas lingüísticos para regiões do território românico.

Dentre outros importantes nomes para a formação da Dialetologia como disciplina autônoma - como Georg Wenker (1852 - 1911), Graziadio Ascoli (1829 - 1907) e Jules Cornu (1849 - 1919) - iremos aqui destacar apenas o trabalho de Jules Gilliéron (1854 -1926). Essa escolha se dá em função de algumas características que passaremos agora a analisar.

Com efeito, o trabalho de Gilliéron é importante, pois introduz, nos estudos históricocomparados, uma mudança na camada documental. Se antes a principal fonte documental era o texto escrito, agora os dados coletados em pesquisas de campo passam a ser centrais na dialetologia.

O trabalho de Gilliéron é inovador, e historicamente importante, antes de mais nada, por sua metodologia: ao passo que os comparatistas utilizavam principalmente fontes escritas (documentos antigos, glossários e dicionários dos dialetos, textos dialetais etc.), Gilliéron dá prioridade aos dados que resultam de uma pesquisa de campo. (ILARI, 1999, p. 26, sublinhados nossos)

Essas pesquisas de campo foram feitas através da aplicação de "um questionário de 1920 perguntas em 639 pontos do território dos dialetos galo-românicos. A aplicação do questionário, (...) compreendia perguntas destinadas a levantar dados não só sobre fonética, mas também sobre morfologia e sintaxe (...)" (ILARI, 1999, p. 26, sublinhados nossos). Ainda em termos documentais, Ilari destaca o quanto o método proposto por Gilliéron fez surgir "uma quantidade de dados antes não catalogados". Suas pesquisas serviram ainda para refutar a "concepção comparatista segundo a qual a dialetação do latim teria resultado sem outras complicações de um tratamento fonético diferenciado que as expressões do latim vulgar teriam recebido em cada região" (ILARI, 1999, p. 26). 
Gilliéron mostrou que essa perspectiva era infundada, e que além da evolução fonética operou crucialmente na formação dos dialetos românicos a criatividade dos falantes, particularmente ativa toda vez que se tornava necessário desfazer colisões homonímicas e salvar palavras foneticamente pouco consistentes, ou toda vez que a etimologia popular alterou a forma de uma palavra para relacioná-la a algum paradigma conhecido. (ILARI, 1999, p. 26, sublinhados nossos)

Faraco (2005, p.178), ao se referir à dialetologia, diz que, diferentemente das concepções imanentistas, essa disciplina é uma das que "têm procurado interpretar a história das línguas, integrando-a com a vida e a história das sociedades que as falam". O exemplo selecionado por Ilari a respeito da influência da criatividade do falante na mudança linguística é bastante eloquente em demonstrar essa relação língua e sociedade.

Um exemplo célebre de como a etimologia popular interfere na evolução fonética
segundo Gilliéron é a história da palavra francesa fumier, "monturo": o latim tinha
para "esterco" a palavra fimus, $i$, sobre a qual deve ter sido formada *fimarium,
"lugar onde se junta esterco"; entretanto para chegar-se à forma francesa, é preciso
passar por fumarium. Para Gilliéron esta forma deve ter sido criada, efetivamente,
por influência do verbo fumare: o monturo deve ter sido representado em algum
momento como um lugar de onde se exalam fumaças, provavelmente a partir do
hábito europeu de queimar neles durante o outono as soqueiras dos cereais colhidos
no verão. A palavra fumier, em suma, teria ganho sua forma atual ao ser incorporada
por uma família de palavras com a qual não tinha de início nenhuma relação.
(ILARI, 1999, p. 26, sublinhados nossos)

O interessante deste exemplo é que ele demonstra a limitação das leis fonéticas para se explicar a evolução da palavra francesa fumier, que significa monturo. Sua origem é a palavra latina fimus, $i$, (esterco), que teria servido de base para a forma *fimarium (lugar onde se junta esterco). No entanto, utilizando-se apenas das leis fonéticas seria impossível chegar à forma francesa contemporânea fumier. É exatamente neste ponto que entra a tese de Gilliéron sobre a criatividade do falante, saindo, assim, de uma perspectiva de análise puramente imanentista da língua, nas palavras de Faraco (2005), para uma abordagem que considera também aspectos sociais/culturais para explicar a evolução fonética. No caso da palavra ora em análise, isso pode ser visto pela interferência do hábito europeu de queimar, nos monturos, as soqueiras dos cereais colhidos no verão, o que gerava, obviamente, fumaça. Esse fato cultural explicaria a interferência do verbo fumare, já que o monturo era um local de onde também saía fumaça. Assim, esse verbo teria influenciado na formação da palavra francesa fumier, que, como já dissemos, significa atualmente monturo.

Passando para o domínio luso, temos alguns estudiosos importantes na formação da dialetologia portuguesa. Daremos, no entanto, destaque apenas a dois deles, Adolfo Coelho (1847-1919) e Leite de Vasconcelos (1858-1941). 
Adolfo Coelho publica, em 1868, a obra A lingua portugueza, onde desenvolve estudos a respeito dos dialetos portugueses, entre outros temas. Nela é possível também observar algo que falaremos mais adiante, que é a ideia de que o dialeto conserva características de estágios mais antigos da língua, assim, quando um pesquisador estuda sincronicamente um determinado dialeto, este lhe fornece dados dessa língua em outras sincronias.

Um appendix á obra [o autor faz referência a outros volumes que serão publicados
para compor a coleção A Lingua Portugueza] tractará dos dialectos portuguezes,
porque ha verdadeiros dialectos portuguezes; o gallego, por exemplo, não é um
dialecto hespanhol, mas sim um dialecto portuguez, mais proximo do fallar de D.
Diniz que a nossa linguagem de hoje, assim como o dialecto de Ceylão, que é não
como se imaginou uma corrupção da nossa lingua, mas no essencial bom portuguez
archaico. Nesse appendix, que é trabalho inteiramente novo, teremos occasião de
applicar observações que se têm feito sobre dialectos d'outras linguas, e que os
fazem olhar como de sua natureza conservadores. (COELHO, 1868, p. IV,
sublinhados nossos)

Assim, para o autor, o estudo do galego e do dialeto do Ceilão possibilita ao pesquisador um retrato de estágios da língua recuados historicamente. Na análise de Coelho, que escreve no século XIX, tais dialetos mais se parecem com o Português dos séculos XI/XII e com o "portuguez archaico", respectivamente. Essa percepção a respeito dos dialetos proporciona uma espécie de "volta ao passado" para se explicar o presente, o que, naturalmente, gerou um grande interesse dos pesquisadores por esse tipo de estudo, dada a possibilidade de obtenção de dados linguísticos até então desconhecidos.

Já Leite de Vasconcelos (1858-1941), é autor da obra Esquisse d'une dialectologie portugaise, tese de doutoramento sobre os dialetos do Português, publicada em 1901, além de outras obras dialetológicas, como O Dialecto mirandez: contribuição para o estudo da dialectologia romanica no dominio glottologico hispanolusitano, de 1882. Com efeito, sua produção representa um estágio já mais estruturado e desenvolvido da dialetologia portuguesa.

Barros Ferreira (1994) qualifica este período de atuação de Leite de Vasconcelos como o de início de um real interesse pelo falar interiorano de Portugal. Julgamos que a explicação para tal interesse seja a concepção de que os dialetos eram conservadores quanto aos estágios anteriores da língua, questão por nós já discutida anteriormente. Tal fenômeno também pode ser visto, no Brasil, em estudos sobre o dialeto caipira realizados por Amadeu Amaral (1875-1929). Neles, o autor também aponta para o caráter conservador desse dialeto em relação à fala contemporânea, possibilitando, assim, um rico estudo da evolução do Português. 
(...) uma vez reconhecido que o fundo do dialeto representa um estado atrasado do português, e que sobre esse fundo se vieram sucessivamente entretecendo os produtos de uma evolução divergente, o seu acurado exame pode auxiliar a explicação de certos fatos ainda mal elucidados da fonologia, da morfologia e da sintaxe histórica da língua. Por exemplo: a pronunciação clara de $e$ e $o$ átonos finais comprova o fato de que o ensurdecimento dessas vozes só começou em época relativamente próxima, pois de outro modo não se compreenderia porque o caipira analfabeto pronuncia lado, verdade, quando os portugueses pronunciam ladu, verdad'. (AMARAL, 1955 [1920], p.55, sublinhados nossos)

Com efeito, Amaral também destaca que os estudos dialetológicos podem também servir para explicar aspectos que não são satisfatoriamente resolvidos pela Gramática HistóricoComparada.

Iniciamos esta seção falando que uma parte dos estudos dialetológicos se estruturam justamente a partir da percepção de que os métodos da Gramática Histórico-Comparada apresentavam certa limitação na análise, principalmente no que se refere ao estudo dos dialetos neolatinos. No entanto, é importante lembrar que a dialetologia não se constituiu como disciplina apenas a partir dessa relação com o histórico-comparativismo, mas, também, se utilizou das técnicas da Lexicografia, gerando, assim, "dicionários", "vocabulários" ou "glossários" que tentavam retratar a diversidade lexical de um país em relação a outro, notadamente no eixo exmetrópole versus ex-colônias, ou demais especificidades, como o linguajar de uma determinada profissão ou grupo social. Alguns exemplos desse tratamento são o Novo vocabulario brasileiro: $\mathrm{II}^{\mathrm{a}}$. serie das apostillas ao diccionario de vocabulos brasileiros, de Carlos Teschauer (1851-1930), publicado em 1918 ou o Vocabulário de caça, de Claudo Ribeiro de Lessa (? - ?), de 1944, dentre tantos outros (cf. Quadro 3A - Apêndice A).

O primeiro registro da variedade dialetal brasileira costuma ser atribuído ao Visconde de Pedra Branca (1780-1855), que escreve, em 1826, um capítulo para o livro Introduction à l'Atlas ethnographique du globe, onde aponta características do Português utilizado no Brasil.

A primeira manifestação específica, que se pode caracterizar de natureza dialetal, sobre o português do Brasil deve-se a Domingos Borges de Barros, Visconde de Pedra Branca, que escreveu, em 1826, quando era ministro plenipotenciário do Brasil na França e a pedido do geógrafo vêneto Balbi, um capítulo para o livro Introduction à l'Atlas ethnographique du globe no qual apontava características da língua no novo mundo. Descrevendo a língua do Brasil, o Visconde de Pedra Branca dizia refletir, ela, a doçura do clima e dos habitantes e ter sido enriquecida por palavras e expressões novas, tomadas de empréstimo às línguas indígenas e inexistentes no português continental. (CARDOSO; FERREIRA, 1994, p.34) 
Assim, Cardoso e Ferreira (1994, p.34) estabelecem o ano de 1826 como o de início da primeira fase da dialetologia brasileira, período que se encerra em 1920, com a publicação da obra O dialeto caipira, de Amadeu Amaral (1875-1929), marco do início da segunda fase. A principal característica dessa fase inicial é a "produção de trabalhos voltados, basicamente, para o estudo do léxico e de suas especificidades no Português do Brasil, de que resultaram numerosos dicionários, vocabulários e léxicos regionais". No entanto, O idioma hodierno de Portugal comparado com o do Brasil, de José Jorge Paranhos da Silva (1839-?), publicado em 1879, representa uma exceção a esse viés lexicográfico, pois é o "primeiro estudo de natureza gramatical" (CARDOSO; FERREIRA, 1994, p.39).

Ainda quanto ao século XIX, Coelho e Silva (2018, p. 81-82) também destacam que o estudo do léxico foi o principal interesse dos estudos dialetológicos desse período. Os autores apresentam algumas obras que indicam que havia na época ora um interesse mais geral quanto ao "dialeto brasileiro", ora um interesse mais regional, abordando estados específicos. Como mostraremos, esse tipo de estudo geral/específico também pode ser visto nas obras do início do século XX, em análise na presente tese.

Entre as décadas de 1850 e 1890 , foram publicadas obras especificamente dirigidas
à descrição do léxico brasileiro. Como já se mencionou, há obras que se apresentam
como sínteses gerais - Vocabulário brasileiro para servir de complemento aos
dicionários da língua portuguesa, de Brás da Costa Rubim (1817-1871);
Diccionario brasileiro da língua portuguesa, de Antônio Joaquim de Macedo
Soares (1838-1905), e o Dicionário de vocábulos brasileiros, do Visconde
Henrique de Beaurepaire-Rohan (1812-1894) -, e outras que enfocam
particularidades regionais (por exemplo, o Vocabulário indígena de uso na
província do Ceará, com explicaçóes etimológicas, ortográficas, topográficas,
históricas, de Paulino Nogueira, o Vocabulário sul-riograndense, de Romaguera J.
Correa, a Collecção de vocábulos e frases usados na província de São Pedro do
Rio Grande do Sul, de Antônio Álvares Pereira Coruja.

Outro aspecto sublinhado pelos autores e que também encontra eco nos materiais lexicográficos analisados nesta tese é a diferença existente no aprofundamento das obras. Algumas são apenas listas de termos, sem nenhum comentário ou informação adicional elaborados pelo autor, outras, por sua vez, realizam estudos mais detidos, incluindo, às vezes, uma primeira parte de estudos teóricos, para só, na segunda parte, apresentar o dicionário/vocabulário/glossário. Voltaremos a essas características mais à frente, mas julgamos importante aqui destacar a ligação das obras lexicográficas do século XIX com as do XX.

A esses textos [referem-se aos textos mencionados na citação anterior] juntam-se artigos e trabalhos monográficos, de caráter mais reflexivo, entre os quais se destacam novamente os publicados por Macedo Soares, que foram organizados no volume póstumo Estudos lexicográficos do dialeto brasileiro. Heterogêneos, os 
dicionários podem ou não conter notas etimológicas, ter verbetes mais descritivos ou opinativos, trazer ou não informações sobre usos (distribuição geográfica, grupos sociais, contextos). Os artigos e notas da coletânea ora acompanham a forma e o estilo dos dicionários, ora permitem a discussão de problemas teóricos, de bibliografia em circulação, de tarefas para aquela geração de estudiosos. (COELHO; SILVA, 2018, p. 82)

\subsection{Camada contextual}

Antes de começarmos a analisar as camadas teórica, técnica e documental (Swiggers, 2004) das obras dialetológicas brasileiras, é preciso fazer menção a um aspecto contextual que as influenciou fortemente: o nacionalismo.

Diferentemente do que ocorreu com os demais países hispano-americanos, a Independência do Brasil, em 1822, não instaurou no país uma república, mas sim um império constitucional, que, conquanto independente de Portugal, foi comandado por dois imperadores portugueses: D. Pedro I, até 1831, e D. Pedro II, seu filho, até 1889. Assim, os vínculos do Brasil com sua ex-metrópole não cessaram com a Independência, mas se mantiveram ativos, embora de forma redimensionada, até a Proclamação da República, em 1889, ou seja, praticamente até o início do século XX.

Dado esse cenário, é natural que houvesse, na sociedade brasileira, sentimentos antilusitanos e de busca por uma identidade verdadeiramente nacional. "O antilusitanismo, além de estruturar-se por motivos econômicos, foi uma maneira de afirmar uma nacionalidade em construção, mediante a ruptura com o passado colonial, e como tal deve ser entendido". (SOUZA, 2005, p. 133)

São várias as ações que emergem no país que guardam relação com os sentimentos anteriormente mencionados, mas aqui faremos menção a apenas dois eventos: o Modernismo brasileiro e a fundação da Revista do Brasil.

Ao analisar o Modernismo brasileiro ${ }^{77}$, Lafetá (2000, p.21, itálicos do autor) afirma enxergar nesse movimento a presença de dois projetos formativos diferentes, embora dialeticamente interligados. "Distinguimos o projeto estético do Modernismo (renovação dos

\footnotetext{
${ }^{77}$ Cronologicamente, costuma-se associar o início do Modernismo brasileiro à Semana de Arte Moderna, ocorrida em 1922.
} 
meios, ruptura da linguagem tradicional) do seu projeto ideológico (consciência do país, desejo e busca de uma expressão artística nacional, caráter de classe de suas atitudes e produções)".

Assim, é correto dizer que o Modernismo foi uma estética que não ficou limitada apenas à literatura, às artes plásticas ou à música, mas desempenhou importante papel na pesquisa, tentativa de definição e valoração da cultura e da expressão verdadeiramente nacionais. Saindo da influência direta de Portugal, o começo do século XX era o momento de se olhar para o país e compreender a identidade nacional.

Enquanto certos escritores procuravam exprimir a forma e a essência do seu país, outros mais arrojados porfiavam em pesquisar, em experimentar formas novas e descobrir sentimentos ocultos. (...) A segunda linha, quiçá mais típica, aborda temas análogos com espírito diferente. Mais humour, maior ousadia formal, elaboração mais autêntica do folclore e dos dados etnográficos, irreverência mais conseqüente, produzindo uma crítica bem mais profunda. Sobretudo a descoberta de símbolos e alegorias densamente sugestivos, carregados de obscura irregularidade; a adesão franca aos elementos recalcados da nossa civilização, como o negro, o mestiço, o filho de imigrantes, o gosto vistoso do povo, a ingenuidade, a malandrice. É toda a vocação dionisíaca de Oswald de Andrade, Raul Bopp, Mário de Andrade; este haveria, aliás, de elaborar as diversas tendências do movimento numa síntese superior. A poesia Pau Brasil e a Antropofagia, animadas pelo primeiro, exprimem a atitude de devoração em face dos valores europeus, e a manifestação de um lirismo telúrico, ao mesmo tempo crítico, mergulhado no inconsciente individual e coletivo, de que Macunaíma seria a mais alta expressão. (CANDIDO, 2008, p. 129130, itálicos do autor e sublinhados nossos)

Com efeito, a Antropofagia muito bem representou essa busca pela identidade nacional e a forma de se encontrá-la: inicialmente, seria necessário "deglutir" tudo aquilo que serviu para a formação do povo brasileiro, tanto os "elementos recalcados da nossa civilização, como o negro, o mestiço, o filho de imigrantes, [etc]" como a cultura portuguesa, já que essa deixou, através dos séculos, marcas culturais indeléveis no Brasil. Dessa forma, a proposta antropofágica estabelecia que a identidade nacional seria o resultado da "digestão" de todas essas influências, ou seja, após serem misturadas, processadas e submetidas a uma síntese, chegaríamos ao que é ser brasileiro.

No plano dos estudos linguísticos, é justamente a dialetologia que conseguiu melhor contribuir no sentido de responder qual era a identidade linguística nacional ou, em outros termos, como falava o brasileiro.

Outro importante núcleo de propaganda nacionalista, no início do século $\mathrm{XX}$, foi a Revista do Brasil, durante a chamada $1^{a}$ fase, período compreendido entre 1916 e 1925 (ALTMAN, 2020). A autora também reproduz trecho do Editorial do primeiro número da revista, 
local em que a ideia a respeito da oposição cultura nacional versus estrangeira fica bem evidenciada.

O que ha por traz do titulo desta Revista e dos nomes que a patrocinam é uma coisa
simples e immensa; o desejo, a deliberação, a vontade firme de constituir um nucleo
de propaganda nacionalista. Ainda não somos uma nação que se conheça, que se
estime, que se baste, ou, com mais acerto, somos uma nação que ainda não teve o
animo de romper sósinha para a frente numa projecção vigorosa e fulgurante da sua
personalidade. Vivemos desde que existimos como nação, quer no Império quer na
Republica, sob a tutela directa ou indirecta, senão politica ao menos moral do
estrangeiro. Pensamos pela cabeça do estrangeiro, vestimo-nos pelo alfaiate
estrangeiro, comemos pela cozinha estrangeira e, para coroar essa obra de
servilismo collectivo, calamos, em nossa, patria, muitas vezes, dentro dos nossos
lares, a lingua materna para falar a língua do estrangeiro! (REVISTA DO BRASIL,
1916a, p.2, editorial, sublinhados nossos)

Com efeito, animados por este sentimento anti-estrangeiro e de valorização do nacional,

é na Revista do Brasil em que ocorre a primeira publicação d'O dialeto caipira, de Amadeu Amaral (1875-1929), inicialmente em formato de fascículos, nos números 9 e 10 de 1916, e depois em livro, já no ano de 1920 e editado pela Casa Editora O Livro. Vejamos como Amaral inicia o primeiro fascículo, o que depois será transportado, com algumas modificações, para a Introdução do livro.

Tivemos, até ha cerca de vinte e cinco a trinta annos, um começo de dialectação bem pronunciado, no territorio da antiga provincia de S. Paulo. É de todos sabido que o nosso falar caipira - bastante característico para ser notado pelos mais desprevenidos como um systema distincto e inconfundível - dominava em absoluto a grande maioria da população e estendia a sua influencia á própria minoria culta. As mesmas classes educadas e as pessoas bem falantes não se podiam esquivar a essa influencia. Foi o que criou aos paulistas, ha já bastante tempo, a fama de corromperem o vernáculo com muitos e feios vicios de linguagem. Quando se tratou, no Senado do Império, de criar os cursos jurídicos no Brasil, tendo-se proposto São Paulo para séde de um delles, houve quem allegasse contra isto o linguajar dos naturaes, que inconvenientemente contaminaria os futuros bacharéis, oriundos de differentes circumscripções do paiz... (REVISTA DO BRASIL, 1916b, p.22, editorial, sublinhados nossos)

Quando Amaral destaca que o Português falado em São Paulo era malvisto dada a influência do falar caipira, o autor traz à baila uma tópica bastante cara à dialetologia: a noção de erro. Mais à frente, trataremos desse aspecto de forma mais detida, mas é importante já deixar aqui consignado que Amaral se posiciona no sentido de nuançar o erro linguístico (ALTMAN, 2020).

Outro exemplo desse cenário de disputa nacionalista em torno da língua pode ser visto em boa parte das obras presentes no grupo descrição dialetológica do Português do Brasil (cf. 
Apêndice A - Quadro 3A). Com maior ou menor intensidade, há em tais materiais discussões em torno de o Brasil ter ou não uma língua diferente da de Portugal. Sanches (1940, p.1, sublinhados nossos), no livro Lingua brasileira, obra que é uma espécie de resenha do pensamento de vários autores a respeito do tema marcado em seu título, faz uma observação que bem resume o clima de opinião do período (Koerner, 1989) acerca da questão.

É velha e longa controversia a existencia de uma lingua brasileira. Largo estudo e debate teem feito os mais illustres homens de lettras da nossa terra e de Portugal. Dividem-se as opiniões, formam-se as correntes. Sustentam uns que a lingua fallada no Brasil é a mesma lingua portuguesa; outros, que entre nós se formou, com as alterações soffridas, no espaço de quatrocentos annos, uma linguagem que não é nem pode ser mais o mesmo idioma dos portugueses. Não é de agora que os brasileiros teem observado entre o seu fallar e os dos lusitanos grandes differenças, que cada dia mais se accentuam.

Para que se dimensione a importância dessa discussão e o quanto ela ocupou a intelectualidade da época, basta dizer que o então novo texto constitucional, que fora promulgado em 1946, encampou a celeuma em torno da nacionalidade do Português utilizado no Brasil. No artigo 35 das disposições transitórias, o texto legislador assevera: “O Govêrno nomeará comissão de professôres, escritores e jornalistas, que opine sobre a denominação do idioma nacional". (BRASIL, 1946, sublinhamos)

Com efeito, tal comissão foi formada por ordem de Ernesto de Sousa Campos (1882 1970), ministro da Educação e Saúde do presidente Eurico Gaspar Dutra (1883 - 1974). Para a relatoria foi escolhido o professor e filólogo Sousa da Silveira (1883 - 1967), que encerra seu parecer com a seguinte conclusão:

À vista do que fica exposto, a Comissão reconhece e proclama esta verdade: o idioma nacional do Brasil é a LÍNGUA PORTUGUÊSA. E, em conseqüência, opina que a denominação do idioma nacional do Brasil continue a ser: Língua Portuguêsa. Essa denominação, além de corresponder à verdade dos fatos, tem a vantagem de lembrar, em duas palavras - Língua Portuguêsa -, a história da nossa origem e a base fundamental da nossa formação de povo civilizado. Rio de Janeiro, 15 de outubro de 1946. (SILVEIRA ${ }^{78}$ et al., 1946, apud SENNA, 1953, p.44)

Chama a atenção, no final do parecer, a consideração do relator quanto ao fato de as palavras "língua" e "portuguesa" conferirem ao Brasil o estatuto de país civilizado, já que originário de uma nação europeia, Portugal. Assim, caso fosse realizada a alteração para língua

\footnotetext{
${ }^{78}$ SILVEIRA, et al. Sobre a língua nacional. Rio de Janeiro, 1946. 8 p. Relatório apresentado ao Sr. Ministro da Educação e Saúde pela Comissão nomeada para cumprir a determinação contida no art. 5 do Ato das Disposições Transitórias, apenso à Constituição de 18-9-1946.
} 
brasileira ou algo congênere, tal condição estaria ameaçada e poderia apontar para a caráter incivilizado ou mesmo bárbaro do Brasil. Embora não mencione explicitamente, fica subentendida a referência às influências, no Português do Brasil, das línguas indígenas e africanas, processo que para muitos não deveria ser evidenciado.

Embora houvesse o nacionalismo que anteriormente descrevemos, não se deve ignorar que tal sentimento, na sociedade brasileira, convivia dialeticamente com outro, que era o que advogava pela manutenção dos vínculos identitários com Portugal. Com efeito, tal sentimento também pode ser encontrado nas obras dialetológicas analisadas neste capítulo, já que elas refletem o clima de opinião da época (Koerner, 1989).

\subsection{Camada teórica}

Swiggers (1981, p.12, tradução e sublinhados nossos), ao desenvolver o conceito de programa de investigação, diz que "um programa inclui várias teorias que, apesar das diferenças

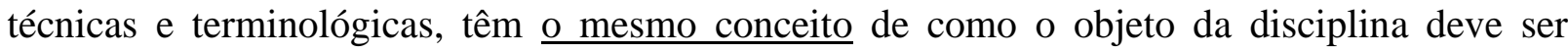
investigado". Assim, no caso do programa dialetológico, é preciso dizer que, no início do século XX, ele era constituído por dois modelos teóricos diferentes: a Lexicografia e a Gramática Histórico-Comparada. Ainda Swiggers (1981, p.12, tradução e sublinhados nossos), ao falar a respeito do que confere unidade a um determinado programa de investigação, diz que "tanto o objeto quanto o método são definidos intra-teoricamente; mas a unidade de um programa reside nas concepções semelhantes de como um determinado método deve "lidar" com o objeto de uma determinada disciplina”. No caso da dialetologia brasileira do início do século XX, o objeto era apontar e estudar a variação do Português do Brasil e a essa tarefa se dedicaram, embora com métodos diferentes, os dois modelos teóricos anteriormente mencionados.

Embora tivessem esse objeto comum, o fato de pertencerem a diferentes tradições teoréticas implica, naturalmente, em algumas diferenças quanto à maneira de conceber a dialetação. Vejamos, então, como a Lexicografia e a Gramática Histórico-Comparada vislumbravam tal processo linguístico.

Quanto ao modelo histórico-comparativo, realizamos, inicialmente, um levantamento das concepções teóricas dos autores-dialetólogos a respeito do conceito de dialeto e de como 
enxergavam, nesse contexto, o Português do Brasil. O resultado a que chegamos pode ser visto no Quadro 14B, presente no Apêndice B, mas aqui apresentaremos uma síntese dos principais trechos.

\title{
Quadro 17 - Síntese das ideias sobre o processo de dialetação presente nas obras dialetológicas não-lexicográficas
}

\begin{abstract}
"Tivemos, até cerca de vinte e cinco a trinta anos atrás, um dialeto bem pronunciado, no território da antiga província de S. Paulo. É de todos sabido que o nosso falar caipira - bastante característico para ser notado pelos mais desprevenidos como um sistema distinto e inconfundível - dominava em absoluto a grande maioria da população e estendia a sua influência à própria minoria culta. (...) O processo dialetal iria longe, se as condições do meio não houvessem sofrido uma série de abalos, que partiram os fios à continuidade da sua evolução. (...) A substituição do braço escravo pelo assalariado afastou da convivência cotidiana dos brancos grande parte da população negra, modificando assim um dos fatores da nossa diferenciação dialetal. (...) A população cresceu e mesclou-se de novos elementos. Construíram-se vias de comunicação por toda a parte, intensificou-se o comércio, os pequenos centros populosos que viviam isolados passaram a trocar entre si relações de toda a espécie, e a província entrou por sua vez em contato permanente com a civilização exterior. A instrução, limitadíssima, tomou extraordinário incremento. Era impossível que o dialeto caipira deixasse de sofrer com tão grandes alterações do meio social." (AMARAL, 1955 [1920], p. 41-42, sublinhados nossos)
\end{abstract}

"É extranhavel mesmo que, um assunto tão importante qual seja esse das modificações sofridas pelo português na America, tenha sido tratado até hoje com tanto indiferentismo pelos nossos linguistas e filologos. Somos, no entanto, quarenta milhões de pessôas que falamos uma lingua transplantada ha quatro seculos para um novo meio, onde tem estado exposta aos influxos modificadores de clima diferente, de ambiente diverso, sofrendo ainda o contacto intimo de dois grupos etnicos e gloticos extranhos. Nossa língua ter-se-á transformado, da mesma forma que o português falado em Portugal no seculo XVI se alterou apenas pelo impulso genial da evolução das línguas, apesar de não ter estado em contacto com fatores externos de modificação. O português do seculo XVI é o ponto de partida de uma evolução divergente. Enquanto em Portugal se modificava num sentido, no Brasil, envolvido por fatores mesologicos étnicos e geograficos radicalmente diversos, orientou diferentemente a sua evolução." (MARROQUIM, 1934, p. 5-6, sublinhados nossos)

"Querem uns que as variedades só constituam dialeto quando houver dificuldade de compreensão mutua entre os que a falam e os que os falam a língua mãe; dão outros, como o insigne Leite de Vasconcelos, a maior autoridade em dialectologia portuguesa, o nome de dialeto às diferenciações locais de uma língua, admitindo dentro dos dialetos os subdialetos e dentro destes as variedades. Haja ou não haja dialeto brasileiro, questão que se discute desde a celebre polemica entre Alencar e Castilho, o que não se pode contestar é a existencia de variação entre a língua do Brasil e a de sua antiga metropole e é isso principalmente o que nos interessa e o que nos cumpre estudar." (NASCENTES, 1953 [1922], p. 12, sublinhados nossos)

"Dialeto é a variedade regional de uma lingua. Instrumento de comunicação, a lingua não é estatica. Como nada da natureza. Transportando para o cenário americano, diverso do de 
Portugal, instrumento de uma população mestiça de processos de expressão diferentes, o português quinhentista tinha de alterar-se, de modificar-se. E assim não é nada extraordinario que depois de quatrocentos anos apresente caracteres diversos do português ultramarino. Se até este diverge bastante do quinhentista. (...) O processo de dialetação é um facto normal em linguistica. Como é o da diferenciação na natureza. E suas causas parte pertencem ao dominio geral, parte ao particular a cada país e a cada povo, que é o que imprime feição nacional ás linguas." (TEIXEIRA, 1938, p.8-9, sublinhados nossos)

Com efeito, o que nos parece comum a estas obras, e a outras que veremos mais adiante, é aquilo que está sintetizado nas palavras de Teixeira (1938, p.8): "Dialeto é a variedade regional de uma língua". Ao explicar esse conceito, os autores afirmam que ao se mudar o local onde uma determinada língua é falada, consequentemente se altera também o contexto social de uso. Tais alterações regionais e sociais impactam a língua, criando, assim, um ambiente favorável ao surgimento de dialetos. Marroquim (1934, p. 6) explicita algumas variáveis que são responsáveis pela criação de novos dialetos: "um novo meio, onde tem estado exposta [a língua] aos influxos modificadores de clima diferente, de ambiente diverso, sofrendo ainda o contacto intimo de dois grupos etnicos e gloticos extranhos".

Assim, o que os dialetólogos do início do século XX parecem concordar é que uma determinada língua, ao ser utilizada em outra região, sofre, inexoravelmente, alterações/dialetação, dadas as novas variáveis socioculturais que lá encontrará.

É importante dizer que esse olhar, que considera fatores extralinguísticos como responsáveis pela variação da língua, é o que justifica a presença de obras que vão descrever, além dos dialetos regionais, os falares de grupos sociais específicos, como a gíria de ladrões e malandros; o vocabulário dos caçadores; o linguajar médico, entre outros. Esse cenário justifica a divisão das 92 obras que localizamos em dois grupos: descrição dialetológica do Português do Brasil e descrição de dialetos regionais e sociais.

De forma subsidiária e com o fito de aprofundarmos a visão de língua predominante no programa dialetológico, também consultamos, além das obras estudadas neste capítulo, as gramáticas históricas, já analisadas no capítulo 4 (cf. seção 4.2). O primeiro motivo é de ordem teórica, já que essas gramáticas e uma parte das obras dialetológicas não-lexicográficas estão ligadas à Gramática Histórica-Comparada. O segundo diz respeito ao fato de os programas de ensino do início do século XX incluírem o estudo do Português do Brasil (cf. Apêndice B Quadro 10B) como tópico de estudo obrigatório no Secundário, o que levava as gramáticas 
históricas, que à época estavam todas ligadas à escola, a abordarem esse tema de forma compulsória.

O resultado da busca que realizamos pelos conceitos de dialeto, dialetologia e o Português do Brasil pode ser visto no Quadro 13B, presente no Apêndice B, ali alocado em função de seu tamanho. De forma sintética, o que pode ser visto como ponto comum a quase todas as gramáticas históricas é um olhar para a dialetação como um processo histórico inerente às línguas, fruto do uso diferenciado que os falantes de diferentes regiões fazem de uma mesma língua.

Assim, o Português, ao ser trazido para o Brasil pelos portugueses, não poderia ser o mesmo Português falado em Portugal, dadas as diferenciações locais, regionais. Destarte, segundo essa visão, o Português do Brasil seria um dialeto do Português de Portugal. Da mesma forma, as línguas neolatinas seriam dialetos relativamente ao Latim. Vejamos o que fala Coutinho (1938, p.31, itálicos do autor) a esse respeito: "Língua e dialeto são, pois, têrmos relativos. O italiano, francês, o espanhol, o português, etc., que, tomados separadamente, constituem verdadeiras línguas, com relação ao latim, não passam de simples dialetos”.

Como já dissemos, há ainda um segundo grupo de obras que está ligado a outro modelo teórico, a Lexicografia. Ao analisarmos essas obras, percebemos que é nelas que o nacionalismo mencionado na seção 5.2 se encontra mais explícito. Nelas, há uma clara intenção de mostrar que o léxico brasileiro não pode ser visto como mera extensão do léxico português. Muitos autores de nosso levantamento se insurgiram contra os dicionários portugueses utilizados no Brasil, como o de Cândido de Figueiredo (1846-1925), pois viam neles menosprezo às contribuições brasileiras ao léxico do Português. Taunay (1926, p.2-3), por exemplo, diz que "ha cem mil palavras vulgares, correntes no Brasil que o Snr. Candido de Figueiredo desconhece" e que "além dos numerosissimos brasileirismos deturpados, falhos, insufficientes e até disparatados, ha no léxico figueiredeano numerosas heresias scientificas". Ribeiro (1933, p. 7-8, sublinhado nosso), por seu turno, ao falar sobre o sucesso que, na época, faziam os consultórios gramaticais, destaca que eles "nos instruem nas fantasias do bem falar ou do bem escrever, e nos dizem como se fala e escreve em... Coimbra ou em Lisboa". O autor continua explorando essa relação de submissão ao falar lusitano, pois para ele "parece todavia incrivel que a nossa Independencia ainda conserve essa algema nos pulsos, e que a personalidade de americanos pague tributo á submissão das palavras". 
Ao percebemos esse viés nacionalista nas obras da dialetologia lexicográfica, realizamos um exame mais detido em todos esses materiais, buscando, ali, trechos que exaltassem a importância do Português do Brasil. Novamente por uma questão de espaço, reunimos os principais trechos no Apêndice B, Quadro 15B. Além das passagens acima mencionadas, vejamos outras, resultado de nossa pesquisa.

Com efeito, percebemos, em algumas obras, que a manifestação do nacionalismo linguístico se materializava também através do regionalismo, ou seja, em vez que exaltar os aspectos lexicais do Português do Brasil como um todo, esses autores exaltavam os usos característicos de sua região e quanto estes contribuíam de forma relevante para o enriquecimento da língua nacional. Não raro, apareciam, nessas obras, algum tipo de reclamação quanto a se valorizar uma região em detrimento de outra, como pode ser visto na queixa de Daisson (1925, p. 9-10, sublinhados nossos), dirigida a Affonso de Taunay (1876-1958):

Pouco tenho viajado escreve [o autor está parafraseando Affonso de E. Taunay] -nas diversas zonas do paiz a não ser quanto a S. Paulo, Rio de Janeiro e Minas, mas sempre me succedeu descobrir regionalismos, por vezes numerosos, ao percorrer novas directrizes, sobretudo, pondo-me em contacto com pessoas do povo, caipiras e caboclos. É essa uma historia a que já estamos acostumados e, por isso, não nos admiramos. A's vezes, parece mesmo que o olhar do escriptor carioca não vae além de S. Paulo e de Minas. Alcança a Europa e outros continentes, mas o sul do Brasil é, não raramente, para elle, como se não existisse. Os Estados do Paraná, de Santa Catharina e do Rio Grande do Sul ficam quasi sempre esquecidos. Pois é pena que o sr. Affonso de E. Taunay não tenha ainda viajado pelo Rio Grande do Sul, porque encontraria aqui, não sem sorpreza, uma fonte inexgottavel de termos, em muitos dos quaes nunca ouviu falar, e outros que figuram nos diccionarios, mas com significação differente, ou, melhor ainda, com applicação differente.

Aqui, parece que estamos diante do mesmo tipo de crítica, motivada pelo conflito entre regiões, sejam elas nacionais ou regionais: o brasileiro Taunay ${ }^{79}$ reclamava que o português Cândido de Figueiredo (1846-1925) não dava o devido valor às contribuições brasileiras à Língua Portuguesa, mas o gaúcho Augusto Daisson (? - ?) reclamava do mesmo Taunay, pois considerava que este menosprezava os brasileirismos produzidos pelos estados do Sul.

Finalmente, é necessário ainda destacar um aspecto. Como demonstramos aqui, é consenso entre os autores que fatores externos à língua são responsáveis pela dialetação. No

\footnotetext{
${ }^{79}$ Afonso Taunay nasceu em Florianópolis, mas passou a infância e início da fase adulta no Rio de Janeiro, estudou no tradicional Colégio Pedro II e depois na Escola Politécnica do Rio de Janeiro, onde se formou engenheiro. Logo após concluir o curso, mudou-se para São Paulo e exerceu vários cargos públicos, como professor da Escola Politécnica da USP e depois da Faculdade de Filosofia, Letras e Ciências Humanas da mesma universidade, quando abandona a engenharia em favor dos estudos historiográficos. Dessa forma, o autor, apesar do local de nascimento, pertencia ao eixo cultural Rio-São Paulo.
} 
entanto, apesar dessa premissa, algumas obras optam por realizam suas análises utilizando-se apenas de dados linguísticos, ao passo que outras entrecruzam dados externos, como folclore, história, geografia, aos dados linguísticos, mostrando como aqueles interferem nestes. Tais opções estão ligadas à camada técnica dessas obras, tema a que nos dedicaremos na próxima seção.

\subsection{Descrição de dialetos regionais e sociais}

\subsubsection{Camada técnica}

Como já adiantamos na seção anterior, as obras dialetológicas estão ligadas a dois modelos teóricos diferentes: a Gramática Histórico-Comparada e a Lexicografia. Além disso, apontamos também para o fato de existirem diferentes formas de se lidar com dados linguísticos: uma perspectiva que estuda a dialetação lidando exclusivamente com os dados linguísticos e outra, que se vale de dados externos à língua, estudando os dialetos de um ponto de vista sociocultural. Tal visão se preocupa em incluir, além do corpus linguístico, aspectos como folclore, história, geografia e etnologia, ligados ao dialeto em análise, uma vez que, segundo esse ponto de vista, não é possível estudar um determinado dialeto sem se estudar também tais variáveis extralinguísticas.

Nas obras ligadas ao grupo descrição de dialetos regionais e sociais (cf. Quadro 3A Apêndice A), encontramos as visões que acima sumariamos estruturadas da seguinte forma:

- Obras que estudam os dialetos apenas pela Gramática Histórico-Comparada, sem dados extralinguísticos $(5)^{80}$;

- Obras em que o estudo da língua está inserido no conjunto de elementos que formam o folclore daquela determinada região e/ou grupo social (6);

- Obras que estudam os dialetos apenas pela Lexicografia, sem dados extralinguísticos (25);

\footnotetext{
${ }^{80}$ Os números entre parênteses indicam a quantidade de obras em relação ao tipo de abordagem. Aqui estamos considerando apenas as obras as quais tivemos acesso, ou seja, 36. Quanto às outras 5 obras, infelizmente não conseguimos localizá-las.
} 
Vejamos inicialmente a produção ligada ao primeiro tipo de abordagem.

Quadro 18 - Estudo dos dialetos: apenas Gramática Histórico-Comparada

\begin{tabular}{|c|l|}
\hline AMARAL, Amadeu & - O dialeto caipira (1920) $\boldsymbol{\beta}$ \\
\hline MARROQUIM, Mário & - A lingua do nordeste (Alagôas e Pernambuco) (1934) $\boldsymbol{\beta}$ \\
\hline NASCENTES, Antenor & - O linguajar carioca em 1922 (1922) $\boldsymbol{\beta}$ \\
\hline $\begin{array}{c}\text { PAES, Elpidio Ferreira } \\
\text { TEIXEIRA, José de } \\
\text { Aparecida }\end{array}$ & - O falar mineiro (1938) $\boldsymbol{\beta}$ \\
- Estudos de dialetologia portuguesa (1944) & \multicolumn{1}{|c|}{$\boldsymbol{\beta}$} \\
\hline TOTAL & $\mathbf{5}$ obras \\
\hline
\end{tabular}

No capítulo 4, mostramos o importante papel que têm os metaplasmos (metátese, síncope, assimilação, etc) para o estudo da evolução fonética. Aqui, no entanto, Amadeu Amaral, n'O dialeto caipira, utiliza tais categorias de análise para explicar processos sincrônicos da língua, ou seja, a comparação que faz entre o dialeto caipira e o Português-padrão.

\section{$3^{\circ}$. MODIFICAÇÕES ISOLADAS}

26. Além das alterações francamente normais, que ficaram registradas ha toda uma multidão de modificações acidentais, de que daremos alguns exemplos:

a) abrandamento: guspe = cuspo, musga = música. É de notar que nos esdrúxulos cócega, náfego e látego se dá o contrário: cócica (e coçca), náfico, lático.

b) assimilação - progressiva: Carro = Carlos; regressiva: birro = bilro; açcançá = alcançar; digêro $=$ ligeiro $(g$ palatal explosivo $=d g)$.

c) Aférese: (a)parece, (i)magina, (ar)rependeu, (ar)ranca, (a)lambique, (al)gibêra.

d) Síncope: pês (se) co = pêssego, mus(i)ga = música, isp(i)rito, $c a(\mathrm{~s}) t i c ̧ a r$,

Jeró(ni)mo, ridíc(ul)o.

e) Apócope: Ligite (mo).

f) Prótese: alembrá = lembrar, avoá = voar, arripiti $=$ repetir .

g) Epêntese: rec-u-luta, Ing-a-laterra, g-a-rampo.

h) Epítese: paletor.

i) Metátese: perciso, pertende, purcissão, partelera, agardecê, aquerditá (r).

i) Hipértese: agordão (algodão), cardaço, chacoalhá(r), largato. (AMARAL,

1955[1920], p.53-54, negritos do autor e sublinhados nossos)

\footnotetext{
${ }^{81}$ Aborda o falar goiano.
} 
Esse tipo de abordagem aparece da mesma forma nas obras de Antenor Nascentes (1886 - 1972), Mário Marroquim (1896 - ?) e José A. Teixeira (? - ?). Com efeito, no trecho a seguir, Nascentes (1953[1922], p.64, sublinhado nosso) deixa bastante claro o uso que faz do instrumental teórico-analítico da gramática histórica para seus estudos dialetológicos da sincronia: "SINCOPE. A sincope das postonicas que se deu na passagem do latim para o português, continua atuando na classe inculta, com grandes alterações na estrutura das palavras: relampago-relampo, passaro-passo, arvore-arve, marmo-re-marme ${ }^{82}$, polvora-porva."

Seguindo o mesmo modelo, Marroquim (1934, p. 92) aponta a importância da assimilação no linguajar nordestino: “Assimilação. Abundam os exemplos de assimilação no linguajar nordestino e é esse um dos fatores mais gerais de modificação: Alamanha, mustura, Cisso de Cicero através de Cirço, tabalião, premessa, Carro = Carlos, Jinuáro, jinela."

Passemos, agora, à análise do segundo tipo de abordagem que identificamos neste grupo, ou seja, das obras em que o estudo da língua está inserido no conjunto de elementos que formam o folclore daquela determinada região e/ou grupo social.

\section{Quadro 19 - Estudo dos dialetos via folclore}

\begin{tabular}{|c|l|}
\hline $\begin{array}{c}\text { MACHADO } \\
\text { FILHO, Aires } \\
\text { da Mata }\end{array}$ & - O negro e o garimpo em Minas Gerais (1943) $\boldsymbol{\beta}$ \\
\hline $\begin{array}{c}\text { MOTTA, } \\
\text { Leonardo }\end{array}$ & - Cantadores: poesia e linguagem do sertão cearense (1921) $\boldsymbol{\beta}$ \\
& - Violeiros do norte: poesia e linguagem do sertão nordestino (1925) $\boldsymbol{\beta}$ \\
& - Sertão alegre: poesia e linguagem do sertão nordestino (1928) $\boldsymbol{\beta}$ \\
\hline $\begin{array}{c}\text { RIBEIRO, } \\
\text { Joaquim }\end{array}$ & - Folklore dos bandeirantes (1946) $)^{83} \boldsymbol{\beta}$ \\
\hline $\begin{array}{c}\text { TESCHAUER, } \\
\text { Carlos }\end{array}$ & $\begin{array}{l}\text { - Poranduba rio-grandense: investigações sobre o idioma fallado no } \\
\text { Brarticularmente no Rio Grande do Sul (1921_2 }{ }^{\mathrm{a}} \text { ed.) }\end{array}$ \\
\hline
\end{tabular}

\footnotetext{
${ }^{82}$ Em nota de rodapé, Nascentes credita "marme" à obra Esquisse d'une dialectologie portugaise, de Leite de Vasconcellos. Há também frequentes citações a essa obra n'O dialeto caipira, como vimos.

${ }^{83}$ Neste livro, há três capítulos, um deles é chamado "Dialetologia bandeirante", característica que nos fez incluir esta obra em nosso levantamento.

${ }^{84}$ Esta obra aborda apenas aspectos linguístico e tem 81 páginas. Localizamos outra, publicada em 1929 , de 468 páginas, em que o subtítulo é extraído, ficando apenas Poranduba riograndense. Nessa, não só aspectos dialetológicos são tratados, mas também outros aspectos culturais do Rio Grande do Sul. Na obra mais ampla, um dos capítulos tem exatamente o mesmo nome que foi atribuído ao subtítulo da obra de 1921 .
} 
A respeito da pertinência de se incluir os estudos das línguas em uma obra de folclore, Teschauer (1929, p.39, sublinhado nosso) diz que:

Pode parecer, á primeira vista, ter pouca relação com o objeto da "Poranduba" o assumpto acima proposto [investigações sobre o idioma falado no Brasil e particularmente no Rio Grande do Sul, título do capítulo 2 da obra]. Longe porém de sahir das suas raias este estudo vae ter a um archivo onde jazem documentos historicos tanto mais valioso quanto menos conhecidos e apreciados. Ninguem sabe melhor isto do que os historiadores modernos que não julgam conhecer a historia de um povo si não conhecem a fundo a sua lingua e até a historia e ethnologia dela.

Ao analisarmos estas obras, pudemos notar a predominância dos estudos de vocabulário e, em alguns casos, de pronúncia. Tomemos como exemplo a obra $\mathbf{O}$ negro e o garimpo em Minas Gerais, de Aires da Mata Machado Filho (1909-1985), publicado em 1943. Na "Advertência", o autor nos informa que a obra é fruto do interesse que lhe foi despertado por ouvir "umas cantigas em língua africana", quando passava férias em São João da Chapada, município de Diamantina. Ainda segundo o autor, esse interesse fez com que ele fosse "ter com um dos conhecedores, o meu bom amigo João Tameirão, que, com solicitude, satisfez à minha curiosidade de aprender cantigas" (MACHADO FILHO, 1943, p.8). Há, portanto, na obra a reprodução e o estudo de várias cantigas, rezas e demais cânticos colhidos na região de São João da Chapada. Vejamos uma delas, entremeada por um comentário de Machado Filho:

Vissungos

PADRE-NOSSOS

I

SOLO:

Otê! Pade-Nosso cum Ave-Maria, securo camera qui t'Angananzambê, aiô...

CÔRO:

Aiô!... T’Angananzambê, aiô!...

Aiô!... T’Angananzambé, aiô!...

Ê calunga qui tom' ossemá,

ê calunga qui tom' Anzambi, aió!... 
(O negro, ao começar o trabalho, pede a Deus e a Nossa Senhora que abençoem o seu serviço e a sua comida). Bom exemplo de sincretismo religioso. Com o Padre-Nosso, começavam os negros as séries de vissungos. Servia também, e ainda serve, nas festas de mastro.

II

\author{
Ai! ai! ai! ai! \\ Pade-Nosso cum Ave-Maria, \\ qui tá Angananzambê-opungo. \\ Ei! curietê! \\ Ai! ail ai! ai! \\ Pade-Nosso cum Ave-Maria \\ qui tá Angananzambê-opungo \\ Ei! dunduriê ê
}

etc. (MACHADO FILHO, 1943, p.69).

Ao longo da obra, o autor vai apresentando essas cantigas e comentando-as. Na sequência, insere também as respectivas partituras, para que o leitor possa compreender a melodia com que eram cantadas ou entoadas. Nos dois últimos capítulos, o autor apresenta um "vocabulário do dialeto crioulo sanjoanense" e uma síntese em que comenta aspectos do "dialeto crioulo de São João da Chapada". Nesse último, aponta para um aspecto importante quanto à relação das línguas africanas analisadas com o Português.

O exame dos termos das cantigas revela seu carater banto. De fato, alguns conhecedores da "língua", com quem conversámos, falam em língua d'Angola e língua banguela (nunca dizem benguela), embora também se refiram ao nagô. Os textos, pela maior parte, são vazados em ambundo, mas, pelo menos em uma das canções, encontram-se termos nagô, conforme ficou indicado. As cantigas afronegras de mineração distribuem-se em três grupos: o primeiro constituido de peças em puro ambundo; o segundo, mais numeroso, com palavras nativas dos africanos, misturadas com vocábulos vernáculos; o terceiro, em puro português do Brasil. (...) O canto contribuiu para conservar entre eles a língua materna. São cantigas trazidas da pátria distante, aqui naturalmente transformadas. E a tríplice divisão atrás indicada traça os estágios sucessivos da adaptação do negro ao idioma assimilado. (MACHADO FILHO, 1943, p.113, sublinhado nosso).

Finalmente, vejamos como são realizadas as análises nas obras que estudam os dialetos apenas pela Lexicografia, sem dados extralinguísticos.

CAFUA - Prisão de colegiais eqüivalente a "quarto escuro". Morais a regista no Rio-Grande. Etim. - Quimbundo. Origina-se de kufundu. 
CAFUNDÓ - Distância. Longínquo. Penetração. Têrmo da geografia do RioGrande. Arroios e linhas coloniais em Bento-Gonçalves, Taquari e Montenegro. Etim. Quimbundo. Deriva-se de kufundu, segundo Mendonça, cravar, com a substituieção do prefixo ku por ka e dissimilação do u final em $\mathbf{0}$.

CAFUSO - Mestiço de índio e negro. Etim. - Nelson de Sena põe suas dúvidas quanto a procedência africana de cafuso.

CALOMBO Diz Morais: "Descendência degenerada do gado zebú. O boi calombo, abundou outrora no Rio-Grande mas atualmente desapareceu. Era um produto da mestiçagem praticada à revelia dos preceitos zootécnicos. A mestiçagem deve aquí ser tomada no sentido científico, e não de cruzamento. - Inchação, formando saliência". Etim. - Quimbundo, seg. M. Soares, de kalumba. (LAYTANO, 1936, p.37, negritos do autor e sublinhados nossso)

Com efeito, a técnica envolvida é a mesma daquela tradicionalmente usada na Lexicografia, ou seja, a organização da obra em verbetes dispostos em ordem alfabética, (i) definição do significado da palavra de entrada, (ii) sua origem etimológica e, em alguns casos, (iii) algum tipo de abonação, como menção a outro dicionário ou obra de referência.

A diferença, no caso específico das obras dialetológicas, é que todas essas características apontadas são colocadas, evidentemente, em prol da descrição dialetológica. Isso pode ser verificado no trecho acima, extraído da obra Os africanismos no dialeto gaúcho, de Dante de Laytano (1908-2000). Nestes verbetes, a ligação entre as duas variáveis presentes no título africanismo e Rio Grande do Sul - está garantida pela explicação etimológica, vinda, nestes casos, do Kimbundo e pela menção de que tais termos são utilizados no referido estado brasileiro. Há ainda referência a um especialista nos estudos africanistas, Nelson de Senna (1876 - 1952), quando Laytano manifesta sua incerteza em relação à origem africana da palavra cafuso.

Cumpre, por fim, destacar que nem todas as obras lexicográficas presentes neste grupo seguem a mencionada estrutura, sendo que algumas são mais sintéticas ou mesmo organizadas em formato de listas de palavras.

\subsubsection{Camada documental}

Swiggers (2004, p.134) diz que a camada documental corresponde "a la documentación lingüística y filológica (numero de lenguas, tipos de fuentes y de datos) sobre la cual se basa el 
estudio lingüístico". Assim estabelecido, analisaremos essas duas variáveis apontadas por Swiggers quanto à documentação linguística, isto é: (i) o número de línguas presente nas obras e (ii) o tipo de fontes e de dados utilizados.

Em relação à primeira variável, constatamos que as obras dialetológicas se utilizam de documentação nas seguintes línguas:

- Português, naturalmente;

- Línguas africanas que influenciaram o Português, como o Kimbundo, por exemplo. Em benefício da concisão do texto, não repetiremos outros trechos em que essa influência é apontada, uma vez que tal processo já foi demonstrado na página anterior, nos verbetes das palavras "cafua", "cafundó" e "calombo", todas de origem kimbunda, derivadas de $k u f u n d u$, no caso das duas primeiras, e de kalumba, relativamente ao último termo. Como já apontamos, esses exemplos estão em Laytano (1936, p.37);

- Línguas indígenas que influenciaram o Português, como o Tupi-Guarani. Nesse caso, apresentaremos, mais à frente, o trecho em que tal influência é apontada.

Também em benefício da concisão do texto, não analisaremos separadamente as obras quanto às línguas, pois aproveitaremos a segunda variável, isto é, o tipo de fontes e de dados utilizados, para demostrar como as línguas acima mencionadas são utilizadas pelos dialetólogos do Português do Brasil.

Para estudar a camada documental, tal como fizemos quanto à camada técnica, seguiremos a divisão que realizamos entre as obras dialetológicas lexicográficas e as obras dialetológicas não-lexicográficas (cf. Apêndice B - Quadros 16B e 17B, respectivamente). Vejamos, então, as obras do primeiro grupo.

Com efeito, ao analisarmos as 25 obras relacionadas a esta seção, pudemos identificar uma característica bastante marcante: o uso da pesquisa documental para a elaboração dos verbetes.

Quanto à forma como essa pesquisa aparece nos verbetes, verificamos algumas variações, o que é natural em um universo de 25 trabalhos. Muitas delas apresentam uma bibliografia (algumas suscintas e outras bastante extensas) e depois os livros ali mencionados vão aparecendo ao longo dos verbetes, indicando, assim, a fonte de pesquisa. Em outras, não há bibliografia, mas menção direta das obras nos próprios verbetes. Em outras, ainda, os materiais consultados vão sendo citados ao longo do prefácio ou outro texto introdutório, momento em que o autor aproveita para comentar a importância dessas obras para a sua pesquisa. 
Já em relação à natureza das publicações utilizadas na confecção desses livros que analisamos, notamos também algumas diferenças de perfil: (i) há considerável uso de literatura regional para a coleta de termos específicos de uma região, (ii) menção a outros trabalhos dialetológicos, (iii) além do uso de bibliografia técnica relativa ao tema da obra, como a menção a trabalhos de botânica e zoologia para a elaboração de um dicionário sobre o linguajar amazônico, por exemplo.

Vejamos, agora, trechos que exemplificam os três perfis acima mencionados, começando pelo uso da literatura regional para abonar um termo. No caso abaixo, o autor recorre à reprodução integral do poema.

AGALHAS, subs. velhaco, esperto, finorio. É empregado sempre no plural.

Se tinha agalhas o negro!

Com elle trovar quem ousa?

Não se cansa nem repousa;

Eu é que agora abria o ôlho:

Aonde este negro zarolho

Foi aprender tanta cousa?

ARAUJO GÓES, Manduca cypriano (CALLAGE, 1926, p.10, sublinhados nossos)

Essa referência literária também pode vir de forma mais suscinta.

ACUCHILLAR, v. arremetter de faca alguem; esfaquear. Voc. platino, de cuchillo, faca ou facão. - "e ali mesmo lo acuchilhei, como rez, no sangradouro..." (Alcides Maya, Alma Barbara, pag. 85.) (CALLAGE, 1926, p.10, itálicos do autor e sublinhados nossos)

Quanto ao segundo tipo de material utilizado na elaboração dos verbetes, ou seja, o uso e a referência a outros trabalhos dialetológicos, temos abaixo o exemplo do Vocabulário dos pescadores do Rio-Grande-Sul: etimologia dos têrmos praieiros usados na costa nordeste, de Dante de Laytano (1908 - 2000), em que são citadas três obras dialetológicas.

COBREIRO - Def. Ferida. Etimol. Luiz Carlos de Morais a recolhe, no seu "Vocabulário Sul-Rio-Grandense": Ferida que alastra pelo corpo, principalmente nas crianças, o que é atribuído ao fato de ter passado uma cobra por sobre a roupa, quando estendida no quarador, conforme a crendice popular Teschauer, no "Vocabulário Nacional" R.-G.-do-Sul: "erupcão cutânea que dizem provir de um animal peçonhento que passou pelo corpo ou pela roupa que se vestiu". $\underline{\text { Amadeu }}$ Amaral nos dá, no "Dialeto caipira": cobrero, cobrelo (cobra e suf. eiro). Cobrelo aparece no Dic. de Morais, como "Doença que se crê proceder de passar cobra por cima das camisas, ou roupa de vestir; mas é espécie de herpes; herpes miliares". Os dicionaristas modernos dão a palavra como erupção cutânea, zona (cobrero in C. João de Deus, etc.). Cobrelo - pequena cobra. Erupção na pele atribuída pelo vulgo à passagem de cobra pelo fato que se vestiu. Fig. I, 475. (LAYTANO, 1937, p.17, sublinhados nossos) 
Finalmente, quanto à utilização de bibliografia técnica relativa ao tema da obra dialetológica, terceiro tipo de abonação que mencionamos, reproduzimos um exemplo da Contribuição ao estudo do vocabulario amazonense, de Alfredo Augusto da Matta (1870 1954), verbete em que o autor, para falar de uma fruta típica da região, utiliza-se de um artigo científico identificado como "Monographia sobre o Ananás", publicado nos "Anuários Cientificos Paraguaios”, em 1919. Além da referência bibliográfica, este verbete nos mostra um caso em que a influência de uma língua indígena no Português é apontada, sendo, neste caso, o Guarani.

\begin{abstract}
Abacaxi (Bot.) -Bromeliacea Ananas sativus Lintlev diversas variedades (Arruda, Mart., Peckolt, Corrêa, Hume \& Miller). Grupo especifico por seu fructo (syncarpo) cylindro de gado, com variedades até horticolas e bastante apreciadas todo o Brasil. Lembram pelo aspecto volumosa espiga de milho. Lê-se em Bertoni ser avachi o milho em guarani, e avacachi corruptela do proprio guarani, de que proveio a vulgarisação de abacaxi, em quasi todo o Brasil. Dizem tambem provir do tupi yba.fructo e cati cheiroso. Encontram-se o abacaxí roxo var. pyramidalis com a sub-variedade macrocarpus Dony e a branca-albus Mill. (An. Cientificos Paraguaios, 1919, n. ${ }^{\circ}$ 4, monographia sobre o Ananás). (MATTA, 1938, p.34, sublinhados nosso)
\end{abstract}

Outra fonte de pesquisa para subsidiar a produção das obras lexicográficas com interesse dialetológico é a coleta de termos, acepções e usos relativos ao tema do livro em preparação, via registro pessoal do autor. Tal expediente pareceu-nos funcionar como dado subsidiário, sendo, portanto, minoritário ante a pesquisa bibliográfica. Vejamos menções, nos prefácios, a esse tipo de prática:

O material bruto que aí está, ainda que lhe faleça outros méritos, tem, por certo, uma virtude: foi todo éle colhido, com fidelidade, durante mais de um decênio, na tradição oral do povo sertanejo junto aos confins geográficos de três estados: São Paulo, Minas e Mato-Grosso, tendo como pivot o município paulista - Tanabí - que elegemos para nosso habitat. (OLIVEIRA, 1940, p.11, sublinhados nossos)

A titulo de modesta contribuição para o estudo das transformações por que vae passando a lingua portugueza no Brazil, ha cerca de quatro annos, iniciamos a compilação deste nosso VOCABULARIO. Todos os vocabulos que aqui figuram, muitos dos quaes completamente desconhecidos no sul, são de uso corrente nos Estados do norte e especialmente no Ceará, onde os colhemos das nossas relações directas com o povo, cuja pittoresca linguagem, eriçada de barbarismos, não foi ainda desfigurada pela macaqueação do extrangeiro. (MAGALHÃES, 1911, p.7, sublinhados nossos)

Como já dissemos anteriormente, o que percebemos, pela análise desses 25 livros, é que as declarações, como as acima reproduzidas, se misturam com aquelas em que o autor cita e diz 
o quão devedor é de outras publicações, sejam elas de literatura regional, dialetologia ou técnica sobre o tema da obra. Com efeito, tais expedientes empregados na composição dessas obras não nos parecem muito diferentes dos utilizados pela lexicografia tradicional, ou seja, a entendida aqui como não dialetológica.

Optamos por iniciar esta seção, pela análise documental das obras dialetológicas lexicográficas. Concluída esta parte, passaremos agora às obras não-lexicográficas, que, por sua vez, estão divididas em dois grupos: Estudo dos dialetos - Apenas Gramática Histórico-Comparada e Estudo dos dialetos via folclore (cf. Quadros 17 e 18, respectivamente, seção 5.4.1 [camada técnica]).

Quanto à obtenção de fontes para a análise dos respectivos dialetos, percebemos que não há grandes diferença em relação ao que apontamos para as obras lexicográficas, ou seja, as fontes são, predominantemente, (i) textos literários regionais ou universais, (ii) outras obras dialetológicas e (iii) registro pessoal do autor a respeito do dialeto em estudo.

Do grupo ligado à Gramática Histórico-Comparada, tomemos como exemplo a análise que Marroquim (1934, p. 174-175, grifos do autor) faz do uso do "pronome nominativo", na região nordeste, comparativamente ao uso no sul do país. Para o caso nordestino, utiliza-se de uma cantiga, texto da tradição literária oral, coletada por Leonardo Motta (1891-1948), para a sua obra Cantadores: poesia e linguagem do sertão cearense, publicada em 1921.

A tendencia para o uso do pronome nominativo faz que o matuto, da mesma forma que altera a sintaxe portuguesa com o fim de empregar o caso reto, se conserve a ela fiel quando a língua culta autoriza o uso daquele caso.

"Me leve pr'onde quizé

Pr' eu fazê' todo os mandado

Pru mode eu brocá de foice"...

Anselmo Vieira - "Cantadôres", 211.

Por outro lado, para ilustrar o uso no sul do país, além de mencionar o que disseram Nascentes e Amaral, recorre à citação de um trecho de Macunaíma, de Mário de Andrade (18931945).

Entretanto, no sul do país, segundo observação e testemunho de Antenor Nascentes e Amadeu Amaral, nessas orações, o pronome toma, no dialeto, o caso obliquo: "isto é para mim levar", "Ele trôxe uma fruita para mim comê".

"Jiguê, meu companheiro Jiguê, quando você volta do mercado bate primeiro na porta bate todos os dias uma porção de tempo pra mim ficar contente e ir cozinhar a macaxeira". 
Mario de Andrade - "Macunaima" - pg. 203. (MARROQUIM, 1934, p.175, itálicos do autor)

Finalmente, o autor conclui reclamando do fato de o filólogo português Júlio Moreira (1854-1911) generalizar o uso "pra mim + verbo" como uma característica geral do Brasil, apontando seu desconhecimento quanto aos dialetos nordestinos.

Essa construção é desconhecida no nordéste. Por não haver sido ainda estudado o dialeto desta região do Brasil, Julio Moreira [Estudos da Lingua Portuguêsa, pg.26] atribúi ao Brasil, em geral, essa sintaxe que aqui não existe. "Em Portugal o sujeito de uma oração infinitiva dependente da preposição para é a forma do nominativo, eu, que no Brasil é substituida por mim". (MARROQUIM, 1934, p.175, negritos nossos)

Passemos, agora, à análise do segundo grupo, aquele que estuda os dialetos via folclore de uma determinada região e/ou grupo social.

Quanto ao tipo de dado linguístico utilizado e à forma empregada para sua obtenção, os trabalhos de Leonardo Mota (1891-1948) seguem na mesma linha do que foi exposto a respeito do livro de Machado Filho (1943, p.69) (cf. 5.4.1 - camada técnica), ou seja, coleta in loco de textos de literatura oral tradicionais de um determinado grupo social, ligados a uma região específica. No caso de um dos livros de Mota, Cantadores: poesia e linguagem do sertão cearense, de 1921, o autor coleta pessoalmente uma grande quantidade de cantigas, cantadas por 8 autores diferentes. Como praticamente o livro inteiro é formado por esses textos, o autor vai comentando essa produção oral ao longo da obra e, no final, insere um vocabulário relativo às cantigas. Processo semelhante ocorre com as outras obras de Mota, Violeiros do norte: poesia e linguagem do sertão nordestino, de 1925, e Sertão alegre: poesia e linguagem do sertão nordestino, de 1928.

Com efeito, podemos dizer que estas obras de Machado Filho e Mota constituem importantes corpora de matéria linguística. Esse aspecto é merecedor de destaque, já que nesse período, até onde pudemos avaliar, predominava o uso de material bibliográfico, ou seja, de fontes secundárias para a pesquisa dialetológica, aspecto por nós já destacado anteriormente.

Quanto às demais obras presentes na tabela "Estudo dos dialetos via folclore" (Poranduba rio-grandense, Os ciganos do Brasil e Folklore dos bandeirantes), todas utilizaram predominantemente a pesquisa bibliográfica como fonte para obtenção de seus corpora. No caso do trabalho sobre os bandeirantes, tal opção é natural, uma vez que o autor 
propõe fazer uma dialetologia de um período bastante recuado historicamente, propondo-se, inclusive, a fazer uma "reconstituição do dialeto dos bandeirantes".

\subsection{Descrição dialetológica do Português do Brasil}

\subsubsection{Camada técnica}

Quanto às obras analisadas nesta seção, ou seja, aquelas dedicadas à descrição dialetológica do Português do Brasil, no que diz respeito à camada técnica, reafirmamos o que dissemos em relação às obras de descrição de dialetos regionais e sociais (cf. seção 5.4.1). Isso equivale a dizer que tais publicações estão ligadas a dois modelos teóricos diferentes: a Gramática Histórico-Comparada e a Lexicografia. Além disso, apontamos também para o fato de existirem diferentes formas de se lidar com dados linguísticos: uma perspectiva que estuda a dialetação lidando exclusivamente com os dados linguísticos e outra, que se vale de dados externos à língua, estudando os dialetos de um ponto de vista sociocultural. Tal visão se preocupa em incluir, além do corpus linguístico, aspectos como folclore, história, geografia e etnologia, ligados ao dialeto em análise, uma vez que, segundo esse ponto de vista, não é possível estudar um determinado dialeto sem se estudar também tais variáveis extralinguísticas.

Embora exista a coincidência dos aspectos acima apontados, encontramos, nas obras relativas à dialetação do Português do Brasil, um tipo de produção não encontrado no grupo anterior. Estamos nos referindo a um tipo de obra em que prevalece o trabalho de viés teórico, ensaístico em alguns casos, no qual o autor se limita a comentar, concordando ou discordando, da bibliografia dialetológica brasileira anteriormente produzida, acrescentando um ou outro ponto autoral. Nesse tipo de produção, o trabalho de análise da língua acaba sendo diluído ao longo dos comentários acima mencionados. Trata-se, principalmente, de marcar uma posição em face da polêmica.

Assim, esquematicamente, podemos dizer que as técnicas de análise linguística que são utilizadas nas obras ligadas ao grupo de descrição dialetológica do Português do Brasil (cf. Quadro 3A - Apêndice A) são as seguintes: 
- Obras que estudam os dialetos apenas pela Gramática Histórico-Comparada ou outro modelo teórico, sem dados extralinguísticos $(6)^{85}$;

- Obras em que o estudo da língua está inserido em um conjunto de aspectos extralinguísticos que influenciaram na formação do Português do Brasil, como a história, a geografia, a etnologia e o folclore. Nessas obras, as técnicas de análise são da Gramática Histórico-Comparada ou da Lexicografia (8);

- Obras de viés teórico, ensaístico (13);

- Obras que estudam os dialetos apenas pela Lexicografia, sem dados extralinguísticos (18).

Vejamos, inicialmente, as publicações do primeiro tipo de abordagem e depois algumas análises a elas relacionadas.

Quadro 20 - Estudo dos dialetos: apenas Gramática Histórico-Comparada ou outro modelo teórico $^{86}$

\begin{tabular}{|c|l|}
\hline JUCÁ (filho), Cândido & $\begin{array}{l}\text { - Língua nacional: as diferenciações entre o português de } \\
\text { Portugal e o do Brasil autorizam a existência de um ramo } \\
\text { dialetal do português peninsular? (1937) } \boldsymbol{\beta}\end{array}$ \\
- A pronúncia brasileira (1939) $\boldsymbol{\beta}$ \\
\hline $\begin{array}{c}\text { MARTINS, Maria de } \\
\text { Lourdes de Paula }\end{array}$ & $\begin{array}{l}\text { - A influência indígena no Português do Brasil: estudo } \\
\text { do vocabulário (1944) (T) } \boldsymbol{\beta}\end{array}$ \\
\hline $\begin{array}{c}\text { MELO, Gladstone Chaves } \\
\text { de }\end{array}$ & - Língua do Brasil (1946) ${ }^{87} \boldsymbol{\beta}$ \\
\hline $\begin{array}{c}\text { MONTEIRO, Clóvis } \\
\text { RAIMUNDO, Jacques }\end{array}$ & - Da influência do Tupi no Português (1926) (T) ${ }^{88} \boldsymbol{\beta}$ \\
\hline
\end{tabular}

\footnotetext{
85 Os números entre parênteses indicam a quantidade de obras em relação ao tipo de abordagem. Aqui estamos considerando apenas as obras as quais tivemos acesso, ou seja, 45. Quanto às outras 5 obras, infelizmente não conseguimos localizá-las.

${ }^{86}$ As obras de Jucá (filho) realizam suas análises sobre o Português do Brasil valendo-se da gramática tradicional. Por ser o único autor que se vale de tal modelo, optamos por não analisar trechos de sua obra, já que ela não representa uma prática recorrente no programa de investigação dialetológico do início do século XX, mas sim uma postura individual desse autor.

${ }^{87} \mathrm{O}$ ano de edição do livro é 1946, porém destaca o autor - no prefácio à obra datado de 25/1/1945 - que os dois primeiros capítulos foram escritos anteriormente a essas datas: o primeiro, em 1942 e o segundo acabou por não ser publicado na época, o sendo apenas em 1946.

${ }^{88}$ Da tendência na evolução de nosso idioma (1926) e Da influência do Tupi no Português (1926) - apresentados inicialmente como teses - são reunidos e publicados como livro, em 1931, sob o título Português da Europa e Português da América: aspectos da evolução do nosso idioma.
} 


\begin{tabular}{|c|l|}
\hline TOTAL & 6 obras \\
\hline
\end{tabular}

Legenda: (T): Tese

Como vimos no capítulo 4, os autores das gramáticas históricas recorriam à análise dos metaplasmos para o estudo da evolução fonética. Além dos processos fonéticos, também vimos as técnicas envolvidas quanto à morfologia e a sintaxe. Com efeito, já dissemos que os dialetólogos se valeram do instrumental analítico da Gramática Histórico-Comparada para descrever e analisar seus corpora, ou seja, os dialetos. Já vimos esse uso com as obras dialetológicas de descrição regional e social e agora veremos sua aplicação nas obras de descrição dialetológica do Português do Brasil.

Para analisar as influências que o Kimbundo teria exercido sobre o Português do Brasil, Renato Mendonça (1912-1990), na obra A influência africana no português do Brasil, de 1933, abre espaço, embora reduzido, para estudos de natureza fonética e morfológica a respeito do Kimbundo, destacando a influência dessa língua no Português do Brasil. Vejamos um exemplo de fonética.

As tónicas, em geral, conservam-se na passagem para o português:

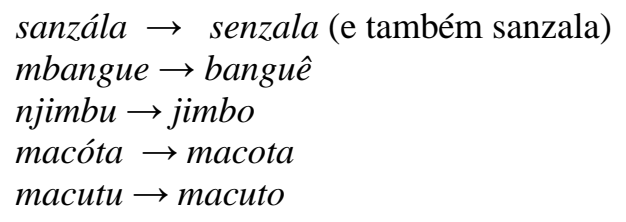

As átonas sofrem alterações:

a) síncope de pretónica:

caricúnda $\rightarrow$ carcunda

b) assimilação:

cakimbu $\rightarrow$ cacumbú

nzangu $\rightarrow$ zungú

cazuli $\rightarrow$ caçula

c) dissimilação muito mais comum:

kijila $\rightarrow$ quezila

kitútu $\rightarrow$ quitute

mbirimbau $\rightarrow$ marimbau

d) $\underline{u \text { final passa a } o \text { surdo em português, } u \text { medial gera } i \text { algumas vezes: }}$

nguzu $\rightarrow$ guzu

macutu $\rightarrow$ macuto

lubambu $\rightarrow$ libambo

munhoca $\rightarrow$ minhoca

(...) (MENDONÇA, 1948[1933], p.96-97, sublinhados nossos) 
Quanto ao nível morfológico, Mendonça (1948[1933], p.125, sublinhados nossos) aponta para a pouca influência deixada pelas línguas africanas, o que ele justifica pelas "profundas diferenças entre as línguas indo-europeias e africanas". O constante recurso à comparação entre as línguas, como apontado no trecho abaixo, é um outro indício de valorização de técnicas da Gramática Histórico-Comparada. Nesse caso, são curiosamente confrontados aspectos da fala "dos caipiras e dos matutos" com os de uma criança que fala Francês, em busca de uma maior generalização daquilo que observa em dados particulares.

Na morfologia o negro deixou apenas vestígios o que é explicável pela diferença profunda entre as línguas indo-europeias e africanas. O vestígio mais notável achase no plural conservado pela linguagem dos caipiras e matutos que, deixando o substantivo invariável, dizem sempre: as casa, os caminho, aquelas hora. $\mathrm{O}$ adjunto predicativo entra na mesma regra: as criança tavum quetu, as criação ficarum pestiadu. Um $s$ prostético, nascido da ligação na frase perde este carácter e agregase à palavra: os óio $\rightarrow$ pron. $u$-zó-io e aparece a palavra zóio. Isto também acontece em embora, zimbora: ele foi zimbora. "Há que zano!" ou "Que zano!" é uma expressão do dialecto caipira em que se deu o mesmo. Aliás, isto sucede à criança francesa que diz: un zoiseau porque agrega a oiseau o $s$ da ligação: les oiseaux.

Finalmente, quanto à sintaxe, o autor faz apenas uma breve observação, destacando que nesse nível quase não há influência das línguas africanas no Português do Brasil.

Na sintaxe, a influência africana é ainda menos sensível. Os fenômenos de mais importância seriam os de decalque, em que o negro traduziria suas ideias em português, partindo do seu modo de falar africano. Estes todavia não persistiram nem deixaram de si vestígios. Podemos augurar da sua existência por frases soltas de uma pastoral de D. Correia Neri que assim faz falar um preto: "Por conta de quem camaná, F. não bate caliquaqua?" O Cambône responde: - "Por conta de caussê (“Apud Nina Rodrigues, Os africanos no Brasil, págs. 380-2.”) e mais adiante: "Por conta de quem camaná, F. não tem café cá - tudo?". Nota-se em ambos a partícula $c a$ que é sem dúvida o prefixo denotativo de alguma classe. (MENDONÇA, 1948[1933], p.128, sublinhados nossos)

O recurso aos metaplasmos também pode ser encontrado nas obras que analisam a influência indígena no Português do Brasil. Vejamos um caso, extraído da obra A influência indígena no Português do Brasil: estudo do vocabulário, de Maria de Lourdes de Paula Martins, publicada em 1944.

Após falar da língua tupi-guarani em si, Martins abre capítulo intitulado "A acomodação lingüística no Brasil", em que analisa dois processos de "acomodação": (i) "acomodação portuguêsa do vocabulário indígena" e (ii) "acomodação indígena do vocabulário português", segundo os termos da autora. 
Esse processo de alteração linguística em função do contato entre duas civilizações diferentes é assim destacado por Martins (1944, p.21): “A concorrência das línguas portuguêsa e tupi-guarani, no Brasil, criava idêntica situação: verificaram-se, com efeito, alterações no vocabulário assimilado pelo ádvena e alterações no vocabulário assimilado pelo íncola". $\mathrm{Na}$ sequência, sob o título "acomodação portuguêsa do vocabulário indígena", a autora apresenta uma lista de dez processos envolvidos nesse processo de acomodação, entre os quais uma lista de metaplasmos.

\section{Metaplasmos:}

a) aférese: a akangusú.........canguçu isabitú..............sabitu, bitu

b) prótese: guapé.............. aguapé mandupí...........amendoim

c) síncope: kabureýba......... cabreúva karaguata............crautá guyra-húna.........graúna Tạaaratýba.......... Traituba

d) epêntese: kaabók...........caboclo

e) transposições: massampará/ massarambá murundu/ munduru

9. Dissimilações: jurutũi............jurịti posóka...........paçoca
typyóka.........tapioca

Martins (1944, p.23, sublinhados da autora e negritos nossos)

Vejamos outro exemplo em que a Gramática Histórico-Comparada é utilizada para analisar a influência africana no Português do Brasil, neste caso, para explicar um fenômeno visto no registro popular do Português, a semivocalização do fonema palatal molhado $l h$.

Considera [Renato] MENDONÇA como de origem africana a semivocalização do fonema palatal molhado $l h$, que se observa na pronúncia popular de certas regiões do Brasil: muyé, por mulher; fiyo, por filho; paya, por palha, etc. O mesmo fato é apresentado por alguns tupinistas como fruto de ação da língua indígena. E, quando nos ocupamos deste último tema, vimos que a transformação $l h>y$ é românica, podendo-se pois explicá-la sem pedir interferência da "língua geral" ou dos idiomas africanos. Sem embargo, porém, de ser evolução românica a $l h>y$, sou inclinado a explicá-la, aqui no Brasil, por influência africana, uma vez que o fato ocorre de regra nas zonas mais africanizadas, sendo quase geral num ponto intensamente trabalhado dos negros, S. João da Chapada, em Minas, segundo nos informa AIRES DA MATA MACHADO (O negro e o garimpo em Minas Gerais, pág. 115). (MELO, 1946, p.65) 
Quanto à morfologia, Renato Mendonça (1912-1990) apresenta explicações a respeito da formação de palavras do Português do Brasil sob influência africana.

\begin{abstract}
A maioria dos substantivos derivados [do Português] são híbridos formados de um radical africano a que se apôs um sufixo vernáculo: xuxusada, quitandeiro, quiabento, quituteiro, maxixeiro. Um termo muito usado entre os negros quilombola, aplicado ao escravo fugido para o quilombo, apresenta a mesma natureza híbrida, denunciada pelo sufixo latino - ola. Um vestigio em nossa morfologia das línguas africanas se encontra em algumas palavras, onde o prefixo ca- indica ainda o diminutivo: camondongo (rato pequeno), calunga (bonequinho), caçula (filho mais novo, o menor), calombo (tumor pequeno), cacimba (poço de dimensões reduzidas para tirar agua), carimbo (sinête ou chancela). (MENDONÇA, 1936, p. 191, itálicos do autor e sublinhados nossos)
\end{abstract}

Além das técnicas da Gramática Histórico-Comparada, dissemos que outras três também foram utilizadas nas obras que reunimos nesta seção. Passemos agora àquelas em que além da língua, outras variáveis são também consideradas na análise, como a cultura, a história, o folclore, etc.

Quadro 21 - Estudo dos dialetos via folclore, história, geografia, etc

\begin{tabular}{|c|c|}
\hline CASTRO, Eugenio de & - Geographia linguística e cultura brasileira (1937) $\boldsymbol{\beta}$ \\
\hline $\begin{array}{l}\text { CHINA, José B. } \\
\text { D’Oliveira }\end{array}$ & $\begin{array}{l}\text { - Os ciganos do Brasil: subsidios historicos, ethnographicos } \\
\text { e linguisticos (1936) } \Sigma\end{array}$ \\
\hline MENDONÇA, Renato & $\begin{array}{l}\text { - A influência africana no português do Brasil (1933) } \boldsymbol{\beta} \\
\text { - O português do Brasil: origens, evoluções, tendências } \\
\text { (1936) } \boldsymbol{\beta}\end{array}$ \\
\hline RAIMUNDO, Jacques & $\begin{array}{l}\text { - O negro brasileiro e outros escritos (1936) } \Sigma \\
\text { - Guinêanos e sudanenses: etnologia e linguagem (s/d })^{89} \mathbf{\Omega}\end{array}$ \\
\hline RIBEIRO, João & - O elemento negro: historia, folklore, linguística (1939) $\boldsymbol{\beta}$ \\
\hline SENNA, Nelson de & $\begin{array}{l}\text { - Os africanos no Brasil: estudos sobre os negros africanos e } \\
\text { influencias afro-negras sobre a linguagem e costumes do povo } \\
\text { (1938) } \boldsymbol{\beta}\end{array}$ \\
\hline
\end{tabular}

${ }^{89} \mathrm{Na}$ relação de obras do autor, presente n'O negro brasileiro e outros escritos (1936), há menção à referida obra, sem, no entanto, informar sua data de publicação, dizendo apenas que ela ocorrerá em breve. Nessa mesma obra, o autor afirma que Guinêanos e sudanenses "é um trabalhinho suplementar ao nosso $\mathbf{O}$ elemento afro-negro na lingua portuguesa (Rio,1933)”(RAIMUNDO, 1936, p.34) 


\begin{tabular}{|c|l|}
\hline $\begin{array}{c}\text { SILVA NETO, Serafim } \\
\text { da }\end{array}$ & $\begin{array}{l}\text { - Capítulos de história da língua portuguesa no Brasil } \\
(1946) \boldsymbol{\beta}\end{array}$ \\
\hline TOTAL & $\mathbf{9}$ obras \\
\hline
\end{tabular}

Mendonça (1936, p.196, sublinhados nossos), explica que houve influência do folclore negro no Português do Brasil, dado o longo período da escravidão. Durante esse tempo, as crianças eram cuidadas por negros e negras "de casa", ou seja, aqueles que eram retirados das senzalas para serviram na casas-grandes. De acordo com o autor, esse contato mais íntimo propiciava a transmissão da cultura de origem africana à criança branca, por meio de contos populares, cânticos e demais manifestações folclóricas, que eram ditos em Português, mas também continham palavras de línguas africanas. Para Mendonça, tal contato entre as culturas branca e negra não se limitava a simples incorporação de termos africanos ao léxico do Português do Brasil, mas sim "deixaria por força uma contribuição extensa e profunda na alma brasileira". Vejamos, a seguir, o trecho completo.

Esquecido alguns séculos a trabalhar no eito, em vez de rebelar-se como o indio, sofreu o negro no Brasil uma injustiça de que já está redimido, graças aos estudos e escritos de toda natureza a seu respeito. $\underline{O}$ próprio folclore, onde fazia falta um balanço sério e minucioso, encontra-se em dia graças ao trabalho de Artur Ramos sobre $O$ folk-lore negro do Brasil. A convivência do escravo preto, ensinando aos ioiozinhos e iaiázinhas toda a sorte de conhecimentos elementares, deixaria por força uma contribuição extensa e profunda na alma brasileira. Os mitos negros, narrados sob a forma ingênua e fresca dos contos populares, formam para o leitor atual uma fonte rica de atração e entretenimento. Muitos versos deixaram os negros, em que misturavam palavras suas com termos do nosso idioma, algumas incompreensiveis pelo significado esquecido, outras mais embalantes como esta "berceuse":

"Sussú sossegue,

Vai dormir seu sono,

Deixe o amor dos outros

Que já tem seu dono" (111).

(111) Renato Mendonça, O negro no folk-lore e na literatura do Brasil, in Estudos Afro-Brasileiros, Ariel, Rio, 1935, pg. 6. (MENDONÇA, 1936, p.196, sublinhados nossos)

Passemos agora para o penúltimo tipo de abordagem que localizamos nas obras desta seção. Nelas, prevalece o trabalho de viés teórico, ensaístico em alguns casos, no qual o autor se limita a comentar, concordando ou discordando da bibliografia dialetológica brasileira anteriormente produzida, acrescentando um ou outro ponto autoral. Nesse tipo de produção, o 
trabalho de análise da língua acaba sendo diluído ao longo dos comentários acima mencionados. Trata-se, principalmente, de marcar uma posição em face da polêmica.

Quadro 22 - Obras de dialetologia com viés teórico, ensaístico

\begin{tabular}{|c|l|}
\hline ELIA, Sílvio & - O problema da língua brasileira (1940) $\boldsymbol{\beta}$ \\
\hline LEDA, João & - A chimera da língua brasileira (1939) $\boldsymbol{\beta}$ \\
\hline LEITE, Solidônio & - A Lingua Portuguesa no Brasil (1922) $\boldsymbol{\beta}$ \\
\hline LEMOS, Virgilio de & - A Lingua Portuguesa no Brasil (1916) $\boldsymbol{\beta}$ \\
\hline LOPES, Domingos de Castro & - A lingua brazileira (1935) $\boldsymbol{\beta}$ \\
\hline MARQUES, Xavier & - Cultura da lingua nacional (1933) $\boldsymbol{\beta}$ \\
\hline MOTTA, João & - O Portuguez falado no Brazil (1905) $\boldsymbol{\beta}$ \\
\hline NEIVA, Arthur & - Estudos de lingua nacional (1940) $\boldsymbol{\beta}$ \\
\hline PÁDUA, Ciro T. de & - O dialeto brasileiro (1942) $\boldsymbol{\beta}$ \\
\hline PEREIRA, Altamirano Nunes & - Breves considerações a propósito da língua \\
& brasileira (1946) $\boldsymbol{\beta}$ \\
\hline SANCHES, Edgard & - Lingua brasileira (1940) $\boldsymbol{\beta}$ \\
\hline SILVA NETO, & - Diferenciação e unificação do Português do \\
Brasil (1946) $\boldsymbol{\beta}$
\end{tabular}

Esse perfil teórico, ensaístico, em que o forte diálogo com a bibliografia dialetológica brasileira é uma grande marca, pode ser exemplificado no trabalho de Ciro T. de Pádua (? - ?), O dialeto brasileiro, publicado em 1942. Selecionamos trechos em que o autor se refere a João Ribeiro (1860-1934), mas procedimento semelhante é feito com outros autores ao longo do livro. Em muitos casos, o referido diálogo assume caráter quase de resenha das demais obras especializadas. Para ilustrar tal procedimento, no trecho abaixo, usamos a estratégia de suprimir 
praticamente todo o conteúdo da análise feita por Pádua, tentando mostrar apenas o tipo de aproveitamento realizado pelo autor em relação ao trabalho de João Ribeiro.

Ninguem desconhece a contribuição filológica de João Ribeiro no sentido de esclarecer as questões linguísticas do português falado no Brasil. (...) Tentarei provar que João Ribeiro não se arreceava de mudar de opinião, se chegasse a concluir pelo acerto de estudos que retificassem trabalhos anteriores. Aliás, semelhante norma de proceder só nos pode merecer todo o acatamento possivel, pois ninguem é infalivel. Em 1889 a Livraria Clássica de Alves \& Cia., Editores, dava a lume um dos primeiros trabalhos de João Ribeiro: "Dicionário Gramatical", por ele compilado. Recebido pela crítica do tempo com encômios, não teve outra edição e hoje é uma obra rara. E é uma pena, tanto é o seu valor do ponto de vista filológico. Nesse livro, João Ribeiro estuda, nos verbetes: "Brasileirismos", "Dialetos", "Negro", e "Tupí", todas as modificações sofridas pelo português no Brasil. Interessa-nos, o que escreveu sobre os dois primeiros. Das páginas 136 a 143 trata dos "dialetos". João Ribeiro principia (...). Prosseguindo, João Ribeiro alude ao que Sílvio Romero escreveu às páginas 109,110 e 111 do tomo I da sua famosa "História da Literatura Brasileira" (...). À página 324, João Ribeiro elucida: (...). Na parte em que estuda os "Brasileirismos", João Ribeiro nos ministra outros esclarecimentos: (...). À página 75 assinala: (...). À página 78 diz: (...). À página 80: (...). Por fim, à página 89 , no verbete: "Brasileirismos", conclue: (...). Esse o João Ribeiro de 1889. Em 1921 ele publicou "A Língua Nacional", edição da "Revista do Brasil", Monteiro Lobato \& Cia., desta capital. Do cotejo entre o que escreveu nos fins do século XIX e nas vésperas do centenário da nossa independência política veremos que João Ribeiro (...). (PÁDUA, 1942, p. 21-25)

Nas obras que se utilizam desse tipo de abordagem, como acima ficou evidenciado, a análise a respeito da dialetação do Português não é feita a partir de um corpora linguístico específico, definido e coletado pelo autor, mas sim de maneira indireta, discutindo, validando ou não, os dados e as análises feitas por um outro dialetólogo.

Finalmente, deveríamos falar a respeito da última técnica de análise que identificamos nas obras desta seção, isto é, a Lexicografia. Com efeito, não há aqui diferenças significativas em relação ao que dissemos, na seção anterior, quanto às obras lexicográficas de descrição dialetológica dos dialetos regionais e sociais (cf. seção 5.5.1 - camada técnica). Dada essa característica e em benefício da fluidez do texto, optamos por analisar tais materiais apenas quanto à camada documental, o que será feito logo na sequência, na próxima seção. 


\subsubsection{Camada documental}

Tal como fizemos em relação aos dialetos regionais e sociais (cf. seção 5.4.2), aqui também analisaremos as duas variáveis apontadas por Swiggers (2004) quanto à documentação linguística, isto é: (i) o número de línguas presente nas obras e (ii) o tipo de fontes e de dados utilizados.

Quanto à primeira variável, constatamos que as obras dialetológicas lexicográficas se utilizam de documentação nas seguintes línguas:

- Português, naturalmente;

- Línguas africanas que influenciaram o Português, como o Iorubá, por exemplo.

- Línguas indígenas que influenciaram o Português, como o Tupi-Guarani. Analisamos essa relação na seção anterior, quando falamos do trabalho de Martins (1944).

Em benefício da concisão do texto, não analisaremos separadamente as obras quanto às línguas, pois aproveitaremos a segunda variável, isto é, o tipo de fontes e de dados utilizados, para demostrar como as línguas acima mencionadas são utilizadas pelos dialetólogos do Português do Brasil.

Para estudar a camada documental, manteremos a divisão bipartite que estamos utilizando neste capítulo, ou seja, obras dialetológicas lexicográficas e as obras dialetológicas não-lexicográficas (cf. Apêndice B - Quadros 18B e 19B, respectivamente). Vejamos, então, das obras do primeiro grupo.

Ao analisá-las, percebemos que elas possuem as mesmas características que apontamos para a dialetologia regional e social, apresentando apenas mudança no objeto de análise, ou seja, a preocupação em se analisar o Português do Brasil como um todo, em especial, contrastando-o com o Português de Portugal, para assim achar os chamados brasileirismos, isto é, os termos, sentidos ou expressões típicos do Brasil. Tal semelhança refere-se ao fato de haver também nessas obras a predominância da pesquisa documental como expediente metodológico essencial para a elaboração dos verbetes.

Há semelhança também quanto ao registro desse material bibliográfico nas obras. Verificamos que muitas delas apresentam uma bibliografia (algumas sucintas e outras bastante extensas) e depois os livros ali mencionados vão aparecendo ao longo dos verbetes, indicando, assim, $a(s)$ fonte( $(s)$ de pesquisa de cada item. Em outras, não há bibliografia, mas menção direta das obras nos próprios verbetes. Em outras, ainda, os materiais consultados vão sendo citados ao 
longo do prefácio ou outro texto introdutório, momento em que o autor aproveita para comentar a importância dessas obras para a sua.

Já em relação à natureza das publicações utilizadas como fontes para a confecção desses livros que analisamos, notamos também algumas diferenças de perfil: (i) há considerável uso de literatura brasileira e portuguesa, principalmente para contrastar as diferenças entre o Português do Brasil e o Português de Portugal; (ii) menção a outros trabalhos dialetológicos; (iii) uso de bibliografia técnica relativa a algum termo mais específico; (iv) utilização de dicionários gerais da Língua Portuguesa, de autores portugueses, para assim, por contraste, chegar aos termos e acepções brasileiros.

Vejamos, agora, trechos que exemplificam as quatro estratégias metodológicas mencionadas acima, começando pelo uso da literatura brasileira e portuguesa para abonar um termo. Temos, nos trechos abaixo, duas abonações: uma de Coelho Neto (1864-1934) e outra de Juvenal Galeno (1838-1931), escritor e poeta cearense.

INDEZ s.m. o mesmo ou melhor que endes, o ovo que se bota ou deixa no ninho para a galinha pôr lá outro. “... deixando em cada ninho o indez, para que a ave não abandonasse o lugar". (Coelho Neto, Treva, fertilidade) [lat. index].

INCULPE, adj. innocente.

"Entre elles vae aljemado

O moço Andrada illustrado

Inculpe embora..."

(Juvenal Galeno, Lendas e canções populares) (TESCHAUER, 1918, p. 114-115, sublinhados nossos)

Quanto ao segundo tipo de estratégia de abonação utilizada na elaboração dos verbetes, ou seja, o uso e a referência a outros trabalhos dialetológicos, temos abaixo o exemplo do Dicionário da terra e da gente do Brasil, de Bernardino José de Souza (1884-1949), em que é citada a obra dialetológica Léxico de lacunas: subsídios para os dicionarios da Lingua Portugueza, de Affonso D'Escragnolle Taunay (1876-1958), publicado em 1914.

Aciolismo: registado por Affonso Taunay em seu "Lexico de Lacunas", onde se lê: "Pittoresco neologismo da imprensa brasileira, que designa a monopolização de cargos publicos por uma familia dominante na politica (De Accioly, nome proprio)". Este Accioly não é outro senão o Dr. Antonio Pinto Nogueira Accioly, que por três vezes exerceu a Presidencia do Estado do Ceará (1896-1900, 19041908, 1908-1912) e por longos anos chefiou a politica desse Estado. (SOUZA, 1939 , p. 2, sublinhados nossos) 
Outro exemplo de citação desse tipo pode ser visto no Novo vocabulario brasileiro: II $^{\text {a }}$. serie das apostillas ao diccionario de vocabulos brasileiros, de Carlos Teschauer (1851-1930), em que aparece menção a José Romaguera Corrêa (1863-1910), autor do Vocabulario sul riograndense, de 1898 .

INVERNADA S. f. (R. Gr. d. S. e mais Estados do Sul.) pastagens cercadas de obstaculos naturaes ou artificiaes para descansarem os animaes e recuperarem as forças perdidas nos serviços ou para engordarem novilhos etc. "Ha tambem invernadas destinadas para outros fins, como para cruzamento de raças, para desterneirar vaccas, etc.” (R, Correia).

INVERNAR v. tr. (R. Gr. d. S.) pôr em invernada. "Invernar, encerrar em alambrados o gado que se quer engordar". (R. Correa). (TESCHAUER, 1918, p. 119, sublinhados nossos)

Quanto à utilização de bibliografia técnica relativa ao tema da obra dialetológica, terceiro tipo de abonação que mencionamos, reproduzimos dois exemplos presentes no Léxico de lacunas: subsídios para os dicionarios da Lingua Portugueza, de Affonso D'Escragnolle Taunay (1876-1958).

\begin{abstract}
Abaixador, s. m. Nome que os pescadores bahianos dão aos homens que mergulham para verificar se nas redes há bastante peixe preso. Cf. Almirante Alves Câmara, Pescas e peixes da Bahia, p. 20.

Amarellão, s. m. Grande arvore da flora cearense que parece ser uma Terminalia. Vd. Explorações Botânicas no Ceará de Adolpho Ducke (TAUNAY, 1914, p. 15; 22, sublinhados nossos)
\end{abstract}

Outro exemplo de citação de textos especializados, podemos ver no Dicionário da terra e da gente do Brasil, de Bernardino José de Souza (1884-1949).

Achadouro: denominação adotada pelo "Serviço do Patrimônio Histórico e
Artístico Nacional", criado no Brasil. pelo Decreto- Lei n. ${ }^{\text {. }} 25$ de 30 de Novembro
de 1937, para designar os sitios onde são encontrados vestigios do passado
prehistórico. Em exposição feita ao Ministro da Educação e Saude Publica a
respeito dos trabalhos que deviam ser executados, no correr do ano de 1938, diz o
seu Diretor, Dr. Rodrigo M. F. de Andrade: "Levantamento topografico dos
"achadouros" de material arqueologico e etnografico existentes no país e execução
de obras de proteção aos mesmos, particularmente no Estado do Pará". (SOUZA,
1939, p. 2, sublinhados nossos)

Finalmente, há ainda um último tipo de abonação, ou seja, o uso de dicionaristas portugueses para comparações entre o Português do Brasil e o Português de Portugal. Nesses casos, os autores brasileiros usavam esses dicionários como referenciais para chegarem aos 
brasileirismos, uma vez que todos os termos e acepções que não estavam abonados nas obras lusitanas poderiam ser classificados, então, como de uso típico dos brasileiros.

Usaremos, como exemplo, o livreto Brasileirismos, do baiano Afrânio Peixoto (18761947), obra em que o autor utiliza sua própria produção literária para compará-la com o dicionário do português Cândido de Figueiredo (1846 - 1925). Vejamos o que fala Peixoto (1924, p.3) em relação aos objetivos da obra, bem como a respeito da dificuldade de separar com exatidão o que era lusitanismo e o que era brasileirismo.

A autoridade de Figueiredo serviu-me, ás vezes, para separar o que era brasileiro, do que podera ser português: talvez nem sempre o tenha conseguido. Direi aqui, como a respeito das trovas populares: "Não é facil em nós distinguir o que temos de próprio e o que é lusitano. Quando Portugal o reclamar lh’o restituiremos, e já é muito; quando não, é nosso, pois fomos delle e ainda não somos bem nossos".

Com efeito, nos parece que esse comentário de Peixoto pode ser estendido a todos os autores que usaram metodologia semelhante, notadamente os que arrolamos na tabela que abre esse grupo lexicográfico. Abaixo reproduzimos um trecho em que essa técnica é colocada em prática.

ACOCHAR, apertar, apressar. Figueiredo não dá esta última acepção:

Acocha, minha gente!

Afrânio Peixoto - Fruta do Mato, VII, 158.

Acocha, Elisiário!

Id., ib., X, 220.

ANAGUA, saia branca, saia de baixo: é têrmo português, desusado no Rio ou em Lisboa, mas usado no norte do Brasil:

Anáguas e ternos engomados,

A. P. - Maria Bonita, V, 55. (PEIXOTO, 1924, p.3, sublinhados nossos)

Vejamos agora o tipo de fontes e de dados utilizados pelos autores das obras dialetológicas não-lexicográficas (cf. Quadro 19B - Apêndice B).

Jacques Raimundo (? - 1960?), n'O elemento afro-negro na lingua portuguesa, publicado em 1933, na análise referente ao Português falado pelos africanos, lançou mão de textos literários, a tragicomédia "Frágoa de amor" e a farsa "O clérigo da Beira”, de Gil Vicente, século XVI. Raimundo ressalta, no entanto, a evidente insuficiência das fontes a que pôde ter acesso para uma exploração mais acurada da língua falada pelos negros. 
A escassez do documento escrito, a não ser o imitado de modo sem-dúvida imperfeito por autores de obras regionais, a remotidade da época da escravatura, não havendo já sequer um remanescente afro-negro, empecem sobremaneira a eficácia de pesquisa e observação para se determinar a influência do escravo no fonetismo e no ritmo da fala popular. (RAIMUNDO, 1933, p.72-73, sublinhados nossos)

Mais à frente, acrescenta que "a linguagem do negro que Gil Vicente ilustrou incluindoo entre as personagens do seu teatro, é uma como amostra ou antecipação de como seria a do escravo importado para o Brasil" (RAIMUNDO, 1933, p.67). Finalmente, antes de propor o estudo fonético, morfológico e sintático do Português falado pelos africanos no Brasil, o autor afirma que, de maneira subsidiária, conseguiu usar documentação não literária, pois teve acesso a "rarissimos documentos autógrafos, da época da escravatura, existentes nos arquivos ou transcritos por um ou outro autor" (RAIMUNDO, 1933, p.68).

Assim, utilizando-se do texto vicentino, Raimundo (1933, p.23) apresenta as características do Português falado pelos negros no Brasil. O autor faz tais descrições seguindo a divisão tripartite tradicional da gramática. Selecionamos um exemplo de sintaxe.

a) Concordância nominal: não obedecia em rigor a nenhum preceito, por assim caótica, tendo-se em vista o que se aponta quanto ao género e ao número. b) Emprêgo das formas oblíquas tónicas do pronome pessoal, regidas ou não da prep. $a$, em vez das formas rectas: não sabe mi essa careira, mi não fala zombaria, como mi saba primeiro; a mi falla guiné, a mi abre oio, quando a mi more da fome, etc. (...)

Nesta obra, quando a descrição se refere às línguas africanas, não há menção a fontes ou corpus específicos; os fenômenos fonéticos, morfológicos ou sintáticos são simplesmente expostos sem qualquer tipo de abonação. Vejamos um exemplo de descrição do Ioruba, presente na sessão de fonética:

A elisão e crase de vogais são factos constantes e até notáveis por exigidas pelo ritmo da frase: rà ashò > rà shò; mò ara rè > mò ra ré; kpa irò > kpurò. Do encontro de $a$ e $i$, ambos com qualquer timbre e duração, resulta sempre $u$ : sá ire> sure, correr, arremessar. O ioruba é uma língua musical e de intonação, causa principal de os seus vocábulos, trasladados ao português, serem sempre agudos. (RAIMUNDO, 1933, p.44, sublinhados nossos).

Outro autor que analisa a influência africana no Português do Brasil é Renato Mendonça (1912 - 1990), que, em 1933, publica A influência africana no português do Brasil. Nela, tal como nas obras lexicográficas, podemos encontrar exemplos de uso de bibliografia especializada, tanto nacional quanto estrangeira. No trecho a seguir, o autor recruta a obra Esquisse d'une 
dialectologie portugaise, tese de doutorado de Leite de Vasconcelos $(1858$ - 1941) sobre os dialetos do Português e A lingua portugueza: dificuldades e dúvidas, de Filipe Franco de Sá (1841- ?). Tais referências aparecem quando Mendonça (1948[1933], p.120-121) analisa alguns metaplasmos.

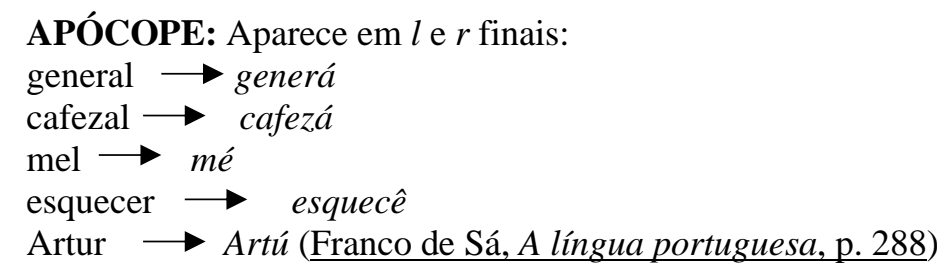

A queda no $r$ final aparece também nos dialectos crioulos da África: cabo-verdiano - onde às vezes cai: chegar $\longrightarrow$ chegá da ilha de S. Tomé - onde às vezes cai: cuié em vez de colher, ou se troca em $l$ arc irmon $\longrightarrow$ limò, ou recebe $\mathbf{i}$ de apoio: flor $\longrightarrow$ flori da ilha do Príncipe - cai: vender $\longrightarrow$ vendê da ilha de Ano Bom - ou cai: matar $\longrightarrow$ matá, ou recebe um $e$ de apoio: mulher miere, outal com l: Senhor Chiol (L.d Vasconcelos, Esquisse, pp. 184-192.).

O $\boldsymbol{r}$ final desaparece no infinito dos verbos franceses desde o século XVI: aime (r), porte $(\mathrm{r})$. Mesmo na linguagem culta do Brasil, or final soa levemente.

Finalmente, além do dado linguístico escrito, predominante em todo o programa dialetológico do início do século XX, também encontramos o uso de dado oral, coletado na observação individual do autor.

Maria de Lourdes de Paula Martins (? -?), em sua tese A influência indígena no Português do Brasil: estudo do vocabulário, publicada em 1944, explica a fonte que utilizou para a obtenção desses dois tipos de dado linguístico.

No final da tese, após a bibliografia, intitulada "Relação das principais obras de consulta (obras em que foi colhida exemplificação)”, Martins (1944, p.65, sublinhados nossos) afirma que “Alguns exemplos citados provêm de observações pessoais feitas nesta Capital e no interior do Estado; outras resultam de informações obtidas de alguns baianos e cearenses; finalmente outras, de viajantes e paraguaios." Em tal bibliografia, apesar de haver também menção a obras literárias, predominam obras de filologia, como gramáticas históricas, dicionários, obras especializadas em línguas indígenas e muitos trabalhos de dialetologia brasileira, como $\mathbf{O}$ dialeto caipira, de Amadeu Amaral (1875-1929), por exemplo. 


\section{CONSIDERAÇÕES FINAIS}

Na presente tese, examinamos como se organizou, no Brasil, a reflexão sobre o Português nas quatro primeiras décadas do século XX. Examinamos o papel desempenhado pelos diferentes gêneros textuais e pelas diferentes práticas de tratamento da língua no interior dos três programas de investigação (gramatical, filológico e dialetológico) que eram utilizados para os estudos relativos ao Português, no início dos novecentos. Esse percurso foi feito com o objetivo de verificarmos a validade de nossa hipótese a respeito da perda de primazia da gramática frente a essas novas possibilidades investigativas.

Até o século XIX, podemos dizer que as gramáticas do Português - aqui consideradas como um gênero textual inserido, conceptual e terminologicamente, na longa tradição de origem greco-latina - eram o locus privilegiado para as reflexões e discussões de ordem linguística, além de servirem como material de ensino. Assim, a gramática era a arena para onde diferentes públicos convergiam: (i) os professores, especialistas e estudiosos do Português; (ii) o cidadão comum, usuário da língua que buscava nesse manual solução para suas dúvidas linguísticas e/ou para seu bem escrever e (iii) os alunos de escolas primárias e secundárias.

Metodologicamente, nossa primeira ação para verificarmos se teria ocorrido ou não essa perda de primazia da gramática foi realizar um levantamento de pretensão exaustiva de toda a produção linguística acerca do Português. Em um primeiro momento, o objetivo era saber, além da gramática, quais eram os outros tipos de publicação que se dedicavam a estudar o Português no início do século XX. Também era nossa intenção quantificar cada tipo encontrado e assim saber quais eram aqueles de maior prevalência e como se comportavam frente às gramáticas. Realizada essa etapa, pudemos separar toda a produção segundo suas especificidades - ou, nesse caso, seus programas de investigação (Swiggers, 1987) - e assim iniciar o estudo de tipo qualitativo dessas obras.

Assim, dividiremos essa conclusão em duas partes, (i) uma mais ligada ao levantamento quantitativo e aos aspectos contextuais que ajudam a explicar a divisão da produção linguística sobre o Português do início dos 1900 em diferentes gêneros textuais e não mais concentrada apenas na gramática e (ii) outra, relacionada às questões de ordem linguística, que, nesta tese, foram analisadas por meio das camadas do conhecimento linguístico (Swiggers, 2004), o que nos possibilitou dimensionar como esses outros gêneros estudavam o Português e suas diferenças ou não frente às gramáticas. 
Com efeito, nosso levantamento de pretensão exaustiva chegou ao total de $\mathbf{5 8 1}$ obras, das quais 366 foram por nós analisadas. Esse processo fez com que pudéssemos, a partir das especificidades dessas obras, separá-las em três programas de investigação diferentes gramatical, filológico e dialetológico - analisados nos capítulos 2 e 3; 4 e 5, respectivamente. No interior de cada programa, realizamos subdivisões com o objetivo de separar as gramáticas dos demais tipos de publicação. Assim, chegamos ao seguinte cenário da produção linguística sobre o Português no início do século XX:

- Programa de investigação gramatical: 400 obras, entre produções escolares e nãoescolares, ou seja, de referência:

- Escolares: 239 obras, divididas em:

- Gramáticas escolares completas: $\mathbf{5 1}$ obras;

- Obras de temas gramaticais específicos: 101 obras;

- Livros didáticos de Português: 87 obras;

- De referência: 161 obras, divididas em:

- Gramáticas de referência completas: 4 obras;

- Obras de referência de temas gramaticais específicos: 157 obras.

- Programa de investigação filológico: 89 obras, divididas nos seguintes gêneros:

- Gramáticas históricas (escolares): 30 obras;

- Obras de temas filológicos específicos: $\mathbf{5 1}$ obras;

- Tratamento (edição) de texto: $\mathbf{8}$ obras.

- Programa de investigação dialetológico: 92 obras, divididas nos seguintes recortes temáticos:

- Descrição de dialetos regionais e sociais: 42 obras;

- Descrição dialetológica do Português do Brasil: 50 obras.

Quantitativamente, o programa gramatical é, sem dúvida, o mais volumoso, mas se considerarmos apenas o gênero gramática completa, a situação precisa ser avaliada com mais cuidado. O primeiro aspecto a ser considerado é a desproporção numérica entre as gramáticas escolares, 51 obras, e as gramáticas de referência, 4 obras, ou seja, sob o ponto de vista quantitativo, a gramática, no início dos novecentos, passa a ser um gênero predominantemente escolar, processo que denominamos como didatização da gramática brasileira. No entanto, ao analisarmos o programa gramatical como um todo, considerando tanto os textos escolares quanto os de referência, veremos que a produção de tipo gramatical ocorreu preferencialmente nas obras 
monográficas e nos livros didáticos de Português, já que a proporção é de 55 gramáticas completas para 345 obras monográficas/ livros didáticos de Português.

Do ponto de vista contextual, o que explica essa desproporção é a maior especialização pela qual passou a produção linguística sobre o Português nas quatro primeiras décadas do século XX. Esse processo de especialização não se limitou ao programa gramatical, mas também ocorreu nos programas filológico e dialetológico, como veremos mais adiante. $\mathrm{O}$ início do século XX foi, para o Brasil, um momento de intensa busca pela modernização, de uma tentativa de rompimento com o passado rural, dando início, assim, a um processo de urbanização que se estenderá, aproximadamente, até as décadas de 1960/1970, quando haverá, pela primeira vez, predominância da população urbana frente a rural. Um sociedade mais complexa e que também crescia a altas taxas - em 1900, havia 17.438.434 habitantes no Brasil, ao passo que, em 1940, esse número já era de 41.236 .315 (cf. Razzini, 2000, p.20) - gerava demandas mais específicas, especialmente quanto aos processos de educação da população, que agora precisava ir além dos estudos primários, avançando, principalmente, até o Secundário, nível de ensino incipiente durante o século XIX.

Destarte, nas décadas iniciais do século XX, haverá um significativo crescimento e a consequente estruturação do ensino secundário, acompanhados pela maior demanda por materiais didáticos. Isso fez não só a gramática completa se tornar um material destinado predominantemente ao ambiente escolar, mas também estimulou a produção de obras mais específicas, especializadas que visavam a atender as necessidades específicas do Secundário, ou seja, aquelas que classificamos como obras escolares de temas gramaticais específicos e dos livros didáticos de Português (cf. 2.3.2 e 2.3.3, respectivamente). Tais demandas podem ser vistas, por exemplo, na produção de obras para os alunos se prepararem para os Exames de Admissão, ou para se aprofundarem em um tema mais difícil presente nos programas oficiais de ensino ou mesmo no uso do livro didático seriado em volumes avulsos, que também representou uma maior especialização, pois era uma marca do fim do ensino secundário avulso, de frequência não obrigatória e também dos "exames avulsos" ao curso superior, características do século XIX e começo do XX, especificamente até 1931, data da Reforma Educacional Francisco de Campos.

Por outro lado, quanto às obras de referência também houve um processo de especialização. Ao analisarmos as 157 obras de referência de temas gramaticais específicos, veremos que há, nesse conjunto, obras que tinham diferentes propósitos, atendendo, assim, a diferentes públicos. 79 delas, por exemplo, são publicações do tipo consultório gramatical, obras onde eram esclarecidos aspectos do Português considerados difíceis, fossem eles sugeridos pelo 
autor ou pelo público consulente. Essas obras visavam a atender não aos professores, especialistas, mas sim ao público letrado comum, geralmente adulto, que, fora da escola, sentiase inseguro quanto ao uso da norma-padrão. Por outro lado, havia outros gêneros que atendiam ao público especializado, que nosso levantamento apontou serem as obras em que se estudam as ideias gramaticais (ou a linguagem) de um determinado autor e as que trazem as polêmicas gramaticais entre autores (crítica, réplica e tréplica), que totalizam 25 publicações e também as teses elaboradas para os concursos de ingresso à docência secundária ou superior, que, apesar do baixo número, 8 teses apenas ${ }^{90}$, representam um importante processo de especialização dos estudos sobre o Português.

A existência de apenas 4 gramáticas completas de referência no século XX frente às 157 obras gramaticais monográficas demostra claramente que, do ponto de vista do gênero textual, a gramática completa, fora do contexto escolar, deixa de ser um instrumento de interesse da população e também dos especialistas, que além das obras de viés gramatical anteriormente mencionadas, encontrarão, nas obras presentes nos programas filológico e dialetológico, um espaço privilegiado para a discussão especializada.

Quanto às obras do programa filológico, ocorre o mesmo processo de especialização. Não só a escola se especializou, mas a ciência linguística também. Assim, não era mais possível congregar, em um só lugar, isto é, na gramática completa, tarefas tão diferentes entre si, o ensino básico e a discussão científica, ou em termos mais sintéticos, a escola e a ciência.

Das 89 obras presentes nesse programa, as 51 presentes no grupo obras de temas filológicos específicos (cf. seção 4.3) e as 8 incluídas no grupo tratamento (edição) de texto (cf. seção 4.4) estão ligadas ao desenvolvimento da ciência linguística, sem conexão com o universo escolar.

Por outro lado, o terceiro grupo, o das gramáticas históricas do Português, conecta a ciência linguística predominante à época, ou seja, a Gramática Histórico-Comparada, ao ensino, já que todas as 30 gramáticas históricas foram escritas para serem usadas na escola.

Essa conexão pode ser explicada por dois aspectos: primeiro, pelo fato que já analisamos no capítulo 4, isto é, as discussões feitas pelos estudiosos ligados ao histórico-comparativismo já eram tão volumosas e complexas que não podiam mais ser reunidas em um só volume, em uma gramática, requerendo, assim, livros específicos para tratar de maneira mais verticalizadas os poucos temas que eram estudados nesses materiais. Assim, essas gramáticas históricas escolares,

\footnotetext{
${ }^{90}$ Localizamos outras 12 teses, mas como não tivemos acesso a elas, não podendo classificá-las quanto aos programas de investigação, optamos por não incluí-las em nosso levantamento.
} 
por mais que houvesse algumas mais completas do que outras, representavam uma síntese didática, uma amostra do que, à época, se discutia no âmbito da ciência linguística. O segundo aspecto é o prestígio que gozava a Gramática Histórico-Comparada, o que fez com que ela fosse incluída nos programas de ensino do Secundário, mesmo que de forma desproporcional frente à gramática tradicional (a proporção era, no geral, de 1 ano de gramática histórica para 3 de tradicional). Assim, a escola mantinha ativa a tradição secular de ensino da gramática tradicional, mas também não deixava de mostrar-se conectada com a moderna ciência linguística.

Com efeito, as obras ligadas ao programa dialetológico passaram também por um processo de especialização. Os estudos a respeito da variação do Português do Brasil até a Proclamação da República, em 1889, e o rompimento oficial com Portugal, eram praticamente inexistentes. As exceções não estavam ligadas a um programa de investigação coletivo em busca de se estudar o Português utilizado no Brasil, mas eram fruto de iniciativas individuais de alguns poucos autores, além de serem, como já dissemos, pontuais.

As décadas iniciais do século XX foram não só um período de acelerada urbanização e modernização da sociedade brasileira, mas foram também um momento de busca pela identidade nacional, já que os laços oficiais com Portugal tinham sido cortados. Há, por parte da sociedade, um sentimento nacionalista, o que vai favorecer um movimento introspectivo, de autoconhecimento, no sentido de se compreender quem era afinal o brasileiro e sua cultura. É nesse clima de opinião que a dialetologia brasileira encontrará espaço para se desenvolver como um programa de investigação autônomo, contribuindo para responder qual era a identidade linguística nacional ou, em outros termos, como falava o brasileiro.

Nosso levantamento demonstra um número significativo de publicações, um verdadeiro tour de force dialetológico: são 92 obras, sendo que 42 delas estão voltadas às descrição dos dialetos regionais e sociais e as outras 50, à descrição dialetológica do Português do Brasil como um todo, aqui considerando também os contrastes com o Português de Portugal. Aqui, tal como ocorria com o programa filológico, desenvolver estudos dialetológicos significava, na época, estar conectado à moderna ciência linguística.

Realizada a primeira parte de nossas considerações finais, passemos agora à outra, aquela em que faremos uma análise do três programas de investigação quanto às camadas do conhecimento linguístico (Swiggers, 2004), por nós estudadas ao longo dos capítulos 2, 4 e 5. Com isso, será possível afirmarmos se, do ponto de vista linguístico, ou seja, quanto às camadas teórica, técnica e documental, houve perda ou não da primazia da gramática frente às novas possibilidades de tratamento da língua. 
Quanto às 400 obras do programa gramatical, - tanto nas gramáticas completas quanto nos outros gêneros textuais (obras monográficas e livros didáticos de Português), sendo eles escolares ou de referência - não identificamos diferenças significativas relativamente às concepções de língua (camada teórica), técnicas de análise linguística (camada técnica) e tipo de documentação linguística utilizada (camada documental). Assim, é possível dizer que houve perda da primazia apenas do gênero textual gramática completa (55), mas não dos conceitos e práticas do programa de investigação gramatical, que continuaram a ser utilizados nas obras monográficas (258) e nos livros didáticos de Português (87 obras). Isso prova, com efeito, que o programa gramatical, na verdade, se especializou, se adaptou para atender às novas demandas, escolares e não-escolares, da sociedade brasileira do início do século XX.

Como força diferenciadora daquilo que já propunha o programa gramatical, temos nos programas filológico e dialetológico as principais novas possibilidades de tratamento da língua, as quais o subtítulo desta tese alude. Quanto à camada teórica, os valores da filologia e da dialetologia são radicalmente diferentes daqueles vistos no programa gramatical. Enquanto este preocupava-se fundamentalmente com o bom uso, com a prescrição da norma-padrão, aqueles tinham como objetivo, respectivamente, estudar historicamente o Português e analisar os processos de dialetação do Português do Brasil, ambos processos não-normativos.

Essa não-normatividade pode ser vista também na camada documental dos programas filológico e dialetológico. Ambos utilizavam predominantemente a documentação literária, mas de forma completamente diferente do que ocorria no programa gramatical. Neste, a literatura era usada como referencial do bom uso, daquele praticado pelos autores clássicos e consagrados da língua, já no programa filológico, ela era usada como forma de atestar as diferentes formas da língua em seus diferentes estágios históricos. No caso do programa dialetológico, usava-se o texto literário como forma de comprovar os diferentes usos dialetais do Português do Brasil, já que a coleta de dado oral, também feita nesse programa, era ainda bastante incipiente, muito por limitações técnicas, como a inexistência de gravador portátil para uso em campo, por exemplo. Os autores que relatavam o uso de dado oral em seus trabalhos diziam que suas observações empíricas da dialetação eram anotadas em seus cadernos e depois transcritas em suas obras.

Finalmente, quanto à camada técnica, podemos dizer que a Gramática HistóricoComparada, modelo teórico utilizado pelas obras do programa filológico e parte do dialetológico, representou, efetivamente, uma nova forma de se estudar o Português, tanto em sua dimensão histórica quanto dialetológica, possibilitando análises que antes, com o modelo da 
gramática tradicional, não puderam ser feitas, já que nele havia uma outra visão de língua, ou em outros termos, uma diferente camada teórica. 


\section{REFERÊNCIAS BIBLIOGRÁFICAS ${ }^{91}$}

\section{Fontes primárias}

ABREU, A. E. Grammatica popular da Lingua Portugueza. Rio de Janeiro: Pap Santa Helena, 1923.

ALI, Manuel Said. Dificuldades da Língua Portuguêsa: estudos e observações. Rio de Janeiro: Livraria Acadêmica, 1966 [1.ed.1908].

Melhoramentos, 1923.

Formação de palavras e syntaxe do Portuguez historico. São Paulo:

Grammatica secundaria da Lingua Portugueza. $3^{\mathrm{a}}$ ed. São Paulo; Cyeiras;

Rio de Janeiro: Melhoramentos, [19--], [1 $1^{\mathrm{a}}$ ed. 1924].

Grammatica elementar da Lingua Portugueza. $3^{\mathrm{a}}$ ed. São Paulo; Cyeiras; Rio de Janeiro; Recife: Melhoramentos, [19--], [1 ${ }^{\mathrm{a}}$ ed.1923].

Simões, 1951 [1.ed. 1927].

Meios de expressão e alterações semânticas. Rio de Janeiro: Organizações

Grammatica historica da lingua portugueza. São Paulo: Melhoramentos, 1931.

ALVES, Achilles. Breves noções de Grammatica portugueza. $5^{\text {a }}$ ed. Rio de Janeiro: Livraria Editora Freitas Bastos, 1936.

AMARAL, Afrânio do. Biologia e linguística. São Paulo, 1945.

AMARAL, Amadeu. O dialecto caipira: gramática, vocabulário. São Paulo: Editora Anhembi Limitada, 1955 [1920].

ANDRADE, Gustavo de. Grammatica ecletica da Lingua Portugueza: curso superior. Bahia: Livraria Catilina, 1917.

Livraria Catilina, 1935.

Grammatica intuitiva da Lingua Portugueza: curso elementar. $8^{\mathrm{a}}$ ed. Bahia:

BANDEIRA, Adelia Ennes. Grammatica portugueza pratica. Rio de Janeiro/São Paulo/Belo Horizonte: Livraria Francisco Alves, 1911.

BARBUDA, Pedro Julio. Grammatica. Bahia: Estabelecimento dos Dois Mundos, 1926.

BARRETO, Mário. Estudos de lingua portuguesa. Rio de Janeiro: Viuva Azevedo, 1903.

\footnotetext{
${ }^{91}$ De acordo com a Associação Brasileira de Normas Técnicas (ABNT NBR 6023).
} 
. Novos estudos da lingua portuguesa. Rio de Janeiro/São Paulo/Belo Horizonte: Livraria Francisco Alves, 1911.

Novíssimos estudos da língua portuguesa. Rio de Janeiro/São Paulo/Belo Horizonte: Livraria Francisco Alves, 1914. 1916].

. Factos da língua portuguesa. Rio de Janeiro: Organizações Simões, 1954 [1.ed. 1922].

. De gramática e de linguagem. Rio de Janeiro: Organizações Simões, 1955 [1.ed. [1.ed. 1927].

. Através do dicionário e da gramática. Rio de Janeiro: Organizações Simões, 1954 . Últimos estudos. Rio de Janeiro: Epasa, 1944.

BERGO, Vittorio. Erros e dúvidas de linguagem. Rio de Janeiro/São Paulo: Livraria Editora Freitas Bastos, 1942.

BRUNO, Anibal. Lingua Portuguesa para quarta série ginasial. São Paulo: Editora Nacional, 1941.

BUENO, Silveira. Páginas floridas. São Paulo: Saraiva \& Cia e Livraria Acadêmica, 1938a. Português pelo rádio. São Paulo: Saraiva \& Cia e Livraria Acadêmica, 1938b.

. O auto das regateiras de Lisboa. Tése de concurso apresentada á cadeira de "Filologia Portuguesa" da Faculdade de Filosofia, Ciências e Letras da Universidade de S. Paulo - Brasil. São Paulo: Saraiva \& Cia e Livraria Acadêmica, 1939.

Acadêmica, 1946.

Estudos de filologia portuguêsa. I Volume. São Paulo: Saraiva \& Cia e Livraria

CALLAGE, Roque. Vocabulário gaúcho. Porto Alegre: Globo, 1926.

CAMPOS, João Luis de. O problema do infinitivo. São Paulo: Melhoramentos, 1924.

CARREIRO, Carlos Porto. Grammatica da lingua nacional: methodo pratico: segundo anno. Rio de Janeiro: Jacintho Ribeiro dos Santos Editor, 1918.

CARVALHO, Alfredo de. O Tupi na chorographia pernambucana: elucidário etymologico. Recife: Typ. do Jornal do Recife, 1907.

CASASSANTA, Mario. A palavra MESMO. Tese de Concurso. Bello Horizonte, Oliveira, Costa \& Cia Officinas Graphicas, 1935.

Notas de Raul Soares à Gramática de João Ribeiro. Belo Horizonte: Editora Paulo Bluhm, 1941.

CINTRA, Geraldo de Ulhôa. O conceito perene de filologia. Tese (Concurso de Filologia Portuguesa, da Universidade de São Paulo). São Paulo, 1939.

CHINA, José B. D’Oliveira. Estudos de filologia e linguistica. São Paulo: Spadari \& Cia, 1924.

COELHO, Adolpho. A lingua portugueza: phonologia, etymologia, morfologia e syntaxe. Coimbra: Imprensa da Universidade, 1868. 
COUTINHO, Ismael de Lima. A crase: tese de livre escolha, apresentada à Congregação do Lyceu de Humanidades de Campos, para o concurso á $1^{\text {a }}$ Cadeira de Português. Rio de Janeiro: Off. Grap. Typ. Aurora-H. Santigo, dez. 1928.

As criações internas do idioma: tese sorteada para o concurso á $1^{\text {a }}$ Cadeira de Português do Lyceu de Humanidades de Campos. Rio de Janeiro: Off. Grap. Typ. Aurora-H. Santigo, dez. 1928.

Pontos de gramática histórica. São Paulo/Rio de Janeiro/Recife/Porto Alegre: Companhia Editora Nacional, 1938.

COUTINHO, J. J. de Freitas. Licções de grammatica portugueza. Uberaba: Typographia Aredio; Livraria Seculo XX Editora, 1909.

COUTINHO, Alfredo Alvares de Macedo. Gramática portuguesa: curso elementar. $8^{\mathrm{a}}$ ed. Rio de Janeiro: J. R. de Oliveira \& CIA, 1939.

CRUZ, José Marques. Português prático: gramática para as 4 séries do curso ginasial. $18^{\mathrm{a}}$ ed. São Paulo: Edições Melhoramentos, 1947.

D’AlBuQUERQUE, A. Tenório. A evolução das palavras: a transformação morfologica e semantica dos vocábulos portugueses. Rio de Janeiro: Editora Getúlio Costa, 1940.

DOMINGUES, Pinheiro. Camilo e a lexicografia de Laudelino Freire. Rio de Janeiro: Pap. Cruzeiro, 1927.

FREIRE DA SILVA, Augusto. Compendio da grammatica portugueza. São Paulo: Typ. a Vap. De Jorge Seckler \& Comp., 1886.

FREITAS, Paulo de. O nosso idioma: sintaxe geral. São Paulo, Companhia Editora Nacional, 1938.

GALVÃO, Ramiz. Vocabulario etymologico orthographico e prosodico das palavras portuguezas derivadas da lingua grega. Rio de Janeiro/São Paulo/Belo Horizonte: Livraria Francisco Alves, 1909.

GARCIA, Rodolfo. Diccionario de brasileirismos: peculiaridades pernambucanas. Rio de Janeiro: J. Ribeiro dos Santos, 1915.

GEENEN, Henrique. Palestras philologicas: 1ª serie. São Paulo: Est. Graf. Irmãos Ferraz, 1931. GÓES, Carlos. Método de análise. Rio de Janeiro: Paulo de Azevedo e Cia, 1940 [1.ed.1912]. . Sintaxe de concordância. São Paulo: Francisco Alves, 1958 [1.ed.1916]. [1.ed.1924].

Sintaxe de regência. Rio de Janeiro: Paulo de Azevedo \& Comp. Ltda, 1945 [1.ed.1932].

Sintaxe de construção. Rio de Janeiro: Paulo de Azevedo \& Comp. Ltda, 1945

Diccionario de affixos e desinencias. Rio de Janeiro/São Paulo/Belo Horizonte: Francisco Alves, 1937.

Diccionario de raízes e cognatos da Lingua Portugueza. Bello Horizonte Imprensa Official do Estado de Minas Geraes, 1921. 
GOMES, Alfredo. Grammatica portugueza. Rio de Janeiro/São Paulo/Belo Horizonte: Francisco Alves, 1930.

GRAÇA, Heraclito. Factos da linguagem: esboço critico de alguns assertos do snr. Candido de Figueiredo. Rio de Janeiro: Viuva Azevedo, 1904.

GUÉRIOS, Rosario Farani Mansur. Pontos de gramática histórica portuguesa. São Paulo: Saraiva \& Cia e Livraria Acadêmica, 1937.

HORTA, Brant. Gramática Intuitiva da Língua Portuguesa. Rio de Janeiro: J. R. de Oliveira e Cia, 1938.

e Cia, s/d.

. Noções de gramática histórica da língua nacional. Rio de Janeiro: J. R. de Oliveira

JUCÁ (filho), Cândido. Língua nacional: as diferenciações entre o português de Portugal e o do Brasil autorizam a existência de um ramo dialetal do português peninsular? Rio de Janeiro: Editora J. R. de Oliveira, 1937. $\overline{1945\left[1^{\text {a }} \text { ed. } 1943\right] .}$

. Gramática brasileira do Português contemporâneo. $2^{\mathrm{a}}$ ed. Rio de Janeiro: Epasa, . Gramática histórica do Português contemporâneo. Rio de Janeiro: Epasa, 1945. . Índice alfabético e crítico da obra de Mário Barreto: Organização e comentários de Cândido Jucá Filho. Colab. do Conde de Pinheiro Domingues. Rio de Janeiro: Fundação Casa de Rui Barbosa, 1981.

LAYTANO, Dante de. Os africanismos do dialeto gaúcho. Porto Alegre: Oficinas Gráficas da Livraria do Globo, 1936.

Vocabulário dos pescadores do Rio-Grande-do-Sul. Porto Alegre: Oficinas Gráficas da Livraria do Globo, 1937.

LIMA, Mario Pereira de Souza. Theoria da construcção gramatical: these para o concurso á cadeira de Portuguez no gymnasio Official de S. Paulo. São Paulo: Secção de obras d' "O Estado de S. Paulo", 1923.

LOBO, Vaz. Grammatica historica: programma de Portuguez da $4^{\text {a }}$ série gymnasial. Rio de Janeiro/São Paulo/Belo Horizonte: Livraria Francisco Alves, 1936.

MACIEL, Maximino. Grammatica descriptiva. Rio de Janeiro/São Paulo/Belo Horizonte: Livraria Francisco Alves, 1931.

Lições elementares de Lingua Portugueza. 20 ed. São Paulo; Bello Horizonte: Livraria Francisco Alves, 1938, [1. ed. 1903].

MACHADO FILHO, Aires da Mata. O negro e o garimpo em Minas Gerais. Rio de Janeiro: José Olympio Editora, 1943.

MAGALHÃES, Raymundo. Vocabulario popular: augmentado com grande numero de locuções populares brasileiras. Pará: Typ. da Livraria Escolar, 1911.

MARROQUIM, Mário. A lingua do nordeste: Alagôas e Pernambuco. São Paulo: Companhia Editora Nacional, 1934. 
MARTINS, Jaime de Sousa. Elementos de gramática histórica: para a quarta série. São Paulo: Companhia Editora Nacional, 1937.

MARTINS, Maria de Lourdes de Paula. A influência indígena no Português do Brasil: estudo do vocabulário. Tese de doutoramento em Letras, apresentada à Cadeira de Filologia Portuguêsa, da Faculdade de Filosofia, Ciências e Letras, da Universidade de São Paulo. São Paulo, 1944.

MATTA, Contribuição ao estudo do vocabulario amazonense. Manaus: Instituto Histórico e Geográphico do Amazonas, 1938.

MELO, Gladstone Chaves de. Língua do Brasil. Rio de Janeiro/São Paulo/Belo Horizonte: Agir, 1946.

MELO, Mário. Toponymia pernambucana. Recife: Imprensa Official, 1931.

MELLO, Pedro de. Novas theorias grammaticaes: these de concurso. São Paulo: Typ. a Vap.Espindola, Siqueira \& Comp., 1900.

MENDONÇA, Renato. A influência africana no português do Brasil. Porto: Livraria Figueirinhas, 1948[1.ed.1933].

Brasileira, 1936.

O português do Brasil: origens, evoluções, tendências. Rio de Janeiro: Civilisação

MONTEIRO, Clóvis. Português da Europa e Português da América: aspectos da evolução do nosso idioma. Rio de Janeiro: J. Leite, 1931.

. Da tendência na evolução de nosso idioma. Tese apresentada em concurso, à Congregação do Colégio Pedro II. Rio de Janeiro, Pongetti, 1926.

Editora, 1926.

Da influência do Tupi no Português. Rio de Janeiro: Empreza Graphica

MOTTA, Othoniel. Ensaio linguistico. São Paulo: Typ. Falcone, 1905.

. Lições de Português. São Paulo: Editora Nacional, 1937 [1.ed.1915].

. O meu idioma. São Paulo: Editora Nacional, 1935 [1.ed.1916].

Genoud, 1916.

O pronome "SE": réplica ao professor Said Ali. Campinas: Typ. da Casa

$\overline{\text { Nacional, } 1937 .}$

Horas philologicas. São Paulo/Rio de Janeiro/Recife: Companhia Editora

NASCENTES, Antenor. Método prático de análise lógica. Rio de Janeiro/São Paulo/Belo Horizonte: Livraria Francisco Alves, 1930 [1.ed.1920].

Método prático de análise gramatical. Rio de Janeiro/São Paulo/Belo Horizonte: Livraria Francisco Alves, 1930 [1.ed.1921].

O linguajar carioca. Rio de Janeiro: Organização Simões, 1953 [1922].

- Dicionário etimológico da Língua Portuguêsa. Rio de Janeiro: Livraria

Acadêmica/Livraria Francisco Alves/Livraria São José/Livros de Portugal, 1955[1932].

O idioma nacional. Rio de Janeiro: Acadêmica, 1960 [1.ed.1926]. 
[1.ed.1927].

O idioma nacional: volume 2. São Paulo: Companhia Editora Nacional, 1942 O idioma nacional: volume 3. São Paulo: Companhia Editora Nacional, 1942 [1.ed.1928].

[1.ed.1928].

O idioma nacional: volume 4. São Paulo: Companhia Editora Nacional, 1942 . Estudos filológicos. Rio de Janeiro: Academia Brasileira de Letras, 2003 [1. ed. 1939].

NIMER, Miguel. Influências Orientais na Língua Portuguesa: os vocábulos árabes, arabizados, persas e turcos. São Paulo: Escolas Profissionais Salesianas, 1943.

NOGUEIRA, Julio. Programa de Português: gramática. São Paulo: Companhia Editora Nacional, 1948.

NUNES, José de Sá. Comentários à "Réplica" de Rui Barbosa, visando exclusivamente aos arcaísmos: tese de concurso à cadeira de filologia portuguesa da Faculdade de Filosofia, Ciências e Letras da Universidade de São Paulo. São Paulo, 1939.

OITICICA. José de. Estudos de phonologia: tese de concurso de Português ao Collegio Pedro II. Rio de Janeiro: Oficinas Tipográficas Apolo, 1916.

Manual de análise: léxica e sintática. Rio de Janeiro/São Paulo/Belo Horizonte: Livraria Francisco Alves, 1953.

OLIVEIRA, Agenor Lopes de. Toponímia carioca. Rio de Janeiro: Prefeitura do Distrito Federal/Secretaria Geral de Educação e Cultura, 1935.

OLIVEIRA, Sebastião Almeida. Expressões do populário sertanejo: vocabulário e superstições. São Paulo: Empresa Gráfica das "Revistas dos Tribunais”, 1940.

P.S. Syntaxe e grammatica historica da Língua Portugueza. Porto Alegre: Selbach \& Mayer, 1909.

PEIXOTO, Afrânio. Brasileirismos. São Paulo: Nova Era, (s/d) [1924].

PEIXOTO, Almir Câmara de Matos. Novos rumos em filologia. Rio de Janeiro: Zélio Valverde, 1942.

PEREIRA, Carlos de Brito. Analyse syntactica: noções indispensáveis e suficientes ao preparatório de português. These facultativa para Concurso da segunda Cadeira de Português do Gymnasio Paranaense. Curityba: Typ. da "A Cruzada”,1928.

Etymologia: classificação de etymologias. These sorteada para Concurso da segunda Cadeira de Português do Gymnasio Paranaense. Curityba: Typ. da "A Cruzada", 1928.

Saraiva \& COMP., 1942.

Manual de gramática portuguesa. $5^{\mathrm{a}}$ ed. São Paulo: Livraria Acadêmica e

PEREIRA, Eduardo Carlos. Questões de philologia: resposta aos criticos da "Grammatica expositiva". São Paulo: Typographia Falcone, 1907.

1913.

Grammatica expositiva: curso superior. $4^{\mathrm{a}}$ ed. São Paulo: Weiszflog Irmãos, 
Nacional, 1929.

Grammatica expositiva: curso superior. $27^{\mathrm{a}}$ ed. São Paulo: Companhia Editora

Grammatica expositiva: curso elementar. 95a ed. São Paulo; Rio de Janeiro; Baía; Recife; Pôrto Alegre: Companhia Editora Nacional, 1943.

Grammatica historica. São Paulo: Weiszflog Irmãos \& Co., 1916.

PINTO, Alfredo Cl. Primeiras noções de grammatica: $1^{\circ}$ curso. $17^{\mathrm{a}}$ ed. Porto Alegre: Livraria Selbach de J. R. da Fonseca \& CIA, [19--], [1 $1^{\mathrm{a}}$ ed.1906].

Primeiras noções de grammatica: $1^{\circ}$ curso. $9^{\mathrm{a}}$ ed. Porto Alegre: Livraria Selbach de J. R. da Fonseca \& CIA, [19--] [1.ed.1907].

PINTO, P.A. Vocábulos médicos e de outra natureza. Rio de Janeiro, Ed. Científica, 1944.

RAIMUNDO, Jacques. O elemento afro-negro na Lingua Portuguesa. Rio de Janeiro: Renascença Editora, 1933.

O negro brasileiro e outros escritos. Rio de Janeiro: Record, 1936.

RIBEIRO, Ernesto Carneiro. Serões grammaticaes ou nova grammatica portugueza. Bahia: Livraria Catilina de Romualdo dos Santos, 1919.

RIBEIRO, João. Gramática portuguesa. Curso médio (2. Ano). Rio de Janeiro: Alves \& Cia, 1887 [39.ed. 1930].

Editor, 1902.

Estudos philologicos. Rio de Janeiro: Jacintho Ribeiro dos Santos, Livreiro-

Gramática portuguesa (Curso primário $1^{\circ}$ ano de Português). Rio de Janeiro/São Paulo/Belo Horizonte: Livraria Francisco Alves, 1951. 1887 [21.ed. 1930].

Gramática portuguesa. Curso superior (3. Ano). Rio de Janeiro: Alves \& Cia,

A língua nacional: notas aproveitaveis. São Paulo: Companhia Editora Nacional, 1933 [1.ed.1921].

Melhoramentos, 1927.

Curiosidades verbais: estudos aplicáveis à língua nacional. São Paulo:

RIBEIRO, Joaquim. Origem da Língua Portuguêsa. Rio de Janeiro: Record, 1935.

RIBEIRO, Julio. Grammatica portuguesa. 1. ed., São Paulo: Typ. de Jorge Seckler, 1881.

RIBEIRO, Maria Luisa Santos. História da educação brasileira: a organização escolar. Campinas: Editora Autores Associados, 1995.

SÁ, Filippe Franco de. A lingua portugueza: dificuldades e dúvidas. Maranhão: Imp. Official, 1915. 
SAMPAIO, B. Elementos de Gramática Portuguesa. Campinas, SP: Livraria João Amendola, $1931^{92}$.

SAMPAIO, Francisco Ribeiro. Questões de Português: reparos aos erros de gramática do Prof. Silveira Bueno. São Paulo: Edições Aurora, 1939.

SAMPAIO, Theodoro. O tupi na geographia nacional. São Paulo: Casa Eclética, 1901.

SANTOS, João Henrique dos. Filologia jurídica. Porto Alegre: Typ. Esperança, 1934.

Acentuação gráfica. Porto Alegre: Editora Livraria Andradas, 1943.

SANCHES, Edgard. Lingua brasileira. São Paulo: Companhia Editora Nacional, 1940.

SENNA, Nelson de. Africanos no Brasil: estudos sobre os nêgros africanos e influencias afro nêgras sobre a linguagem e costumes do povo brasileiro. Belo Horizonte: Of. Gráf. Queiroz Breyner, 1938.

SILVA JUNIOR, Pacheco da; ANDRADE, Lameira de. Noções de grammatica portugueza. Rio de Janeiro: J. G. de Azevedo-Editor, 1887.

Grammatica da lingua portugueza. Rio de Janeiro: Alves \& Cia, 1894.

SILVA JUNIOR, Pacheco da; BOSCOLI, José Ventura. Noções de analyse: phonetica, etymologia e syntaxica. Rio de Janeiro: Imprensa Nacional, 1888.

SILVA JUNIOR, Pacheco da. Noções de semântica. Rio de Janeiro/São Paulo/Belo Horizonte: Livraria Francisco Alves, 1903.

D. M. Hazlett, 1878.

Grammatica historica da Lingua Portugueza. Rio de Janeiro: Typ. a Vap. de

SILVA NETO, Serafim da. Manual de gramática histórica portuguesa. São Paulo/Rio de Janeiro/Recife/Porto Alegre: Companhia Editora Nacional, 1942.

Janeiro: 1942.

Rusgas filológicas: réplica a Jucá inestudioso, implicante e roncador. Rio de

Rumos filológicos. Rio de Janeiro: [S. L], 1942.

SILVEIRA, Sousa da. Lições de Português. Rio de Janeiro: Civilização Brasileira, 1934 [1.ed.1923].

SOTERO DOS REIS. Postillas de grammatica geral, aplicada á língua portugueza. Maramhão: 1870.

SOUZA, Bernardino José de. Dicionário da terra e da gente do Brasil. São Paulo/Rio de Janeiro/Recife/Porto Alegre: Companhia Editora Nacional, 1939.

TAUNAY, Afonso D’Escragnolle. Léxico de lacunas: subsídios para dicionários da Lingua Portugueza, Tours: Arrault e Cia, 1914.

\footnotetext{
${ }^{92} \mathrm{Na}$ folha de rosto, consta, como data de publicação, o ano de 1931, mas, na capa cartonada, aparece registrado 1932. Como não há outros elementos para checar a data correta, adotaremos a data da folha de rosto, local onde estão os demais dados bibliográficos.
} 
. Reparos ao novo diccionario de Candido de Figueiredo. Tours: Arrault e Cia, 1926.

Insufficiencia e deficiencia dos grandes diccionarios portugueses: polemica com o Snr. Cândido de Figueiredo. Tours: Arrault e Cia, 1928.

TEIXEIRA, José Aparecida. O falar mineiro. [S.L.]: [s.c.], 1938.

TESCHAUER, Carlos. Apostillas ao "Diccionario de vocabulos brasileiros". Petrópolis: Vozes de Petropolis, 1912.

. Novo vocabulário brasileiro: $11^{\mathrm{a}}$ serie das apostilas ao diccionario de vocabulos brasileiros. Petrópolis: Vozes de Petropolis, 1918.

. Porandúba riograndense. Porto Alegre: Livraria do Globo, 1929.

TÔRRES, Artur de Almeida. Compêndio de Língua portuguêsa: gramática para curso ginasial. São Paulo: Companhia Editora Nacional, 1947.

. Compêndio de Língua portuguêsa: gramática e antologia para a terceira série ginasial. São Paulo: Companhia Editora Nacional, 1953.

Questões filológicas. Rio de Janeiro: Irmãos Pongetti Editores, 1943.

VIEIRA, Verissimo. Grammatica portugueza: curso preliminar. (Instrucção Primaria). Rio de Janeiro/São Paulo/Belo Horizonte: Livraria Francisco Alves, 1922.

\section{Estudos}

ALONSO, Miguel Cuevas. Multidimensionalidad, complejidad y dinamismo en la historiografía linguiística y en su definición del concepto tradición. Todas as letras, São Paulo, v.14, n.1, p. 71-86, 2012.

ALTMAN, Cristina. Fragmentos do século XX. Bibliografia cronológica e comentada sobre produção lingüística brasileira. In: Eberhard Gärtner. (Org.). Pesquisas linguiísticas em Portugal e no Brasil. Frankfurt/Main; Madrid: Iberoamericana Vervuert, 1997, v.4, p. 41-78.

A pesquisa linguística no Brasil (1968-1988). 2.ed., São Paulo: Humanitas, 2004.

. Filologia e linguística outra vez. Filologia e linguística portuguesa. São Paulo: Humanitas, v.6, p. 161-168, 2004a.

Cem anos de dialeto caipira (1920-2020). In: BARONAS, Roberto Leiser; PAGLIARINI, Maria Inês. (Org.). Linguística popular/folk linguistics: práticas, proposições e polêmicas. Campinas: Pontes Editores, 2020, p. 141-163. 
ASENCIO, José J. Gómez; DEL ARCO, Esteban T. Montoro; SWIGGERS, Pierre. Principios, tareas, métodos e instrumentos en historiografía lingüística. In: CALERO, María Luisa et al (eds.): Métodos y resultados actuales en historiografía de la linguiística. Munster: Nodus Publikationen, 2014, p.266-301.

AUROUX, Sylvain. A revolução tecnológica da gramatização. Campinas: Editora da Unicamp, 1992.

AZEVEDO FILHO, Leodegário A. de. Os estudos filológicos e lingüísticos no Brasil - uma tentativa de periodização. In: AZEVEDO FILHO, Leodegário A. de; RODRIGUES, Marina Machado (Org.). Congresso Internacional de Lexicografia e Literaturas no Mundo Lusofônico. Rio de Janeiro: Editora Ágora da Ilha, 2002.

BARROS FERREIRA, M. Retrospectiva da dialetologia portuguesa. Revista Internacional de Língua Portuguesa. Lisboa, n. 12, p. 108-118, dez. 1994.

BASSETTO, Bruno Fregni. Conceito de filologia. Revista philologus, ano 4, nº 12, 1998.

BATISTA, Antônio Augusto Gomes. O conceito de "livros didáticos". In: BATISTA, Antônio Augusto Gomes; GALVÃO, Ana Maria de Oliveira (Org.). Livros escolares no Brasil: elementos para uma história. Campinas: Mercado de Letras, 2009.

BECCARI, Alessandro Jocelito. Uma abordagem da gramática especulativa de Thomas de Erfurt: antecedentes históricos, metalinguagem, classes do nome e do pronome, sintaxe. 2007. 226 f. Dissertação (Mestrado em Estudos Linguísticos) - Setor de Ciências Humanas, Letras e Artes, Universidade Federal do Paraná, Curitiba, 2007.

BITTAR, Marisa; BITTAR, Mariluce. História da educação no Brasil: a escola pública no processo de democratização da sociedade. Acta scientiarum, Maringá, v.34, p. 157-168, juldez., 2012, n.2.

BITTENCOURT, Circe M. F. Autores e editores de compêndios e livros de leitura (1810-1910). Educação e pesquisa, v. 30, n. 3, set./dez. 2004, p. 476-491.

BLIKSTEIN, Isidoro. Cem anos de Linguística no Brasil. O Estado de São Paulo, São Paulo, 7 fev. 1976, n59. Suplemento do Centenário, Cem anos de língua portuguesa no Brasil - 2, p. 45 .

BORGES, Patrícia de Souza. Línguas africanas e Português brasileiro: análise historiográfica de fontes e métodos de estudos no Brasil (séc. XIX-XX). 239 f. Dissertação (Mestrado em Semiótica e Linguística Geral) - Faculdade de Filosofia, Letras e Ciências Humanas, Universidade de São Paulo, São Paulo, 2015.

BORGES NETO, José. Para uma história da linguística no Brasil. Letras. Curitiba, n. 51, p. 133 139, Editora da UFPR, jan./jun. 1999.

Gramática tradicional e linguística contemporânea: continuidade ou ruptura?

Todas as letras, São Paulo, v.14, n.1, p. 87-98, 2012. 
A naturalização da gramática tradicional e seu uso protocolar. Texto da conferência proferida durante o VIII Congresso da ABRALIN, Natal, 2013.

. História da gramática. Curitiba: 2018. No prelo.

BRASIL. Ministério da Educação e Saúde Pública. Gabinete do Ministro. Portaria (s/n), de 30 de junho de 1931. Regulamenta o art. 10. do decreto n. 19.800, de 18 de abril de 1931. Diário Oficial da União, Rio de Janeiro, DF, 31 jul. 1931, p. 12405.

Constituição (1946). Constituição da República Federativa do Brasil. Brasília, DF: Senado Federal: Centro Gráfico, 1946.

Decreto-Lei $\mathrm{n}^{\circ} 19.890$, de 18 de abril de 1931. Dispõe sobre a organização do Ensino Secundário. In: BICUDO, Joaquim de Campos. O ensino secundário no Brasil e sua atual legislação (1931 a 1941). São Paulo: Associação dos Inspetores Federais de Ensino Secundário 1942.

Portaria $\mathrm{n}^{\circ} 479$, de 30 de novembro de 1940. Estabelece os tópicos cobrados no exame de admissão. In: BICUDO, Joaquim de Campos. O ensino secundário no Brasil e sua atual legislação (1931 a 1941). São Paulo: Associação dos Inspetores Federais de Ensino Secundário 1942.

Portaria $\mathrm{n}^{\mathrm{o}}$ 170, de 11 de julho de 1942. Expede e determina que se executem os programas das disciplinas de línguas e de ciências do curso ginasial secundário. In: CRUZ, JOSÉ Marques da. Português prático: gramática para as 4 séries do Curso Ginasial. São Paulo: Edições Melhoramentos, 1947.

Portaria $n^{\circ} 172$, de 15 de julho de 1942. Instruções metodológicas para execução do programa de Português. In: CRUZ, JOSÉ Marques da. Português prático: gramática para as 4 séries do Curso Ginasial. São Paulo: Edições Melhoramentos, 1947.

CÂMARA JR, Joaquim Mattoso. A linguística brasileira. In: NARO, Anthony Julius (Org.). Tendências atuais da linguística e da filologia no Brasil. Rio de Janeiro: Francisco Alves, 1976, p. 47-66.

Os estudos de português no Brasil. In: UCHÔA, Carlos Eduardo Falcão (Org.). Dispersos de J. Mattoso Câmara Jr.. Rio de Janeiro: Lucerna, 2004 [1. ed. 1972], p. 231-258.

CANDIDO, Antonio. Literatura e sociedade. Rio de Janeiro: Ouro sobre Azul, 2008.

CARDOSO, Suzana; FERREIRA, Carlota. A dialetologia no Brasil. São Paulo: Editora Contexto, 1994.

CASTILHO. Ataliba Teixeira. Estudos linguísticos no Brasil. Alfa, n², p. 135-143, 1962.

CAVALIERE, Ricardo. Fonologia e morfologia na gramática científica brasileira. Niterói: EdUFF, 2000. 
Uma proposta de periodização dos estudos linguísticos. Confluência, Rio de Janeiro, vol. 23 , p. $102-119,1^{\circ}$ sem. 2002.

O conceito de gramática no percurso da gramaticografia brasileira do século XX. Revista argentina de historiografia linguiística, VII, 2, pp. 115-125, 2015.

CHAPANSKI, Gissele. Uma tradução da Téchnē grammatiké, de Dionísio Trácio, para o Português. 2003. 190 f. Dissertação (Mestrado em Estudos Linguísticos) - Setor de Ciências Humanas, Letras e Artes, Universidade Federal do Paraná, Curitiba, 2003.

CHRISTINO, Beatriz. O papel do negro na formação do português brasileiro na visão dos estudiosos dos anos 1920 a 1945. Historiografia da lingüística brasileira, São Paulo, v. 7, p. 45-60, 2004. Boletim especial 10 anos do CEDOCH.

CHOPPIN, Alain. História dos livros e das edições didáticas: sobre o estado da arte. Educação e pesquisa, v. 30, n. 3, p. 549-566, set./dez. 2004.

COELHO, Olga Ferreira. Serafim da Silva Neto (1917-1960) e a filologia brasileira: um ensaio historiográfico sobre o papel da liderança na articulação de um paradigma em ciência da linguagem. 1998. 185 f. Dissertação (Mestrado em Semiótica e Linguística Geral) - Faculdade de Filosofia, Letras e Ciências Humanas, Universidade de São Paulo, São Paulo, 1998.

Documenta, gramaticae et historiae (Português): a formação de uma tradição gramatical brasileira. São Paulo: CEDOCH-DL-USP, 2010 - 2014.

; DANNA, Stela Maris D.G.; POLACHINI, Bruna S. O português do Brasil em gramáticas brasileiras do século XIX. In: Confluência, Rio de Janeiro, vol. 46, p. 115 - 141, $1^{\circ}$ sem. 2014.

(Org.). A historiografia linguística no Brasil (1993-2018): memória, estudos. Campinas: Pontes Editores, 2018.

; SILVA, Wellington Santos da. Páginas de história da terminologia relativa ao português brasileiro. In: CASTILHO, Ataliba Teixeira (Coord.) História do Português brasileiro: o português brasileiro em seu contexto histórico. São Paulo, Contexto, 2018, p. 72 96.

COSERIU, Eugenio. Teoria da linguagem e lingüística geral: cinco estudos. Rio de Janeiro/ São Paulo: Presença/EDUSP, 1979.

CUNHA, Luiz Antônio. A Universidade temporã. Rio de Janeiro: Francisco Alves, 1986.

DANNA. A língua espanhola no Brasil: história de sua presença em materiais linguísticos produzidos entre 1919 e 1961. 2019. 227 f. Tese (Doutorado em Semiótica e Linguística Geral) - Faculdade de Filosofia, Letras e Ciências Humanas, Universidade de São Paulo, São Paulo, 2019.

ELIA, Silvio. Ensaios de filologia e linguística. São Paulo: Grifo, 1975. 
FARACO, Carlos Alberto. A questão da língua: revisitando Alencar, Machado de Assis e cercanias. In: Línguas e instrumentos linguísticos n 7. Campinas, SP: Pontes Editores, 2001.

Norma-padrão brasileira: desembaraçando alguns nós. In: BAGNO, Marcos (org.). Lingúística da norma. São Paulo: Edições Loyola, 2002.

Lingüística histórica: uma introdução ao estudo da história das línguas. São Paulo: Parábola Editorial, 2005.

História sociopolítica da Língua Portuguesa. São Paulo: Parábola Editorial, 2016.

Breve retrospectiva do pensamento linguístico-histórico no Brasil. In: CASTILHO, Ataliba Teixeira (Coord.). História do Português brasileiro: o português brasileiro em seu contexto histórico. São Paulo, Contexto, 2018, p. 32-71.

FIGUEIREDO, Antonio Joaquim de. Resenha breve das idéias gramaticais, dos gregos aos nossos dias. Rio de Janeiro: Imprensa do Exército, 1957.

GALLY, Christianne de Menezes. Construção e circulação das gramáticas de Língua Portuguesa no Brasil no século XIX: o Tratado de Língua Vernácula de Brício Cardoso. 2013. 246 f. Tese (Doutorado em Língua Portuguesa) - Programa de Pós-Graduação em Língua Portuguesa, Pontifícia Universidade Católica de São Paulo, São Paulo, 2013.

GONÇALVES, Maria Filomena. Gramáticas do português na transição do século XIX para o século XX: a "gramática científica". Actas del XVI Congreso Internacional de la ALFAL. Alcalá: 2011, p. 2571-2579.

GUIMARÃES, Eduardo. Sinopse dos Estudos do Português no Brasil: a gramatização brasileira. In: GUIMARÃES, Eduardo; ORLANDI, Eni Puccinelli (Orgs.). Língua e cidadania: o português no Brasil. Campinas: Pontes, 1996, p. 127-138.

HAIDAR, Maria de Lourdes Mariotto. O ensino secundário no Brasil Império. São Paulo: Edusp, 2008.

HAMPEJS, Zdenek. Filologos brasileiros. Boletín de filología (del Instituto de Filología de la Universidad de Chile), Santiago do Chile, tomo XIII, p. 167-234, 1961.

HYMES, Dell. Traditions and Paradigms. In

Essays in the history of linguistic anthropology. Amsterdam/Philadelphia: John Benjamins Publishing Company, 1983.

ILARI, Rodolfo. Lingüística românica. São Paulo: Editora Ática, 1999.

INSTITUTO BRASILEIRO DE GEOGRAFIA E ESTATÍSTICA. Anuário estatístico do Brasil. Ano V- 1939/1940, Rio de Janeiro: IBGE/Conselho Nacional de Estatística, 1941.

KOERNER, E. F. Konrad. Models in linguistic historiography. In: Practing linguistic historiography. Amsterdam/Philadelphia: John Benjamins Publishing Company, p. 47-59, 1989. 
. Linguística e filologia. O eterno debate. Filologia e linguística portuguesa. São Paulo: Humanitas, 1997, v.1, p. 7-20.

Quatro décadas de historiografia linguística: estudos selecionados. Vila Real: Universidade de Trás-os-Montes e Alto Douro, Centro de Estudos em Letras, Coleção Linguística 11, 2014.

KUHN, Thomas S. A estrutura das revoluções científicas. Editora Perspectiva: São Paulo, 1975 [1.ed. 1962].

LAFETÁ, João Luiz. 1930: a crítica e o modernismo. Editora 34/Livraria Duas Cidades: São Paulo, 2000.

LAKATOS, Imre; MUSGRAVE, Alan (Org.). A crítica e o desenvolvimento do conhecimento: quarto volume das atas do Colóquio Internacional sobre Filosofia da Ciência, realizado em Londres em 1965. São Paulo: Editora Cultrix/ EDUSP, 1979.

LEHMANN, Winfred P. Introduccion a la lingüística histórica. Madrid: Editorial Gredos, 1969.

LEITE, Marli Quadros. Metalinguagem e discurso: a configuração do purismo brasileiro. São Paulo: Humanitas, 1999.

O nascimento da gramática portuguesa: uso \& norma. São Paulo: Humanitas/Paulistana, 2007.

LEROY, Maurice. As grandes correntes da lingüística moderna. São Paulo: Editora Cultrix, 1977.

MARCONDES, Iara Lucia. Os consultórios gramaticais: um estudo de preconceito e intolerância lingüísticos. 188 f. Dissertação (Mestrado em Filologia e Língua Portuguesa) Faculdade de Filosofia, Letras e Ciências Humanas, Universidade de São Paulo, São Paulo, 2008.

MARTINS, Ana Maria. Gramáticas históricas do Português. In: Inês Duarte \& Matilde Miguel, Actas do XI Encontro Nacional da Associação Portuguesa de Linguística, 3 (Gramática e varia), Lisboa, Colibri, 1996, pp. 53-71.

MINISTERIO DA AGRICULTURA, INDUSTRIA E COMMERCIO. Annuario estatistico do Brazil: volume III: cultos, assistencia, repressão e instrucção. $1^{\circ}$ ano (1908-1912) V, Rio de Janeiro: Typographia da estatística, 1927.

MOREL PINTO, Rolando. Cem anos de gramática portuguesa no Brasil. O Estado de São Paulo, São Paulo, 7 fev. 1976, n 59. Suplemento do Centenário, Cem anos de língua portuguesa no Brasil - 2, p. 1-2.

MURRAY, O. Stephen. Theory groups and the study of language in North America: a social history. Amsterdam/Philadelphia: John Benjamins Publishing Company, 1994.

NAGLE, Jorge. Educação e sociedade na primeira república. 3. ed., São Paulo: Edusp, 2009. 
NEVES, Maria Helena de Moura. A sintaxe de Apolônio Díscolo. Classica - Revista Brasileira de Estudos Clássicos. [S.1.: s.n.], número extraordinário 2, p. 69-74, 1993.

A gramática: história, teoria e análise, ensino. São Paulo, Editora da UNESP, 2002.

A vertente grega da gramática tradicional: uma visão do pensamento grego sobre a linguagem. 2. ed., São Paulo: Editora da UNESP, 2005.

PAGOTTO, Emílio Gozze. Norma e condescendência; ciência e pureza. In: Línguas e instrumentos linguísticos nº 2. Campinas: Pontes Editores, 1998.

PENHA, João Alves Pereira. Nossas gramáticas históricas. Actas do XII encontro da APL, Braga, Portugal, v. 2, n. 12, p.521-524, 1996.

. Filólogos brasileiros. Franca: Editora Ribeirão Gráfica, 2002.

PERCIVAL, Keith. The applicability of Kuhn's paradigms to the history of linguistics. Language. Washington, v. 52, n. 2, 1976, p. 285-294.

PILETTI, Nelson. História da educação no Brasil. São Paulo: Editora Ática, 2000.

POLACHINI, Bruna Soares. O tratamento da sintaxe em gramáticas brasileiras do século XIX: um estudo historiográfico. 2013. 219 f. Dissertação (Mestrado em Semiótica e Linguística Geral) - Faculdade de Filosofia, Letras e Ciências Humanas, Universidade de São Paulo, São Paulo, 2013.

. Uma história serial e conceitual da gramática brasileira oitocentista de Língua Portuguesa. 2018. 427 f. Tese (Doutorado em Semiótica e Linguística Geral) - Faculdade de Filosofia, Letras e Ciências Humanas, Universidade de São Paulo, São Paulo, 2018.

RAZZINI, Márcia de Paula Gregório. O espelho da nação: a Antologia nacional e o ensino de Português e literatura (1838-1971). 2000. 442 f. Tese (Doutorado em Teoria Literária) - Instituto de Estudos da Linguagem, Universidade de Campinas, Campinas, 2000.

REVISTA DO BRASIL. São Paulo: Propriedade de uma sociedade anonyma, v. 1, n. 1, jan. 1916a. Mensal.

REVISTA DO BRASIL. São Paulo: Propriedade de uma sociedade anonyma, v. 3, n. 9, set. 1916b. Mensal. Anno 1.

REY, Alain. Usos, julgamentos e prescrições linguísticas. In: BAGNO, Marcos (org). Norma lingüística. São Paulo: Edições Loyola, 2001.

RIBEIRO, Julio. Procellarias. São Paulo: Edições Cultura Brasileira, [1935?].

RIBEIRO, Maria Luisa Santos. História da educação brasileira: a organização escolar. Campinas: Editora Autores Associados, 1995.

ROBIS, R.H. Pequena história da linguística. Rio de Janeiro: Ao Livro Técnico, 1983. 
ROMANELLI, Otaíza de Oliveira. História da educação no Brasil: 1930/1973. Petrópolis: Editora Vozes, 1990.

SENNA, Homero. O problema da língua brasileira. Rio de Janeiro: Serviço de documentação/MEC, 1953.

SILVA, José Pereira da; AZEVEDO FILHO, Leodegário A. de. (Org.). Dicionário biobibliográfico da Academia Brasileira de Filologia. Versão preliminar, sem revisão dos autores. Rio de Janeiro: ABRAFIL, 2012. Disponível em: https://filologiauefs.files.wordpress.com/2015/03/dicionc3a1rio-biobibliogrc3a1fico-daacademia-brasileira-de-filologia.pdf . Acesso em: 12 fev. 2017.

SILVA, Maximiano de Carvalho e. A palavra filologia e as suas diversas acepções: os problemas da polissemia. Confluência, Rio de Janeiro, vol. 23, p. 53-70, 2005.

SOUZA, Ricardo Luiz de. O antilusitanismo e a afirmação da nacionalidade. Politeia: Hist. e Soc., Vitória da Conquista, vol. 5, n.1, p. 133-151, 1ºm. 2002.

SWIGGERS, Pierre. The history writing of linguistics: a methodological note. General linguistic, n. 21, v. 1, p. 11-16, 1981.

- Histoire et historiographie de l'enseignement du français: modèles, objets et analyses". Études de linguistique appliquée, n.78, p. 27-44, abr.- jun, 1990.

. L'historiographie des sciences du language: intérêts et programmes. Internacional Congress of Linguistics, 14, 1987 (August 10 - August 15), Berlin/GDR, Proceedings, Berlin: Akademie-Verlag, p.2713-2716, 1991.

. L'émergence de la grammaire occidentale comme art empirique. Histoire de la Pensée Linguistique. Paris: Presses Universitaires de France, pp. 9-68, 1997.

. Filologia e linguística: enlace, divórcio, reconciliação. Filologia e linguística portuguesa. São Paulo: Humanitas, 1998, v.2, p. 5-18.

- Modelos, métodos y problemas en la historiografía de la lingüística. Nuevas aportaciones a la historiografía lingüística. Actas del IV Congreso Internacional de la SEHL. La Laguna (Tenerife), 22 al 25 de octubre de 2003, p. 113-146, 2004.

La historiografia de la linguística: apuntes y reflexiones. Revista argentina de historiografia linguística, I, 1, pp. 67-76, 2009.

Le métalangage de la linguistique: reflexions à propôs de la terminologie e de la terminographie linguistiques. Revista do GEL, 7.2. 2010.

- História e historiografia da lingüística: status, modelos e classificações. Eutonomia, ano III, vol. 2, dez. 2010, pp. 1-17.

Linguistic historiography: object, methodology, modelization. Dossiê Historiografia Linguística da Revista todas as letras. São Paulo: Editora Mackenzie, 2012. 
Historiografía de la gramaticografía didáctica: apuntes metodológicos con referencia a la (historia de la) gramática española y francesa. VILA RUBIO, Neus (Ed.), Lengua, literarura y educación en la españa del siglo XX. Bern/Berlin: Peter Lang; Lerida: Edicions i Publicacions de la Universitat de Lleida, 2012, p.15-37.

A historiografia linguística: objeto, objetivos, organização. Confluência. Revista do Instituto de Língua Portuguesa do Liceu Literário Português. 44-5. Rio de Janeiro: Liceu Literário Português, 2013.

- La historiografía de la gramática: técnica, modelización, estrategias y condicionamiento material". VAQUERA, M.L. CALERO et al. (Ed), Métodos y resultados actuales en historiografía de la lingüística. Münster: Nodus, 2014, p. 722-731.

. Linguistic historiography: a metatheorical synopsis. Todas as Letras. São Paulo, v.19, n. 2, p. 73-96, maio/agosto 2017.

TANURI, L.M. Contribuição para o estudo da escola normal no Brasil. Pesquisa e planejamento. São Paulo, v.13, dez.1970, p. 7-98.

UNIVERSIDADE DE SÃO PAULO. Sistema Integrado de Bibliotecas. DEDALUS: banco de dados bibliográficos da USP. São Paulo, 2019. Disponível em: http://dedalus.usp.br. Acesso em: 15 maio 2019.

VIDAL, Diana G.; FARIA FILHO, Luciano M. História da educação no Brasil: a constituição histórica do campo (1880-1970). Revista Brasileira de História, v. 23, n. 45, 2003, p. 37-70.

VIDAL NETO, José Bento Cardoso. A Grammatica portugueza, de Julio Ribeiro: um corte epistemológico na gramaticografia brasileira e a questão da língua portuguesa no Brasil. 2010. 141 f. Dissertação (Mestrado em Filologia e Língua Portuguesa) - Faculdade de Filosofia, Letras e Ciências Humanas, Universidade de São Paulo, São Paulo, 2010.

VIEIRA, Francisco Eduardo. A gramática tradicional: história crítica. São Paulo: Parábola, 2018. 
APÊNDICE A

Este apêndice contém o levantamento completo da produção linguística brasileira (19001940) dividido em três programas de investigação diferentes:

QUADRO 1A - Produção linguística brasileira (1900-1940): programa de investigação gramatical

QUADRO 2A - Produção linguística brasileira (1900-1940): programa de investigação filológico

QUADRO 3A - Produção linguística brasileira (1900-1940): programa de investigação dialetológico 


\section{QUADRO 1A - Produção linguística brasileira (1900-1940): programa de investigação gramatical}

\begin{tabular}{|c|c|c|c|c|c|}
\hline & \multicolumn{3}{|c|}{ Escolares } & \multicolumn{2}{|c|}{ De referência } \\
\hline Obras $^{93}$ & $\begin{array}{c}\text { Gramáticas } \\
\text { completas }\end{array}$ & $\begin{array}{c}\text { Obras de } \\
\text { temas } \\
\text { gramaticais } \\
\text { específicos }\end{array}$ & $\begin{array}{c}\text { Livros } \\
\text { didáticos de } \\
\text { Português }\end{array}$ & $\begin{array}{c}\text { Gramáticas } \\
\text { completas }\end{array}$ & $\begin{array}{c}\text { Obras de } \\
\text { temas } \\
\text { gramaticais } \\
\text { específicos }\end{array}$ \\
\hline \multicolumn{6}{|c|}{$\mathbf{A}$} \\
\hline $\begin{array}{l}\text { ABREU, A. } \\
\text { E. } \\
(?-?)\end{array}$ & & & & $\begin{array}{l}- \\
\text { Grammatica } \\
\text { popular da } \\
\text { Lingua } \\
\text { Portugueza } \\
\text { (1923) } \boldsymbol{\beta}\end{array}$ & \\
\hline $\begin{array}{c}\text { ABREU, } \\
\text { Modesto de } \\
(1901-1996)\end{array}$ & $\begin{array}{l}\text { Coleção } \\
\text { nova }{ }^{94} \text { : }\end{array}$ & $\begin{array}{l}\text { - Correção } \\
\text { de textos: } \\
\text { para exames }\end{array}$ & $\begin{array}{l}\text { Coleção antiga: } \\
\text { - Idioma pátrio: } \\
\text { seleta, }\end{array}$ & & \\
\hline
\end{tabular}

\section{${ }^{93}$ Legenda:}

及: Obra pertencente ao acervo pessoal do pesquisador.

$\Sigma$ : Obra consultada em bibliotecas.

$\Omega$ : Indica que a referência a esta obra foi localizada em um outro livro, nas páginas normalmente denominadas "Outras obras da editora" ou "Demais publicações do autor". Tais páginas estão localizadas ou na quarta capa ou nas páginas iniciais do livro. Isso significa, obviamente, que não tivemos acesso físico à obra e que as informações editoriais foram obtidas nesse contexto mais limitado. Esse símbolo indica também obras localizadas em listas em que constam apenas o título e o autor, como foi o caso, por exemplo, dos livros encontrados no Diário Oficial da União, em uma publicação da "Comissão Nacional do Livro Didático", de 1947. Também indica obras localizadas on-line, nos catálogos de bibliotecas.

T: Teses.

${ }^{94}$ A coleção Idioma pátrio tem duas apresentações: uma relativa ao "antigo programa", composta de 5 volumes, e outra do "novo programa", formada por 3 volumes. Há, obviamente, algumas diferenças que aqui explicitaremos: a coleção de 5 volumes segue a estruturação clássica para os livros didáticos de Português da época, presente em quase todas as coleções didáticas que aqui relacionamos. Dos volumes 1 a 4, conteúdo gramatical, de leitura e de redação e o $5^{\circ}$ volume destinado aos estudos da história da Literatura e da estilística, fato, aliás, que nos fez não incluir esses volumes no presente levantamento. Na coleção nova, de 3 volumes, o autor fez a seguinte estruturação: volume 1, para as $1^{\mathrm{a}} \mathrm{e} 2^{\mathrm{a}}$ séries do Secundário, seleta literária destinada à leitura e interpretação, volume 2 , o mesmo conteúdo, só que para as $3^{\mathrm{a}}$ e $4^{\mathrm{a}}$ séries e o volume 3, destinado a todos os anos do Secundário, é uma gramática expositiva e histórica, além de conter também "noções de estilística e literatura", conteúdo esse que, na coleção antiga, era apresentado no volume 5 . 


\begin{tabular}{|c|c|c|c|c|c|}
\hline \multirow[b]{2}{*}{ Obras ${ }^{93}$} & \multicolumn{3}{|c|}{ Escolares } & \multicolumn{2}{|c|}{ De referência } \\
\hline & $\begin{array}{l}\text { Gramáticas } \\
\text { completas }\end{array}$ & $\begin{array}{c}\text { Obras de } \\
\text { temas } \\
\text { gramaticais } \\
\text { específicos }\end{array}$ & $\begin{array}{l}\text { Livros } \\
\text { didáticos de } \\
\text { Português }\end{array}$ & $\begin{array}{l}\text { Gramáticas } \\
\text { completas }\end{array}$ & $\begin{array}{c}\begin{array}{c}\text { Obras de } \\
\text { temas }\end{array} \\
\text { gramaticais } \\
\text { específicos }\end{array}$ \\
\hline & $\begin{array}{l}\text { - Idioma } \\
\text { pátrio: } \\
\text { volume } 3^{95} \text { : } \\
\text { gramática } \\
\text { expositiva e } \\
\text { histórica; } \\
\text { noções de } \\
\text { estilística e } \\
\text { literatura } \\
\text { (1944) } \boldsymbol{\beta}\end{array}$ & $\begin{array}{l}\text { e concursos } \\
(1940) \boldsymbol{\Omega} \\
\\
\text { - Admissão: } \\
\text { lições e } \\
\text { exercícios: } \\
\text { Português } \\
\text { (1944_?ed.) } \\
\mathbf{\Omega}\end{array}$ & $\begin{array}{l}\text { gramática, } \\
\text { exercícios }\left(1^{\mathrm{a}}\right. \\
\text { série) } \\
\left(19392^{\mathrm{a} e d} .\right)^{97} \\
\mathbf{\Omega} \\
\text { - Idioma pátrio: } \\
\text { seleta, } \\
\text { gramática, } \\
\text { exercícios (2 } \\
\text { série) (1937) } \mathbf{\Omega} \\
\text { - Idioma pátrio: } \\
\text { seleta, } \\
\text { gramática, } \\
\text { exercícios (3 } \\
\text { série) (1939) } \mathbf{\Omega}\end{array}$ & & \\
\hline $\begin{array}{c}\text { ADRIÃO, } \\
\text { (Padre) } \\
\text { Pedro } \\
(?-?)\end{array}$ & & & & & $\begin{array}{l}\text { - Tradições } \\
\text { clássicas da } \\
\text { Língua } \\
\text { Portuguesa } \\
\text { (1945) 及 }\end{array}$ \\
\hline $\begin{array}{l}\text { AGUIAR, } \\
\text { Porfirio de } \\
(?-?)\end{array}$ & & & & & $\begin{array}{l}\text { - Umas } \\
\text { questões de } \\
\text { lingua (1903) } \\
\beta\end{array}$ \\
\hline $\begin{array}{l}\text { ALBUQUE } \\
\text { RQUE, } \\
\text { Acir }^{98} \\
\text { Tenorio de } \\
\\
(1899-1973) \\
\end{array}$ & & $\begin{array}{l}\text { - Correção } \\
\text { de frases: } \\
\text { lições para } \\
\text { alunos e } \\
\text { candidatos } \\
\text { adotado em } \\
\end{array}$ & $\begin{array}{l}\text { - Curso de } \\
\text { Português para } \\
\text { ginásios: } \\
\text { primeira serie: } \\
\text { gramática, } \\
\text { antologia, }\end{array}$ & & $\begin{array}{l}- \\
\text { Questiuncul } \\
\text { as de } \\
\text { português: g } \\
\text { alicismo de } \\
\text { Camilo e } \\
\end{array}$ \\
\hline
\end{tabular}

\footnotetext{
${ }^{95}$ Como explicado na nota anterior, os volumes 1 e 2 são seletas literárias, fato que motivou a não inclusão dessas obras no levantamento.

${ }^{96}$ Os livros para Admissão são divididos em 4 volumes: Português, Matemática, Geografia e História do Brasil.

${ }^{97}$ Quando não conseguimos acesso à data da $1^{\mathrm{a}}$ edição, registramos a data/edição mais antiga a que tivermos acesso.

${ }^{98}$ Há registros também de seu primeiro nome grafado como Arcy.
} 
1. Obras do programa de investigação GRAMATICAL

\begin{tabular}{|c|c|c|c|c|c|}
\hline & \multicolumn{3}{|c|}{ Escolares } & \multicolumn{2}{|c|}{ De referência } \\
\hline Obras $^{93}$ & $\begin{array}{c}\text { Gramáticas } \\
\text { completas }\end{array}$ & $\begin{array}{c}\text { Obras de } \\
\text { temas } \\
\text { gramaticais } \\
\text { específicos }\end{array}$ & $\begin{array}{c}\text { Livros } \\
\text { didáticos de } \\
\text { Português }\end{array}$ & $\begin{array}{c}\text { Gramáticas } \\
\text { completas }\end{array}$ & $\begin{array}{c}\text { Obras de } \\
\text { temas } \\
\text { gramaticais } \\
\text { específicos }\end{array}$ \\
\hline & & $\begin{array}{l}\text { varios cursos } \\
\text { de } \\
\text { preparatórios } \\
\text { (1940) } \boldsymbol{\beta} \\
\text { - Manual de } \\
\text { concurso: } \\
\text { um grosso } \\
\text { volume } \\
\text { escrito de } \\
\text { acôrdo com } \\
\text { os programas } \\
\text { para concurso } \\
\text { do DASP } \\
\text { (1943_4ed.) } \\
\mathbf{\Omega} \\
\text { - Pontos de } \\
\text { concurso: } \\
\text { rigorosament } \\
\text { e de acôrdo } \\
\text { com os } \\
\text { programas } \\
\text { para os } \\
\text { concursos do } \\
\text { DASP } \\
\text { (1943_2aed.) } \\
\mathbf{\Omega} \\
\text { - Pontos de } \\
\text { Português: } \\
\text { para os } \\
\text { concursos do }\end{array}$ & $\begin{array}{l}\text { exercícios } \\
\text { (1946) } \mathbf{\Omega} \\
\text { - Curso de } \\
\text { Português para } \\
\text { ginásios: } \\
\text { segunda serie: } \\
\text { gramática, } \\
\text { antologia, } \\
\text { exercícios } \\
(1943)^{103} \mathbf{\Omega} \\
\\
\text { - Curso de } \\
\text { Português para } \\
\text { ginásios: } \\
\text { terceira serie: } \\
\text { gramática, } \\
\text { antologia, } \\
\text { exercícios } \\
\text { (1946) } \boldsymbol{\Omega}\end{array}$ & & $\begin{array}{l}\text { outros } \\
\text { despretencios } \\
\text { os artigos } \\
\text { (1935) } \boldsymbol{\Omega} \\
\text { - } \\
\text { Gallicismos: } \\
\text { influência da } \\
\text { lingua } \\
\text { francesa no } \\
\text { Português } \\
\text { (1937) } \boldsymbol{\beta} \\
\text { - } \\
\text { Estrangeiris } \\
\text { mos: termos } \\
\text { espurios } \\
\text { empregados } \\
\text { no português: } \\
\text { estrangeirism } \\
\text { os de Ruy } \\
\text { Barbosa e de } \\
\text { Camillo } \\
\text { Castello } \\
\text { Branco } \\
\text { (1937) } \boldsymbol{\Omega} \\
\text { - Deslizes } \\
\text { grammatica } \\
\text { es: estudo da } \\
\text { linguagem de } \\
\text { Rui e de } \\
\text { Camilo } \\
\text { Castelo } \\
\text { Branco } \\
\text { (1938) } \Omega \\
\text { (19ano }\end{array}$ \\
\hline
\end{tabular}

${ }^{103}$ Localizamos esta coleção na quarta capa do Dicionário de gramática, de Orlando Mendes de Morais, publicado, em 1946, pela Editora Getulio Costa, a mesma que publicava boa parte dos livros de Acir Tenorio de Albuquerque. Além desse registro, localizamos apenas mais um outro: um exemplar do volume 2, publicado em 1943. 


\begin{tabular}{|c|c|c|c|c|c|}
\hline \multirow[b]{2}{*}{$\begin{array}{l}\text { Obras }^{93} \\
\text { Autores }\end{array}$} & \multicolumn{3}{|c|}{ Escolares } & \multicolumn{2}{|c|}{ De referência } \\
\hline & $\begin{array}{c}\text { Gramáticas } \\
\text { completas }\end{array}$ & $\begin{array}{l}\text { Obras de } \\
\text { temas } \\
\text { gramaticais } \\
\text { específicos }\end{array}$ & $\begin{array}{c}\text { Livros } \\
\text { didáticos de } \\
\text { Português }\end{array}$ & $\begin{array}{c}\text { Gramáticas } \\
\text { completas }\end{array}$ & $\begin{array}{c}\text { Obras de } \\
\text { temas } \\
\text { gramaticais } \\
\text { específicos }\end{array}$ \\
\hline & & $\begin{array}{l}\text { DASP }\left(2^{a} \text { ed. }\right. \\
\text { 1943 })^{99} \boldsymbol{\beta} \\
\text { - Exercícios } \\
\text { de } \\
\text { Português: } \\
\text { mais de } 300 \\
\text { exercicios: } \\
\text { mais de } 1000 \\
\text { questões } \\
(1943)^{100} \boldsymbol{\beta} \\
\text { - } \\
\text { Questionário } \\
\text { de sintaxe: } \\
\text { para auxiliar } \\
\text { os concursos } \\
\text { oficiais de } \\
\text { português: } \\
\text { centenas de } \\
\text { questões de } \\
\text { acordo com a } \\
\text { orientação } \\
\text { dos } \\
\text { concursos } \\
\text { oficiais, com } \\
\text { as respectivas } \\
\text { respostas na } \\
\text { segunda } \\
\text { parte. (1945) } \\
\boldsymbol{\Omega}\end{array}$ & & & $\begin{array}{l}\text { - } \\
\text { Contradiçõe } \\
\text { s de Rui } \\
\text { (1939) } \boldsymbol{\Omega} \\
\text { - Linguagem } \\
\text { de Ruy } \\
\text { Barbosa: } \\
\text { observações } \\
\text { gramaticais, } \\
\text { riqueza } \\
\text { vocabular, } \\
\text { estrangeirism } \\
\text { o (19--) } \boldsymbol{\beta} \\
\\
\text { - Estudos de } \\
\text { Português: } \\
\text { influência do } \\
\text { Francês no } \\
\text { Português, } \\
\text { sintaxe do } \\
\text { verbo haver, } \\
\text { infinito } \\
\text { pessoal, } \\
\text { questões de } \\
\text { semântica, } \\
\text { estrangeirism } \\
\text { os, etc. } \\
\text { (1937) } \boldsymbol{\Omega} \\
\text { - Atentados } \\
\text { à gramática } \\
\text { (1940) } \boldsymbol{\beta}\end{array}$ \\
\hline
\end{tabular}

${ }^{99}$ A Biblioteca Nacional do Rio de Janeiro (doravante BNRJ) possui um volume, com data provável de 1941, com o seguinte subtítulo: "português, matemática, corografia, estatística, direito civil, constitucional, administrativo, contabilidade e escrituração mercantil".

${ }^{100} \mathrm{Na} 4^{\mathrm{a}}$ edição, publicada em 1952, o subtítulo da obra é alterado para: "500 questões objetivas sôbre programas de concursos: orientação para avaliação de provas: treino para provas de concursos: diversas provas dadas em concursos do DASP". 


\begin{tabular}{|c|c|c|c|c|c|}
\hline \multirow[b]{2}{*}{ Obras $^{93}$} & \multicolumn{3}{|c|}{ Escolares } & \multicolumn{2}{|c|}{ De referência } \\
\hline & $\begin{array}{l}\text { Gramáticas } \\
\text { completas }\end{array}$ & $\begin{array}{c}\text { Obras de } \\
\text { temas } \\
\text { gramaticais } \\
\text { específicos }\end{array}$ & $\begin{array}{c}\text { Livros } \\
\text { didáticos de } \\
\text { Português }\end{array}$ & $\begin{array}{l}\text { Gramáticas } \\
\text { completas }\end{array}$ & $\begin{array}{l}\text { Obras de } \\
\text { temas } \\
\text { gramaticais } \\
\text { específicos }\end{array}$ \\
\hline & & $\begin{array}{l}\text { - Prática de } \\
\text { linguagem } \\
(1945)^{101} \boldsymbol{\Omega} \\
\text { - Manual de } \\
\text { verbos } \\
(1945)^{102} \boldsymbol{\Omega}\end{array}$ & & & \\
\hline $\begin{array}{l}\text { ALI, Said } \\
(1861-1953)\end{array}$ & \begin{tabular}{|l}
- \\
Grammatic \\
a \\
elementar \\
da Lingua \\
Portugueza \\
$(1923) \beta$ \\
- \\
Grammatic \\
a \\
secundária \\
da Lingua \\
Portugueza \\
(1923) $\beta$
\end{tabular} & & & & \\
\hline $\begin{array}{l}\text { ALMEIDA, } \\
\text { Napoleão } \\
\text { Mendes de } \\
\text { (1911-1998) }\end{array}$ & $\begin{array}{l}\text { - Gramática } \\
\text { metódica } \\
\text { da Língua } \\
\text { ortuguesa: } \\
\text { curso único } \\
\text { e }\end{array}$ & $\begin{array}{l}\text { - Crase, } \\
\text { colocação } \\
\text { dos } \\
\text { pronomes } \\
\text { oblíquos, } \\
\text { infinito } \\
\text { pessoal } \\
(1941) \Sigma\end{array}$ & & & $\begin{array}{l}\text { - Questões } \\
\text { vernaculas: I } \\
\text { parte (1937) } \\
\Sigma \\
\text { - Questões } \\
\text { vernaculas: }\end{array}$ \\
\hline
\end{tabular}

\footnotetext{
${ }^{101}$ Não conseguimos verificar o subtítulo desta edição, mas consta na BNRJ um volume, com data provável de 1948, com o seguinte subtítulo: "explicações, dezenas de verbos, concordância, pontuação, questões gramaticais: para os concursos do DASP e cursos preparatórios".

${ }^{102}$ Em uma outra obra do autor, provavelmente da década de 1950, no final do livro, consta a seguinte informação: "A parte da gramática em que o estudante encontra maiores dificuldades é, certamente, a que trata dos verbos. Manual de verbos foi escrito para auxiliar o estudante no seguro e pormenorizado estudo dos verbos, sem dúvida uma das mais importantes partes da gramática".
} 


\begin{tabular}{|c|c|c|c|c|c|}
\hline \multirow[b]{2}{*}{ Obras ${ }^{93}$} & \multicolumn{3}{|c|}{ Escolares } & \multicolumn{2}{|c|}{ De referência } \\
\hline & $\begin{array}{c}\text { Gramáticas } \\
\text { completas }\end{array}$ & $\begin{array}{c}\text { Obras de } \\
\text { temas } \\
\text { gramaticais } \\
\text { específicos }\end{array}$ & $\begin{array}{c}\text { Livros } \\
\text { didáticos de } \\
\text { Português }\end{array}$ & $\begin{array}{c}\text { Gramáticas } \\
\text { completas }\end{array}$ & $\begin{array}{c}\text { Obras de } \\
\text { temas } \\
\text { gramaticais } \\
\text { específicos }\end{array}$ \\
\hline & $\begin{array}{l}\text { completo }^{104} \\
\text { (1943) } \Sigma\end{array}$ & & & & $\begin{array}{l}\text { II parte } \\
(1938)^{105} \boldsymbol{\Sigma} \\
\text { - Questões } \\
\text { vernaculas: } \\
\text { III parte } \\
\text { (1939) } \boldsymbol{\Omega}\end{array}$ \\
\hline $\begin{array}{l}\text { ALMEIDA, } \\
\text { Rui } \\
(?-?)\end{array}$ & & & & & $\begin{array}{l}\text { Cooperemos } \\
\text { para a boa } \\
\text { linguagem: } \\
\text { mais de } 200 \\
\text { textos } \\
\text { corrigidos e } \\
\text { anotados } \\
(1944) \boldsymbol{\beta}\end{array}$ \\
\hline $\begin{array}{c}\text { ALVES, } \\
\text { A. Hilario } \\
\text { Travassos } \\
(?-?)\end{array}$ & & $\begin{array}{l}\text { - Verbos da } \\
\text { Lingua } \\
\text { Portuguesa: } \\
\text { conjugação } \\
\text { completa, } \\
\text { para cursos } \\
\text { elementar e } \\
\text { complementa } \\
\text { r (1921_2 } 2^{\mathrm{a}} \\
\text { ed.) } \boldsymbol{\Omega}\end{array}$ & & & \\
\hline $\begin{array}{c}\text { ALVES, } \\
\text { Achilles } \\
(1898-1972)\end{array}$ & $\begin{array}{l}\text { - Breves } \\
\text { noções de } \\
\text { grammatic } \\
\text { a }\end{array}$ & & $\begin{array}{l}\text { - O idioma } \\
\text { portuguez nas } \\
\text { classes }\end{array}$ & & \\
\hline
\end{tabular}

${ }^{104} \mathrm{O}$ autor afirma ser contra a elaboração de gramáticas com diferentes níveis de dificuldade, dividindo-as, por exemplo, em elementares ou superiores. Ainda de acordo com o autor, tal objeção é o que justifica o fato de sua gramática ser um "curso único e completo". Apesar dessa restrição, ele divide os tópicos de sua gramática segundo o que se deveria estudar em cada uma das quatro séries ginasiais. Essa ação não deixa dúvidas quanto ao nível escolar ao qual se destinava essa obra.

105 Na capa da obra, há a indicação do ano de 1937. Por outro lado, a folha de rosto informa o ano de 1938. Não há mais informações ao longo do livro que possam dirimir esse impasse. 


\begin{tabular}{|c|c|c|c|c|c|}
\hline \multirow[b]{2}{*}{ Obras ${ }^{93}$} & \multicolumn{3}{|c|}{ Escolares } & \multicolumn{2}{|c|}{ De referência } \\
\hline & $\begin{array}{c}\text { Gramáticas } \\
\text { completas }\end{array}$ & $\begin{array}{c}\text { Obras de } \\
\text { temas } \\
\text { gramaticais } \\
\text { específicos }\end{array}$ & $\begin{array}{c}\text { Livros } \\
\text { didáticos de } \\
\text { Português }\end{array}$ & $\begin{array}{c}\text { Gramáticas } \\
\text { completas }\end{array}$ & $\begin{array}{c}\text { Obras de } \\
\text { temas } \\
\text { gramaticais } \\
\text { específicos }\end{array}$ \\
\hline & $\begin{array}{l}\text { portugueza } \\
\text { : contendo } \\
\text { os } \\
\text { elementos } \\
\text { indispensav } \\
\text { eis de } \\
\text { grammatica } \\
\text { seguidos de } \\
\text { numerosos } \\
\text { exercicios e } \\
\text { modelos de } \\
\text { analyse: } \\
\text { paginas e } \\
\text { leitura } \\
\text { praticáveis. } \\
\text { (1936_5aed. } \\
\text { ) } \beta\end{array}$ & & $\begin{array}{l}\text { elementares } \\
(1930) \Omega\end{array}$ & & \\
\hline $\begin{array}{l}\text { AMARAN } \\
\text { TE, } \\
\text { Persicophob } \\
\text { o do } \\
(?-?)\end{array}$ & & & & & $\begin{array}{l}\text { - Notas de } \\
\text { portuguez á } \\
\text { margem de } \\
\text { um livro do } \\
\text { prof. } \\
\text { Pessegueiro } \\
\text { do Amaral: I } \\
\text { - rascunho de } \\
\text { grammatica } \\
\text { aplicada } \\
\text { (1917) } \Sigma\end{array}$ \\
\hline $\begin{array}{l}\text { ANDRADE } \\
\text { Francellino } \\
\text { de } \\
(?-?)\end{array}$ & & & & & $\begin{array}{l}\text { - Réplica ás } \\
\text { criticas do } \\
\text { Dr. Candido } \\
\text { de } \\
\text { Figueiredo } \\
\text { sobre a } \\
\text { monographi } \\
\text { a da crase } \\
\text { (1913) } \beta\end{array}$ \\
\hline
\end{tabular}




\begin{tabular}{|c|c|c|c|c|c|}
\hline \multirow[b]{2}{*}{ Obras ${ }^{93}$} & \multicolumn{3}{|c|}{ Escolares } & \multicolumn{2}{|c|}{ De referência } \\
\hline & $\begin{array}{c}\text { Gramáticas } \\
\text { completas }\end{array}$ & $\begin{array}{c}\text { Obras de } \\
\text { temas } \\
\text { gramaticais } \\
\text { específicos }\end{array}$ & $\begin{array}{c}\text { Livros } \\
\text { didáticos de } \\
\text { Português }\end{array}$ & $\begin{array}{c}\text { Gramáticas } \\
\text { completas }\end{array}$ & $\begin{array}{c}\text { Obras de } \\
\text { temas } \\
\text { gramaticais } \\
\text { específicos }\end{array}$ \\
\hline & & & & & $\begin{array}{l}\text { Monographi } \\
\text { a sobre o } \\
\text { emprego da } \\
\text { crase } \\
\left(1919 \_2^{a} \text { ed.) }\right. \\
\boldsymbol{\beta} \\
\text { - Vernáculo } \\
\text { (1920) } \boldsymbol{\beta} \\
\text { - A lingua } \\
\text { sem a } \\
\text { grammatica: } \\
\text { consultório } \\
\text { linguistico } \\
\text { (1929) } \boldsymbol{\Omega}\end{array}$ \\
\hline $\begin{array}{l}\text { ANDRADE } \\
\text {, Gustavo } \\
\text { de }^{106} \\
(1857-1913)\end{array}$ & $\begin{array}{l}\text { Grammatic } \\
\text { a intuitiva } \\
\text { da Lingua } \\
\text { Portuguez: } \\
\text { elementar }^{107} \\
\text { (1911) } \boldsymbol{\beta}\end{array}$ & $\begin{array}{l}\text { - Extixologia } \\
\text { ou } \\
\text { pontuação: } \\
\text { impresso } \\
\text { especialment } \\
\text { e para uso } \\
\text { dos alunos da } \\
\text { escola } \\
\text { comercial da }\end{array}$ & & $\begin{array}{l}\text { Grammatica } \\
\text { ecletica da } \\
\text { Lingua } \\
\text { Portugueza: } \\
\text { curso } \\
\text { superior } \\
\text { (1917) } \boldsymbol{\beta}\end{array}$ & $\begin{array}{l}\text { - Glosas } \\
\text { hêterodoxas } \\
\mathbf{1 0 8}(1914 ?) \Omega \\
\\
\text { - Cacolexias } \\
\text { ou vicios de } \\
\text { linguagem } \\
\text { (1914) } \Sigma\end{array}$ \\
\hline
\end{tabular}

${ }^{106}$ Nos anexos à Grammatica ecletica, obra que foi publicada postumamente, foram reunidas manifestações a respeito da morte de Gustavo de Andrade. Emygdio H. Souza, em texto publicado no Diario da Bahia, em 24/11/1914, diz: "Deixou alguns livros didacticos, dentre os quaes se destacam a - Grammatica intuitiva e as Cacolexias -, sendo este ultimo de grande utilidade não só para os estudiosos, mas tambem para todos os que falam a bella lingua de Camões porque contem a maioria dos vocabulos que por sua má ortographia prosódica e pela sua descendencia, enfermam e infestam a lingua portugueza."

${ }^{107}$ No prefácio à obra, assinado por T.B. (não foi possível descobrir quem é o autor de tal inicial), é informado que a Grammatica intuitiva foi "logo adotada nas escolas municipais e estaduais", sem, no entanto, informar em que séries isso ocorreu, se só na Bahia e em quais municípios houve a adoção ou demais informações sobre a aplicação e uso da obra.

${ }^{108}$ Nos mesmos anexos à Grammatica ecletica, um leitor, que assina apenas JEMR, em texto publicado no jornal A Epoca, n.1, em 02/11/1914, diz: "Adversario temivel, de que são prova cabal as Glosas heterodoxas, nas quaes, numa formidavel critica á Estylistica, [de Pedro Julio Barbuda] apresentou as incorrecções e a linguagem viviada em que fòra redigida". 


\begin{tabular}{|c|c|c|c|c|c|}
\hline \multirow[b]{2}{*}{ Obras $^{93}$} & \multicolumn{3}{|c|}{ Escolares } & \multicolumn{2}{|c|}{ De referência } \\
\hline & $\begin{array}{l}\text { Gramáticas } \\
\text { completas }\end{array}$ & $\begin{array}{c}\text { Obras de } \\
\text { temas } \\
\text { gramaticais } \\
\text { específicos }\end{array}$ & $\begin{array}{c}\text { Livros } \\
\text { didáticos de } \\
\text { Português }\end{array}$ & $\begin{array}{l}\text { Gramáticas } \\
\text { completas }\end{array}$ & $\begin{array}{c}\text { Obras de } \\
\text { temas } \\
\text { gramaticais } \\
\text { específicos }\end{array}$ \\
\hline & & $\begin{array}{l}\text { Bahia (1912) } \\
\mathbf{\Omega}\end{array}$ & & & \\
\hline $\begin{array}{c}\text { APOCALY } \\
\text { PSE, Raul } \\
\text { (? - ?) }\end{array}$ & & & & & $\begin{array}{l}\text { - Estudos de } \\
\text { Português } \\
\text { (1924) } \boldsymbol{\beta}\end{array}$ \\
\hline $\begin{array}{c}\text { AQUINO, } \\
\text { Jeronimo de } \\
(?-?)\end{array}$ & & & & & $\begin{array}{l}- \\
\text { Apontament } \\
\text { os de } \\
\text { gramática e } \\
\text { estilo (1940) } \\
\Sigma\end{array}$ \\
\hline $\begin{array}{c}\text { ARAGÃO, } \\
\text { Jarbas } \\
\text { Cavalcante } \\
\text { de } \\
(1904-1991)\end{array}$ & & & & & $\begin{array}{l}\text { - A } \\
\text { passividade } \\
\text { verbal em } \\
\text { seus vários } \\
\text { aspectos } \\
\text { (1944) } \boldsymbol{\beta}\end{array}$ \\
\hline $\begin{array}{c}\text { ARCANCH } \\
\text { Y, Alcides } \\
\text { d' } \\
\text { (1894-?) }\end{array}$ & & & & & $\begin{array}{l}\text { - Pingos } \\
\text { grammatica } \\
\text { es (1915) } \boldsymbol{\Omega} \\
\text { - Pela } \\
\text { reforma } \\
\text { gramatical: } \\
\text { réplica aos } \\
\text { srs. Osório } \\
\text { Duque- } \\
\text { Estrada e } \\
\text { Tristão de } \\
\text { Athayde } \\
(1922) \boldsymbol{\beta}\end{array}$ \\
\hline $\begin{array}{l}\text { ASSIS, José } \\
\text { Patricio de }\end{array}$ & & & & & $\begin{array}{l}\text { - Estudinhos } \\
\text { de } \\
\text { português: }\end{array}$ \\
\hline
\end{tabular}




\begin{tabular}{|c|c|c|c|c|c|}
\hline \multirow[b]{2}{*}{$\begin{array}{l}\text { Obras }^{93} \\
\text { Autores }\end{array}$} & \multicolumn{3}{|c|}{ Escolares } & \multicolumn{2}{|c|}{ De referência } \\
\hline & $\begin{array}{c}\text { Gramáticas } \\
\text { completas }\end{array}$ & $\begin{array}{l}\text { Obras de } \\
\text { temas } \\
\text { gramaticais } \\
\text { específicos }\end{array}$ & $\begin{array}{c}\text { Livros } \\
\text { didáticos de } \\
\text { Português }\end{array}$ & $\begin{array}{c}\text { Gramáticas } \\
\text { completas }\end{array}$ & $\begin{array}{c}\text { Obras de } \\
\text { temas } \\
\text { gramaticais } \\
\text { específicos }\end{array}$ \\
\hline$(?-?)$ & & & & & $\begin{array}{l}\text { artigos e } \\
\text { cartas (1925) } \\
\Sigma\end{array}$ \\
\hline \multicolumn{6}{|c|}{ B } \\
\hline $\begin{array}{l}\text { BARRETO, } \\
\text { Mário } \\
\text { (1879-1931) }\end{array}$ & & & & & $\begin{array}{l}\text { - Estudos de } \\
\text { Lingua } \\
\text { Portugueza } \\
(1903) \boldsymbol{\beta} \\
\text { - Novos } \\
\text { estudos da } \\
\text { Lingua } \\
\text { Portuguesa } \\
\text { (1911) } \boldsymbol{\beta} \\
\text { - Novíssimos } \\
\text { estudos de } \\
\text { Língua } \\
\text { Portuguesa: } \\
\text { colecção de } \\
\text { artigos } \\
\text { (1914) } \boldsymbol{\beta} \\
\\
\text { - Factos da } \\
\text { Língua } \\
\text { Portuguesa: } \\
\text { correio de } \\
\text { consulentes } \\
\text { (1916) } \boldsymbol{\beta} \\
\text { - De } \\
\text { gramática e } \\
\text { de } \\
\text { linguagem: } \\
\text { correio de }\end{array}$ \\
\hline
\end{tabular}




\begin{tabular}{|c|c|c|c|c|c|}
\hline \multirow[b]{2}{*}{ Obras $^{93}$} & \multicolumn{3}{|c|}{ Escolares } & \multicolumn{2}{|c|}{ De referência } \\
\hline & $\begin{array}{c}\text { Gramáticas } \\
\text { completas }\end{array}$ & $\begin{array}{c}\text { Obras de } \\
\text { temas } \\
\text { gramaticais } \\
\text { específicos }\end{array}$ & $\begin{array}{c}\text { Livros } \\
\text { didáticos de } \\
\text { Português }\end{array}$ & $\begin{array}{c}\text { Gramáticas } \\
\text { completas }\end{array}$ & $\begin{array}{c}\text { Obras de } \\
\text { temas } \\
\text { gramaticais } \\
\text { específicos }\end{array}$ \\
\hline & & & & & $\begin{array}{l}\text { consulentes } \\
\text { (1922) } \boldsymbol{\beta} \\
\text { - Através do } \\
\text { dicionário e } \\
\text { da } \\
\text { gramática: } \\
\text { correio de } \\
\text { consulentes } \\
\text { (1927) } \boldsymbol{\beta} \\
\text { - Últimos } \\
\text { estudos: } \\
\text { vários: a } \\
\text { nossa língua, } \\
\text { a sra. } \\
\text { gramática } \\
(1944)^{109} \boldsymbol{\beta}\end{array}$ \\
\hline $\begin{array}{c}\text { BACHELE } \\
\text { T, Mário } \\
(?-?)\end{array}$ & & & $\begin{array}{l}\text { - Novo manual } \\
\text { de Lingua } \\
\text { Portugueza }^{110} \text { : } \\
\text { grammatica, } \\
\text { lexicologia, } \\
\text { analyse, } \\
\text { composição: } \\
\text { para uso das } \\
\text { escolas } \\
\text { primárias: curso }\end{array}$ & & \\
\hline
\end{tabular}

\footnotetext{
${ }^{109}$ Publicação póstuma.

${ }^{110}$ Há uma oscilação quanto ao registro da autoria dos livros pertencentes a esta coleção da editora F.T.D. Em nossa pesquisa, encontramos alguns volumes assinados por Mário Bachelet e outros por "Por uma seleção de professores". Pelos dados a que tivemos acesso, não conseguimos encontrar uma justificativa para tal oscilação. A edição que possuímos, do curso médio (s.d), por exemplo, é assinada por Bachelet. Na BNRJ, todos os exemplares são assinados por esse autor. No presente levantamento, optamos por seguir os registros da BNRJ.
} 


\begin{tabular}{|c|c|c|c|c|c|}
\hline \multirow[b]{2}{*}{ Obras ${ }^{93}$} & \multicolumn{3}{|c|}{ Escolares } & \multicolumn{2}{|c|}{ De referência } \\
\hline & $\begin{array}{c}\text { Gramáticas } \\
\text { completas }\end{array}$ & $\begin{array}{c}\text { Obras de } \\
\text { temas } \\
\text { gramaticais } \\
\text { específicos }\end{array}$ & $\begin{array}{c}\text { Livros } \\
\text { didáticos de } \\
\text { Português }\end{array}$ & $\begin{array}{c}\text { Gramáticas } \\
\text { completas }\end{array}$ & $\begin{array}{l}\text { Obras de } \\
\text { temas } \\
\text { gramaticais } \\
\text { específicos }\end{array}$ \\
\hline & & & $\begin{array}{l}\text { preparatório }^{111} \\
\text { (1919) }^{112} \boldsymbol{\Omega} \\
\text { - Novo manual } \\
\text { de Lingua } \\
\text { Portugueza: } \\
\text { grammatica, } \\
\text { lexicologia, } \\
\text { analyse, } \\
\text { composição: } \\
\text { para uso das } \\
\text { escolas } \\
\text { primárias: curso } \\
\text { preparatório: } \\
\text { livro do mestre } \\
\text { (1919) } \boldsymbol{\Omega} \\
\text { - Novo manual } \\
\text { de Lingua } \\
\text { Portugueza: } \\
\text { grammatica, } \\
\text { lexicologia, } \\
\text { analyse, } \\
\text { composição: } \\
\text { curso elementar } \\
\text { (1932) } \boldsymbol{\Omega}\end{array}$ & & \\
\hline
\end{tabular}

${ }^{111}$ De acordo com a quarta capa, esta coleção apresenta a seguinte estruturação: "10 CURSO PREPARATORIO: Theoria grammatical muito simples, em linguagem facil, com 274 exercicios de applicação das regras, illustrado. Estudantes de 7 e 8 annos de idade. $2^{\mathbf{0}}$ CURSO ELEMENTAR: Desenvolve e amplia gradualmente a theoria e multiplica os exercicios em numero de 632. Estudantes de 9 e 10 annos de idade. $3^{\circ}$ CURSO MEDIO: Dirige-se a estudantes de 11, 12, 13 annos. A theoria é mais completa. Traz noções precisas e claras sobre analyse e estilo com 1052 exercicios de applicação. $4^{\mathbf{0}}$ CURSO SECUNDARIO: Este volume offerece tudo quanto de verdadeiramente pedagogico e assimilavel pelo joven estudioso, se tem determinado até o presente sobre a língua portugueza, 758 exercicios variadissimos. Estudantes de 14 a 15 annos. $5^{\circ}$ CURSO SUPERIOR: Trata das principaes questões atinentes á lingua, dando a súmmula do que a respeito escreveram os grammaticos mais abalisados. - Literatura e historia literaria. -550 exercicios. $6^{\circ}$ CURSO COMPLEMENTAR: É a grammatica historica da lingua portugueza posta ao alcance de todos os candidatos a exames. Trechos de todas as epocas. Numerosas gravuras amenizam e documentam o texto".

112 Com exceção do volume do curso secundário, livro do mestre, que é de 1912, todos os demais volumes desta coleção têm datas prováveis de publicação, segundo informam os registros das fichas catalográficas da BNRJ e da USP (no caso do curso superior). 


\begin{tabular}{|c|c|c|c|c|c|}
\hline \multirow[b]{2}{*}{ Obras ${ }^{93}$} & \multicolumn{3}{|c|}{ Escolares } & \multicolumn{2}{|c|}{ De referência } \\
\hline & $\begin{array}{c}\text { Gramáticas } \\
\text { completas }\end{array}$ & $\begin{array}{c}\text { Obras de } \\
\text { temas } \\
\text { gramaticais } \\
\text { específicos }\end{array}$ & $\begin{array}{c}\text { Livros } \\
\text { didáticos de } \\
\text { Português }\end{array}$ & $\begin{array}{c}\text { Gramáticas } \\
\text { completas }\end{array}$ & $\begin{array}{c}\text { Obras de } \\
\text { temas } \\
\text { gramaticais } \\
\text { específicos }\end{array}$ \\
\hline & & & $\begin{array}{l}\text { - Novo manual } \\
\text { de Lingua } \\
\text { Portugueza: } \\
\text { grammatica, } \\
\text { lexicologia, } \\
\text { analyse, } \\
\text { composição: } \\
\text { para uso das } \\
\text { escolas } \\
\text { primárias: curso } \\
\text { elementar: livro } \\
\text { do mestre } 113 \\
\text { (1930) } \Omega \\
\text { - Novo manual } \\
\text { de Língua } \\
\text { Portuguêsa: } \\
\text { curso médio } \\
\text { (1932) } \boldsymbol{\beta} \\
\text { - Novo manual } \\
\text { de Língua } \\
\text { Portuguêsa: } \\
\text { curso médio: } \\
\text { livro do mestre } \\
\text { (1937) } \Omega \\
\text { - Novo manual } \\
\text { de Lingua } \\
\text { Portugueza: } \\
\text { grammatica, } \\
\text { lexicologia, } \\
\text { analyse, } \\
\text { composição: } \\
\text { escolas } \\
\text { secundárias: }\end{array}$ & & \\
\hline
\end{tabular}

${ }^{113}$ De acordo com as fichas bibliográficas da BNRJ, os "livros do mestre" têm uma quantidade de páginas bem superior aos "livros do aluno", às vezes chegando ao dobro. 


\begin{tabular}{|c|c|c|c|c|c|}
\hline \multirow[b]{2}{*}{ Obras ${ }^{93}$} & \multicolumn{3}{|c|}{ Escolares } & \multicolumn{2}{|c|}{ De referência } \\
\hline & $\begin{array}{c}\text { Gramáticas } \\
\text { completas }\end{array}$ & $\begin{array}{l}\text { Obras de } \\
\text { temas } \\
\text { gramaticais } \\
\text { específicos }\end{array}$ & $\begin{array}{c}\text { Livros } \\
\text { didáticos de } \\
\text { Português }\end{array}$ & $\begin{array}{c}\text { Gramáticas } \\
\text { completas }\end{array}$ & $\begin{array}{c}\text { Obras de } \\
\text { temas } \\
\text { gramaticais } \\
\text { específicos }\end{array}$ \\
\hline & & & $\begin{array}{l}\text { curso secundário } \\
\text { (1930) } \boldsymbol{\Omega} \\
\text { - Novo manual } \\
\text { de Lingua } \\
\text { Portugueza: } \\
\text { grammatica, } \\
\text { lexicologia, } \\
\text { analyse, } \\
\text { composição: } \\
\text { para uso das } \\
\text { escolas } \\
\text { secundárias: } \\
\text { curso } \\
\text { secundário: livro } \\
\text { do mestre } \\
\text { (1912) } \Omega \\
\\
\text { - Novo manual } \\
\text { de Lingua } \\
\text { Portuguesa } \\
\text { luso-brasileira: } \\
\text { curso superior } \\
\text { (1925) } \boldsymbol{\beta} \\
\text { - Novo manual } \\
\text { de Lingua } \\
\text { Portuguesa } \\
\text { luso-brasileira: } \\
\text { curso superior: } \\
\text { livro do mestre } \\
\text { (1925) } \Omega\end{array}$ & & \\
\hline $\begin{array}{c}\text { BACHELE } \\
\text { T, Mário } \\
(?-?) \\
\text { NUNES, } \\
\text { José de Sá }\end{array}$ & $\begin{array}{l}\text { - Novo } \\
\text { manual da } \\
\text { Língua } \\
\text { Portuguêsa } \\
\text { : gramática: } \\
\text { para as } 4\end{array}$ & & & & \\
\hline
\end{tabular}




\begin{tabular}{|c|c|c|c|c|c|}
\hline \multirow[b]{2}{*}{$\begin{array}{l}\text { Obras }^{93} \\
\text { Autores }\end{array}$} & \multicolumn{3}{|c|}{ Escolares } & \multicolumn{2}{|c|}{ De referência } \\
\hline & $\begin{array}{c}\text { Gramáticas } \\
\text { completas }\end{array}$ & $\begin{array}{c}\text { Obras de } \\
\text { temas } \\
\text { gramaticais } \\
\text { específicos }\end{array}$ & $\begin{array}{c}\text { Livros } \\
\text { didáticos de } \\
\text { Português }\end{array}$ & $\begin{array}{c}\text { Gramáticas } \\
\text { completas }\end{array}$ & $\begin{array}{c}\text { Obras de } \\
\text { temas } \\
\text { gramaticais } \\
\text { específicos }\end{array}$ \\
\hline$(?-1955)$ & $\begin{array}{l}\text { séries do } \\
\text { ciclo } \\
\text { ginasial }^{114} \\
(1943) \Omega\end{array}$ & & & & \\
\hline $\begin{array}{l}\text { BARBOSA, } \\
\text { Rui } \\
(1849-1923)\end{array}$ & & & & & $\begin{array}{l}\text { - Parecer do } \\
\text { Senador Ruy } \\
\text { Barbosa } \\
\text { sobre a } \\
\text { redacção do } \\
\text { projecto da } \\
\text { Camara dos } \\
\text { Deputados } \\
\text { (1902) } \beta \\
\\
\text { - Replica do } \\
\text { senador Ruy } \\
\text { Barbosa as } \\
\text { defesas da } \\
\text { redacção do } \\
\text { projecto da } \\
\text { Camara dos } \\
\text { Deputados } \\
\text { (1902) } \beta\end{array}$ \\
\hline $\begin{array}{l}\text { BARBUDA } \\
\text {, Pedro } \\
\text { Julio } \\
\\
(?-?)\end{array}$ & & & & $\begin{array}{l}\text { - } \\
(1926) \boldsymbol{\beta}\end{array}$ & \\
\hline $\begin{array}{l}\text { BARRETO, } \\
\text { Paulo } \\
\text { Emilio de } \\
\text { Noronha } \\
\text { Menna } \\
\text { (?-?) }\end{array}$ & & & & & $\begin{array}{l}\text { - Tres } \\
\text { questões de } \\
\text { grammatica: } \\
\text { topologia } \\
\text { pronominal, } \\
\text { crase, } \\
\text { impessoalida }\end{array}$ \\
\hline
\end{tabular}

114 Também encontramos esta obra com o título ligeiramente diferente: Novo manual da Língua Portuguêsa lusobrasileira: gramática: para as 4 séries do ciclo ginasial. Os demais dados bibliográficos são os mesmos, com o acréscimo apenas do "luso-brasileiro" no título. 


\begin{tabular}{|c|c|c|c|c|c|}
\hline \multirow[b]{2}{*}{ Obras $^{93}$} & \multicolumn{3}{|c|}{ Escolares } & \multicolumn{2}{|c|}{ De referência } \\
\hline & $\begin{array}{c}\text { Gramáticas } \\
\text { completas }\end{array}$ & $\begin{array}{c}\text { Obras de } \\
\text { temas } \\
\text { gramaticais } \\
\text { específicos }\end{array}$ & $\begin{array}{c}\text { Livros } \\
\text { didáticos de } \\
\text { Português }\end{array}$ & $\begin{array}{c}\text { Gramáticas } \\
\text { completas }\end{array}$ & $\begin{array}{c}\text { Obras de } \\
\text { temas } \\
\text { gramaticais } \\
\text { específicos }\end{array}$ \\
\hline & & & & & $\begin{array}{l}\text { de e } \\
\text { pessoalidade } \\
\text { do infinito } \\
\text { (1938) } \boldsymbol{\beta}\end{array}$ \\
\hline $\begin{array}{l}\text { BELLUCI, } \\
\text { Arnaldo } \\
(?-?)\end{array}$ & & $\begin{array}{l}\text { - Pontos de } \\
\text { Português: } \\
\text { análise léxica } \\
\text { e lógica } \\
\text { (1934) } \beta\end{array}$ & & & \\
\hline $\begin{array}{l}\text { BERGO, } \\
\text { Vittorio } \\
(1902-?)\end{array}$ & & & & & $\begin{array}{l}\text { - Erros e } \\
\text { duvidas de } \\
\text { linguagem: } \\
\text { dispostos em } \\
\text { ordem } \\
\text { alfabética } \\
\text { (1941) } \boldsymbol{\beta} \\
\text { - Erros e } \\
\text { duvidas de } \\
\text { linguagem: } \\
\text { dispostos em } \\
\text { ordem } \\
\text { alfabética: } \\
\text { vol. } 2 \text { (1944) } \\
\boldsymbol{\beta} \\
\text { - Consultor } \\
\text { de gramatica } \\
\text { e de } \\
\text { estilistica: } \\
\text { em ordem } \\
\text { alfabética } \\
\text { (1942) } \Omega\end{array}$ \\
\hline $\begin{array}{c}\text { BITTENCO } \\
\text { URT, } \\
\text { Arthur }\end{array}$ & & $\begin{array}{l}\text { - Tratado } \\
\text { pratico de } \\
\text { analyse }\end{array}$ & & & \\
\hline
\end{tabular}




\begin{tabular}{|c|c|c|c|c|c|}
\hline \multirow[b]{2}{*}{$\begin{array}{l}\text { Obras }^{93} \\
\text { Autores }\end{array}$} & \multicolumn{3}{|c|}{ Escolares } & \multicolumn{2}{|c|}{ De referência } \\
\hline & $\begin{array}{c}\text { Gramáticas } \\
\text { completas }\end{array}$ & $\begin{array}{l}\text { Obras de } \\
\text { temas } \\
\text { gramaticais } \\
\text { específicos }\end{array}$ & $\begin{array}{c}\text { Livros } \\
\text { didáticos de } \\
\text { Português }\end{array}$ & $\begin{array}{c}\text { Gramáticas } \\
\text { completas }\end{array}$ & $\begin{array}{c}\text { Obras de } \\
\text { temas } \\
\text { gramaticais } \\
\text { específicos }\end{array}$ \\
\hline$(?-?)$ & & $\begin{array}{l}\text { lexica e } \\
\text { logica }(1922) \\
\Omega\end{array}$ & & & \\
\hline $\begin{array}{l}\text { BITTENCO } \\
\text { URT, } \\
\text { Liberato } \\
\text { (1869-1948) }\end{array}$ & & $\begin{array}{l}\text { - Exame de } \\
\text { admissão } \\
\text { (1933) } \Omega\end{array}$ & & & $\begin{array}{l}\text { - Estudo da } \\
\text { Lingua } \\
\text { Portuguesa } \\
(1921) \Omega \\
\\
\text { - Impurezas } \\
\text { da } \\
\text { linguagem } \\
\text { no dominio } \\
\text { scientífico } \\
\text { (1927) } \Omega \\
\\
\text { - Psicologia } \\
\text { gramatical } \\
\text { de falso } \\
\text { Aristarco ou } \\
\text { 3 mil erros } \\
\text { de gramatica } \\
\text { (1933) } \Omega\end{array}$ \\
\hline $\begin{array}{l}\text { BOECHAT, } \\
\text { Walter } \\
\text { Monteiro } \\
(1915-1982)\end{array}$ & & $\begin{array}{l}\text { - O meu } \\
\text { exame de } \\
\text { admissão } \\
(1936) \Omega\end{array}$ & & & \\
\hline $\begin{array}{c}\text { BRITO } \\
\text { PEREIRA, } \\
\text { Carlos de } \\
(?-?)\end{array}$ & $\begin{array}{l}\text { - Manual } \\
\text { de } \\
\text { gramática } \\
\text { portuguesa } \\
\text { (1933) } \beta\end{array}$ & & & & $\begin{array}{l}\text { - Analyse } \\
\text { syntactica: } \\
\text { noções } \\
\text { indispensavei } \\
\text { s e } \\
\text { suficientes ao } \\
\text { preparatorio } \\
\text { de Português } \\
(1928)(\mathrm{T}) \boldsymbol{\beta}\end{array}$ \\
\hline
\end{tabular}




\begin{tabular}{|c|c|c|c|c|c|}
\hline \multirow[b]{2}{*}{ Obras $^{93}$} & \multicolumn{3}{|c|}{ Escolares } & \multicolumn{2}{|c|}{ De referência } \\
\hline & $\begin{array}{l}\text { Gramáticas } \\
\text { completas }\end{array}$ & $\begin{array}{c}\text { Obras de } \\
\text { temas } \\
\text { gramaticais } \\
\text { específicos }\end{array}$ & $\begin{array}{c}\text { Livros } \\
\text { didáticos de } \\
\text { Português }\end{array}$ & $\begin{array}{l}\text { Gramáticas } \\
\text { completas }\end{array}$ & $\begin{array}{c}\text { Obras de } \\
\text { temas } \\
\text { gramaticais } \\
\text { específicos }\end{array}$ \\
\hline $\begin{array}{l}\text { BRITO, } \\
\text { Frederico } \\
\text { Carlos da } \\
\text { Costa } \\
(?-?)\end{array}$ & & $\begin{array}{l}\text { - Exercicios } \\
\text { de analyse } \\
\text { portuguesa: } \\
\text { lexicologica e } \\
\text { syntactica } \\
(1908)^{115} \mathbf{\Omega}\end{array}$ & & & \\
\hline $\begin{array}{c}\text { BRITO, } \\
\text { Paulino de } \\
\text { Almeida } \\
\text { (1858-1919) }\end{array}$ & $\begin{array}{l}\text { - } \\
\text { Gramática } \\
\text { primaria } \\
\text { da Lingua } \\
\text { Portuguesa } \\
\text { : para uso } \\
\text { das escolas } \\
\left(18991^{a}\right. \\
\text { ed.) } \\
\left(1943 \_26^{a} \mathrm{e}\right. \\
\text { d.) } \mathbf{\Omega} \\
\text { - A } \\
\text { grammatic } \\
\text { a do } \\
\text { professor } \\
\text { (1908) } \boldsymbol{\Omega}\end{array}$ & & & & $\begin{array}{l}\text { - Collocação } \\
\text { dos } \\
\text { pronomes: } \\
\text { artigos } \\
\text { publicados na } \\
\text { Provincia do } \\
\text { Pará (1906- } \\
\text { 1907) (1907) } \\
\mathbf{\Omega} \\
- \\
\text { Brasileirism } \\
\text { os de } \\
\text { colocação de } \\
\text { pronomes: } \\
\text { resposta ao } \\
\text { Snr. Candido } \\
\text { de Figueiredo } \\
\text { (1908) } \beta\end{array}$ \\
\hline $\begin{array}{l}\text { BRUNO, } \\
\text { Aníbal } \\
(1890-1976)\end{array}$ & $\begin{array}{l}\text { - Língua } \\
\text { Portuguesa } \\
\text { : gramática } \\
\text { e exercícios } \\
\text { para as } \\
\text { quarto } \\
\text { séries } \\
\text { ginasiais } \\
(1944 \text { 19 } \\
\text { ed.) } \beta\end{array}$ & & $\begin{array}{l}\text { - Língua } \\
\text { Portuguesa: } \\
\text { para a } 1^{\mathrm{a}} \text { série } \\
\text { ginasial } \\
\left(19382^{\mathrm{a}} \text { ed.) } \mathbf{\Omega}\right. \\
\text { - Língua } \\
\text { Portuguesa: } \\
\text { para a } 2^{\mathrm{a}} \text { série } \\
\text { ginasial } \\
\left(1939 ?^{\mathrm{a}} \text { ed.) } \mathbf{\Omega}\right.\end{array}$ & & \\
\hline
\end{tabular}

115 A referência a esta obra consta em outro livro de nosso acervo, publicado em 1908. Não é possível afirmar que essa é a data da $1^{a}$ edição de Exercicios de analyse portugueza, mas apenas que, em 1908, ela já havia sido publicada. 


\begin{tabular}{|c|c|c|c|c|c|}
\hline \multirow[b]{2}{*}{ Obras ${ }^{93}$} & \multicolumn{3}{|c|}{ Escolares } & \multicolumn{2}{|c|}{ De referência } \\
\hline & $\begin{array}{c}\text { Gramáticas } \\
\text { completas }\end{array}$ & $\begin{array}{l}\text { Obras de } \\
\text { temas } \\
\text { gramaticais } \\
\text { específicos }\end{array}$ & $\begin{array}{c}\text { Livros } \\
\text { didáticos de } \\
\text { Português }\end{array}$ & $\begin{array}{c}\text { Gramáticas } \\
\text { completas }\end{array}$ & $\begin{array}{c}\text { Obras de } \\
\text { temas } \\
\text { gramaticais } \\
\text { específicos }\end{array}$ \\
\hline & & & $\begin{array}{l}\text { - Língua } \\
\text { Portuguesa: } \\
\text { para a } 3^{\mathrm{a}} \text { série } \\
\text { ginasial, as } \\
\text { escolas normais } \\
\text { e as escolas de } \\
\text { comércio } \\
\text { (1938_? ed.) } \mathbf{\Omega} \\
\text { - Língua } \\
\text { Portuguesa: } \\
\text { para os cursos } \\
\text { clássicos e } \\
\text { cientifico. } 1^{\mathrm{a}} \\
\text { série (1945_? } \\
\text { ed.) } \mathbf{\Omega}\end{array}$ & & \\
\hline $\begin{array}{l}\text { BUCHLER, } \\
\text { G. A. }{ }^{116} \\
(?-?)\end{array}$ & & & & & $\begin{array}{l}\text { - Guia de } \\
\text { conjugação } \\
(1934) \Omega \\
\text { - Caderno de } \\
\text { conjugação } \\
(\mathrm{s} / \mathrm{d})^{117} \boldsymbol{\Omega}\end{array}$ \\
\hline $\begin{array}{c}\text { BUENO, } \\
\text { Silveira } \\
\text { (1898-1989) }\end{array}$ & $\begin{array}{l}\text { Gramática } \\
\text { normativa } \\
\text { da Língua } \\
\text { Portuguêsa } \\
\text { : curso } \\
\text { superior } \\
\text { (1944) } \beta\end{array}$ & & $\begin{array}{l}\text { - Páginas } \\
\text { floridas }^{118}: 40 \\
\text { leituras em } \\
\text { prosa e verso, } 60 \\
\text { lições e } \\
\text { numerosos } \\
\text { comentários } \\
\text { gramaticais. }\left(1^{\mathrm{a}}\right. \\
\text { série: curso }\end{array}$ & & $\begin{array}{l}\text { - Português } \\
\text { pelo rádio } \\
\text { (1938) } \boldsymbol{\beta}\end{array}$ \\
\hline
\end{tabular}

${ }^{116} \mathrm{O}$ autor assina G. A. Buchler, mas seu nome completo é George Augusto Buchler.

117 Não conseguimos acesso a dados que pudessem apontar a data de publicação deste livro, mas ele aparece na relação de "Edições da Casa - Cia Melhoramentos de S. Paulo" presente no Livro de exercícios para apprender os elementos da Grammatica portugueza, de P.S, editada no início do século XX por essa mesma casa editorial. ${ }^{118}$ Em 1942, a coleção passou a chamar-se Páginas floridas: seleta e gramática. 


\begin{tabular}{|c|c|c|c|c|c|}
\hline \multirow[b]{2}{*}{ Obras ${ }^{93}$} & \multicolumn{3}{|c|}{ Escolares } & \multicolumn{2}{|c|}{ De referência } \\
\hline & $\begin{array}{c}\text { Gramáticas } \\
\text { completas }\end{array}$ & $\begin{array}{c}\text { Obras de } \\
\text { temas } \\
\text { gramaticais } \\
\text { específicos }\end{array}$ & $\begin{array}{l}\text { Livros } \\
\text { didáticos de } \\
\text { Português }\end{array}$ & $\begin{array}{c}\text { Gramáticas } \\
\text { completas }\end{array}$ & $\begin{array}{c}\text { Obras de } \\
\text { temas } \\
\text { gramaticais } \\
\text { específicos }\end{array}$ \\
\hline & & & 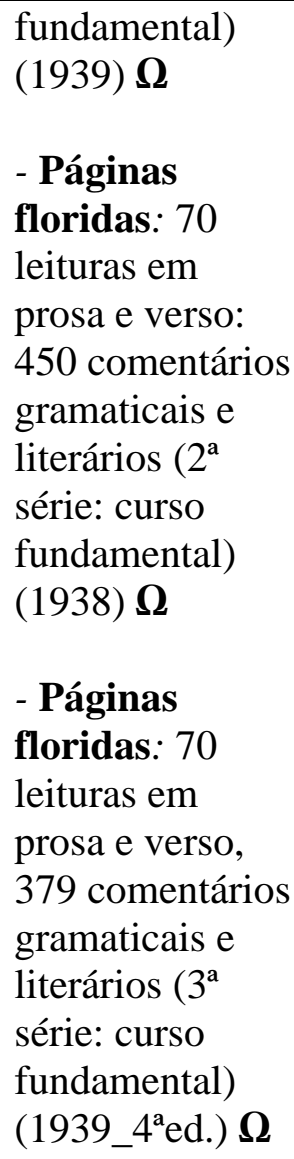 & & \\
\hline $\begin{array}{c}\text { BUENO, } \\
\text { Silveira } \\
(1898-1989) \\
\text { SPICACCI, } \\
\text { Frederico } \\
\text { Carlos } \\
(?-?) \\
\text { AMARAL, } \\
\text { João Miguel } \\
\text { (? - ?) }\end{array}$ & & $\begin{array}{l}\text { - Curso de } \\
\text { admissão aos } \\
\text { ginásios }^{119} \\
\text { (1939) } \Omega\end{array}$ & & & \\
\hline
\end{tabular}

119 "Programa do Exame de Admissão aos Ginásios, segundo a reforma do Ensino (decreto n 19.890) de 18 de Abril de 1931/ 509p.”. 


\begin{tabular}{|c|c|c|c|c|c|}
\hline \multirow[b]{2}{*}{ Obras ${ }^{93}$} & \multicolumn{3}{|c|}{ Escolares } & \multicolumn{2}{|c|}{ De referência } \\
\hline & $\begin{array}{c}\text { Gramáticas } \\
\text { completas }\end{array}$ & $\begin{array}{c}\text { Obras de } \\
\text { temas } \\
\text { gramaticais } \\
\text { específicos }\end{array}$ & $\begin{array}{c}\text { Livros } \\
\text { didáticos de } \\
\text { Português }\end{array}$ & $\begin{array}{c}\text { Gramáticas } \\
\text { completas }\end{array}$ & $\begin{array}{c}\text { Obras de } \\
\text { temas } \\
\text { gramaticais } \\
\text { específicos }\end{array}$ \\
\hline $\begin{array}{c}\text { PACKER, } \\
\text { Adolfo } \\
(?-?)\end{array}$ & & & & & \\
\hline $\begin{array}{l}\text { LEAL, } \\
\text { Antônio de } \\
\text { Sousa } \\
(?-?)\end{array}$ & & & & & \\
\hline $\begin{array}{l}\text { SOUSA, } \\
\text { Enéias } \\
\text { Bastos } \\
(?-?)\end{array}$ & & & & & \\
\hline \multicolumn{6}{|c|}{$\mathbf{C}$} \\
\hline $\begin{array}{l}\text { CALBUCC } \\
\text { I, Ernani } \\
(1912-1964)\end{array}$ & & & & & $\begin{array}{l}\text { - } \\
\text { Questiúncul } \\
\text { as de Língua } \\
\text { Portuguêsa } \\
\text { (1941) } \beta \\
\text { - Léxico de } \\
\text { dúvidas de } \\
\text { linguagem } \\
(\mathrm{s} / \mathrm{d})^{120} \Omega\end{array}$ \\
\hline $\begin{array}{l}\text { CÂMARA } \\
\text { JR., } \\
\text { Joaquim } \\
\text { Mattoso } \\
\text { (1904-1970) }\end{array}$ & $\begin{array}{l}\text { Gramática: } \\
1^{\mathrm{a}} \text { e } 2^{\mathrm{a}} \\
\text { séries } \\
\text { ginasiais } \\
(1944) \boldsymbol{\beta}\end{array}$ & & $\begin{array}{l}\text { - Elementos de } \\
\text { língua pátria: } \\
\text { volume } 1 \\
\text { (1938_2a ed.) } \mathbf{\Omega} \\
\text { - Elementos de } \\
\text { língua pátria: }\end{array}$ & & \\
\hline
\end{tabular}

\footnotetext{
${ }^{120}$ Não há referência, nesta obra, de seu ano de publicação. Optamos por inclui-la neste levantamento, pois as demais obras do autor são do final da década de 1930 e começo da de 1940, o que nos fez supor que o livro em questão deva ter sido publicado também nesse período.
} 
1. Obras do programa de investigação GRAMATICAL

\begin{tabular}{|c|c|c|c|c|c|}
\hline & \multicolumn{3}{|c|}{ Escolares } & \multicolumn{2}{|c|}{ De referência } \\
\hline $\begin{array}{l}\text { Obras }^{93} \\
\text { Autores }\end{array}$ & $\begin{array}{c}\text { Gramáticas } \\
\text { completas }\end{array}$ & $\begin{array}{c}\text { Obras de } \\
\text { temas } \\
\text { gramaticais } \\
\text { específicos }\end{array}$ & $\begin{array}{c}\text { Livros } \\
\text { didáticos de } \\
\text { Português }\end{array}$ & $\begin{array}{c}\text { Gramáticas } \\
\text { completas }\end{array}$ & $\begin{array}{c}\text { Obras de } \\
\text { temas } \\
\text { gramaticais } \\
\text { específicos }\end{array}$ \\
\hline & $\begin{array}{l}\text { Gramática: } \\
3^{\mathrm{a}} \text { e } 4^{\mathrm{a}} \\
\text { séries } \\
\text { ginasiais } \\
(1945) \mathbf{\Omega}\end{array}$ & & $\begin{array}{l}\text { volume } 2 \\
\text { (1938_2 ed.) } \mathbf{\Omega} \\
\text { - Elementos de } \\
\text { língua pátria: } \\
\text { volume } 3 \\
\text { (1938_2 ed.) } \mathbf{\Omega}\end{array}$ & & \\
\hline $\begin{array}{l}\text { CAMPINH } \\
\text { OS, } \\
\text { Newman } \\
\text { José } \\
\text { Barroso } \\
(?-?)\end{array}$ & & & $\begin{array}{l}\text { - Lições de } \\
\text { língua pátria } \\
\left(1940 \_2^{\mathrm{a}} \text { ed.) } \boldsymbol{\Omega}\right. \\
\text { - Português: } 2^{\circ} \\
\text { ciclo. } 1^{\mathrm{a}} \text { série } \\
(1946) \boldsymbol{\Omega} \\
\text { - Português: } 2^{\circ} \\
\text { ciclo. } 2^{\mathrm{a}} \text { série } \\
(1946) \boldsymbol{\beta}\end{array}$ & & \\
\hline $\begin{array}{l}\text { CAMPOS, } \\
\text { Hippolyto } \\
\text { de Oliveira } \\
(1849-?)\end{array}$ & & & & & $\begin{array}{l}\text { - Casos } \\
\text { grammatica } \\
\text { es (1908?) } \Omega\end{array}$ \\
\hline $\begin{array}{l}\text { CARDOSO } \\
\text {, Bricio } \\
(1844-1924)\end{array}$ & $\begin{array}{l}\text { - Tratado } \\
\text { da lingua } \\
\text { vernacula: } \\
\text { grammatica } \\
(1932)^{121} \boldsymbol{\beta}\end{array}$ & & & & \\
\hline
\end{tabular}

${ }^{121}$ Apesar de ser uma produção do século XIX, foi publicada em formato de livro apenas em 1932, com $2^{\mathrm{a}}$ edição em 1944, fato que justifica sua inclusão na relação de gramáticas correspondentes ao século XX. Vejamos como Gally (2013, p.97): "Escrito em 1875, aprovado pelo Conselho Superior de Instrução Pública da Bahia em 1878 e revisado pela última vez pelo autor em 1914, o Tratado da Língua Vernácula (Grammatica) foi somente impresso pela Gráfica Sauer, de Fred H. Sauer, no Rio de Janeiro, em 1932, oito anos depois da morte de seu criador, Brício Cardoso". 
1. Obras do programa de investigação GRAMATICAL

\begin{tabular}{|c|c|c|c|c|c|}
\hline & \multicolumn{3}{|c|}{ Escolares } & \multicolumn{2}{|c|}{ De referência } \\
\hline $\begin{array}{l}\text { Obras }^{33} \\
\text { Autores }\end{array}$ & $\begin{array}{c}\text { Gramáticas } \\
\text { completas }\end{array}$ & $\begin{array}{c}\text { Obras de } \\
\text { temas } \\
\text { gramaticais } \\
\text { específicos }\end{array}$ & $\begin{array}{c}\text { Livros } \\
\text { didáticos de } \\
\text { Português }\end{array}$ & $\begin{array}{c}\text { Gramáticas } \\
\text { completas }\end{array}$ & $\begin{array}{c}\text { Obras de } \\
\text { temas } \\
\text { gramaticais } \\
\text { específicos }\end{array}$ \\
\hline $\begin{array}{l}\text { CARREIR } \\
\text { O, Carlos } \\
\text { Porto } \\
(1865-1932)\end{array}$ & $\begin{array}{l}- \\
\text { Grammatic } \\
\text { a da lingua } \\
\text { nacional: } \\
\text { methodo } \\
\text { pratico: } \\
\text { segundo } \\
\text { anno (1918) } \\
\boldsymbol{\beta}\end{array}$ & & & & \\
\hline $\begin{array}{l}\text { CARVALH } \\
\text { O, José } \\
\text { Mesquita de } \\
(?-?)\end{array}$ & $\begin{array}{l}\text { Gramática } \\
\text { ginasial: } \\
\text { para as } \\
\text { quatro } \\
\text { séries de } \\
\text { acordo com } \\
\text { a nova } \\
\text { programaçã } \\
\text { o de ensino, } \\
\text { e com o } \\
\text { novo } \\
\text { vocabulário } \\
\text { ortográfico } \\
\text { oficial } \\
\text { (1945) } \beta\end{array}$ & $\begin{array}{l}\text { - Método de } \\
\text { análise (193- } \\
\text { ) } \Omega\end{array}$ & $\begin{array}{l}\text { - Grammatica e } \\
\text { anthologia } \\
\text { nacional: } 1^{\mathrm{a}}, 2^{\mathrm{a}} \\
\text { séries } \\
\left(19352^{\mathrm{a}} \text { ed.) } \mathbf{\Omega}\right. \\
\text { - Grammatica e } \\
\text { anthologia } \\
\text { nacional: } 3^{\mathrm{a}} \text { e } 4^{\mathrm{a}} \\
\text { séries (1935) } \boldsymbol{\Omega} \\
\text { - Pontos de } \\
\text { Português: para } \\
\text { a } 3^{\mathrm{a}} \text { e } 4^{\mathrm{a}} \text { séries } \\
\text { ginasiais, } \\
\text { organizados de } \\
\text { conformidade } \\
\text { com o novo } \\
\text { programa de } \\
\text { ensino (1942) } \\
\mathbf{\Omega}\end{array}$ & & $\begin{array}{l}\text { - Lições } \\
\text { práticas } \\
\text { sobre a } \\
\text { língua } \\
\text { nacional: a } \\
\text { gramática ao } \\
\text { alcance de } \\
\text { todos (1942) } \\
\boldsymbol{\beta} \\
\text { - Ortografia } \\
\text { e acentos } \\
\text { (1942) } \Omega \\
\text { - Os quatro } \\
\text { obstáculos } \\
\text { da lingua } \\
\text { nacional } \\
(1942)^{123} \boldsymbol{\beta}\end{array}$ \\
\hline
\end{tabular}

${ }^{122}$ É de se supor que haja o volume referente às $1^{\mathrm{a}}$ e $2^{\mathrm{a}}$ séries, mas como não o localizamos em nenhum arquivo, optamos por não incluí-lo de maneira presumida.

${ }^{123}$ A obra aborda quatro tópicos: o emprego do infinito pessoal; pontuação; acentuação e crase e colocação de pronomes. 


\begin{tabular}{|c|c|c|c|c|c|}
\hline \multirow[b]{2}{*}{ Obras ${ }^{93}$} & \multicolumn{3}{|c|}{ Escolares } & \multicolumn{2}{|c|}{ De referência } \\
\hline & $\begin{array}{l}\text { Gramáticas } \\
\text { completas }\end{array}$ & $\begin{array}{c}\text { Obras de } \\
\text { temas } \\
\text { gramaticais } \\
\text { específicos }\end{array}$ & $\begin{array}{c}\text { Livros } \\
\text { didáticos de } \\
\text { Português }\end{array}$ & $\begin{array}{l}\text { Gramáticas } \\
\text { completas }\end{array}$ & $\begin{array}{l}\text { Obras de } \\
\text { temas } \\
\text { gramaticais } \\
\text { específicos }\end{array}$ \\
\hline $\begin{array}{c}\text { CASASAN } \\
\text { TA, Mario } \\
\\
(1898- \\
1963)\end{array}$ & & & & & $\begin{array}{l}\text { - A palavra } \\
\text { MESMO (T) } \\
(1935)^{124} \boldsymbol{\beta} \\
\\
\text { - Notas de } \\
\text { Raul Soares } \\
\text { à Gramática } \\
\text { de João } \\
\text { Ribeiro } \\
\text { (1941) } \boldsymbol{\beta}\end{array}$ \\
\hline $\begin{array}{c}\text { CERQUEIR } \\
\text { A, Antonio } \\
\text { Alves } \\
\text { (1883-?) }\end{array}$ & & & & & $\begin{array}{l}\text { - Dúvidas de } \\
\text { linguagem } \\
(1926) \Sigma\end{array}$ \\
\hline $\begin{array}{l}\text { CHINA, } \\
\text { José } \\
\text { Benedito de } \\
\text { Oliveira } \\
\text { (1874-?) }\end{array}$ & & & & & $\begin{array}{l}\text { - Emprego } \\
\text { da crase em } \\
\text { Portuguez } \\
(1917) \Sigma\end{array}$ \\
\hline $\begin{array}{l}\text { CINTRA, } \\
\text { (Francisco } \\
\text { de) Assis } \\
(1897-1953)\end{array}$ & & & & & $\begin{array}{l}\text { - Questões } \\
\text { de Português } \\
(1921)^{125} \boldsymbol{\beta} \\
\text { - O que é } \\
\text { correcto?: } \\
\text { apostillas de } \\
\text { Português } \\
\text { (1922) } \boldsymbol{\Sigma}\end{array}$ \\
\hline
\end{tabular}

${ }^{124}$ Nesta obra, não há data de publicação, mas em outra obra do autor, Notas de Raul Soares à Gramática de João Ribeiro, na relação de obras por ele publicadas, informa-se 1935 como data de publicação da tese.

$125 \mathrm{O}$ subtítulo da $2^{\mathrm{a}}$ edição é elucidativo quanto ao conteúdo da obra: "[com pref. de Ruy Barbosa] sintaxe, orthographia e prosódia". 


\begin{tabular}{|c|c|c|c|c|c|}
\hline \multirow[b]{2}{*}{$\begin{array}{l}\text { Obras }^{93} \\
\text { Autores }\end{array}$} & \multicolumn{3}{|c|}{ Escolares } & \multicolumn{2}{|c|}{ De referência } \\
\hline & $\begin{array}{c}\text { Gramáticas } \\
\text { completas }\end{array}$ & $\begin{array}{c}\text { Obras de } \\
\text { temas } \\
\text { gramaticais } \\
\text { específicos }\end{array}$ & $\begin{array}{c}\text { Livros } \\
\text { didáticos de } \\
\text { Português }\end{array}$ & $\begin{array}{c}\text { Gramáticas } \\
\text { completas }\end{array}$ & $\begin{array}{c}\text { Obras de } \\
\text { temas } \\
\text { gramaticais } \\
\text { específicos }\end{array}$ \\
\hline $\begin{array}{l}\text { CINTRA, } \\
\text { Geraldo de } \\
\text { Ulhoa } \\
(1913-?)\end{array}$ & & & $\begin{array}{l}\text { - Língua } \\
\text { portuguesa: } \\
\text { literatura, } \\
\text { história da } \\
\text { literatura, } \\
\text { gramática, } \\
\text { leitura e } \\
\text { exercícios para } \\
\text { as } 1^{\mathrm{a}}, 2^{\mathrm{a}} \text { e } 3^{\mathrm{a}} \\
\text { séries dos } \\
\text { colégios clássico } \\
\text { e científico de } \\
\text { acordo com os } \\
\text { últimos } \\
\text { programas } \\
\text { (1943) } \boldsymbol{\beta}\end{array}$ & & \\
\hline $\begin{array}{c}\text { COELHO, } \\
\text { Teixeira } \\
(?-?)\end{array}$ & & & & & $\begin{array}{l}\text { - A questão } \\
\text { do pronome } \\
\text { SE: em } \\
\text { defesa da sua } \\
\text { subjectividad } \\
\text { e (1918) } \boldsymbol{\beta}\end{array}$ \\
\hline $\begin{array}{c}\text { CORRÊA, } \\
\text { G. } \\
\text { Guimarães } \\
(?-?)\end{array}$ & & & $\begin{array}{l}\text { - O programa } \\
\text { de vernáculo: } \\
\text { curso ginasial: } \\
1^{\mathrm{a}} \text { e } 2^{\mathrm{a}} \text { séries }{ }^{126} \\
\text { (1946) } \Omega\end{array}$ & & \\
\hline $\begin{array}{l}\text { CORREIA, } \\
\text { Jonas } \\
(1903-?)\end{array}$ & & & & & $\begin{array}{l}\text { - Estudos de } \\
\text { Português: } \\
\text { ortografia e } \\
\text { pontuação } \\
(1940) \boldsymbol{\beta}\end{array}$ \\
\hline
\end{tabular}

${ }^{126}$ Quanto ao outro volume, referente às $3^{\mathrm{a}}$ e $4^{\mathrm{a}}$ séries, é bem provável que esteja fora do nosso recorte temporal, pois a $2^{\mathrm{a}}$ edição é de 1954 . Não conseguimos localizar informações a respeito da $1^{\mathrm{a}}$ edição. O que nos parece é que o autor publicou o volume das $1^{\mathrm{a}}$ e $2^{\mathrm{a}}$ séries e bem depois o das $3^{\mathrm{a}}$ e $4^{\mathrm{a}}$ séries. A título de comparação, enquanto o primeiro volume, em 1959, já estava em sua $13^{a}$ edição, o segundo, em 1954, estava apenas na $2^{a}$ edição. 
1. Obras do programa de investigação GRAMATICAL

\begin{tabular}{|c|c|c|c|c|c|}
\hline & \multicolumn{3}{|c|}{ Escolares } & \multicolumn{2}{|c|}{ De referência } \\
\hline $\begin{array}{l}\text { Obras }^{93} \\
\text { Autores }\end{array}$ & $\begin{array}{c}\text { Gramáticas } \\
\text { completas }\end{array}$ & $\begin{array}{c}\text { Obras de } \\
\text { temas } \\
\text { gramaticais } \\
\text { específicos }\end{array}$ & $\begin{array}{c}\text { Livros } \\
\text { didáticos de } \\
\text { Português }\end{array}$ & $\begin{array}{c}\text { Gramáticas } \\
\text { completas }\end{array}$ & $\begin{array}{c}\text { Obras de } \\
\text { temas } \\
\text { gramaticais } \\
\text { específicos }\end{array}$ \\
\hline $\begin{array}{l}\text { COSTA, } \\
\text { Affonso }^{127} \\
(1885-?)\end{array}$ & & & & & $\begin{array}{l}\text { - Questões } \\
\text { grammatica } \\
\text { es: estudos e } \\
\text { factos da } \\
\text { Lingua } \\
\text { Portugueza. } \\
\text { (1908) } \boldsymbol{\beta} \\
\text { - Lingua } \\
\text { Portuguesa: } \\
\text { resposta á } \\
\text { critica } \\
\text { (1911) } \\
\\
\text { - Gallicismos } \beta \\
\text { e não } \\
\text { gallicismos } \\
\text { (1929) } \boldsymbol{\Omega}\end{array}$ \\
\hline $\begin{array}{c}\text { COSTA }^{129} \text {, } \\
\text { Aida } \\
(?-?) \\
\text { PASQUAL } \\
\text { E, } \\
\text { Renato } \\
(?-?) \\
\text { BRANDÃO } \\
\text {, Marcius } \\
\text { (? - ?) }\end{array}$ & & $\begin{array}{l}\text { - Admissão } \\
\text { ao ginásio } \\
\text { (1943) } \Omega\end{array}$ & & & \\
\hline
\end{tabular}

${ }^{127}$ Affonso Gonçalves Ferreira da Costa

128 "Reply to a series of articles published by Candido de Figueiredo in the section Lingua portugueza of the Jornal do commercio, criticising the author's book, Questões grammaticaes, published 1908". (UNIVERSIDADE DE SÃO PAULO, 2019).

129 Aída Costa (Português), Renato Pasquale/Marcius Brandão (Matemática), Aurélia Marino (História do Brasil) e Renato Stempniewski (Geografia). 
1. Obras do programa de investigação GRAMATICAL

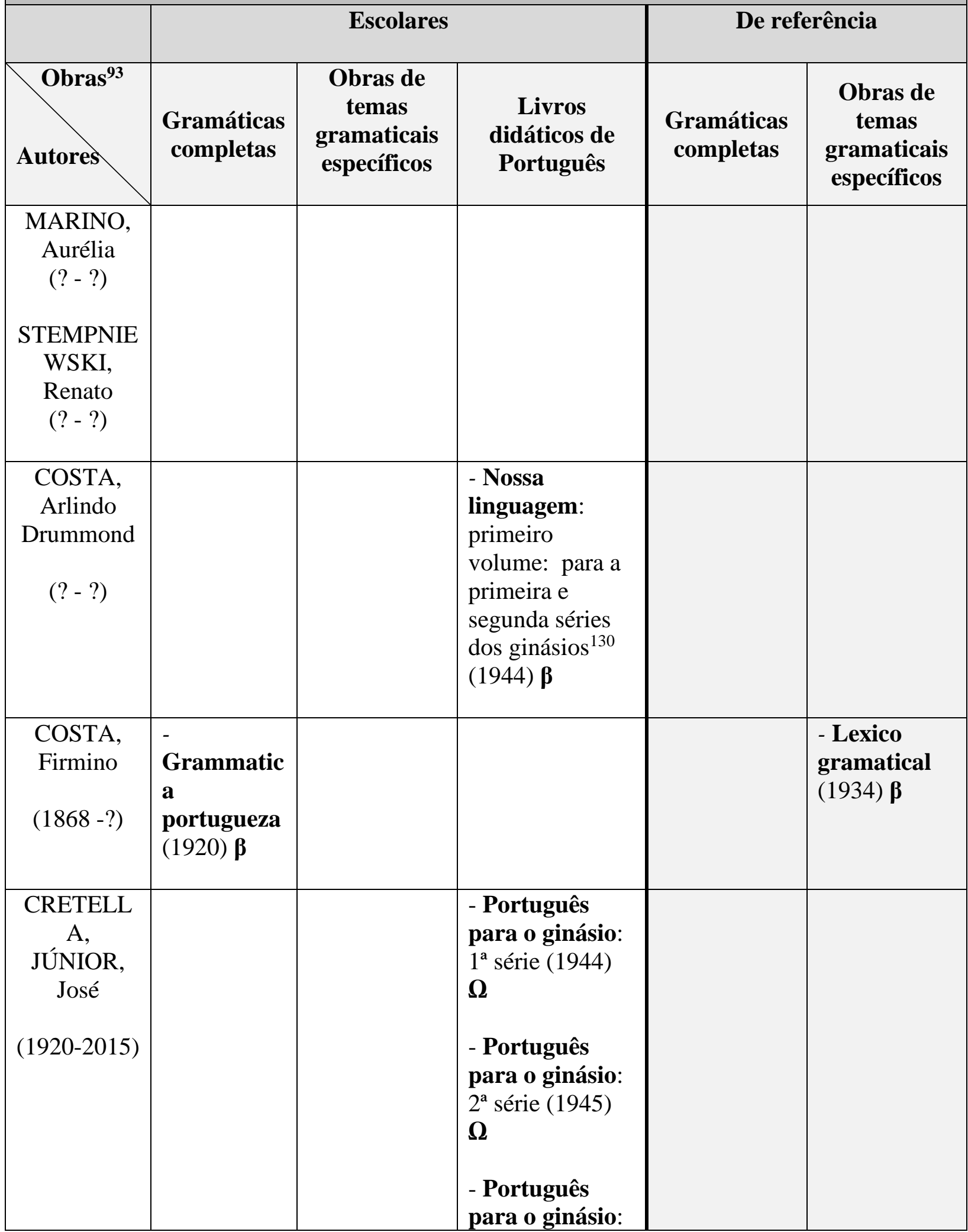

${ }^{130}$ É de se supor que haja o "segundo volume: para a terceira e quarta séries ginasiais", porém não o localizamos em nenhum arquivo. Em função disso, optamos por não incluí-lo de maneira presumida, já que por algum infortúnio pode não ter ocorrido sua publicação. 


\begin{tabular}{|c|c|c|c|c|c|}
\hline & \multicolumn{3}{|c|}{ Escolares } & \multicolumn{2}{|c|}{ De referência } \\
\hline & $\begin{array}{c}\text { Gramáticas } \\
\text { completas }\end{array}$ & $\begin{array}{c}\text { Obras de } \\
\text { temas } \\
\text { gramaticais } \\
\text { específicos }\end{array}$ & $\begin{array}{c}\text { Livros } \\
\text { didáticos de } \\
\text { Português }\end{array}$ & $\begin{array}{c}\text { Gramáticas } \\
\text { completas }\end{array}$ & $\begin{array}{c}\text { Obras de } \\
\text { temas } \\
\text { gramaticais } \\
\text { específicos }\end{array}$ \\
\hline & & & $\begin{array}{l}3^{\mathrm{a}} \text { série (1945) } \\
\mathbf{\Omega}\end{array}$ & & \\
\hline $\begin{array}{c}\text { CRUZ, } \\
\text { Estêvão } \\
\text { (1902-1937) }\end{array}$ & & & $\begin{array}{l}\text { - Programa de } \\
\text { vernáculo: } \\
\text { gramática e } \\
\text { antologia: } \\
\text { contém toda a } \\
\text { matéria exigida } \\
\text { para o estudo } \\
\text { das } 1^{\mathrm{a}} \text { e } 2^{\mathrm{a}} \text { séries } \\
(1936) \mathbf{\Omega} \\
\text { - Programa de } \\
\text { vernáculo: } \\
\text { gramática e } \\
\text { antologia: } \\
\text { contém toda a } \\
\text { matéria exigida } \\
\text { para o estudo da } \\
3^{\mathrm{a}} \text { série (1936) } \\
\mathbf{\Omega}\end{array}$ & & \\
\hline $\begin{array}{l}\text { CRUZ, José } \\
\text { Marques da } \\
(1888-1958)\end{array}$ & $\begin{array}{l}\text { - Português } \\
\text { prático: } \\
\text { gramática } \\
\text { para as } 4 \\
\text { séries do } \\
\text { curso } \\
\text { ginasial } \\
\text { (1944_15ª } \\
\text { d.) } \boldsymbol{\beta}\end{array}$ & & $\begin{array}{l}\text { - Português } \\
\text { prático: para a } \\
1^{\mathrm{a}} \text { e } 2^{\mathrm{a}} \text { séries } \\
\text { ginasiais } \\
\left(1942 \_2^{\mathrm{a}} \mathrm{ed}\right)^{131} \\
\mathbf{\Omega} \\
\\
\text { - Português } \\
\text { prático: para a }\end{array}$ & & $\begin{array}{l}\text { - Vícios de } \\
\text { linguagem } \\
(1920) \Omega\end{array}$ \\
\hline
\end{tabular}

${ }^{131}$ Não conseguimos acesso às datas da $1^{\text {a }}$ edição dos quatro volumes das obras destinadas ao ensino ginasial, apenas a da $2^{\text {a }}$ edição, 1922. No entanto, na relação de obras do autor presente no volume Português prático: para a $1^{\mathrm{a}}$ série do colégio, de 1944, há o registro de que os quatro referidos volumes estão esgotados. Nessa mesma relação, registra que Português prático: 4 séries ginasiais - o "volume único" da obra - está em sua 15a edição. Com essas informações, supomos que a editora resolveu esgotar a versão em 4 volumes e editar apenas o volume que abarca as quatro séries ginasiais em um só volume. 


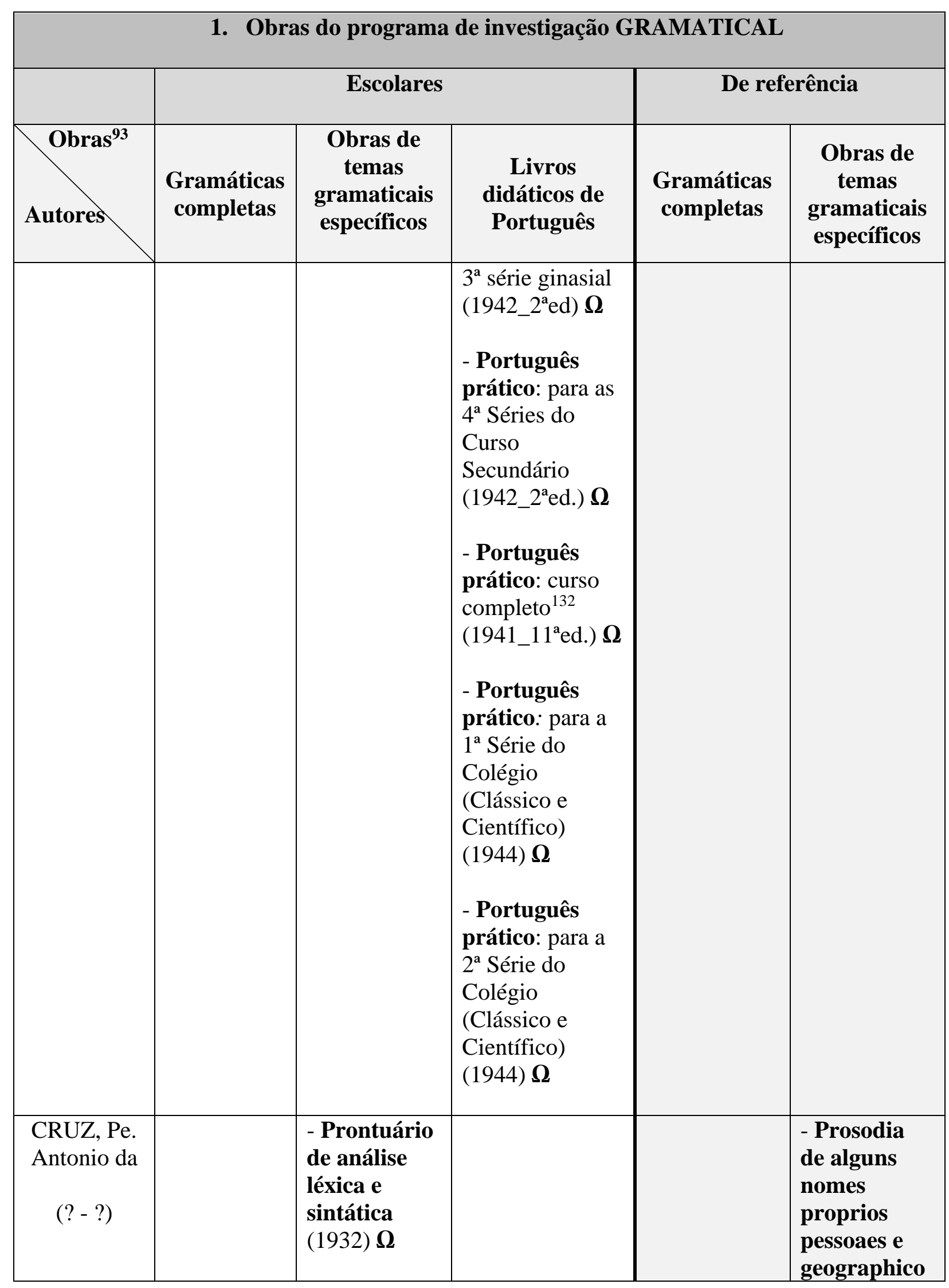

${ }^{132}$ Como indica o título, o volume aborda todos os tópicos do curso secundário: gramática expositiva e histórica, além da seleta de textos literários. 


\begin{tabular}{|c|c|c|c|c|c|}
\hline \multirow[b]{2}{*}{ Obras $^{93}$} & \multicolumn{3}{|c|}{ Escolares } & \multicolumn{2}{|c|}{ De referência } \\
\hline & $\begin{array}{c}\text { Gramáticas } \\
\text { completas }\end{array}$ & $\begin{array}{c}\text { Obras de } \\
\text { temas } \\
\text { gramaticais } \\
\text { específicos }\end{array}$ & $\begin{array}{c}\text { Livros } \\
\text { didáticos de } \\
\text { Português }\end{array}$ & $\begin{array}{c}\text { Gramáticas } \\
\text { completas }\end{array}$ & $\begin{array}{c}\text { Obras de } \\
\text { temas } \\
\text { gramaticais } \\
\text { específicos }\end{array}$ \\
\hline & & & & & $\begin{array}{l}\mathbf{S} \\
\left(1929 \_2^{\mathrm{a}} \text { ed.) }\right. \\
\mathbf{\Omega} \\
\text { - Ó e ô: } \\
\text { particularidad } \\
\text { es numéricas } \\
\text { das palavras } \\
\text { (1934) } \boldsymbol{\beta} \\
\\
\text { - Regimes de } \\
\text { substantivos } \\
\text { e adjetivos } \\
\text { (1941) } \boldsymbol{\Omega}\end{array}$ \\
\hline $\begin{array}{l}\text { CUNHA, J. } \\
\text { Alcides } \\
(?-?)\end{array}$ & & $\begin{array}{l}\text { - Collocação } \\
\text { do pronome } \\
\text { pessoal } \\
\text { complement } \\
\text { o: estudo do } \\
\text { infinito } \\
\left(19232^{\mathrm{a}} \mathrm{ed} .\right) \\
\boldsymbol{\beta} \\
\\
\text { - Methodo } \\
\text { de analyse } \\
\text { syntactica } \\
\text { (1924) } \boldsymbol{\beta}\end{array}$ & & & \\
\hline \multicolumn{6}{|c|}{$\mathbf{D}$} \\
\hline $\begin{array}{c}\text { DEISTER, } \\
\text { Jorge C. } \\
(?-?)\end{array}$ & & $\begin{array}{l}\text { - Lições } \\
\text { práticas de } \\
\text { gramática e } \\
\text { ortografia } \\
\text { para as }\end{array}$ & & & \\
\hline
\end{tabular}




\begin{tabular}{|c|c|c|c|c|c|}
\hline \multirow[b]{2}{*}{ Obras $^{93}$} & \multicolumn{3}{|c|}{ Escolares } & \multicolumn{2}{|c|}{ De referência } \\
\hline & $\begin{array}{c}\text { Gramáticas } \\
\text { completas }\end{array}$ & $\begin{array}{c}\text { Obras de } \\
\text { temas } \\
\text { gramaticais } \\
\text { específicos }\end{array}$ & $\begin{array}{c}\text { Livros } \\
\text { didáticos de } \\
\text { Português }\end{array}$ & $\begin{array}{c}\text { Gramáticas } \\
\text { completas }\end{array}$ & $\begin{array}{c}\text { Obras de } \\
\text { temas } \\
\text { gramaticais } \\
\text { específicos }\end{array}$ \\
\hline & & $\begin{array}{l}\text { escolas } \\
\text { primárias }^{133} \\
\left(1946 \_7^{\mathrm{a} e d .}\right) \\
\mathbf{\Omega}\end{array}$ & & & \\
\hline $\begin{array}{c}\text { DOMINGU } \\
\text { ES, } \\
\text { Pinheiro } \\
(?-?)\end{array}$ & & & & & $\begin{array}{l}\text { - Camilo e a } \\
\text { lexicografia } \\
\text { de Laudelino } \\
\text { Freire } \\
\left(19272^{a} \text { ed }\right) \\
\boldsymbol{\beta} \\
\text { - Variação } \\
\text { do gênero } \\
\text { dos nomes } \\
(1931) \Omega\end{array}$ \\
\hline $\begin{array}{l}\text { DÓRIA, } \\
\text { Antonio de } \\
\text { Sampaio } \\
\text { (1883-1964) }\end{array}$ & & $\begin{array}{l}- \text { Como se } \\
\text { aprende a } \\
\text { lingua }\left(2^{\mathrm{a} e d} .\right. \\
1922)^{134} \boldsymbol{\Omega}\end{array}$ & 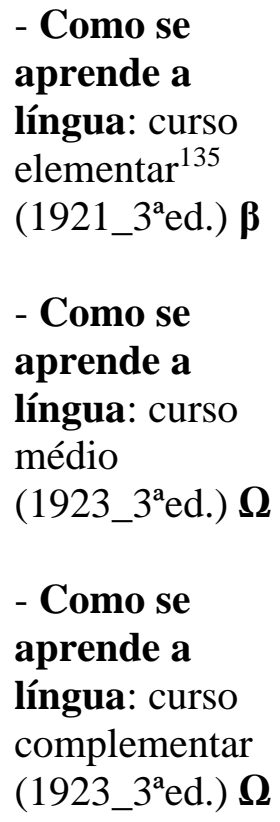 & & \\
\hline
\end{tabular}

\footnotetext{
133 "Elaboradas segundo o método da Escola Ativa. $7^{\text {a }}$ edição revista de acordo com a reforma oficial."

134 “Approvado pela Directoria geral de instrucção publica de S. Paulo, em 7 de Dezembro de 1921"/ Título da "2ª edição da "Analyse Logica".

${ }^{135}$ Esta obra aborda pontos de morfologia e sintaxe, desenvolvidos em formato de lições. Não pudemos fazer essa análise quanto aos demais volumes da coleção, pois a eles não tivemos acesso.
} 


\begin{tabular}{|c|c|c|c|c|c|}
\hline \multirow[b]{2}{*}{ Obras ${ }^{93}$} & \multicolumn{3}{|c|}{ Escolares } & \multicolumn{2}{|c|}{ De referência } \\
\hline & $\begin{array}{c}\text { Gramáticas } \\
\text { completas }\end{array}$ & $\begin{array}{c}\text { Obras de } \\
\text { temas } \\
\text { gramaticais } \\
\text { específicos }\end{array}$ & $\begin{array}{c}\text { Livros } \\
\text { didáticos de } \\
\text { Português }\end{array}$ & $\begin{array}{c}\text { Gramáticas } \\
\text { completas }\end{array}$ & $\begin{array}{c}\text { Obras de } \\
\text { temas } \\
\text { gramaticais } \\
\text { específicos }\end{array}$ \\
\hline & & & $\begin{array}{l}\text { - Como se } \\
\text { aprende a } \\
\text { língua ou nova } \\
\text { gramática: } \\
\text { curso primário } \\
\text { (1932) } \boldsymbol{\Omega} \\
\\
\text { - Como se } \\
\text { aprende a } \\
\text { língua: curso } \\
\text { geral (1931_6 } \\
\text { ed.) } \Omega\end{array}$ & & \\
\hline $\begin{array}{l}\text { DUQUE- } \\
\text { ESTRADA, } \\
\text { Osório } \\
\text { (1870-1927) }\end{array}$ & $\begin{array}{l}\text { - Noções } \\
\text { elementare } \\
\text { s de } \\
\text { grammatic } \\
\text { a } \\
\text { portugueza } \\
\text { : de acordo } \\
\text { com o } \\
\text { programma } \\
\text { das escolas } \\
\text { primarias } \\
(1900) \Omega\end{array}$ & $\begin{array}{l}\text { - Analyse } \\
\text { Syntactica: } \\
\text { noções } \\
\text { essenciaes } \\
(1919)^{137} \boldsymbol{\Sigma}\end{array}$ & & & $\begin{array}{l}\text { - Questões } \\
\text { de } \\
\text { Portuguez } \\
(1919 ?)^{138} \mathbf{\Omega}\end{array}$ \\
\hline \multicolumn{6}{|c|}{$\mathbf{F}$} \\
\hline $\begin{array}{c}\text { FERNAND } \\
\text { ES, } \\
\text { Francisco } \\
(1900-1965)\end{array}$ & & & & & $\begin{array}{l}\text { - Dicionário } \\
\text { de verbos e } \\
\text { regimes: } \\
\text { mais de } 10 \\
000 \text { verbos } \\
\text { em suas }\end{array}$ \\
\hline
\end{tabular}

\footnotetext{
136 Consta no frontispício: "Para uso dos alunos das Escolas Normaes e dos institulos de instrucção primaria e secundaria da Republica”.

${ }^{137}$ A Biblioteca Nacional aponta 1919 como possível data de publicação.

${ }^{138}$ Este livro consta na "relação de obras do autor" presente em uma outra obra de Osório Duque-Estrada: Analyse syntactica: noções essenciaes (1919).
} 


\begin{tabular}{|c|c|c|c|c|c|}
\hline \multirow[b]{2}{*}{ Obras ${ }^{93}$} & \multicolumn{3}{|c|}{ Escolares } & \multicolumn{2}{|c|}{ De referência } \\
\hline & $\begin{array}{c}\text { Gramáticas } \\
\text { completas }\end{array}$ & $\begin{array}{c}\text { Obras de } \\
\text { temas } \\
\text { gramaticais } \\
\text { específicos }\end{array}$ & $\begin{array}{c}\text { Livros } \\
\text { didáticos de } \\
\text { Português }\end{array}$ & $\begin{array}{c}\text { Gramáticas } \\
\text { completas }\end{array}$ & $\begin{array}{c}\text { Obras de } \\
\text { temas } \\
\text { gramaticais } \\
\text { específicos }\end{array}$ \\
\hline & & & & & $\begin{array}{l}\text { diversas } \\
\text { acepções e } \\
\text { regências } \\
\text { (1939) } \boldsymbol{\beta}\end{array}$ \\
\hline $\begin{array}{l}\text { FERREIRA } \\
\text {, Julio Pires } \\
(1868-1930)\end{array}$ & $\begin{array}{l}- \\
\text { Grammatic } \\
\text { a } \\
\text { portuguesa } \\
\text { : para o uso } \\
\text { dos } \\
\text { Cursos } \\
\text { Primários } \\
\text { (s/d) } \beta \\
\text { - } \\
\text { Grammatic } \\
\text { a } \\
\text { portuguesa } \\
: 2^{\circ} \text { anno: } \\
\text { Curso } \\
\text { Médio e do } \\
\text { Curso } \\
\text { Superior } \\
\text { (1921_6 } \\
\text { ed.) } \boldsymbol{\beta}\end{array}$ & & & & $\begin{array}{l}\text { - Consultas } \\
\text { sobre a } \\
\text { Lingua } \\
\text { Portugueza: } \\
\text { consultório } \\
\text { do Jornal } \\
\text { Pequeno } \\
\text { (1918) } \Omega\end{array}$ \\
\hline $\begin{array}{l}\text { FIGUEIRE } \\
\text { DO, } \\
\text { (Coronel) } \\
\text { José } \\
\text { Sandoval de } \\
(1880-?)\end{array}$ & & $\begin{array}{l}\text { - Vicios de } \\
\text { linguagem, } \\
\text { estrangeiris } \\
\text { mos, } \\
\text { regimes, etc: } \\
\text { para uso dos } \\
\text { alumnos do } \\
\text { curso } \\
\text { especial } \\
\text { militar da } \\
\text { força publica } \\
\text { do Estado de }\end{array}$ & & & \\
\hline
\end{tabular}




\begin{tabular}{|c|c|c|c|c|c|}
\hline \multirow[b]{2}{*}{ Obras ${ }^{93}$} & \multicolumn{3}{|c|}{ Escolares } & \multicolumn{2}{|c|}{ De referência } \\
\hline & $\begin{array}{c}\text { Gramáticas } \\
\text { completas }\end{array}$ & $\begin{array}{l}\text { Obras de } \\
\text { temas } \\
\text { gramaticais } \\
\text { específicos }\end{array}$ & $\begin{array}{c}\text { Livros } \\
\text { didáticos de } \\
\text { Português }\end{array}$ & $\begin{array}{c}\text { Gramáticas } \\
\text { completas }\end{array}$ & $\begin{array}{c}\text { Obras de } \\
\text { temas } \\
\text { gramaticais } \\
\text { específicos }\end{array}$ \\
\hline & & $\begin{array}{l}\text { São Paulo } \\
(1927) \boldsymbol{\beta} \\
- \\
\text { Concordanci } \\
\text { a da Lingua } \\
\text { Portuguesa: } \\
\text { para uso dos } \\
\text { alumnos do } \\
\text { curso } \\
\text { especial } \\
\text { militar (1929) } \\
\mathbf{\Omega}\end{array}$ & & & \\
\hline $\begin{array}{l}\text { FLEURY, } \\
\text { Renato } \\
\text { Sêneca }\end{array}$ & & & & & $\begin{array}{l}\text { - Consultor } \\
\text { popular da } \\
\text { Língua } \\
\text { Portugueza: } \\
\text { contendo um } \\
\text { vocabulário } \\
\text { orthographic } \\
\text { o com mais } \\
\text { de } 4000 \\
\text { termos } \\
(\mathrm{s} / \mathrm{d})^{139} \boldsymbol{\beta}\end{array}$ \\
\hline $\begin{array}{l}\text { FONSECA, } \\
\text { Alcides da } \\
(?-?) \\
\\
\text { ARAGÃO, } \\
\text { Jarbas } \\
\text { Cavalcante } \\
\text { de } \\
(1904- \\
1991) \\
\end{array}$ & $\begin{array}{l}\text { - A Língua } \\
\text { Portuguesa } \\
\text { : gramática } \\
\text { para as } \\
\text { quatro } \\
\text { séries } \\
\text { ginasiais } \\
\text { (1943) } \Omega\end{array}$ & $\begin{array}{l}\text { - Exercícios } \\
\text { comentados } \\
\text { de análise: } \\
\text { lexicológica, } \\
\text { lexicológico- } \\
\text { sintática e } \\
\text { sintática } \\
\text { (1945) } \Sigma\end{array}$ & $\begin{array}{l}\text { - A Língua } \\
\text { Portuguesa: } \\
\text { gramática e } \\
\text { antologia (1940) } \\
\mathbf{\Omega} \\
\text { - A Língua } \\
\text { Portuguesa: } \\
\text { programa para o } \\
\text { curso ginasial, } \\
\text { escola }\end{array}$ & & \\
\hline
\end{tabular}

${ }^{139}$ Não conseguimos acesso a dados que pudessem apontar a data de publicação deste livro, mas ele aparece na relação de "Edições da Casa - Cia Melhoramentos de S. Paulo" presente no Livro de exercícios para apprender os elementos da Grammatica portugueza, de P.S, editada no início do século XX por essa mesma casa editorial. 


\begin{tabular}{|c|c|c|c|c|c|}
\hline \multirow[b]{2}{*}{ Obras $^{93}$} & \multicolumn{3}{|c|}{ Escolares } & \multicolumn{2}{|c|}{ De referência } \\
\hline & $\begin{array}{c}\text { Gramáticas } \\
\text { completas }\end{array}$ & $\begin{array}{c}\begin{array}{c}\text { Obras de } \\
\text { temas }\end{array} \\
\text { gramaticais } \\
\text { específicos }\end{array}$ & $\begin{array}{c}\text { Livros } \\
\text { didáticos de } \\
\text { Português }\end{array}$ & $\begin{array}{c}\text { Gramáticas } \\
\text { completas }\end{array}$ & $\begin{array}{c}\text { Obras de } \\
\text { temas } \\
\text { gramaticais } \\
\text { específicos }\end{array}$ \\
\hline & & & $\begin{array}{l}\text { preparatória de } \\
\text { cadetes e curso } \\
\text { preparatório à } \\
\text { Escola Militar } \\
\text { (1940) } \Omega\end{array}$ & & \\
\hline $\begin{array}{c}\text { FONSECA, } \\
\text { José J. de } \\
\text { Oliveira } \\
(?-?)\end{array}$ & & & & & $\begin{array}{l}\text { Observações } \\
\text { sobre as } \\
\text { emendas do } \\
\text { sr. senador } \\
\text { Ruy Barbosa } \\
\text { com } \\
\text { additamento } \\
\text { sobre a } \\
\text { "Replica" } \\
\text { (1904) } \Omega\end{array}$ \\
\hline $\begin{array}{l}\text { FREIRE, } \\
\text { Laudelino } \\
\text { (1873-1937) }\end{array}$ & & $\begin{array}{l}\text { - Sintaxe da } \\
\text { Língua } \\
\text { Portuguesa } \\
\text { (1937) } \boldsymbol{\beta}\end{array}$ & & & $\begin{array}{l}\text { - Gallicismos } \\
\text { (1921) } \boldsymbol{\beta} \\
\text { - Verbos } \\
\text { portugueses } \\
\text { (1924) } \boldsymbol{\beta} \\
\text { - Livros de } \\
\text { Camilo: } \\
\text { lexicografia, } \\
\text { syntaxe, } \\
\text { estilo: } \\
\text { volume 1 } \\
\text { (1927) } \boldsymbol{\Sigma} \\
\text { - Regras } \\
\text { práticas } \\
\text { para } \\
\text { escrever } \\
\text { bem (1936) } \boldsymbol{\beta}\end{array}$ \\
\hline
\end{tabular}




\begin{tabular}{|c|c|c|c|c|c|}
\hline \multirow[b]{2}{*}{ Obras ${ }^{93}$} & \multicolumn{3}{|c|}{ Escolares } & \multicolumn{2}{|c|}{ De referência } \\
\hline & $\begin{array}{c}\text { Gramáticas } \\
\text { completas }\end{array}$ & $\begin{array}{l}\text { Obras de } \\
\text { temas } \\
\text { gramaticais } \\
\text { específicos }\end{array}$ & $\begin{array}{c}\text { Livros } \\
\text { didáticos de } \\
\text { Português }\end{array}$ & $\begin{array}{c}\text { Gramáticas } \\
\text { completas }\end{array}$ & $\begin{array}{c}\text { Obras de } \\
\text { temas } \\
\text { gramaticais } \\
\text { específicos }\end{array}$ \\
\hline & & & & & $\begin{array}{l}\text { - Linguagem } \\
\text { e estilo } \\
\text { (1937) } \boldsymbol{\beta} \\
\\
\text { - Estudos de } \\
\text { linguagem } \\
\text { (1937) } \boldsymbol{\beta}\end{array}$ \\
\hline $\begin{array}{c}\text { FREITAS } \\
\text { COUTINH } \\
\text { O, J. J. de } \\
(?-?)\end{array}$ & $\begin{array}{l}\text { - Licções de } \\
\text { grammatic } \\
\text { a } \\
\text { portugueza } \\
(1909) \boldsymbol{\beta}\end{array}$ & & & & \\
\hline $\begin{array}{c}\text { FREITAS, } \\
\text { Gaspar de } \\
(?-?)\end{array}$ & $\begin{array}{l}\text { - Lições } \\
\text { praticas de } \\
\text { grammatic } \\
\text { a } \\
\text { portugueza } \\
\text { : de accordo } \\
\text { com o } \\
\text { exame de } \\
\text { admissão ao } \\
\text { curso } \\
\text { secundário } \\
\text { accrescida } \\
\text { de muitas } \\
\text { notas } \\
\text { supplement } \\
\text { ares para os } \\
\text { alumnos do } \\
1^{\circ} \text { anno } \\
\text { gymnasial } \\
(1927)^{140} \boldsymbol{\beta}\end{array}$ & $\begin{array}{l}\text { - Exercícios } \\
\text { de gramatica } \\
\text { e modelos de } \\
\text { analyses: } \\
\text { para uso de } \\
\text { todas as } \\
\text { classes } \\
\text { primárias em } \\
\text { corresponden } \\
\text { cia com a } \\
\text { "Grammatica } \\
\text { portuguesa" } \\
(1932)^{141} \mathbf{\Omega}\end{array}$ & & & \\
\hline
\end{tabular}

${ }^{140}$ Em 1936, a obra teve ligeira modificação em seu título: Lições praticas de gramática portuguêsa: para as classes primárias, exame de admissão ao curso secundario; com muitas notas suplementares para os alumnos do $1^{\circ}$ anno gymnasial e um dicionario de analyse das palavras susceptiveis de diversas classificações.

${ }^{141} \mathrm{Em}$ 1941, a obra teve ligeira modificação em seu título: Exercícios de gramatica e modelos de analise: em correspondencia com a "Gramatica portuguesa" do mesmo autor: com um dicionario de análise léxica e noções de redação. 


\begin{tabular}{|c|c|c|c|c|c|}
\hline \multirow[b]{2}{*}{$\begin{array}{l}\text { Obras }^{93} \\
\text { Autores }\end{array}$} & \multicolumn{3}{|c|}{ Escolares } & \multicolumn{2}{|c|}{ De referência } \\
\hline & $\begin{array}{c}\text { Gramáticas } \\
\text { completas }\end{array}$ & $\begin{array}{c}\text { Obras de } \\
\text { temas } \\
\text { gramaticais } \\
\text { específicos }\end{array}$ & $\begin{array}{c}\text { Livros } \\
\text { didáticos de } \\
\text { Português }\end{array}$ & $\begin{array}{c}\text { Gramáticas } \\
\text { completas }\end{array}$ & $\begin{array}{c}\text { Obras de } \\
\text { temas } \\
\text { gramaticais } \\
\text { específicos }\end{array}$ \\
\hline $\begin{array}{l}\text { FREITAS, } \\
\text { Paulo de } \\
(1899-?)\end{array}$ & & & $\begin{array}{l}\text { - O nosso } \\
\text { idioma: curso } \\
\text { elementar } \\
\text { (1936) } \boldsymbol{\beta} \\
\text { - O nosso } \\
\text { idioma: } \\
\text { antologia e } \\
\text { gramatica } \\
\text { aplicada: } \\
\text { morfologia: } 1^{\text {a }} \\
\text { parte (1936) } \boldsymbol{\beta} \\
\text { - O nosso } \\
\text { idioma: sintaxe } \\
\text { geral (1937) } \boldsymbol{\beta} \\
\text { - O nosso } \\
\text { idioma: sintaxe } \\
\text { das categorias } \\
\text { gramaticais: } 3^{\text {a }} \\
\text { parte (1938) } \boldsymbol{\beta}\end{array}$ & & \\
\hline \multicolumn{6}{|c|}{$\mathbf{G}$} \\
\hline $\begin{array}{l}\text { GALLI, } \\
\text { João } \\
\text { Eugênio } \\
(?-?)\end{array}$ & & $\begin{array}{l}\text { - Lições de } \\
\text { análise } \\
\text { léxica e } \\
\text { sintática } \\
\text { (1947) } \Omega\end{array}$ & & & \\
\hline $\begin{array}{c}\text { GÓES, } \\
\text { Carlos }^{142} \\
(1881-1934)\end{array}$ & $\begin{array}{l}- \\
\text { Gramática } \\
\text { expositiva } \\
\text { primária } \\
\text { (1919) } \beta\end{array}$ & $\begin{array}{l}\text { - Método de } \\
\text { análise: } \\
\text { léxica e } \\
\text { lógica ou } \\
\text { sintaxe das }\end{array}$ & & & $\begin{array}{l}\text { - Diccionario } \\
\text { de } \\
\text { gallicismos } \\
\text { (1920) } \boldsymbol{\beta}\end{array}$ \\
\hline
\end{tabular}

${ }^{142}$ Em algumas obras o autor assina Carlos Góis. 


\begin{tabular}{|c|c|c|c|c|c|}
\hline \multirow[b]{2}{*}{$\begin{array}{l}\text { Obras }^{93} \\
\text { Autores }\end{array}$} & \multicolumn{3}{|c|}{ Escolares } & \multicolumn{2}{|c|}{ De referência } \\
\hline & $\begin{array}{c}\text { Gramáticas } \\
\text { completas }\end{array}$ & $\begin{array}{l}\text { Obras de } \\
\text { temas } \\
\text { gramaticais } \\
\text { específicos }\end{array}$ & $\begin{array}{c}\text { Livros } \\
\text { didáticos de } \\
\text { Português }\end{array}$ & $\begin{array}{c}\text { Gramáticas } \\
\text { completas }\end{array}$ & $\begin{array}{c}\text { Obras de } \\
\text { temas } \\
\text { gramaticais } \\
\text { específicos }\end{array}$ \\
\hline & & 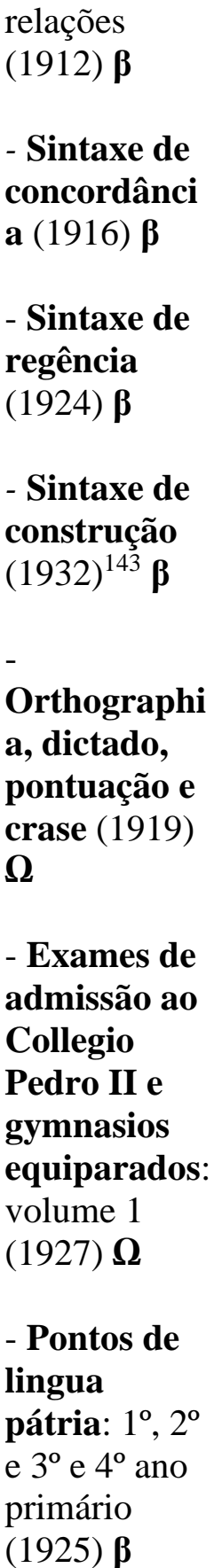 & & & \\
\hline
\end{tabular}

${ }^{143}$ Como esclarece o autor no "Anteloquio" de Sintaxe de construção, na $1^{\text {a }}$ edição, esse é o último livro da série, que conjuntamente com os três volumes anteriores (Manual de análise, Sintaxe de concordância e Sintaxe de regência) integram o Curso de Syntaxe da Lingua Portugueza. 


\begin{tabular}{|c|c|c|c|c|c|}
\hline \multirow[b]{2}{*}{ Obras ${ }^{93}$} & \multicolumn{3}{|c|}{ Escolares } & \multicolumn{2}{|c|}{ De referência } \\
\hline & $\begin{array}{c}\text { Gramáticas } \\
\text { completas }\end{array}$ & $\begin{array}{c}\text { Obras de } \\
\text { temas } \\
\text { gramaticais } \\
\text { específicos }\end{array}$ & $\begin{array}{c}\text { Livros } \\
\text { didáticos de } \\
\text { Português }\end{array}$ & $\begin{array}{c}\text { Gramáticas } \\
\text { completas }\end{array}$ & $\begin{array}{c}\text { Obras de } \\
\text { temas } \\
\text { gramaticais } \\
\text { específicos }\end{array}$ \\
\hline $\begin{array}{l}\text { GOMES, } \\
\text { Alfredo } \\
\text { (1859-1924) }\end{array}$ & & $\begin{array}{l}\text { - Exames de } \\
\text { admissão: } \\
\text { aos cursos } \\
\text { fundamentais } \\
\text { das escolas } \\
\text { normais e } \\
\text { ginásios } \\
\text { (1939) } \boldsymbol{\Omega}\end{array}$ & & & \\
\hline $\begin{array}{c}\text { GONÇALV } \\
\text { ES, Antônio } \\
(?-?) \\
\text { RODRIGU } \\
\text { ES, Geraldo } \\
(?-?) \\
\text { MESQUIT } \\
\text { A, Marcelo } \\
(?-?)\end{array}$ & & $\begin{array}{l}\text { - Exames de } \\
\text { admissão aos } \\
\text { cursos } \\
\text { ginasiais } \\
\left(1938 \_22^{a} \text { ed. }\right. \\
)^{144} \boldsymbol{\beta} \\
\text { - } \\
\text { Preparatório } \\
\text { S ao alcance } \\
\text { de todos: } \\
\text { edição } \\
\text { popular do } \\
\text { livro } \\
\text { "Exames de } \\
\text { admissão ao } \\
\text { Ginásio" } \\
\text { (1944_24aed. } \\
\text { ) } \boldsymbol{\Omega}\end{array}$ & & & \\
\hline $\begin{array}{c}\text { GONÇALV } \\
\text { ES, } \\
\text { Francisco } \\
(?-?)\end{array}$ & & $\begin{array}{l}\text { - A palavra } \\
\text { Quê: } \\
\text { funções, } \\
\text { observações, } \\
\text { concordância, } \\
\text { exercícios }\end{array}$ & & & \\
\hline
\end{tabular}

144 “Pontos de português, aritmética, geografia, história do Brasil, morfologia, geometria e ciências físicas e naturais, de acordo com o programa oficial, publicada no diário oficial de 29/10/1931”. 


\begin{tabular}{|c|c|c|c|c|c|}
\hline \multirow[b]{2}{*}{ Obras $^{93}$} & \multicolumn{3}{|c|}{ Escolares } & \multicolumn{2}{|c|}{ De referência } \\
\hline & $\begin{array}{l}\text { Gramáticas } \\
\text { completas }\end{array}$ & $\begin{array}{l}\text { Obras de } \\
\text { temas } \\
\text { gramaticais } \\
\text { específicos }\end{array}$ & $\begin{array}{c}\text { Livros } \\
\text { didáticos de } \\
\text { Português }\end{array}$ & $\begin{array}{l}\text { Gramáticas } \\
\text { completas }\end{array}$ & $\begin{array}{c}\text { Obras de } \\
\text { temas } \\
\text { gramaticais } \\
\text { específicos }\end{array}$ \\
\hline & & $\begin{array}{l}\text { práticos } \\
\text { (1943) } \beta\end{array}$ & & & \\
\hline $\begin{array}{c}\text { GONÇALV } \\
\text { ES, } \\
\text { Maximiano } \\
\text { Augusto } \\
\text { (1912 -?) }\end{array}$ & & $\begin{array}{l}\text { - Topologia } \\
\text { das } \\
\text { variações } \\
\text { pronominais } \\
(1931) \boldsymbol{\Omega} \\
\text { - Questoes } \\
\text { de } \\
\text { linguagem e } \\
\text { trechos para } \\
\text { corrigir } \\
(1940) \boldsymbol{\beta} \\
\\
\text { - Tratado de } \\
\text { analise: } \\
\text { lexica e } \\
\text { sintatica } \\
\text { (1942) } \boldsymbol{\Omega}\end{array}$ & & & \\
\hline $\begin{array}{l}\text { GRAÇA, } \\
\text { Heráclito } \\
\text { (1837-1914) }\end{array}$ & & & & & $\begin{array}{l}\text { - Factos da } \\
\text { linguagem } \\
(1904) \boldsymbol{\beta}\end{array}$ \\
\hline $\begin{array}{l}\text { GUÉRIOS, } \\
\text { Rosário } \\
\text { Mansur } \\
\text { (1907-1987) }\end{array}$ & $\begin{array}{l}\text { - Português } \\
\text { ginasial: } \\
\text { gramática e } \\
\text { exercícios } \\
\text { para a } 1^{\mathrm{a}}, 2^{\mathrm{a}}, \\
3^{\mathrm{a}} \mathrm{e} 4^{\mathrm{a}} \\
\text { séries } \\
(1944)^{145} \boldsymbol{\beta}\end{array}$ & & & & \\
\hline
\end{tabular}

$145 \mathrm{O}$ presente volume é formado por uma gramática tradicional e uma gramática histórica. Em função dessa característica "dois em um", a incluímos tanto aqui como no levantamento das obras do programa filológico, no grupo das "gramáticas históricas" (cf. Tabela 2A - Apêndice A). 


\begin{tabular}{|c|c|c|c|c|c|}
\hline \multirow[b]{2}{*}{$\begin{array}{l}\text { Obras }^{93} \\
\text { Autores }\end{array}$} & \multicolumn{3}{|c|}{ Escolares } & \multicolumn{2}{|c|}{ De referência } \\
\hline & $\begin{array}{c}\text { Gramáticas } \\
\text { completas }\end{array}$ & $\begin{array}{c}\text { Obras de } \\
\text { temas } \\
\text { gramaticais } \\
\text { específicos }\end{array}$ & $\begin{array}{c}\text { Livros } \\
\text { didáticos de } \\
\text { Português }\end{array}$ & $\begin{array}{c}\text { Gramáticas } \\
\text { completas }\end{array}$ & $\begin{array}{c}\text { Obras de } \\
\text { temas } \\
\text { gramaticais } \\
\text { específicos }\end{array}$ \\
\hline \multicolumn{6}{|c|}{$\mathrm{H}$} \\
\hline $\begin{array}{l}\text { HENRIQU } \\
\text { E, João } \\
(1885-1952)\end{array}$ & & $\begin{array}{l}\text { - Pontuação } \\
\text { na escrita } \\
\left(19433^{\mathrm{a}} \mathrm{ed} .\right) \\
\mathbf{\Omega}\end{array}$ & & & \\
\hline $\begin{array}{c}\text { HORTA, } \\
\text { Brant }^{147} \\
(1876-1959)\end{array}$ & $\begin{array}{l}\text { Gramática } \\
\text { intuitiva da } \\
\text { Língua } \\
\text { Portuguesa } \\
\text { : para os } \\
\text { dois } \\
\text { primeiros } \\
\text { anos do } \\
\text { curso } \\
\text { ginasial e } \\
\text { normal } \\
\text { (1938) } \beta\end{array}$ & $\begin{array}{l}\text { - Lições de } \\
\text { análises } \\
\text { lexical e } \\
\text { sintática } \\
\text { (1945) } \beta\end{array}$ & & & \\
\hline \multicolumn{6}{|c|}{$\mathbf{J}$} \\
\hline $\begin{array}{c}\text { JOVIANO, } \\
\text { A. }{ }^{148} \\
(1862- \\
1934)\end{array}$ & & & $\begin{array}{l}\text { - Lingua pátria: } \\
\text { volume } 1 \text { (1918) } \\
\Omega \\
\text { - Lingua pátria: } \\
\text { volume } 2 \text { (1919) } \\
\mathbf{\Omega} \\
\text { - Lingua pátria: } \\
\text { volume } 3 \text { (1921) } \\
\mathbf{\Omega}\end{array}$ & & \\
\hline
\end{tabular}

${ }^{146} \mathrm{O}$ autor assinava suas obras apenas com estes dois nomes. Seu nome completo, porém, é João Henrique dos Santos.

${ }^{147}$ Francisco Eugenio Brant Horta

148 Arthur Joviano. 


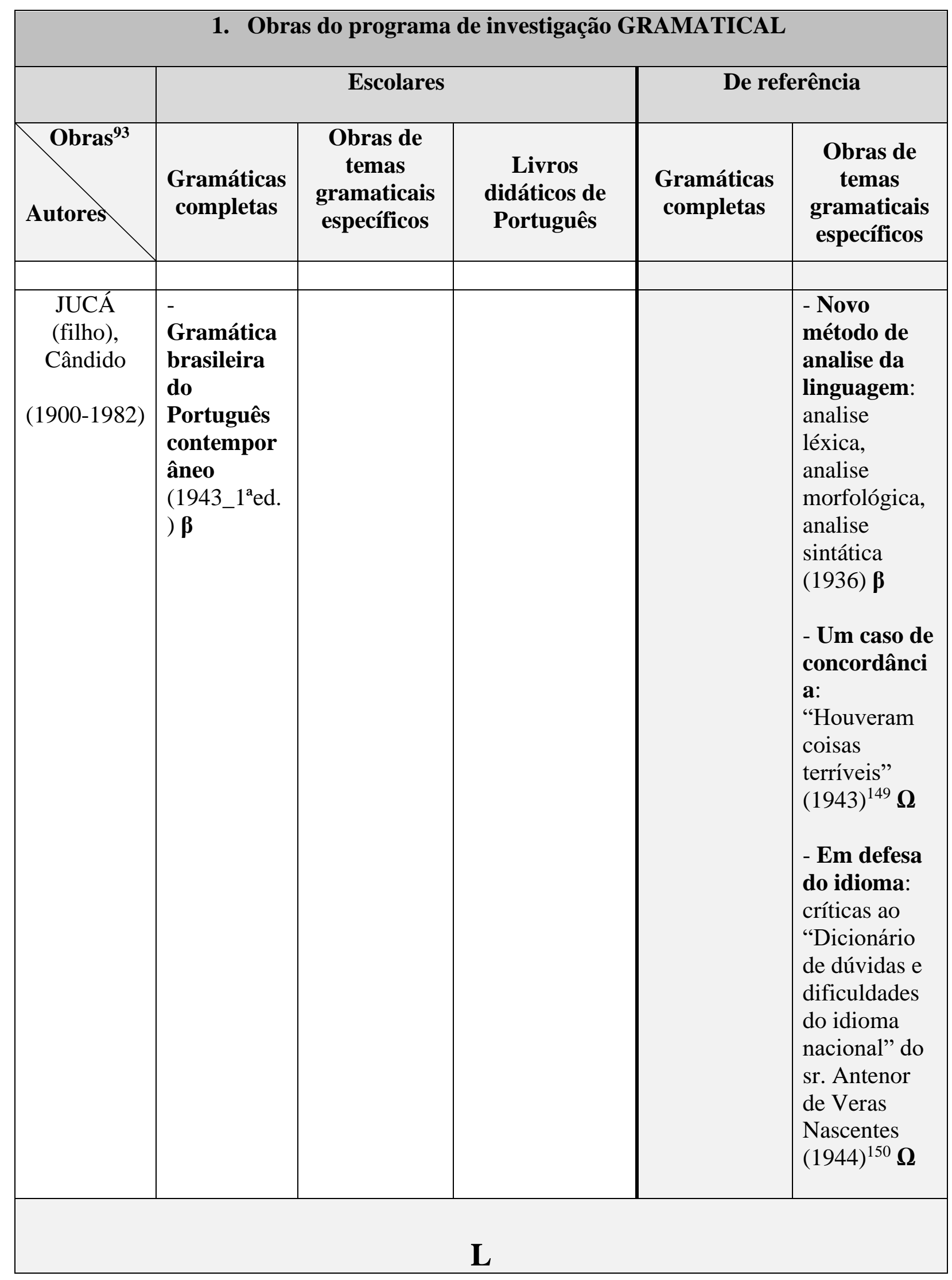

${ }^{149}$ Em coautoria com Pinheiro Domingues e Artur Tôrres.

${ }^{150}$ Em coautoria com Antônio J. Chediak, Pedro A. Pinto, Pinheiro Domingues, Ruy Almeida. 
1. Obras do programa de investigação GRAMATICAL

\begin{tabular}{|c|c|c|c|c|c|}
\hline & \multicolumn{3}{|c|}{ Escolares } & \multicolumn{2}{|c|}{ De referência } \\
\hline $\begin{array}{l}\text { Obras }^{93} \\
\text { Autores }\end{array}$ & $\begin{array}{c}\text { Gramáticas } \\
\text { completas }\end{array}$ & $\begin{array}{c}\text { Obras de } \\
\text { temas } \\
\text { gramaticais } \\
\text { específicos }\end{array}$ & $\begin{array}{c}\text { Livros } \\
\text { didáticos de } \\
\text { Português }\end{array}$ & $\begin{array}{c}\text { Gramáticas } \\
\text { completas }\end{array}$ & $\begin{array}{c}\text { Obras de } \\
\text { temas } \\
\text { gramaticais } \\
\text { específicos }\end{array}$ \\
\hline $\begin{array}{l}\text { LACERDA, } \\
\text { Luiz de } \\
(?-?)\end{array}$ & & & & & $\begin{array}{l}\text { - Teoria da } \\
\text { acentuação } \\
\text { (1923) } \Omega\end{array}$ \\
\hline $\begin{array}{l}\text { LAGO, } \\
\text { Candido } \\
(?-?)\end{array}$ & & & & & $\begin{array}{l}\text { - O que é } \\
\text { correcto: a } \\
\text { verdade na } \\
\text { analyse - } \\
\text { respostas a } \\
\text { consulentes - } \\
\text { Brazil (com } \\
\text { Z) (1932) } \Sigma \\
\text { - Pronomes } \\
\text { pessoaes } \\
\text { encliticos: } \\
\text { sua colocação } \\
\text { (1922) } \Omega\end{array}$ \\
\hline $\begin{array}{l}\text { LEAL, } \\
\text { Antônio de } \\
\text { Sousa } \\
(?-?)\end{array}$ & & $\begin{array}{l}\text { - Análise } \\
\text { lógica: } 2^{\mathrm{a}} \text { e } 3^{\mathrm{a}} \\
\text { séries do } \\
\text { curso } \\
\text { fundamental } \\
\text { dos ginásios, } \\
\text { escolas } \\
\text { normais e do } \\
\text { comércio } \\
\text { (1939) } \Omega \\
\text { - } \\
\text { Analisemos.. } \\
\therefore \text { análise } \\
\text { lógica: v.2 } \\
\text { (1941) } \Omega \\
\text { - Vamos } \\
\text { analisar...: }\end{array}$ & & & \\
\hline
\end{tabular}




\begin{tabular}{|c|c|c|c|c|c|}
\hline \multirow[b]{2}{*}{ Obras $^{93}$} & \multicolumn{3}{|c|}{ Escolares } & \multicolumn{2}{|c|}{ De referência } \\
\hline & $\begin{array}{c}\text { Gramáticas } \\
\text { completas }\end{array}$ & $\begin{array}{l}\text { Obras de } \\
\text { temas } \\
\text { gramaticais } \\
\text { específicos }\end{array}$ & $\begin{array}{c}\text { Livros } \\
\text { didáticos de } \\
\text { Português }\end{array}$ & $\begin{array}{c}\text { Gramáticas } \\
\text { completas }\end{array}$ & $\begin{array}{c}\text { Obras de } \\
\text { temas } \\
\text { gramaticais } \\
\text { específicos }\end{array}$ \\
\hline & & $\begin{array}{l}\text { método } \\
\text { teórico- } \\
\text { prático: v.1 } \\
(1947)^{151} \mathbf{\Omega} \\
\text { - Vamos } \\
\text { analisar...: } \\
\text { método } \\
\text { teórico- } \\
\text { prático: v.2 } \\
\text { (1947) } \Omega\end{array}$ & & & \\
\hline $\begin{array}{l}\text { LEITE, José } \\
\text { Marques } \\
\text { (1904 -?) } \\
\text { CINTRA, } \\
\text { Geraldo de } \\
\text { Ulhoa } \\
\text { (1913-?) }\end{array}$ & $\begin{array}{l}\text { - Língua } \\
\text { portuguesa } \\
\text { : gramática: } \\
\text { para as } \\
\text { quatro } \\
\text { séries dos } \\
\text { ginásios } \\
(1946)^{152} \boldsymbol{\beta}\end{array}$ & & & & \\
\hline $\begin{array}{c}\text { LIMA } \\
\text { COUTINH } \\
\text { O, Ismael } \\
\text { de } \\
\text { (1900-1965) }\end{array}$ & & $\begin{array}{l}\text { - Methodo } \\
\text { de analyse } \\
\text { logica (1927) } \\
\boldsymbol{\beta}\end{array}$ & & & $\begin{array}{l}- \text { A crase } \\
(1928)(\mathrm{T})^{153} \\
\boldsymbol{\beta}\end{array}$ \\
\hline $\begin{array}{l}\text { LIMA, } \\
\text { Mario } \\
\text { Pereira de } \\
\text { Souza }\end{array}$ & $\begin{array}{l}\text { Grammatic } \\
\text { a } \\
\text { expositiva } \\
\text { da lingua } \\
\end{array}$ & & & & $\begin{array}{l}\text { - Theoria da } \\
\text { construcção } \\
\text { grammatical } \\
(1923)^{155}(\mathrm{~T}) \\
\boldsymbol{\beta}\end{array}$ \\
\hline
\end{tabular}

${ }^{151} \mathrm{Na}$ obra, constam as seguintes informações: “mais de 70 espécimes de análise lógica, 40 análises étimo-fonéticoortográficas, exercícios, exemplos e questionários, testes especiais para sabatinas, provas parciais e finais".

152 Compõe a coleção didática, além da referida gramática, dois volumes de antologias: um para as $1^{\mathrm{a}}$ e $2^{\mathrm{a}}$ séries ginasiais e outro para as $3^{\mathrm{a}}$ e $4^{\mathrm{a}}$ séries ginasiais. São eles: Língua Portuguesa: antologia e exercícios: primeira e segunda séries ginasiais e Língua Portuguesa: antologia e exercícios: terceira e quarta séries ginasiais.

153 “These de livre escolha, apresentada á Congregação do Lyceu de Humanidades de Campos, para o concurso á $1^{\mathrm{a}}$ Cadeira de Português".

155 “These para o concurso a cadeira de Portuguez, no Gymnasio Official de S. Paulo". 


\begin{tabular}{|c|c|c|c|c|c|}
\hline \multirow[b]{2}{*}{ Obras $^{93}$} & \multicolumn{3}{|c|}{ Escolares } & \multicolumn{2}{|c|}{ De referência } \\
\hline & $\begin{array}{l}\text { Gramáticas } \\
\text { completas }\end{array}$ & $\begin{array}{c}\text { Obras de } \\
\text { temas } \\
\text { gramaticais } \\
\text { específicos }\end{array}$ & $\begin{array}{c}\text { Livros } \\
\text { didáticos de } \\
\text { Português }\end{array}$ & $\begin{array}{l}\text { Gramáticas } \\
\text { completas }\end{array}$ & $\begin{array}{c}\text { Obras de } \\
\text { temas } \\
\text { gramaticais } \\
\text { específicos }\end{array}$ \\
\hline$(?-?)$ & $\begin{array}{l}\text { portuguesa } \\
\text { : para uso } \\
\text { das escolas } \\
\text { secundarias } \\
(1937)^{154} \boldsymbol{\Sigma} \\
- \\
\text { Elementos } \\
\text { de } \\
\text { gramática } \\
\text { (1938) } \boldsymbol{\Omega}\end{array}$ & & & & \\
\hline $\begin{array}{c}\text { LIMA, } \\
\text { Rocha }\end{array}$ & & & & & $\begin{array}{l}\text { - Teoria da } \\
\text { análise } \\
\text { sintática } \\
(1943) \beta \\
\text { - Anotações } \\
\text { a textos } \\
\text { errados } \\
(1943) \Sigma\end{array}$ \\
\hline $\begin{array}{c}\text { LIMA, } \\
\text { Rocha } \\
\text { (1915-1991) } \\
\\
\text { ROCHA, } \\
\text { Mario } \\
\text { Penna da } \\
(?-?)\end{array}$ & & & $\begin{array}{l}\text { - O programa } \\
\text { de Português } \\
\text { no } 2^{\circ} \text { Ciclo: } \\
\text { cursos clássico e } \\
{\text { científico } 1^{\mathrm{a}}} \\
\text { série }^{156}(1945) \boldsymbol{\beta} \\
\text { - O programa } \\
\text { de Português } \\
\text { no } 2^{\circ} \text { Ciclo: }\end{array}$ & & \\
\hline
\end{tabular}

${ }^{154}$ Em 1945, a obra sai com o seguinte título: Gramática portuguêsa: ed. rev. e aum. de acordo com o Programa Oficial, para as 4 séries. Não foi possível obter o número dessa edição.

${ }^{156} \mathrm{O}$ volume da $1^{\text {a }}$ série que possuímos, de 1945, tem como autoria apenas Rocha Lima e Mario Penna da Rocha. No entanto, no $2^{\circ}$ volume, de 1947, consta, no prefácio, uma explicação do motivo que levou Raul Léllis a se juntar ao demais autores apenas naquele momento. Ainda nesse mesmo volume, na relação de obras publicadas, consta o nome e Raul Léllis como autor também do $1^{\circ}$ volume o que nos faz supor que o autor deve ter participado das revisões para essa nova edição de 1947 e então passado a assinar, junto aos demais autores, toda a coleção a partir dessa data. 
1. Obras do programa de investigação GRAMATICAL

\begin{tabular}{|c|c|c|c|c|c|}
\hline & \multicolumn{3}{|c|}{ Escolares } & \multicolumn{2}{|c|}{ De referência } \\
\hline $\begin{array}{l}\text { Obras }^{93} \\
\text { Autores }\end{array}$ & $\begin{array}{c}\text { Gramáticas } \\
\text { completas }\end{array}$ & $\begin{array}{c}\text { Obras de } \\
\text { temas } \\
\text { gramaticais } \\
\text { específicos }\end{array}$ & $\begin{array}{c}\text { Livros } \\
\text { didáticos de } \\
\text { Português }\end{array}$ & $\begin{array}{c}\text { Gramáticas } \\
\text { completas }\end{array}$ & $\begin{array}{c}\text { Obras de } \\
\text { temas } \\
\text { gramaticais } \\
\text { específicos }\end{array}$ \\
\hline $\begin{array}{l}\text { LÉLLIS, } \\
\text { Raul } \\
\text { Moreira } \\
\text { (1906 - ?) }\end{array}$ & & & $\begin{array}{l}\text { cursos clássico e } \\
\text { científico } 2^{\mathrm{a}} \\
\text { série }(1947)^{157} \boldsymbol{\beta}\end{array}$ & & \\
\hline $\begin{array}{c}\text { LIMA, } \\
\text { Rocha } \\
(1915-1991) \\
\text { LÉLLIS, } \\
\text { Raul } \\
\text { Moreira } \\
\text { (1906 - ?) }\end{array}$ & & & $\begin{array}{l}\text { - O programa } \\
\text { de Português } \\
\text { no Curso } \\
\text { Comercial, } \\
\text { Cursos } \\
\text { Técnicos: } 1^{\mathrm{a}} \\
\text { série (1947) } \Omega\end{array}$ & & \\
\hline $\begin{array}{l}\text { LINTZ, } \\
\text { Dario } \\
\text { Gouveia } \\
(?-?)\end{array}$ & & & $\begin{array}{l}\text { - Lingua } \\
\text { Portugueza: } \\
\text { curso } \\
\text { elementar }^{158} \\
(1928) \boldsymbol{\beta}\end{array}$ & & \\
\hline $\begin{array}{l}\text { LOBO, Ari } \\
\text { Maurell } \\
(1900-?)\end{array}$ & & & & & $\begin{array}{l}\text { - Cânones } \\
\text { gramaticas e } \\
\text { estilísticos } \\
\text { para bem } \\
\text { escrever a } \\
\text { língua } \\
\text { nacional: } \\
\text { aplicação do } \\
\text { método } \\
\text { estatístico aos } \\
\text { fatos da } \\
\text { linguagem } \\
\text { luso- }\end{array}$ \\
\hline
\end{tabular}

\footnotetext{
${ }^{157}$ No volume para a $2^{\mathrm{a}}$ série, de 1947 , há menção ao fato de o volume para a $3^{\mathrm{a}}$ série estar no prelo. No entanto, não encontramos, em nenhum arquivo, referência a esse $3^{\circ}$ volume. É provável também que, caso ele tenha sido efetivamente publicado, o ano em que isso ocorreu esteja fora dos limites temporais da presente tese.

${ }^{158} \mathrm{O}$ autor informa, no prefácio, que este livro deve ser usado em conjunto com a Anthologia nacional, de Fausto Barreto e Carlos de Laet, obra editada entre 1895 e 1969. Esse uso combinado justifica-se porque o autor utiliza os textos literários presentes na Anthologia e com eles apresenta exercícios e atividades, como ditado; interpretação do texto; significado e pronúncia das palavras; além de tópicos gramaticais.
} 


\begin{tabular}{|c|c|c|c|c|c|}
\hline \multirow[b]{2}{*}{$\begin{array}{l}\text { Obras }^{93} \\
\text { Autores }\end{array}$} & \multicolumn{3}{|c|}{ Escolares } & \multicolumn{2}{|c|}{ De referência } \\
\hline & $\begin{array}{c}\text { Gramáticas } \\
\text { completas }\end{array}$ & $\begin{array}{l}\text { Obras de } \\
\text { temas } \\
\text { gramaticais } \\
\text { específicos }\end{array}$ & $\begin{array}{c}\text { Livros } \\
\text { didáticos de } \\
\text { Português }\end{array}$ & $\begin{array}{c}\text { Gramáticas } \\
\text { completas }\end{array}$ & $\begin{array}{c}\text { Obras de } \\
\text { temas } \\
\text { gramaticais } \\
\text { específicos }\end{array}$ \\
\hline & & & & & $\begin{array}{l}\text { brasileira } \\
\text { (1939) } \Omega\end{array}$ \\
\hline $\begin{array}{c}\text { LOPES, } \\
\text { Castro } \\
(1827-1901)\end{array}$ & & & & & $\begin{array}{l}\text { - Artigos } \\
\text { philologicos } \\
(1910)^{159} \boldsymbol{\beta}\end{array}$ \\
\hline \multicolumn{6}{|c|}{$\mathbf{M}$} \\
\hline $\begin{array}{c}\text { MACEDO } \\
\text { COUTINH } \\
\text { O, Alfredo } \\
\text { Alvares de } \\
\quad(?-?)\end{array}$ & $\begin{array}{l}\text { - Gramática } \\
\text { portuguesa } \\
: \text { curso } \\
\text { elementar } \\
\left(1939 \_8^{\mathrm{a}} \mathrm{ed} .\right. \\
) \boldsymbol{\beta}\end{array}$ & & & & \\
\hline $\begin{array}{l}\text { MACHAD } \\
\text { O FILHO, } \\
\text { Aires da } \\
\text { Mata } \\
\text { (1909-1985) }\end{array}$ & & & & & $\begin{array}{l}\text { - Escrever } \\
\text { certo: } 1^{\mathrm{a}} \\
\text { série }(1935) \boldsymbol{\beta} \\
\text { - Escrever } \\
\text { certo: } 2^{\mathrm{a}} \\
\text { série }(1938) \boldsymbol{\beta} \\
\text { - Problemas } \\
\text { da língua } \\
\text { (1941) } \boldsymbol{\Omega} \\
\text { - Em busca } \\
\text { do têrmo } \\
\text { próprio } \\
\text { (1947) } \boldsymbol{\beta}\end{array}$ \\
\hline $\begin{array}{l}\text { MACIEL, } \\
\text { Maximino }\end{array}$ & $\begin{array}{l}\text { - Lições } \\
\text { elementare } \\
\text { s de Lingua }\end{array}$ & & & & \\
\hline
\end{tabular}

${ }^{159}$ Publicação póstuma. 


\begin{tabular}{|c|c|c|c|c|c|}
\hline \multirow[b]{2}{*}{ Obras $^{93}$} & \multicolumn{3}{|c|}{ Escolares } & \multicolumn{2}{|c|}{ De referência } \\
\hline & $\begin{array}{c}\text { Gramáticas } \\
\text { completas }\end{array}$ & $\begin{array}{c}\text { Obras de } \\
\text { temas } \\
\text { gramaticais } \\
\text { específicos }\end{array}$ & $\begin{array}{c}\text { Livros } \\
\text { didáticos de } \\
\text { Português }\end{array}$ & $\begin{array}{c}\text { Gramáticas } \\
\text { completas }\end{array}$ & $\begin{array}{c}\text { Obras de } \\
\text { temas } \\
\text { gramaticais } \\
\text { específicos }\end{array}$ \\
\hline & $\begin{array}{l}\text { Portugueza } \\
{ }^{160}(1903) \boldsymbol{\beta}\end{array}$ & & & & \\
\hline $\begin{array}{c}\text { MAGALH } \\
\text { AES, E. } \\
\text { Pereira de } \\
(?-?) \\
\text { SILVA, } \\
\text { Valter } \\
\text { Toledo } \\
(?-?) \\
\text { CANABRA } \\
\text { VA, Alice } \\
\text { (? - ?) } \\
\text { GUTIERRE } \\
\text { Z, Rui } \\
\text { (? - ?) }\end{array}$ & & $\begin{array}{l}\text { - Exames de } \\
\text { admissão: } \\
\text { livro de } \\
\text { pontos (1945) } \\
\mathbf{\Omega} \\
\\
\text { - Exames de } \\
\text { admissão: } \\
\text { livro de } \\
\text { exercícios } \\
\text { (1945) } \boldsymbol{\Omega}\end{array}$ & & & \\
\hline $\begin{array}{l}\text { MAGNE, } \\
\text { Augusto } \\
(1887-1966)\end{array}$ & & $\begin{array}{l}\text { - Noções } \\
\text { elementares } \\
\text { de análise } \\
\text { lógica (1931) } \\
\boldsymbol{\beta}\end{array}$ & & & \\
\hline $\begin{array}{c}\text { MAIA } \\
\text { JUNIOR, } \\
\text { Manoel } \\
(?-?)\end{array}$ & & & & & $\begin{array}{l}\text { - Refutações } \\
\text { e estudos da } \\
\text { Lingua } \\
\text { Portuguesa } \\
\text { (1924) } \beta\end{array}$ \\
\hline $\begin{array}{c}\text { MARTINS, } \\
\text { Mário R. } \\
\text { (?-?) }\end{array}$ & & & $\begin{array}{l}\text { - A evolução da } \\
\text { língua }\end{array}$ & & $\begin{array}{l}\text { - A } \\
\text { acentuação } \\
\text { nas reformas } \\
\text { ortográficas } \\
\text { (1939) } \Omega\end{array}$ \\
\hline
\end{tabular}

${ }^{160}$ Obra destinada ao $1^{\circ}$ ano do curso ginasial. 


\begin{tabular}{|c|c|c|c|c|c|}
\hline \multirow[b]{2}{*}{ Obras ${ }^{93}$} & \multicolumn{3}{|c|}{ Escolares } & \multicolumn{2}{|c|}{ De referência } \\
\hline & $\begin{array}{c}\text { Gramáticas } \\
\text { completas }\end{array}$ & $\begin{array}{c}\begin{array}{c}\text { Obras de } \\
\text { temas }\end{array} \\
\text { gramaticais } \\
\text { específicos }\end{array}$ & $\begin{array}{c}\text { Livros } \\
\text { didáticos de } \\
\text { Português }\end{array}$ & $\begin{array}{c}\text { Gramáticas } \\
\text { completas }\end{array}$ & $\begin{array}{c}\text { Obras de } \\
\text { temas } \\
\text { gramaticais } \\
\text { específicos }\end{array}$ \\
\hline & & & $\begin{array}{l}\text { nacional }^{161} \\
(1943) \boldsymbol{\beta}\end{array}$ & & $\begin{array}{l}\text { - Estudo } \\
\text { sistematico } \\
\text { dos verbos } \\
\text { portugueses } \\
\left(19422^{\mathrm{a}} \mathrm{ed} .\right) \\
\Sigma\end{array}$ \\
\hline $\begin{array}{l}\text { MAURO, } \\
\text { Antonio } \\
(?-?)\end{array}$ & & & & & $\begin{array}{l}\text { - Estudos de } \\
\text { Portuguez } \\
\text { (1921) } \boldsymbol{\beta}\end{array}$ \\
\hline $\begin{array}{l}\text { MELLO, } \\
\text { Pedro de } \\
(?-?)\end{array}$ & & & & & $\begin{array}{l}\text { - Novas } \\
\text { teorias } \\
\text { grammatica } \\
\text { es: these de } \\
\text { concurso } \\
\text { (1900) (T) } \beta \\
\\
\text { - O pronome } \\
\text { "SE" } \\
\text { indefinido/ } \\
\text { Notas } \\
\text { philologicas } \\
162 \text { (1926) } \beta\end{array}$ \\
\hline $\begin{array}{l}\text { MELO, } \\
\text { Manuel } \\
(?-?)\end{array}$ & & $\begin{array}{l}\text { - Prontuário } \\
\text { de análise } \\
\text { morfológica } \\
\text { e sintática: } \\
\text { Língua }\end{array}$ & & & \\
\hline
\end{tabular}

${ }^{161}$ Esta obra, basicamente, tem como tema a morfologia. Há alguns poucos tópicos de sintaxe e um breve capítulo de "prosódia", em que o autor lista palavras e suas respectivas pronúncias. Há também exercícios e, no final, uma sequência de textos errados e corrigidos. Além deste volume, o autor publicou outros dois ligados à literatura: A evolução da literatura brasileira: volume 1: notas biográficas e A evolução da literatura brasileira: volume 2: estudos.

${ }^{162}$ Foram publicados dois livros em um só volume. O segundo, ressalte-se, é uma reunião de colunas publicadas no "Jornal de Piracicaba" sobre aspectos gramaticais polêmicos. 


\begin{tabular}{|c|c|c|c|c|c|}
\hline \multirow[b]{2}{*}{$\begin{array}{l}\text { Obras }^{93} \\
\text { Autores }\end{array}$} & \multicolumn{3}{|c|}{ Escolares } & \multicolumn{2}{|c|}{ De referência } \\
\hline & $\begin{array}{c}\text { Gramáticas } \\
\text { completas }\end{array}$ & $\begin{array}{c}\text { Obras de } \\
\text { temas } \\
\text { gramaticais } \\
\text { específicos }\end{array}$ & $\begin{array}{c}\text { Livros } \\
\text { didáticos de } \\
\text { Português }\end{array}$ & $\begin{array}{c}\text { Gramáticas } \\
\text { completas }\end{array}$ & $\begin{array}{c}\text { Obras de } \\
\text { temas } \\
\text { gramaticais } \\
\text { específicos }\end{array}$ \\
\hline & & $\begin{array}{l}\text { Portuguesa } \\
\text { (1943) } \boldsymbol{\Omega}\end{array}$ & & & \\
\hline $\begin{array}{l}\text { MELO, } \\
\text { Paulo de } \\
(?-?)\end{array}$ & & & & & $\begin{array}{l}\text { - Lições } \\
\text { práticas de } \\
\text { Português } \\
\text { (1941) } \boldsymbol{\beta} \\
\text { - Linguagem } \\
\text { médica } \\
\text { (1943) } \boldsymbol{\beta}\end{array}$ \\
\hline $\begin{array}{l}\text { MILANO, } \\
\text { Miguel } \\
(1885-1971)\end{array}$ & & 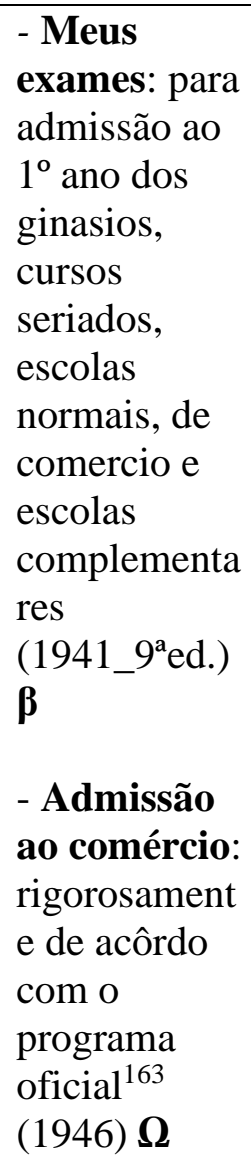 & & & \\
\hline
\end{tabular}

${ }^{163}$ Contém as seguintes disciplinas escolares: Português, Francês, Aritmética e Geografia. 


\begin{tabular}{|c|c|c|c|c|c|}
\hline \multirow[b]{2}{*}{$\begin{array}{l}\text { Obras }^{93} \\
\text { Autores }\end{array}$} & \multicolumn{3}{|c|}{ Escolares } & \multicolumn{2}{|c|}{ De referência } \\
\hline & $\begin{array}{c}\text { Gramáticas } \\
\text { completas }\end{array}$ & $\begin{array}{c}\text { Obras de } \\
\text { temas } \\
\text { gramaticais } \\
\text { específicos }\end{array}$ & $\begin{array}{c}\text { Livros } \\
\text { didáticos de } \\
\text { Português }\end{array}$ & $\begin{array}{c}\text { Gramáticas } \\
\text { completas }\end{array}$ & $\begin{array}{c}\text { Obras de } \\
\text { temas } \\
\text { gramaticais } \\
\text { específicos }\end{array}$ \\
\hline $\begin{array}{c}\text { MORAES, } \\
\text { João } \\
\text { Barbosa de } \\
\quad(?-?)\end{array}$ & & $\begin{array}{l}\text { - Exercícios } \\
\text { de } \\
\text { linguagem: } \\
\text { coleção de } \\
350 \\
\text { exercícios de } \\
\text { linguagem } \\
\text { elaborados de } \\
\text { acordo com } \\
\text { os atuais } \\
\text { programas da } \\
5^{\text {a }} \text { série } \\
\text { primária, do } \\
\text { curso de } \\
\text { admissão e } \\
\text { do } 1^{\circ} \text { ano } \\
\text { secundário } \\
\text { (1941_3aed.) } \\
\mathbf{\Omega} \\
\\
\text { - Para as } \\
\text { classes de } \\
\text { Português: } \\
\text { sintaxe, } \\
\text { análise } \\
\text { lógica, } \\
\text { composição } \\
\text { de palavras }{ }^{164} \\
\text { (1943) } \boldsymbol{\beta}\end{array}$ & & & \\
\hline $\begin{array}{l}\text { MORAIS, } \\
\text { Bento } \\
\text { Bueno de } \\
(?-?)\end{array}$ & $\begin{array}{l}\text { - A nossa } \\
\text { língua: } \\
\text { Português } \\
\text { para as } 1^{\mathrm{a}} \mathrm{e}\end{array}$ & & $\begin{array}{l}\text { - A nossa } \\
\text { lingua: } 1^{\mathrm{a}} \text { série } \\
\text { do curso } \\
\text { fundamental: } 50 \\
\text { lições de } \\
\text { gramática, } 77 \\
\text { exercícios, } 53\end{array}$ & & \\
\hline
\end{tabular}
${ }_{164} \mathrm{Na}$ folha de rosto, consta ainda: "Várias centenas de exercícios elaborados de acordo com os novos programas
da recente reforma do ensino secundário". 
1. Obras do programa de investigação GRAMATICAL

\begin{tabular}{|c|c|c|c|c|c|}
\hline & \multicolumn{3}{|c|}{ Escolares } & \multicolumn{2}{|c|}{ De referência } \\
\hline Obras ${ }^{93}$ & $\begin{array}{l}\text { Gramáticas } \\
\text { completas }\end{array}$ & $\begin{array}{c}\text { Obras de } \\
\text { temas } \\
\text { gramaticais } \\
\text { específicos }\end{array}$ & $\begin{array}{l}\text { Livros } \\
\text { didáticos de } \\
\text { Português }\end{array}$ & $\begin{array}{l}\text { Gramáticas } \\
\text { completas }\end{array}$ & $\begin{array}{c}\text { Obras de } \\
\text { temas } \\
\text { gramaticais } \\
\text { específicos }\end{array}$ \\
\hline & $\begin{array}{l}2^{2^{\mathrm{a}} \text { séries }}{ }^{165} \\
\left(1944 \_2^{\mathrm{a}} \mathrm{ed} .\right. \\
) \boldsymbol{\beta}\end{array}$ & & $\begin{array}{l}\text { leituras em } \\
\text { prosa e verso } \\
\text { (1941) }\end{array}$ & & \\
\hline $\begin{array}{c}\text { MORAIS, } \\
\text { Bento } \\
\text { Bueno de } \\
(?-?) \\
\text { ARCHERO } \\
\text { JR., } \\
\text { Achilles } \\
\text { (1907-2000) }\end{array}$ & & $\begin{array}{l}\text { - Exames de } \\
\text { admissão ao } \\
\text { comércio } \\
(1944) \Omega\end{array}$ & & & \\
\hline $\begin{array}{l}\text { MORAIS, } \\
\text { Orlando } \\
\text { Mendes de } \\
(?-?)\end{array}$ & & $\begin{array}{l}\text { - Dicionário } \\
\text { de } \\
\text { gramática }{ }^{167} \\
(1946)\end{array}$ & & & \\
\hline $\begin{array}{l}\text { MOTTA, } \\
\text { João } \\
(?-?)\end{array}$ & $\begin{array}{l}- \\
\text { Grammatic } \\
\text { a } \\
\text { elementar } \\
\text { da Lingua } \\
\text { Portugueza } \\
\text { : destinada } \\
\text { ao primeiro }\end{array}$ & & & & \\
\hline
\end{tabular}

${ }^{165}$ Essa obra é uma gramática escolar, organizada em lições, e composta por 2 volumes: o primeiro, para as $1^{\mathrm{a}}$ e $2^{\mathrm{a}}$ séries ginasiais e o segundo volume para as $3^{\mathrm{a}} \mathrm{e} 4^{\mathrm{a}}$ séries. No exemplar que possuímos, $1^{\circ}$ volume, $7^{\mathrm{a}}$ edição de 1953 , há indicação da publicação do $2^{\circ}$ volume, mas não localizamos demais informações sobre o autor/obra em nenhum arquivo. Como nosso exemplar é da década de 50, não temos como garantir que o $2^{\circ}$ tenha sido publicado dentro do nosso recorte temporal, motivo que fez com que não o incluíssemos no presente levantamento.

${ }^{166}$ Como mencionamos na nota anterior, há grande escassez de informações sobre este autor. Além do exemplar que possuímos, o único registro que conseguimos sobre o autor e sua obra foi este, da BNRJ. Como já mencionamos em outras notas, é bastante provável a existência de outros volumes da coleção, normalmente formada por 5 volumes, um para cada ano do Secundário/Ginásio. Na ausência de registros, optamos por não incluí-los aqui de maneira presumida.

${ }^{167} \mathrm{Na}$ folha de rosto, há as seguintes informações: "Organizado por um grupo de professôres sob a orientação do Prof. Orlando Mendes de Morais. Destinado aos alunos dos cursos ginasial e superior e também aos Srs. Professôres". 
1. Obras do programa de investigação GRAMATICAL

\begin{tabular}{|c|c|c|c|c|c|}
\hline & \multicolumn{3}{|c|}{ Escolares } & \multicolumn{2}{|c|}{ De referência } \\
\hline $\begin{array}{l}\text { Obras }^{93} \\
\text { Autores }\end{array}$ & $\begin{array}{c}\text { Gramáticas } \\
\text { completas }\end{array}$ & $\begin{array}{c}\text { Obras de } \\
\text { temas } \\
\text { gramaticais } \\
\text { específicos }\end{array}$ & $\begin{array}{c}\text { Livros } \\
\text { didáticos de } \\
\text { Português }\end{array}$ & $\begin{array}{c}\text { Gramáticas } \\
\text { completas }\end{array}$ & $\begin{array}{c}\text { Obras de } \\
\text { temas } \\
\text { gramaticais } \\
\text { específicos }\end{array}$ \\
\hline & $\begin{array}{l}\text { anno dos } \\
\text { gymnasios } \\
(1905) \Omega\end{array}$ & & & & \\
\hline $\begin{array}{l}\text { MOTTA, } \\
\text { Othoniel } \\
(1878-1951)\end{array}$ & & $\begin{array}{l}\text { - Chave da } \\
\text { lingua: } \\
\text { primeiras } \\
\text { noções de } \\
\text { grammatica } \\
\text { ministradas a } \\
\text { infância } \\
\text { (1930) } \beta\end{array}$ & $\begin{array}{l}\text { - Lições de } \\
\text { Português } \\
\text { (1915) } \boldsymbol{\beta}\end{array}$ & & $\begin{array}{l}\text { - O pronome } \\
\text { "se" (1916) } \beta\end{array}$ \\
\hline $\begin{array}{c}\text { MOURA, } \\
\text { Americo } \\
\text { Braziliense } \\
\text { Antunes de } \\
\text { (1881-1953) }\end{array}$ & & & & & $\begin{array}{l}\text { - A } \\
\text { "Grammatic } \\
\text { a expositiva" } \\
\text { e o "se" } \\
\text { sujeito } \\
(1907){ }^{168} \boldsymbol{\beta}\end{array}$ \\
\hline $\begin{array}{l}\text { MOURA, } \\
\text { Maria } \\
\text { Lacerda de } \\
\\
(1887-1945)\end{array}$ & & & $\begin{array}{l}\text { - Português } \\
\text { para os cursos } \\
\text { comerciais: } \\
\text { rigorosamente } \\
\text { de acordo com o } \\
\text { decreto oficial } \\
\text { da Divisão de } \\
\text { Ensino } \\
\text { Comercial } \\
\text { (1940) } \Omega\end{array}$ & & \\
\hline & & & $\mathbf{N}$ & & \\
\hline $\begin{array}{l}\text { NASCENT } \\
\text { ES, Antenor }\end{array}$ & $\begin{array}{l}\text { - O idioma } \\
\text { nacional: } \\
\text { gramática }\end{array}$ & $\begin{array}{l}\text { - Método } \\
\text { prático de } \\
\text { análise }\end{array}$ & $\begin{array}{l}\text { - Apostilas de } \\
\text { Português } \\
(1923) \Omega\end{array}$ & & $\begin{array}{l}\text { - Dicionário } \\
\text { de dúvidas e } \\
\text { dificuldades }\end{array}$ \\
\hline
\end{tabular}

${ }^{168}$ O autor refere-se aqui à Grammatica expositiva, de Eduardo Carlos Pereira, publicada em 1907. 
1. Obras do programa de investigação GRAMATICAL

\begin{tabular}{|c|c|c|c|c|c|}
\hline & \multicolumn{3}{|c|}{ Escolares } & \multicolumn{2}{|c|}{ De referência } \\
\hline $\begin{array}{l}\text { Obras }^{93} \\
\text { Autores }\end{array}$ & $\begin{array}{c}\text { Gramáticas } \\
\text { completas }\end{array}$ & $\begin{array}{c}\text { Obras de } \\
\text { temas } \\
\text { gramaticais } \\
\text { específicos }\end{array}$ & $\begin{array}{c}\text { Livros } \\
\text { didáticos de } \\
\text { Português }\end{array}$ & $\begin{array}{c}\text { Gramáticas } \\
\text { completas }\end{array}$ & $\begin{array}{c}\text { Obras de } \\
\text { temas } \\
\text { gramaticais } \\
\text { específicos }\end{array}$ \\
\hline (1886-1972) & $\begin{array}{l}\text { para as } \\
\text { quatro } \\
\text { séries } \\
\text { ginasiais } \\
(1944) \boldsymbol{\beta}\end{array}$ & $\begin{array}{l}\text { lógica (1920) } \\
\boldsymbol{\beta} \\
\text { - Método } \\
\text { prático de } \\
\text { análise } \\
\text { gramatical } \\
\text { (1921) } \boldsymbol{\beta}\end{array}$ & $\begin{array}{l}\text { - O idioma } \\
\text { nacional: } \\
\text { volume 1 (1926) } \\
\boldsymbol{\beta} \\
\text { - O idioma } \\
\text { nacional: } \\
\text { volume 2 (1927) } \\
\boldsymbol{\beta} \\
\text { - O idioma } \\
\text { nacional: } \\
\text { volume } 3 \text { (1928) } \\
\boldsymbol{\beta} \\
\text { - O idioma } \\
\text { nacional: } \\
\text { síntese dos três } \\
\text { primeiros } \\
\text { volumes (1937) } \\
\mathbf{\Omega} \\
\text { - O idioma } \\
\text { nacional: } \\
\text { gramática para o } \\
\text { colégio } \\
\text { (1944) }{ }^{169} \boldsymbol{\beta}\end{array}$ & & $\begin{array}{l}\text { do idioma } \\
\text { nacional } \\
(1941) \boldsymbol{\beta} \\
\text { - Lexico de } \\
\text { nomenclatur } \\
\text { a gramatical } \\
\text { brasileira } \\
\text { (1946) } \boldsymbol{\beta}\end{array}$ \\
\hline
\end{tabular}

169 Apesar do nome, essa obra não é exatamente uma gramática. Na verdade, trata-se de um livro didático que abrange o conteúdo previsto no programa oficial para os cursos clássico e científico do Secundário, isto é, os três últimos anos do ensino secundário. Nesses anos, diferentemente dos anos iniciais do Secundário, o programa estabelece o estudo de poucos tópicos de gramática, predominando, assim, o estudo da Literatura. Dessa forma, neste volume encontramos aspectos de história da literatura e de teoria literária, além de alguns tópicos gramaticais e, em outro volume, $\mathbf{O}$ idioma nacional: antologia para o colégio, lançado em conjunto com $\mathbf{O}$ idioma nacional: gramática para o colégio, uma seleta de textos literários. Ambos formam, portanto, o material didático de Português necessário para acompanhar os cursos clássico e científico da década de 1940. 
1. Obras do programa de investigação GRAMATICAL

\begin{tabular}{|c|c|c|c|c|c|}
\hline & \multicolumn{3}{|c|}{ Escolares } & \multicolumn{2}{|c|}{ De referência } \\
\hline $\begin{array}{l}\text { Obras }^{93} \\
\text { Autores }\end{array}$ & $\begin{array}{c}\text { Gramáticas } \\
\text { completas }\end{array}$ & $\begin{array}{c}\text { Obras de } \\
\text { temas } \\
\text { gramaticais } \\
\text { específicos }\end{array}$ & $\begin{array}{c}\text { Livros } \\
\text { didáticos de } \\
\text { Português }\end{array}$ & $\begin{array}{c}\text { Gramáticas } \\
\text { completas }\end{array}$ & $\begin{array}{c}\text { Obras de } \\
\text { temas } \\
\text { gramaticais } \\
\text { específicos }\end{array}$ \\
\hline $\begin{array}{l}\text { NASCIME } \\
\text { NTO, } \\
\text { Augusto do } \\
(?-?)\end{array}$ & & & $\begin{array}{l}\text { - Português: } \\
\text { volume segundo } \\
(1942)^{170} \mathbf{\Omega}\end{array}$ & & \\
\hline $\begin{array}{c}\text { NEME, } \\
\text { Mário } \\
\text { (1912-1973) }\end{array}$ & & $\begin{array}{l}\text { - A } \\
\text { acentuação } \\
\text { na } \\
\text { ortografía } \\
\text { simplificada } \\
(1941) \Omega\end{array}$ & & & \\
\hline $\begin{array}{c}\text { NEVES, } \\
\text { Maria do } \\
\text { Carmo } \\
\text { Vidigal } \\
\text { Pereira das } \\
(?-?)\end{array}$ & & $\begin{array}{l}\text { - Exercicios } \\
\text { de } \\
\text { linguagem: } \\
\text { primeiro livro } \\
\text { (1938) } \boldsymbol{\Omega} \\
\text { - Exercicios } \\
\text { de } \\
\text { linguagem: } \\
\text { segundo livro } \\
\text { (1938) } \boldsymbol{\Omega} \\
\text { - Exercicios } \\
\text { de } \\
\text { linguagem: } \\
\text { terceiro livro } \\
\text { (1938) } \boldsymbol{\Omega}\end{array}$ & & & \\
\hline $\begin{array}{c}\text { NOBREGA } \\
\text {, Artur } \\
\text { Raggio } \\
(?-?)\end{array}$ & & & & & $\begin{array}{l}\text { - Estudos de } \\
\text { Português: } \\
\text { duas } \\
\text { monografias: } \\
\text { A acentuação } \\
\text { do A e } \\
\text { Sintaxe dos }\end{array}$ \\
\hline
\end{tabular}

170 Não conseguimos encontrar mais nenhuma referência a respeito desse autor e de suas obras. É logicamente plausível que deva haver o "volume primeiro" desta coleção, mas, em função da ausência de registros, mesmo que indiretos, optamos por não incluí-lo neste levantamento. 


\begin{tabular}{|c|c|c|c|c|c|}
\hline \multirow[b]{2}{*}{ Obras ${ }^{93}$} & \multicolumn{3}{|c|}{ Escolares } & \multicolumn{2}{|c|}{ De referência } \\
\hline & $\begin{array}{c}\text { Gramáticas } \\
\text { completas }\end{array}$ & $\begin{array}{c}\text { Obras de } \\
\text { temas } \\
\text { gramaticais } \\
\text { específicos }\end{array}$ & $\begin{array}{c}\text { Livros } \\
\text { didáticos de } \\
\text { Português }\end{array}$ & $\begin{array}{c}\text { Gramáticas } \\
\text { completas }\end{array}$ & $\begin{array}{c}\text { Obras de } \\
\text { temas } \\
\text { gramaticais } \\
\text { específicos }\end{array}$ \\
\hline & & & & & $\begin{array}{l}\text { pronomes } \\
\text { pessoais } \\
(1900) \Sigma \\
\text { - O } \\
\text { problema da } \\
\text { crase: } \\
\text { filologia } \\
\text { portuguesa } \\
\text { (1916) } \Sigma \\
\text { - Syntaxe do } \\
\text { infinito: } \\
\text { emprego do } \\
\text { infinito } \\
\text { pessoal e do } \\
\text { impessoal } \\
\text { (1930) } \Sigma\end{array}$ \\
\hline $\begin{array}{l}\text { NOGUEIR } \\
\text { A, Julio } \\
(1873-?)\end{array}$ & $\begin{array}{l}\text { - Programa } \\
\text { de } \\
\text { Português: } \\
\text { gramática } \\
\left(1948 \_7 e d .\right) \\
\boldsymbol{\beta}\end{array}$ & $\begin{array}{l}\text { - Programa } \\
\text { de } \\
\text { português: } \\
\text { exame de } \\
\text { admissão e } \\
\text { antologia } \\
\text { primária } \\
\text { (1944_5aed.) } \\
\mathbf{\Omega}\end{array}$ & $\begin{array}{l}\text { - Programa de } \\
\text { Português: 1a. } \\
\text { série secundária } \\
\text { (1939) } \Omega \\
\text { - Programa de } \\
\text { Português: 2a. } \\
\text { série secundária } \\
\text { (1939) } \Omega \\
\text { - Programa de } \\
\text { Português: 3a. } \\
\text { série secundária } \\
\text { (1939) } \Omega \\
\text { - Programa de } \\
\text { Português: de } \\
1^{\mathrm{a}} \text { e } 2^{\mathrm{a}} \text { séries }\end{array}$ & & \\
\hline
\end{tabular}




\begin{tabular}{|c|c|c|c|c|c|}
\hline \multirow[b]{2}{*}{ Obras $^{93}$} & \multicolumn{3}{|c|}{ Escolares } & \multicolumn{2}{|c|}{ De referência } \\
\hline & $\begin{array}{c}\text { Gramáticas } \\
\text { completas }\end{array}$ & $\begin{array}{c}\text { Obras de } \\
\text { temas } \\
\text { gramaticais } \\
\text { específicos }\end{array}$ & $\begin{array}{c}\text { Livros } \\
\text { didáticos de } \\
\text { Português }\end{array}$ & $\begin{array}{c}\text { Gramáticas } \\
\text { completas }\end{array}$ & $\begin{array}{c}\text { Obras de } \\
\text { temas } \\
\text { gramaticais } \\
\text { específicos }\end{array}$ \\
\hline & & & $\begin{array}{l}\text { secundária }{ }^{171} \\
\left(1942 \_7^{a} \text { ed.) } \boldsymbol{\beta}\right.\end{array}$ & & \\
\hline $\begin{array}{l}\text { NUNES, } \\
\text { José de } \\
\text { Sá1 }{ }^{172} \\
(?-1955)\end{array}$ & & & $\begin{array}{l}\text { - Língua } \\
\text { vernácula: } \\
\text { grammatica e } \\
\text { anthologia: } 1^{\mathrm{a}} \mathrm{e} \\
2^{\mathrm{a}} \text { série }(1935) \\
\mathbf{\Omega} \\
\text { - Língua } \\
\text { vernácula: } \\
\text { grammatica e } \\
\text { anthologia: } 3^{\mathrm{a}} \\
\text { série (1936) } \mathbf{\Omega}\end{array}$ & & $\begin{array}{l}\text { - Aprendei a } \\
\text { língua } \\
\text { nacional: } \\
\text { consultório } \\
\text { filológico: } \\
\text { vol. 1 (1938) } \\
\beta \\
\text { - Aprendei a } \\
\text { língua } \\
\text { nacional: } \\
\text { consultório } \\
\text { filológico: } \\
\text { vol. } 2 \text { (1938) } \\
\beta \\
\text { - O } \\
\text { sinclitismo } \\
\text { pronominal } \\
\text { no idioma } \\
\text { luso- } \\
\text { brasileiro } \\
\text { (1920) (T) } \Omega \\
\text { - } \\
\text { Comentários } \\
\text { à "Réplica" } \\
\text { de Rui } \\
\text { Barbosa, } \\
\text { visando } \\
\text { exclusivame } \\
\text { nte aos }\end{array}$ \\
\hline
\end{tabular}

\footnotetext{
${ }^{171}$ Quanto ao Programa de Português: de $3^{\mathrm{a}}$ e $4^{\mathrm{a}}$ séries secundária, só conseguimos localizar exemplares fora de nosso recorte temporal. O mais antigo que encontramos é a $7^{a}$ edição, de 1955.

172 Professor Catedrático de Português no Ginásio Paranaense, em Curitiba, Paraná. A partir de 1939, passa a ser professor de Filologia Portuguesa, na Faculdade de Filosofia, Ciências e Letras, da Universidade de São Paulo.
} 


\begin{tabular}{|c|c|c|c|c|c|}
\hline & \multicolumn{3}{|c|}{ Escolares } & \multicolumn{2}{|c|}{ De referência } \\
\hline Obras ${ }^{93}$ & $\begin{array}{l}\text { Gramáticas } \\
\text { completas }\end{array}$ & $\begin{array}{c}\text { Obras de } \\
\text { temas } \\
\text { gramaticais } \\
\text { específicos }\end{array}$ & $\begin{array}{c}\text { Livros } \\
\text { didáticos de } \\
\text { Português }\end{array}$ & $\begin{array}{l}\text { Gramáticas } \\
\text { completas }\end{array}$ & $\begin{array}{c}\text { Obras de } \\
\text { temas } \\
\text { gramaticais } \\
\text { específicos }\end{array}$ \\
\hline & & & & & $\begin{array}{l}\text { arcaismos } \\
(1939)(\mathrm{T}) \boldsymbol{\beta}\end{array}$ \\
\hline \multicolumn{6}{|c|}{ O } \\
\hline $\begin{array}{l}\text { OITICICA, } \\
\text { José de } \\
(1882-1957)\end{array}$ & $\begin{array}{l}\text { - Manual } \\
\text { de análise: } \\
\text { léxica e } \\
\text { sintática }{ }^{173} \\
(1919) \boldsymbol{\beta}\end{array}$ & & & & $\begin{array}{l}\text { - Manual de } \\
\text { estilo (1925) } \\
\boldsymbol{\beta} \\
\text { - Estudos de } \\
\text { fonologia } \\
\text { (1916) } \boldsymbol{\beta}(\mathrm{T})\end{array}$ \\
\hline $\begin{array}{l}\text { OLIVEIRA, } \\
\text { Honorato } \\
\text { Faustino de } \\
(1867-1948)\end{array}$ & & $\begin{array}{l}\text { - Lições } \\
\text { práticas de } \\
\text { pontuação e } \\
\text { de } \\
\text { accentuação } \\
\text { do "A" pela } \\
\text { figura } \\
\text { "crase" } \\
(1919 \text { 2a ed.) } \\
\mathbf{\Omega}\end{array}$ & & & \\
\hline \multicolumn{6}{|c|}{$\mathbf{P}$} \\
\hline $\begin{array}{c}\text { P.S } \\
\text { (Pedro } \\
\text { Schneider) } \\
(1866-1931)\end{array}$ & $\begin{array}{l}\text { - Syntaxe e } \\
\text { grammatic } \\
\text { a historica } \\
\text { da Lingua } \\
\text { Portuguesa } \\
(1909)^{174} \boldsymbol{\beta}\end{array}$ & & & & \\
\hline
\end{tabular}

${ }^{173}$ Apesar do título, trata-se de uma gramática completa.

${ }^{174} \mathrm{O}$ presente volume é formado por uma gramática tradicional e uma gramática histórica. Em função dessa característica "dois em um", a incluímos tanto aqui como no levantamento das obras do programa filológico, no grupo das "gramáticas históricas" (cf. Tabela 2A - Apêndice A). 


\begin{tabular}{|c|c|c|c|c|c|}
\hline \multirow[b]{2}{*}{$\begin{array}{l}\text { Obras }^{93} \\
\text { Autores }\end{array}$} & \multicolumn{3}{|c|}{ Escolares } & \multicolumn{2}{|c|}{ De referência } \\
\hline & $\begin{array}{c}\text { Gramáticas } \\
\text { completas }\end{array}$ & $\begin{array}{c}\text { Obras de } \\
\text { temas } \\
\text { gramaticais } \\
\text { específicos }\end{array}$ & $\begin{array}{c}\text { Livros } \\
\text { didáticos de } \\
\text { Português }\end{array}$ & $\begin{array}{c}\text { Gramáticas } \\
\text { completas }\end{array}$ & $\begin{array}{c}\text { Obras de } \\
\text { temas } \\
\text { gramaticais } \\
\text { específicos }\end{array}$ \\
\hline $\begin{array}{l}\text { PAES DE } \\
\text { ANDRADE } \\
\text {, J. M. } \\
\text { (? - ?) }\end{array}$ & & & & & $\begin{array}{l}\text { - Nos } \\
\text { domínios do } \\
\text { vernaculo: } \\
\text { notas } \\
\text { didacticas } \\
\text { (1925) } \boldsymbol{\beta}\end{array}$ \\
\hline $\begin{array}{l}\text { PASSOS, } \\
\text { Alexandre } \\
(1903-?)\end{array}$ & & & & & $\begin{array}{l}\text { - Arte de } \\
\text { pontuar: } \\
\text { notações } \\
\text { sintáticas } \\
\text { (1943) } \Omega\end{array}$ \\
\hline $\begin{array}{c}\text { PEREIRA } \\
\text { JUNIOR, } \\
\text { Francisco } \\
\text { Augusto } \\
(?-?)\end{array}$ & & & & $\begin{array}{l}\text { - Gramatica } \\
\text { pratica: } \\
\text { unica do } \\
\text { curso } \\
\text { superior } \\
\text { completo } \\
(1924) \Sigma\end{array}$ & \\
\hline $\begin{array}{l}\text { PEREIRA, } \\
\text { Altamirano } \\
\text { Nunes } \\
(1898-?)\end{array}$ & & & & & $\begin{array}{l}\text { - Estudo da } \\
\text { palavra } \\
\text { QUE (1939) } \\
\Sigma \\
\text { - O } \\
\text { problema da } \\
\text { análise } \\
\text { sintática e } \\
\text { sua solução } \\
\text { racional } \\
\text { (1938) } \Omega\end{array}$ \\
\hline $\begin{array}{l}\text { PEREIRA, } \\
\text { Eduardo } \\
\text { Carlos } \\
(1855-1923)\end{array}$ & $\begin{array}{l}\text { Gramática } \\
\text { expositiva: } \\
\text { curso }\end{array}$ & & & & $\begin{array}{l}\text { - Questões } \\
\text { de } \\
\text { philologia: } \\
\text { resposta aos } \\
\text { criticos da }\end{array}$ \\
\hline
\end{tabular}




\begin{tabular}{|c|c|c|c|c|c|}
\hline \multirow[b]{2}{*}{ Obras ${ }^{93}$} & \multicolumn{3}{|c|}{ Escolares } & \multicolumn{2}{|c|}{ De referência } \\
\hline & $\begin{array}{c}\text { Gramáticas } \\
\text { completas }\end{array}$ & $\begin{array}{c}\text { Obras de } \\
\text { temas } \\
\text { gramaticais } \\
\text { específicos }\end{array}$ & $\begin{array}{c}\text { Livros } \\
\text { didáticos de } \\
\text { Português }\end{array}$ & $\begin{array}{c}\text { Gramáticas } \\
\text { completas }\end{array}$ & $\begin{array}{c}\text { Obras de } \\
\text { temas } \\
\text { gramaticais } \\
\text { específicos }\end{array}$ \\
\hline & $\begin{array}{l}\text { superior }{ }^{175} \\
(1907) \boldsymbol{\beta} \\
- \\
\text { Gramática } \\
\text { expositiva: } \\
\text { curso } \\
\text { elementar } \\
\text { (1908) } \boldsymbol{\beta}\end{array}$ & & & & $\begin{array}{l}\text { "Grammatica } \\
\text { expositiva" } \\
\text { (1907) } \boldsymbol{\beta}\end{array}$ \\
\hline $\begin{array}{l}\text { PEREIRA, } \\
\text { Miguel } \\
(?-?)\end{array}$ & & & & & $\begin{array}{l}\text { - Funcções } \\
\text { do pronome } \\
\text { SE e da } \\
\text { partícula } \\
\text { QUÊE / } \\
\text { Adjectivos } \\
\text { gentilicos e } \\
\text { patrios } \\
\text { (1918) } \beta\end{array}$ \\
\hline $\begin{array}{c}\text { PINTO, } \\
\text { Alfredo } \\
\text { Clemente } \\
\end{array}$ & $\begin{array}{l}\text { - Primeiras } \\
\text { noções de } \\
\text { grammatic } \\
\text { a: } 1^{\circ} \text { curso } \\
(1906) \boldsymbol{\beta} \\
\\
\text { - Primeiro } \\
\text { anno de } \\
\text { grammatic } \\
\text { a por meio } \\
\text { de } \\
\text { exercicios } \\
\text { praticos: } 2^{\circ} \\
\text { curso } \\
\text { (1907) } \beta\end{array}$ & & & & \\
\hline
\end{tabular}

175 Obra destinada ao $2^{\circ}$ e $3^{\circ}$ anos do curso ginasial. Quanto ao $4^{\circ}$ ano, o autor publicou, em 1916, a Grammatica historica, tema desse ano específico.

176 Obra destinada ao $1^{\circ}$ ano do curso ginasial. 


\begin{tabular}{|c|c|c|c|c|c|}
\hline \multirow[b]{2}{*}{$\begin{array}{l}\text { Obras }^{93} \\
\text { Autores }\end{array}$} & \multicolumn{3}{|c|}{ Escolares } & \multicolumn{2}{|c|}{ De referência } \\
\hline & $\begin{array}{c}\text { Gramáticas } \\
\text { completas }\end{array}$ & $\begin{array}{l}\text { Obras de } \\
\text { temas } \\
\text { gramaticais } \\
\text { específicos }\end{array}$ & $\begin{array}{c}\text { Livros } \\
\text { didáticos de } \\
\text { Português }\end{array}$ & $\begin{array}{c}\text { Gramáticas } \\
\text { completas }\end{array}$ & $\begin{array}{c}\text { Obras de } \\
\text { temas } \\
\text { gramaticais } \\
\text { específicos }\end{array}$ \\
\hline $\begin{array}{c}\text { PINTO, } \\
\text { Leonardo } \\
\text { (1891- } \\
1947)\end{array}$ & & $\begin{array}{l}\text { - } \\
\text { Conjuncções } \\
\text { : notas } \\
\text { elucidativas e } \\
\text { exercicios } \\
\text { práticos } \\
\text { (1922) } \boldsymbol{\beta}\end{array}$ & & & $\begin{array}{l}\text { - Da } \\
\text { collocação } \\
\text { dos } \\
\text { pronomes } \\
\text { complement } \\
\text { os (1923) } \Omega \\
\\
\text { - Gallicismo: } \\
\text { lexicos e } \\
\text { fraseologicos } \\
(1936) \Omega\end{array}$ \\
\hline $\begin{array}{l}\text { PINTO, P. } \\
\text { A. }{ }^{177} \\
(1882-1971)\end{array}$ & & & & & $\begin{array}{l}\text { - Nugas e } \\
\text { rugas de } \\
\text { linguagem } \\
\text { portuguesa: } \\
\text { notas de } \\
\text { vário tempo } \\
\text { (1919) } \Sigma \\
\text { - Notas de } \\
\text { advocacia } \\
\text { gramatical: } \\
\text { estudinhos de } \\
\text { linguagem } \\
\text { portuguesa } \\
\text { (1922) } \Sigma \\
\\
\text { - Termos e } \\
\text { locuções: } \\
\text { miùdezas de } \\
\text { linguagem } \\
\text { luso- } \\
\text { brasileira } \\
\text { (1924) } \beta \\
\end{array}$ \\
\hline
\end{tabular}

\footnotetext{
${ }^{177} \mathrm{O}$ autor assina suas obras desta forma, usando iniciais. Seu nome completo é Pedro Augusto Pinto.
} 


\begin{tabular}{|c|c|c|c|c|c|}
\hline \multirow[b]{2}{*}{ Obras $^{93}$} & \multicolumn{3}{|c|}{ Escolares } & \multicolumn{2}{|c|}{ De referência } \\
\hline & $\begin{array}{l}\text { Gramáticas } \\
\text { completas }\end{array}$ & $\begin{array}{l}\text { Obras de } \\
\text { temas } \\
\text { gramaticais } \\
\text { específicos }\end{array}$ & $\begin{array}{c}\text { Livros } \\
\text { didáticos de } \\
\text { Português }\end{array}$ & $\begin{array}{l}\text { Gramáticas } \\
\text { completas }\end{array}$ & $\begin{array}{c}\text { Obras de } \\
\text { temas } \\
\text { gramaticais } \\
\text { específicos }\end{array}$ \\
\hline & & & & & $\begin{array}{l}\text { miùdezas de } \\
\text { linguagem } \\
\text { luso- } \\
\text { brasileira } \\
(1926) \Sigma \\
\text { - Crítica } \\
\text { miúda: } \\
\text { Camilo } \\
\text { torturado } \\
\text { (1928) } \Omega \\
\text { - Língua } \\
\text { materna: } \\
\text { miùdezas de } \\
\text { linguagem } \\
\text { luso- } \\
\text { brasileira } \\
\text { (1934) } \beta\end{array}$ \\
\hline $\begin{array}{c}\text { POSADA, } \\
\text { Hortênsia } \\
(?-?)\end{array}$ & & $\begin{array}{l}\text { - Breve } \\
\text { estudo de } \\
\text { analyse } \\
\text { sintactica: } \\
\text { para os } \\
\text { alunos das } \\
\text { escolas } \\
\text { primarias. } \\
\text { (1923) } \Omega\end{array}$ & & & \\
\hline $\begin{array}{l}\text { PUENTE, } \\
\text { André Leão } \\
(1855-1920)\end{array}$ & $\begin{array}{l}\text { - } \\
\text { Grammatic } \\
\text { a primária } \\
\text { da Lingua } \\
\text { Portugueza } \\
(1903) \Omega\end{array}$ & & & & \\
\hline & & & & & \\
\hline
\end{tabular}




\begin{tabular}{|c|c|c|c|c|c|}
\hline \multirow[b]{2}{*}{ Obras $^{93}$} & \multicolumn{3}{|c|}{ Escolares } & \multicolumn{2}{|c|}{ De referência } \\
\hline & $\begin{array}{c}\text { Gramáticas } \\
\text { completas }\end{array}$ & $\begin{array}{l}\text { Obras de } \\
\text { temas } \\
\text { gramaticais } \\
\text { específicos }\end{array}$ & $\begin{array}{c}\text { Livros } \\
\text { didáticos de } \\
\text { Português }\end{array}$ & $\begin{array}{c}\text { Gramáticas } \\
\text { completas }\end{array}$ & $\begin{array}{c}\text { Obras de } \\
\text { temas } \\
\text { gramaticais } \\
\text { específicos }\end{array}$ \\
\hline $\begin{array}{l}\text { REIS, Otelo } \\
\text { de Souza } \\
(1890-1948)\end{array}$ & & $\begin{array}{l}\text { - Analyse } \\
\text { lexica: } \\
\text { palavras que } \\
\text { podem ter } \\
\text { diversas } \\
\text { classificações } \\
\text { (1921) } \boldsymbol{\Omega} \\
\text { - Guia } \\
\text { elementar de } \\
\text { análise } \\
\text { léxica ou } \\
\text { gramatical: } \\
\text { para se } \\
\text { resolverem } \\
\text { algumas } \\
\text { dificuldades } \\
\text { taxionômicas } \\
\text { (1938_2aed.) } \\
\mathbf{\Omega} \\
\\
\text { - Textos } \\
\text { para corrigir } \\
\text { (1931) } \boldsymbol{\beta}\end{array}$ & & & $\begin{array}{l}\text { - Tres } \\
\text { palavrinhas: } \\
\text { breviário de } \\
\text { emendas } \\
\text { referentes á } \\
\text { linguagem } \\
(1931) \Sigma \\
\text { - Breviário } \\
\text { da } \\
\text { conjugação } \\
\text { de verbos } \\
\text { (1931) } \boldsymbol{\beta}\end{array}$ \\
\hline $\begin{array}{l}\text { RÉVEILLE } \\
\text { AU, A. } \\
(?-?)\end{array}$ & $\begin{array}{l}\text { - A prova } \\
\text { de } \\
\text { Português } \\
\text { na Escola } \\
\text { Militar ou } \\
\text { gramatica } \\
\text { mixta da } \\
\text { Lingua } \\
\text { Portuguêsa } \\
\text { : livro } \\
\text { destinado a } \\
\text { qualquer } \\
\text { série } \\
\text { ginasial de }\end{array}$ & $\begin{array}{l}\text { - Método de } \\
\text { analise } \\
\text { morfológica } \\
\text { e oracional } \\
\text { (1930) } \Omega \\
\text { - O terceiro } \\
\text { ano } \\
\text { secundário: } \\
\text { desenvolvime } \\
\text { nto do } \\
\text { programa de } \\
\text { Português } \\
\text { (1936) } \Omega\end{array}$ & & & \\
\hline
\end{tabular}




\begin{tabular}{|c|c|c|c|c|c|}
\hline \multirow[b]{2}{*}{ Obras $^{93}$} & \multicolumn{3}{|c|}{ Escolares } & \multicolumn{2}{|c|}{ De referência } \\
\hline & $\begin{array}{c}\text { Gramáticas } \\
\text { completas }\end{array}$ & $\begin{array}{c}\text { Obras de } \\
\text { temas } \\
\text { gramaticais } \\
\text { específicos }\end{array}$ & $\begin{array}{c}\text { Livros } \\
\text { didáticos de } \\
\text { Português }\end{array}$ & $\begin{array}{c}\text { Gramáticas } \\
\text { completas }\end{array}$ & $\begin{array}{c}\text { Obras de } \\
\text { temas } \\
\text { gramaticais } \\
\text { específicos }\end{array}$ \\
\hline & $\begin{array}{l}\text { Português } \\
(1938)^{178} \boldsymbol{\beta}\end{array}$ & & & & \\
\hline $\begin{array}{l}\text { RIBEIRO, } \\
\text { Clovis } \\
(?-?) \\
\text { JORGE, } \\
\text { Felipe } \\
(?-?) \\
\text { LOURENÇ } \\
\text { O, José } \\
\text { (? - ?) } \\
\text { WEY, } \\
\text { Valter } \\
\text { (? - ?) }\end{array}$ & & & $\begin{array}{l}\text { - Língua } \\
\text { portuguêsa: } \\
\text { primeiro } \\
\text { volume: } 1^{\mathrm{a}} \text { série } \\
\text { dos cursos } \\
\text { clássico e } \\
\text { científico (1944) } \\
\boldsymbol{\beta} \\
\text { - Língua } \\
\text { portuguêsa: } \\
\text { segundo } \\
\text { volume: } 2^{\mathrm{a}} \text { série } \\
\text { dos cursos } \\
\text { clássico e } \\
\text { científico } \\
\text { (1944_2aed.) } \boldsymbol{\beta}\end{array}$ & & \\
\hline $\begin{array}{c}\text { RIBEIRO, } \\
\text { Ernesto } \\
\text { Carneiro } \\
\text { (1839-1920) }\end{array}$ & & & & & $\begin{array}{l}\text { - Ligeiras } \\
\text { observações } \\
\text { sobre as } \\
\text { emendas do } \\
\text { dr. Ruy } \\
\text { Barbosa } \\
\text { feitas á } \\
\text { redação da } \\
\text { projecto do } \\
\text { Codigo Civil } \\
\text { (1902) } \beta \\
\text { - A redacção } \\
\text { do projecto } \\
\text { do codigo } \\
\text { civil e a }\end{array}$ \\
\hline
\end{tabular}

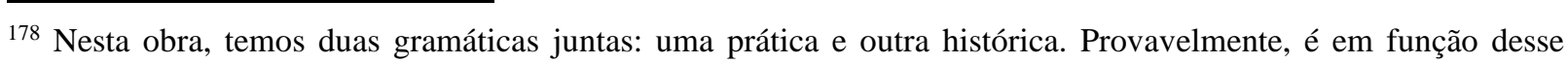
aspecto que o autor chamou sua obra de "gramática mista". 


\begin{tabular}{|c|c|c|c|c|c|}
\hline \multirow[b]{2}{*}{ Obras $^{93}$} & \multicolumn{3}{|c|}{ Escolares } & \multicolumn{2}{|c|}{ De referência } \\
\hline & $\begin{array}{l}\text { Gramáticas } \\
\text { completas }\end{array}$ & $\begin{array}{c}\text { Obras de } \\
\text { temas } \\
\text { gramaticais } \\
\text { específicos }\end{array}$ & $\begin{array}{c}\text { Livros } \\
\text { didáticos de } \\
\text { Português }\end{array}$ & $\begin{array}{c}\text { Gramáticas } \\
\text { completas }\end{array}$ & $\begin{array}{c}\text { Obras de } \\
\text { temas } \\
\text { gramaticais } \\
\text { específicos }\end{array}$ \\
\hline & & & & & $\begin{array}{l}\text { replica do } \\
\text { dr. Ruy } \\
\text { Barbosa: } \\
\text { tréplica } \\
(1905) \beta\end{array}$ \\
\hline $\begin{array}{l}\text { RIBEIRO, } \\
\text { João } \\
\text { (1860-1934) }\end{array}$ & & $\begin{array}{l}\text { - Livro de } \\
\text { exercicios }^{179} \\
(1903) \boldsymbol{\Omega} \\
\text { - Exame de } \\
\text { admissão } \\
\text { para os } \\
\text { ginásios }{ }^{180} \\
(1916) \boldsymbol{\Omega}\end{array}$ & & & \\
\hline $\begin{array}{l}\text { RIZZO, } \\
\text { José } \\
(?-?)\end{array}$ & & & & & $\begin{array}{l}\text { - Estudos da } \\
\text { Língua } \\
\text { Portuguesa } \\
(1922) \boldsymbol{\beta} \\
\text { - Da } \\
\text { colocação } \\
\text { dos } \\
\text { pronomes } \\
\text { pessoais } \\
\text { (1939) } \boldsymbol{\Sigma} \\
\text { - Farfalhas } \\
\text { vernáculas } \\
\text { (1939) } \boldsymbol{\beta}\end{array}$ \\
\hline
\end{tabular}

\footnotetext{
${ }^{179} \mathrm{Na}$ lista de obras do autor, presente em todas as suas publicações, há a informação de que este material é destinado "para servir com a gramática do $1^{\circ}$ ano", ou seja, deve ser o livro de exercícios dessa gramática.

${ }^{180}$ Novamente, uma outra obra do autor informa que este livro contém os "prontuários das matérias exigidas para o exame de admissão no Colégio Pedro II". Este livro foi escrito em coautoria com Raja Gabaglia e não é um livro apenas de Português, mas de todas as matérias que compõem o exame de admissão, como Matemática, História, Geografia, etc.
} 
1. Obras do programa de investigação GRAMATICAL

\begin{tabular}{|c|c|c|c|c|c|}
\hline & \multicolumn{3}{|c|}{ Escolares } & \multicolumn{2}{|c|}{ De referência } \\
\hline $\begin{array}{l}\text { Obras }^{93} \\
\text { Autores }\end{array}$ & $\begin{array}{c}\text { Gramáticas } \\
\text { completas }\end{array}$ & $\begin{array}{l}\text { Obras de } \\
\text { temas } \\
\text { gramaticais } \\
\text { específicos }\end{array}$ & $\begin{array}{c}\text { Livros } \\
\text { didáticos de } \\
\text { Português }\end{array}$ & $\begin{array}{c}\text { Gramáticas } \\
\text { completas }\end{array}$ & $\begin{array}{c}\text { Obras de } \\
\text { temas } \\
\text { gramaticais } \\
\text { específicos }\end{array}$ \\
\hline $\begin{array}{c}\text { ROCHA, } \\
\text { Mario } \\
\text { Penna } \\
(?-?)\end{array}$ & & $\begin{array}{l}\text { - Curso } \\
\text { prático de } \\
\text { Português: } \\
\text { dez aulas na } \\
\text { Rádio-Escola } \\
\text { Municipal } \\
\text { (PRD-5), em } \\
\text { combinação } \\
\text { com PRA-2, } \\
\text { do Ministério } \\
\text { da Educação } \\
\text { (1939) } \boldsymbol{\Omega}\end{array}$ & & & \\
\hline $\begin{array}{l}\text { RODRIGU } \\
\text { ES, J. } \\
(?-?)\end{array}$ & $\begin{array}{l}\text { Grammatic } \\
\text { a } \\
\text { portuguesa } \\
: 1^{\mathrm{a}}, 2^{\mathrm{a}}, 3^{\mathrm{a}}, \\
4^{\mathrm{a}} \text { e } 5^{\mathrm{a}} \\
\text { séries } \\
\text { gymnasiaes } \\
(1935) \boldsymbol{\beta}\end{array}$ & & & & \\
\hline $\begin{array}{l}\text { ROMANO, } \\
\text { Raul } \\
\text { (? - ?) }\end{array}$ & & & $\begin{array}{l}\text { - Pequenas } \\
\text { lições de } \\
\text { Português } \\
(1925) \Omega\end{array}$ & & \\
\hline & & & $\mathbf{S}$ & & \\
\hline $\begin{array}{l}\text { SAMPAIO, } \\
\text { B. }{ }^{181} \\
(?-?)\end{array}$ & $\begin{array}{l}\text { - } \\
\text { Elementos } \\
\text { de } \\
\text { gramática }\end{array}$ & & & & $\begin{array}{l}\text { - Questões } \\
\text { da língua } \\
(1938)^{183} \boldsymbol{\beta}\end{array}$ \\
\hline
\end{tabular}

${ }^{181} \mathrm{O}$ autor assina suas obras assim. Seu nome completo é Benedito Sampaio.

${ }^{183}$ Não há nenhuma indicação de data de publicação no volume consultado. A BNRJ, porém, dá como provável data de publicação 1938 . 


\begin{tabular}{|c|c|c|c|c|c|}
\hline \multirow[b]{2}{*}{$\begin{array}{l}\text { Obras }^{93} \\
\text { Autores }\end{array}$} & \multicolumn{3}{|c|}{ Escolares } & \multicolumn{2}{|c|}{ De referência } \\
\hline & $\begin{array}{c}\text { Gramáticas } \\
\text { completas }\end{array}$ & $\begin{array}{c}\text { Obras de } \\
\text { temas } \\
\text { gramaticais } \\
\text { específicos }\end{array}$ & $\begin{array}{c}\text { Livros } \\
\text { didáticos de } \\
\text { Português }\end{array}$ & $\begin{array}{c}\text { Gramáticas } \\
\text { completas }\end{array}$ & $\begin{array}{c}\text { Obras de } \\
\text { temas } \\
\text { gramaticais } \\
\text { específicos }\end{array}$ \\
\hline & $\begin{array}{l}\text { portuguesa } \\
(1931)^{182} \boldsymbol{\beta}\end{array}$ & & & & $\begin{array}{l}\text { - Falar certo } \\
\text { (1939) } \boldsymbol{\beta} \\
\text { - Polemica } \\
\text { alegre de } \\
\text { gramática: } \\
\text { reposta ao } \\
\text { crítico } \\
\text { português } \\
\text { Vasco } \\
\text { Botelho do } \\
\text { Amaral, da } \\
\text { Revista } \\
\text { Brotéria } \\
\text { (1940) } \Omega\end{array}$ \\
\hline $\begin{array}{l}\text { SAMPAIO, } \\
\text { Francisco } \\
\text { Ribeiro } \\
\text { (1909-1988) }\end{array}$ & & & & & $\begin{array}{l}\text { - Questões } \\
\text { de } \\
\text { Português: } \\
\text { reparos aos } \\
\text { erros de } \\
\text { gramática do } \\
\text { professor } \\
\text { Silveira } \\
\text { Bueno (1939) } \\
\boldsymbol{\beta}\end{array}$ \\
\hline $\begin{array}{c}\text { SAMPAIO, } \\
\text { Guimarães } \\
(?-?)\end{array}$ & & & & & $\begin{array}{l}\text { - Idioma } \\
\text { nacional } \\
(1942) \Sigma\end{array}$ \\
\hline $\begin{array}{c}\text { SANCTIS, } \\
\text { Baptista de } \\
(?-?)\end{array}$ & & $\begin{array}{l}\text { - Analyse } \\
\text { lexica e } \\
\text { sintatica } \\
(1923) \boldsymbol{\beta}\end{array}$ & & & \\
\hline
\end{tabular}

$182 \mathrm{Na}$ folha de rosto, consta, como data de publicação, o ano de 1931, mas, na capa cartonada, aparece registrado 1932. Como não há outros elementos para checar a data correta, adotaremos a data da folha de rosto, local onde estão os demais dados bibliográficos. 


\begin{tabular}{|c|c|c|c|c|c|}
\hline \multirow[b]{2}{*}{ Obras ${ }^{93}$} & \multicolumn{3}{|c|}{ Escolares } & \multicolumn{2}{|c|}{ De referência } \\
\hline & $\begin{array}{l}\text { Gramáticas } \\
\text { completas }\end{array}$ & $\begin{array}{c}\text { Obras de } \\
\text { temas } \\
\text { gramaticais } \\
\text { específicos }\end{array}$ & $\begin{array}{c}\text { Livros } \\
\text { didáticos de } \\
\text { Português }\end{array}$ & $\begin{array}{l}\text { Gramáticas } \\
\text { completas }\end{array}$ & $\begin{array}{c}\text { Obras de } \\
\text { temas } \\
\text { gramaticais } \\
\text { específicos }\end{array}$ \\
\hline $\begin{array}{c}\text { SANTOS, } \\
\text { J. França } \\
(?-?)\end{array}$ & & $\begin{array}{l}\text { - Pontos de } \\
\text { Português } \\
\text { prático para } \\
\text { concursos } \\
\text { (1944) } \Omega\end{array}$ & & & \\
\hline $\begin{array}{l}\text { SANTOS, } \\
\text { Maximo de } \\
\text { Moura } \\
(1894-1961)\end{array}$ & & $\begin{array}{l}\text { - Notas de } \\
\text { gramatica: } \\
\text { para analise } \\
\text { gramatical e } \\
\text { logica } \\
(1932)^{184} \boldsymbol{\Omega} \\
- \\
\text { Preparatório } \\
\text { s para } \\
\text { admissão aos } \\
\text { gymnasios e } \\
\text { aos cursos } \\
\text { fundamenta } \\
\text { es das } \\
\text { escolas } \\
\text { normaes } \\
\text { (1936) } \Omega\end{array}$ & & & \\
\hline $\begin{array}{c}\text { SATURNI } \\
\text { NO, José } \\
(?-?)\end{array}$ & & $\begin{array}{l}\text { - Língua } \\
\text { Portuguesa: } \\
\text { ligeiras } \\
\text { observações } \\
\text { apresentadas } \\
\text { ao curso de } \\
\text { férias da } \\
\text { A.B.E. } \\
\text { (1941) } \mathbf{\Omega}\end{array}$ & & & \\
\hline
\end{tabular}

\footnotetext{
${ }^{184} \mathrm{Na} 2^{\mathrm{a}}$ edição, em 1940, a obra passa a ter o seguinte título: Análise gramatical e lógica: notas de gramatica. Como pode ser visto, nessa edição, o novo título resulta da inversão do título e do subtítulo da $1^{\text {a }}$ edição. 185 "Português, Matemática - Aritmética, História - História do Brasil, Geografia, Ciências Naturais".
} 


\begin{tabular}{|c|c|c|c|c|c|}
\hline \multirow[b]{2}{*}{$\begin{array}{l}\text { Obras }^{93} \\
\text { Autores }\end{array}$} & \multicolumn{3}{|c|}{ Escolares } & \multicolumn{2}{|c|}{ De referência } \\
\hline & $\begin{array}{c}\text { Gramáticas } \\
\text { completas }\end{array}$ & $\begin{array}{c}\text { Obras de } \\
\text { temas } \\
\text { gramaticais } \\
\text { específicos }\end{array}$ & $\begin{array}{c}\text { Livros } \\
\text { didáticos de } \\
\text { Português }\end{array}$ & $\begin{array}{c}\text { Gramáticas } \\
\text { completas }\end{array}$ & $\begin{array}{c}\text { Obras de } \\
\text { temas } \\
\text { gramaticais } \\
\text { específicos }\end{array}$ \\
\hline $\begin{array}{c}\text { SENRA, } \\
\text { José } \\
(?-?)\end{array}$ & & $\begin{array}{l}\text { - Noções de } \\
\text { analyse } \\
\text { portugueza } \\
(1930) \Sigma\end{array}$ & & & \\
\hline $\begin{array}{c}\text { SENRA, } \\
\text { José } \\
(?-?) \\
\text { TEIXEIRA, } \\
\text { J. M. } \\
(?-?)\end{array}$ & & $\begin{array}{l}\text { - Analyse } \\
\text { portugueza } \\
(1901) \Omega\end{array}$ & & & \\
\hline $\begin{array}{l}\text { SILVEIRA, } \\
\text { Agenor } \\
(1880-1955)\end{array}$ & & & & & $\begin{array}{l}\text { - Collocação } \\
\text { dos } \\
\text { pronomes: } \\
\text { regras e notas } \\
\text { explicativas } \\
\left(1920 \_2^{\mathrm{a}} \text { ed.) }\right. \\
\boldsymbol{\Sigma}\end{array}$ \\
\hline $\begin{array}{c}\text { SOUZA, } \\
\text { Sylvio } \\
\text { Aguiar } \\
(?-?)\end{array}$ & & $\begin{array}{l}\text { - A analyse } \\
\text { lógica no } \\
\text { diagramma } \\
\text { (1935) } \boldsymbol{\beta}\end{array}$ & & & \\
\hline & & & $\mathbf{T}$ & & \\
\hline $\begin{array}{c}\text { TABORDA } \\
\text {, Raul } \\
(?-?)\end{array}$ & & & & & $\begin{array}{l}\text { - O idioma } \\
\text { de Camões: } \\
\text { ensaios } \\
\text { philologicos } \\
\text { (1923) } \boldsymbol{\beta}\end{array}$ \\
\hline
\end{tabular}


1. Obras do programa de investigação GRAMATICAL

\begin{tabular}{|c|c|c|c|c|c|}
\hline & \multicolumn{3}{|c|}{ Escolares } & \multicolumn{2}{|c|}{ De referência } \\
\hline Obras $^{93}$ & $\begin{array}{c}\text { Gramáticas } \\
\text { completas }\end{array}$ & $\begin{array}{c}\text { Obras de } \\
\text { temas } \\
\text { gramaticais } \\
\text { específicos }\end{array}$ & $\begin{array}{c}\text { Livros } \\
\text { didáticos de } \\
\text { Português }\end{array}$ & $\begin{array}{c}\text { Gramáticas } \\
\text { completas }\end{array}$ & $\begin{array}{c}\text { Obras de } \\
\text { temas } \\
\text { gramaticais } \\
\text { específicos }\end{array}$ \\
\hline $\begin{array}{l}\text { TORRES, } \\
\text { Arthur de } \\
\text { Almeida } \\
\text { (1911 - ?) }\end{array}$ & $\begin{array}{l}\text { - } \\
\text { Compêndio } \\
\text { de Língua } \\
\text { Portuguesa } \\
\text { : gramática } \\
\text { (para o } \\
\text { Curso } \\
\text { Ginasial) } \\
\text { (1943) } \beta\end{array}$ & $\begin{array}{l}\text { - Pontos de } \\
\text { Português } \\
\text { para } \\
\text { concurso: } \\
\text { D.A.S.P } \\
(1945)^{186} \Omega\end{array}$ & $\begin{array}{l}\text { - Compêndio de } \\
\text { Língua } \\
\text { Portuguesa: } 1^{\mathrm{a}} \\
\text { série ginasial } \\
\text { (1938) } \Omega \\
\text { - Compêndio de } \\
\text { Língua } \\
\text { Portuguesa: } 2^{\mathrm{a}} \\
\text { série ginasial } \\
\text { (1939_2 }{ }^{\mathrm{a} e d .)} \boldsymbol{\Omega} \\
\\
\text { - Compêndio de } \\
\text { Língua } \\
\text { Portuguesa: } 3^{\mathrm{a}} \\
\text { série ginasial } \\
\text { (1938) } \boldsymbol{\beta} \\
\text { - Manual de } \\
\text { Língua } \\
\text { Portuguêsa: } \\
\text { para a primeira } \\
\text { série dos cursos } \\
\text { clássico e } \\
\text { científico } \\
\text { (1945_2aed.) } \Omega \\
\text { - Manual de } \\
\text { Língua } \\
\text { Portuguêsa: }\end{array}$ & & $\begin{array}{l}\text { - Regência } \\
\text { verbal } \\
(1931)^{187} \\
\text { - Estudos de } \\
\text { Português: } \\
\text { colocação de } \\
\text { pronomes, } \\
\text { crase, } \\
\text { pontuação, } \\
\text { concordância, } \\
\text { regência, etc } \\
\text { (1938) } \boldsymbol{\beta} \\
\\
\text { - Questões } \\
\text { filológicas } \\
\text { (1943) } \boldsymbol{\beta}\end{array}$ \\
\hline
\end{tabular}

\footnotetext{
${ }^{186}$ A referência a esta obra consta em outra do autor, de 1945, presente em nosso acervo. Não é possível afirmar que essa é a data da $1^{a}$ edição, mas apenas que, em 1945, ela já havia sido publicada.

${ }^{187}$ Trata-se de um dicionário de regência verbal. No início do livro, em parecer, Laudelino Freire compara esta obra ao Dicionário de construccion y regimen, de Cuervo. Freire assevera que Torres pode ser considerado o "Cuervo brasileiro", por este e outros trabalhos sobre o assunto.

${ }^{188}$ Esta obra é a reunião de polêmicas que o autor travou, em colunas de jornal, com Sousa da Silveira, Serafim da Silva Neto, José de Sá Nunes, Melchíades Picanço e Modesto de Abreu, além de alguns artigos independentes. Nas polêmicas, o autor reproduziu a sequência de textos seus e também dos seus oponentes. Tendo essa natureza diversa, apenas metade do livro (duas polêmicas) referem-se a questões de gramática histórica. A outra metade refere-se a questões normativas, gramaticais. Dessa forma, julgamos conveniente incluir essa obra tanto nas obras da tradição gramatical quanto na filológica.
} 


\begin{tabular}{|c|c|c|c|c|c|}
\hline \multirow[b]{2}{*}{ Obras ${ }^{93}$} & \multicolumn{3}{|c|}{ Escolares } & \multicolumn{2}{|c|}{ De referência } \\
\hline & $\begin{array}{l}\text { Gramáticas } \\
\text { completas }\end{array}$ & $\begin{array}{c}\begin{array}{c}\text { Obras de } \\
\text { temas } \\
\text { gramaticais } \\
\text { específicos }\end{array} \\
\end{array}$ & $\begin{array}{c}\text { Livros } \\
\text { didáticos de } \\
\text { Português }\end{array}$ & $\begin{array}{l}\text { Gramáticas } \\
\text { completas }\end{array}$ & 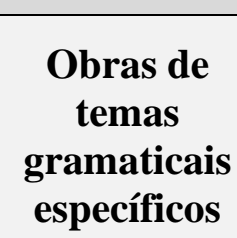 \\
\hline & & & $\begin{array}{l}\text { para a segunda } \\
\text { série dos cursos } \\
\text { clássico e } \\
\text { científico } \\
\text { (1945_2ed.) } \beta\end{array}$ & & \\
\hline \multicolumn{6}{|c|}{ V } \\
\hline $\begin{array}{l}\text { VEIGA, } \\
\text { Maria } \\
\text { Doralice } \\
\text { Marcondes } \\
(?-?)\end{array}$ & & $\begin{array}{l}\text { - Admissão } \\
\text { comercial }^{189} \\
(1939) \boldsymbol{\Omega}\end{array}$ & & & \\
\hline $\begin{array}{l}\text { VERGARA } \\
\text {, Oswaldo } \\
\text { (1883-1973) }\end{array}$ & & & & & $\begin{array}{l}\text { - Problemas } \\
\text { de Português } \\
\text { (1918) } \boldsymbol{\Omega} \\
\text { - Questões } \\
\text { vernáculas: } \\
\text { primeira série } \\
\text { (1913) } \boldsymbol{\Omega}\end{array}$ \\
\hline $\begin{array}{l}\text { VIANA, } \\
\text { Breno } \\
(?-?)\end{array}$ & & & $\begin{array}{l}\text { - Trechos } \\
\text { escolhidos: com } \\
130 \text { exercicios } \\
\text { de linguagem } \\
\text { oral e escripta e } \\
\text { um appendice de } \\
181 \\
\text { proverbios } \\
\text { (1934) } \\
\text { - Trechos } \\
\text { escolhidos: } 2^{\text {a }} \\
\end{array}$ & & \\
\hline
\end{tabular}

189 "Português, Francês, Matemática - Aritmética, Geografia".

190 "Em harmonia com a nova regulamentação do ensino commercial no Brasil". 


\begin{tabular}{|c|c|c|c|c|c|}
\hline \multirow[b]{2}{*}{ Obras ${ }^{93}$} & \multicolumn{3}{|c|}{ Escolares } & \multicolumn{2}{|c|}{ De referência } \\
\hline & $\begin{array}{l}\text { Gramáticas } \\
\text { completas }\end{array}$ & $\begin{array}{c}\text { Obras de } \\
\text { temas } \\
\text { gramaticais } \\
\text { específicos }\end{array}$ & $\begin{array}{c}\text { Livros } \\
\text { didáticos de } \\
\text { Português }\end{array}$ & $\begin{array}{l}\text { Gramáticas } \\
\text { completas }\end{array}$ & $\begin{array}{l}\text { Obras de } \\
\text { temas } \\
\text { gramaticais } \\
\text { específicos }\end{array}$ \\
\hline & & & $\begin{array}{l}\text { série com } 113 \\
\text { exercicios de } \\
\text { linguagem oral e } \\
\text { escrita: para os } \\
\text { cursos } \\
\text { propedêutico do } \\
\text { comércio e } \\
\text { secundário } \\
\text { (1937) }\end{array}$ & & \\
\hline $\begin{array}{c}\text { VIANA, } \\
\text { Hermógene } \\
\text { s } \\
(?-?)\end{array}$ & $\begin{array}{l}\text { - } \\
\text { Gramática } \\
\text { primária } \\
\text { da Língua } \\
\text { Portuguêsa } \\
\text { (1940) } \Omega\end{array}$ & & & & \\
\hline $\begin{array}{l}\text { VIEIRA, } \\
\text { Verissimo } \\
(1855-?)\end{array}$ & 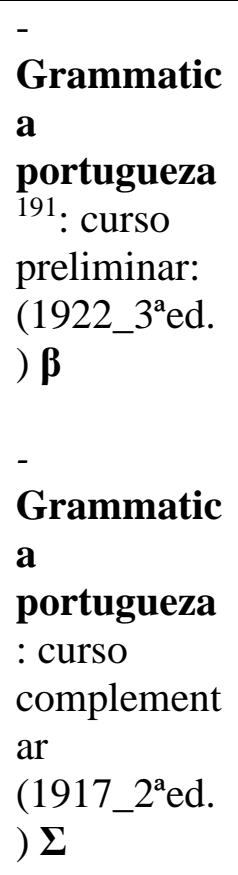 & & & & \\
\hline
\end{tabular}

${ }^{191}$ As informações sobre as gramáticas de Verissimo Vieira são um pouco confusas. No entanto, nos parece que temos três gramáticas para a "instrucção primaria", divididas em três cursos: elementar, preliminar e complementar. Quanto ao primeiro, ele não consta em nosso levantamento, pois sua $1^{\mathrm{a}}$ edição é de 1898. 


\begin{tabular}{|c|c|c|c|c|c|}
\hline & \multicolumn{3}{|c|}{ Escolares } & \multicolumn{2}{|c|}{ De referência } \\
\hline $\begin{array}{l}\text { Obras }^{93} \\
\text { Autores }\end{array}$ & $\begin{array}{c}\text { Gramáticas } \\
\text { completas }\end{array}$ & $\begin{array}{c}\text { Obras de } \\
\text { temas } \\
\text { gramaticais } \\
\text { específicos }\end{array}$ & $\begin{array}{c}\text { Livros } \\
\text { didáticos de } \\
\text { Português }\end{array}$ & $\begin{array}{c}\text { Gramáticas } \\
\text { completas }\end{array}$ & $\begin{array}{c}\text { Obras de } \\
\text { temas } \\
\text { gramaticais } \\
\text { específicos }\end{array}$ \\
\hline \multicolumn{6}{|c|}{$\mathbf{Z}$} \\
\hline $\begin{array}{l}\text { ZILLER, } \\
\text { Trentino } \\
(1878-?)\end{array}$ & & & & & $\begin{array}{l}\text { - Pequenos } \\
\text { reparos } \\
\text { philologicos } \\
\text { (1923) } \boldsymbol{\beta}\end{array}$ \\
\hline
\end{tabular}

Obras em que não é possível identificar a autoria (obras coletivas ou assinadas apenas por iniciais)

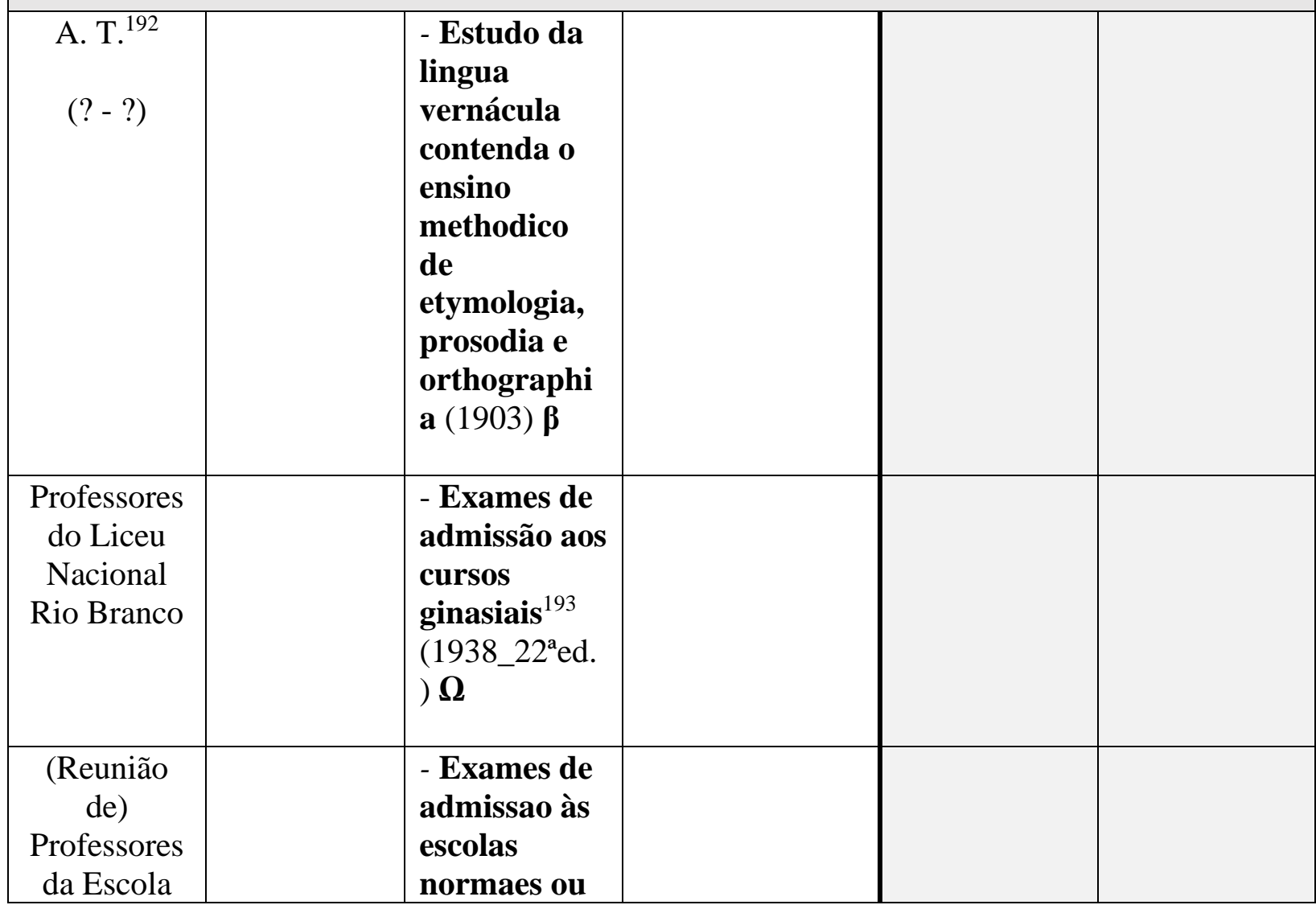

192 O autor assina A.T., marcando, assim, o caráter anônimo de sua obra.

193 "Pontos de Português, Aritmética, Geografia, História do Brasil, Morfologia, Geometria e Ciências Físicas e Naturais, de acordo com o programa oficial, publicada no Diário Oficial de 29/10/1931”. 


\begin{tabular}{|c|c|c|c|c|c|}
\hline \multirow[b]{2}{*}{$\begin{array}{l}\text { Obras }^{33} \\
\text { Autores }\end{array}$} & \multicolumn{3}{|c|}{ Escolares } & \multicolumn{2}{|c|}{ De referência } \\
\hline & $\begin{array}{c}\text { Gramáticas } \\
\text { completas }\end{array}$ & $\begin{array}{l}\text { Obras de } \\
\text { temas } \\
\text { gramaticais } \\
\text { específicos }\end{array}$ & $\begin{array}{c}\text { Livros } \\
\text { didáticos de } \\
\text { Português }\end{array}$ & $\begin{array}{c}\text { Gramáticas } \\
\text { completas }\end{array}$ & $\begin{array}{c}\text { Obras de } \\
\text { temas } \\
\text { gramaticais } \\
\text { específicos }\end{array}$ \\
\hline $\begin{array}{l}\text { Normal e da } \\
\text { Escola } \\
\text { Complemen } \\
\text { tar }\end{array}$ & & $\begin{array}{l}\text { cursos das } \\
\text { escolas } \\
\text { complement } \\
\text { ares }(1930) \\
\Omega\end{array}$ & & & \\
\hline $\begin{array}{l}\text { São Paulo } \\
\text { (Estado) } \\
\text { Força } \\
\text { Pública }\end{array}$ & & $\begin{array}{l}\text { Programmas } \\
\text { para exame } \\
\text { de admissão } \\
\text { e vestibular: } \\
\text { aos cursos do } \\
\text { centro de } \\
\text { instrução } \\
\text { militar } \\
\left(1937 \_2^{\text {aa }} \text {.) }\right. \\
\mathbf{\Omega}\end{array}$ & & & \\
\hline $\begin{array}{c}\text { Um amigo } \\
\text { da } \\
\text { instrucção }\end{array}$ & & $\begin{array}{l}\text { - Exercícios } \\
\text { de } \\
\text { grammatica: } \\
\text { analyse } \\
\text { lexicologica e } \\
\text { syntactica e } \\
\text { redacção: } 1^{\text {a }} \\
\text { parte: curso } \\
\text { primário: } \\
\text { livro do } \\
\text { discipulo } \\
\text { (s/d) }{ }^{194} \mathbf{\Omega} \\
\\
\text { - Exercícios } \\
\text { de } \\
\text { grammatica: } \\
\text { analyse } \\
\text { lexicologica e } \\
\text { syntactica e } \\
\text { redacção: } 2^{\text {a }}\end{array}$ & & & \\
\hline
\end{tabular}

194 “Nova edição correta e aumentada: passada para a nova ortografia pelo Prof. Dr. Mario Barreto". 


\begin{tabular}{|c|c|c|c|c|c|}
\hline \multirow[b]{2}{*}{ Obras ${ }^{93}$} & \multicolumn{3}{|c|}{ Escolares } & \multicolumn{2}{|c|}{ De referência } \\
\hline & $\begin{array}{c}\text { Gramáticas } \\
\text { completas }\end{array}$ & $\begin{array}{c}\text { Obras de } \\
\text { temas } \\
\text { gramaticais } \\
\text { específicos }\end{array}$ & $\begin{array}{c}\text { Livros } \\
\text { didáticos de } \\
\text { Português }\end{array}$ & $\begin{array}{c}\text { Gramáticas } \\
\text { completas }\end{array}$ & $\begin{array}{c}\text { Obras de } \\
\text { temas } \\
\text { gramaticais } \\
\text { específicos }\end{array}$ \\
\hline & & $\begin{array}{l}\text { parte: curso } \\
\text { secundário: } \\
\text { livro do } \\
\text { discipulo } \\
(1906)^{195} \boldsymbol{\beta} \\
\text { - Exercícios } \\
\text { de } \\
\text { grammatica: } \\
\text { analyse } \\
\text { lexicologica e } \\
\text { syntactica e } \\
\text { redacção: } 2^{\text {a }} \\
\text { parte: curso } \\
\text { secundário: } \\
\text { livro do } \\
\text { professor } \\
\text { (1906) }^{196} \boldsymbol{\Omega}\end{array}$ & & & \\
\hline $\begin{array}{c}\text { Total } \\
\text { parcial de } \\
\text { obras }\end{array}$ & 51 & 101 & 87 & 4 & 157 \\
\hline $\begin{array}{l}\text { TOTAL de } \\
\text { OBRAS }\end{array}$ & & & 400 obras & & \\
\hline $\begin{array}{l}\text { TOTAL de } \\
\text { AUTORES }\end{array}$ & & 170 autore & e 3 obras de & ia coletiva & \\
\hline
\end{tabular}

${ }^{195} \mathrm{Na}$ capa, encontramos a informação que se trata de "nova edição augmentada", porém ela não indica o número da edição.

196 A mesma informação da nota anterior.

${ }^{197}$ Para evitar distorções na relação livros/autores, as obras escritas em coautoria foram contabilizadas como escritas por apenas 1 autor. 
QUADRO 2A - Produção linguística brasileira (1900-1940): programa de investigação filológico

\begin{tabular}{|c|c|c|c|}
\hline Autores & $\begin{array}{l}\text { Gramáticas } \\
\text { históricas }\end{array}$ & $\begin{array}{l}\text { Obras de temas } \\
\text { filológicos específicos }\end{array}$ & $\begin{array}{l}\text { Tratamento } \\
\text { (edição) de texto }\end{array}$ \\
\hline $\begin{array}{c}\text { ABREU, } \\
\text { Modesto de } \\
(1901-1996)\end{array}$ & $\begin{array}{l}\text { Coleção antiga }{ }^{199} \text { : } \\
\text { - Idioma pátrio: } \\
\text { seleta, gramática, } \\
\text { exercícios: } 4^{\mathrm{a}} \text { série } \\
\text { (1940) } \Omega \\
\text { Coleção nova: } \\
\text { - Idioma pátrio: } \\
\text { volume } 3^{200} \text { : } \\
\text { gramática expositiva } \\
\text { e histórica; noções } \\
\text { de estilística e } \\
\text { literatura (1944) } \boldsymbol{\beta}\end{array}$ & & \\
\hline
\end{tabular}

${ }^{198}$ Legenda:

$\boldsymbol{\beta}$ : Obra pertencente ao acervo pessoal do pesquisador.

$\Sigma$ : Obra consultada em bibliotecas.

$\boldsymbol{\Omega}$ : Indica que a referência a esta obra foi localizada em um outro livro, nas páginas normalmente denominadas "Outras obras da editora" ou "Demais publicações do autor". Tais páginas estão localizadas ou na quarta capa ou nas páginas iniciais do livro. Isso significa, obviamente, que não tivemos acesso físico à obra e que as informações editoriais foram obtidas nesse contexto mais limitado. Esse símbolo indica também obras localizadas em listas em que constam apenas o título e o autor, como foi o caso, por exemplo, dos livros encontrados no Diário Oficial da União, em uma publicação da "Comissão Nacional do Livro Didático", de 1947. Também indica obras localizadas on-line, nos catálogos de bibliotecas.

T: Teses.

199 A coleção Idioma pátrio tem duas apresentações: uma relativa ao "antigo programa", composta de 5 volumes, e outra do "novo programa", formada por 3 volumes. Há, obviamente, algumas diferenças que aqui explicitaremos: a coleção de 5 volumes segue a estruturação clássica para os livros didáticos de Português da época, presente em quase todas as coleções didáticas que aqui relacionamos. Dos volumes 1 a 4 , conteúdo gramatical, de leitura e de redação e $5^{\circ}$ volume destinado aos estudos da história da Literatura e da estilística, fato, aliás, que nos fez não incluir esses volumes no presente levantamento. Na coleção nova, de 3 volumes, o autor fez a seguinte estruturação: volume 1 , para as $1^{\mathrm{a}}$ e $2^{\mathrm{a}}$ séries do Secundário, seleta literária destinada à leitura e interpretação, volume 2 , o mesmo conteúdo, só que para as $3^{\text {a }}$ e $4^{\text {a }}$ séries e o volume 3 , destinado a todos os anos do Secundário, é uma gramática expositiva e histórica, além de conter também "noções de estilística e literatura", conteúdo esse que, na coleção antiga, era apresentado no volume 5 .

${ }^{200}$ Como explicado na nota anterior, os volumes 1 e 2 são seletas literárias, fato que motivou a não inclusão dessas obras no levantamento. 


\section{Textos inseridos na tradição FILOLÓGICA}

\begin{tabular}{|c|c|c|c|}
\hline Obras ${ }^{198}$ & $\begin{array}{l}\text { Gramáticas } \\
\text { históricas }\end{array}$ & $\begin{array}{l}\text { Obras de temas } \\
\text { filológicos específicos }\end{array}$ & $\begin{array}{c}\text { Tratamento } \\
\text { (edição) de texto }\end{array}$ \\
\hline $\begin{array}{l}\text { ALBUQUERQ } \\
\text { UE, Acir }{ }^{201} \\
\text { Tenorio de } \\
\\
(1899-1973)\end{array}$ & $\begin{array}{l}\text { - Curso de } \\
\text { Português para } \\
\text { ginásios: quarta } \\
\text { serie: gramática, } \\
\text { antologia, exercícios } \\
\text { (1946) } \Omega\end{array}$ & $\begin{array}{l}\text { - Evolução das } \\
\text { palavras: a } \\
\text { transformacao } \\
\text { morfologica e semantica } \\
\text { dos vocabulos } \\
\text { portugueses (1940) } \boldsymbol{\beta}\end{array}$ & \\
\hline $\begin{array}{c}\text { ALI, Said } \\
(1861-1953)\end{array}$ & & $\begin{array}{l}\text { - Dificuldades da } \\
\text { Lingua Portugueza } \\
\text { (1908) } \boldsymbol{\beta} \\
\text { - Lexeologia do } \\
\text { Portuguez historico } \\
\text { (1921) } \boldsymbol{\beta} \\
\text { - Formação de palavras } \\
\text { e syntaxe do Portuguez } \\
\text { historico (1923) } \\
\\
\text { - Meios } \boldsymbol{\beta} \\
\text { alterações semânticas } \\
\text { (1927) } \boldsymbol{\beta}\end{array}$ & \\
\hline $\begin{array}{l}\text { AMARAL, } \\
\text { Afrânio do } \\
(1894-?)\end{array}$ & & $\begin{array}{l}\text { - Biologia e linguística } \\
\text { (1945) } \Sigma\end{array}$ & \\
\hline $\begin{array}{l}\text { AYROSA, } \\
\text { Plinio } \\
(1895-1961)\end{array}$ & & $\begin{array}{l}\text { - Têrmos Tupís no } \\
\text { Português do Brasil } \\
\text { (1937) } \beta\end{array}$ & \\
\hline $\begin{array}{c}\text { BASILE, Ragy } \\
(?-?)\end{array}$ & & $\begin{array}{l}\text { - Dicionario etimologico } \\
\text { dos vocábulos } \\
\text { portugueses derivados } \\
\text { do Arabe (194-) (8 vols.) } \\
\mathbf{\Omega}\end{array}$ & \\
\hline $\begin{array}{l}\text { BERGO, } \\
\text { Vittorio }\end{array}$ & & $\begin{array}{l}\text { - Da gradacao } \\
\text { dimensiva e intensiva }\end{array}$ & \\
\hline
\end{tabular}

201 Há registros também de seu primeiro nome grafado como Arcy.

${ }^{202}$ As obras Lexeologia do português histórico (1921) e Formação de palavras e sintaxe do Português histórico (1923), quando de suas segundas edições (1931), passaram a ser publicadas com o nome de Grammatica historica da Lingua Portugueza. Para que não haja duplicidade de registro, não incluiremos 


\section{Textos inseridos na tradição FILOLÓGICA}

\begin{tabular}{|c|c|c|c|}
\hline Abras ${ }^{198}$ & $\begin{array}{l}\text { Gramáticas } \\
\text { históricas }\end{array}$ & $\begin{array}{l}\text { Obras de temas } \\
\text { filológicos específicos }\end{array}$ & $\begin{array}{c}\text { Tratamento } \\
\text { (edição) de texto }\end{array}$ \\
\hline$(1902-?)$ & & $\begin{array}{l}\text { (these a concurso) }(\mathrm{T})^{203} \\
(1935) \boldsymbol{\beta}\end{array}$ & \\
\hline $\begin{array}{c}\text { BRUNO, Aníbal } \\
\text { (1890-1976) }\end{array}$ & $\begin{array}{l}\text { - Língua } \\
\text { Portuguesa: para a } \\
4^{\mathrm{a}} \text { série ginasial } \\
\text { (1940) } \boldsymbol{\beta}\end{array}$ & & \\
\hline $\begin{array}{c}\text { BUENO, } \\
\text { Silveira } \\
(1898-1989)\end{array}$ & $\begin{array}{l}\text { - Páginas floridas: } \\
\text { gramática histórica, } \\
\text { comentários } \\
\text { etimológicos, textos } \\
\text { arcaicos e modernos: } \\
4^{\mathrm{a}} \text { série: curso } \\
\text { fundamental (1938) } \\
\boldsymbol{\beta}\end{array}$ & $\begin{array}{l}\text { - Estudos de filologia } \\
\text { portuguêsa (1946) } \boldsymbol{\beta}\end{array}$ & $\begin{array}{l}\text { - O auto das } \\
\text { regateiras de } \\
\text { Lisboa: composto } \\
\text { por hum frade loyo, } \\
\text { filho de hua dellas } \\
(1939)^{204}(\mathrm{~T}) \boldsymbol{\beta}\end{array}$ \\
\hline $\begin{array}{l}\text { CÂMARA JR., } \\
\text { Joaquim } \\
\text { Mattoso } \\
\\
\text { (1904-1970) }\end{array}$ & $\begin{array}{l}\text { - Elementos de } \\
\text { língua pátria: } \\
\text { volume } 4\left(1938 \_2^{\mathrm{a}}\right. \\
\text { ed. }{ }^{205} \boldsymbol{\Omega}\end{array}$ & & \\
\hline $\begin{array}{l}\text { CAMPOS, } \\
\text { J. L. de }{ }^{206} \\
(1900-1945)\end{array}$ & & $\begin{array}{l}\text { - O problema do } \\
\text { infinitivo (1924) } \beta \\
\\
\text { - Divisão de vocabulos: } \\
\text { estudo completo para a } \\
\text { partilha, facil e } \\
\text { scientifica, de palavras } \\
\text { no fim da linha, com } \\
\text { regras grammaticaes, } \\
\text { philologicamente } \\
\text { justificadas e seguidas de } \\
\text { exuberante } \\
\text { exemplificação, } \\
\text { contendo, em }\end{array}$ & \\
\hline
\end{tabular}

${ }^{203}$ Originalmente apresentada como tese ao concurso para provimento da cadeira de Português do Gymnasio Mineiro.

204 "Reprodução do texto publicado em 1919 por Francisco Maria Estêves Pereira segundo o manuscrito n. 8.581 da Biblioteca Nacional de Lisboa": p. [97]-117".

${ }^{205}$ Quando não conseguimos acesso à data da $1^{\mathrm{a}}$ edição, registramos a data/edição mais antiga a que tivermos acesso.

${ }^{206}$ O nome completo do autor é João Luis de Campos. 


\begin{tabular}{|c|c|c|c|}
\hline \multicolumn{4}{|c|}{ 2. Textos inseridos na tradição FILOLÓGICA } \\
\hline Pbras $^{198}$ & $\begin{array}{l}\text { Gramáticas } \\
\text { históricas }\end{array}$ & $\begin{array}{l}\text { Obras de temas } \\
\text { filológicos específicos }\end{array}$ & $\begin{array}{c}\text { Tratamento } \\
\text { (edição) de texto }\end{array}$ \\
\hline & & $\begin{array}{l}\text { complemento, selecto: } \\
\text { diccionario de scisões } \\
(\mathrm{s} / \mathrm{d})^{207} \boldsymbol{\beta}\end{array}$ & \\
\hline $\begin{array}{c}\text { CARVALHO, } \\
\text { Alfredo Ferreira } \\
\text { de } \\
(1870-1916)\end{array}$ & & $\begin{array}{l}\text { - Phrases e palavras: } \\
\text { problemas historico- } \\
\text { etymologicos. (1. Serie) } \\
(1906) \Sigma \\
\text { - O Tupi na chorografia } \\
\text { pernambucana: } \\
\text { elucidario etymologico } \\
\text { (1907) } \boldsymbol{\beta}\end{array}$ & \\
\hline $\begin{array}{l}\text { CHINA, José B. } \\
\text { D’Oliveira } \\
(?-?)\end{array}$ & & $\begin{array}{l}\text { - Estudos de filologia e } \\
\text { linguistica (1924) } \boldsymbol{\beta}\end{array}$ & \\
\hline $\begin{array}{l}\text { COQUEIRO, } \\
\text { Mota } \\
(?-?)\end{array}$ & & $\begin{array}{l}\text { - Monografia da } \\
\text { palavra "Araraquara": } \\
\text { estudo histórico- } \\
\text { lingüístico do nome da } \\
\text { cidade de Araraquara } \\
\text { (1936) } \Sigma\end{array}$ & \\
\hline $\begin{array}{l}\text { COUTINHO, } \\
\text { Ismael de Lima } \\
\\
(1900-1965)\end{array}$ & $\begin{array}{l}\text { - Pontos de } \\
\text { gramática histórica } \\
\text { (1938) } \boldsymbol{\beta}\end{array}$ & $\begin{array}{l}\text { - As criações internas } \\
\text { do idioma }(1928)(\mathrm{T})^{208} \\
\boldsymbol{\beta}\end{array}$ & \\
\hline $\begin{array}{l}\text { CRETELLA, } \\
\text { JÚNIOR, José } \\
(1920-2015)\end{array}$ & $\begin{array}{l}\text { - Português para o } \\
\text { ginásio: } 4^{\mathrm{a}} \text { série } \\
(1945) \boldsymbol{\Omega}\end{array}$ & & \\
\hline $\begin{array}{l}\text { CRUZ, Estêvão } \\
\text { (1902-1937) }\end{array}$ & $\begin{array}{l}\text { - Programa de } \\
\text { vernáculo: } \\
\text { gramática e } \\
\text { antologia: contém } \\
\text { toda a matéria }\end{array}$ & & \\
\hline
\end{tabular}

${ }^{207}$ A obra não apresenta ano de edição, mas consta na relação de "edições da casa" de um outro livro de 1934.
208 "These sorteada para o concurso á $1^{\text {a }}$ Cadeira de Português do Lyceu de Humanidades de Campos". 


\begin{tabular}{|c|c|c|c|}
\hline Abras ${ }^{198}$ & $\begin{array}{l}\text { Gramáticas } \\
\text { históricas }\end{array}$ & $\begin{array}{l}\text { Obras de temas } \\
\text { filológicos específicos }\end{array}$ & $\begin{array}{c}\text { Tratamento } \\
\text { (edição) de texto }\end{array}$ \\
\hline & $\begin{array}{l}\text { exigida para o estudo } \\
\text { da } 3^{\text {a }} \text { série (1936) } \Omega\end{array}$ & & \\
\hline $\begin{array}{l}\text { CRUZ, José } \\
\text { Marques da } \\
(1888-1958)\end{array}$ & $\begin{array}{l}\text { - Português prático: } \\
\text { para a } 4^{\mathrm{a}} \text { série } \\
\text { ginasial }\left(1922 \_2^{\mathrm{a}} \mathrm{ed}\right) \\
\mathbf{\Omega}\end{array}$ & & \\
\hline $\begin{array}{l}\text { CUNHA, Celso } \\
\text { Ferreira da } \\
(1917-1989)\end{array}$ & & & $\begin{array}{l}\text { - O cancioneiro de } \\
\text { Paay Gómez } \\
\text { Charinho, trovador } \\
\text { do século XIII: } \\
\text { Aspectos literários; } \\
\text { Texto crítico (1945) } \\
\mathbf{\Omega}\end{array}$ \\
\hline $\begin{array}{l}\text { GALVÃO, } \\
\text { Ramiz } \\
\text { (1846-1938) }\end{array}$ & & $\begin{array}{l}\text { - Vocabulario } \\
\text { etymologico, } \\
\text { orthographico e } \\
\text { prosodico das palavras } \\
\text { portuguezas derivadas } \\
\text { da Lingua Grega (1909) } \\
\boldsymbol{\beta}\end{array}$ & \\
\hline $\begin{array}{l}\text { GARCIA, } \\
\text { Rodopho } \\
(1873-1949)\end{array}$ & & $\begin{array}{l}\text { - Nomes de aves em } \\
\text { lingua Tupi: } \\
\text { contribuição para a } \\
\text { lexicografia portuguêsa } \\
\text { (1911) } \beta\end{array}$ & \\
\hline $\begin{array}{c}\text { GEENEN, } \\
\text { Henrique } \\
(?-?)\end{array}$ & $\begin{array}{l}\text { - Questões de } \\
\text { grammatica } \\
\text { historica latino- } \\
\text { portugueza (1911) } \\
\mathbf{\Omega}\end{array}$ & $\begin{array}{l}\text { - Palestras philologicas: } \\
1^{\text {a }} \text { serie }(1931) \boldsymbol{\beta}\end{array}$ & \\
\hline $\begin{array}{c}\text { GÓES, Carlos }^{209} \\
\text { (1881-1934) }\end{array}$ & & $\begin{array}{l}\text { - Diccionario de affixos, } \\
\text { desinencias e outros } \\
\text { elementos de } \\
\text { composição (1913) } \boldsymbol{\beta}\end{array}$ & \\
\hline
\end{tabular}

${ }^{209}$ Em algumas obras o autor assina Carlos Góis. 


\begin{tabular}{|c|c|c|c|}
\hline Abras ${ }^{198}$ & $\begin{array}{l}\text { Gramáticas } \\
\text { históricas }\end{array}$ & $\begin{array}{l}\text { Obras de temas } \\
\text { filológicos específicos }\end{array}$ & $\begin{array}{c}\text { Tratamento } \\
\text { (edição) de texto }\end{array}$ \\
\hline & & $\begin{array}{l}\text { - Diccionario de raizes e } \\
\text { cognatos da Lingua } \\
\text { Portugueza (1921) } \beta\end{array}$ & \\
\hline $\begin{array}{c}\text { GOMES, Arthur } \\
(?-?)\end{array}$ & & $\begin{array}{l}\text { - Estudo da maior parte } \\
\text { dos verbos da lingua } \\
\text { moderna por meio de } \\
\text { sua formação e } \\
\text { composição baseado } \\
\text { sobre o Latim (1901) } \Sigma\end{array}$ & \\
\hline $\begin{array}{l}\text { GONÇALVES, } \\
\text { Maximiano } \\
\text { Augusto } \\
\\
(1912-?)\end{array}$ & $\begin{array}{l}- \text { Pontos de } \\
\text { grammatica } \\
\text { histórica (1932) } \mathbf{\Omega}\end{array}$ & & \\
\hline $\begin{array}{c}\text { GUÉRIOS, } \\
\text { Rosário Mansur } \\
(1907-1987)\end{array}$ & $\begin{array}{l}\text { - Pontos de } \\
\text { gramática histórica } \\
\text { portuguesa: } 4^{\mathrm{a}} \text { série: } \\
\text { de acordo com o } \\
\text { programa oficial } \\
\text { (1937) } \boldsymbol{\beta} \\
\text { - Português } \\
\text { ginasial: gramática e } \\
\text { exercícios para a } 1^{\mathrm{a}} \text {, } \\
2^{\mathrm{a}}, 3^{\mathrm{a}} \text { e } 4^{\mathrm{a}} \text { séries } \\
(1944)^{210} \boldsymbol{\beta}\end{array}$ & & \\
\hline $\begin{array}{l}\text { HENRIQUE, } \\
\text { João }^{211} \\
\text { (1884-1952) }\end{array}$ & & $\begin{array}{l}\text { - Filologia jurídica } \\
\text { (1934) } \boldsymbol{\beta} \\
\text { - Acentuação gráfica } \\
\text { (1943) } \boldsymbol{\beta}\end{array}$ & \\
\hline
\end{tabular}

\footnotetext{
${ }^{210} \mathrm{O}$ presente volume é formado por uma gramática tradicional e uma gramática histórica. Em função dessa característica "dois em um", a incluímos tanto aqui como no levantamento das obras do programa gramatical, no grupo das "gramáticas completas" (cf. Tabela 1A - Apêndice A).

${ }^{211} \mathrm{O}$ autor assinava suas obras apenas com estes dois nomes. Seu nome completo, porém, é João Henrique dos Santos.
} 


\section{Textos inseridos na tradição FILOLÓGICA}

\begin{tabular}{|c|c|c|c|}
\hline Abras ${ }^{198}$ & $\begin{array}{l}\text { Gramáticas } \\
\text { históricas }\end{array}$ & $\begin{array}{l}\text { Obras de temas } \\
\text { filológicos específicos }\end{array}$ & $\begin{array}{c}\text { Tratamento } \\
\text { (edição) de texto }\end{array}$ \\
\hline & & $\begin{array}{l}\text { - Origem e significação } \\
\text { dos nomes de pessoas: } \\
\text { estudo antroponimico } \\
\text { (s/d) }[1932]^{212} \boldsymbol{\beta}\end{array}$ & \\
\hline $\begin{array}{c}\text { HORTA, } \\
\text { Brant }^{213} \\
(1876-1959)\end{array}$ & $\begin{array}{l}\text { - Noções de } \\
\text { gramática histórica } \\
\text { da língua } \\
\text { nacional }{ }^{214}([\text { entre } \\
1928 \text { e } 1934])^{215} \boldsymbol{\beta}\end{array}$ & & \\
\hline $\begin{array}{l}\text { JUCÁ (filho), } \\
\text { Cândido } \\
(1900-1982)\end{array}$ & $\begin{array}{l}\text { - Gramática } \\
\text { histórica do } \\
\text { Português } \\
\text { contemporâneo } \\
\text { (1945) } \beta\end{array}$ & & \\
\hline $\begin{array}{c}\text { LOBO, Vaz } \\
(?-?)\end{array}$ & $\begin{array}{l}\text { - Grammatica } \\
\text { historica: } \\
\text { programma de } \\
\text { Portuguez da } 4^{\mathrm{a}} \text { série } \\
\text { gymnasial }(1936) \boldsymbol{\beta}\end{array}$ & & \\
\hline $\begin{array}{l}\text { MAGNE, } \\
\text { Augusto }^{216} \\
(1887-1966)\end{array}$ & & & $\begin{array}{l}\text { - A demanda do } \\
\text { Santo Graal: } \\
\text { reprodução fac- } \\
\text { similar e transcrição } \\
\text { crítica do códice } \\
2594 \text { da Biblioteca } \\
\text { Nacional de Viena: }\end{array}$ \\
\hline
\end{tabular}

\footnotetext{
${ }^{212}$ A obra não apresenta data de publicação, mas o exemplar consultado apresenta uma dedicatória datada de 1932.

${ }^{213}$ Francisco Eugenio Brant Horta

${ }^{214}$ Este é o título estampado na capa dura (editorial) do livro, mas na folha de rosto aparece um título ligeiramente modificado: Noções de gramática histórica da Lingua Portugueza.

${ }^{215}$ Nesta obra, há um prefácio de João Ribeiro, local em que ele faz referência a outras duas gramáticas históricas brasileiras: a de Eduardo Carlos Pereira, que é de 1916, e a de Antenor Nascentes, que é de 1928. Como Ribeiro morreu em 1934, podemos afirmar que a publicação deve ter ocorrido entre 1928 e 1934 . O exemplar que possuímos tem a mesma apresentação gráfica que outra obra de Brant, a Gramática intuitiva da Língua Portuguesa, $4^{\mathrm{a}}$ edição, de 1938. Nosso exemplar da Gramática histórica é a $3^{a}$ edição, porém sem data.

${ }^{216}$ Augusto Magne nasceu na França, mas emigrou para o Brasil em 1907 e já no ano seguinte se naturalizou brasileiro, fato que nos fez incluí-lo em nosso levantamento.
} 


\begin{tabular}{|c|c|c|c|}
\hline Autores & $\begin{array}{l}\text { Gramáticas } \\
\text { históricas }\end{array}$ & $\begin{array}{l}\text { Obras de temas } \\
\text { filológicos específicos }\end{array}$ & $\begin{array}{c}\text { Tratamento } \\
\text { (edição) de texto }\end{array}$ \\
\hline & & & $\begin{array}{l}\text { volume } 1(1944)^{217} \\
\Sigma \\
\text { - A demanda do } \\
\text { Santo Graal: } \\
\text { reprodução fac- } \\
\text { similar e transcrição } \\
\text { crítica do códice } \\
2594 \text { da Biblioteca } \\
\text { Nacional de Viena: } \\
\text { volume } 2 \text { (1944) } \Sigma \\
\\
\text { - A demanda do } \\
\text { Santo Graal: } \\
\text { reprodução fac- } \\
\text { similar e transcrição } \\
\text { crítica do códice } \\
2594 \text { da Biblioteca } \\
\text { Nacional de Viena: } \\
\text { volume } 3 \text { (1944) } \Sigma\end{array}$ \\
\hline $\begin{array}{l}\text { MARTINS, } \\
\text { Jaime de Souza } \\
(?-?)\end{array}$ & $\begin{array}{l}\text { - Elementos de } \\
\text { gramática } \\
\text { histórica: para a } \\
\text { quarta série (1937) } \boldsymbol{\beta}\end{array}$ & & \\
\hline $\begin{array}{l}\text { MELO, Mário } \\
\text { (1824-1959) }\end{array}$ & & $\begin{array}{l}\text { - Toponymia } \\
\text { pernambucana (1931) } \boldsymbol{\beta}\end{array}$ & \\
\hline $\begin{array}{l}\text { MONTEIRO, } \\
\text { Clóvis } \\
(1898-1961)\end{array}$ & & $\begin{array}{l}\text { - Da tendência na } \\
\text { evolução de nosso } \\
\text { idioma }(1926)(T)^{218} \boldsymbol{\beta}\end{array}$ & \\
\hline $\begin{array}{l}\text { MOTTA, } \\
\text { Othoniel }\end{array}$ & $\begin{array}{l}\text { - O meu idioma } \\
\text { (1916) } \boldsymbol{\beta}\end{array}$ & $\begin{array}{l}\text { - Ensaio linguistico } \\
\text { (1905) } \boldsymbol{\beta}\end{array}$ & \\
\hline
\end{tabular}

217 "Edição completa, e como tal a primeira, do texto medieval português da Demanda do graal [códice 2594 da Biblioteca Nacional de Viena]"--v. 1, p. [7], [31]".

${ }^{218}$ Da tendência na evolução de nosso idioma (1926) e Da influência do Tupi no Português (1926) - apresentados inicialmente como teses - são reunidos e publicados como livro, em 1931, sob o título Português da Europa e Português da América: aspectos da evolução do nosso idioma. 


\begin{tabular}{|c|c|c|c|}
\hline Autores & $\begin{array}{l}\text { Gramáticas } \\
\text { históricas }\end{array}$ & $\begin{array}{l}\text { Obras de temas } \\
\text { filológicos específicos }\end{array}$ & $\begin{array}{c}\text { Tratamento } \\
\text { (edição) de texto }\end{array}$ \\
\hline$(1878-1951)$ & & $\begin{array}{l}\text { - Horas philologicas } \\
\text { (1937) } \boldsymbol{\beta}\end{array}$ & \\
\hline $\begin{array}{l}\text { MOURA, } \\
\text { Americo } \\
\text { Braziliense } \\
\text { Antunes de } \\
\\
(1881-1953)\end{array}$ & & $\begin{array}{l}\text { - A função subjectiva } \\
\text { do pronome SE (1906) } \\
(\mathrm{T})^{219} \boldsymbol{\beta}\end{array}$ & \\
\hline $\begin{array}{l}\text { NASCENTES, } \\
\text { Antenor } \\
(1886-1972)\end{array}$ & $\begin{array}{l}\text { - O idioma } \\
\text { nacional: volume } 4 \\
\text { (1928) } \boldsymbol{\beta}\end{array}$ & $\begin{array}{l}\text { - Dicionário etimológico } \\
\text { da Língua Portuguesa: } \\
\text { volume } 1 \text { (1932) } \boldsymbol{\beta}\end{array}$ & \\
\hline $\begin{array}{l}\text { NIMER, } \\
\text { Miguel } \\
\text { (1895 - ?) }\end{array}$ & & $\begin{array}{l}\text { - Influências orientais } \\
\text { na Língua Portuguesa: } \\
\text { os vocábulos árabes, } \\
\text { arabizados, persas e } \\
\text { turcos - tomo I / } \\
\text { etimologia aplicações } \\
\text { analíticas - primeira parte } \\
\text { (1943) } \boldsymbol{\beta} \\
\text { - Influências orientais } \\
\text { na Língua Portuguesa: } \\
\text { os vocábulos árabes, } \\
\text { arabizados, persas e } \\
\text { turcos - tomo I / } \\
\text { etimologia aplicações } \\
\text { analíticas - segunda parte } \\
\text { (1943) } \boldsymbol{\beta}\end{array}$ & \\
\hline $\begin{array}{l}\text { NOGUEIRA, } \\
\text { Julio } \\
(1873-?)\end{array}$ & $\begin{array}{l}\text { - O exame de } \\
\text { Portuguez: obra } \\
\text { indicada no } \\
\text { programma official } \\
\text { do Collegio Pedro II } \\
\text { (1918) } \boldsymbol{\beta}\end{array}$ & & \\
\hline
\end{tabular}

\footnotetext{
${ }^{219}$ No frontispício o autor não usa a palavra "these", mas sim "monographia". Ao final do trabalho, ele assevera: "Damos por demostrada nossa these". (p.64). Apesar da questão terminológica, o trabalho foi apresentado ao concurso "á cadeira de Portuguez do Gymnasio de Campinas".
} 


\section{Textos inseridos na tradição FILOLÓGICA}

\begin{tabular}{|c|c|c|c|}
\hline Qbras $^{198}$ & $\begin{array}{l}\text { Gramáticas } \\
\text { históricas }\end{array}$ & $\begin{array}{l}\text { Obras de temas } \\
\text { filológicos específicos }\end{array}$ & $\begin{array}{c}\text { Tratamento } \\
\text { (edição) de texto }\end{array}$ \\
\hline & $\begin{array}{l}\text { - Programa de } \\
\text { Português: 4a. série } \\
\text { secundária (1941) } \boldsymbol{\beta}\end{array}$ & & \\
\hline $\begin{array}{l}\text { NUNES, José de } \\
\text { Sá }^{220} \\
(1893-1955)\end{array}$ & $\begin{array}{l}\text { - Língua vernácula: } \\
\text { grammatica historica } \\
\text { e anthologia: } 4^{a} \text { série } \\
\text { (1938) } \Sigma\end{array}$ & & \\
\hline $\begin{array}{c}\text { OLIVEIRA, } \\
\text { Agenor Lopes } \\
\text { de } \\
(1896-1935)\end{array}$ & & $\begin{array}{l}\text { - Toponímia carioca } \\
\text { (1935) } \boldsymbol{\beta}\end{array}$ & \\
\hline $\begin{array}{c}\text { P.S } \\
\text { (Pedro } \\
\text { Schneider) } \\
(1866-1931)\end{array}$ & $\begin{array}{l}\text { - Syntaxe e } \\
\text { grammatica } \\
\text { histórica da Lingua } \\
\text { Portuguesa } \\
(1909)^{221} \boldsymbol{\beta}\end{array}$ & & \\
\hline $\begin{array}{l}\text { PEIXOTO, } \\
\text { Almir Câmara } \\
\text { Matos } \\
(?-?)\end{array}$ & & $\begin{array}{l}\text { - Novos rumos em } \\
\text { filologia (1942) } \boldsymbol{\beta}\end{array}$ & \\
\hline $\begin{array}{c}\text { PEREIRA, } \\
\text { Carlos de Britto } \\
(?-?)\end{array}$ & & $\begin{array}{l}\text { - Etymologia: } \\
\text { classificação de } \\
\text { etymologias (1928) (T) } \boldsymbol{\beta}\end{array}$ & \\
\hline $\begin{array}{l}\text { PEREIRA, } \\
\text { Eduardo Carlos } \\
\\
(1855-1923)\end{array}$ & $\begin{array}{l}\text { - Grammatica } \\
\text { historica }(1916) \boldsymbol{\beta}\end{array}$ & & \\
\hline $\begin{array}{c}\text { PINTO, P. A. }{ }^{222} \\
(1882-1971)\end{array}$ & & $\begin{array}{l}\text { - A margem dos } \\
\text { Lusiadas: alguns nomes } \\
\text { geograficos (1924) } \boldsymbol{\Sigma}\end{array}$ & \\
\hline
\end{tabular}

${ }^{220}$ Professor Catedrático de Português no Ginásio Paranaense, em Curitiba, Paraná. A partir de 1939, passa a ser professor de Filologia Portuguesa, na Faculdade de Filosofia, Ciências e Letras, da Universidade de São Paulo.

${ }^{221} \mathrm{O}$ presente volume é formado por uma gramática tradicional e uma gramática histórica. Em função dessa característica "dois em um", a incluímos tanto aqui como no levantamento das obras do programa gramatical, no grupo das "gramáticas completas" (cf. Tabela 1A - Apêndice A).

$222 \mathrm{O}$ autor assina suas obras desta forma, usando iniciais. Seu nome completo é Pedro Augusto Pinto. 


\begin{tabular}{|c|c|c|c|}
\hline Autores & $\begin{array}{l}\text { Gramáticas } \\
\text { históricas }\end{array}$ & $\begin{array}{l}\text { Obras de temas } \\
\text { filológicos específicos }\end{array}$ & $\begin{array}{c}\text { Tratamento } \\
\text { (edição) de texto }\end{array}$ \\
\hline & & $\begin{array}{l}\text { - Estudinhos de } \\
\text { etimologias: notas ao } \\
\text { correr da pena: } 1^{\mathrm{a}} \text { série } \\
\text { (1935) } \boldsymbol{\beta} \\
\text { - Estudinhos de } \\
\text { etimologias: escritos ao } \\
\text { correr da pena: } 2^{\mathrm{a}} \text { série } \\
(1937)^{223} \boldsymbol{\beta} \\
\text { - Vocábulos médicos e } \\
\text { de outra natureza } \\
\text { (1944) } \Sigma\end{array}$ & \\
\hline $\begin{array}{l}\text { RESENDE, A. } \\
\text { de Lara } \\
(?-?)\end{array}$ & $\begin{array}{l}\text { - Lições de } \\
\text { grammatica } \\
\text { historica: de acordo } \\
\text { com o Programma } \\
\text { do Collegio Pedro II } \\
\text { (1918) } \boldsymbol{\Omega}\end{array}$ & & \\
\hline $\begin{array}{l}\text { RIBEIRO, } \\
\text { João } \\
\text { (1860-1934) }\end{array}$ & & $\begin{array}{l}\text { - Estudos philologicos } \\
(1902)^{224} \boldsymbol{\Sigma} \\
\text { - Curiosidades verbais } \\
\text { (1927) } \boldsymbol{\beta}\end{array}$ & \\
\hline $\begin{array}{c}\text { RIBEIRO, } \\
\text { Joaquim } \\
(1907-1964)\end{array}$ & & $\begin{array}{l}\text { - Origem da Lingua } \\
\text { Portuguêsa }(1935) \boldsymbol{\beta}\end{array}$ & \\
\hline $\begin{array}{l}\text { SÁ, Filippe } \\
\text { Franco de } \\
(1841-?)\end{array}$ & & $\begin{array}{l}\text { - A Lingua Portugueza: } \\
\text { dificuldades e dúvidas } \\
\text { (1915) } \boldsymbol{\beta}\end{array}$ & \\
\hline
\end{tabular}

\footnotetext{
${ }^{223} \mathrm{Na}$ folha de rosto, há a informação de que a obra contém "notas de divulgação; crítica ao dicionário do Sr. Antenor Nascentes".

${ }^{224} 1902$ é a data da $1^{\text {a }}$ edição em versão livro, porém antes já havia sido publicado em jornais. Vejamos o que informa a própria obra: “compõe-se este opusculo das notas philologicas publicadas n' A Semana, dos primeiros mezes do anno de 1887; tambem dos Estudos Philologicos publicados em folheto impresso na typ. da Gaz. de Noticias, em $1885^{\prime}$. Como a publicação da $1^{\mathrm{a}}$ edição em livro ocorreu já no século XX, incluímos esta obra no presente levantamento.
} 


\begin{tabular}{|c|c|c|c|}
\hline Auras ${ }^{198}$ & $\begin{array}{l}\text { Gramáticas } \\
\text { históricas }\end{array}$ & $\begin{array}{l}\text { Obras de temas } \\
\text { filológicos específicos }\end{array}$ & $\begin{array}{c}\text { Tratamento } \\
\text { (edição) de texto }\end{array}$ \\
\hline $\begin{array}{c}\text { SAMPAIO } \\
\text { Teodoro } \\
(1855-1937)\end{array}$ & & $\begin{array}{l}\text { - O tupi na geografia } \\
\text { nacional (1901) } \boldsymbol{\beta}\end{array}$ & \\
\hline $\begin{array}{l}\text { SCROSOPPI, } \\
\text { Horacio } \\
(1850-1928)\end{array}$ & & $\begin{array}{l}\text { - Cartas anepigraphas: } \\
\text { questões philologicas } \\
\text { seguidas dum } \\
\text { vocabulário portuguez- } \\
\text { hellenico de nomes } \\
\text { próprios de homens, etc. } \\
\text { (1915) } \boldsymbol{\beta}\end{array}$ & \\
\hline $\begin{array}{l}\text { SILVA NETO, } \\
\text { Serafim da } \\
(1917-1960)\end{array}$ & $\begin{array}{l}\text { - Manual de } \\
\text { gramática histórica } \\
\text { portuguesa: de } \\
\text { acordo com o } \\
\text { Programa Oficial do } \\
4^{\circ} \text { ano (1942) } \boldsymbol{\beta}\end{array}$ & $\begin{array}{l}\text { - Divergência e } \\
\text { convergência na } \\
\text { evolução fonética }(T)^{225} \\
(1939) \boldsymbol{\Omega} \\
\text { - Rusgas filológicas: } \\
\text { réplica a Jucá } \\
\text { inestudioso, implicante e } \\
\text { roncador }^{226}(1942) \boldsymbol{\beta} \\
\text { - Rumos filológicos } \\
\text { (1942) } \boldsymbol{\beta}\end{array}$ & $\begin{array}{l}\text { - A. de Resende. A } \\
\text { santa vida e } \\
\text { religiosa } \\
\text { conversação de frei } \\
\text { Pedro. Edição } \\
\text { facsimile do único } \\
\text { exemplar conhecido, } \\
\text { acompanhada de } \\
\text { introdução e notas } \\
\text { (1947) } \boldsymbol{\Omega}\end{array}$ \\
\hline $\begin{array}{l}\text { SILVEIRA, } \\
\text { Sousa da } \\
(1883-1967)\end{array}$ & 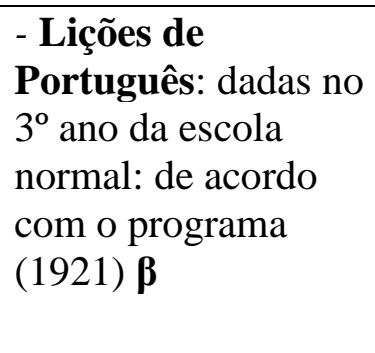 & & $\begin{array}{l}\text { - Poesias de } \\
\text { Casimiro de } \\
\text { Abreu (1940) } \Omega \\
\\
\text { - Textos } \\
\text { quinhentistas } \\
\text { (1945) } \beta\end{array}$ \\
\hline
\end{tabular}

${ }^{225}$ Como esclarece o autor, essa tese constitui uma separata, um capítulo de uma outra obra sua, a História da Língua Portuguesa.

${ }^{226}$ A obra é, basicamente, uma resposta às críticas feitas por Cândido Jucá (filho) ao Manual de gramática histórica portuguesa: de acordo com o Programa Oficial do $4^{\circ}$ ano), de Serafim da Silva Neto.

227 Essa obra é uma resposta às críticas feitas por Almir Câmara de Matos Peixoto, no livro Novos rumos em filologia: imprestabilidade dos velhos quadros (1942), à tese apresentada por Silva Neto intitulada Divergência e convergência na evolução fonética, em 1939. 
2. Textos inseridos na tradição FILOLÓGICA

\begin{tabular}{|c|c|c|c|}
\hline Obras ${ }^{198}$ & $\begin{array}{l}\text { Gramáticas } \\
\text { históricas }\end{array}$ & $\begin{array}{l}\text { Obras de temas } \\
\text { filológicos específicos }\end{array}$ & $\begin{array}{l}\text { Tratamento } \\
\text { (edição) de texto }\end{array}$ \\
\hline $\begin{array}{c}\text { TORRES, } \\
\text { Arthur de } \\
\text { Almeida } \\
(1903-?)\end{array}$ & $\begin{array}{l}\text { - Compêndio de } \\
\text { Língua Portuguesa: } \\
4^{a} \text { série ginasial } \\
\text { (1937) } \mathbf{\Omega}\end{array}$ & $\begin{array}{l}\text { - Questões filológicas } \\
(1943)^{228} \boldsymbol{\beta}\end{array}$ & \\
\hline $\begin{array}{l}\text { Reunião de } \\
\text { professores } \\
\text { (obra coletiva) }\end{array}$ & $\begin{array}{l}\text { - Novo manual de } \\
\text { Lingua Portuguesa: } \\
\text { grammatica } \\
\text { historica: Curso } \\
\text { Complementar } \\
\text { (1925) } \boldsymbol{\beta}\end{array}$ & & \\
\hline $\begin{array}{c}\text { Total parcial de } \\
\text { obras }\end{array}$ & 30 & 51 & 8 \\
\hline $\begin{array}{l}\text { TOTAL de } \\
\text { OBRAS }\end{array}$ & \multicolumn{3}{|c|}{87 obras } \\
\hline $\begin{array}{l}\text { TOTAL de } \\
\text { AUTORES }\end{array}$ & \multicolumn{3}{|c|}{56 autores } \\
\hline
\end{tabular}

${ }^{228}$ Esta obra é a reunião de polêmicas que o autor travou, em colunas de jornal, com Sousa da Silveira, Serafim da Silva Neto, José de Sá Nunes, Melchíades Picanço e Modesto de Abreu, além de alguns artigos independentes. Nas polêmicas, o autor reproduziu a sequência de textos seus e também dos seus oponentes. Tendo essa natureza diversa, apenas metade do livro (duas polêmicas) referem-se a questões de gramática histórica. A outra metade refere-se a questões normativas, gramaticais. Dessa forma, julgamos conveniente incluir essa obra tanto nas obras da tradição gramatical quanto na filológica. 
QUADRO 3A - Produção linguística brasileira (1900-1940): programa de investigação dialetológico

\begin{tabular}{|c|c|c|}
\hline $\mathrm{C}_{\text {Autores }}^{\text {Obras }^{229}}$ & $\begin{array}{l}\text { Descrição de dialetos regionais } \\
\text { e sociais }\end{array}$ & $\begin{array}{l}\text { Descrição dialetológica do } \\
\text { Português do Brasil }\end{array}$ \\
\hline $\begin{array}{l}\text { ALBUQUERQUE, } \\
\text { Acir }^{230} \text { Tenorio de } \\
(1899-1973)\end{array}$ & & $\begin{array}{l}\text { - Falsos brasileirismos: } \\
\text { argentinismos e americanismos } \\
\text { erradamente apontados como } \\
\text { brasileirismos (1942) } \boldsymbol{\beta}\end{array}$ \\
\hline $\begin{array}{l}\text { AMARAL, Amadeu } \\
(1875-1929)\end{array}$ & - O dialeto caipira (1920) $\beta$ & \\
\hline $\begin{array}{l}\text { CALLAGE, Roque } \\
\qquad(1886-1931)\end{array}$ & $\begin{array}{l}\text { - Vocabulario gaúcho: contendo } \\
\text { mais de } 2 \text { mil termos usados no } \\
\text { linguajar rio-grandense (1926) } \Sigma\end{array}$ & \\
\hline $\begin{array}{l}\text { CAMPOS JÚNIOR, } \\
\text { Joaquim Gomes de } \\
(?-?)\end{array}$ & $\begin{array}{l}\text { - Dialeto rio-grandense (1909) } \\
\mathbf{\Omega}\end{array}$ & \\
\hline $\begin{array}{c}\text { CARVALHO, Elysio } \\
\text { de } \\
(1880-1925)\end{array}$ & $\begin{array}{l}\text { - Giria dos gatunos cariocas } \\
\text { (1913) } \boldsymbol{\beta}\end{array}$ & \\
\hline $\begin{array}{c}\text { CASTRO, Eugenio de } \\
(1882-1947)\end{array}$ & & $\begin{array}{l}\text { - Geographia linguística e } \\
\text { cultura brasileira (1937) } \boldsymbol{\beta}\end{array}$ \\
\hline $\begin{array}{l}\text { CHINA, José B. } \\
\text { D’Oliveira } \\
(1874-?)\end{array}$ & $\begin{array}{l}\text { - Os ciganos do Brasil: } \\
\text { subsidios historicos, } \\
\text { ethnographicos e linguisticos } \\
(1936) \Sigma\end{array}$ & \\
\hline
\end{tabular}

${ }^{229}$ Legenda:

$\boldsymbol{\beta}$ : Obra pertencente ao acervo pessoal do pesquisador.

$\Sigma$ : Obra consultada em bibliotecas.

$\mathbf{\Omega}$ : Indica que a referência a esta obra foi localizada em um outro livro, nas páginas normalmente denominadas "Outras obras da editora" ou "Demais publicações do autor". Tais páginas estão localizadas ou na quarta capa ou nas páginas iniciais do livro. Isso significa, obviamente, que não tivemos acesso físico à obra e que as informações editoriais foram obtidas nesse contexto mais limitado. Esse símbolo indica também obras localizadas em listas em que constam apenas o título e o autor, como foi o caso, por exemplo, dos livros encontrados no Diário Oficial da União, em uma publicação da "Comissão Nacional do Livro Didático", de 1947. Também indica obras localizadas on-line, nos catálogos de bibliotecas.

T: Teses.

${ }^{230}$ Há registros também de seu primeiro nome grafado como Arcy. 


\begin{tabular}{|c|c|c|}
\hline $\mathrm{C}_{\text {Autores }}^{\text {Obras }^{229}}$ & $\begin{array}{c}\text { Descrição de dialetos regionais } \\
\text { e sociais }\end{array}$ & $\begin{array}{l}\text { Descrição dialetológica do } \\
\text { Português do Brasil }\end{array}$ \\
\hline $\begin{array}{c}\text { CORRÊA, José } \\
\text { Romaguera } \\
(1863-1910)\end{array}$ & $\begin{array}{l}\text { - Vocabulario sul rio- } \\
\text { grandense }(1898) \Sigma\end{array}$ & \\
\hline $\begin{array}{l}\text { COSTA, Francisco } \\
\text { Augusto Pereira da } \\
\quad(1851-1923)\end{array}$ & $\begin{array}{l}\text { - Vocabulário pernambucano } \\
(1916)^{231} \Sigma\end{array}$ & \\
\hline $\begin{array}{l}\text { CUNHA, } \\
\text { Ciro Vieira da } \\
(1897-1976)\end{array}$ & $\begin{array}{l}\text { - O dialeto brasileiro }(1933)^{232} \\
\text { (T) } \Omega\end{array}$ & \\
\hline $\begin{array}{c}\text { DAISSON, Augusto } \\
(?-?)\end{array}$ & & $\begin{array}{l}\text { - Å margem de alguns } \\
\text { brasileirismos (1925) } \boldsymbol{\beta}\end{array}$ \\
\hline $\begin{array}{l}\text { ELIA, Sílvio } \\
(1913-1998)\end{array}$ & & $\begin{array}{l}\text { - O problema da língua } \\
\text { brasileira (1940) } \boldsymbol{\beta}\end{array}$ \\
\hline $\begin{array}{c}\text { GARCIA, Rodolfo } \\
\text { Augusto de Amorim } \\
\text { (1873-1949) }\end{array}$ & $\begin{array}{l}\text { - Diccionario de brasileirismos: } \\
\text { peculiaridades pernambucanas } \\
\text { (1915) } \boldsymbol{\beta}\end{array}$ & \\
\hline $\begin{array}{l}\text { JUCÁ (filho), Cândido } \\
\text { (1900-1982) }\end{array}$ & & $\begin{array}{l}\text { - Língua nacional: as } \\
\text { diferenciações entre o português } \\
\text { de Portugal e o do Brasil } \\
\text { autorizam a existência de um } \\
\text { ramo dialetal do português } \\
\text { peninsular? (1937) } \boldsymbol{\beta} \\
\text { - A pronúncia brasileira } \\
\text { (1939) } \boldsymbol{\beta}\end{array}$ \\
\hline $\begin{array}{l}\text { LAYTANO, Dante de } \\
(1908-2000)\end{array}$ & $\begin{array}{l}\text { - Os africanismos do dialeto } \\
\text { gaúcho (1936) } \boldsymbol{\beta}\end{array}$ & \\
\hline
\end{tabular}

${ }^{231}$ Publicação póstuma. “'Separata do vol. XXXIV da Revista do Instituto Archeológico, Histórico e Geográphico Pernambucano'. Em 1916, a Revista do Instituto Arqueológico, Histórico e Geográfico Pernambucano iniciou a publicação do interessantíssimo trabalho de Pereira da Costa, modestamente intitulado Apontamentos para um vocabulario pernambucano. Não pôde, entretanto, ir além da letra B.” (UNIVERSIDADE DE SÃO PAULO, 2019).

${ }^{232}$ Esta obra é fruto da tese apresentada pelo autor para o concurso de provimento à $2^{\mathrm{a}}$ cadeira de Português da Escola Normal Pedro II, de Vitória. Foi editado pela Imprensa Oficial de Vitória. 


\begin{tabular}{|c|c|c|}
\hline$\underbrace{\text { Obras }^{229}}_{\text {Autores }}$ & $\begin{array}{c}\text { Descrição de dialetos regionais } \\
\text { e sociais }\end{array}$ & $\begin{array}{l}\text { Descrição dialetológica do } \\
\text { Português do Brasil }\end{array}$ \\
\hline & $\begin{array}{l}\text { - Vocabulário dos pescadores } \\
\text { do Rio-Grande-Sul: etimologia } \\
\text { dos têrmos praieiros usados na } \\
\text { costa nordeste (1937) } \boldsymbol{\beta}\end{array}$ & \\
\hline $\begin{array}{l}\text { LEDA, João } \\
(1876-1955)\end{array}$ & & $\begin{array}{l}\text { - A chimera da língua } \\
\text { brasileira (1939) } \boldsymbol{\beta}\end{array}$ \\
\hline $\begin{array}{l}\text { LEITE, Solidônio } \\
(1867-1930)\end{array}$ & & $\begin{array}{l}\text { - A Lingua Portuguesa no } \\
\text { Brasil (1922) } \boldsymbol{\beta}\end{array}$ \\
\hline $\begin{array}{l}\text { LEMOS, Virgilio de } \\
\quad(1863-1926)\end{array}$ & & $\begin{array}{l}\text { - A Lingua Portuguesa no } \\
\text { Brasil (1916) } \boldsymbol{\beta}\end{array}$ \\
\hline $\begin{array}{c}\text { LESSA, Claudo } \\
\text { Ribeiro de } \\
(?-?)\end{array}$ & - Vocabulário de caça (1944) $\beta$ & \\
\hline $\begin{array}{l}\text { LOPES, Domingos de } \\
\text { Castro }^{233} \\
(1862-1921)\end{array}$ & & $\begin{array}{l}\text { - A língua brazileira }(1935)^{234} \\
\boldsymbol{\beta}\end{array}$ \\
\hline $\begin{array}{c}\text { MACHADO } \\
\text { FILHO, Aires da } \\
\text { Mata } \\
(1909-1985)\end{array}$ & $\begin{array}{l}\text { - O negro e o garimpo em } \\
\text { Minas Gerais (1943) } \boldsymbol{\beta}\end{array}$ & \\
\hline $\begin{array}{l}\text { MAGALHÃES, } \\
\text { Raimundo } \\
(?-?)\end{array}$ & $\begin{array}{l}\text { - Vocabulario popular: } \\
\text { augmentado com grande numero } \\
\text { de locuções populares brasileiras } \\
\text { (1911) } \boldsymbol{\beta}\end{array}$ & \\
\hline $\begin{array}{l}\text { MARQUES, Xavier } \\
\quad(1861-1942)\end{array}$ & & $\begin{array}{l}\text { - Cultura da lingua nacional } \\
\text { (1933) } \boldsymbol{\beta}\end{array}$ \\
\hline $\begin{array}{l}\text { MARROQUIM, } \\
\text { Mário } \\
(1896-?)\end{array}$ & $\begin{array}{l}\text { - A lingua do nordeste (Alagôas } \\
\text { e Pernambuco) (1934) } \boldsymbol{\beta}\end{array}$ & \\
\hline
\end{tabular}

${ }^{233} \mathrm{O}$ autor em questão é filho de Castro Lopes.

234 Publicação póstuma. 


\begin{tabular}{|c|c|c|}
\hline $\mathrm{C}_{\text {Autores }}^{\text {Obras }^{229}}$ & $\begin{array}{c}\text { Descrição de dialetos regionais } \\
\text { e sociais }\end{array}$ & $\begin{array}{l}\text { Descrição dialetológica do } \\
\text { Português do Brasil }\end{array}$ \\
\hline $\begin{array}{l}\text { MARTINS, Maria de } \\
\text { Lourdes de Paula } \\
(?-?)\end{array}$ & & $\begin{array}{l}\text { - A influência indígena no } \\
\text { Português do Brasil: estudo do } \\
\text { vocabulário (1944) (T) } \boldsymbol{\beta}\end{array}$ \\
\hline $\begin{array}{l}\text { MATTA, Alfredo } \\
\text { Augusto da } \\
(1870-1954)\end{array}$ & $\begin{array}{l}\text { - Contribuição ao estudo do } \\
\text { vocabulario amazonense (1938) } \\
235 \boldsymbol{\Sigma}\end{array}$ & \\
\hline $\begin{array}{l}\text { MELO, Gladstone } \\
\text { Chaves de } \\
(1917-2001)\end{array}$ & & $\begin{array}{l}\text { - A influência africana no } \\
\text { Português do Brasil (1945) } \boldsymbol{\Omega} \\
\text { - Língua do Brasil }(1946)^{236} \boldsymbol{\beta}\end{array}$ \\
\hline $\begin{array}{l}\text { MENDES, José } \\
\text { Amando } \\
(?-?)\end{array}$ & $\begin{array}{l}\text { - Vocabulário amazônico: } \\
\text { estudos (1942) } \mathbf{\Omega}\end{array}$ & \\
\hline $\begin{array}{l}\text { MENDONÇA, Renato } \\
(1912-1990)\end{array}$ & & $\begin{array}{l}\text { - A influência africana no } \\
\text { Português do Brasil (1933) } \boldsymbol{\beta} \\
\text { - O Português do Brasil: } \\
\text { origens, evoluções, tendências } \\
\text { (1936) } \boldsymbol{\beta}\end{array}$ \\
\hline $\begin{array}{l}\text { MIRANDA, Vicente } \\
\text { Chermont de } \\
(1873-1949)\end{array}$ & $\begin{array}{l}\text { - Glossario paraense: ou } \\
\text { collecção de vocabulos } \\
\text { peculiares á Amazonia e } \\
\text { especialmente á ilha do Marajó } \\
(1905) \Sigma\end{array}$ & \\
\hline $\begin{array}{l}\text { MONTEIRO, Clóvis } \\
(1898-1961)\end{array}$ & $\begin{array}{l}\text { - A linguagem dos cantadores: } \\
\text { contribuicao para o estudo de } \\
\text { Portugues popular no nordeste } \\
\text { do Brasil (1933) (T) }{ }^{237} \boldsymbol{\Omega}\end{array}$ & $\begin{array}{l}\text { - Da influência do Tupi no } \\
\text { Português (1926) }(\mathrm{T})^{238} \boldsymbol{\beta}\end{array}$ \\
\hline
\end{tabular}

235 Em 1939, a obra sai com o título alterado para Vocabulario amazonense: contribuição para o seu estudo. 236 O ano de edição do livro é 1946, porém destaca o autor - no prefácio à obra datado de 25/1/1945 - que os dois primeiros capítulos foram escritos anteriormente a essas datas: o primeiro, em 1942 e o segundo acabou por não ser publicado na época, o sendo apenas em 1946.

237 "segundo textos coligidos e publicados por Leonardo Mota"; "tese de concurso para a congregação do Colégio Pedro II".

${ }^{238}$ Da tendência na evolução de nosso idioma (1926) e Da influência do Tupi no Português (1926) - apresentados inicialmente como teses - são reunidos e publicados como livro, em 1931, sob o título Português da Europa e Português da América: aspectos da evolução do nosso idioma. 


\begin{tabular}{|c|c|c|}
\hline Autores & $\begin{array}{c}\text { Descrição de dialetos regionais } \\
\text { e sociais }\end{array}$ & $\begin{array}{l}\text { Descrição dialetológica do } \\
\text { Português do Brasil }\end{array}$ \\
\hline $\begin{array}{l}\text { MORAES, Luiz } \\
\text { Carlos de } \\
(1876-?)\end{array}$ & $\begin{array}{l}\text { - Vocabulário sul-rio- } \\
\text { grandense (1935) } \Sigma\end{array}$ & \\
\hline $\begin{array}{l}\text { MORAES, Raimundo } \\
\quad(1872-1941)\end{array}$ & $\begin{array}{l}\text { - O meu diccionario da } \\
\text { Amazonia (2 volumes) (1931) } \boldsymbol{\beta}\end{array}$ & \\
\hline $\begin{array}{l}\text { MOTA, Fernando de } \\
\text { Oliveira } \\
(1916-1967)\end{array}$ & $\begin{array}{l}\text { - Aspectos linguísticos do } \\
\text { Nordeste (1944) (T) }{ }^{239} \boldsymbol{\Omega}\end{array}$ & \\
\hline $\begin{array}{l}\text { MOTTA, João } o^{240} \\
(?-?)\end{array}$ & & $\begin{array}{l}\text { - O Portuguez falado no } \\
\text { Brazil (1905) } \boldsymbol{\beta}\end{array}$ \\
\hline $\begin{array}{c}\text { MOTTA, Leonardo } \\
\text { (1891-1948) }\end{array}$ & $\begin{array}{l}\text { - Cantadores: poesia e } \\
\text { linguagem do sertão cearense } \\
(1921) \boldsymbol{\beta} \\
\text { - Violeiros do norte: poesia e } \\
\text { linguagem do sertão nordestino } \\
\text { (1925) } \boldsymbol{\beta} \\
\\
\text { - Sertão alegre: poesia e } \\
\text { linguagem do sertão nordestino } \\
\text { (1928) } \boldsymbol{\beta}\end{array}$ & \\
\hline $\begin{array}{l}\text { NASCENTES, } \\
\text { Antenor } \\
(1886-1972)\end{array}$ & $\begin{array}{l}\text { - O linguajar carioca em } 1922 \\
(1922) \boldsymbol{\beta}\end{array}$ & $\begin{array}{l}\text { - Tesouro da fraseologia } \\
\text { brasileira (1945) } \boldsymbol{\beta}\end{array}$ \\
\hline $\begin{array}{l}\text { NEIVA, Arthur } \\
(1880-1943)\end{array}$ & & $\begin{array}{l}\text { - Estudos de lingua nacional } \\
\text { (1940) } \beta\end{array}$ \\
\hline $\begin{array}{c}\text { OLIVEIRA, Sebastião } \\
\text { Almeida } \\
(?-?)\end{array}$ & $\begin{array}{l}\text { - Expressões do populário } \\
\text { sertanejo: vocabulário e } \\
\text { superstições (1940) } \boldsymbol{\beta}\end{array}$ & \\
\hline $\begin{array}{c}\text { PÁDUA, Ciro T. de } \\
(?-?)\end{array}$ & & $\begin{array}{l}\text { - O dialeto brasileiro: ensaio } \\
\text { de filologia e sociologia sobre a } \\
\text { língua falada no Brasil (1942) } \beta\end{array}$ \\
\hline
\end{tabular}

239 "Tese com que o professor Fernando de Oliveira Mota, que também se assina Fernando Mota, comparece ao concurso para provimento da segunda cadeira de Português da Escola Normal Oficial, de Pernambuco". Informação presente no frontispício da obra.

240 João Nepomuceno Nogueira da Motta. 


\begin{tabular}{|c|c|c|}
\hline $\mathrm{C}_{\text {Autores }}^{\text {Obras }^{229}}$ & $\begin{array}{c}\text { Descrição de dialetos regionais } \\
\text { e sociais }\end{array}$ & $\begin{array}{l}\text { Descrição dialetológica do } \\
\text { Português do Brasil }\end{array}$ \\
\hline $\begin{array}{l}\text { PAES, Elpidio } \\
\text { Ferreira } \\
(1902-1972)\end{array}$ & $\begin{array}{l}\text { - Alguns aspectos da fonética } \\
\text { sul-riograndense: contribuição } \\
\text { ao "Congresso de língua nacional } \\
\text { cantada" (1938) } \boldsymbol{\beta}\end{array}$ & \\
\hline $\begin{array}{l}\text { PEDERNEIRAS, Raul } \\
(1874-1953)\end{array}$ & $\begin{array}{l}\text { - Geringonça carioca: verbetes } \\
\text { para um diccionario da gíria } \\
\text { (1922) } \boldsymbol{\beta}\end{array}$ & \\
\hline $\begin{array}{l}\text { PEIXOTO, Afrânio } \\
\quad(1876-1947)\end{array}$ & & $\begin{array}{l}\text { - Brasileirismos (s/d) }[1924]^{241} \\
\boldsymbol{\beta}\end{array}$ \\
\hline $\begin{array}{l}\text { PERDIGÃO, } \\
\text { Edmylson } \\
(1913-2003)\end{array}$ & $\begin{array}{l}\text { - Linguajar da malandragem } \\
\text { (1940) } \boldsymbol{\beta}\end{array}$ & \\
\hline $\begin{array}{l}\text { PEREIRA, Altamirano } \\
\text { Nunes } \\
(?-?)\end{array}$ & & $\begin{array}{l}\text { - Breves considerações a } \\
\text { propósito da língua brasileira } \\
\text { (1946) } \boldsymbol{\beta}\end{array}$ \\
\hline $\begin{array}{l}\text { PINTO, P. A. }{ }^{242} \\
(1882-1971)\end{array}$ & $\begin{array}{l}\text { - Dicionário de termos médicos } \\
\text { (1926) } \beta \\
\text { - Os sertões de Euclides da } \\
\text { Cunha: vocabulário e notas } \\
\text { lexicográficas (1930) } \boldsymbol{\beta} \\
\text { - Brasileirismos e supostos } \\
\text { brasileirismos de Os sertões de } \\
\text { Euclides da Cunha (1931) } \boldsymbol{\beta}\end{array}$ & \\
\hline $\begin{array}{l}\text { RAIMUNDO, Jacques } \\
\quad(?-1960 ?)\end{array}$ & & $\begin{array}{l}\text { - A influência do Tupi no } \\
\text { Português (1926) } \Omega \\
\text { - O elemento afro-negro na } \\
\text { Lingua Portuguesa (1933) } \beta\end{array}$ \\
\hline
\end{tabular}

\footnotetext{
${ }^{241}$ Não consta na obra o ano de publicação, mas há a informação de que ela é uma separata da Revista de Filologia Portuguesa, nº 6, 7, 8 e 9. Tais números desta revista foram publicados em 1924.

${ }^{242} \mathrm{O}$ autor assina suas obras desta forma, usando iniciais. Seu nome completo é Pedro Augusto Pinto.
} 


\begin{tabular}{|c|c|c|}
\hline Autores Obras $^{229}$ & $\begin{array}{l}\text { Descrição de dialetos regionais } \\
\text { e sociais }\end{array}$ & $\begin{array}{l}\text { Descrição dialetológica do } \\
\text { Português do Brasil }\end{array}$ \\
\hline & & $\begin{array}{l}\text { - Vocabulários indígenas de } \\
\text { Venezuela: da importância dos } \\
\text { idiomas ameríndios nas relações } \\
\text { com o português-brasileiro } \\
\text { (1934) } \boldsymbol{\beta} \\
\text { - O negro brasileiro e outros } \\
\text { escritos (1936) } \boldsymbol{\Sigma} \\
\text { - A Lingua Portuguesa no } \\
\text { Brasil: expansão, penetração, } \\
\text { unidade e estado atual (1941) } \boldsymbol{\beta} \\
\text { - Guinêanos e sudanenses: } \\
\text { etnologia e linguagem (s/d) }\end{array}$ \\
\hline $\begin{array}{l}\text { RIBEIRO, João } \\
\text { (1860-1934) }\end{array}$ & & $\begin{array}{l}\text { - Frazes feitas: estudo } \\
\text { conjectural de locuções, ditados } \\
\text { e proverbios (1908) } \boldsymbol{\beta} \\
\text { - A lingua nacional (1921) } \boldsymbol{\beta} \\
\text { - O elemento negro: historia, } \\
\text { folklore, linguística (1939) } \boldsymbol{\beta}\end{array}$ \\
\hline $\begin{array}{l}\text { RIBEIRO, Joaquim } \\
\text { (1907 - 1964) }\end{array}$ & $\begin{array}{l}\text { - Folklore dos bandeirantes } \\
(1946)^{244} \boldsymbol{\beta}\end{array}$ & \\
\hline $\begin{array}{l}\text { SANCHES, Edgard } \\
\quad(1891-1972)\end{array}$ & & - Lingua brasileira (1940) $\beta$ \\
\hline $\begin{array}{l}\text { SÃO PAULO, } \\
\text { Fernando } \\
(1887-1973)\end{array}$ & $\begin{array}{l}\text { - Linguagem médica popular } \\
\text { no Brasil }(1936)^{245} \Sigma\end{array}$ & \\
\hline $\begin{array}{l}\text { SENNA, Nelson de } \\
(1876-1952)\end{array}$ & & $\begin{array}{l}\text { - Os africanos no Brasil: } \\
\text { estudos sobre os negros }\end{array}$ \\
\hline
\end{tabular}

\footnotetext{
${ }^{243}$ Na relação de obras do autor, presente no $\mathbf{O}$ negro brasileiro e outros escritos (1936) há menção à referida obra, sem, no entanto, informar sua data de publicação, dizendo apenas que ela ocorrerá em breve. Nessa mesma obra, o autor afirma que Guinêanos e sudanenses "é um trabalhinho suplementar ao nosso $\mathbf{O}$ elemento afro-negro na lingua portuguesa (Rio,1933)" (RAIMUNDO, 1936, p.34)

${ }^{244}$ Neste livro, há três capítulos, um deles é chamado "Dialetologia bandeirante", característica que nos fez incluir esta obra no presente levantamento.

${ }^{245}$ Obra em 2 volumes.
} 


\begin{tabular}{|c|c|c|}
\hline Autores & $\begin{array}{c}\text { Descrição de dialetos regionais } \\
\text { e sociais }\end{array}$ & $\begin{array}{l}\text { Descrição dialetológica do } \\
\text { Português do Brasil }\end{array}$ \\
\hline & & $\begin{array}{l}\text { africanos e influencias afro- } \\
\text { negras sobre a linguagem e } \\
\text { costumes do povo (1938) } \boldsymbol{\beta} \\
\text { - A influência do índio na } \\
\text { linguagem brasileira }(1947)^{246} \\
\boldsymbol{\beta}\end{array}$ \\
\hline $\begin{array}{l}\text { SILVA NETO, } \\
\text { Serafim da } \\
(1917-1960)\end{array}$ & & $\begin{array}{l}\text { - Capítulos de história da } \\
\text { Língua Portuguesa no Brasil } \\
\text { (1946) } \beta \\
\text { - Diferenciação e unificação } \\
\text { do Português do Brasil (1946) } \\
\boldsymbol{\beta}\end{array}$ \\
\hline $\begin{array}{l}\text { SOARES, Macedo } \\
\quad(1838-1905)\end{array}$ & & $\begin{array}{l}\text { - Estudos lexicográficos do } \\
\text { dialeto brasileiro }(1943)^{248} \boldsymbol{\beta}\end{array}$ \\
\hline $\begin{array}{c}\text { SOUZA, Bernardino } \\
\text { José de } \\
(1884-1949)\end{array}$ & & $\begin{array}{l}\text { - Dicionário da terra e da } \\
\text { gente do Brasil }(1910)^{249} \boldsymbol{\beta}\end{array}$ \\
\hline $\begin{array}{c}\text { TAUNAY, Affonso } \\
\text { D'Escragnolle } \\
(1876-1958)\end{array}$ & $\begin{array}{l}\text { - Lexico de termos technicos e } \\
\text { scientificos ainda nao } \\
\text { apontados nos diccionarios da } \\
\text { lingua portugueza (1909) } \beta \\
\\
\text { - Insufficiencia e deficiencia } \\
\text { dos grandes diccionarios } \\
\text { portuguezes (1928) } \beta\end{array}$ & $\begin{array}{l}\text { - Léxico de lacunas: subsídios } \\
\text { para os dicionarios da Lingua } \\
\text { Portugueza }(1914)^{250} \boldsymbol{\beta} \\
\text { - Vocabulario de omissões: } \\
\text { collectanea de milheiro e meio } \\
\text { de palavras correntes no Brasil, } \\
\text { e em Portugal, não registadas }\end{array}$ \\
\hline
\end{tabular}

\footnotetext{
246 "Conferência proferida pelo professor Nelson de Senna (da Universidade de Minas), a convite do exmo. sr. general Rondon, na sessão de encerramento da "celebração da terceira semana do indio do Brasil", a 30 de abril de 1946, na sede do Conselho Nacional de Proteção aos Índios, na capital federal.”; "Separata da publicação n 101. Impresso pelo CNPI".

${ }^{247}$ Antonio Joaquim Macedo Soares.

${ }^{248}$ Nesta obra póstuma, reúnem-se vários textos avulsos publicados pelo autor, no final do século XIX, em diferentes veículos. Como a publicação em livro se deu em 1943, optamos por inclui-la em nosso levantamento.

${ }^{249}$ Este é o título da $4^{a}$ edição, publicada em 1939 e que permaneceu até edições mais recentes, como a de 2006. Nomenclatura geografica peculiar ao Brasil foi a título dado à $1^{\mathrm{a}} \mathrm{e}$ à $2^{\mathrm{a}}$ edições, respectivamente, de $1910 \mathrm{e} 1917$. Onomastica geral da geografia brasileira foi o título da $3^{a}$ edição, em 1927. Como o autor esclarece na Advertencia preliminar, da $4^{\mathrm{a}}$ edição, são "tres nomes diferentes para o mesmo trabalho".

${ }^{250}$ Depois da folha de rosto, aparece o seguinte texto: "LÉXICO DE termos vulgares, correntes no Brazil, sobretudo no Estado de São Paulo, e de accepções de numerosos vocábulos, ainda: não apontados nos grandes diccionarios da língua portugueza".
} 


\begin{tabular}{|c|c|c|}
\hline Autores & $\begin{array}{l}\text { Descrição de dialetos regionais } \\
\text { e sociais }\end{array}$ & $\begin{array}{l}\text { Descrição dialetológica do } \\
\text { Português do Brasil }\end{array}$ \\
\hline & & $\begin{array}{l}\text { [sic] na terceira ed. do Novo } \\
\text { diccionario da lingua } \\
\text { portuguesa do Sr. Candido de } \\
\text { Figueiredo (1924) } \boldsymbol{\Omega} \\
\text { - Reparos ao novo diccionario } \\
\text { de Candido de Figueiredo } \\
\text { (1926) } \boldsymbol{\beta} \\
\text { - Inopia scientifica e } \\
\text { vocabular dos grandes } \\
\text { diccionarios portuguezes } \\
\text { (1932) } \boldsymbol{\beta}\end{array}$ \\
\hline $\begin{array}{c}\text { TEIXEIRA, José de } \\
\text { Aparecida } \\
(?-?)\end{array}$ & $\begin{array}{l}\text { - O falar mineiro (1938) } \boldsymbol{\beta} \\
\text { - Estudos de dialetologia } \\
\text { portuguesa }(1944)^{251} \boldsymbol{\beta}\end{array}$ & \\
\hline $\begin{array}{c}\text { TERÊNCIO, Paulo } \\
\text { (1882-1971) }\end{array}$ & $\begin{array}{l}\text { - Estudos euclidianos: notas } \\
\text { para o vocabulario de "Os } \\
\text { sertões" [de Euclydes da Cunha] } \\
\text { (1929) } \Sigma\end{array}$ & \\
\hline $\begin{array}{l}\text { TESCHAUER, Carlos } \\
(1851-1930)\end{array}$ & $\begin{array}{l}\text { - Poranduba rio-grandense: } \\
\text { investigações sobre o idioma } \\
\text { fallado no Brasil e } \\
\text { particularmente no Rio Grande } \\
\text { do Sul253 }\left(19212^{2}{ }^{2} \text { ed. }\right)^{254} \boldsymbol{\beta}\end{array}$ & $\begin{array}{l}\text { - Apostillas ao "Diccionario de } \\
\text { vocabulos brasileiros": I serie } \\
\text { (1912) } \boldsymbol{\beta} \\
\text { - Novo vocabulario brasileiro: } \\
\text { II'. serie das apostillas ao } \\
\text { diccionario de vocabulos } \\
\text { brasileiros (1918) } \boldsymbol{\beta} \\
\text { - Novo vocabulário nacional: } \\
\text { III serie (1923) } \boldsymbol{\Omega}\end{array}$ \\
\hline
\end{tabular}

\footnotetext{
251 Aborda o falar goiano.

${ }^{252}$ Paulo Terêncio é o pseudônimo de P.A. Pinto.

${ }^{253}$ Esta obra aborda apenas aspectos linguístico e tem 81 páginas. Localizamos outra, publicada em 1929, de 468 páginas, em que o subtítulo é extraído, ficando apenas Poranduba riograndense. Nessa, não só aspectos dialetológicos são tratados, mas também outros aspectos culturais do Rio Grande do Sul. Na obra mais ampla, um dos capítulos tem exatamente o mesmo nome que foi atribuído ao subtítulo da obra de 1921.

254 Quando não conseguimos acesso à data da $1^{\text {a }}$ edição, registramos a data/edição mais antiga a que tivermos acesso.
} 


\begin{tabular}{|c|c|c|}
\hline Autores & $\begin{array}{l}\text { Descrição de dialetos regionais } \\
\text { e sociais }\end{array}$ & $\begin{array}{l}\text { Descrição dialetológica do } \\
\text { Português do Brasil }\end{array}$ \\
\hline & & $\begin{array}{l}\text { - Novo diccionario nacional } \\
(1923)^{255} \Sigma\end{array}$ \\
\hline $\begin{array}{l}\text { TORRES, Arthur de } \\
\text { Almeida }\end{array}$ & & $\begin{array}{l}\text { - O Português falado no Brasil } \\
\text { (1941) } \boldsymbol{\Omega}\end{array}$ \\
\hline $\begin{array}{l}\text { VALE, Quintino do } \\
\qquad(?-?)\end{array}$ & & $\begin{array}{l}\text { - A influência do Tupi no } \\
\text { Português (1926) } \boldsymbol{\Omega}\end{array}$ \\
\hline $\begin{array}{c}\text { VIANNA FILHO, } \\
\text { Luiz } \\
(1908-1990)\end{array}$ & & - A lingua do Brasil (1936) $\boldsymbol{\beta}$ \\
\hline $\begin{array}{l}\text { VIOTTI, Manuel } \\
(?-?)\end{array}$ & $\begin{array}{l}\text { - Dicionário da gíria brasileira } \\
\text { (1945) } \beta\end{array}$ & \\
\hline $\begin{array}{l}\text { Total parcial de } \\
\text { obras }\end{array}$ & 42 & 50 \\
\hline TOTAL de OBRAS & \multicolumn{2}{|c|}{92 obras } \\
\hline $\begin{array}{l}\text { TOTAL de } \\
\text { AUTORES }\end{array}$ & \multicolumn{2}{|c|}{63 autores } \\
\hline
\end{tabular}

255 “[em 1928 sai a] 2. ed. (das tres series de vocabulos brasileiros) muito augm. por Carlos Teschauer, S.J”. 


\section{APÊNDICE B}

Este apêndice contém quadros parciais relativos ao levantamento completo de obras (cf. Apêndice A) e outros quadros preparados para subsidiar algumas análises realizadas ao longos dos capítulos.

O conteúdo de cada um dos 19 quadros pode ser consultado no início desta tese, no "Sumário".

Para maior concisão nas tabelas parciais, retiramos as biodatas dos autores. Para consultar essa informação, ver o levantamento completo.

\section{A legenda abaixo é válida para todas as tabelas deste apêndice:}

$\boldsymbol{\beta}$ : Obra pertencente ao acervo pessoal do pesquisador.

$\boldsymbol{\Sigma}$ : Obra consultada em bibliotecas.

$\mathbf{\Omega}$ : Indica que a referência a esta obra foi localizada em um outro livro, nas páginas normalmente denominadas "Outras obras da editora" ou "Demais publicações do autor". Tais páginas estão localizadas ou na quarta capa ou nas páginas iniciais do livro. Isso significa, obviamente, que não tivemos acesso físico à obra e que as informações editoriais foram obtidas nesse contexto mais limitado. Esse símbolo indica também obras localizadas em listas em que constam apenas o título e o autor, como foi o caso, por exemplo, dos livros encontrados no Diário Oficial da União, em uma publicação da "Comissão Nacional do Livro Didático", de 1947. Também indica obras localizadas on-line, nos catálogos de bibliotecas.

T: Teses. 
QUADRO 1B - Gramáticas escolares completas

\section{Gramáticas primárias}

\begin{tabular}{|c|c|}
\hline ALI, Said & - Grammatica elementar da Lingua Portugueza (1923) $\beta$ \\
\hline BRITO, Paulino de Almeida & $\begin{array}{l}\text { - Gramática primaria da lingua portuguesa: para uso das } \\
\text { escolas }\left(1899 \_1^{\mathrm{a}} \text { ed.) }\left(1943 \_26^{\mathrm{a}} \text { ed.) } \boldsymbol{\Omega}\right.\right.\end{array}$ \\
\hline $\begin{array}{l}\text { DUQUE-ESTRADA, } \\
\text { Osório }\end{array}$ & $\begin{array}{l}\text { - Noções elementares de grammatica portugueza: de acordo } \\
\text { com o programma das escolas primarias }(1900) \boldsymbol{\Omega}\end{array}$ \\
\hline FREITAS, Gaspar de & $\begin{array}{l}\text { - Lições praticas de grammatica portugueza: de accordo com } \\
\text { o exame de admissão ao curso secundário accrescida de muitas } \\
\text { notas supplementares para os alumnos do } 1^{\circ} \text { anno gymnasial } \\
(1927)^{256} \boldsymbol{\beta}\end{array}$ \\
\hline FERREIRA, Julio Pires & $\begin{array}{l}\text { - Grammatica portuguesa: para o uso dos Cursos Primários } \\
\text { (s/d) } \boldsymbol{\beta}\end{array}$ \\
\hline GÓES, Carlos 257 & - Gramática expositiva primária (1919) $\boldsymbol{\beta}$ \\
\hline PUENTE, André Leão & - Grammatica primária da Lingua Portugueza (1903) $\mathbf{\Omega}$ \\
\hline VIANA, Hermógenes & - Gramática primária da Língua Portuguêsa (1940) $\mathbf{\Omega}$ \\
\hline VIEIRA, Verissimo & $\begin{array}{l}\text { - Grammatica portugueza }{ }^{258} \text { : curso preliminar }\left(1922 \_3^{\mathrm{a}} \text { ed. }\right)^{259} \\
\boldsymbol{\beta} \\
\text { - Grammatica portugueza: curso complementar }\left(1917 \_2^{\mathrm{a} e d .}\right) \boldsymbol{\Sigma}\end{array}$ \\
\hline $\begin{array}{l}\text { Total de gramáticas } \\
\text { primárias: }\end{array}$ & 10 obras \\
\hline
\end{tabular}

${ }^{256}$ Em 1936, a obra teve ligeira modificação no seu título: "Lições praticas de gramática portuguêsa: para as classes primárias, exame de admissão ao curso secundario; com muitas notas suplementares para os alumnos do $1^{\circ}$ anno gymnasial e um dicionario de analyse das palavras susceptiveis de diversas classificações”.

${ }^{257}$ Em algumas obras o autor assina Carlos Góis.

258 As informações sobre as gramáticas de Verissimo Vieira são um pouco confusas. No entanto, nos parece que temos três gramáticas para a "instrucção primaria", divididas em três cursos: elementar, preliminar e complementar. Quanto ao primeiro, ele não consta em nosso levantamento, pois sua $1^{\text {a }}$ edição é de 1898.

${ }^{259}$ Quando não conseguimos acesso à data da $1^{\mathrm{a}}$ edição, registramos a data da edição mais antiga a que tivermos acesso. 


\begin{tabular}{|c|c|}
\hline \multicolumn{2}{|r|}{ Gramáticas secundárias } \\
\hline ABREU, Modesto de & $\begin{array}{l}\text { - Idioma pátrio: volume 3: gramática expositiva e histórica; } \\
\text { noções de estilística e literatura (1944) } \boldsymbol{\beta}\end{array}$ \\
\hline $\begin{array}{l}\text { ALMEIDA, Napoleão } \\
\text { Mendes de }\end{array}$ & $\begin{array}{l}\text { - Gramática metódica da língua portuguesa: curso único e } \\
\text { completo }^{260}(1943) \Sigma\end{array}$ \\
\hline ALI, Said & - Grammatica secundária da Lingua Portugueza (1923) $\beta$ \\
\hline $\begin{array}{l}\text { BACHELET, Mário } \\
\text { NUNES, José de Sá }\end{array}$ & $\begin{array}{l}\text { - Novo manual da Língua Portuguêsa: gramática: para as } 4 \\
\text { séries do ciclo ginasial261 (1943) } \mathbf{\Omega}\end{array}$ \\
\hline $\begin{array}{l}\text { BRITO PEREIRA, Carlos } \\
\text { de }\end{array}$ & - Manual de gramática portuguesa (1933) $\beta$ \\
\hline BRUNO, Aníbal & $\begin{array}{l}\text { - Língua Portuguesa: gramática e exercícios para quarto séries } \\
\text { ginasiais }\left(1944 \_19^{\mathrm{a}} \text { ed.) } \boldsymbol{\beta}\right.\end{array}$ \\
\hline $\begin{array}{l}\text { BUENO, Francisco da } \\
\text { Silveira }\end{array}$ & - Gramática normativa da Língua Portuguêsa (1944) B \\
\hline $\begin{array}{l}\text { CÂMARA JR., Joaquim } \\
\text { Mattoso }\end{array}$ & $\begin{array}{l}\text { - Gramática: } 1^{\mathrm{a}} \text { e } 2^{\mathrm{a}} \text { séries ginasiais (1944) } \boldsymbol{\beta} \\
\text { - Gramática: } 3^{\mathrm{a}} \text { e } 4^{\mathrm{a}} \text { séries ginasiais (1945) } \boldsymbol{\Omega}\end{array}$ \\
\hline CARDOSO, Bricio & - Tratado da lingua vernacula: grammatica $(1932)^{262} \boldsymbol{\beta}$ \\
\hline CARREIRO, Carlos Porto & $\begin{array}{l}\text { - Grammatica da lingua nacional: methodo pratico: segundo } \\
\text { anno (1918) } \boldsymbol{\beta}\end{array}$ \\
\hline CRUZ, José Marques da & $\begin{array}{l}\text { - Português prático: gramática para as } 4 \text { séries do curso ginasial } \\
\left(1944 \_15^{\mathrm{a} e d .)} \boldsymbol{\beta}\right.\end{array}$ \\
\hline
\end{tabular}

\footnotetext{
${ }^{260} \mathrm{O}$ autor afirma ser contra a elaboração de gramáticas com diferentes níveis de dificuldade, dividindo-as, por exemplo, em elementares ou superiores. Ainda de acordo com o autor, tal objeção é o que justifica o fato de sua gramática ser um "curso único e completo". Apesar dessa restrição, ele divide os tópicos de sua gramática segundo o que se deveria estudar em cada uma das quatro séries ginasiais. Essa ação não deixa dúvidas quanto ao nível escolar ao qual se destinava essa obra.

${ }^{261}$ Também encontramos essa obra com o título ligeiramente diferente: Novo manual da Língua Portuguêsa lusobrasileira: gramática: para as 4 séries do ciclo ginasial. Os demais dados bibliográficos são os mesmos, com o acréscimo apenas do "luso-brasileiro" no título.

${ }^{262}$ Apesar de ser uma produção do século XIX, foi publicada em formato de livro apenas em 1932, com $2^{\mathrm{a}}$ edição em 1944, fato que justifica sua inclusão na relação de gramáticas correspondentes ao século XX. A esse respeito, vejamos a explicação dada por Gally (2013, p.97): "Escrito em 1875, aprovado pelo Conselho Superior de Instrução Pública da Bahia em 1878 e revisado pela última vez pelo autor em 1914, o Tratado da Língua Vernácula (Grammatica) foi somente impresso pela Gráfica Sauer, de Fred H. Sauer, no Rio de Janeiro, em 1932, oito anos depois da morte de seu criador, Brício Cardoso". O fato de ser uma obra escrita no século XIX explica o fato de seu conteúdo ser bastante distinto daquele encontrado nas gramáticas escritas no início do século XX.
} 


\begin{tabular}{|c|c|}
\hline $\begin{array}{l}\text { CARVALHO, José } \\
\text { Mesquita de }\end{array}$ & $\begin{array}{l}\text { - Gramática ginasial: para as quatro séries de acordo com a } \\
\text { nova programação de ensino, e com o novo vocabulário } \\
\text { ortográfico oficial (1945) } \boldsymbol{\beta}\end{array}$ \\
\hline $\begin{array}{l}\text { FONSECA, Alcides da } \\
\text { ARAGÃO, Jarbas } \\
\text { Cavalcante de }\end{array}$ & $\begin{array}{l}\text { - A Língua Portuguesa: gramática para as quatro séries } \\
\text { ginasiais (1943) } \Omega\end{array}$ \\
\hline FERREIRA, Julio Pires & $\begin{array}{l}\text { - Grammatica portuguesa: } 2^{\circ} \text { anno: Curso Médio e do Curso } \\
\text { Superior (1921_6 ed.) } \boldsymbol{\beta}\end{array}$ \\
\hline HORTA, Brant ${ }^{263}$ & $\begin{array}{l}\text { - Gramática intuitiva da Língua Portuguesa: para os dois } \\
\text { primeiros anos do curso ginasial e normal (1938) } \boldsymbol{\beta}\end{array}$ \\
\hline JUCÁ (filho), Cândido & $\begin{array}{l}\text { - Gramática brasileira do português contemporâneo } \\
\text { (1943_1 ed.) } \boldsymbol{\beta}\end{array}$ \\
\hline $\begin{array}{l}\text { LEITE, José Marques } \\
\text { CINTRA, Geraldo de Ulhoa }\end{array}$ & $\begin{array}{l}\text { - Língua portuguesa: gramática: para as quatro séries dos } \\
\text { ginásios }\left(1947 \_4^{\mathrm{a}} \mathrm{ed} .\right)^{264} \Omega\end{array}$ \\
\hline $\begin{array}{l}\text { LIMA, Mario Pereira de } \\
\text { Souza }\end{array}$ & $\begin{array}{l}\text { - Grammatica expositiva da lingua portuguesa: para uso das } \\
\text { escolas secundarias }(1937)^{265} \Sigma\end{array}$ \\
\hline MACIEL, Maximino & - Lições elementares de lingua portugueza ${ }^{266}$ (1903) $\boldsymbol{\beta}$ \\
\hline MORAIS, Bento Bueno de & 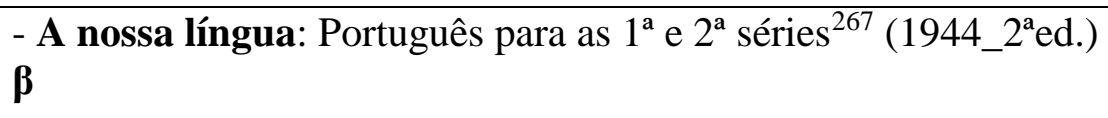 \\
\hline MOTTA, João & $\begin{array}{l}\text { - Grammatica elementar da Lingua Portugueza: destinada ao } \\
\text { primeiro anno dos gymnasios (1905) } \mathbf{\Omega}\end{array}$ \\
\hline NASCENTES, Antenor & $\begin{array}{l}\text { - O idioma nacional: gramática para as quatro séries ginasiais } \\
\text { (1944) } \boldsymbol{\beta}\end{array}$ \\
\hline NOGUEIRA, Julio & - Programa de Português: gramática (1948_7ed.) $\boldsymbol{\beta}$ \\
\hline
\end{tabular}

${ }^{263}$ Francisco Eugenio Brant Horta

${ }^{264}$ Compõe a coleção didática, além da referida gramática, dois volumes de antologias: um para as $1^{\mathrm{a}}$ e $2^{\mathrm{a}}$ séries ginasiais e outro para as $3^{\mathrm{a}}$ e $4^{\mathrm{a}}$ séries ginasiais. São eles: Língua Portuguesa: antologia e exercícios: primeira e segunda séries ginasiais e Língua Portuguesa: antologia e exercícios: terceira e quarta séries ginasiais.

${ }^{265}$ Em 1945, a obra sai com o seguinte título: Gramática portuguêsa: ed. rev. e aum. de acordo com o Programa Oficial, para as 4 séries. Não foi possível obter o número dessa edição.

${ }^{266}$ Obra destinada ao $1^{\circ}$ ano do curso ginasial.

${ }^{267}$ Esta obra é uma gramática escolar, organizada em lições, e composta por 2 volumes: o primeiro, para as $1^{\mathrm{a}} \mathrm{e} 2^{\mathrm{a}}$ séries ginasiais e o segundo volume para as $3^{\mathrm{a}} \mathrm{e} 4^{\mathrm{a}}$ séries. No exemplar que possuímos, $1^{\circ}$ volume, $7^{\mathrm{a}}$ edição de 1953 , há indicação da publicação do $2^{\circ}$ volume, mas não localizamos demais informações sobre o autor/obra em nenhum arquivo. Como nosso exemplar é da década de 50, não temos como garantir que o $2^{\circ}$ tenha sido publicado dentro do nosso recorte temporal, motivo que fez com que não o incluíssemos no presente levantamento. 


\begin{tabular}{|c|c|}
\hline OITICICA, José de & - Manual de análise (léxica e sintática) ${ }^{268}(1919) \boldsymbol{\beta}$ \\
\hline PEREIRA, Eduardo Carlos & $\begin{array}{l}\text { - Gramática expositiva: curso superior }{ }^{269}(1907) \boldsymbol{\beta} \\
\text { - Gramática expositiva: curso elementar }{ }^{270}(1908) \boldsymbol{\beta}\end{array}$ \\
\hline $\begin{array}{c}\text { P.S } \\
\text { (Pedro Schneider) }\end{array}$ & $\begin{array}{l}\text { - Syntaxe e grammatica historica da Lingua Portuguesa } \\
(1909)^{271} \boldsymbol{\beta}\end{array}$ \\
\hline RÉVEILLEAU, A. & $\begin{array}{l}\text { - A prova de Português na Escola Militar ou gramatica mixta } \\
\text { da Lingua Portuguêsa: livro destinado a qualquer série ginasial } \\
\text { de Português }(1938)^{272} \boldsymbol{\beta}\end{array}$ \\
\hline RODRIGUES, J. & $\begin{array}{l}\text { - Grammatica portuguesa: } 1^{\mathrm{a}}, 2^{\mathrm{a}}, 3^{\mathrm{a}}, 4^{\mathrm{a}} \text { e } 5^{\mathrm{a}} \text { séries gymnasiaes } \\
\text { (1935) } \boldsymbol{\beta}\end{array}$ \\
\hline $\begin{array}{l}\text { TORRES, Arthur de } \\
\text { Almeida }\end{array}$ & $\begin{array}{l}\text { - Compêndio de língua portuguesa: gramática: para o Curso } \\
\text { Ginasial (1943) } \boldsymbol{\beta}\end{array}$ \\
\hline $\begin{array}{l}\text { Total de gramáticas } \\
\text { secundárias: }\end{array}$ & 31 obras \\
\hline \multicolumn{2}{|c|}{$\begin{array}{l}\text { Gramáticas em que não há informações explícitas sobre o nível de ensino para o qual se } \\
\text { destina }\end{array}$} \\
\hline ANDRADE, Gustavo de ${ }^{273}$ & $\begin{array}{l}\text { - Grammatica intuitiva da Lingua Portugueza: elementar }{ }^{274} \\
\left(1911_{1} 1^{\mathrm{e} e d .}\right) \boldsymbol{\beta}\end{array}$ \\
\hline
\end{tabular}

\footnotetext{
${ }^{268}$ Apesar do título, trata-se de uma gramática completa, com seções sobre fonologia, morfologia e sintaxe.

${ }^{269}$ Obra destinada ao $2^{\circ}$ e $3^{\circ}$ anos do curso ginasial. Quanto ao $4^{\circ}$ ano, o autor publicou, em 1916, a Grammatica histórica, tema desse ano específico.

${ }^{270}$ Obra destinada ao $1^{\circ}$ ano do curso ginasial.

${ }^{271} \mathrm{O}$ presente volume é formado por uma gramática tradicional e uma gramática histórica. Em função dessa característica "dois em um", a incluímos tanto aqui como no levantamento das obras do programa filológico, no grupo das "gramáticas históricas" (cf. Tabela 2A - Apêndice A). Apesar de o título mencionar apenas "syntaxe", na parte relativa à gramática tradicional, o exame da obra mostrou haver o estudo dos três níveis: fonologia, morfologia e sintaxe, ou seja, é uma gramática completa.

${ }^{272}$ Nessa obra, temos duas gramáticas juntas: uma prática e outra histórica. Provavelmente, é em função desse aspecto que o autor chamou sua obra de "gramática mista".

${ }^{273}$ Nos anexos à Grammatica ecletica, obra que foi publicada postumamente, foram reunidas manifestações a respeito da morte de Gustavo de Andrade. Emygdio H. Souza, em texto publicado no Diario da Bahia, em 24/11/1914, diz: "Deixou alguns livros didacticos, dentre os quaes se destacam a - Grammatica intuitiva e as Cacolexias -, sendo este ultimo de grande utilidade não só para os estudiosos, mas tambem para todos os que falam a bella lingua de Camões porque contem a maioria dos vocabulos que por sua má ortographia prosódica e pela sua descendencia, enfermam e infestam a lingua portugueza."

${ }^{274}$ No prefácio à obra, assinado por T.B. (não foi possível descobrir quem é o autor de tal inicial), é informado que a Grammatica intuitiva foi "logo adotada nas escolas municipais e estaduais", sem, no entanto, informar em que séries isso ocorreu, se só na Bahia e em quais municípios houve a adoção ou demais informações sobre a aplicação e uso da obra.
} 


\begin{tabular}{|c|c|}
\hline ALVES, Achilles & $\begin{array}{l}\text { - Breves noções de grammatica portugueza: contendo os } \\
\text { elementos indispensaveis de grammatica seguidos de numerosos } \\
\text { exercicios e modelos de analyse: paginas e leitura praticáveis. } \\
\left(1936 \_5 \text { ead.) } \boldsymbol{\beta}\right.\end{array}$ \\
\hline BRITO, Paulino de Almeida & - A grammatica do professor (1908) $\mathbf{\Omega}$ \\
\hline COSTA, Firmino & - Grammatica portugueza (1920) $\boldsymbol{\beta}$ \\
\hline COUTINHO, J. J. de Freitas & - Licções de grammatica portugueza (1909) $\boldsymbol{\beta}$ \\
\hline $\begin{array}{l}\text { COUTINHO, Alfredo } \\
\text { Alvares de Macedo }\end{array}$ & - Gramática portuguesa: curso elementar (1939_8 ed.) $\boldsymbol{\beta}$ \\
\hline $\begin{array}{l}\text { LIMA, Mario Pereira de } \\
\text { Souza }\end{array}$ & - Elementos de gramática (1938) $\mathbf{\Omega}$ \\
\hline PINTO, Alfredo Clemente & $\begin{array}{l}\text { - Primeiras noções de grammatica: } 1^{\circ} \text { curso (1906) } \beta \\
\text { - Primeiro anno de grammatica por meio de exercicios } \\
\text { praticos: } 2^{\circ} \text { curso (1907) } \beta\end{array}$ \\
\hline SAMPAIO, B. ${ }^{275}$ & - Elementos de gramática portuguesa $\left(1932 \_1^{\mathrm{a} e d}\right.$.) $\boldsymbol{\beta}$ \\
\hline $\begin{array}{l}\text { Total de gramáticas em } \\
\text { que não há informações } \\
\text { explícitas sobre o nível de } \\
\text { ensino para o qual se } \\
\text { destina }\end{array}$ & 10 obras \\
\hline AUTORES: & 43 autorias $^{276}$ \\
\hline TOTAL GERAL: & 51 obras \\
\hline
\end{tabular}

${ }^{275} \mathrm{O}$ autor assina suas obras assim. Seu nome completo é Benedito Sampaio.

${ }^{276}$ Obras em coautoria foram consideradas no conjunto, ou seja, apenas uma autoria. 
QUADRO 2B - Definições de gramática: grupo das gramáticas escolares completas

\section{Gramáticas primárias}

\begin{tabular}{|c|c|}
\hline $\begin{array}{l}\text { ALI, Said. Grammatica } \\
\text { elementar da Lingua } \\
\text { Portugueza. } \beta\end{array}$ & $\begin{array}{l}\text { Grammatica Portugueza é a exposição methodica das } \\
\text { regras que ensinam a falar e escrever correctamente a lingua } \\
\text { portugueza, nascida em Poertugal e ha quatro seculos } \\
\text { implantada no Brasil. ([19--], p.5) }\end{array}$ \\
\hline $\begin{array}{l}\text { BRITO, Paulino de Almeida. } \\
\text { Gramática primaria da lingua } \\
\text { portuguesa: para uso das escolas } \\
\left(1899 \_1^{\mathrm{a}} \text { ed. }\right)\left(1943 \_26^{\mathrm{a}} \text { ed. } \boldsymbol{\Omega}\right.\end{array}$ & Obra não consultada. \\
\hline $\begin{array}{l}\text { DUQUE-ESTRADA, Osório. } \\
\text { Noções elementares de } \\
\text { grammatica portugueza: de } \\
\text { acordo com o programma das } \\
\text { escolas primarias (1900) } \boldsymbol{\Omega}\end{array}$ & Obra não consultada. \\
\hline $\begin{array}{l}\text { FREITAS, Gaspar de. Lições } \\
\text { praticas de grammatica } \\
\text { portugueza: de accordo com o } \\
\text { exame de admissão ao curso } \\
\text { secundário accrescida de muitas } \\
\text { notas supplementares para os } \\
\text { alumnos do } 1^{\circ} \text { anno gymnasial. } \beta\end{array}$ & $\begin{array}{l}\text { Gramática Portuguêsa é a coordenação dos fatos e } \\
\text { normas da língua portuguêsa. (1952 [1927], p.3) }\end{array}$ \\
\hline $\begin{array}{l}\text { FERREIRA, Julio Pires. } \\
\text { Grammatica portuguesa: para o } \\
\text { uso dos Cursos Primários } \boldsymbol{\beta}\end{array}$ & $\begin{array}{l}\text { Gramática Portuguesa é o conjunto das regras pelas quais } \\
\text { se fala e se escreve corretamente a Lingua Portuguesa. } \\
\text { ([19--], p.3) }\end{array}$ \\
\hline $\begin{array}{l}\text { GÓES, Carlos. Gramática } \\
\text { expositiva primária. } \beta\end{array}$ & $\begin{array}{l}\text { A lingua está sujeita a uma disciplina ou norma. Essa } \\
\text { disciplina ou norma chama-se "Grammatica". Portanto: } \\
\text { Grammatica é a norma para falar ou escrever bem uma } \\
\text { lingua. (1928, p.6) }\end{array}$ \\
\hline $\begin{array}{l}\text { PUENTE, André Leão. } \\
\text { Grammatica primária da } \\
\text { Lingua Portugueza (1903) } \boldsymbol{\Omega}\end{array}$ & Obra não consultada. \\
\hline $\begin{array}{l}\text { VIANA, Hermógenes. } \\
\text { Gramática primária da Língua } \\
\text { Portuguêsa }(1940) \Omega\end{array}$ & Obra não consultada. \\
\hline
\end{tabular}




\begin{tabular}{|c|c|}
\hline $\begin{array}{l}\text { VIEIRA, Verissimo. } \\
\text { Grammatica portugueza: curso } \\
\text { preliminar. } \boldsymbol{\beta}\end{array}$ & $\begin{array}{l}\text { As palavras de uma lingua devem ser faladas e escriptas de } \\
\text { accordo com as regras estabelecidas. A grammatica } \\
\text { estabelece as regras a seguir para se falar ou escrever bem } \\
\text { uma lingua. A grammatica portuguesa ensina a falar } \\
\text { escrever correctamente a lingua portugueza. (1922, p.15) }\end{array}$ \\
\hline $\begin{array}{l}\text { VIEIRA, Verissimo. } \\
\text { Grammatica portugueza: curso } \\
\text { complementar. } \Sigma\end{array}$ & $\begin{array}{l}\text { GRAMMATICA - As palavras e as proposições, com que } \\
\text { reproduzimos as idéas e os juizos que formamos, constituem } \\
\text { o que se chama factos da lingua. A exposição methodica e } \\
\text { o estudo dos factos de uma lingua constituem o objecto da } \\
\text { Grammatica. } \\
\text { Grammatica portugueza é a disciplina que trata da } \\
\text { exposição methodica e do estudo dos factos da lingua } \\
\text { portugueza. }(1917, \text { p.16) }\end{array}$ \\
\hline Total de gramáticas primárias: & 10 obras \\
\hline \multicolumn{2}{|r|}{ Gramáticas secundárias } \\
\hline $\begin{array}{l}\text { ABREU, Modesto de. Idioma } \\
\text { pátrio: volume 3: gramática } \\
\text { expositiva e histórica; noções de } \\
\text { estilística e literatura } \boldsymbol{\beta}\end{array}$ & $\begin{array}{l}\text { DEFINIÇÃO. - Gramática de uma língua é o estudo } \\
\text { sistemático dos fatos dessa língua. Gramática Portuguesa é, } \\
\text { portanto, o estudo sistemático dos fatos da Língua } \\
\text { Portuguesa. } \\
\text { OBJETO. - A Gramática, como conjunto de conhecimentos } \\
\text { teóricos, é um ramo da Lingüística ou Glotologia, ciência da } \\
\text { linguagem; como sistematização de conhecimentos práticos, } \\
\text { é uma arte, ou técnica, e tem por finalidade essencial } \\
\text { ensinar-nos a falar e escrever a nossa língua com correção e } \\
\text { propriedade. } \\
\text { DIVISÃO. - A Gramática pode ser: a) Expositiva ou } \\
\text { descritiva, quando trata dos fatos da Língua no seu estado } \\
\text { atual; b) Histórica ou comparada, quando acompanha a } \\
\text { evolução da Língua desde suas origens e em comparação } \\
\text { com outras línguas. (1944, p.15) }\end{array}$ \\
\hline $\begin{array}{l}\text { ALMEIDA, Napoleão Mendes de. } \\
\text { Gramática metódica da língua } \\
\text { portuguesa: curso único e } \\
\text { completo }(1943) \Sigma\end{array}$ & Obra não consultada. \\
\hline
\end{tabular}




\begin{tabular}{|c|c|}
\hline $\begin{array}{l}\text { ALI, Said. Grammatica } \\
\text { secundária da Lingua } \\
\text { Portugueza. } \beta\end{array}$ & $\begin{array}{l}\text { Grammatica é o conjunto das regras, observadas em um ou } \\
\text { mais idiomas, relativas aos sons ou phonemas, ás formas dos } \\
\text { vocabulos e á combinação destes em proposições. } \\
\text { A grammatica de uma lingua pode ser historica ou } \\
\text { descriptiva. } \\
\text { Grammatica historica é aquella que estuda a evolução dos } \\
\text { diversos factos da lingua desde a sua origem até a epoca } \\
\text { presente. Grammatica descriptiva é a que expõe os factos } \\
\text { da lingua actual. A grammatica descriptiva é pratica } \\
\text { quando tem principalmente em vista ensinar a falar e a } \\
\text { escrever correctamente; é scientifica quando procura } \\
\text { esclarecer varios factos á luz da sciencia da linguagem e da } \\
\text { grammatica historica. As regras grammaticaes são } \\
\text { estabelecidas segundo o uso geral, a pratica das pessoas } \\
\text { cultas e a dos bons escriptores. Regras communs ás linguas } \\
\text { mais conhecidas ou a um grupo de linguas congeneres, } \\
\text { costumam-se chamar, exageradamente, regras ou principios } \\
\text { de grammatica geral. Grammatica comparativa é a que } \\
\text { estuda duas ou mais linguas do mesmo typo, mostrando as } \\
\text { semelhanças e dissemelhanças existentes entre as mesmas. } \\
\text { (ALI, [19--], p.5) }\end{array}$ \\
\hline $\begin{array}{l}\text { BACHELET, Mário; NUNES, } \\
\text { José de Sá. Novo manual da } \\
\text { Língua Portuguêsa: gramática: } \\
\text { para as } 4 \text { séries do ciclo ginasial } \\
\text { (1943) } \boldsymbol{\Omega}\end{array}$ & Obra não consultada. \\
\hline $\begin{array}{l}\text { BRITO PEREIRA, Carlos de. } \\
\text { Manual de gramática } \\
\text { portuguesa. } \boldsymbol{\beta}\end{array}$ & $\begin{array}{l}\text { Gramática é a exposição metódica dos fatos constitutivos } \\
\text { da linguagem ([que] é o meio de que o homem se serve para } \\
\text { representar e comunicar idéias). (1942, p. 1-2) }\end{array}$ \\
\hline $\begin{array}{l}\text { BRUNO, Aníbal. Língua } \\
\text { Portuguesa: gramática e } \\
\text { exercícios para quarto séries } \\
\text { ginasiais. } \beta\end{array}$ & $\begin{array}{l}\text { O autor não define gramática. } \\
\text { [Consultamos a } 41^{a} \text { edição, de 1952. A mais antiga que } \\
\text { encontramos é } 19^{a} \text { edição, de 1944.] }\end{array}$ \\
\hline $\begin{array}{l}\text { CÂMARA JR., Joaquim Mattoso. } \\
\text { Gramática: } 1^{\mathrm{a}} \text { e } 2^{\mathrm{a}} \text { séries } \\
\text { ginasiais. } \boldsymbol{\beta}\end{array}$ & $\begin{array}{l}\text { O autor não define gramática. } \\
\text { [Consultamos a } 4^{a} \text { edição, de 1955] }\end{array}$ \\
\hline $\begin{array}{l}\text { CÂMARA JR., Joaquim Mattoso. } \\
\text { Gramática: } 3^{\mathrm{a}} \text { e } 4^{\mathrm{a}} \text { séries } \\
\text { ginasiais (1945) } \mathbf{\Omega}\end{array}$ & Obra não consultada. \\
\hline
\end{tabular}




\begin{tabular}{|c|c|}
\hline $\begin{array}{l}\text { CARREIRO, Carlos Porto. } \\
\text { Grammatica da lingua nacional: } \\
\text { methodo pratico: segundo anno. } \boldsymbol{\beta}\end{array}$ & $\begin{array}{l}\text { Grammatica é a sciencia da linguagem. } \\
\text { A Grammatica portugueza é o conjunto das regras que se } \\
\text { devem seguir para bem falar e escrever a lingua portugueza. } \\
(1918, \text { p.23) }\end{array}$ \\
\hline $\begin{array}{l}\text { CRUZ, José Marques da. } \\
\text { Português prático: gramática } \\
\text { para as } 4 \text { séries do curso ginasial. } \\
\boldsymbol{\beta}\end{array}$ & $\begin{array}{l}\text { Gramática (do grego: gramma = letra) - é a ciência das } \\
\text { palavras e suas e suas relações, e a arte de usar bem, quando } \\
\text { exprimimos os nossos pensamentos: } \\
\text { a) gramática expositiva - quando expõe, com método, os } \\
\text { fatos atuais de uma língua; } \\
\text { b) gramática histórica - quando expõe, com método, as } \\
\text { transformações de uma língua, na sua evolução histórica. } \\
\text { Uma língua é um organismo vivo que evoluciona. (1947, } \\
\text { p.26) }\end{array}$ \\
\hline $\begin{array}{l}\text { CARVALHO, José Mesquita de. } \\
\text { Gramática ginasial: para as } \\
\text { quatro séries de acordo com a } \\
\text { nova programação de ensino, e } \\
\text { com o novo vocabulário } \\
\text { ortográfico oficial. } \beta\end{array}$ & $\begin{array}{l}\text { Gramática (do grego gramma: letra) é a arte que ensina a } \\
\text { ler, escrever e falar corretamente uma língua, isto é, é a } \\
\text { sistematização dos fatos de uma linguagem comum a um } \\
\text { povo. } \\
\text { A gramática é particular, quando estuda os fatos de uma } \\
\text { língua particular: gramática francesa, gramática } \\
\text { portuguêsa. } \\
\text { É geral quando estuda, sob comparação, um grupo de } \\
\text { línguas de mesmo ramo ou família: Gramática das línguas } \\
\text { românicas. } \\
\text { É expositiva quando expõe os fatos de uma linguagem. } \\
\text { É histórica quando desenvolve o estudo das transformações } \\
\text { de uma língua no tempo e no espaço. (1948, p.17) }\end{array}$ \\
\hline $\begin{array}{l}\text { FONSECA, Alcides da; } \\
\text { ARAGÃO, Jarbas Cavalcante de. } \\
\text { A Língua Portuguesa: gramática } \\
\text { para as quatro séries ginasiais } \\
(1943) \Omega\end{array}$ & Obra não consultada. \\
\hline $\begin{array}{l}\text { FERREIRA, Julio Pires. } \\
\text { Grammatica portuguesa: } 2^{\circ} \\
\text { anno: Curso Médio e do Curso } \\
\text { Superior. } \beta\end{array}$ & $\begin{array}{l}\text { Grammatica, em geral, é a exposição metodica dos factos } \\
\text { da linguagem. } \\
\text { Grammatica portugueza é o conjunto das regras pelas } \\
\text { quaes é falada, ou escrita, correctamente a Lingua } \\
\text { portugueza. }(1921, \text { p.5) }\end{array}$ \\
\hline $\begin{array}{l}\text { HORTA, Brant. Gramática } \\
\text { intuitiva da Língua Portuguesa: } \\
\text { para os dois primeiros anos do } \\
\text { curso ginasial e normal. } \beta\end{array}$ & $\begin{array}{l}\text { A GRAMATICA ou conjunto de regras que ensinam a falar } \\
\text { e a escrever com acerto. Há várias línguas diferentes e cada } \\
\text { uma delas tem as suas regras especiais que ensinam como } \\
\text { deve ser falada ou escrita. }\end{array}$ \\
\hline
\end{tabular}




\begin{tabular}{|c|c|}
\hline & $\begin{array}{l}\text { Assim, para falarmos ou escrevermos bem uma lingua, } \\
\text { é necessário que a falemos ou escrevamos, obedecendo as } \\
\text { suas regras. } \\
\text { A reunião de todas as regras de uma lingua constitue a } \\
\text { sua gramática. } \\
\text { No Brasil, fala-se o português e a reunião de todas as } \\
\text { regras que ensinam a falar e a escrever com correção a lingua } \\
\text { portuguesa, chama-se gramática portuguesa. }(1938, \text { p.11) }\end{array}$ \\
\hline $\begin{array}{l}\text { JUCÁ, (filho), Cândido. } \\
\text { Gramática brasileira do } \\
\text { português contemporâneo. } \beta\end{array}$ & $\begin{array}{l}\text { O autor não define gramática. } \\
\text { [Consultamos a } 2^{a} \text { edição, de 1945.] }\end{array}$ \\
\hline $\begin{array}{l}\text { LEITE, José Marques; CINTRA, } \\
\text { Geraldo de Ulhoa. Língua } \\
\text { portuguesa: gramática: para as } \\
\text { quatro séries dos ginásios } \beta\end{array}$ & $\begin{array}{l}\text { O autor não define gramática. } \\
\text { [Consultamos a } 1^{a} \text { edição, de 1946.] }\end{array}$ \\
\hline $\begin{array}{l}\text { LIMA, Mario Pereira de Souza. } \\
\text { Grammatica expositiva da } \\
\text { lingua portuguesa: para uso das } \\
\text { escolas secundarias (1937) } \Sigma\end{array}$ & Obra não consultada. \\
\hline $\begin{array}{l}\text { MACIEL, Maximino. Lições } \\
\text { elementares de lingua } \\
\text { portuguesa }^{277} \boldsymbol{\beta}\end{array}$ & $\begin{array}{l}\text { Grammatica portugueza é o estudo methodico dos factos } \\
\text { da lingua portuguesa. }(1938, \text { p. 11) }\end{array}$ \\
\hline $\begin{array}{l}\text { MORAIS, Bento Bueno de. A } \\
\text { nossa língua: Português para as } 1^{\text {a }} \\
\text { e } 2^{\mathrm{a}} \text { séries. } \boldsymbol{\beta}\end{array}$ & $\begin{array}{l}\text { Gramática é o conjunto de regras para falar e escrever } \\
\text { corretamente. }\end{array}$ \\
\hline $\begin{array}{l}\text { MOTTA, João. Grammatica } \\
\text { elementar da Lingua } \\
\text { Portugueza: destinada ao } \\
\text { primeiro anno dos gymnasios } \\
\text { (1905) } \boldsymbol{\Omega}\end{array}$ & Obra não consultada. \\
\hline $\begin{array}{l}\text { NASCENTES, Antenor. } \mathbf{O} \\
\text { idioma nacional: gramática para } \\
\text { as quatro séries ginasiais } \boldsymbol{\beta}\end{array}$ & $\begin{array}{l}\text { O autor não define gramática. } \\
\text { [Consultamos a } 1^{a} \text { edição, de 1944.] }\end{array}$ \\
\hline $\begin{array}{l}\text { NOGUEIRA, Julio. Programa de } \\
\text { Português: gramática. } \beta\end{array}$ & $\begin{array}{l}\text { O autor não define gramática. } \\
\text { [Consultamos a } 7^{a} \text { edição, de 1948.] }\end{array}$ \\
\hline
\end{tabular}

${ }^{277}$ Obra destinada ao $1^{\circ}$ ano do curso ginasial. 


\begin{tabular}{|c|c|}
\hline $\begin{array}{l}\text { PEREIRA, Eduardo Carlos. } \\
\text { Gramática expositiva: curso } \\
\text { superior }^{278} \cdot \boldsymbol{\beta}\end{array}$ & $\begin{array}{l}\text { Grammatica (gr. gramma = letra) é a sciencia das palavras } \\
\text { e suas relações, ou a arte de usar as palavras com acerto na } \\
\text { expressão do pensamento. } \\
\text { Obs. A concepção de grammatica como sciencia, escreve A. } \\
\text { Darmesteter, é, podemos dizel-o, uma idéa nova nascida } \\
\text { com a linguistica moderna. Assim entendida, é a grammatica } \\
\text { de uma lingua a determinação das leis naturaes que a regem } \\
\text { em sua evolução historica. A grammatica, accrescenta elle, } \\
\text { pode ser considerada como arte. Deste modo a encararam os } \\
\text { gregos e os latinos, a edade-média, e assim a encaram os } \\
\text { grammaticos modernos que não se prendem á escola } \\
\text { historica. Da antiga Roma nos veio esta definição: A } \\
\text { grammatica é a arte de escrever e fallar correctamente. } \\
\text { Existe uma boa tradição: a grammatica tem o dever de a } \\
\text { tornar conhecida e defendel-a contra qualquer alteração. É } \\
\text { ensinando o bom uso que ella não se contenta em ser } \\
\text { sciencia, e torna-se arte. (Gr. Historique, pgs. } 6 \text { e } 9 \text { ). } \\
\text { Divide-se em geral e particular, historica e expositiva. } \\
\text { Grammatica geral é a exposição methodica dos factos da } \\
\text { linguagem encarados em sua generalidade. Grammatica } \\
\text { particular é a exposição methodica dos factos de uma } \\
\text { lingua estudados em sua fórma actual ou em sua evolução } \\
\text { historica. Grammatica historica é o estudo comparativo } \\
\text { das transformações de uma lingua no decurso de sua } \\
\text { historia. } \\
\text { Nota. A comparação se faz entre os diversos periodos da } \\
\text { lingua e com as transformações parallelas de linguas ou } \\
\text { dialectos da mesma familia. Grammatica expositiva, } \\
\text { descriptiva ou practica é a que expõe ou descreve } \\
\text { methodicamente os factos actuaes de uma lingua } \\
\text { determinada. Grammatica expositiva portugueza é a } \\
\text { exposição methodica das regras relativas ao uso actual } \\
\text { correcto da lingua portugueza. (1913, p.2-3) }\end{array}$ \\
\hline $\begin{array}{l}\text { PEREIRA, Eduardo Carlos. } \\
\text { Gramática expositiva: curso } \\
\text { elementar }^{279} \cdot \boldsymbol{\beta}\end{array}$ & $\begin{array}{l}\text { Gramática Portuguesa é o estudo das regras para se falar e } \\
\text { escrever corretamente a língua portuguesa. (1943, p.2-3) }\end{array}$ \\
\hline $\begin{array}{l}\text { RÉVEILLEAU, A.. A prova de } \\
\text { Português na Escola Militar ou } \\
\text { gramatica mixta da Lingua } \\
\text { Portuguêsa: livro destinado a }\end{array}$ & O autor não define gramática. (1938) \\
\hline
\end{tabular}

${ }^{278}$ Obra destinada ao $2^{\circ}$ e $3^{\circ}$ anos do curso ginasial. Quanto ao $4^{\circ}$ ano, o autor publicou, em 1916, a Grammatica histórica, tema desse ano específico.

${ }^{279}$ Obra destinada ao $1^{\circ}$ ano do curso ginasial. 


\begin{tabular}{|c|c|}
\hline $\begin{array}{l}\text { qualquer série ginasial de } \\
\text { Português. } \beta\end{array}$ & \\
\hline $\begin{array}{l}\text { RODRIGUES, J.. Grammatica } \\
\text { portuguesa: } 1^{\mathrm{a}}, 2^{\mathrm{a}}, 3^{\mathrm{a}}, 4^{\mathrm{a}} \text { e } 5^{\mathrm{a}} \\
\text { séries gymnasiaes. } \boldsymbol{\beta}\end{array}$ & $\begin{array}{l}\text { Grammatica Portugueza é o estudo das leis por que se rege } \\
\text { a lingua portugueza quer fallada quer escripta. } \\
\text { Baseada no estudo dos nossos escriptores e na evolução } \\
\text { natural da linguagem considerada sob todos os seus } \\
\text { aspectos, pode tambem definir-se: o estudo systematico dos } \\
\text { elementos constitutivos da lingua portugueza, a saber: sons, } \\
\text { formas das palavras e modos de construcção. (1935, p.7) }\end{array}$ \\
\hline $\begin{array}{l}\text { TORRES, Arthur de Almeida. } \\
\text { Compêndio de língua } \\
\text { portuguesa: gramática: para o } \\
\text { Curso Ginasial } \beta\end{array}$ & $\begin{array}{l}\text { O autor não define gramática. } \\
\text { [Consultamos a } 7^{a} \text { edição, de 1947.] }\end{array}$ \\
\hline Total de gramáticas secundárias: & 27 obras \\
\hline \multicolumn{2}{|c|}{$\begin{array}{c}\text { Gramáticas em que não há informações explícitas sobre o nível de ensino para o qual se } \\
\text { destina }\end{array}$} \\
\hline $\begin{array}{l}\text { ANDRADE, Gustavo de. } \\
\text { Grammatica intuitiva da } \\
\text { Lingua Portugueza: elementar. } \beta\end{array}$ & $\begin{array}{l}\text { Já lá se foram os ominosos tempos em que a Grammatica } \\
\text { era considerada a arte de ensinar a falar e escrever } \\
\text { correctamente; hoje tal definição seria o maior dos absurdos } \\
\text { ou illogismo. Grammatica, em sentido lato, é o codice da } \\
\text { linguagem natural de um ou mais povos, presos ao mesmo } \\
\text { idioma. Grammatica, em sentido estricto, não tem por fim } \\
\text { ensinar a falar e a escrever correctamente, não; apenas } \\
\text { reune umas tantas regras que servem de base ao grande } \\
\text { edificio da linguagem, a qual se inicia na familia, se } \\
\text { desenvolve no convivio social e se consolida na acurada } \\
\text { leitura dos classicos. (1935, p.I-II, itálicos do autor) } \\
\text { Grammatica é o codice da linguagem natural de um ou } \\
\text { mais povos, presos ao mesmo idioma (1). Grammatica } \\
\text { Portugueza é o codice da linguagem puramente portugueza. } \\
\text { Grammatica Intuitiva é a que estuda a linguagem natural, } \\
\text { com methodo, segurança e clareza. Linguagem é o facto por } \\
\text { meio do qual se manifesta o pensamento. O pensamento } \\
\text { manifesta-se por - palavras ou signaes convencionaes. } \\
\text { Palavra é a forma intuitiva da idéa. Idéa é a elaboração do } \\
\text { que se passa no espirito. Os signaes convencionaes } \\
\text { abrangem: a linguagem escripta e a linguagem mimica. (1) } \\
\text { Codice é o documento escripto. (1935, p.9, itálicos do autor) }\end{array}$ \\
\hline
\end{tabular}




\begin{tabular}{|c|c|}
\hline $\begin{array}{l}\text { ALVES, Achilles. Breves noções } \\
\text { de grammatica portugueza: } \\
\text { contendo os elementos } \\
\text { indispensaveis de grammatica } \\
\text { seguidos de numerosos exercicios } \\
\text { e modelos de analyse: paginas e } \\
\text { leitura praticáveis. } \beta\end{array}$ & $\begin{array}{l}\text { GRAMMATICA é a arte que nos ensina as regras para nos } \\
\text { expressarmos com acerto. } \\
\text { Grammatica descriptiva é a que expõe os factos actuaes de } \\
\text { um determinado idioma. Grammatica historica é a que } \\
\text { estuda as transformações soffridas por uma lingua durante a } \\
\text { sua evolução. Grammatica comparada é a que se ocupa } \\
\text { dos factos de duas ou mais linguas comparadas entre si. } \\
\text { (1936, p.14) }\end{array}$ \\
\hline $\begin{array}{l}\text { BRITO, Paulino de Almeida. A } \\
\text { grammatica do professor }(1908) \\
\mathbf{\Omega}\end{array}$ & Obra não consultada. \\
\hline $\begin{array}{l}\text { COSTA, Firmino. Grammatica } \\
\text { portugueza. } \beta\end{array}$ & $\begin{array}{l}\text { O sentido, como parte essencial da palavra, norteará a } \\
\text { organização desta grammatica, e a elle subordinar-se-á a } \\
\text { fórma vocabular. Desprendido assim dos laços, em parte } \\
\text { artificiosos, que ainda cingem os estudos grammaticaes, este } \\
\text { compendio apresentará uma nova feição, tomará caminho } \\
\text { differente do de seus congeneres, pretenderá simplificar e } \\
\text { melhorar o ensino da lingua patria. } \\
\text { O sentido das palavras é representativo ou de uma idéa ou } \\
\text { de uma combinação de ideas. A esta ultima se dá o nome de } \\
\text { juizo, que na linguagem popular equivale a pensamento. } \\
\text { Das expressões das idéas e dos pensamentos por meio da } \\
\text { fala ou da escripta é que trata a grammatica. (1920, p.4) }\end{array}$ \\
\hline $\begin{array}{l}\text { COUTINHO, J. J. de Freitas. } \\
\text { Licções de grammatica } \\
\text { portuguesa. } \beta\end{array}$ & $\begin{array}{l}\text { Grammatica é o conjuncto methodico das regras relativas } \\
\text { ao uso correcto da linguagem. Póde ser geral, descriptiva ou } \\
\text { expositiva, historica, comparativa e historico-comparativa. } \\
\text { GRAMMATICA GERAL é a que procura as regras } \\
\text { referidas, estudando muitas linguas ou um grupo de linguas. } \\
\text { GRAMMATICA DESCRIPTIVA ou EXPOSITIVA é a que } \\
\text { estabelece as regras relativas ao uso correcto de uma } \\
\text { determinada lingua. GRAMMATICA HISTORICA é a que } \\
\text { considera a lingua desde a origem e formação até os tempos } \\
\text { actuaes, GRAMMATICA COMPARATIVA é a que estuda } \\
\text { uma lingua comparando-a com outra ou outras linguas da } \\
\text { mesma familia. A linguagem é o meio que empregamos para } \\
\text { dar a conhecer nossas idéas ou pensamentos. (...) Na } \\
\text { linguagem usamos de palavras e phrases. A PALAVRA é a } \\
\text { expressão de uma idéa. A PHRASE é a expressão de um } \\
\text { pensamento. A phrase de sentido incompleto tem o nome de } \\
\text { LOCUÇÃO, ex.: a menina estudiosa; o livro da menina etc. } \\
\text { A phrase de sentido completo tem o nome de ORAÇÃO, } \\
\text { PROPOSIÇÃO OU SENTENÇA, ex.: a menina é estudiosa; } \\
o \text { livro da menina é util. Tendo a grammatica por fim o } \\
\text { estudo da linguagem e sendo esta a expressão de uma idéa } \\
\text { ou de um pensamento, segue-se d'ahi logicamente a divisão }\end{array}$ \\
\hline
\end{tabular}




\begin{tabular}{|c|c|}
\hline & $\begin{array}{l}\text { da grammatica em duas partes: lexeologia e syntaxe. A } \\
\text { LEXELOGIA estuda isoladamente as palavras como } \\
\text { expressão de uma idéa. A SYNTAXE estuda as palavras } \\
\text { combinadas para a expressão dos pensamentos. (1909, p.7- } \\
\text { 8) }\end{array}$ \\
\hline $\begin{array}{l}\text { COUTINHO, Alfredo Alvares de } \\
\text { Macedo. Gramática portuguesa: } \\
\text { curso elementar. } \beta\end{array}$ & $\begin{array}{l}\text { Gramatica geral é a ciência que ensina os fatos e as leis da } \\
\text { linguagem humana. Gramatica particular é a ciência que } \\
\text { ensina os fatos e as leis de uma única lingua. Gramática } \\
\text { portuguesa é a ciência que ensina os fatos e as leis comuns } \\
\text { à lingua portuguesa. }(1939, \text { p.5) }\end{array}$ \\
\hline $\begin{array}{l}\text { LIMA, Mario Pereira de Souza. } \\
\text { Elementos de gramática (1938) } \\
\mathbf{\Omega}\end{array}$ & Obra não consultada. \\
\hline $\begin{array}{l}\text { PINTO, Alfredo Clemente. } \\
\text { Primeiras noções de } \\
\text { grammatica: } 1^{\circ} \text { curso. } \boldsymbol{\beta}\end{array}$ & $\begin{array}{l}\text { A grammatica nos ensina a falar e a escrever } \\
\text { correctamente, isto é, sem erros. ([19--], p.6) }\end{array}$ \\
\hline $\begin{array}{l}\text { PINTO, Alfredo Clemente. } \\
\text { Primeiro anno de grammatica } \\
\text { por meio de exercicios praticos: } \\
2^{\circ} \text { curso } \beta\end{array}$ & Idem à definição do $1^{\circ}$ curso. ([19--], p.5) \\
\hline $\begin{array}{l}\text { SAMPAIO, B.. Elementos de } \\
\text { gramática portuguesa. } \beta\end{array}$ & $\begin{array}{l}\text { Gramática portuguesa é o conjunto das regras segundo as } \\
\text { quais se fala e escreve a língua portuguesa. Estas regras não } \\
\text { foram inventadas pelos gramáticos. Êles formularam-nas, } \\
\text { depois de ter observado os fatos da linguagem, tais como } \\
\text { esses fatos se apresentam nos escritores notáveis. (1931, p.7) }\end{array}$ \\
\hline $\begin{array}{l}\text { Total de gramáticas em que não } \\
\text { há informações explícitas sobre } \\
\text { o nível de ensino para o qual se } \\
\text { destina }\end{array}$ & 10 obras \\
\hline TOTAL GERAL: & 47 obras \\
\hline
\end{tabular}


QUADRO 3B - O estudo da gramática e suas divisões

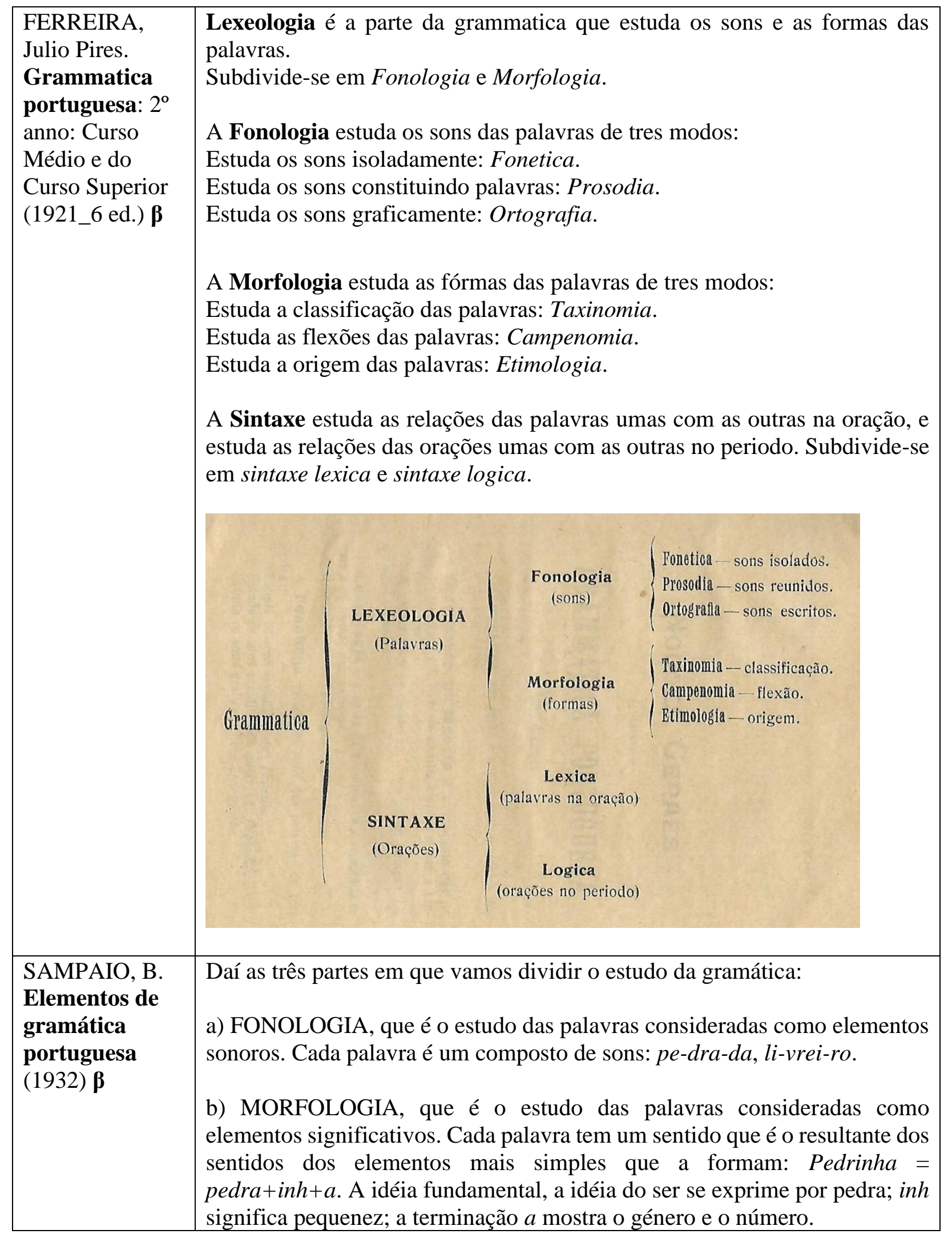




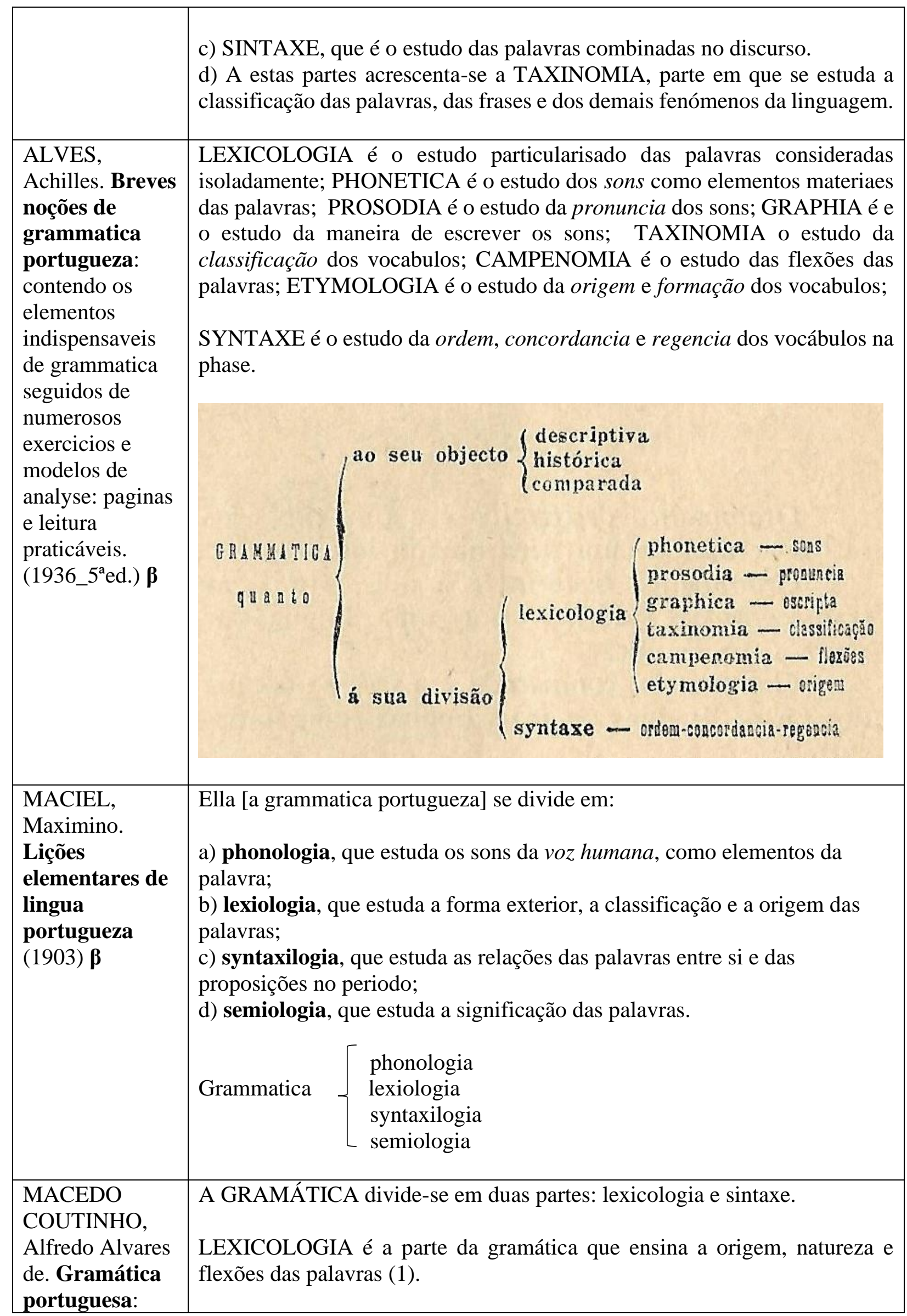




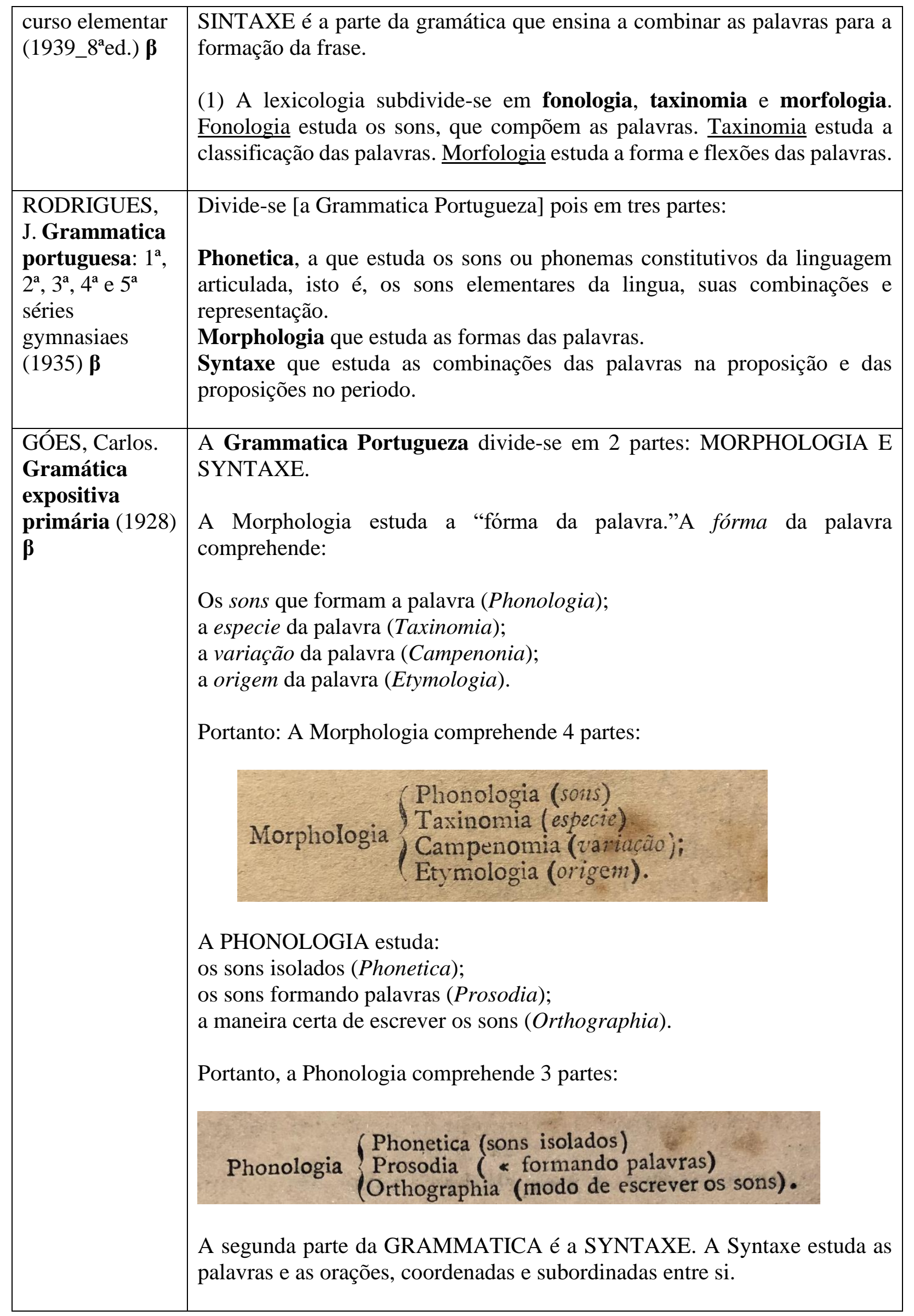




\begin{tabular}{|c|c|}
\hline $\begin{array}{l}\text { FREITAS } \\
\text { COUTINHO, J. } \\
\text { J. de. Licções de } \\
\text { grammatica } \\
\text { portugueza } \\
\text { (1909) } \boldsymbol{\beta}\end{array}$ & 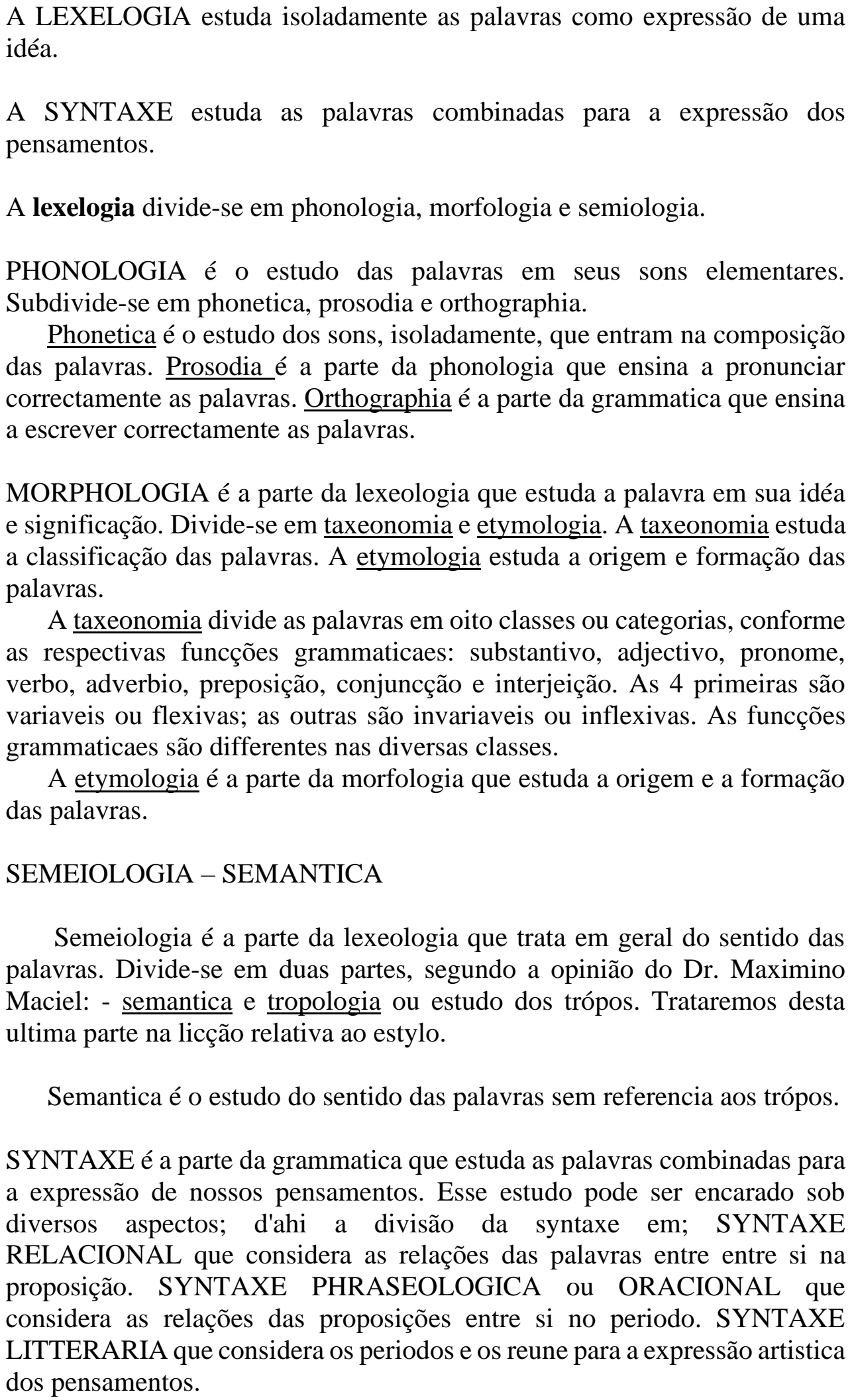 \\
\hline $\begin{array}{l}\text { FERREIRA, } \\
\text { Julio Pires. } \\
\text { Grammatica }\end{array}$ & A gramática se divide em duas partes: LEXIOLOGIA E SINTAXE. \\
\hline
\end{tabular}




\begin{tabular}{|c|c|}
\hline $\begin{array}{l}\text { portuguesa: } \\
\text { para o uso dos } \\
\text { Cursos } \\
\text { Primários (s/d) } \boldsymbol{\beta}\end{array}$ & $\begin{array}{l}\text { Lexiologia é a parte da gramática que trata dos sons e das fórmas das } \\
\text { palavras. Subdivide-se em Fonologia e Morfologia. } \\
\text { Fonologia trata dos sons separados, ou juntos formando palavras, ou } \\
\text { representados na escrita. Na Fonologia estudamos a pronuncia das palavras } \\
\text { e sua escrita correta, isto é, a sua ortografia. } \\
\text { Morfologia trata da classificação, das flexões e da origem das palavras. Na } \\
\text { Morfologia estudamos a conhecer o substantivo; o adjetivo, o verbo, etc., a } \\
\text { formar o gênero; o número, o gráu das palavras e finalmente procuramos } \\
\text { saber de que Lingua elas se derivam. } \\
\text { Sintaxe é a parte da gramática que trata das relações das palavras ou das } \\
\text { orações. Subdivide-se em Léxica e Lógica. } \\
\text { Léxica trata das relações das palavras umas com as outras na oração. } \\
\text { Lógica trata das relações das orações umas com as outras no discurso. }\end{array}$ \\
\hline $\begin{array}{l}\text { PEREIRA, } \\
\text { Eduardo Carlos. } \\
\text { Gramática } \\
\text { expositiva: } \\
\text { curso elementar } \\
\text { (1908) } \boldsymbol{\beta}\end{array}$ & $\begin{array}{l}\text { O estudo da Gramática divide-se em duas partes: a primeira estuda as } \\
\text { palavras em si, isoladamente, e chama-se Lexeologia; a segunda estuda as } \\
\text { palavras combinadas, que formam a frase, e chama-se Sintaxe. } \\
\text { Lexeologia é o estudo das palavras isoladas. Divide-se naturalmente em } \\
\text { duas partes: a primeira estuda as palavras em sua forma material, e chama- } \\
\text { se Fonologia; a segunda estuda as palavras em sua idéia ou elementos } \\
\text { significativos, e se diz Morfologia. } \\
\text { Fonologia é a parte da LEXEOLOGIA que estuda os elementos materiais da } \\
\text { palavra, isto é, os sons elementares da voz humana, representados pelas } \\
\text { letras na palavra escrita. Os sons elementares podem estudar-se ISOLADOS, } \\
\text { COMBINADOS OU FIGURADOS na escrita pelas letras. Daí as três } \\
\text { divisões da } \\
\qquad \begin{array}{l}\text { Fonética } \\
\text { Prosódia } \\
\text { Fonologia Ortografia }\end{array} \\
\text { Fonética é a parte da FONOLOGIA que estuda os sons elementares da voz } \\
\text { humana, chamados sons vocais ou articulados, considerados em si ou } \\
\text { isolados. Êsses sons vocais ou articulados têm o nome de FONEMAS, e são } \\
\text { representados na escrita pelas LETRAS. } \\
\text { Prosódia é a parte da FONOLOGIA que estuda a boa pronúncia das palavras, } \\
\text { bem como os fonemas combinados na sua formação. } \\
\text { Ortografia é a parte da FONOLOGIA que trata da escrituração correta das } \\
\text { palavras. Escrevem-se umas palavras conforme a pronúncia, e a ortografia } \\
\text { se diz, então, SÔNICA OU FONÉTICA, em outras, além da pronúncia, } \\
\text { atende-se à origem, isto é, a sua etimologia ou forma primitiva na lingua } \\
\text { donde elas provêm, e a ortografia, neste caso, se diz ETIMOLÓGICA. É em }\end{array}$ \\
\hline
\end{tabular}




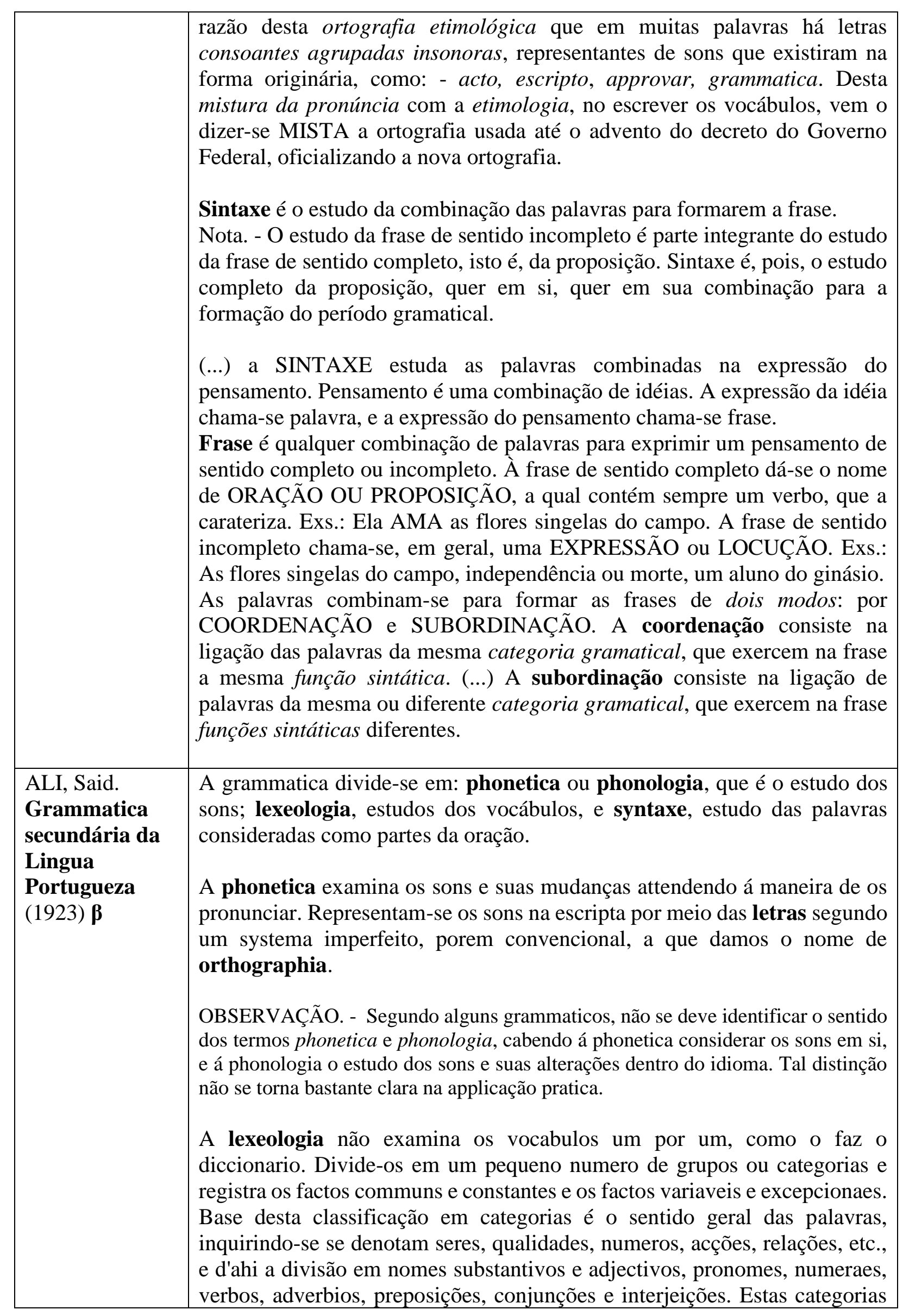




\begin{tabular}{|c|c|}
\hline & $\begin{array}{l}\text { subdividem-se na maior parte em diversas especiaes. Dentro destas } \\
\text { classificações occupa-se a lexeologia da significação quer da parte mais ou } \\
\text { menos estavel do vocabulo, denominada radical.ou thema, quer dos } \\
\text { elementos variaveis, terminações, suffixos e prefixos, tambem chamados } \\
\text { elementos formativos. } \\
\text { OBSERVAÇÃO. - Em virtude da attenção dada aos elementos formativos, } \\
\text { preferem alguns applicar a esta parte da grammatica o nome de morphologia (do } \\
\text { grego morphos, forma, e logos, tratado, sciencia), porem a denominação serve } \\
\text { melhor á grammatica latina ou grega, em que ha mais riqueza de flexões. } \\
\text { Parte complementar da lexeologia é a que trata da formação das palavras } \\
\text { umas das outras por meio da derivação e da composição. O nome de } \\
\text { etymologia que algumas vezes se dá a esta parte da grammatica, só pode ser } \\
\text { entendido em sentido restricto. Por etymologia tambem se entende a } \\
\text { investigação das significações primitivas e a origem de qualquer vocabulo } \\
\text { existente em uma lingua. } \\
\text { A syntaxe considera a oração ou proposição como um todo, e as palavras } \\
\text { que a constituem como termos essenciaes ou secundarios da proposição. O } \\
\text { que em lexeologia e analyse lexica é substantivo, como termo de oração é } \\
\text { sujeito ou objecto; o que lá se classifica como verbo, por denotar acção ou } \\
\text { estado, na oração faz papel de predicado e chama-se predicado; o que num } \\
\text { caso se denomina adjectivo, no outro, attendendo á função oracional, é ou } \\
\text { attributo ou predicado. Não obstante esta palpavel differença entre a } \\
\text { lexeologia e a syntaxe, ha comtudo varios factos grammaticaes cuja } \\
\text { classificação é litigiosa, reinando duvidas entre as maiores summidades da } \\
\text { linguistica sobre se devem vir comprehendidos no estudo dos vocabulos ou } \\
\text { lexeologia, ou se devem fazer parte da syntaxe. }\end{array}$ \\
\hline $\begin{array}{l}\text { CARVALHO, } \\
\text { José Mesquita } \\
\text { de. Gramática } \\
\text { ginasial: para as } \\
\text { quatro séries de } \\
\text { acordo com a } \\
\text { nova } \\
\text { programação de } \\
\text { ensino, e com o } \\
\text { novo } \\
\text { vocabulário } \\
\text { ortográfico } \\
\text { oficial (1945) } \beta\end{array}$ & $\begin{array}{l}\text { LEXEOLOGIA é a parte que estuda os vocábulos, isolados, considerados } \\
\text { entre si, isto é, quanto à forma, à pronunciação, à significação taxeonômica. } \\
\text { A lexeologia subdivide-se em duas partes: } \\
\text { a) a fonologia que estuda os sons elementares da palavra articulada; } \\
\text { b) a morfologia que estuda as categorias gramaticais e suas propriedades em } \\
\text { relação à forma e à idéia; e a origem das palavras. } \\
\text { A fonologia compreende: } \\
\text { a) a fonética que é o estudo dos sons elementares, orais ou articulados, } \\
\text { considerados entre si; } \\
\text { b) a prosódia, o estudo da correta pronunciação dos vocábulos; } \\
\text { c) a ortografia, o estudo sobre o modo correto de se escreverem as palavras, } \\
\text { segundo as regras estipuladas. }\end{array}$ \\
\hline
\end{tabular}


A morfologia compreende:

a) a taxeonomia, o estudo da palavra segundo a categoria gramatical a que pertence, e suas propriedades em relação à idéia;

b) a etimologia que é o estudo da origem e construção das palavras.

SINTAXE é a parte da gramática que estuda as palavras relacionadas para a formação da frase, isto é, a combinação das palavras na oração; a pontuação, a concordância e as particularidades de função das categorias gramaticais, em relação umas com as outras, na frase.

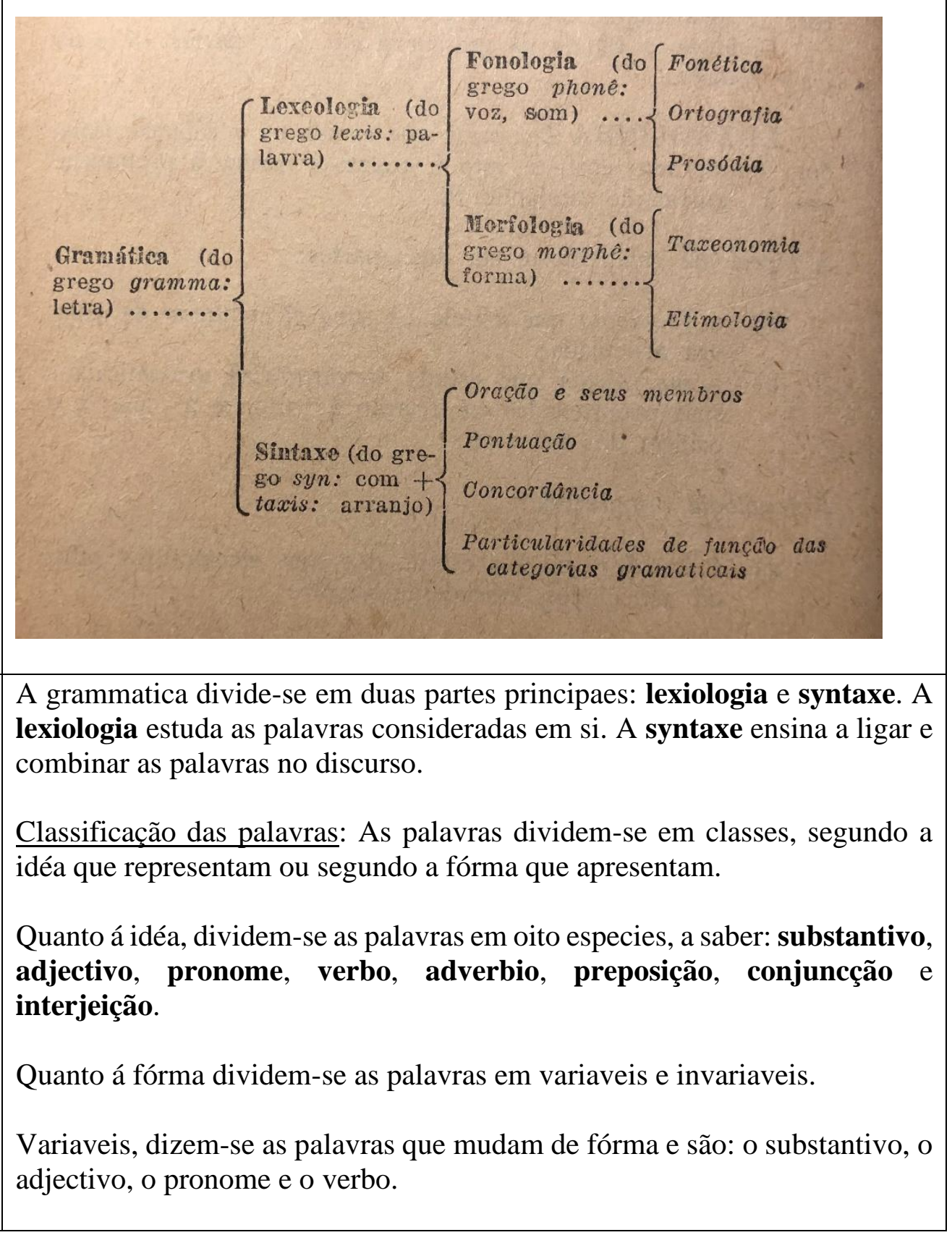

PINTO, Alfredo

Clemente.

Primeiro anno de grammatica por meio de exercicios praticos: $2^{\circ}$ curso (1907) $\boldsymbol{\beta}$
A grammatica divide-se em duas partes principaes: lexiologia e syntaxe. A lexiologia estuda as palavras consideradas em si. A syntaxe ensina a ligar e combinar as palavras no discurso.

Classificação das palavras: As palavras dividem-se em classes, segundo a idéa que representam ou segundo a fórma que apresentam.

Quanto á idéa, dividem-se as palavras em oito especies, a saber: substantivo, adjectivo, pronome, verbo, adverbio, preposição, conjuncção e interjeição.

Quanto á fórma dividem-se as palavras em variaveis e invariaveis.

Variaveis, dizem-se as palavras que mudam de fórma e são: o substantivo, o adjectivo, o pronome e o verbo. 


\begin{tabular}{|c|c|}
\hline & $\begin{array}{l}\text { Invariaveis, as que não mudam de fórma, taes são: o adverbio, a preposição, } \\
\text { a conjuncção e a interjeição. } \\
\text { Nas palavras variaveis é preciso distinguir dous elementos: } \\
\text { a radical e a terminação ou flexão. A radical é o elemento que representa a idea } \\
\text { principal e não muda; a terminação ou flexão é o elemento que varia e indica as } \\
\text { idéas accessorias do genero, numero, modo, tempo, pessoa. Assim, nas palavras } \\
\text { menino, menina, meninos, meninas -; menin é a radical, - o, a , os, as são as } \\
\text { terminações ou flexões de genero e numero; - em amo, amarei, amamos, amava; } \\
\text { am é a radical, e - o, arei , amos , ava são as flexões de modo, tempo, pessoa e } \\
\text { numero. } \\
\text { Syntaxe } \\
\text { Falando ou escrevendo, communicamos aos outros os nossos pensamentos, } \\
\text { os nossos sentimentos, os nossos desejos. Para isso nos servimos não de } \\
\text { palavras soltas, como fazem as crianças que começam a falar, mas de } \\
\text { palavras ligadas umas as outras e combinadas de maneira que formem } \\
\text { sentidos, isto é, orações. As orações por sua vez, nós as ligamos e agrupamo- } \\
\text { las de maneira que formem um tudo completo, a que se dá o nome de periodo } \\
\text { grammatical. A parte da grammatica que nos ensina a ligar e combinar com } \\
\text { clareza e correcção as palavras em orações, e estas em periodos, chama-se } \\
\text { Syntaxe. } \\
\text { Oração ou proposição é uma ou mais palavras que formam um sentido, ex.: } \\
\text { Estudo. Nós estudamos a lição. } \\
\text { Periodo grammatical é uma ou mais orações que formam um sentido } \\
\text { completo. } \\
\text { Exemplo de periodo de uma só oração: } \\
\text { Um avarento perdêrá um saquitel com regular somma de dinheiro em ouro. } \\
\text { exemplo de periodo formado de mais orações: } \\
\text { declarativa, ex.: A terra é redonda. A terra não é chata. } \\
\text { Ou perguntamos alguma cousa, e chama-se oração interrogativa, ex.: Porque } \\
\text { vieste tão tarde? }\end{array}$ \\
\hline $\begin{array}{l}\text { FREITAS, } \\
\text { Gaspar de. } \\
\text { Lições praticas } \\
\text { de grammatica } \\
\text { portugueza: de } \\
\text { accordo com o } \\
\text { exame de }\end{array}$ & \\
\hline
\end{tabular}




\begin{tabular}{|c|c|}
\hline $\begin{array}{l}\text { admissão ao } \\
\text { curso secundário } \\
\text { accrescida de } \\
\text { muitas notas } \\
\text { supplementares } \\
\text { para os alumnos } \\
\text { do } 1^{\circ} \text { anno } \\
\text { gymnasial. } \\
(1952[1927]) \boldsymbol{\beta}\end{array}$ & 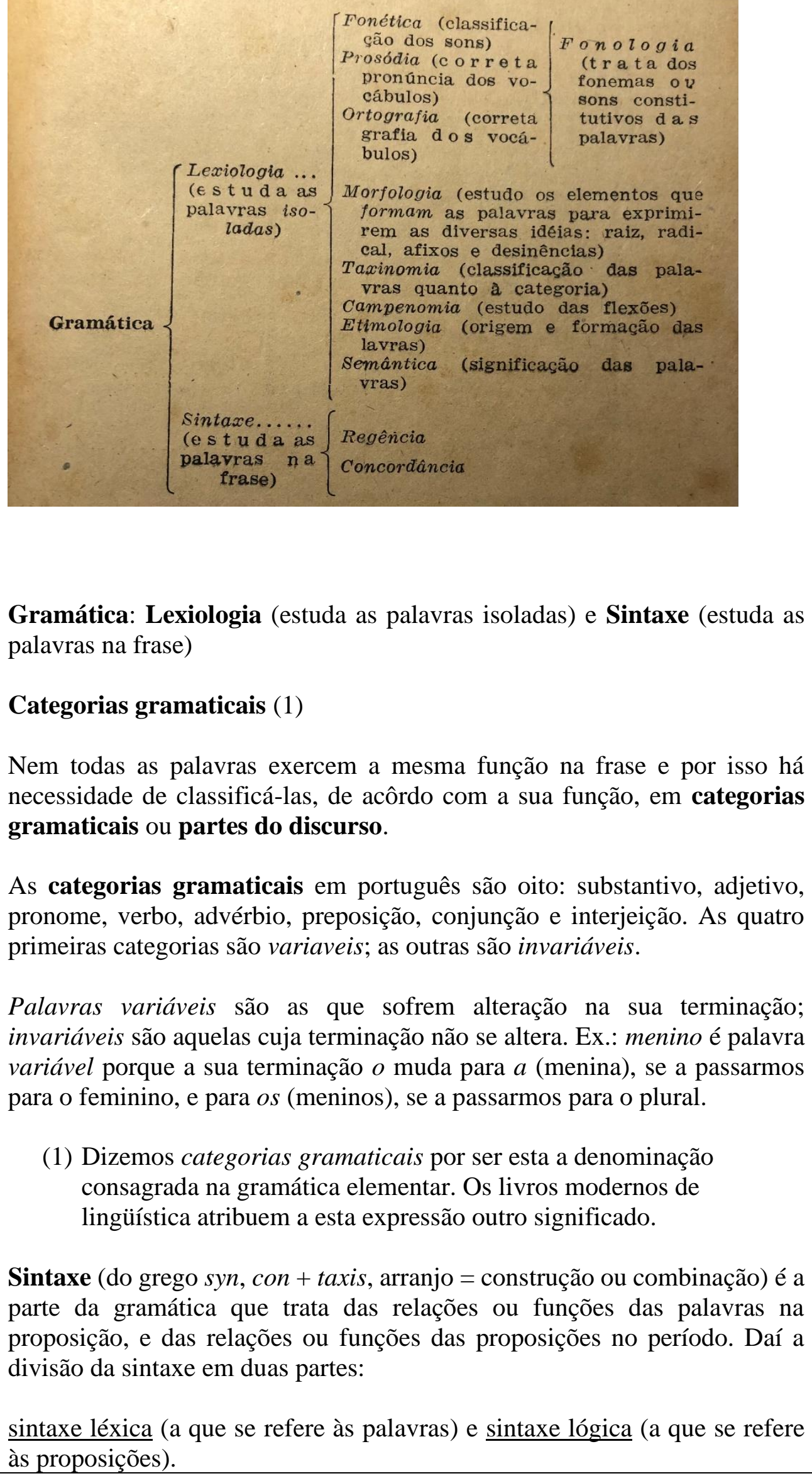 \\
\hline
\end{tabular}




\begin{tabular}{|c|c|}
\hline & $\begin{array}{l}\text { Sintaxe léxica - Proposição e seus elementos } \\
\text { Proposição ou oração é a expressão verbal de um juízo ou pensamento. } \\
\text { Pode ser constituída por uma só palavra (estudava) ou por mais de uma } \\
\text { (quando entraste). Os elementos ou têrmos essenciais de uma proposição são } \\
\text { 2: sujeito e predicado. } \\
\text { Sintaxe lógica - Período e sua divisão } \\
\text { Período é uma proposição ou reunião de proposições que forma sentido } \\
\text { completo e é indicado por um ponto. Se o período consta de uma só oração, } \\
\text { chama-se simples; no caso contrário, é composto. } \\
\text { Para saber quantas proposições há num período, basta verificar quantos } \\
\text { verbos no modo finito (claros ou ocultos) há nesse período; o número de } \\
\text { verbos no modo finito é igual ao número de proposições. }\end{array}$ \\
\hline $\begin{array}{l}\text { VIEIRA, } \\
\text { Verissimo. } \\
\text { Grammatica } \\
\text { portugueza: } \\
\text { curso } \\
\text { preliminar. } \\
\text { (1922) } \boldsymbol{\beta}\end{array}$ & $\begin{array}{l}\text { [O autor não sistematiza como entender ser dividida a gramática. Abaixo } \\
\text { reproduzimos algumas definições coletadas ao longo do texto.] } \\
\text { PARTES VARIAVEIS DA ORAÇÃO - SUBSTANTIVO - ARTIGO - } \\
\text { ADJECTIVO - PRONOME } \\
\text { O professor, como parte preliminar da lição, explicará: que todas as palavras } \\
\text { de que fazemos uso se chamam partes da oração ou partes do discurso; - } \\
\text { que toda phrase terá tantas partes da oração quantas forem as palavras que } \\
\text { nellas houver; - que essas partes da oração constituem nove especies } \\
\text { distinctas de palavras, formando dous grandes grupos: o das palavras } \\
\text { variaveis e o das invariaveis; - mostrará com exemplos pronunciados e } \\
\text { exemplos escriptos, o que vem a ser palavra variavel e palavra invariavel, e } \\
\text { servindo-se de processos os mais praticos possiveis, fará com que os alumnos } \\
\text { estabeleçam por si mesmos a differença entre esses dous grupos de palavras; } \\
\text { e dirá que cinco especies de palavras fazem parte do primeiro grupo, isto é, } \\
\text { do grupo das palavras chamadas variaveis: o substantivo, o artigo, o } \\
\text { adjectivo, o pronome e o verbo, que são as que por ora devem os alumnos } \\
\text { conhecer. Passará depois a formular phrases para o quadro preto, de modo } \\
\text { que nellas se encontre em grande numero a primeira especie de palavras - o } \\
\text { substantivo. } \\
\text { (...) }\end{array}$ \\
\hline
\end{tabular}


com o que já foi exposto (...) essas partes do discurso são chamadas invariaveis, porque não alteram as suas respectivas terminações; e passará então a escrever no quadro preto phrases, em que se encontre com frequencia o adverbio, que elle dirá ser a parte da oração, de que vae tratar.

\section{ESTUDO DAS PROPOSIÇÕES}

As phrases do quadro preto devem ser pouco extensas, consistindo a principio em proposições simples, depois em proposições compostas. Antes, porém de escrever, o professor deverá deixar bem estabelecido para os alumnos: que os juizos são formados por idéas, - as idéas representadas pela falla ou pela escripta chamam-se palavras, - com palavras se póde portanto representar um juizo, - o juizo representado por palavras chama-se proposição.

Os meninos estão no recreio. - O professor acompanha os alumnos. - As meninas correm..Os meninos brincam. - As alumnas saem da aula. (...)

O professor fará ver aos alumnos que as primeiras phrases do quadro preto, constituem cada qual o que se chama uma proposição, representando um juizo. Dirá de novo o que vem a ser juizo (representação de um facto por meio de uma ou mais de uma idéa); e dirá que assim como o juizo se forma por meio das idéas, a proposição se forma por meio das palavras. Demonstrará que o verbo representa um papel muito importante na formação das proposições; - mas que não é qualquer expressão verbal, que para isso serve: é preciso que estteja o verbo em modo finito - no modo indicativo, no condicional, no imperativo, ou no subjunctivo;- e mostrará por meio de exemplos que os verbos no modo infinito ou no participio, não formam proposição, senão caso muito especiaes, de que por ora não convem tratar, e de que só mais tarde serão conhecedores.

Os alumnos serão levados pelo professor a formar proposições com os respectivos verbos em um dos modos finitos citados, tomando como modelo as proposições exaradas no quadro preto.

Quando os meninos estiverem já bastante senhores do assumpto, acerca das proposições simples, o professor entrará na explicação das proposições compostas; - dirá que uma proposição pode ter um só ou mais de um verbo do modo finito; - que a proposição com mais de um verbo do modo finito se chama proposição composta, como por exemplo uma das phrases do quadro preto, onde se encontramos verbos alagou e destruiu. O professor dará exemplos de proposições compostas tendo dous ou mais verbos do modo finito - O menino sahiu e ainda não voltou - proposição composta formada por duas proposições simples: uma, com o verbo sahiu, outra, com o verbo voltou; - em seguida chamará attenção para as demais phrases restantes do quadro preto, e explicará que ellas são sempre formadas de proposições simples, que serão tantas em uma proposição composta, quantos forem os verbos do modo finito, que houver, visto que a cada verbo corresponde uma proposição simples. 


\begin{tabular}{|c|c|}
\hline $\begin{array}{l}\text { VIEIRA, } \\
\text { Verissimo. } \\
\text { Grammatica } \\
\text { portugueza: } \\
\text { curso } \\
\text { complementar } \\
\left(1917 \_2^{\mathrm{a} e d .)} \Sigma\right.\end{array}$ & $\begin{array}{l}\text { Ella [a grammatica portuguesa] se divide em duas partes distinctas: uma - a } \\
\text { Lexiologia - que estudas as palavras consideradas de per si; outra - a } \\
\text { Syntaxe - que estuda as palavras em relação umas com as outras } \\
\text { formando proposições. } \\
\text { As palavras e as proposições com que reproduzimos as idéas e os juízos que } \\
\text { formamos, constituem o objecto da Grammatica. }\end{array}$ \\
\hline $\begin{array}{l}\text { CARREIRO, } \\
\text { Carlos Porto. } \\
\text { Grammatica da } \\
\text { lingua } \\
\text { nacional: } \\
\text { methodo } \\
\text { pratico: segundo } \\
\text { anno. (1918) } \boldsymbol{\beta}\end{array}$ & 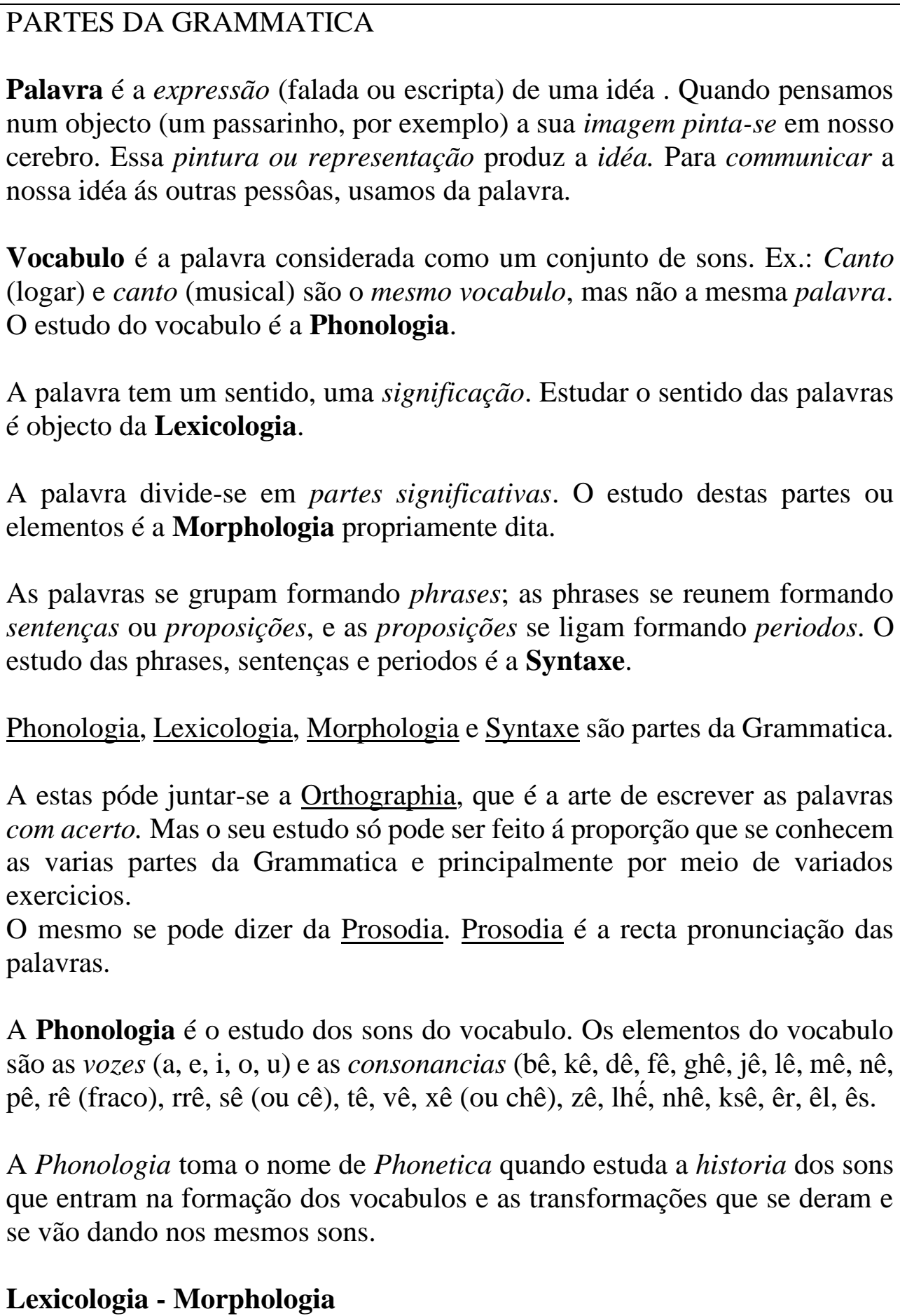 \\
\hline
\end{tabular}


O estudo do Lexico, isto é, o estudo e exame das palavras que formam a lingua é a Lexicologia. Como não é possivel nem necessario o conhecimento de todas as palavras de uma lingua, basta estudar (de modo geral) a origem (Etymologia), a natureza e as propriedades das palavras (Lexicologia), classificando-as em grupos (Taxinomia).

A taxinomia ensina a classificar as palavras segundo a sua natureza e propriedades. Mas este estudo não pode ser separado do estudo das fórmas dos vocabulos, na sua estructura e nos elementos significativos.

A Morphologia é o estudo da palavra nas suas fórmas, na sua estructura, nos seus elementos significativos.

\section{Syntaxe}

As palavras nada significariam isoladas. É preciso que ellas se juntem, se coordenem, se relacionem e constituam grupos separados uns dos outros, mas formando um só sentido geral. É o objecto da Syntaxe.

A Syntaxe é a parte da Grammatica que relaciona, agrupa e subordina as palavras entre si.

O estudo da Syntaxe não pode ser feito em separado do estudo das outras partes: depende do da Morphologia e tem estreita relação com o da Lexicologia.

Taxinomia das palavras é a sua classificação. Para classificar as palavras temos de reunil-as em especies ou categorias conformes com a natureza das idéas que ellas exprimem.

Especies de palavras: Ha oito espécies de palavras: substantivo, adjectivo, pronome, verbo, preposição, adverbio, conjuncção, interjeição.

Radical e terminação: Morphologicamente se distinguem na palavra duas partes significativas essenciaes: uma parte que ordinariamente não muda, e outra parte que muda por natureza.

A parte que não muda é a radical. A parte que póde mudar é a terminação (ou desinencia).

Na radical está a idéa principal expressa pela palavra. Na terminação estão as ideas secundarias que modificam a principal.

Palavras variaveis. Chamam-se palavras variaveis aquellas que podem mudar de terminação, sem mudar de natureza. São variaveis: o substantivo, o pronome, o adjectivo, e o verbo.

Palavras invariaveis. Chamam-se invariaveis as palavras que não podem mudar de terminação, sem perder a sua natureza. São invariaveis: a preposição, o adverbio, a conjuncção e a interjeição. 


\begin{tabular}{|c|c|}
\hline & $\begin{array}{l}\text { Flexões. As mudanças de desinencias são as flexões. (...) O estudo das } \\
\text { flexões chama-se Kampenomia. } \\
\text { Concordancia. As palavras variaveis concordam umas com as outras. Ex.: } \\
\text { O homem honesto vive feliz. Os homens honestos vivem felizes. Nestes } \\
\text { exemplos as palavras o, honesto, vive, feliz concordam com homem; se se } \\
\text { mudar homem em homens, diremos: os, homens, honestos, vivem, felizes; são } \\
\text { palavras variáveis. }\end{array}$ \\
\hline $\begin{array}{l}\text { MORAIS, Bento } \\
\text { Bueno de. A } \\
\text { nossa língua: } \\
\text { Português para } \\
\text { as } 1^{\mathrm{a}} \text { e } 2^{\mathrm{a}} \text { séries } \\
\text { (1944__2 ed.) } \boldsymbol{\beta}\end{array}$ & $\begin{array}{l}\text { NOÇÕES PRELIMINARES - GRAMATICA } \\
\text { Divide-se [a gramática] em duas partes: LEXIOLOGIA E SINTAXE. } \\
\text { A Lexiologia estuda as palavras isoladas e a Sintaxe estuda as palavras } \\
\text { agrupadas formando sentenças. } \\
\text { Gramática }\left\{\begin{array}{l}\text { Lexiologia - palavras isoladas - flor, rã, etc. } \\
\text { Sintaxe - palavras agrupadas - venci grande distância. }\end{array}\right. \\
\text { Fonologia é uma das partes da Lexiologia que estuda as palavras quanto aos } \\
\text { sons de que são constituídas. } \\
\text { Outra parte da Lexiologia é a Morfologia que abrange a Taxionomia, que } \\
\text { estuda as categorias gramaticais e a Etimologia, que estuda a origem das } \\
\text { palavras. } \\
\text { Lexiologia Fonфlogia estuda os sons. } \\
\quad \text { Mołfologia estuda a significação e as formas. } \\
\text { CATEGORIAS DAS PALAVRAS } \\
\text { Há em português, oito categorias de palavras, a saber: substantivo, adjetivo, } \\
\text { pronome, verbo, preposição, conjunção, advérbio e interjeição. E estas } \\
\text { categorias dividem-se em dois grupos: palavras variáveis e palavras } \\
\text { invariáveis. Palavras variáveis são aquelas que podem trocar a sua } \\
\text { terminação: o substantivo, o pronome, o adjetivo e o verbo. Palavras } \\
\text { invariáveis são aquelas que não podem trocar a sua terminação: a preposição, } \\
\text { a conjunção, o advérbio e a interjeição. } \\
\text { período é simples e a oração se diz absoluta e, no segundo caso, o período é } \\
\text { composto. Vê-se portanto que a oração é um sentido parcial, no período } \\
\text { composto. A soma das orações forma o sentido total - o período. } \\
\text { reproduzimos alguns conceitos a ela ligados.] } \\
\text { pensamento em pensamentos parciais que se apresentam como partes }\end{array}$ \\
\hline
\end{tabular}




\begin{tabular}{|c|c|}
\hline & $\begin{array}{l}\text { integrantes do período. Os sinais de pontuação indicam os limites entre as } \\
\text { orações de um período. Pode-se classificar o período em: } \\
\text { a) simples - formado de uma só oração; } \\
\text { b) composto - formado de duas ou mais orações; } \\
\text { e pode ser composto por coordenação - quando as orações são ligadas por } \\
\text { conjunções coordenativas; por subordinação - quando são ligadas por } \\
\text { conjunções subordinativas; e por coordenação e subordinaçâo, ao mesmo } \\
\text { tempo - quando umas orações são coordenadas e outras são subordinadas; } \\
\text { c) lógico - é o sentido completo e não se prende a outro por nenhum nexo; } \\
\text { d) gramatical - é o de sentido incompleto ou prende-se a outro por um } \\
\text { nexo coordenativo. } \\
\text { O período de sentido completo, terminá por um ponto final, interrogação ou } \\
\text { exclamação; o de sentido incompleto termina por reticência, dois pontos } \\
\text { antes de uma interrogação, resposta, citação ou explicação; o de sentido } \\
\text { implícito, quando uma só palavra tem fôrça de uma afirmação, todos os } \\
\text { têrmos reunidos num só. }\end{array}$ \\
\hline $\begin{array}{l}\text { RÉVEILLEAU, } \\
\text { A. A prova de } \\
\text { Português na } \\
\text { Escola Militar } \\
\text { ou gramatica } \\
\text { mixta da } \\
\text { Lingua } \\
\text { Portuguêsa: } \\
\text { livro destinado a } \\
\text { qualquer série } \\
\text { ginasial de } \\
\text { Português } \\
\text { (1938) } \beta\end{array}$ & 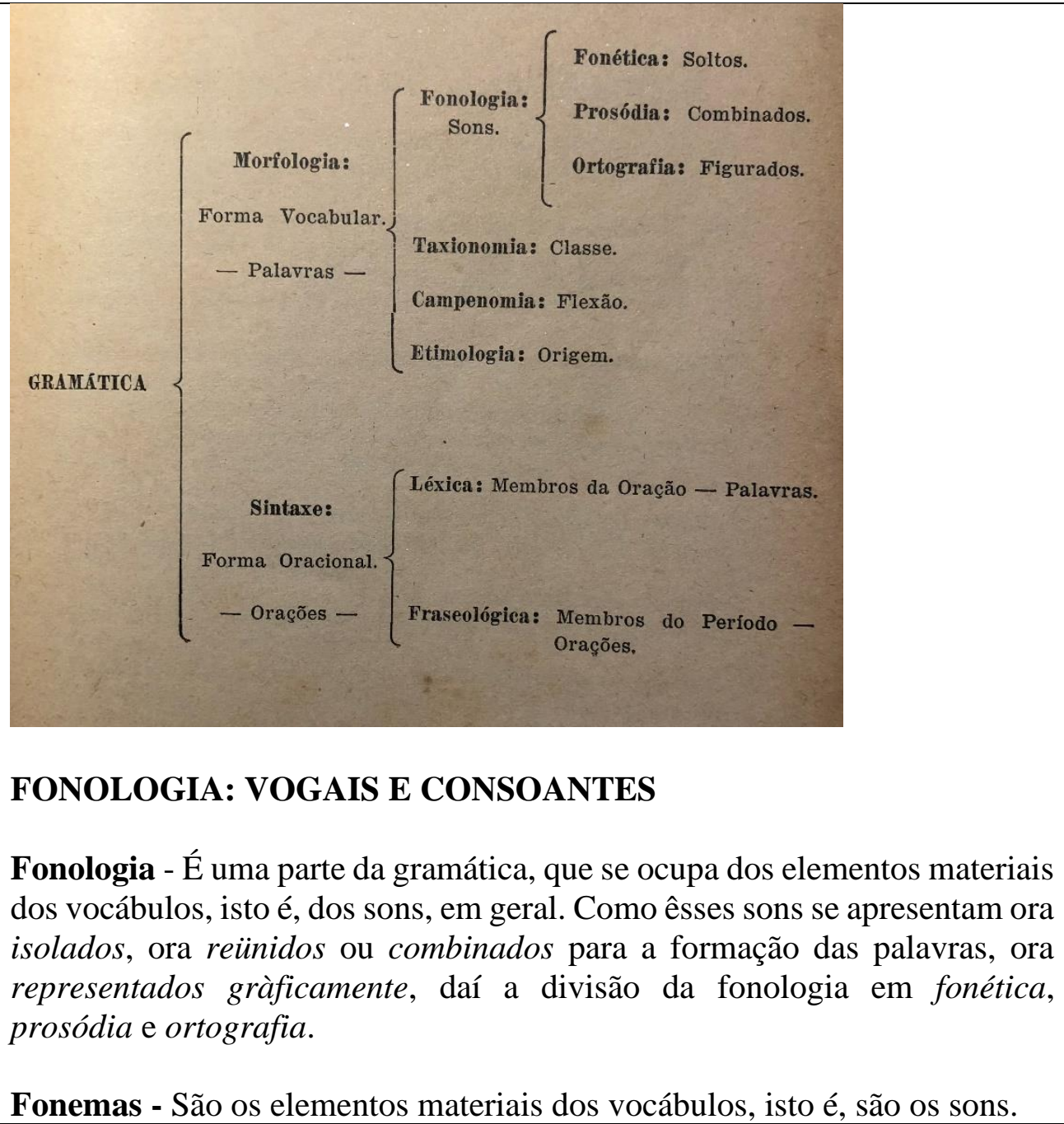 \\
\hline
\end{tabular}


Aos fonemas também chamam sons ou vozes. Os representantes dos fonemas são as letras, os quais se dividem em vozes puras e articuladas.

[Não localizamos uma definição para Prosódia]

Ortografia - É uma parte da fonologia que ensina a escrita correta dos vocábulos.

\section{CATEGORIAS GRAMATICAIS}

Categoria - É denominação pertencente à lógica e que exprime uma classe de pensamento, um grupo de idéias, segundo João Ribeiro. São sete as categorias gramaticais, chamadas partes do discurso: substantivo, adjetivo, pronome, verbo, advérbio, preposição, conjunção.

Constituem estas partes dois grandes grupos: o das palavras variáveis, inflexas, flexíveis ou de flexão, e o das palavras invariáveis, ininflexas, inflexíveis ou sem flexão.

São variáveis: substantivo, adjetivo, pronome e verbo; são invariáveis: advérbio, preposição, conjunção.

A parte da morfologia que se ocupa da classificação das palavras, segundo a idéia que elas indicam, é denominada taxinomia.

Notas e Observações

Varia muito, entre os gramáticos, o número das chamadas partes da oração. Autores há que contam dez categorias, com inclusão do artigo e do particípio; outros não incluem a interjeição; finalmente, outros as reduzem. A. Darmesteter, por exemplo, diz que "l'interjection n'est pas un mot et n'appartient pas, en realité, aux parties du discours; c'est un cri exprimant d'une façon vague un sentiment plus ou moins vif."

Adotei sete espécies, arrolando o artigo entre os adjetivos determinativos, e o particípio, entre o verbo.

Campenomia - Ptoseonomia - Flexeologia ou Flexionismo --- É a parte da gramática referente à flexão das palavras.

Flexão - É a variante das palavras, com as quais se exprimem as idéias acessórias de gênero, número, grau, pessoa, tempo, modo. Seis são, pois, as flexões, chamadas genérica, numérica, gradativa, pessoal, temporal, modal.

A flexão é nominal ou verbal.

Flexões Nominais - São as que dizem respeito ao gênero, número, grau. Flexões Verbais São as que se relacionam ao verbo.

Podem as palavras ser, quanto à mudança de terminação, variáveis ou inflexas e invariáveis ou ininflexas. 
São flexivas: substantivo, adjetivo, pronome, verbo; são inflexivas: advérbio, preposição, conjunção, interjeição.

As palavras variáveis são, também, chamadas orgânicas, sendo reservado o nome inorgânicas às invariáveis.

Flexão verbal: Para indicação do tempo, modo, número, pessoa, apresenta o verbo várias modificações acidentais, sendo das palavras de flexão a que maior número de variações tem. Pode o verbo apresentar, ainda, alteração referente ao gênero. Cinco são, portanto, as flexões verbais: temporal, modal, numeral, pessoal, genérica.

Etimologia - É o estudo histórico da palavra: origem e formação.

\section{FUNÇÕES DAS PALAVRAS OU EXPRESSÕES NO ORGANISMO DA PROPOSIÇÃO}

Função - É o ofício que a palavra desempenha em a sentença. No seio da proposição, pode a palavra ter função léxica e sintática.

Sabemos que o papel sintático, representado pela palavra na oração, diz respeito ao sujeito, predicado, complemento, atributo, restrição $e$ circunstância.

Há, pois, as seguintes funções ou relações:

1.a Subjetiva ou de Sujeito.

2.a Predicativa ou de Predicado.

3.a Objetiva ou Completiva ou de Objeto ou Complemento.

4.a Atributiva ou de Adjunto Atributivo.

5.a Restritiva ou de Adjunto Restritivo.

6.a Circunstancial ou de Adjunto Circunstancial.

A função completiva essencial comprende o complemento direto, o indireto, $o$ predicativo e o terminativo, porque são complementos secundários os apresentados sob a denominação de adjuntos.

\section{SINTAXE DE REGÊNCIA}

Regência - É um capítulo da sintaxe que se ocupa das relações de dependência mantidas entre elementos. Nessas relações de determinação há subordinação, porque certas palavras são completadas por outras. Sob êste ponto de vista, são as palavras regentes, subordinantes ou modificadas e regidas subordinadas ou modificadoras.

\section{SINTAXE DE CONSTRUÇÃO}

(...) é um capítulo da gramática, onde se estuda a maneira de colocar os termos proposicionais. 
[Não localizamos uma definição explícita para a sintaxe de concordância, mas reproduzimos a definição dada para o processo de concordância.]

Concordância - É a correspondência de flexões, existente entre palavras que se relacionam. Assim, se empregarmos a palavra homem e um adjetivo que com ela mantenha relação sintática, é claro que haverá identidade de flexões: o adjetivo tomará o gênero e o número do substantivo:

Homem alto - Homens altos.

Se a palavra usada fôr verbo, este se apresentará de forma que esteja de acôrdo com a pessoa e o número do sujeito:

Êle chega hoje.

Regra Geral - O adjetivo concorda em gênero e número com o substantivo a que se refere:

"Naturalmente escreverás dez linhas sinceras da minha necrologia" (C. C. Branco).

Observação - Há duas espécies de concordância: a nominal e a verbal.

Aquela compreende o adjetivo, o substantivo adjetivado, o pronome e o particípio. É evidente abranger a concordância só as palavras que se podem flexionar. Ora, há adjetivos uniformes, pronomes invariáveis, substantivos de forma só masculina ou feminina, assim como nem sempre o particípio passado é aplicado com função atributiva.

\section{BRITO} PEREIRA,

Carlos de.

Manual de gramática portuguesa (1933) $\boldsymbol{\beta}$
Divide-se a gramática em três partes: fonologia, morfologia e sintaxe.

A divisão clássica é a de Jerônimo Soares Barbosa: ortoépia, ortografia, etimologia e sintaxe. Daí para cá tem variado os gramaticógrafos, embora nem todos quanto ao número de partes, mas quasi todos quanto ao nome e ordem de cada uma, e à matéria, que estudam. A melhor divisão, porem, é a tripartida fonologia, morfologia e sintaxe - de Frederico Diez, MeyerLübke, Epifanio Dias e Hemetério dos Santos, porque consulta perfeitamente às três partes distintas do discurso: o som, a palavra e a combinação de palavras.

Fonologia é a parte da gramática que trata dos sons.

Morfologia é a parte da gramática que se ocupa das palavras em si, ou isoladamente.

Sintaxe é a parte da gramática que tem por objeto as palavras relacionadas umas com as outras, para a expressão do pensamento.

Subdivide-se a fonologia em três partes: fonética, prosódia e ortografia.

Fonética é o estudo dos fonemas. 
Prosódia ou ortoepia é o estudo da pronúncia dos sons.

Ortografia é o estudo da escrita dos sons.

Subdivide-se a morfologia em três partes: taxinomia, camptologia e tematologia.

Taxinomia e o estudo da classificação das palavras.

Camptologia, campenomia ou flexionismo é o estudo da flexão das palavras.

Tematologia é o estudo da formação das palavras no seio da língua, pelos processos vernáculos da derivação e da composição.

Quando se tratar de gramática histórica, a tematologia tomará o nome de etimologia, que é o estudo da origem e desenvolvimento do léxico.

A sintaxe compreende a regência, a concordância e a colocação ou ordem dos termos da oração.

\section{DA ORAÇÃO E SEUS TERMOS}

Oração é uma ou mais palavras com que enunciamos uma afirmação. Toda oração há-de conter um verbo, claro ou oculto. A oração consta de três termos: sujeito, predicado e complemento.

Denominam-se os dois primeiros termos essenciais e o último, termo acessório. Embora considerado termo essencial, pode o sujeito deixar de existir, quando o verbo é impessoal. Ex.: Chove. Faz calor.

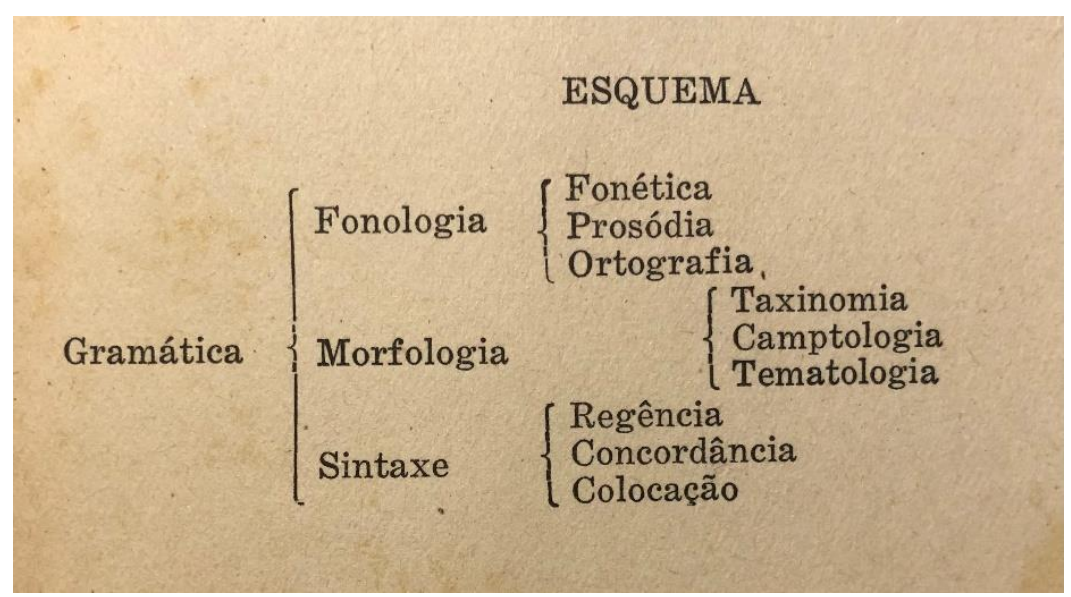

Taxinomia é a parte da morfologia que trata da classificação das palavras.

A classificação mais importante das palavras é a que toma por base a idéia. Quanto à idéia, classificam-se as palavras em oito espécies ou categorias: substantivo, adjetivo, pronome, verbo, advérbio, preposição, conjunção e interjeição. 


\begin{tabular}{|c|c|}
\hline & $\begin{array}{l}\text { Os gramáticos antigos mencionavam dez categorias gramaticais, acrescentando às } \\
\text { atuais o artigo e o particípio, incluidos agora na classe dos adjetivos. } \\
\text { Quanto à flexão, dividem-se as categorias. gramaticais em variaveis e } \\
\text { invariaveis. Variaveis são as que mudam de terminação: substantivo, } \\
\text { adjetivo, pronome e verbo. Invariaveis são as que não sofrem mudança na } \\
\text { terminação: advérbio, preposição, conjunção e interjeição. } \\
\text { Quanto à formação, classificam-se as palavras em primitivas e derivadas, } \\
\text { simples e compostas. }\end{array}$ \\
\hline $\begin{array}{l}\text { ANDRADE, } \\
\text { Gustavo de. } \\
\text { Grammatica } \\
\text { intuitiva da } \\
\text { Lingua } \\
\text { Portugueza: } \\
\text { elementar } \\
\text { (1911_1 } 1^{\mathrm{a} e d .)} \boldsymbol{\beta}\end{array}$ & $\begin{array}{l}\text { A grammatica portuguesa divide-se em lexiogia e syntaxe. } \\
\text { Lexilogia é a parte da grammatica que estuda as palavras, com relação aos } \\
\text { seus elementos materiaes. A lexilogia divide-se em: phonologia e } \\
\text { morphologia. } \\
\text { Phonologia é a parte da lexilogia que estuda os sons ou os signaes contidos } \\
\text { na palavra. A phonologia divide-se em: phonetica, phonografia, orthophonia } \\
\text { (2) e ortographia. } \\
\text { (2) O Termo orthophonia é mais expressivo do que prosodia erthoepia: a prosódia } \\
\text { abrange as linguas mortas; a orthoepia as lingua vivas, ao passo que a orthophonia } \\
\text { abrange as duas. } \\
\text { Phonetica é a parte da phonologia que estuda os sons ou phonemas. } \\
\text { Phonographia é a parte da phonologia que estuda as letras e os signaes } \\
\text { diacriticos. } \\
\text { Orthophonia é a parte da phonologia que estuda a bôa pronuncia das } \\
\text { palavras. } \\
\text { Orthographia é a parte da phonologia que ensina o modo convencional de } \\
\text { bem escrever as palavras. } \\
\text { Morphologia é a parte da lexiologia que estuda as palavras em grupos e os } \\
\text { seus elementos componentes. } \\
\text { A morphologia divide-se em taxinomia e campenomia. } \\
\text { TAXINOMIA } \\
\text { Taxinomia é a parte dá morphologia que estuda a classificação das palavras. } \\
\text { A taxinomia classifica as palavras em oito grupos ou categorias } \\
\text { grammaticaes: substantivos, adjectivos, pronomes, verbos; preposições, } \\
\text { adverbios, conjuncções e interjeições. } \\
\text { Destas, quatro são variaveis : substantivos, adjectivos, pronomes, verbos; } \\
\text { substantivo e adjectivo são variaveis em: genero, numero e grao; o pronome } \\
\text { em: genero, numero, pessôa e caso; o verbo em: modo, tempo, numero e } \\
\text { pessôa. }\end{array}$ \\
\hline
\end{tabular}


CAMPENOMIA

Campenomia é a parte da morphologia que estuda as flexões das palavras. Flexão é a variação por que passam as palavras para exprimir os seus diversos accidentes. Toda palavra consta de duas partes distinctas: radical e affixos.

Quando o elemento indica o genero, numero, gráo, modo e tempo, chama-se - flexão.

A flexão é nominal ou verbal.

Flexão nomimal é a que exprime os accidentes do substantivo e do adjectivo.

A flexão do substantivo e do adjectivo é de genero, numero e gráo.

Flexão verbal é a propriedade que têm os verbos de designar o modo, o tempo, o numero e a pessôa.

Syntaxe é a parte da grammatica que estuda as palavras relacionadas entre si, formando orações e periodos. A syntaxe divide-se em oracional, relacional, de concordancia, de regencia e de collocação ou construccão.

Syntaxe oracional é a que estuda a oração e os seus termos constitutivos.

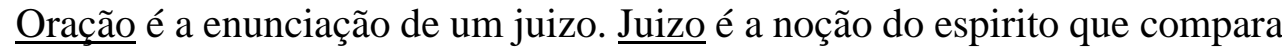
os sujeito com o predicado.

Dois são, portanto, os termos essenciaes da oração: sujeito e predicado.

Syntaxe relacional é a conformidade que palavras guardam entre si. São oito estas relações:

a) Relação subjectiva é a do sujeito para com o predicado: Fundeou o vapor.

b) Relação predicativa é a do verbo para com o sujeito: Fundeou o vapor.

c) Relação objectiva é a do objecto directo ou indirecto para com o verbo de acção transitiva: O menino colheu flores e fructas; Necessito de repouso.

d) Relação nominal é a do objecto indirecto para com o substantivo ou adjectivo: Fidelidade á religião; Dependente de um emprego.

e) Relação adverbial é a do adverbio ou palavras equivalentes para com aquella que modificam: Não vou hoje; espere-me no sabbado.

f ) Relação attributiva é a do adjectivo ou palavras equivalentes para com o substantivo que modificam: Mulher de caprichos.

g) Relação appositiva é a do apposto para com o substantivo fundamental: "A Bahia, heroina de seios titanicos".

h) Relação compellativa é a do vocativo para com a pessôa que fala: $\mathrm{Meu}$ Deus! onde a vossa justiça!

\section{Syntaxe de concordância}

Concordancia é a juxteza flexional que as palavras devem ter entre si. Duas são as concordancias: nominal e verbal.

Concordancia nominal é a juxteza flexional entre o adjectivo e o substantivo. 


\begin{tabular}{|c|c|}
\hline & $\begin{array}{l}\text { Concordancia verbal é a juxteza pessoal e numerica entre o verbo e o } \\
\text { sujeito da oração, ex.: Vós mereceis um premio. O verbo concorda com o } \\
\text { sujeito em numero e pessôa. } \\
\text { Syntaxe de regencia é a dependencia subordinante ou subordinada que } \\
\text { relaciona as palavras entre si. As palavras, quanto á regencia, são: } \\
\text { subordinantes ou regentes e subordinadas ou regidas. } \\
\text { Subordinantes ou regentes são as que exigem outra para lhes integrar o } \\
\text { sentido, ex.: Amigo da pátria. } \\
\text { Subordinadas ou regidas são as que integram o sentido de outras, ex.: } \\
\text { Amigo da Patria. } \\
\text { As palavras regentes têm significação transitiva, significação relativa ou } \\
\text { significação absoluta. } \\
\text { Syntaxe de collocação é a que se ocupa do logar ou ordem das palavras, bem } \\
\text { como dos termos ou das orações entre si. Ha tres ordens: directa ou } \\
\text { analytica, interpolada ou interrupta e inversa ou synthetica. }\end{array}$ \\
\hline $\begin{array}{l}\text { COSTA, } \\
\text { Firmino. } \\
\text { Grammatica } \\
\text { portugueza } \\
(1920) \boldsymbol{\beta}\end{array}$ & $\begin{array}{l}\text { Considerando a proposição como a construcção do pensamento, serão seus } \\
\text { materiaes as palavras, as locuções e clausulas. São estas as expressões das } \\
\text { idéas, assim como proposição é a expressão do pensamento. } \\
\text { Divide-se a grammatica em duas partes: a lexiologia, que é o estudo das } \\
\text { palavras, locuções e clausulas; a syntaxe, que trata das proposições. Uma das } \\
\text { divisões da lexiologia é a taxinomia, que tem por objecto classificar as } \\
\text { expressões das ideas. } \\
\text { Passando a tratar da taxinomia, classificaremos as palavras, as locuções e as } \\
\text { clausulas com relação à sua qualidade principal, isto é, o sentido, e com } \\
\text { referencia ao numero singular, que deve ser considerado como o } \\
\text { denominativo das expressões. } \\
\text { Taxinomia } \\
\text { Estudando as palavras como expressões de idéas, podemos classifical-as em } \\
\text { seis categorias, assim denominadas: substantivo, adjectivo, verbo, adverbio, } \\
\text { connectivo e contraccão, sendo esta ultima apenas uma combinação de } \\
\text { palavras. } \\
\text { Syntaxe } \\
\text { Construir ou compor periodos, desmanchar ou decompor periodos, para bem } \\
\text { comprehendel-os e estudal-os, taes os fins a que se propõe a syntaxe. Ao } \\
\text { primeiro trabalho dá-se o nome de composição; ao segundo, em vez de } \\
\text { decomposição, desde muito convencionou-se denominal-o analyse. A } \\
\text { composição considera os periodos no seu todo, e a analyse os considera em } \\
\text { seus elementos. } \\
\text { Dividiremos, pois, a syntaxe em duas partes: composição e analyse. } \\
\text { (...) } \\
\text { A ANALYSE }\end{array}$ \\
\hline
\end{tabular}




\begin{tabular}{|c|c|}
\hline & $\begin{array}{l}\text { Analyse é o estudo das partes componentes do periodo. Pelo termo periodo } \\
\text { designam-se uma ou mais proposições, que quasi sempre terminam pelo } \\
\text { ponto final. Periodo equivale a proposição, uma ou mais. Estude-se, pois, a } \\
\text { proposição, que assim ter-se-á adeantado o estudo do periodo. A proposição } \\
\text { exprime o pensamento, e este, no sentido aqui usado, nada mais é do que a } \\
\text { affirmação de alguma cousa a respeito de um ser. Dahi ter a proposição dois } \\
\text { elementos: a cousa que se affirma; o ser de que se affirma alguma cousa. } \\
\text { Nesta proposição Tiradentes sacrificou-se pela Patria, aquillo que } \\
\text { affirmamos é sacrificou-se pela Patria, e a pessoa de quem affirmamos esse } \\
\text { heroismo é Tiradentes. O que representa o ser, de quem affirmamos alguma } \\
\text { cousa, chama-se sujeito; aquillo que se affirma do sujeito denomina-se } \\
\text { predicado. Tiradentes, sujeito da proposição; sacrificou-se pela Pátria, } \\
\text { predicado. Sujeito e predicado são, portanto, os dois elementos da } \\
\text { proposição. } \\
\text { (...) } \\
\text { Temos, pois, de uma parte os materiaes da construcção, e de outra parte as } \\
\text { peças da mesma. A analyse destas chama-se analyse logica, e a analyse } \\
\text { daquelles, analyse lexica. A analyse logica é concernente ao predicado, ao } \\
\text { sujeito e aos adjunctos; a analyse lexica é referente ás palavras, ás locuções } \\
\text { e ás clausulas. }\end{array}$ \\
\hline $\begin{array}{l}\text { ABREU, } \\
\text { Modesto. } \\
\text { Idioma pátrio: } \\
\text { volume } 3^{280} \text { : } \\
\text { gramática } \\
\text { expositiva e } \\
\text { histórica; noções } \\
\text { de estilística e } \\
\text { literatura (1944) } \\
\boldsymbol{\beta}\end{array}$ & $\begin{array}{l}\text { A Gramática Expositiva divide-se em: } \\
\text { a) Lexiologia, que considera as palavras isoladamente; } \\
\text { b) Sintaxiologia, que trata das funções que as palavras exercem no discurso. } \\
\text { SUBDIVISÕES } \\
\text { Da Lexiologia: } \\
\text { 1. Fonologia, que trata dos fatos referentes ao som, à voz humana, à formação } \\
\text { e representação dos vocábulos. — Consta de três partes: a) Fonética, que } \\
\text { estuda a formação dos diferentes fonemas; b) Prosódia ou fonoepia, que } \\
\text { regula a pronúncia dos vocábulos; - c) Ortografia, que ensina a grafar os } \\
\text { vocábulos corretamente. } \\
\text { 2. Morfologia, que estuda a formação das palavras. } \\
\text { 3. Campenomia, que se ocupa das flexões sofridas pelas palavras variáveis. } \\
\text { 4. Etimologia, que investiga a origem das palavras. }\end{array}$ \\
\hline
\end{tabular}

\footnotetext{
${ }^{280}$ Esta obra é uma gramática ao estilo “dois em um”. Na primeira parte, é uma gramática expositiva tradicional e, na segunda, uma gramática histórica. Já que temos duas obras autônomas, que estão reunidas apenas fisicamente, consideramos, nesta tese, essas duas gramáticas isoladamente. Quando formos falar das gramáticas históricas, no capítulo 4, retornaremos a ela. Parece-nos que tal junção é justificada por questões comerciais. Antes composta por 5 volumes, a coleção Idioma pátrio passou a ser formada por 3 tomos. Nesse novo formato, os volumes 1 e 2 têm como conteúdo apenas seleta literária. Assim, o terceiro e último volume apresenta os tópicos faltantes exigidos pelos programas de ensino do Secundário, ou seja, a gramática expositiva, a gramática histórica e as noções de estilística e literatura. Eliminar 2 volumes da coleção parece ser uma estratégia comercial mais atrativa, uma vez que tal supressão torna a coleção mais compacta e barata, estimulando, assim, sua adoção nas escolas secundárias da época.
} 


\begin{tabular}{|c|c|}
\hline & $\begin{array}{l}\text { 5. Semasiologia, que explica a significação das palavras, bem como as } \\
\text { alterações do sentido delas. } \\
\text { 6. Taxionomia, que classifica as palavras de acórdo com a natureza de suas } \\
\text { funções na frase, constituindo as "categorias gramaticais". } \\
\text { Da Sintaxiologia: } \\
\text { 1. Sintaxe de concordância, que se ocupa das mudanças de flexão de } \\
\text { umas palavras com relação a outras de que dependem } \\
\text { 2. } \frac{\text { Sintaxe de regência, que se ocupa da interdependência das palavras }}{\text { no discurso. }} \\
\text { 3. } \frac{\text { Sintaxe de construção, que cuida do modo de formar as frases e da }}{\text { posição que nelas devem as palavras ocupar. - Toma também os }} \\
\text { nomes de ordem ou colocação. } \\
\text { 4. Sintaxe relacional, que trata das funções das palavras na oração, } \\
\text { proposição ou frase (período "simples"). } \\
\text { 5. Sintaxe fraseológica, que trata das relações das orações ou } \\
\text { proposições entre si, no período (período "composto"). } \\
\text { 6. Sintaxe literária, ou estilística, que trata dos casos de sintaxe } \\
\text { irregular, não-lógica, afetiva ou psicológica. }\end{array}$ \\
\hline OBSERVAÇÃO & $\begin{array}{l}\text { Em nosso levantamento, há autores que possuem duas gramáticas, como } \\
\text { aquelas divididas em elementar e superior. Nesta tabela, sempre que } \\
\text { percebemos não haver diferenças significativas quanto às definições aqui } \\
\text { reproduzidas, optamos por incluir apenas uma das gramáticas. Estão nessa } \\
\text { situação os seguintes autores: Eduardo Carlos Pereira, Said Ali e Alfredo } \\
\text { Clemente Pinto. }\end{array}$ \\
\hline
\end{tabular}




\section{QUADRO 4B - Obras escolares de temas gramaticais específicos}

\begin{tabular}{|c|c|}
\hline $\begin{array}{l}\text { ALBUQUERQUE, } \\
\text { Acir }{ }^{281} \text { Tenorio de }\end{array}$ & 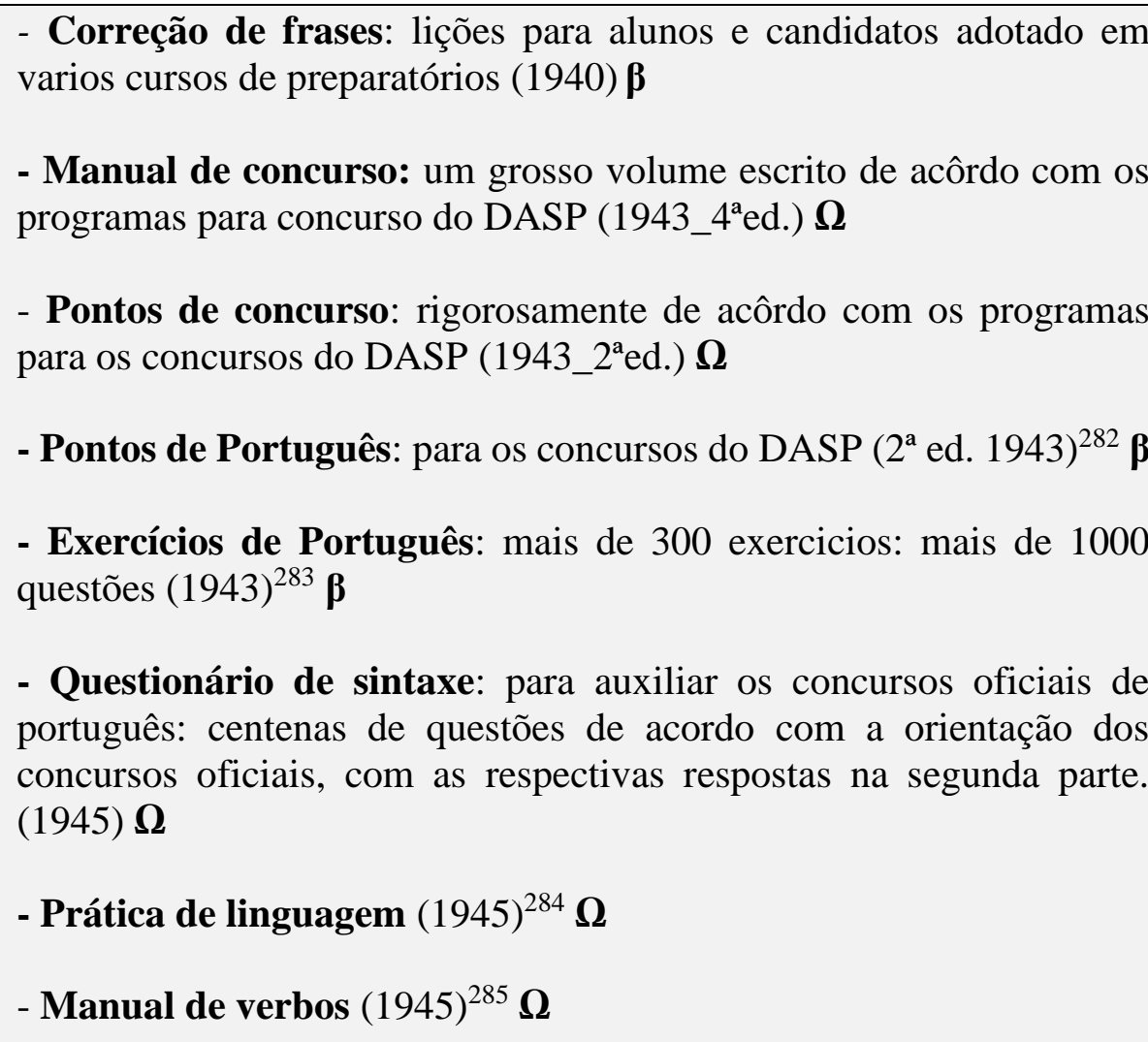 \\
\hline $\begin{array}{l}\text { ANDRADE, } \\
\text { Gustavo de }{ }^{286}\end{array}$ & $\begin{array}{l}\text { - Extixologia ou pontuação: impresso especialmente para uso dos } \\
\text { alunos da escola comercial da Bahia (1912) } \boldsymbol{\Omega}\end{array}$ \\
\hline
\end{tabular}

${ }^{281}$ Há registros também de seu primeiro nome grafado como Arcy.

${ }^{282}$ A Biblioteca Nacional do Rio de Janeiro (doravante BNRJ) possui um volume, com data provável de 1941, com o seguinte subtítulo: "português, matemática, corografia, estatística, direito civil, constitucional, administrativo, contabilidade e escrituração mercantil".

${ }^{283} \mathrm{Na} 4^{\mathrm{a}}$ edição, publicada em 1952, o subtítulo da obra é alterado para: "500 questões objetivas sôbre programas de concursos: orientação para avaliação de provas: treino para provas de concursos: diversas provas dadas em concursos do DASP".

${ }^{284}$ Não conseguimos verificar o subtítulo dessa edição, mas consta na BNRJ um volume, com data provável de 1948, com o seguinte subtítulo: "explicações, dezenas de verbos, concordância, pontuação, questões gramaticais: para os concursos do DASP e cursos preparatórios".

${ }^{285}$ Em uma outra obra do autor, provavelmente da década de 1950, no final do livro, consta a seguinte informação: "A parte da gramática em que o estudante encontra maiores dificuldades é, certamente, a que trata dos verbos. Manual de verbos foi escrito para auxiliar o estudante no seguro e pormenorizado estudo dos verbos, sem dúvida uma das mais importantes partes da gramática".

${ }^{286}$ Nos anexos à Grammatica ecletica, obra que foi publicada postumamente, foram reunidas manifestações a respeito da morte de Gustavo de Andrade. Emygdio H. Souza, em texto publicado no Diario da Bahia, em 24/11/1914, diz: "Deixou alguns livros didacticos, dentre os quaes se destacam a - Grammatica intuitiva e as Cacolexias -, sendo este ultimo de grande utilidade não só para os estudiosos, mas tambem para todos os que falam a bella lingua de Camões porque contem a maioria dos vocabulos que por sua má ortographia prosódica e pela sua descendencia, enfermam e infestam a lingua portugueza." 


\begin{tabular}{|c|c|}
\hline $\begin{array}{c}\text { ALVES, } \\
\text { A. Hilario Travassos }\end{array}$ & $\begin{array}{l}\text { - Verbos da Lingua Portuguesa: conjugação completa, para cursos } \\
\text { elementar e complementar (1921_2 } 2^{\text {a }} \text { ed.) } \boldsymbol{\Omega}\end{array}$ \\
\hline $\begin{array}{l}\text { ABREU, Modesto } \\
\text { de }\end{array}$ & $\begin{array}{l}\text { - Correção de textos: para exames e concursos (1940) } \mathbf{\Omega} \\
\text { - Admissão: lições e exercícios: Português }{ }^{287} \text { (1944_? ed.) } \mathbf{\Omega}\end{array}$ \\
\hline $\begin{array}{l}\text { ALMEIDA, } \\
\text { Napoleão Mendes de }\end{array}$ & $\begin{array}{l}\text { - Crase, colocação dos pronomes oblíquos, infinito pessoal (1941) } \\
\Sigma\end{array}$ \\
\hline BELLUCI, Arnaldo & - Pontos de Português: análise léxica e lógica (1934) $\boldsymbol{\beta}$ \\
\hline $\begin{array}{l}\text { BITTENCOURT, } \\
\text { Arthur }\end{array}$ & - Tratado pratico de analyse lexica e logica (1922) $\boldsymbol{\Omega}$ \\
\hline $\begin{array}{l}\text { BITTENCOURT, } \\
\text { Liberato }\end{array}$ & - Exame de admissão (1933) $\boldsymbol{\Omega}$ \\
\hline $\begin{array}{c}\text { BUENO, Silveira } \\
\text { SPICACCI, } \\
\text { Frederico Carlos } \\
\text { AMARAL, João } \\
\text { Miguel } \\
\text { PACKER, Adolfo } \\
\text { LEAL, Antônio de } \\
\text { Sousa } \\
\text { SOUSA, Enéias } \\
\text { Bastos }\end{array}$ & - Curso de admissão aos ginásios ${ }^{288}(1939) \boldsymbol{\Omega}$ \\
\hline $\begin{array}{l}\text { BOECHAT, Walter } \\
\text { Monteiro }\end{array}$ & - O meu exame de admissão (1936) $\Omega$ \\
\hline $\begin{array}{l}\text { BRITO, Frederico } \\
\text { Carlos da Costa }\end{array}$ & $\begin{array}{l}\text { - Exercicios de analyse portuguesa: lexicologica e syntactica } \\
(1908)^{289} \Omega\end{array}$ \\
\hline $\operatorname{COSTA}^{290}$, Aida & - Admissão ao ginásio (1943) $\mathbf{\Omega}$ \\
\hline
\end{tabular}

${ }^{287}$ Os livros para Admissão são divididos em 4 volumes: Português, Matemática, Geografia e História do Brasil. 288 "Programa do Exame de Admissão aos Ginásios, segundo a reforma do Ensino (decreto n 19.890) de 18 de Abril de 1931/ 509p.".

${ }^{289}$ A referência a essa obra consta em outro livro de nosso acervo, publicado em 1908. Não é possível afirmar que essa é a data da $1^{a}$ edição de Exercicios de analyse portuguesa, mas apenas que, em 1908, ela já havia sido publicada.

${ }^{290}$ Aída Costa (Português), Renato Pasquale/Marcius Brandão (Matemática), Aurélia Marino (História do Brasil) e Renato Stempniewski (Geografia). 


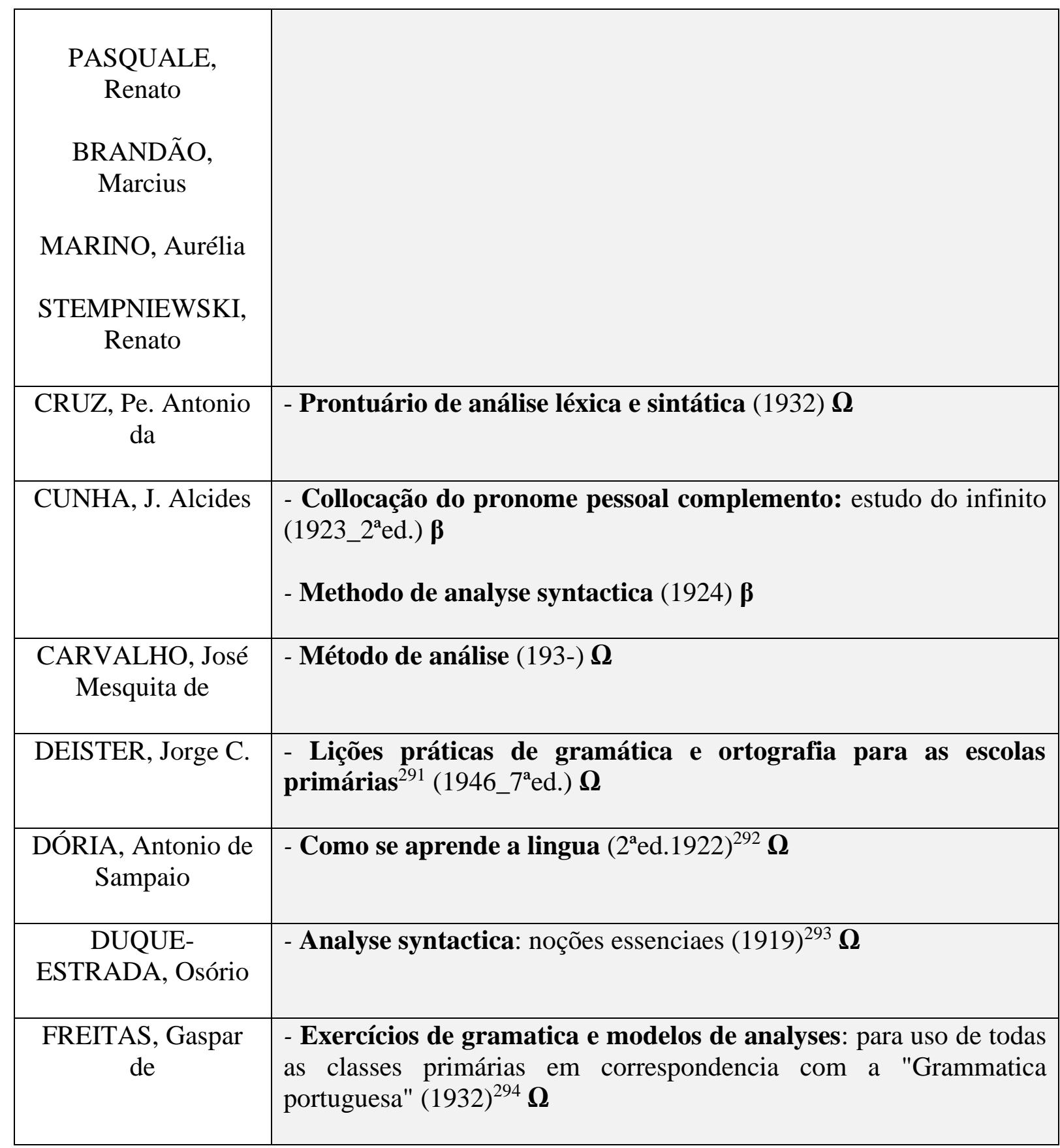

291 "Elaboradas segundo o método da Escola Ativa. 7 7 edição revista de acordo com a reforma oficial."

292 “Approvado pela Directoria geral de instrucção publica de S. Paulo, em 7 de Dezembro de 1921"/ Título da "2 edição da "Analyse Logica". É justamente pelo fato de esse volume ser a $2^{a}$ edição do livro Analyse logica que optamos por incluir apenas esse volume de Como se aprende a lingua no grupo das "obras de temas gramaticais específicos" e os demais tomos dessa coleção no grupo dos "Livros didáticos de Português". Como pode ser verificado nesta tabela, era comum, na época, a publicação de obras específicas de análise lógica (ou sintática) e morfológica (ou léxica). Como não tivemos acesso físico à obra, não pudemos julgar se da $1^{\mathrm{a}}$ para a $2^{\mathrm{a}}$ edição houve uma mudança tão profunda ao ponto de o livro não ser mais uma "análise lógica”. Achamos tal hipótese improvável, motivo pelo qual resolvemos deixar esse volume no presente grupo.

293 A Biblioteca Nacional aponta essa data como possível data de publicação.

${ }^{294}$ Em 1941, a obra teve ligeira modificação no seu título: Exercícios de gramatica e modelos de analise: em correspondencia com a "Gramatica portuguesa" do mesmo autor: com um dicionario de análise léxica e noções de redação. 


\begin{tabular}{|c|c|}
\hline $\begin{array}{c}\text { FONSECA, Alcides } \\
\text { da } \\
\text { ARAGÃO, Jarbas } \\
\text { Cavalcante de }\end{array}$ & $\begin{array}{l}\text { - Exercícios comentados de análise: lexicológica, lexicológico- } \\
\text { sintática e sintática }(1945) \Sigma\end{array}$ \\
\hline $\begin{array}{l}\text { FIGUEIREDO, } \\
\text { (Coronel) José } \\
\text { Sandoval de }\end{array}$ & $\begin{array}{l}\text { - Vicios de linguagem, estrangeirismos, regimes, etc: para uso dos } \\
\text { alumnos do curso especial militar da força publica do Estado de São } \\
\text { Paulo (1927) } \boldsymbol{\beta} \\
\text { - Concordancia da Lingua Portuguesa: para uso dos alumnos do } \\
\text { curso especial militar (1929) } \boldsymbol{\Omega}\end{array}$ \\
\hline FREIRE, Laudelino & - Sintaxe da Língua Portuguesa (1937) $\beta$ \\
\hline GOMES, Alfredo & $\begin{array}{l}\text { - Exames de admissão: aos cursos fundamentais das escolas normais } \\
\text { e ginásios (1939) } \boldsymbol{\Omega}\end{array}$ \\
\hline GÓES, Carlos ${ }^{295}$ & $\begin{array}{l}\text { - Método de análise: léxica e lógica ou sintaxe das relações (1912) } \boldsymbol{\beta} \\
\text { - Sintaxe de concordância (1916) } \boldsymbol{\beta} \\
\text { - Sintaxe de regência (1924) } \boldsymbol{\beta} \\
\text { - Sintaxe de construção }(1932)^{296} \boldsymbol{\beta} \\
\text { - Orthographia, dictado, pontuação e crase (1919) } \boldsymbol{\Omega} \\
\text { - Exames de admissão ao Collegio Pedro II e gymnasios } \\
\text { equiparados: volume } 1(1927) \boldsymbol{\Omega} \\
\text { - Pontos de lingua pátria: } 1^{\circ}, 2^{\circ} \text { e } 3^{\circ} \text { e } 4^{\circ} \text { ano primário (1925) } \boldsymbol{\beta}\end{array}$ \\
\hline $\begin{array}{l}\text { GONÇALVES, } \\
\text { Antônio } \\
\text { RODRIGUES, } \\
\text { Geraldo } \\
\text { MESQUITA, } \\
\text { Marcelo }\end{array}$ & $\begin{array}{l}\text { - Exames de admissão aos cursos ginasiais }\left(1938 \_22^{\mathrm{a} e d .}\right)^{297} \boldsymbol{\beta} \\
\text { - Preparatórios ao alcance de todos: edição popular do livro “Exames } \\
\text { de admissão ao Ginásio" (1944_24ed.) } \mathbf{\Omega}\end{array}$ \\
\hline
\end{tabular}

\footnotetext{
${ }^{295}$ Em algumas obras o autor assina Carlos Góis.

${ }^{296}$ Como esclarece o autor no "Anteloquio" de Sintaxe de construção, na $1^{\text {a }}$ edição, esse é o último livro da série, que conjuntamente com os três volumes anteriores (Manual de análise, Sintaxe de concordância e Sintaxe de regência) integram o Curso de Syntaxe da Lingua Portugueza.

${ }^{297}$ Pontos de português, aritmética, geografia, história do Brasil, morfologia, geometria e ciências físicas e naturais, de acordo com o programa oficial, publicada no diário oficial de 29/10/1931.
} 


\begin{tabular}{|c|c|}
\hline $\begin{array}{l}\text { GONÇALVES, } \\
\text { Francisco }\end{array}$ & $\begin{array}{l}\text { - A palavra Quê: funções, observações, concordância, exercícios } \\
\text { práticos (1943) } \boldsymbol{\beta}\end{array}$ \\
\hline $\begin{array}{l}\text { GONÇALVES, } \\
\text { Maximiano Augusto }\end{array}$ & $\begin{array}{l}\text { - Topologia das variações pronominais (1931) } \mathbf{\Omega} \\
\text { - Questoes de linguagem e trechos para corrigir (1940) } \boldsymbol{\beta} \\
\text { - Tratado de analise: lexica e sintatica (1942) } \boldsymbol{\Omega}\end{array}$ \\
\hline $\begin{array}{l}\text { GALLI, João } \\
\text { Eugênio }\end{array}$ & - Lições de análise léxica e sintática (1947) $\boldsymbol{\Omega}$ \\
\hline HENRIQUE, João ${ }^{298}$ & - Pontuação na escrita (1943_3 $3^{\text {a ed.) } \mathbf{\Omega}}$ \\
\hline HORTA, Brant ${ }^{299}$ & - Lições de análises lexical e sintática (1945) $\beta$ \\
\hline $\begin{array}{l}\text { LEAL, Antônio de } \\
\text { Sousa }\end{array}$ & $\begin{array}{l}\text { - Análise lógica: } 2^{\text {a }} \text { e } 3^{\text {a }} \text { séries do curso fundamental dos ginásios, } \\
\text { escolas normais e do comércio (1939) } \boldsymbol{\Omega} \\
\text { - Analisemos...: análise lógica: v.2 (1941) } \boldsymbol{\Omega} \\
\text { - Vamos analisar...: método teórico-prático: v.1 (1947) })^{300} \boldsymbol{\Omega} \\
\text { - Vamos analisar...: método teórico-prático: v.2 (1947) } \boldsymbol{\Omega}\end{array}$ \\
\hline $\begin{array}{l}\text { LIMA COUTINHO, } \\
\text { Ismael de }\end{array}$ & - Methodo de analyse logica (1927) $\boldsymbol{\beta}$ \\
\hline $\begin{array}{l}\text { MAGALHÃES, E. } \\
\text { Pereira de } \\
\text { SILVA, Valter } \\
\text { Toledo } \\
\text { CANABRAVA, } \\
\text { Alice } \\
\text { GUTIERREZ, Rui }\end{array}$ & $\begin{array}{l}\text { - Exames de admissão: livro de pontos (1945) } \boldsymbol{\Omega} \\
\text { - Exames de admissão: livro de exercícios (1945) } \boldsymbol{\Omega}\end{array}$ \\
\hline MAGNE, Augusto & - Noções elementares de análise lógica (1931) $\beta$ \\
\hline MILANO, Miguel & $\begin{array}{l}\text { - Meus exames: para admissão ao } 1^{\circ} \text { ano dos ginasios, cursos seriados, } \\
\text { escolas normais, de comercio e escolas complementares (1941_9 }{ }^{\mathrm{a}} \mathrm{ed} \text {.) } \\
\boldsymbol{\beta}\end{array}$ \\
\hline
\end{tabular}

${ }^{298}$ O autor assinava suas obras apenas com estes dois nomes. Seu nome completo, porém, é João Henrique dos Santos.

${ }^{299}$ Francisco Eugenio Brant Horta

${ }^{300} \mathrm{Na}$ obra, constam as seguintes informações: "mais de 70 espécimes de análise lógica, 40 análises étimo-fonéticoortográficas, exercícios, exemplos e questionários, testes especiais para sabatinas, provas parciais e finais”. 


\begin{tabular}{|c|c|}
\hline & $\begin{array}{l}\text { - Admissão ao comércio: rigorosamente de acôrdo com o programa } \\
\text { oficial }^{301}(1946) \Omega\end{array}$ \\
\hline $\begin{array}{l}\text { MORAIS, Bento } \\
\text { Bueno de }\end{array}$ & - Exames de admissão ao comércio (1944) $\boldsymbol{\Omega}$ \\
\hline $\begin{array}{l}\text { ARCHERO JR., } \\
\text { Achilles }\end{array}$ & \\
\hline $\begin{array}{l}\text { MORAES, João } \\
\text { Barbosa de }\end{array}$ & $\begin{array}{l}\text { - Exercícios de linguagem: coleção de } 350 \text { exercícios de linguagem } \\
\text { elaborados de acordo com os atuais programas da } 5^{\mathrm{a}} \text { série primária, do } \\
\text { curso de admissão e do } 1^{\circ} \text { ano secundário }\left(1941 \_3^{\mathrm{a}} \text { ed.) } \mathbf{\Omega}\right. \\
\text { - Para as classes de Português: sintaxe, análise lógica, composição } \\
\text { de palavras }{ }^{302} \text { (1943) } \boldsymbol{\beta}\end{array}$ \\
\hline $\begin{array}{l}\text { MORAIS, Orlando } \\
\text { Mendes de }\end{array}$ & - Dicionário de gramática ${ }^{303}$ (1946) \\
\hline MOTTA, Othoniel & $\begin{array}{l}\text { - Chave da lingua: primeiras noções de grammatica ministradas a } \\
\text { infância (1930) } \boldsymbol{\beta}\end{array}$ \\
\hline MELO, Manuel & $\begin{array}{l}\text { - Prontuário de análise morfológica e sintática: Língua Portuguesa } \\
\text { (1943) } \Omega\end{array}$ \\
\hline $\begin{array}{l}\text { NASCENTES, } \\
\text { Antenor }\end{array}$ & $\begin{array}{l}\text { - Método prático de análise lógica (1920) } \boldsymbol{\beta} \\
\text { - Método prático de análise gramatical (1921) } \boldsymbol{\beta}\end{array}$ \\
\hline $\begin{array}{l}\text { NEVES, Maria do } \\
\text { Carmo Vidigal } \\
\text { Pereira das }\end{array}$ & $\begin{array}{l}\text { - Exercicios de linguagem: primeiro livro (1938) } \boldsymbol{\Omega} \\
\text { - Exercicios de linguagem: segundo livro (1938) } \boldsymbol{\Omega} \\
\text { - Exercicios de linguagem: terceiro livro (1938) } \boldsymbol{\Omega}\end{array}$ \\
\hline NOGUEIRA, Julio & $\begin{array}{l}\text { - Programa de português: exame de admissão e antologia primária } \\
\left(1944 \_5^{\mathrm{a}} \text { ed.) } \mathbf{\Omega}\right.\end{array}$ \\
\hline NEME, Mário & - A acentuação na ortografia simplificada (1941) $\mathbf{\Omega}$ \\
\hline
\end{tabular}

${ }^{301}$ Contém as seguintes disciplinas escolares: Português, Francês, Aritmética e Geografia.

${ }^{302} \mathrm{Na}$ folha de rosto, consta ainda: "Várias centenas de exercícios elaborados de acordo com os novos programas da recente reforma do ensino secundário".

${ }^{303} \mathrm{Na}$ folha de rosto, há as seguintes informações: "Organizado por um grupo de professôres sob a orientação do Prof. Orlando Mendes de Morais. Destinado aos alunos dos cursos ginasial e superior e também aos Srs. Professôres". 


\begin{tabular}{|c|c|}
\hline $\begin{array}{l}\text { OLIVEIRA, } \\
\text { Honorato Faustino } \\
\quad \text { de }\end{array}$ & $\begin{array}{l}\text { - Lições práticas de pontuação e de accentuação do "A" pela figura } \\
\text { "crase" (1919_2 } 2^{\text {a }} \text { ed.) } \Omega\end{array}$ \\
\hline PINTO, Leonardo & - Conjuncções: notas elucidativas e exercicios práticos (1922) $\boldsymbol{\beta}$ \\
\hline POSADA, Hortênsia & $\begin{array}{l}\text { - Breve estudo de analyse sintactica: para os alunos das escolas } \\
\text { primarias. (1923) } \boldsymbol{\Omega}\end{array}$ \\
\hline RÉVEILLEAU, A. & $\begin{array}{l}\text { - Método de analise morfológica e oracional (1930) } \boldsymbol{\Omega} \\
\text { - O terceiro ano secundário: desenvolvimento do programa de } \\
\text { Português (1936) } \boldsymbol{\Omega}\end{array}$ \\
\hline RIBEIRO, João & $\begin{array}{l}\text { - Livro de exercicios }{ }^{304}(1903) \boldsymbol{\Omega} \\
\text { - Exame de admissão para os ginásios }{ }^{305} \text { (1916) } \boldsymbol{\Omega}\end{array}$ \\
\hline $\begin{array}{l}\text { REIS, Otelo de } \\
\quad \text { Souza }\end{array}$ & $\begin{array}{l}\text { - Analyse lexica: palavras que podem ter diversas classificações } \\
\text { (1921) } \boldsymbol{\Omega} \\
\text { - Guia elementar de análise léxica ou gramatical: para se resolverem } \\
\text { algumas dificuldades taxionômicas }\left(19382^{\mathrm{a}} \mathrm{ed} \text {.) } \boldsymbol{\Omega}\right. \\
\text { - Textos para corrigir (1931) } \boldsymbol{\beta}\end{array}$ \\
\hline $\begin{array}{l}\text { ROCHA, Mario } \\
\text { Penna }\end{array}$ & $\begin{array}{l}\text { - Curso prático de Português: dez aulas na Rádio-Escola Municipal } \\
\text { (PRD-5), em combinação com PRA-2, do Ministério da Educação } \\
\text { (1939) } \mathbf{\Omega}\end{array}$ \\
\hline SATURNINO, José & $\begin{array}{l}\text { - Língua Portuguesa: ligeiras observações apresentadas ao curso de } \\
\text { férias da A.B.E. (1941) } \boldsymbol{\Omega}\end{array}$ \\
\hline SANTOS, J. França & - Pontos de Português prático para concursos (1944) $\Omega$ \\
\hline $\begin{array}{l}\text { SANTOS, Maximo } \\
\text { de Moura }\end{array}$ & $\begin{array}{l}\text { - Notas de gramatica: para analise gramatical e logica }(1932)^{306} \boldsymbol{\Omega} \\
\text { - Preparatórios para admissão aos gymnasios e aos cursos } \\
\text { fundamentaes das escolas normaes }{ }^{307}(1936) \Omega\end{array}$ \\
\hline
\end{tabular}

\footnotetext{
${ }^{304} \mathrm{Na}$ lista de obras do autor, presente em todas as suas publicações, há a informação de que este material é destinado "para servir com a gramática do $1^{\circ}$ ano", ou seja, deve ser o livro de exercícios dessa gramática.

305 Novamente, uma outra obra do autor informa que este livro contém os "prontuários das matérias exigidas para o exame de admissão no Colégio Pedro II". Este livro foi escrito em coautoria com Raja Gabaglia e não é um livro apenas de Português, mas de todas as matérias que compõem o exame de admissão, como Matemática, História, Geografia, etc.

${ }^{306} \mathrm{Na} 2^{a}$ edição, em 1940, a obra passa a ter o seguinte título: Análise gramatical e lógica: notas de gramatica. Como pode ser visto, nessa edição, o novo título resulta da inversão do título e do subtítulo da $1^{\mathrm{a}}$ edição.

307 "Português, Matemática - Aritmética, História - História do Brasil, Geografia, Ciências Naturais".
} 


\begin{tabular}{|c|c|}
\hline $\begin{array}{l}\text { SANCTIS, Baptista } \\
\text { de }\end{array}$ & - Analyse lexica e sintatica (1923) $\beta$ \\
\hline SENRA, José & - Noções de analyse portugueza (1930) $\Sigma$ \\
\hline $\begin{array}{c}\text { SENRA, José } \\
\text { TEIXEIRA, J. M. }\end{array}$ & - Analyse portugueza (1901) $\boldsymbol{\Omega}$ \\
\hline $\begin{array}{l}\text { SOUZA, Sylvio } \\
\text { Aguiar }\end{array}$ & - A analyse lógica no diagramma (1935) $\boldsymbol{\beta}$ \\
\hline $\begin{array}{l}\text { TORRES, Arthur de } \\
\text { Almeida }\end{array}$ & $\begin{array}{l}\text { - Pontos de Português para concurso: D.A.S.P (1945) }{ }^{308} \mathbf{\Omega} \\
\text { - Manual de Português: para o curso de admissão (1945) } \mathbf{\Omega}\end{array}$ \\
\hline $\begin{array}{c}\text { VEIGA, Maria } \\
\text { Doralice Marcondes }\end{array}$ & - Admissão comercial ${ }^{309}$ (1939) $\mathbf{\Omega}$ \\
\hline A. T. ${ }^{310}$ & $\begin{array}{l}\text { - Estudo da lingua vernácula contenda o ensino methodico de } \\
\text { etymologia, prosodia e orthographia (1903) } \beta\end{array}$ \\
\hline $\begin{array}{l}\text { Professores do Liceu } \\
\text { Nacional Rio Branco }\end{array}$ & - Exames de admissão aos cursos ginasiais ${ }^{311}\left(1938 \_22^{\mathrm{a}} \mathrm{ed}\right.$.) $\boldsymbol{\Omega}$ \\
\hline $\begin{array}{l}\text { (Reunião de) } \\
\text { Professores da } \\
\text { Escola Normal e da } \\
\text { Escola } \\
\text { Complementar }\end{array}$ & $\begin{array}{l}\text { - Exames de admissao às escolas normaes ou cursos das escolas } \\
\text { complementares (1930) } \Omega\end{array}$ \\
\hline $\begin{array}{l}\text { São Paulo (Estado) } \\
\text { Força Pública }\end{array}$ & $\begin{array}{l}\text { - Programmas para exame de admissão e vestibular: aos cursos do } \\
\text { centro de instrução militar (1937_2 }{ }^{\text {a }} \text { ed.) } \mathbf{\Omega}\end{array}$ \\
\hline $\begin{array}{l}\text { Um amigo da } \\
\text { instrucção }\end{array}$ & $\begin{array}{l}\text { - Exercícios de grammatica: analyse lexicologica e syntactica e } \\
\text { redacção: } 1^{\text {a }} \text { parte: curso primário: livro do discipulo (s/d) }{ }^{312} \boldsymbol{\Omega} \\
\text { - Exercícios de grammatica: analyse lexicologica e syntactica e } \\
\text { redacção: } 2^{\text {a }} \text { parte: curso secundário: livro do discipulo }(1906)^{313} \boldsymbol{\Omega}\end{array}$ \\
\hline
\end{tabular}

\footnotetext{
308 A referência a essa obra consta em outra do autor, de 1945, presente em nosso acervo. Não é possível afirmar que essa é a data da $1^{\text {a }}$ edição, mas apenas que, em 1945, ela já havia sido publicada.

309 "Português, Francês, Matemática - Aritmética, Geografia".

${ }^{310} \mathrm{O}$ autor assina A.T., marcando, assim, o caráter anônimo de sua obra.

311 "Pontos de Português, Aritmética, Geografia, História do Brasil, Morfologia, Geometria e Ciências Físicas e Naturais, de acordo com o programa oficial, publicada no Diário Oficial de 29/10/1931".

312 "Nova edição correta e aumentada: passada para a nova ortografia pelo Prof. Dr. Mario Barreto."

${ }^{313} \mathrm{Na}$ capa, encontramos a informação que se trata de "nova edição augmentada", porém não indica o número da edição.
} 


\begin{tabular}{|l|l|}
\hline & $\begin{array}{l}\text { - Exercícios de grammatica: analyse lexicologica e syntactica e } \\
\text { redacção: } 2^{\mathrm{a}} \text { parte: curso secundário: livro do professor }(1906)^{314} \boldsymbol{\Omega}\end{array}$ \\
\hline TOTAL & $\mathbf{1 0 0}$ obras \\
\hline
\end{tabular}

${ }^{314}$ A mesma informação da nota anterior. 


\section{QUADRO 5B - Livros didáticos de Português}

\begin{tabular}{|c|c|}
\hline $\begin{array}{l}\text { ALBUQUERQUE, } \\
\text { Acir }^{315} \text { Tenorio de }\end{array}$ & $\begin{array}{l}\text { - Curso de Português para ginásios: primeira serie: gramática, } \\
\text { antologia, exercícios (1946) } \mathbf{\Omega} \\
\text { - Curso de Português para ginásios: segunda serie: gramática, } \\
\text { antologia, exercícios (1943) }{ }^{316} \boldsymbol{\Omega} \\
\text { - Curso de Português para ginásios: terceira serie: gramática, } \\
\text { antologia, exercícios (1946) } \boldsymbol{\Omega}\end{array}$ \\
\hline ALVES, Achilles & - O idioma portuguez nas classes elementares (1930_1 ${ }^{\text {a } e d .) ~} \boldsymbol{\Omega}$ \\
\hline $\begin{array}{c}\text { ABREU, Modesto } \\
\text { de }\end{array}$ & 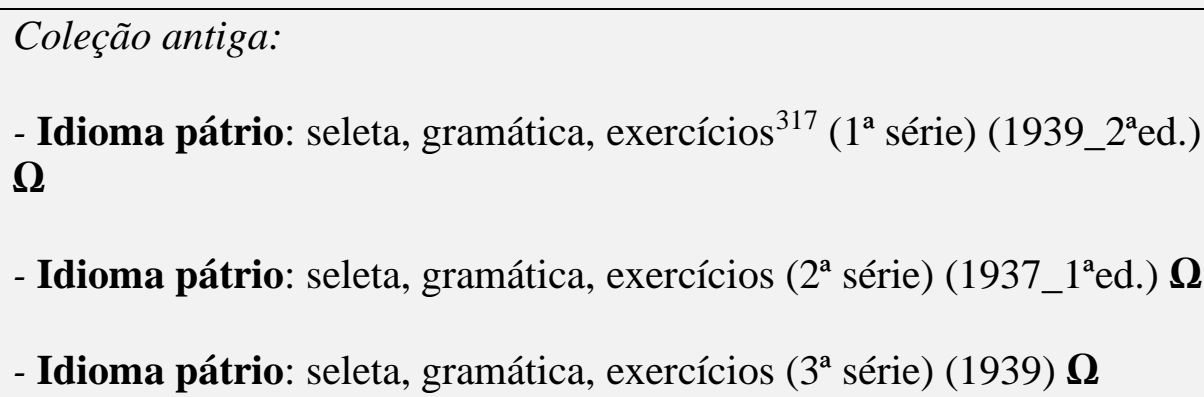 \\
\hline
\end{tabular}

\footnotetext{
315 Há registros também de seu primeiro nome grafado como Arcy.

${ }^{316}$ Localizamos essa coleção na quarta capa do Dicionário de gramática, de Orlando Mendes de Morais, publicado, em 1946, pela Editora Getulio Costa, a mesma que publicava boa parte dos livros de Acir Tenorio de Albuquerque. Além desse registro, localizamos apenas mais um outro: um exemplar do volume 2, publicado em 1943.

${ }^{317}$ A coleção Idioma pátrio tem duas apresentações: uma relativa ao "antigo programa", composta de 5 volumes, e outra do "novo programa", formada por 3 volumes. Há, obviamente, algumas diferenças que aqui explicitaremos: a coleção de 5 volumes segue a estruturação clássica para os livros didáticos de Português da época, presente em quase todas as coleções didáticas que aqui relacionamos. Dos volumes 1 a 4, conteúdo gramatical, de leitura e de redação e $5^{\circ}$ volume destinado aos estudos da história da Literatura e da estilística, fato, aliás, que nos fez não incluir esses volumes no presente levantamento. Na coleção nova, de 3 volumes, o autor fez a seguinte estruturação: volume 1 , para as $1^{\mathrm{a}}$ e $2^{\mathrm{a}}$ séries do Secundário, seleta literária destinada à leitura e interpretação, volume 2, o mesmo conteúdo, só que para as $3^{\mathrm{a}}$ e $4^{\mathrm{a}}$ séries e o volume 3 , destinado a todos os anos do Secundário, é uma gramática expositiva e histórica, além de conter também "noções de estilística e literatura", conteúdo esse que, na coleção antiga, era apresentado no volume 5 .
} 


\begin{tabular}{|c|c|}
\hline $\begin{array}{l}\text { BACHELET, } \\
\text { Mário }\end{array}$ & $\begin{array}{l}\text { - Novo manual de Lingua Portugueza }{ }^{318} \text { : grammatica, lexicologia, } \\
\text { analyse, composição: para uso das escolas primárias: curso } \\
\text { preparatório }{ }^{319}(1919)^{320} \boldsymbol{\Omega} \\
\text { - Novo manual de Lingua Portugueza: grammatica, lexicologia, } \\
\text { analyse, composição: para uso das escolas primárias: curso } \\
\text { preparatório: livro do mestre (1919) } \boldsymbol{\Omega} \\
\text { - Novo manual de Lingua Portugueza: grammatica, lexicologia, } \\
\text { analyse, composição: curso elementar (1932) } \boldsymbol{\Omega} \\
\text { - Novo manual de Lingua Portugueza: grammatica, lexicologia, } \\
\text { analyse, composição: para uso das escolas primárias: curso elementar: } \\
\text { livro do mestre } 321 \text { (1930) } \boldsymbol{\Omega} \\
\text { - Novo manual de Língua Portuguêsa: curso médio (1932) } \boldsymbol{\beta} \\
\text { - Novo manual de Língua Portuguêsa: curso médio: livro do mestre } \\
\text { (1937) } \boldsymbol{\Omega} \\
\text { - Novo manual de Lingua Portugueza: grammatica, lexicologia, } \\
\text { analyse, composição: para uso das escolas secundárias: curso } \\
\text { secundário (1930) } \boldsymbol{\Omega} \\
\text { - Novo manual de Lingua Portugueza: grammatica, lexicologia, } \\
\text { analyse, composição: para uso das escolas secundárias: curso } \\
\text { secundário: livro do mestre (1912) } \boldsymbol{\Omega} \\
\text { - Novo manual de Lingua Portuguesa luso-brasileira: curso superior } \\
\text { (1925) } \boldsymbol{\Omega}\end{array}$ \\
\hline
\end{tabular}

\footnotetext{
${ }^{318}$ Há uma oscilação quanto ao registro da autoria dos livros pertencentes a essa coleção da editora F.T.D. Em nossa pesquisa, encontramos alguns volumes assinados por Mário Bachelet e outros por "Por uma seleção de professores". Pelos dados a que tivemos acesso, não conseguimos encontrar uma justificativa para tal oscilação. A edição que possuímos, do curso médio (s.d), por exemplo, é assinada por Bachelet. Na BNRJ, todos os exemplares são assinados por esse autor. No presente levantamento, optamos por seguir os registros da BNRJ.

${ }^{319}$ De acordo com a quarta capa, essa coleção apresenta a seguinte estruturação: "1 CURSO PREPARATORIO: Theoria grammatical muito simples, em linguagem facil, com 274 exercicios de applicação das regras, illustrado. Estudantes de 7 e 8 annos de idade. $2^{\circ}$ CURSO ELEMENTAR: Desenvolve e amplia gradualmente a theoria e multiplica os exercicios em numero de 632. Estudantes de 9 e 10 annos de idade. $3^{\circ}$ CURSO MEDIO: Dirige-se a estudantes de 11, 12, 13 annos. A theoria é mais completa. Traz noções precisas e claras sobre analyse e estilo com 1052 exercicios de applicação. $4^{\mathbf{0}}$ CURSO SECUNDARIO: Este volume offerece tudo quanto de verdadeiramente pedagogico e assimilavel pelo joven estudioso, se tem determinado até o presente sobre a língua portugueza, 758 exercicios variadissimos. Estudantes de 14 a 15 annos. 5' CURSO SUPERIOR: Trata das principaes questões atinentes á lingua, dando a súmmula do que a respeito escreveram os grammaticos mais abalisados. - Literatura e historia literaria. - 550 exercicios. $6^{\circ}$ CURSO COMPLEMENTAR: É a grammatica historica da lingua portugueza posta ao alcance de todos os candidatos a exames. Trechos de todas as epocas. Numerosas gravuras amenizam e documentam o texto.

${ }^{320}$ Com exceção do volume do curso secundário, livro do mestre, que é de 1912, todos os demais volumes dessa coleção têm datas prováveis de publicação, segundo informam os registros das fichas catalográficas da BNRJ e da USP (no caso do curso superior).

${ }^{321}$ De acordo com as fichas bibliográficas da BNRJ, os "livros do mestre" têm uma quantidade de páginas bem superior aos "livros do aluno", às vezes chegando ao dobro.
} 


\begin{tabular}{|c|c|}
\hline & $\begin{array}{l}\text { - Novo manual de Lingua Portuguesa luso-brasileira: curso } \\
\text { superior: livro do mestre (1925) } \boldsymbol{\Omega}\end{array}$ \\
\hline BRUNO, Aníbal & $\begin{array}{l}\text { - Língua portuguesa: para a } 1^{\mathrm{a}} \text { série ginasial (1938_2a ed.) } \mathbf{\Omega} \\
\text { - Língua portuguesa: para a } 2^{\mathrm{a}} \text { série ginasial (1939_? }{ }^{\mathrm{a}} \text { ed.) } \mathbf{\Omega} \\
\text { - Língua Portuguesa: para a } 3^{\mathrm{a}} \text { série ginasial, as escolas normais e as } \\
\text { escolas de comércio (1938_? ed.) } \mathbf{\Omega} \\
\text { - Língua portuguesa: para os cursos clássicos e cientifico. } 1^{\mathrm{a}} \text { série } \\
\text { (1945_? ed.) } \boldsymbol{\Omega}\end{array}$ \\
\hline BUENO, Silveira & $\begin{array}{l}\text { - Páginas floridas }{ }^{322}: 40 \text { leituras em prosa e verso, } 60 \text { lições e } \\
\text { numerosos comentários gramaticais. ( } 1^{\mathrm{a}} \text { série: curso fundamental) } \\
\text { (1939) } \boldsymbol{\Omega} \\
\text { - Páginas floridas: } 70 \text { leituras em prosa e verso: } 450 \text { comentários } \\
\text { gramaticais e literários ( } 2^{\mathrm{a}} \text { série: curso fundamental) }(1938) \boldsymbol{\Omega} \\
\text { - Páginas floridas: } 70 \text { leituras em prosa e verso, } 379 \text { comentários } \\
\text { gramaticais e literários ( } 3^{\mathrm{a}} \text { série: curso fundamental) }\left(1939 \_4^{\mathrm{a}} \mathrm{ed} .\right) \mathbf{\Omega}\end{array}$ \\
\hline $\begin{array}{l}\text { CÂMARA JR., } \\
\text { Joaquim Mattoso }\end{array}$ & $\begin{array}{l}\text { - Elementos de língua pátria: volume } 1 \text { (1938_2a ed.) } \mathbf{\Omega} \\
\text { - Elementos de língua pátria: volume } 2\left(1938 \_2^{\mathrm{a}} \text { ed.) } \mathbf{\Omega}\right. \\
\text { - Elementos de língua pátria: volume } 3\left(19382^{\mathrm{a}} \text { ed.) } \mathbf{\Omega}\right.\end{array}$ \\
\hline $\begin{array}{l}\text { CORRÊA, G. } \\
\text { Guimarães }\end{array}$ & - O programa de vernáculo: curso ginasial: $1^{\mathrm{a}}$ e $2^{\mathrm{a}} \operatorname{séries}^{323}$ (1946) $\boldsymbol{\Omega}$ \\
\hline $\begin{array}{l}\text { COSTA, Arlindo } \\
\text { Drummond }\end{array}$ & $\begin{array}{l}\text { - Nossa linguagem: primeiro volume: para a primeira e segunda séries } \\
\text { dos ginásios }^{324}(1944) \boldsymbol{\beta}\end{array}$ \\
\hline CRUZ, Estêvão & $\begin{array}{l}\text { - Programa de vernáculo: gramática e antologia: contém toda a } \\
\text { matéria exigida para o estudo das } 1^{\mathrm{a}} \text { e } 2^{\mathrm{a}} \text { séries }(1936) \Omega \\
\text { - Programa de vernáculo: gramática e antologia: contém toda a } \\
\text { matéria exigida para o estudo da } 3^{\mathrm{a}} \text { série }(1936) \Omega\end{array}$ \\
\hline
\end{tabular}

${ }^{322}$ Em 1942 a coleção passou a chamar-se Páginas floridas: seleta e gramática.

${ }^{323}$ Quanto ao outro volume, referente às $3^{\mathrm{a}}$ e $4^{\mathrm{a}}$ séries, é bem provável que esteja fora do nosso recorte temporal, pois a $2^{a}$ edição é de 1954. Não conseguimos localizar informações a respeito da $1^{a}$ edição. O que nos parece é que o autor publicou o volume das $1^{\mathrm{a}}$ e $2^{\mathrm{a}}$ séries e bem depois o das $3^{\mathrm{a}}$ e $4^{\mathrm{a}}$ séries. A título de comparação, enquanto o primeiro volume, em 1959, já estava em sua $13^{a}$ edição, o segundo, em 1954, estava apenas na $2^{a}$ edição.

${ }^{324}$ É de se supor que haja o "segundo volume: para a terceira e quarta séries ginasiais", porém não a localizamos em nenhum arquivo. Em função disso, optamos por não inclui-la de maneira presumida, já que por algum infortúnio pode não ter ocorrido sua publicação. 


\begin{tabular}{|c|c|}
\hline $\begin{array}{c}\text { CINTRA, Geraldo } \\
\text { de Ulhoa }\end{array}$ & $\begin{array}{l}\text { - Língua portuguesa: literatura, história da literatura, gramática, } \\
\text { leitura e exercícios para as } 1^{\mathrm{a}}, 2^{\mathrm{a}} \text { e } 3^{\mathrm{a}} \text { séries dos colégios clássico e } \\
\text { científico de acordo com os últimos programas (1943) } \boldsymbol{\beta}\end{array}$ \\
\hline $\begin{array}{l}\text { CRETELLA, } \\
\text { JÚNIOR, José }\end{array}$ & $\begin{array}{l}\text { - Português para o ginásio: } 1^{\mathrm{a}} \text { série (1944) } \mathbf{\Omega} \\
\text { - Português para o ginásio: } 2^{\mathrm{a}} \text { série (1945) } \boldsymbol{\Omega} \\
\text { - Português para o ginásio: } 3^{\mathrm{a}} \text { série (1945) } \mathbf{\Omega}\end{array}$ \\
\hline $\begin{array}{l}\text { CRUZ, José } \\
\text { Marques da }\end{array}$ & 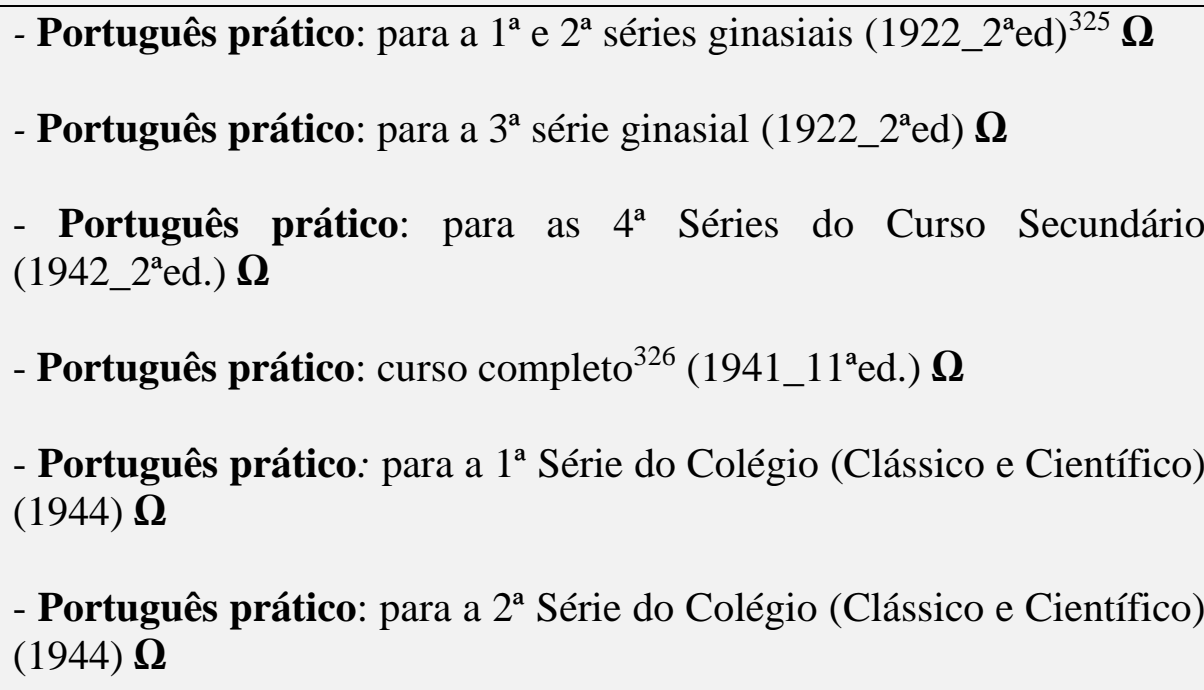 \\
\hline $\begin{array}{l}\text { CARVALHO, José } \\
\text { Mesquita de }\end{array}$ & $\begin{array}{l}\text { - Grammatica e anthologia nacional: } 1^{\mathrm{a}}, 2^{\mathrm{a}} \text { séries }\left(1935 \_2^{\mathrm{a} e d .} \mathbf{\Omega}\right. \\
\text { - Grammatica e anthologia nacional: } 3^{\mathrm{a}} \text { e } 4^{\mathrm{a}} \text { séries }(1935) \boldsymbol{\Omega} \\
\text { - Pontos de Português: para a } 3^{\mathrm{o}} \text { e } 4^{\mathrm{a}} \text { séries ginasiais, organizados de } \\
\text { conformidade com o novo programa de ensino }(1942)^{327} \boldsymbol{\Omega}\end{array}$ \\
\hline $\begin{array}{l}\text { CAMPINHOS, } \\
\text { Newman José } \\
\text { Barroso }\end{array}$ & $\begin{array}{l}\text { - Lições de língua pátria (1940_2a ed.) } \mathbf{\Omega} \\
\text { - Português: } 2^{\text {o }} \text { ciclo. } 1^{\mathrm{a}} \text { série (1946) } \mathbf{\Omega} \\
\text { - Português: } 2^{\circ} \text { ciclo. } 2^{\mathrm{a}} \text { série (1946) } \boldsymbol{\beta}\end{array}$ \\
\hline
\end{tabular}

\footnotetext{
${ }^{325}$ Não conseguimos acesso às datas da $1^{\text {a }}$ edição dos quatro volumes das obras destinadas ao ensino ginasial, apenas a da $2^{\mathrm{a}}$ edição, 1922. No entanto, na relação de obras do autor presente no volume Português prático: para a $1^{\mathrm{a}}$ série do colégio, de 1944, registra que os quatro referidos volumes estão esgotados. Nesta mesma relação, registra que Português prático: 4 séries ginasiais - o "volume único" da obra - está em sua $15^{a}$ edição. Com estas informações, supomos que a editora resolveu esgotar a versão em 4 volumes e editar apenas o volume que abarca as quatro séries ginasiais em um só volume.

${ }^{326}$ Como indica o título, o volume aborda todos os tópicos do curso secundário: gramática expositiva e histórica, além da seleta de textos literários.

${ }^{327}$ É de se supor que haja o volume referente às $1^{\mathrm{a}}$ e $2^{\mathrm{a}}$ séries, mas como não o localizamos em nenhum arquivo, optamos por não inclui-lo de maneira presumida.
} 


\begin{tabular}{|c|c|}
\hline $\begin{array}{l}\text { FONSECA, } \\
\text { Alcides da } \\
\text { ARAGÃO, Jarbas } \\
\text { Cavalcante de }\end{array}$ & $\begin{array}{l}\text { - A Língua Portuguesa: gramática e antologia (1940) } \mathbf{\Omega} \\
\text { - A Língua Portuguesa: programa para o curso ginasial, escola } \\
\text { preparatória de cadetes e curso preparatório à Escola Militar (1940) } \mathbf{\Omega}\end{array}$ \\
\hline $\begin{array}{c}\text { FREITAS, Paulo } \\
\text { de }\end{array}$ & $\begin{array}{l}\text { - O nosso idioma: curso elementar (1936) } \boldsymbol{\beta} \\
\text { - O nosso idioma: antologia e gramatica aplicada: morfologia }\left(1^{\mathrm{a}} \text { parte }\right) \\
\text { (1936) } \boldsymbol{\beta} \\
\text { - O nosso idioma: sintaxe geral }(1937)^{328} \boldsymbol{\beta} \\
\text { - O nosso idioma: sintaxe das categorias gramaticais ( } 3^{\mathrm{a}} \text { parte) (1938) } \\
\boldsymbol{\beta}\end{array}$ \\
\hline JOVIANO, A. ${ }^{329}$ & $\begin{array}{l}\text { - Lingua pátria: volume } 1 \text { (1918) } \mathbf{\Omega} \\
\text { - Lingua pátria: volume } 2 \text { (1919) } \mathbf{\Omega} \\
\text { - Lingua pátria: volume } 3 \text { (1921) } \mathbf{\Omega}\end{array}$ \\
\hline $\begin{array}{l}\text { LINTZ, Dario } \\
\text { Gouveia }\end{array}$ & - Lingua Portugueza: curso elementar ${ }^{330}(1928) \boldsymbol{\beta}$ \\
\hline $\begin{array}{l}\text { LIMA, Rocha } \\
\text { ROCHA, Mario } \\
\text { Penna da } \\
\text { LÉLLIS, Raul } \\
\text { Moreira }\end{array}$ & $\begin{array}{l}\text { - O programa de Português no } \mathbf{2}^{\mathbf{0}} \text { Ciclo: cursos clássico e científico } \\
1^{\text {a }} \text { série }^{331}(1945) \boldsymbol{\beta} \\
\text { - O programa de Português no } 2^{\mathbf{0}} \text { Ciclo: cursos clássico e científico } \\
2^{\text {a }} \text { série }(1947)^{332} \boldsymbol{\beta}\end{array}$ \\
\hline LIMA, Rocha & $\begin{array}{l}\text { - O programa de Português no Curso Comercial, Cursos Técnicos: } \\
1^{\text {a }} \text { série (1947) } \Omega\end{array}$ \\
\hline
\end{tabular}

${ }^{328}$ Apesar de não constar no subtítulo da obra, deduz-se ser esse volume a $2^{\text {a }}$ parte de $\mathbf{O}$ nosso idioma. ${ }^{329}$ Arthur Joviano.

${ }^{330} \mathrm{O}$ autor informa, no prefácio, que este livro deve ser usado em conjunto com a Anthologia nacional, de Fausto Barreto e Carlos de Laet, obra editada entre 1895 e 1969. Esse uso combinado justifica-se porque o autor utiliza os textos literários presentes na Anthologia e com eles apresenta exercícios e atividades, como ditado; interpretação do texto; significado e pronúncia das palavras; além de tópicos gramaticais.

${ }^{331} \mathrm{O}$ volume da $1^{\text {a }}$ série que possuímos, de 1945, tem como autoria apenas Rocha Lima e Mario Penna da Rocha. No entanto, no $2^{\circ}$ volume, de 1947, consta, no prefácio, uma explicação do motivo que levou Raul Léllis a se juntar ao demais autores apenas naquele momento. Ainda nesse mesmo volume, na relação de obras publicadas, consta o nome e Raul Léllis como autor também do $1^{\circ}$ volume o que nos faz supor que o autor deve ter participado das revisões para essa nova edição de 1947 e então passado a assinar, junto aos demais autores, toda a coleção a partir dessa data.

${ }^{332}$ No volume para a $2^{\mathrm{a}}$ série, de 1947 , há menção ao fato de o volume para a $3^{\mathrm{a}}$ série estar no prelo. No entanto, não encontramos, em nenhum arquivo, referência a esse $3^{\circ}$ volume. É provável também que, caso ele tenha sido efetivamente publicado, o ano em que isso ocorreu esteja fora dos limites temporais da presente tese. 


\begin{tabular}{|c|c|}
\hline $\begin{array}{l}\text { LÉLLIS, Raul } \\
\text { Moreira }\end{array}$ & \\
\hline $\begin{array}{l}\text { MOURA, Maria } \\
\text { Lacerda de }\end{array}$ & $\begin{array}{l}\text { - Português para os cursos comerciais: rigorosamente de acordo com } \\
\text { o decreto oficial da Divisão de Ensino Comercial (1940) } \boldsymbol{\Omega}\end{array}$ \\
\hline $\begin{array}{l}\text { MARTINS, Mário } \\
\text { R. }\end{array}$ & - A evolução da língua nacional ${ }^{333}$ (1943) $\boldsymbol{\beta}$ \\
\hline $\begin{array}{l}\text { MORAIS, Bento } \\
\text { Bueno de }\end{array}$ & $\begin{array}{l}\text { - A nossa lingua: } 1^{\text {a }} \text { série do curso fundamental: } 50 \text { lições de } \\
\text { gramática, } 77 \text { exercícios, } 53 \text { leituras em prosa e verso }{ }^{334}(1941)\end{array}$ \\
\hline MOTTA, Othoniel & - Lições de Português (1915) $\beta$ \\
\hline $\begin{array}{l}\text { NASCENTES, } \\
\text { Antenor }\end{array}$ & $\begin{array}{l}\text { - Apostilas de Português (1923) } \boldsymbol{\Omega} \\
\text { - O idioma nacional: volume } 1(1926) \boldsymbol{\beta} \\
\text { - O idioma nacional: volume } 2(1927) \boldsymbol{\beta} \\
\text { - O idioma nacional: volume } 3(1928) \boldsymbol{\beta} \\
\text { - O idioma nacional: síntese dos três primeiros volumes (1937) } \boldsymbol{\Omega} \\
\text { - O idioma nacional: gramática para o colégio }(1944)^{335} \boldsymbol{\beta}\end{array}$ \\
\hline $\begin{array}{l}\text { NASCIMENTO, } \\
\text { Augusto do }\end{array}$ & - Português: volume segundo $(1942)^{336} \mathbf{\Omega}$ \\
\hline
\end{tabular}

\footnotetext{
${ }^{333}$ Esta obra, basicamente, tem como tema a morfologia. Há alguns poucos tópicos de sintaxe e um breve capítulo de "prosódia", em que o autor lista palavras e suas respectivas pronúncias. Há também exercícios e, no final, uma sequência de textos errados e corrigidos. Além deste volume, o autor publicou outros dois ligados à literatura: A evolução da literatura brasileira: volume 1: notas biográficas e A evolução da literatura brasileira: volume 2: estudos.

${ }^{334}$ Como mencionamos na nota anterior, há grande escassez de informações sobre esse autor. Além do exemplar que possuímos, o único registro que conseguimos sobre o autor e sua obra foi esse, da BNRJ. Como já mencionamos em outras notas, é bastante provável a existência de outros volumes da coleção, normalmente formada por 5 volumes, um para cada ano do Secundário/ginásio. Na ausência de registros, optamos por não inclui-los aqui de maneira presumida.

335 Apesar do nome, essa obra não é exatamente uma gramática. Na verdade, trata-se de um livro didático que abrange o conteúdo previsto no programa oficial para os cursos clássico e científico do Secundário, isto é, os três últimos anos do ensino secundário. Nesses anos, diferentemente dos anos iniciais do Secundário, o programa estabelece o estudo de poucos tópicos de gramática, predominando, assim, o estudo da Literatura. Dessa forma, nesse volume encontramos aspectos de história da literatura e de teoria literária, além de alguns tópicos gramaticais e, em outro volume, $\mathbf{O}$ idioma nacional: antologia para o colégio, lançado em conjunto com $\mathbf{O}$ idioma nacional: gramática para o colégio, uma seleta de textos literários. Ambos formam, portanto, o material didático de Português necessário para acompanhar os cursos clássico e científico da década de 1940.

336 Não conseguimos encontrar mais nenhuma referência a respeito desse autor e de suas obras. É logicamente plausível que deva haver o "volume primeiro" desta coleção, mas, em função da ausência de registros, mesmo que indiretos, optamos por não o incluir neste levantamento.
} 


\begin{tabular}{|c|c|}
\hline $\begin{array}{c}\text { NUNES, José de } \\
\text { Sá }^{337}\end{array}$ & $\begin{array}{l}\text { - Língua vernácula: grammatica e anthologia }\left(1^{\mathrm{a}} \text { e } 2^{\mathrm{a}} \text { série) (1935) } \mathbf{\Omega}\right. \\
\text { - Língua vernácula: grammatica e anthologia ( } 3^{\mathrm{a}} \text { série) (1936) } \boldsymbol{\Omega}\end{array}$ \\
\hline NOGUEIRA, Julio & 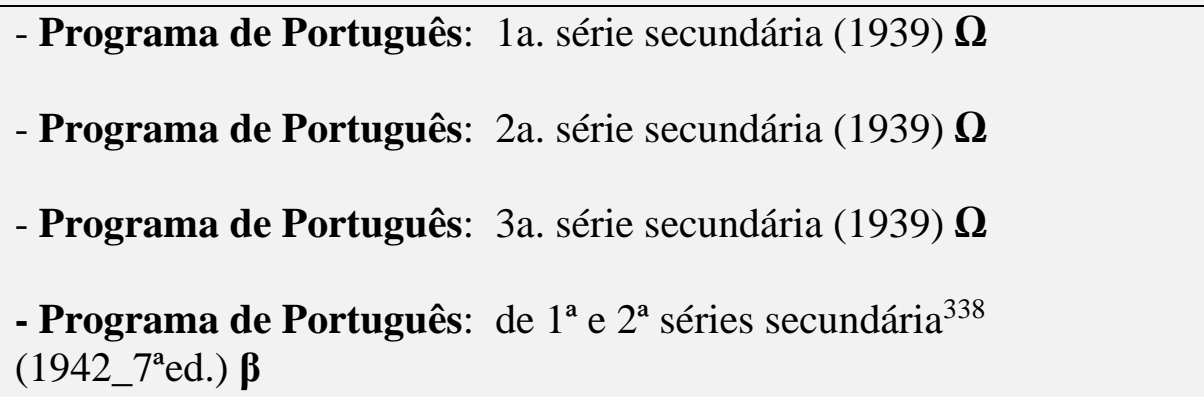 \\
\hline $\begin{array}{l}\text { RIBEIRO, Clovis } \\
\text { JORGE, Felipe } \\
\text { LOURENÇO, José } \\
\text { WEY, Valter }\end{array}$ & $\begin{array}{l}\text { - Língua portuguêsa: primeiro volume: } 1^{\mathrm{a}} \text { série dos cursos clássico e } \\
\text { científico }(1944) \boldsymbol{\beta} \\
\text { - Língua portuguêsa: segundo volume: } 2^{\mathrm{a}} \text { série dos cursos clássico e } \\
\text { científico (1944_2aed.) } \boldsymbol{\beta}\end{array}$ \\
\hline ROMANO, Raul & - Pequenas lições de Português (1925) $\boldsymbol{\Omega}$ \\
\hline $\begin{array}{l}\text { TORRES, Arthur } \\
\text { de Almeida }\end{array}$ & $\begin{array}{l}\text { - Compêndio de língua portuguesa: } 1^{\mathrm{a}} \text { série ginasial (1938) } \mathbf{\Omega} \\
\text { - Compêndio de língua portuguesa: } 2^{\mathrm{a}} \text { série ginasial (1939_2a ed.) } \mathbf{\Omega} \\
\text { - Compêndio de língua portuguesa: } 3^{\mathrm{a}} \text { série ginasial (1938) } \boldsymbol{\beta} \\
\text { - Manual de língua portuguêsa: para a primeira série dos cursos } \\
\text { clássico e científico (1945_2ed.) } \mathbf{\Omega} \\
\text { - Manual de língua portuguêsa: para a segunda série dos cursos } \\
\text { clássico e científico (1945_2ed.) } \boldsymbol{\beta} \\
\text { - Manual de língua portuguêsa: para a terceira série dos cursos } \\
\text { clássico e científico (1945_2ed.) } \boldsymbol{\Omega}\end{array}$ \\
\hline VIANA, Breno & $\begin{array}{l}\text { - Trechos escolhidos: com } 130 \text { exercicios de linguagem oral e escripta } \\
\text { e um appendice de } 181 \text { proverbios }^{339} \text { (1934) } \boldsymbol{\beta} \\
\text { - Trechos escolhidos: } 2^{\text {a }} \text { série com } 113 \text { exercicios de linguagem oral e } \\
\text { escrita: para os cursos propedêutico do comércio e secundário (1937) } \\
\Omega\end{array}$ \\
\hline
\end{tabular}

\footnotetext{
${ }^{337}$ Professor Catedrático de Português no Ginásio Paranaense, em Curitiba, Paraná. A partir de 1939, passa a ser professor de Filologia Portuguesa, na Faculdade de Filosofia, Ciências e Letras, da Universidade de São Paulo.

${ }^{338}$ Quanto ao Programa de Português: de $3^{\mathrm{a}}$ e $4^{\mathrm{a}}$ séries secundária, só conseguimos localizar exemplares fora de nosso recorte temporal. O mais antigo que encontramos é a $7^{\mathrm{a}}$ edição, de 1955.

339 "Em harmonia com a nova regulamentação do ensino commercial no Brasil".
} 
TOTAL

87 obras 
QUADRO 6B - Obras de temas gramaticais específicos

\begin{tabular}{|c|c|}
\hline $\begin{array}{l}\text { ADRIÃO, (Padre) } \\
\text { Pedro }\end{array}$ & - Tradições clássicas da Língua Portuguesa (1945) $\beta$ \\
\hline $\begin{array}{l}\text { AGUIAR, } \\
\text { Porfirio de }\end{array}$ & - Umas questões de lingua (1903) $\beta$ \\
\hline $\begin{array}{c}\text { ALBUQUERQU } \\
\text { E, Acir }{ }^{340} \text { Tenorio } \\
\text { de }\end{array}$ & $\begin{array}{l}\text { - Questiunculas de português: galicismo de Camilo e outros } \\
\text { despretenciosos artigos (1935) } \boldsymbol{\Omega} \\
\text { - Gallicismos: influência da lingua francesa no Português (1937) } \boldsymbol{\beta} \\
\text { - Estrangeirismos: termos espurios empregados no português: } \\
\text { estrangeirismos de Ruy Barbosa e de Camillo Castello Branco (1937) } \boldsymbol{\Omega} \\
\text { - Deslizes grammaticaes: estudo da linguagem de Rui e de Camilo } \\
\text { Castelo Branco (1938) } \boldsymbol{\Omega} \\
\text { - Contradições de Rui (1939) } \boldsymbol{\Omega} \\
\text { - Linguagem de Ruy Barbosa: observações gramaticais, riqueza } \\
\text { vocabular, estrangeirismo (19--) } \boldsymbol{\beta} \\
\text { - Estudos de Português: influência do Francês no Português, sintaxe do } \\
\text { verbo haver, infinito pessoal, questões de semântica, estrangeirismos, etc. } \\
\text { (1937) } \boldsymbol{\Omega} \\
\text { - Atentados à gramática (1940) } \boldsymbol{\beta}\end{array}$ \\
\hline $\begin{array}{c}\text { ALMEIDA, } \\
\text { Napoleão Mendes } \\
\text { de }\end{array}$ & $\begin{array}{l}\text { - Questões vernaculas: I parte (1937) } \boldsymbol{\Sigma} \\
\text { - Questões vernaculas: II parte (1938) }{ }^{341} \boldsymbol{\Sigma} \\
\text { - Questões vernaculas: III parte (1939) } \boldsymbol{\Omega}\end{array}$ \\
\hline ALMEIDA, Rui & $\begin{array}{l}\text { - Cooperemos para a boa linguagem: mais de } 200 \text { textos corrigidos e } \\
\text { anotados (1944) } \boldsymbol{\beta}\end{array}$ \\
\hline $\begin{array}{l}\text { AMARANTE, } \\
\text { Persicophobo do }\end{array}$ & $\begin{array}{l}\text { - Notas de portuguez á margem de um livro do prof. Pessegueiro do } \\
\text { Amaral: I - rascunho de grammatica aplicada (1917) } \Sigma\end{array}$ \\
\hline
\end{tabular}

${ }^{340}$ Há registros também de seu primeiro nome grafado como Arcy.

${ }^{341} \mathrm{Na}$ capa da obra, há a indicação do ano de 1937. Por outro lado, a folha de rosto informa o ano de 1938. Não há mais informações ao longo do livro que possam dirimir esse impasse. 


\begin{tabular}{|c|c|}
\hline $\begin{array}{l}\text { ANDRADE, } \\
\text { Francellino de }\end{array}$ & $\begin{array}{l}\text { - Réplica ás criticas do Dr. Candido de Figueiredo sobre a } \\
\text { monographia da crase (1913) } \boldsymbol{\beta} \\
\text { - Monographia sobre o emprego da crase (1919_2aed.) } \boldsymbol{\beta} \\
\text { - Vernáculo (1920) } \boldsymbol{\beta} \\
\text { - A lingua sem a grammatica: consultório linguistico (1929) } \boldsymbol{\Omega}\end{array}$ \\
\hline $\begin{array}{l}\text { ANDRADE, } \\
\text { Gustavo de }\end{array}$ & $\begin{array}{l}\text { - Glosas hêterodoxas }{ }^{343} \text { (1914?) } \mathbf{\Omega} \\
\text { - Cacolexias ou vicios de linguagem (1914) } \Sigma\end{array}$ \\
\hline $\begin{array}{c}\text { APOCALYPSE, } \\
\text { Raul }\end{array}$ & - Estudos de Português (1924) B \\
\hline $\begin{array}{c}\text { AQUINO, } \\
\text { Jeronimo de }\end{array}$ & - Apontamentos de gramática e estilo (1940) $\Sigma$ \\
\hline $\begin{array}{l}\text { ARAGÃO, Jarbas } \\
\text { Cavalcante de }\end{array}$ & - A passividade verbal em seus vários aspectos (1944) $\boldsymbol{\beta}$ \\
\hline $\begin{array}{l}\text { ARCANCHY, } \\
\text { Alcides d' }\end{array}$ & $\begin{array}{l}\text { - Pingos grammaticaes (1915) } \mathbf{\Omega} \\
\text { - Pela reforma gramatical: réplica aos srs. Osório Duque-Estrada e } \\
\text { Tristão de Athayde (1922) } \boldsymbol{\beta}\end{array}$ \\
\hline $\begin{array}{l}\text { ASSIS, José } \\
\text { Patricio de }\end{array}$ & - Estudinhos de português: artigos e cartas (1925) $\Sigma$ \\
\hline $\begin{array}{l}\text { BARRETO, } \\
\text { Mário }\end{array}$ & $\begin{array}{l}\text { - Estudos de Lingua Portugueza (1903) } \boldsymbol{\beta} \\
\text { - Novos estudos da Lingua Portuguesa (1911) } \boldsymbol{\beta} \\
\text { - Novíssimos estudos de Língua Portuguesa: colecção de artigos (1914) } \\
\boldsymbol{\beta} \\
\text { - Factos da Língua Portuguesa: correio de consulentes (1916) } \boldsymbol{\beta}\end{array}$ \\
\hline
\end{tabular}

${ }^{342}$ Nos anexos à Grammatica ecletica, obra que foi publicada postumamente, foram reunidas manifestações a respeito da morte de Gustavo de Andrade. Emygdio H. Souza, em texto publicado no Diario da Bahia, em 24/11/1914, diz: "Deixou alguns livros didacticos, dentre os quaes se destacam a - Grammatica intuitiva e as Cacolexias -, sendo este ultimo de grande utilidade não só para os estudiosos, mas tambem para todos os que falam a bella lingua de Camões porque contem a maioria dos vocabulos que por sua má ortographia prosódica e pela sua descendencia, enfermam e infestam a lingua portugueza."

${ }^{343}$ Nos mesmos anexos à Grammatica ecletica, um leitor, que assina apenas JEMR, em texto publicado no jornal $\mathbf{A}$ Epoca, n.1, em 02/11/1914, diz: "Adversario temivel, de que são prova cabal as Glosas heterodoxas, nas quaes, numa formidavel critica á Estylistica, [de Pedro Julio Barbuda] apresentou as incorrecções e a linguagem viviada em que fòra redigida." 


\begin{tabular}{|c|c|}
\hline & $\begin{array}{l}\text { - De gramática e de linguagem: correio de consulentes (1922) } \boldsymbol{\beta} \\
\text { - Através do dicionário e da gramática: correio de consulentes (1927) } \boldsymbol{\beta} \\
\text { - Últimos estudos: vários: a nossa língua, a sra. gramática }(1944)^{344} \boldsymbol{\beta}\end{array}$ \\
\hline BARBOSA, Rui & $\begin{array}{l}\text { - Parecer do Senador Ruy Barbosa sobre a redacção do projecto da } \\
\text { Camara dos Deputados (1902) } \beta \\
\text { - Replica do senador Ruy Barbosa as defesas da redacção do projecto } \\
\text { da Camara dos Deputados (1902) } \beta\end{array}$ \\
\hline $\begin{array}{c}\text { BARRETO, } \\
\text { Paulo Emilio de } \\
\text { Noronha Menna }\end{array}$ & $\begin{array}{l}\text { - Tres questões de grammatica: topologia pronominal, crase, } \\
\text { impessoalidade e pessoalidade do infinito (1938) } \boldsymbol{\beta}\end{array}$ \\
\hline BERGO, Vittorio & $\begin{array}{l}\text { - Erros e duvidas de linguagem: dispostos em ordem alfabética (1941) } \boldsymbol{\beta} \\
\text { - Erros e duvidas de linguagem: dispostos em ordem alfabética: vol. } 2 \\
\text { (1944) } \boldsymbol{\beta} \\
\text { - Consultor de gramatica e de estilistica: em ordem alfabética (1942) } \mathbf{\Omega}\end{array}$ \\
\hline $\begin{array}{l}\text { BITTENCOURT, } \\
\text { Liberato }\end{array}$ & $\begin{array}{l}\text { - Estudo da Lingua Portuguesa (1921) } \mathbf{\Omega} \\
\text { - Impurezas da linguagem no dominio scientífico (1927) } \boldsymbol{\Omega} \\
\text { - Psicologia gramatical de falso Aristarco ou } 3 \text { mil erros de gramatica } \\
\text { (1933) } \boldsymbol{\Omega}\end{array}$ \\
\hline $\begin{array}{c}\text { BRITO } \\
\text { PEREIRA, Carlos } \\
\text { de }\end{array}$ & $\begin{array}{l}\text { - Analyse syntactica: noções indispensaveis e suficientes ao preparatorio } \\
\text { de Português (1928) }(\mathrm{T})^{345} \boldsymbol{\beta}\end{array}$ \\
\hline $\begin{array}{l}\text { BRITO, Paulino } \\
\text { de Almeida }\end{array}$ & $\begin{array}{l}\text { - Collocação dos pronomes: artigos publicados na Provincia do Pará } \\
\text { (1906-1907) (1907) } \boldsymbol{\Omega} \\
\text { - Brasileirismos de colocação de pronomes: resposta ao Snr. Candido de } \\
\text { Figueiredo (1908) } \boldsymbol{\beta}\end{array}$ \\
\hline BUCHLER, G. A. & - Guia de conjugação (1934) $\boldsymbol{\Omega}$ \\
\hline
\end{tabular}

344 Publicação póstuma.

345 (T): Tese.

${ }^{346} \mathrm{O}$ autor assina G. A. Buchler, mas seu nome completo é George Augusto Buchler. 


\begin{tabular}{|c|c|}
\hline & - Caderno de conjugação (s/d) ${ }^{347} \mathbf{\Omega}$ \\
\hline BUENO, Silveira & - Português pelo rádio (1938) $\boldsymbol{\beta}$ \\
\hline $\begin{array}{l}\text { CALBUCCI, } \\
\text { Ernani }\end{array}$ & $\begin{array}{l}\text { - Questiúnculas de Língua Portuguêsa (1941) } \beta \\
\text { - Léxico de dúvidas de linguagem (s/d) }{ }^{348} \boldsymbol{\Omega}\end{array}$ \\
\hline $\begin{array}{l}\text { CAMPOS, } \\
\text { Hippolyto de } \\
\text { Oliveira }\end{array}$ & - Casos grammaticaes (1908?) $\mathbf{\Omega}$ \\
\hline $\begin{array}{l}\text { CARVALHO, } \\
\text { José Mesquita de }\end{array}$ & $\begin{array}{l}\text { - Lições práticas sobre a língua nacional: a gramática ao alcance de } \\
\text { todos (1942) } \boldsymbol{\beta} \\
\text { - Ortografia e acentos (1942) } \boldsymbol{\Omega} \\
\text { - Os quatro obstáculos da lingua nacional }(1942)^{349} \boldsymbol{\beta}\end{array}$ \\
\hline $\begin{array}{l}\text { CASASANTA, } \\
\text { Mario }\end{array}$ & $\begin{array}{l}\text { - A palavra MESMO (T) }(1935)^{350} \boldsymbol{\beta} \\
\text { - Notas de Raul Soares à Gramática de João Ribeiro (1941) } \boldsymbol{\beta}\end{array}$ \\
\hline $\begin{array}{l}\text { CERQUEIRA, } \\
\text { Antonio Alves }\end{array}$ & - Dúvidas de linguagem (1926) $\Sigma$ \\
\hline $\begin{array}{l}\text { CHINA, José } \\
\text { Benedito de } \\
\text { Oliveira }\end{array}$ & - Emprego da crase em Portuguez (1917) $\Sigma$ \\
\hline $\begin{array}{l}\text { CINTRA, } \\
\text { (Francisco de) } \\
\text { Assis }\end{array}$ & $\begin{array}{l}\text { - Questões de Português (1921) }{ }^{351} \boldsymbol{\beta} \\
\text { - O que é correcto?: apostillas de Português (1922) } \Sigma\end{array}$ \\
\hline $\begin{array}{l}\text { COELHO, } \\
\text { Teixeira }\end{array}$ & - A questão do pronome SE: em defesa da sua subjectividade (1918) $\boldsymbol{\beta}$ \\
\hline
\end{tabular}

347 Não conseguimos acesso a dados que pudessem apontar a data de publicação deste livro, mas ele aparece na relação de "Edições da Casa - Cia Melhoramentos de S. Paulo" presente no Livro de exercícios para apprender os elementos da Grammatica portuguesa, de P.S, editada no início do século XX por essa mesma casa editorial. ${ }^{348}$ Não há referência, nesta obra, de seu ano de publicação. Optamos por inclui-la neste levantamento, pois as demais obras do autor são do final da década de 1930 e começo da de 1940, o que nos fez supor que o livro em questão deva ter sido publicado também neste período.

349 A obra aborda quatro tópicos: o emprego do infinito pessoal; pontuação; acentuação e crase e colocação de pronomes.

${ }^{350}$ Nessa obra, não há data de publicação, mas em outra obra do autor, Notas de Raul Soares à Gramática de João Ribeiro, na relação de obras por ele publicadas, informa-se 1935 como data de publicação da tese.

${ }^{351} \mathrm{O}$ subtítulo da $2^{\mathrm{a}}$ edição é elucidativo quanto ao conteúdo da obra: "[com pref. de Ruy Barbosa] sintaxe, orthographia e prosódia". 


\begin{tabular}{|c|c|}
\hline CORREIA, Jonas & - Estudos de Português: ortografia e pontuação (1940) $\boldsymbol{\beta}$ \\
\hline $\begin{array}{l}\text { COSTA, } \\
\text { Affonso }^{352}\end{array}$ & $\begin{array}{l}\text { - Questões grammaticaes: estudos e factos da Lingua Portugueza. (1908) } \\
\boldsymbol{\beta} \\
\text { - Lingua Portuguesa: resposta á critica }(1911)^{353} \boldsymbol{\beta} \\
\text { - Gallicismos e não gallicismos (1929) } \boldsymbol{\Omega}\end{array}$ \\
\hline COSTA, Firmino & - Lexico gramatical (1934) $\boldsymbol{\beta}$ \\
\hline $\begin{array}{l}\text { CRUZ, José } \\
\text { Marques da }\end{array}$ & - Vícios de linguagem (1920) $\Omega$ \\
\hline $\begin{array}{l}\text { CRUZ, Pe. } \\
\text { Antonio da }\end{array}$ & $\begin{array}{l}\text { - Prosodia de alguns nomes proprios pessoaes e geographicos } \\
\left(1929 \_2^{\mathrm{a} e d .} \mathbf{\Omega}\right. \\
\text { - Ó e ô: particularidades numéricas das palavras (1934) } \boldsymbol{\beta} \\
\text { - Regimes de substantivos e adjetivos (1941) } \boldsymbol{\Omega}\end{array}$ \\
\hline $\begin{array}{l}\text { DOMINGUES, } \\
\text { Pinheiro }\end{array}$ & $\begin{array}{l}\text { - Camilo e a lexicografia de Laudelino Freire (1927_2 ed) } \boldsymbol{\beta} \\
\text { - Variação do gênero dos nomes (1931) } \boldsymbol{\Omega}\end{array}$ \\
\hline $\begin{array}{l}\text { DUQUE- } \\
\text { ESTRADA, } \\
\text { Osório }\end{array}$ & - Questões de Portuguez (1919?) ${ }^{354} \boldsymbol{\Omega}$ \\
\hline $\begin{array}{l}\text { FERNANDES, } \\
\text { Francisco }\end{array}$ & $\begin{array}{l}\text { - Dicionário de verbos e regimes: mais de } 10000 \text { verbos em suas } \\
\text { diversas acepções e regências } \\
\text { (1939) } \boldsymbol{\beta}\end{array}$ \\
\hline $\begin{array}{l}\text { FERREIRA, Julio } \\
\text { Pires }\end{array}$ & $\begin{array}{l}\text { - Consultas sobre a Lingua Portugueza: consultório do Jornal Pequeno } \\
\text { (1918) } \boldsymbol{\Omega}\end{array}$ \\
\hline $\begin{array}{l}\text { FLEURY, Renato } \\
\text { Sêneca }\end{array}$ & $\begin{array}{l}\text { - Consultor popular da Língua Portugueza: contendo um vocabulário } \\
\text { orthographico com mais de } 4000 \text { termos }(\mathrm{s} / \mathrm{d})^{355} \boldsymbol{\beta}\end{array}$ \\
\hline
\end{tabular}

352 Affonso Gonçalves Ferreira da Costa

353 "Reply to a series of articles published by Candido de Figueiredo in the section Lingua portugueza of the Jornal do commercio, criticising the author's book, Questões grammaticaes, published 1908". (UNIVERSIDADE DE SÃO PAULO, 2019).

${ }^{354}$ Este livro consta na "relação de obras do autor" presente em uma outra obra de Osório Duque-Estrada: Analyse syntactica: noções essenciaes (1919).

355 Não conseguimos acesso a dados que pudessem apontar a data de publicação deste livro, mas ele aparece na relação de "Edições da Casa - Cia Melhoramentos de S. Paulo" presente no Livro de exercícios para apprender os elementos da Grammatica portuguesa, de P.S, editada no início do século XX por essa mesma casa editorial. 


\begin{tabular}{|c|c|}
\hline $\begin{array}{l}\text { FONSECA, José } \\
\text { J. de Oliveira }\end{array}$ & $\begin{array}{l}\text { - Observações sobre as emendas do sr. senador Ruy Barbosa com } \\
\text { additamento sobre a "Replica" (1904) } \boldsymbol{\Omega}\end{array}$ \\
\hline $\begin{array}{l}\text { FREIRE, } \\
\text { Laudelino }\end{array}$ & $\begin{array}{l}\text { - Gallicismos (1921) } \boldsymbol{\beta} \\
\text { - Verbos portugueses (1924) } \boldsymbol{\beta} \\
\text { - Livros de Camilo: lexicografia, syntaxe, estilo: volume 1 (1927) } \boldsymbol{\Sigma} \\
\text { - Regras práticas para escrever bem (1936) } \boldsymbol{\beta} \\
\text { - Linguagem e estilo (1937) } \beta \\
\text { - Estudos de linguagem (1937) } \boldsymbol{\beta}\end{array}$ \\
\hline GÓES, Carlos 356 & - Diccionario de gallicismos (1920) $\boldsymbol{\beta}$ \\
\hline $\begin{array}{l}\text { GRAÇA, } \\
\text { Heráclito }\end{array}$ & - Factos da linguagem (1904) $\beta$ \\
\hline $\begin{array}{l}\text { JUCÁ (filho), } \\
\text { Cândido }\end{array}$ & $\begin{array}{l}\text { - Novo método de analise da linguagem: analise léxica, analise } \\
\text { morfológica, analise sintática (1936) } \boldsymbol{\beta} \\
\text { - Um caso de concordância: "Houveram coisas terríveis" }(1943)^{357} \boldsymbol{\Omega} \\
\text { - Em defesa do idioma: críticas ao "Dicionário de dúvidas e dificuldades } \\
\text { do idioma nacional" do sr. Antenor de Veras Nascentes }(1944)^{358} \boldsymbol{\Omega}\end{array}$ \\
\hline $\begin{array}{l}\text { LACERDA, Luiz } \\
\text { de }\end{array}$ & - Teoria da acentuação (1923) $\mathbf{\Omega}$ \\
\hline LAGO, Candido & $\begin{array}{l}\text { - O que é correcto: a verdade na analyse - respostas a consulentes - } \\
\text { Brazil (com Z) (1932) } \Sigma \\
\text { - Pronomes pessoaes encliticos: sua colocação (1922) } \boldsymbol{\Omega}\end{array}$ \\
\hline $\begin{array}{c}\text { LIMA } \\
\text { COUTINHO, } \\
\text { Ismael de }\end{array}$ & - A crase $(1928)(T)^{359} \boldsymbol{\beta}$ \\
\hline $\begin{array}{l}\text { LIMA, Mario } \\
\text { Pereira de Souza }\end{array}$ & - Theoria da construcção grammatical $(1923)^{360}(\mathrm{~T}) \boldsymbol{\beta}$ \\
\hline
\end{tabular}

${ }^{356}$ Em algumas obras o autor assina Carlos Góis.

${ }^{357}$ Em coautoria com Pinheiro Domingues e Artur Tôrres.

${ }^{358}$ Em coautoria com Antônio J. Chediak, Pedro A. Pinto, Pinheiro Domingues, Ruy Almeida.

359 “These de livre escolha, apresentada á Congregação do Lyceu de Humanidades de Campos, para o concurso á $1^{\mathrm{a}}$ Cadeira de Português".

${ }^{360}$ These para o concurso a cadeira de Portuguez, no Gymnasio Official de S. Paulo. 


\begin{tabular}{|c|c|}
\hline LIMA, Rocha & $\begin{array}{l}\text { - Teoria da análise sintática (1943) } \boldsymbol{\beta} \\
\text { - Anotações a textos errados (1943) } \Sigma\end{array}$ \\
\hline $\begin{array}{l}\text { LOBO, Ari } \\
\text { Maurell }\end{array}$ & $\begin{array}{l}\text { - Cânones gramaticas e estilísticos para bem escrever a língua } \\
\text { nacional: aplicação do método estatístico aos fatos da linguagem luso- } \\
\text { brasileira (1939) } \Omega\end{array}$ \\
\hline LOPES, Castro & - Artigos philologicos $(1910)^{361} \boldsymbol{\beta}$ \\
\hline $\begin{array}{l}\text { MACHADO } \\
\text { FILHO, Aires da } \\
\text { Mata }\end{array}$ & $\begin{array}{l}\text { - Escrever certo: 1a série (1935) } \boldsymbol{\beta} \\
\text { - Escrever certo: 2a série (1938) } \boldsymbol{\beta} \\
\text { - Problemas da língua (1941) } \boldsymbol{\Omega} \\
\text { - Em busca do têrmo próprio (1947) } \boldsymbol{\beta}\end{array}$ \\
\hline $\begin{array}{l}\text { MAIA JUNIOR, } \\
\text { Manoel }\end{array}$ & - Refutações e estudos da Lingua Portuguesa (1924) B \\
\hline $\begin{array}{l}\text { MARTINS, } \\
\text { Mário R. }\end{array}$ & $\begin{array}{l}\text { - A acentuação nas reformas ortográficas (1939) } \mathbf{\Omega} \\
\text { - Estudo sistematico dos verbos portugueses (1942_2 } 2^{\mathrm{a} e d .)} \boldsymbol{\Sigma}\end{array}$ \\
\hline $\begin{array}{l}\text { MAURO, } \\
\text { Antonio }\end{array}$ & - Estudos de Portuguez (1921) $\beta$ \\
\hline $\begin{array}{l}\text { MELLO, Pedro } \\
\text { de }\end{array}$ & $\begin{array}{l}\text { - Novas teorias grammaticaes: these de concurso (1900) (T) } \boldsymbol{\beta} \\
\text { - O pronome "SE" indefinido/ Notas philologicas }{ }^{362}(1926) \boldsymbol{\beta}\end{array}$ \\
\hline MELO, Paulo de & $\begin{array}{l}\text { - Lições práticas de Português (1941) } \beta \\
\text { - Linguagem médica (1943) } \beta\end{array}$ \\
\hline $\begin{array}{l}\text { MOTTA, } \\
\text { Othoniel }\end{array}$ & - O pronome "se" (1916) $\beta$ \\
\hline $\begin{array}{l}\text { MOURA, } \\
\text { Americo } \\
\text { Braziliense } \\
\text { Antunes de }\end{array}$ & - A “Grammatica expositiva" e o "se" sujeito $(1907)^{363} \beta$ \\
\hline
\end{tabular}

${ }^{361}$ Publicação póstuma.

${ }^{362}$ Foram publicados dois livros em um só volume. O segundo, ressalte-se, é uma reunião de colunas publicadas no "Jornal de Piracicaba" sobre aspectos gramaticais polêmicos.

${ }^{363} \mathrm{O}$ autor refere-se aqui à Grammatica expositiva, de Eduardo Carlos Pereira, publicada em 1907. 


\begin{tabular}{|c|c|}
\hline $\begin{array}{l}\text { NASCENTES, } \\
\text { Antenor }\end{array}$ & $\begin{array}{l}\text { - Dicionário de dúvidas e dificuldades do idioma nacional (1941) } \boldsymbol{\beta} \\
\text { - Lexico de nomenclatura gramatical brasileira (1946) } \boldsymbol{\beta}\end{array}$ \\
\hline $\begin{array}{l}\text { NOBREGA, } \\
\text { Artur Raggio }\end{array}$ & $\begin{array}{l}\text { - Estudos de Português: duas monografias: A acentuação do A e Sintaxe } \\
\text { dos pronomes pessoais }(1900) \Sigma \\
\text { - O problema da crase: filologia portuguesa (1916) } \Sigma \\
\text { - Syntaxe do infinito: emprego do infinito pessoal e do impessoal (1930) } \\
\Sigma\end{array}$ \\
\hline $\begin{array}{l}\text { NUNES, José de } \\
\text { Sá }^{364}\end{array}$ & $\begin{array}{l}\text { - Aprendei a língua nacional: consultório filológico: vol. } 1 \text { (1938) } \boldsymbol{\beta} \\
\text { - Aprendei a língua nacional: consultório filológico: vol. } 2 \text { (1938) } \boldsymbol{\beta} \\
\text { - O sinclitismo pronominal no idioma luso-brasileiro (1920) (T) } \boldsymbol{\Omega} \\
\text { - Comentários à “Réplica” de Rui Barbosa, visando exclusivamente } \\
\text { aos arcaismos (1939) (T) } \boldsymbol{\beta}\end{array}$ \\
\hline $\begin{array}{l}\text { OITICICA, José } \\
\text { de }\end{array}$ & $\begin{array}{l}\text { - Manual de estilo (1925) } \boldsymbol{\beta} \\
\text { - Estudos de fonologia (1916) } \boldsymbol{\beta}(\mathrm{T})\end{array}$ \\
\hline $\begin{array}{l}\text { PAES DE } \\
\text { ANDRADE, J. } \\
\text { M. }\end{array}$ & - Nos domínios do vernaculo: notas didacticas (1925) $\boldsymbol{\beta}$ \\
\hline $\begin{array}{l}\text { PASSOS, } \\
\text { Alexandre }\end{array}$ & - Arte de pontuar: notações sintáticas (1943) $\mathbf{\Omega}$ \\
\hline $\begin{array}{l}\text { PEREIRA, } \\
\text { Altamirano Nunes }\end{array}$ & $\begin{array}{l}\text { - Estudo da palavra QUE (1939) } \Sigma \\
\text { - O problema da análise sintática e sua solução racional (1938) } \Omega\end{array}$ \\
\hline $\begin{array}{l}\text { PEREIRA, } \\
\text { Eduardo Carlos }\end{array}$ & $\begin{array}{l}\text { - Questões de philologia: resposta aos criticos da "Grammatica } \\
\text { expositiva" (1907) } \boldsymbol{\beta}\end{array}$ \\
\hline $\begin{array}{l}\text { PEREIRA, } \\
\text { Miguel }\end{array}$ & $\begin{array}{l}\text { - Funcções do pronome SE e da partícula QUÊ / Adjectivos gentilicos } \\
\text { e patrios (1918) } \beta\end{array}$ \\
\hline PINTO, Leonardo & $\begin{array}{l}\text { - Da collocação dos pronomes complementos (1923) } \mathbf{\Omega} \\
\text { - Gallicismo: lexicos e fraseologicos (1936) } \mathbf{\Omega}\end{array}$ \\
\hline
\end{tabular}

${ }^{364}$ Professor Catedrático de Português no Ginásio Paranaense, em Curitiba, Paraná. A partir de 1939, passa a ser professor de Filologia Portuguesa, na Faculdade de Filosofia, Ciências e Letras, da Universidade de São Paulo. 


\begin{tabular}{|c|c|}
\hline PINTO, P. A. ${ }^{365}$ & $\begin{array}{l}\text { - Nugas e rugas de linguagem portuguesa: notas de vário tempo (1919) } \\
\Sigma \\
\text { - Notas de advocacia gramatical: estudinhos de linguagem portuguesa } \\
\text { (1922) } \boldsymbol{\Sigma} \\
\text { - Termos e locuções: miùdezas de linguagem luso-brasileira (1924) } \boldsymbol{\beta} \\
\text { - Vocábulos e frases: miùdezas de linguagem luso-brasileira (1926) } \boldsymbol{\Sigma} \\
\text { - Crítica miúda: Camilo torturado (1928) } \boldsymbol{\Omega} \\
\text { - Língua materna: miùdezas de linguagem luso-brasileira (1934) } \boldsymbol{\beta}\end{array}$ \\
\hline $\begin{array}{l}\text { REIS, Otelo de } \\
\text { Souza }\end{array}$ & $\begin{array}{l}\text { - Tres palavrinhas: breviário de emendas referentes á linguagem (1931) } \\
\Sigma \\
\text { - Breviário da conjugação de verbos (1931) } \boldsymbol{\beta}\end{array}$ \\
\hline $\begin{array}{l}\text { RIBEIRO, } \\
\text { Ernesto Carneiro }\end{array}$ & $\begin{array}{l}\text { - Ligeiras observações sobre as emendas do dr. Ruy Barbosa feitas á } \\
\text { redação da projecto do Codigo Civil (1902) } \beta \\
\text { - A redacção do projecto do codigo civil e a replica do dr. Ruy } \\
\text { Barbosa: tréplica (1905) } \beta\end{array}$ \\
\hline RIZZO, José & $\begin{array}{l}\text { - Estudos da Língua Portuguesa (1922) } \boldsymbol{\beta} \\
\text { - Da colocação dos pronomes pessoais (1939) } \Sigma \\
\text { - Farfalhas vernáculas (1939) } \boldsymbol{\beta}\end{array}$ \\
\hline SAMPAIO, B. ${ }^{366}$ & $\begin{array}{l}\text { - Questões da língua }(1938)^{367} \boldsymbol{\beta} \\
\text { - Falar certo (1939) } \boldsymbol{\beta} \\
\text { - Polemica alegre de gramática: reposta ao crítico português Vasco } \\
\text { Botelho do Amaral, da Revista Brotéria (1940) } \boldsymbol{\Omega}\end{array}$ \\
\hline $\begin{array}{l}\text { SAMPAIO, } \\
\text { Francisco Ribeiro }\end{array}$ & $\begin{array}{l}\text { - Questões de Português: reparos aos erros de gramática do professor } \\
\text { Silveira Bueno (1939) } \boldsymbol{\beta}\end{array}$ \\
\hline $\begin{array}{l}\text { SAMPAIO, } \\
\text { Guimarães }\end{array}$ & - Idioma nacional (1942) $\Sigma$ \\
\hline
\end{tabular}

${ }^{365} \mathrm{O}$ autor assina suas obras dessa forma, usando iniciais. Seu nome completo é Pedro Augusto Pinto.

${ }^{366} \mathrm{O}$ autor assina suas obras assim. Seu nome completo é Benedito Sampaio.

${ }^{367}$ Não há nenhuma indicação de data de publicação no volume consultado. A BNRJ, porém, dá como provável data de publicação 1938 . 


\begin{tabular}{|c|c|}
\hline $\begin{array}{l}\text { SILVEIRA, } \\
\text { Agenor }\end{array}$ & - Collocação dos pronomes: regras e notas explicativas (1920_2aed.) $\Sigma$ \\
\hline TABORDA, Raul & - O idioma de Camões: ensaios philologicos (1923) $\boldsymbol{\beta}$ \\
\hline $\begin{array}{l}\text { TORRES, Arthur } \\
\text { de Almeida }\end{array}$ & $\begin{array}{l}\text { - Regência verbal }(1931)^{368} \\
\text { - Estudos de Português: colocação de pronomes, crase, pontuação, } \\
\text { concordância, regência, etc (1938) } \boldsymbol{\beta} \\
\text { - Questões filológicas }{ }^{369}(1943) \boldsymbol{\beta}\end{array}$ \\
\hline $\begin{array}{l}\text { VERGARA, } \\
\text { Oswaldo }\end{array}$ & $\begin{array}{l}\text { - Problemas de Português (1918) } \mathbf{\Omega} \\
\text { - Questões vernáculas: primeira série (1913) } \mathbf{\Omega}\end{array}$ \\
\hline $\begin{array}{l}\text { ZILLER, } \\
\text { Trentino }\end{array}$ & - Pequenos reparos philologicos (1923) $\boldsymbol{\beta}$ \\
\hline TOTAL & 157 obras \\
\hline
\end{tabular}

\footnotetext{
${ }^{368}$ Trata-se de um dicionário de regência verbal. No início do livro, em parecer, Laudelino Freire compara esta obra ao Dicionário de construccion y regimen, de Cuervo. Freire assevera que Torres pode ser considerado o "Cuervo brasileiro", por este e outros trabalhos sobre o assunto.

${ }^{369}$ Esta obra é a reunião de polêmicas que o autor travou, em colunas de jornal, com Sousa da Silveira, Serafim da Silva Neto, José de Sá Nunes, Melchíades Picanço e Modesto de Abreu, além de alguns artigos independentes. Nas polêmicas, o autor reproduziu a sequência de textos seus e também dos seus oponentes. Tendo essa natureza diversa, apenas metade do livro (duas polêmicas) referem-se a questões de gramática histórica. A outra metade refere-se a questões normativas, gramaticais. Dessa forma, julgamos conveniente incluir essa obra tanto nas obras da tradição gramatical quanto na filológica.
} 
Quadro 7B - Obras que abordam vários temas gramaticais

\begin{tabular}{|c|c|}
\hline $\begin{array}{l}\text { ADRIÃO, (Padre) } \\
\text { Pedro }\end{array}$ & - Tradições clássicas da Língua Portuguesa (1945) $\beta$ \\
\hline $\begin{array}{l}\text { AGUIAR, Porfirio } \\
\text { de }\end{array}$ & - Umas questões de lingua (1903) $\beta$ \\
\hline $\begin{array}{l}\text { ALBUQUERQUE, } \\
\text { Acir }^{370} \text { Tenorio de }\end{array}$ & $\begin{array}{l}\text { - Questiunculas de português: galicismo de Camilo e outros } \\
\text { despretenciosos artigos (1935) } \boldsymbol{\Omega} \\
\text { - Estudos de Português: influência do Francês no Português, sintaxe } \\
\text { do verbo haver, infinito pessoal, questões de semântica, } \\
\text { estrangeirismos, etc. (1937) } \boldsymbol{\Omega} \\
\text { - Atentados à gramática (1940) } \boldsymbol{\beta}\end{array}$ \\
\hline $\begin{array}{l}\text { ALMEIDA, } \\
\text { Napoleão Mendes } \\
\text { de }\end{array}$ & $\begin{array}{l}\text { - Questões vernaculas: I parte }(1937) \boldsymbol{\Sigma} \\
\text { - Questões vernaculas: II parte }(1938)^{371} \boldsymbol{\Sigma} \\
\text { - Questões vernaculas: III parte (1939) } \boldsymbol{\Omega}\end{array}$ \\
\hline ALMEIDA, Rui & $\begin{array}{l}\text { - Cooperemos para a boa linguagem: mais de } 200 \text { textos corrigidos e } \\
\text { anotados (1944) } \boldsymbol{\beta}\end{array}$ \\
\hline $\begin{array}{l}\text { ANDRADE, } \\
\text { Francellino de }\end{array}$ & $\begin{array}{l}\text { - Vernáculo (1920) } \boldsymbol{\beta} \\
\text { - A lingua sem a grammatica: consultório linguistico (1929) } \mathbf{\Omega}\end{array}$ \\
\hline $\begin{array}{l}\text { ANDRADE, } \\
\text { Gustavo de } \mathrm{e}^{372}\end{array}$ & - Cacolexias ou vicios de linguagem (1914) $\Sigma$ \\
\hline $\begin{array}{c}\text { APOCALYPSE, } \\
\text { Raul }\end{array}$ & - Estudos de Português (1924) $\boldsymbol{\beta}$ \\
\hline $\begin{array}{l}\text { AQUINO, } \\
\text { Jeronimo de }\end{array}$ & - Apontamentos de gramática e estilo (1940) $\Sigma$ \\
\hline
\end{tabular}

${ }^{370}$ Há registros também de seu primeiro nome grafado como Arcy.

${ }^{371} \mathrm{Na}$ capa da obra, há a indicação do ano de 1937. Por outro lado, a folha de rosto informa o ano de 1938. Não há mais informações ao longo do livro que possam dirimir esse impasse.

372 Nos anexos à Grammatica ecletica, obra que foi publicada postumamente, foram reunidas manifestações a respeito da morte de Gustavo de Andrade. Emygdio H. Souza, em texto publicado no Diario da Bahia, em 24/11/1914, diz: "Deixou alguns livros didacticos, dentre os quaes se destacam a - Grammatica intuitiva e as Cacolexias -, sendo este ultimo de grande utilidade não só para os estudiosos, mas tambem para todos os que falam a bella lingua de Camões porque contem a maioria dos vocabulos que por sua má ortographia prosódica e pela sua descendencia, enfermam e infestam a lingua portugueza". 


\begin{tabular}{|c|c|}
\hline $\begin{array}{c}\text { ARCANCHY, } \\
\text { Alcides d' }\end{array}$ & - Pingos grammaticaes (1915) $\mathbf{\Omega}$ \\
\hline $\begin{array}{l}\text { ASSIS, José } \\
\text { Patricio de }\end{array}$ & - Estudinhos de português: artigos e cartas (1925) $\Sigma$ \\
\hline BARRETO, Mário & $\begin{array}{l}\text { - Estudos de Lingua Portugueza (1903) } \boldsymbol{\beta} \\
\text { - Novos estudos da Lingua Portuguesa (1911) } \boldsymbol{\beta} \\
\text { - Novíssimos estudos de Língua Portuguesa: colecção de artigos } \\
\text { (1914) } \boldsymbol{\beta} \\
\text { - Factos da Língua Portuguesa: correio de consulentes (1916) } \boldsymbol{\beta} \\
\text { - De gramática e de linguagem: correio de consulentes (1922) } \boldsymbol{\beta} \\
\text { - Através do dicionário e da gramática: correio de consulentes } \\
\text { (1927) } \boldsymbol{\beta} \\
\text { - Últimos estudos: vários: a nossa língua, a sra. gramática }(1944)^{373} \boldsymbol{\beta}\end{array}$ \\
\hline BERGO, Vittorio & $\begin{array}{l}\text { - Erros e duvidas de linguagem: dispostos em ordem alfabética } \\
\text { (1941) } \boldsymbol{\beta} \\
\text { - Erros e duvidas de linguagem: dispostos em ordem alfabética: vol. } \\
2 \text { (1944) } \boldsymbol{\beta} \\
\text { - Consultor de gramatica e de estilistica: em ordem alfabética (1942) } \\
\mathbf{\Omega}\end{array}$ \\
\hline $\begin{array}{l}\text { BITTENCOURT, } \\
\text { Liberato }\end{array}$ & $\begin{array}{l}\text { - Estudo da Lingua Portuguesa (1921) } \boldsymbol{\Omega} \\
\text { - Impurezas da linguagem no dominio scientífico (1927) } \boldsymbol{\Omega} \\
\text { - Psicologia gramatical de falso Aristarco ou } 3 \text { mil erros de } \\
\text { gramatica (1933) } \boldsymbol{\Omega}\end{array}$ \\
\hline BUENO, Silveira & - Português pelo rádio (1938) $\boldsymbol{\beta}$ \\
\hline $\begin{array}{l}\text { CALBUCCI, } \\
\text { Ernani }\end{array}$ & $\begin{array}{l}\text { - Questiúnculas de Língua Portuguêsa (1941) } \boldsymbol{\beta} \\
\text { - Léxico de dúvidas de linguagem (s/d) }{ }^{374} \boldsymbol{\Omega}\end{array}$ \\
\hline
\end{tabular}

373 Publicação póstuma.

374 Não há referência, nesta obra, de seu ano de publicação. Optamos por inclui-la neste levantamento, pois as demais obras do autor são do final da década de 1930 e começo da de 1940, o que nos fez supor que o livro em questão deva ter sido publicado também neste período. 


\begin{tabular}{|c|c|}
\hline $\begin{array}{l}\text { CAMPOS, } \\
\text { Hippolyto de } \\
\text { Oliveira }\end{array}$ & - Casos grammaticaes (1908?) $\boldsymbol{\Omega}$ \\
\hline $\begin{array}{l}\text { CARVALHO, José } \\
\text { Mesquita de }\end{array}$ & $\begin{array}{l}\text { - Lições práticas sobre a língua nacional: a gramática ao alcance de } \\
\text { todos (1942) } \boldsymbol{\beta}\end{array}$ \\
\hline $\begin{array}{l}\text { CERQUEIRA, } \\
\text { Antonio Alves }\end{array}$ & - Dúvidas de linguagem (1926) $\Sigma$ \\
\hline $\begin{array}{l}\text { CINTRA, } \\
\text { (Francisco de) } \\
\text { Assis }\end{array}$ & $\begin{array}{l}\text { - Questões de Português (1921) } \\
\text { - O que é correcto?: apostillas de Português (1922) } \boldsymbol{\Sigma}\end{array}$ \\
\hline $\begin{array}{l}\text { COSTA, } \\
\text { Affonso }^{376}\end{array}$ & $\begin{array}{l}\text { - Questões grammaticaes: estudos e factos da Lingua Portugueza. } \\
\text { (1908) 及 }\end{array}$ \\
\hline $\begin{array}{l}\text { CRUZ, José } \\
\text { Marques da }\end{array}$ & - Vícios de linguagem (1920) $\boldsymbol{\Omega}$ \\
\hline $\begin{array}{l}\text { DUQUE- } \\
\text { ESTRADA, Osório }\end{array}$ & - Questões de Portuguez (1919?) ${ }^{377} \mathbf{\Omega}$ \\
\hline $\begin{array}{l}\text { FERREIRA, Julio } \\
\text { Pires }\end{array}$ & $\begin{array}{l}\text { - Consultas sobre a Lingua Portugueza: consultório do Jornal } \\
\text { Pequeno (1918) } \boldsymbol{\Omega}\end{array}$ \\
\hline $\begin{array}{l}\text { FLEURY, Renato } \\
\text { Sêneca }\end{array}$ & $\begin{array}{l}\text { - Consultor popular da Língua Portugueza: contendo um } \\
\text { vocabulário orthographico com mais de } 4000 \text { termos }(\mathrm{s} / \mathrm{d})^{378} \boldsymbol{\beta}\end{array}$ \\
\hline $\begin{array}{l}\text { FREIRE, } \\
\text { Laudelino }\end{array}$ & $\begin{array}{l}\text { - Regras práticas para escrever bem (1936) } \boldsymbol{\beta} \\
\text { - Linguagem e estilo (1937) } \beta \\
\text { - Estudos de linguagem (1937) } \boldsymbol{\beta}\end{array}$ \\
\hline GRAÇA, Heráclito & - Factos da linguagem (1904) $\boldsymbol{\beta}$ \\
\hline LAGO, Candido & $\begin{array}{l}\text { - O que é correcto: a verdade na analyse - respostas a consulentes - } \\
\text { Brazil (com Z) (1932) } \Sigma\end{array}$ \\
\hline LIMA, Rocha & - Anotacões a textos errados (1943) $\Sigma$ \\
\hline
\end{tabular}

375 O subtítulo da $2^{\mathrm{a}}$ edição é elucidativo quanto ao conteúdo da obra: "[com pref. de Ruy Barbosa] sintaxe, orthographia e prosódia".

376 Affonso Gonçalves Ferreira da Costa

${ }^{377}$ Este livro consta na "relação de obras do autor" presente em uma outra obra de Osório Duque-Estrada: Analyse syntactica: noções essenciaes (1919).

${ }^{378}$ Não conseguimos acesso a dados que pudessem apontar a data de publicação deste livro, mas ele aparece na relação de "Edições da Casa - Cia Melhoramentos de S. Paulo" presente no Livro de exercícios para apprender os elementos da Grammatica portuguesa, de P.S, editada no início do século XX por essa mesma casa editorial. 


\begin{tabular}{|c|c|}
\hline $\begin{array}{l}\text { LOBO, Ari } \\
\text { Maurell }\end{array}$ & $\begin{array}{l}\text { - Cânones gramaticas e estilísticos para bem escrever a língua } \\
\text { nacional: aplicação do método estatístico aos fatos da linguagem luso- } \\
\text { brasileira (1939) } \mathbf{\Omega}\end{array}$ \\
\hline LOPES, Castro & - Artigos philologicos $(1910)^{379} \boldsymbol{\beta}$ \\
\hline $\begin{array}{l}\text { MACHADO } \\
\text { FILHO, Aires da } \\
\text { Mata }\end{array}$ & $\begin{array}{l}\text { - Escrever certo: } 1^{\mathrm{a}} \text { série (1935) } \boldsymbol{\beta} \\
\text { - Escrever certo: } 2^{\mathrm{a}} \text { série (1938) } \boldsymbol{\beta} \\
\text { - Problemas da língua (1941) } \boldsymbol{\Omega} \\
\text { - Em busca do têrmo próprio (1947) } \boldsymbol{\beta}\end{array}$ \\
\hline $\begin{array}{c}\text { MAIA JUNIOR, } \\
\text { Manoel }\end{array}$ & - Refutações e estudos da Lingua Portuguesa (1924) $\boldsymbol{\beta}$ \\
\hline MAURO, Antonio & - Estudos de Portuguez (1921) $\beta$ \\
\hline MELO, Paulo de & - Lições práticas de Português (1941) ß \\
\hline $\begin{array}{c}\text { NASCENTES, } \\
\text { Antenor }\end{array}$ & - Dicionário de dúvidas e dificuldades do idioma nacional (1941) $\beta$ \\
\hline $\begin{array}{c}\text { NUNES, José de } \\
\text { Sá }^{380}\end{array}$ & $\begin{array}{l}\text { - Aprendei a língua nacional: consultório filológico: vol. } 1 \text { (1938) } \boldsymbol{\beta} \\
\text { - Aprendei a língua nacional: consultório filológico: vol. } 2 \text { (1938) } \boldsymbol{\beta}\end{array}$ \\
\hline $\begin{array}{c}\text { PAES DE } \\
\text { ANDRADE, J. M. }\end{array}$ & - Nos domínios do vernaculo: notas didacticas (1925) $\boldsymbol{\beta}$ \\
\hline PINTO, P. A. ${ }^{381}$ & $\begin{array}{l}\text { - Nugas e rugas de linguagem portuguesa: notas de vário tempo } \\
\text { (1919) } \Sigma \\
\text { - Notas de advocacia gramatical: estudinhos de linguagem } \\
\text { portuguesa (1922) } \Sigma \\
\text { - Termos e locuções: miùdezas de linguagem luso-brasileira (1924) } \boldsymbol{\beta} \\
\text { - Vocábulos e frases: miùdezas de linguagem luso-brasileira (1926) } \boldsymbol{\Sigma} \\
\text { - Crítica miúda: Camilo torturado (1928) } \boldsymbol{\Omega}\end{array}$ \\
\hline
\end{tabular}

\footnotetext{
${ }^{379}$ Publicação póstuma.

${ }^{380}$ Professor Catedrático de Português no Ginásio Paranaense, em Curitiba, Paraná. A partir de 1939, passa a ser professor de Filologia Portuguesa, na Faculdade de Filosofia, Ciências e Letras, da Universidade de São Paulo. ${ }^{381} \mathrm{O}$ autor assina suas obras dessa forma, usando iniciais. Seu nome completo é Pedro Augusto Pinto.
} 


\begin{tabular}{|c|c|}
\hline & - Língua materna: miùdezas de linguagem luso-brasileira (1934) $\beta$ \\
\hline $\begin{array}{l}\text { REIS, Otelo de } \\
\text { Souza }\end{array}$ & $\begin{array}{l}\text { - Tres palavrinhas: breviário de emendas referentes á linguagem } \\
\text { (1931) } \Sigma\end{array}$ \\
\hline RIZZO, José & $\begin{array}{l}\text { - Estudos da Língua Portuguesa (1922) } \boldsymbol{\beta} \\
\text { - Farfalhas vernáculas (1939) } \boldsymbol{\beta}\end{array}$ \\
\hline SAMPAIO, B. ${ }^{382}$ & $\begin{array}{l}\text { - Questões da língua }(1938)^{383} \boldsymbol{\beta} \\
\text { - Falar certo (1939) } \boldsymbol{\beta}\end{array}$ \\
\hline $\begin{array}{l}\text { SAMPAIO, } \\
\text { Guimarães }\end{array}$ & - Idioma nacional (1942) $\Sigma$ \\
\hline TABORDA, Raul & - O idioma de Camões: ensaios philologicos (1923) $\boldsymbol{\beta}$ \\
\hline $\begin{array}{l}\text { TORRES, Arthur } \\
\text { de Almeida }\end{array}$ & $\begin{array}{l}\text { - Estudos de Português: colocação de pronomes, crase, pontuação, } \\
\text { concordância, regência, etc (1938) } \boldsymbol{\beta}\end{array}$ \\
\hline $\begin{array}{l}\text { VERGARA, } \\
\text { Oswaldo }\end{array}$ & $\begin{array}{l}\text { - Problemas de Português (1918) } \mathbf{\Omega} \\
\text { - Questões vernáculas: primeira série (1913) } \mathbf{\Omega}\end{array}$ \\
\hline ZILLER, Trentino & - Pequenos reparos philologicos (1923) $\boldsymbol{\beta}$ \\
\hline TOTAL & 78 obras \\
\hline
\end{tabular}

\footnotetext{
$382 \mathrm{O}$ autor assina suas obras assim. Seu nome completo é Benedito Sampaio.

383 Não há nenhuma indicação de data de publicação no volume consultado. A BNRJ, porém, dá como provável data de publicação 1938 .
} 
Quadro 8B - Obras em que se estudam as ideias gramaticais (ou a linguagem) de um determinado autor/ Polêmicas gramaticais entre autores

\begin{tabular}{|c|c|}
\hline $\begin{array}{l}\text { ALBUQUERQUE, } \\
\text { Acir }^{384} \text { Tenorio de }\end{array}$ & $\begin{array}{l}\text { - Estrangeirismos: termos espurios empregados no português: } \\
\text { estrangeirismos de Ruy Barbosa e de Camillo Castello Branco } \\
\text { (1937) } \boldsymbol{\Omega} \\
\text { - Deslizes grammaticaes: estudo da linguagem de Rui e de Camilo } \\
\text { Castelo Branco (1938) } \boldsymbol{\Omega} \\
\text { - Contradições de Rui (1939) } \boldsymbol{\Omega} \\
\text { - Linguagem de Ruy Barbosa: observações gramaticais, riqueza } \\
\text { vocabular, estrangeirismo (19--) } \boldsymbol{\beta}\end{array}$ \\
\hline $\begin{array}{l}\text { AMARANTE, } \\
\text { Persicophobo do }\end{array}$ & $\begin{array}{l}\text { - Notas de portuguez á margem de um livro do prof. Pessegueiro } \\
\text { do Amaral: I - rascunho de grammatica aplicada (1917) } \Sigma\end{array}$ \\
\hline $\begin{array}{l}\text { ANDRADE, } \\
\text { Francellino de }\end{array}$ & $\begin{array}{l}\text { - Réplica ás criticas do Dr. Candido de Figueiredo sobre a } \\
\text { monographia da crase (1913) } \boldsymbol{\beta}\end{array}$ \\
\hline $\begin{array}{l}\text { ANDRADE, Gustavo } \\
\mathrm{de}^{385}\end{array}$ & - Glosas hêterodoxas ${ }^{386}$ (1914?) $\Omega$ \\
\hline $\begin{array}{l}\text { ARCANCHY, Alcides } \\
\text { d' }\end{array}$ & $\begin{array}{l}\text { - Pela reforma gramatical: réplica aos srs. Osório Duque-Estrada e } \\
\text { Tristão de Athayde (1922) } \boldsymbol{\beta}\end{array}$ \\
\hline BARBOSA, Rui & $\begin{array}{l}\text { - Parecer do Senador Ruy Barbosa sobre a redacção do projecto } \\
\text { da Camara dos Deputados (1902) } \beta \\
\text { - Replica do senador Ruy Barbosa as defesas da redacção do } \\
\text { projecto da Camara dos Deputados (1902) } \boldsymbol{\beta}\end{array}$ \\
\hline $\begin{array}{l}\text { BRITO, Paulino de } \\
\text { Almeida }\end{array}$ & $\begin{array}{l}\text {-Brasileirismos de colocação de pronomes: resposta ao Snr. } \\
\text { Candido de Figueiredo (1908) } \boldsymbol{\beta}\end{array}$ \\
\hline
\end{tabular}

${ }^{384}$ Há registros também de seu primeiro nome grafado como Arcy.

385 Nos anexos à Grammatica ecletica, obra que foi publicada postumamente, foram reunidas manifestações a respeito da morte de Gustavo de Andrade. Emygdio H. Souza, em texto publicado no Diario da Bahia, em 24/11/1914, diz: "Deixou alguns livros didacticos, dentre os quaes se destacam a - Grammatica intuitiva e as Cacolexias -, sendo este ultimo de grande utilidade não só para os estudiosos, mas tambem para todos os que falam a bella lingua de Camões porque contem a maioria dos vocabulos que por sua má ortographia prosódica e pela sua descendencia, enfermam e infestam a lingua portugueza."

${ }^{386}$ Nos mesmos anexos à Grammatica ecletica, um leitor, que assina apenas JEMR, em texto publicado no jornal A Epoca, n.1, em 02/11/1914, diz: “Adversario temivel, de que são prova cabal as Glosas heterodoxas, nas quaes, numa formidavel critica á Estylistica, [de Pedro Julio Barbuda] apresentou as incorrecções e a linguagem viviada em que fòra redigida." 


\begin{tabular}{|c|c|}
\hline CASASANTA, Mario & - Notas de Raul Soares à Gramática de João Ribeiro (1941) B \\
\hline COSTA, Affonso ${ }^{387}$ & - Lingua Portuguesa: resposta á critica $(1911)^{388} \boldsymbol{\beta}$ \\
\hline $\begin{array}{l}\text { DOMINGUES, } \\
\text { Pinheiro }\end{array}$ & - Camilo e a lexicografia de Laudelino Freire $\left(19272^{\text {a }}\right.$ ed) $\boldsymbol{\beta}$ \\
\hline $\begin{array}{l}\text { FONSECA, José J. de } \\
\text { Oliveira }\end{array}$ & $\begin{array}{l}\text { - Observações sobre as emendas do sr. senador Ruy Barbosa } \\
\text { com additamento sobre a "Replica" (1904) } \Omega\end{array}$ \\
\hline FREIRE, Laudelino & $\begin{array}{l}\text { - Livros de Camilo: lexicografia, syntaxe, estilo: volume } 1 \text { (1927) } \\
\Sigma\end{array}$ \\
\hline JUCÁ (filho), Cândido & $\begin{array}{l}\text { - Em defesa do idioma: críticas ao "Dicionário de dúvidas e } \\
\text { dificuldades do idioma nacional" do sr. Antenor de Veras Nascentes } \\
(1944)^{389} \boldsymbol{\Omega}\end{array}$ \\
\hline $\begin{array}{l}\text { MOURA, Americo } \\
\text { Braziliense Antunes de }\end{array}$ & - A “Grammatica expositiva” e o "se” sujeito $(1907))^{390} \boldsymbol{\beta}$ \\
\hline NUNES, José de Sá391 & $\begin{array}{l}\text { - Comentários à "Réplica" de Rui Barbosa, visando } \\
\text { exclusivamente aos arcaismos (1939) (T) } \beta\end{array}$ \\
\hline $\begin{array}{l}\text { PEREIRA, Eduardo } \\
\text { Carlos }\end{array}$ & $\begin{array}{l}\text { - Questões de philologia: resposta aos criticos da "Grammatica } \\
\text { expositiva" (1907) } \boldsymbol{\beta}\end{array}$ \\
\hline $\begin{array}{l}\text { RIBEIRO, Ernesto } \\
\text { Carneiro }\end{array}$ & $\begin{array}{l}\text { - Ligeiras observações sobre as emendas do dr. Ruy Barbosa } \\
\text { feitas á redação da projecto do Codigo Civil (1902) } \beta \\
\text { - A redacção do projecto do codigo civil e a replica do dr. Ruy } \\
\text { Barbosa: tréplica (1905) } \beta\end{array}$ \\
\hline SAMPAIO, B. ${ }^{392}$ & $\begin{array}{l}\text { - Polemica alegre de gramática: reposta ao crítico português } \\
\text { Vasco Botelho do Amaral, da Revista Brotéria (1940) } \Omega\end{array}$ \\
\hline $\begin{array}{l}\text { SAMPAIO, Francisco } \\
\text { Ribeiro }\end{array}$ & $\begin{array}{l}\text { - Questões de Português: reparos aos erros de gramática do } \\
\text { professor Silveira Bueno (1939) } \boldsymbol{\beta}\end{array}$ \\
\hline
\end{tabular}

\footnotetext{
${ }^{387}$ Affonso Gonçalves Ferreira da Costa

388 "Reply to a series of articles published by Candido de Figueiredo in the section Lingua portugueza of the Jornal do commercio, criticising the author's book, Questões grammaticaes, published 1908". (UNIVERSIDADE DE SÃO PAULO, 2019).

${ }^{389}$ Em coautoria com Antônio J. Chediak, Pedro A. Pinto, Pinheiro Domingues, Ruy Almeida.

390 O autor refere-se aqui à Grammatica expositiva, de Eduardo Carlos Pereira, publicada em 1907.

${ }^{391}$ Professor Catedrático de Português no Ginásio Paranaense, em Curitiba, Paraná. A partir de 1939, passa a ser professor de Filologia Portuguesa, na Faculdade de Filosofia, Ciências e Letras, da Universidade de São Paulo.

$392 \mathrm{O}$ autor assina suas obras assim. Seu nome completo é Benedito Sampaio.
} 


\begin{tabular}{|c|l|}
\hline $\begin{array}{c}\text { TORRES, Arthur de } \\
\text { Almeida }\end{array}$ & - Questões filológicas $^{393}(1943) \boldsymbol{\beta}$ \\
\hline TOTAL & 25 obras \\
\hline
\end{tabular}

${ }^{393}$ Esta obra é a reunião de polêmicas que o autor travou, em colunas de jornal, com Sousa da Silveira, Serafim da Silva Neto, José de Sá Nunes, Melchíades Picanço e Modesto de Abreu, além de alguns artigos independentes. Nas polêmicas, o autor reproduziu a sequência de textos seus e também dos seus oponentes. Tendo essa natureza diversa, apenas metade do livro (duas polêmicas) referem-se a questões de gramática histórica. A outra metade refere-se a questões normativas, gramaticais. Dessa forma, julgamos conveniente incluir essa obra tanto nas obras da tradição gramatical quanto na filológica. 
QUADRO 9B - Obras de temas filológicos específicos

\begin{tabular}{|c|c|}
\hline $\begin{array}{l}\text { ALBUQUERQUE, } \\
\text { Acir }^{394} \text { Tenorio de }\end{array}$ & $\begin{array}{l}\text { - Evolução das palavras: a transformacao morfologica e } \\
\text { semantica dos vocabulos portugueses (1940) } \boldsymbol{\beta}\end{array}$ \\
\hline ALI, Said & $\begin{array}{l}\text { - Dificuldades da lingua portugueza (1908) } \boldsymbol{\beta} \\
\text { - Lexeologia do português histórico (1921) } \beta \\
\text { - Formação de palavras e sintaxe do português histórico } \\
(1923)^{395} \boldsymbol{\beta} \\
\text { - Meios de expressão e alterações semânticas (1927) } \boldsymbol{\beta}\end{array}$ \\
\hline AMARAL, Afrânio do & - Biologia e linguística (1945) $\Sigma$ \\
\hline AYROSA, Plinio & - Têrmos tupís no Português do Brasil (1937) $\beta$ \\
\hline BASILE, Ragy & $\begin{array}{l}\text { - Dicionario etimologico dos vocábulos portugueses } \\
\text { derivados do arabe (194-) ( } 8 \text { vols.) } \boldsymbol{\Omega}\end{array}$ \\
\hline BERGO, Vittorio & $\begin{array}{l}\text { - Da gradacao dimensiva e intensiva (these a concurso) } \\
(\mathrm{T})^{396}(1935) \boldsymbol{\beta}\end{array}$ \\
\hline BUENO, Silveira & - Estudos de filologia portuguêsa (1946) $\beta$ \\
\hline $\begin{array}{l}\text { CAMPOS, } \\
\text { J. L. de }{ }^{397}\end{array}$ & $\begin{array}{l}\text { - O problema do infinitivo (1924) } \boldsymbol{\beta} \\
\text { - Divisão de vocabulos: estudo completo para a partilha, facil e } \\
\text { scientifica, de palavras no fim da linha, com regras } \\
\text { grammaticaes, philologicamente justificadas e seguidas de } \\
\text { exuberante exemplificação, contendo, em complemento, } \\
\text { selecto: diccionario de scisões (s/d) }{ }^{398} \boldsymbol{\beta}\end{array}$ \\
\hline $\begin{array}{l}\text { CARVALHO, Alfredo } \\
\text { Ferreira de }\end{array}$ & $\begin{array}{l}\text { - Phrases e palavras: problemas historico-etymologicos. (1. } \\
\text { Serie) (1906) } \Sigma \\
\text { - O Tupi na chorografia pernambucana: elucidario } \\
\text { etymologico (1907) } \boldsymbol{\beta}\end{array}$ \\
\hline
\end{tabular}

394 Há registros também de seu primeiro nome grafado como Arcy.

395 As obras Lexeologia do português histórico (1921) e Formação de palavras e sintaxe do Português histórico (1923), quando de suas segundas edições (1931), passaram a ser publicadas com o nome de Grammatica historica.

396 Originalmente apresentada como tese ao concurso para provimento da cadeira de Português do Gymnasio Mineiro.

${ }^{397}$ O nome completo do autor é João Luis de Campos.

398 A obra não apresenta ano de edição, mas consta na relação de "edições da casa" de um outro livro de 1934. 


\begin{tabular}{|c|c|}
\hline $\begin{array}{l}\text { CHINA, José B. } \\
\text { D’Oliveira }\end{array}$ & - Estudos de filologia e linguistica (1924) $\beta$ \\
\hline COQUEIRO, Mota & $\begin{array}{l}\text { - Monografia da palavra "Araraquara": estudo histórico- } \\
\text { lingüístico do nome da cidade de Araraquara (1936) } \Sigma\end{array}$ \\
\hline $\begin{array}{l}\text { COUTINHO, Ismael de } \\
\text { Lima }\end{array}$ & - As criações internas do idioma (1928) $(\mathrm{T})^{399} \boldsymbol{\beta}$ \\
\hline GALVÃO, Ramiz & $\begin{array}{l}\text { - Vocabulario etymologico, orthographico e prosodico das } \\
\text { palavras portuguezas derivadas da Lingua Grega (1909) } \beta\end{array}$ \\
\hline GARCIA, Rodopho & $\begin{array}{l}\text { - Nomes de aves em lingua Tupi: contribuição para a } \\
\text { lexicografia portuguêsa (1911) } \boldsymbol{\beta}\end{array}$ \\
\hline GEENEN, Henrique & - Palestras philologicas: $1^{a}$ serie $(1931) \boldsymbol{\beta}$ \\
\hline GÓES, Carlos ${ }^{400}$ & $\begin{array}{l}\text { - Diccionario de affixos, desinencias e outros elementos de } \\
\text { composição (1913) } \beta \\
\text { - Diccionario de raizes e cognatos da Lingua Portugueza } \\
\text { (1921) } \beta\end{array}$ \\
\hline GOMES, Arthur & $\begin{array}{l}\text { - Estudo da maior parte dos verbos da lingua moderna por } \\
\text { meio de sua formação e composição baseado sobre o Latim } \\
\text { (1901) } \Sigma\end{array}$ \\
\hline HENRIQUE, João ${ }^{401}$ & $\begin{array}{l}\text { - Filologia jurídica (1934) } \boldsymbol{\beta} \\
\text { - Acentuação gráfica (1943) } \boldsymbol{\beta} \\
\text { - Origem e significação dos nomes de pessoas: estudo } \\
\text { antroponimico (s/d)[1932] }]^{402} \boldsymbol{\beta}\end{array}$ \\
\hline MELO, Mário & - Toponymia pernambucana (1931) $\boldsymbol{\beta}$ \\
\hline MONTEIRO, Clóvis & - Da tendência na evolução de nosso idioma (1926) $(\mathrm{T})^{403} \boldsymbol{\beta}$ \\
\hline
\end{tabular}

399 “These sorteada para o concurso á $1^{\text {a }}$ Cadeira de Português do Lyceu de Humanidades de Campos”.

400 Em algumas obras o autor assina Carlos Góis.

${ }^{401} \mathrm{O}$ autor assinava suas obras apenas com estes dois nomes. Seu nome completo, porém, é João Henrique dos Santos.

${ }^{402}$ A obra não apresenta data de publicação, mas o exemplar consultado apresenta uma dedicatória datada de 1932.

403 Da tendência na evolução de nosso idioma (1926) e Da influência do Tupi no Português (1926) apresentados inicialmente como teses - são reunidos e publicados como livro, em 1931, sob o título Português da Europa e Português da América: aspectos da evolução do nosso idioma. 


\begin{tabular}{|c|c|}
\hline $\begin{array}{l}\text { MOURA, Americo } \\
\text { Braziliense Antunes de }\end{array}$ & - A função subjectiva do pronome SE (1906) $(\mathrm{T})^{404} \boldsymbol{\beta}$ \\
\hline MOTTA, Othoniel & $\begin{array}{l}\text { - Ensaio linguistico (1905) } \boldsymbol{\beta} \\
\text { - Horas philologicas (1937) } \boldsymbol{\beta}\end{array}$ \\
\hline NASCENTES, Antenor & $\begin{array}{l}\text { - Dicionário etimológico da Língua Portuguesa: volume } 1 \\
\text { (1932) } \beta\end{array}$ \\
\hline $\begin{array}{l}\text { NIMER, } \\
\text { Miguel }\end{array}$ & $\begin{array}{l}\text { - Influências orientais na Língua Portuguesa: os vocábulos } \\
\text { árabes, arabizados, persas e turcos - tomo I / etimologia } \\
\text { aplicações analíticas - primeira parte (1943) } \boldsymbol{\beta} \\
\text { - Influências orientais na Língua Portuguesa: os vocábulos } \\
\text { árabes, arabizados, persas e turcos - tomo I / etimologia } \\
\text { aplicações analíticas - segunda parte (1943) } \boldsymbol{\beta}\end{array}$ \\
\hline $\begin{array}{l}\text { OLIVEIRA, Agenor } \\
\text { Lopes de }\end{array}$ & - Toponímia carioca (1935) $\boldsymbol{\beta}$ \\
\hline $\begin{array}{l}\text { PEIXOTO, Almir } \\
\text { Câmara Matos }\end{array}$ & - Novos rumos em filologia (1942) $\beta$ \\
\hline $\begin{array}{c}\text { PEREIRA, Carlos de } \\
\text { Britto }\end{array}$ & - Etymologia: classificação de etymologias (1928) (T) $\boldsymbol{\beta}$ \\
\hline PINTO, P. A. ${ }^{405}$ & $\begin{array}{l}\text { - À margem dos Lusiadas: alguns nomes geograficos (1924) } \Sigma \\
\text { - Estudinhos de etimologias: notas ao correr da pena }-1^{\mathrm{a}} \text { série } \\
\text { (1935) } \boldsymbol{\beta} \\
\text { - Estudinhos de etimologias: escritos ao correr da pena - } 2^{\mathrm{a}} \\
\text { série }(1937)^{406} \boldsymbol{\beta} \\
\text { - Vocábulos médicos e de outra natureza (1944) } \boldsymbol{\Sigma}\end{array}$ \\
\hline RIBEIRO, Joaquim & - Origem da Lingua Portuguêsa (1935) $\boldsymbol{\beta}$ \\
\hline RIBEIRO, & - Estudos philologicos $(1902)^{407} \boldsymbol{\Sigma}$ \\
\hline
\end{tabular}

\footnotetext{
${ }^{404}$ No frontispício o autor não usa a palavra "these", mas sim "monographia". Ao final do trabalho, ele assevera: "Damos por demostrada nossa these". (p.64). Apesar da questão terminológica, o trabalho foi apresentado ao concurso "á cadeira de Portuguez do Gymnasio de Campinas".

${ }^{405} \mathrm{O}$ autor assina suas obras desta forma, usando iniciais. Seu nome completo é Pedro Augusto Pinto.

${ }^{406} \mathrm{Na}$ folha de rosto, há a informação de que a obra contém "notas de divulgação; crítica ao dicionário do Sr. Antenor Nascentes".

4071902 é a data da $1^{\text {a }}$ edição em versão livro, porém antes já havia sido publicado em jornais. Vejamos o que informa a própria obra: “compõe-se este opusculo das notas philologicas publicadas n' A Semana, dos primeiros mezes do anno de 1887; tambem dos Estudos Philologicos publicados em folheto impresso na typ. da Gaz. de Noticias, em 1885”. Como a publicação da $1^{\text {a }}$ edição em livro ocorreu já no século XX, incluímos esta obra no presente levantamento.
} 


\begin{tabular}{|c|c|}
\hline João & - Curiosidades verbais (1927) $\boldsymbol{\beta}$ \\
\hline SÁ, Filippe Franco de & - A lingua portugueza: dificuldades e dúvidas (1915) $\boldsymbol{\beta}$ \\
\hline SAMPAIO, Teodoro & - O tupi na geografia nacional (1901) $\beta$ \\
\hline SCROSOPPI, Horacio & $\begin{array}{l}\text { - Cartas anepigraphas: questões philologicas seguidas dum } \\
\text { vocabulário portuguez-hellenico de nomes próprios de homens, } \\
\text { etc. (1915) } \boldsymbol{\beta}\end{array}$ \\
\hline $\begin{array}{l}\text { SILVA NETO, Serafim } \\
\text { da }\end{array}$ & 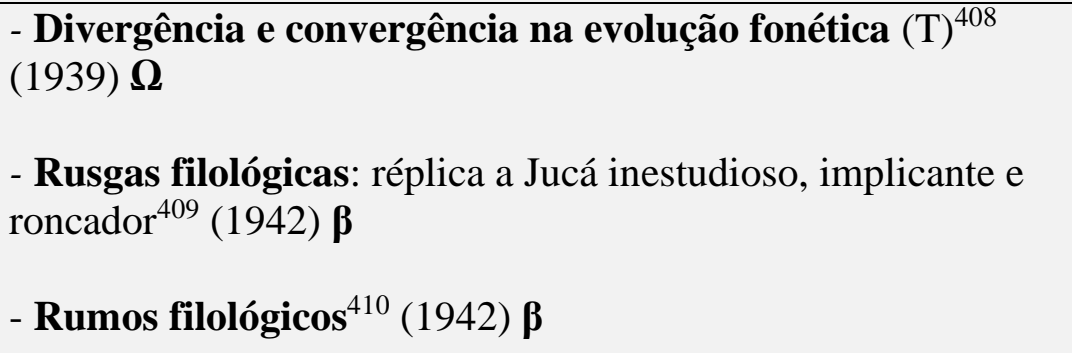 \\
\hline $\begin{array}{c}\text { TORRES, Arthur de } \\
\text { Almeida }\end{array}$ & - Questões filológicas ${ }^{411}$ (1943) $\boldsymbol{\beta}$ \\
\hline TOTAL & 51 obras \\
\hline
\end{tabular}

${ }^{408}$ Como esclarece o autor, essa tese constitui uma separata, um capítulo de uma outra obra sua, a História da Língua Portuguesa.

${ }^{409}$ A obra é, basicamente, uma resposta às críticas feitas por Cândido Jucá (filho) ao Manual de gramática histórica portuguesa: de acordo com o Programa Oficial do $4^{\circ}$ ano), de Serafim da Silva Neto.

${ }^{410}$ Essa obra é uma resposta às críticas feitas por Almir Câmara de Matos Peixoto, no livro Novos rumos em filologia: imprestabilidade dos velhos quadros (1942), à tese apresentada por Silva Neto intitulada Divergência e convergência na evolução fonética, em 1939.

${ }^{411}$ Essa obra é a reunião de polêmicas que o autor travou, em colunas de jornal, com Sousa da Silveira, Serafim da Silva Neto, José de Sá Nunes, Melchíades Picanço e Modesto de Abreu, além de alguns artigos independentes. Nas polêmicas, o autor reproduziu a sequência de textos seus e também dos seus oponentes. Tendo essa natureza diversa, apenas metade do livro (duas polêmicas) referem-se a questões de gramática histórica. A outra metade refere-se a questões normativas, gramaticais. Dessa forma, julgamos conveniente incluir essa obra tanto nas obras da tradição gramatical quanto na filológica. 


\section{QUADRO 10B - Temas de gramática histórica presentes no currículo de Português entre} 1887 e 1961

\section{7 - Programa de Fausto Barreto}

1. - Observações geraes sobre o que se entende por grammatica geral, por grammatica historica ou comparativa e por grammatica descriptiva ou expositiva.

(...)

2. - Da accentuação e da quantidade.

3. - Origem das lettras portuguezas; leis que presidem á permuta das lettras; importancia destas transformações phonicas no processo de derivação das palavras.

4. - Dos Metaplasmas.

5. - Dos systemas de ortographia e das causas de sua irregularidade.

6. - Morphologia: estructura da palavra; raiz; thema; terminação; affixos. Do sentido das palavras deduzido dos elementos morphicos que as constituem; desenvolvimento de sentidos novos nas palavras.

$(\ldots)$

13. - Flexão dos nomes: genero; numero; caso. Noções de declinação latina. Desapparecimento do neutro latino em Portuguez; vestigios de neutro em Portuguez; vestigios da declinação em Portuguez. Origem do s do plural.

(...)

17. - Formação das palavras em geral: composição por prefixos e por juxtaposição. Estudos dos prefixos.

18. - Formação das palavras em geral: derivação propria (por suffixos); derivação impropria (sem suffixos). Estudos dos suffixos.

$(\ldots)$

21. - Etymologia portugueza; principios em que se baseia a etymologia. Leis que presidiram á formação do lexico portuguez.

22. - Da constituição do lexico portuguez. Linguas que maior contingente forneceram ao vocabulario portuguez.

23. - Caracter differencial entre os vocabulos de origem popular e os de formação erudita; duplas ou formas divergentes.

24. - Da creação de palavras novas. Hybridismos.

25. - Etymologia do substantivo e do adjectivo. Influencia dos casos na etymologia dos nomes.

26. - Etymologia do artigo e do pronome.

27. - Etymologia das formas verbaes; comparação da conjugação latina com a portugueza.

28. - Etymologia das palavras invariaveis.

29. - Da syntaxe em geral. Breves noções sobre a estructura oracional, do Latim popular e do Latim culto. Typos syntaxicos divergentes na lingua portugueza.

(...)

45. - Das alterações lexicas e syntaxicas; archaismo e neologismo. 


\section{$3^{\circ}$ ANO}

\section{Português [Curso Realista e Curso Clássico]}

- Gramática: revisão das doutrinas aprendidas no ano anterior com desenvolvimento da morfologia; noções de etimologia portuguesa, exercícios de composição e derivação de palavras sobre vocábulos de formação popular e de origem erudita; análise sintática e etimológica.

\section{$4^{\circ} \mathrm{ANO}$}

\section{Português [Curso Realista e Curso Clássico]}

- Gramática: revisão das doutrinas estudadas no ano anterior, com desenvolvimento da sintaxe. Exercícios de agrupamento de palavras por famílias e de composição e derivação das mesmas; análise sintática e etimológica.

\section{$5^{\circ}$ ANO}

\section{Português [Curso Realista e Curso Clássico]}

- Gramática: revisão das matérias aprendidas no ano anterior; particularidades de construção, idiotismos; vícios de linguagem; arcaísmos; hibridismos; neologismos; provincialismos; brasileirismos; exercícios de agrupamento de palavras por família e por associação de ideias, análise sintática e etimológica.

\section{2, 1915 e 1916 - Programa de ensino do Colégio Pedro II}

\section{$4^{a}$ Série}

$(\ldots)$

2 - Observação sobre o que entende por gramática expositiva, gramática histórica, gramática geral, glotologia, filologia e literatura.

3 - Gramática histórica da língua portuguesa e divisão do seu estudo.

4 - Do vocalismo e do consonantismo. Modificações acidentais do sistema fonético.

5 - Apreciação dos sistemas gráficos.

6 - Da estrutura e do sentido das palavras; das mudanças de sentido.

7 - Estudo comparado das categorias gramaticais.

8 - Princípios em que se baseia a etimologia.

9 - Etimologia das palavras variáveis e das invariáveis.

10 - Elementos de composição e de derivação.

11 - Constituição do léxico português. Formas divergentes.

12 - Estudo comparado geral da sintaxe latina e portuguesa.

13 - Sintaxe histórica das palavras variáveis e das invariáveis. Estrutura oracional românica, especialmente da língua portuguesa.

14 - Alterações mórficas e sintáticas.

15 - Anomalias gramaticais. Dialetos.

(...)

17 - História da língua portuguesa. 


\section{7 - Programa de ensino do Colégio Pedro II}

\section{$3^{\mathbf{0}}$ ano}

1. Distinção entre gramática expositiva, histórica, comparada; glotologia, filologia, literatura.

2. História resumida da língua portuguesa.

3. Estudo sumário das leis fonéticas observadas na transição do latim ao português.

4. Alterações morfológicas: - obliteração dos casos; supressão do gênero neutro; graduação dos substantivos e adjetivos; modificações no quadro das conjugações, formação dos futuros e condicionais românicos; voz passiva.

5. Elementos formadores do léxico português.

6. Processos formativos de palavras. Estudo de prefixos e sufixos.

7. Etimologia. Formas convergentes e divergentes.

8. Mudanças que as alterações morfológicas introduziram na sintaxe e no estilo do idioma.

9. Anomalias gramaticais mais em uso no Brasil e em Portugal. Erros pronúncia. Erros morfológicos. Erros sintáticos. Exercícios para a sua devida correção.

$(\ldots)$

Observação - O programa de gramática histórica, reduzido ao indispensável, pressupõe noções, ainda que elementares, da língua latina, e deve ser exigido não só nos exames finais do Colégio como nos parcelados.

\section{6 - Programa de ensino do Colégio Pedro II}

\section{$3^{\circ}$ ANO}

I - Filiação do português ao latim, revelada pelo léxico, pela morfologia e pela sintaxe. Outros elementos formadores do léxico português.

II - Revisão dos prefixos latinos (por meio de sabatinas).

III - Prefixos e sufixos gregos (estudo sistemático; formas e acepções de cada um).

IV - Plural das palavras terminadas em $\mathbf{l}, \mathbf{m}, \mathbf{n}, \mathbf{s}$ e do ditongo ão.

V - Classificação morfológica; palavras cognatas; famílias de palavras (exercícios práticos).

VI - Estudo sistemático de radicais verbais latinos que deram famílias de palavras em português.

(Várias lições serão consagradas a esse estudo).

$(\ldots)$

\section{8, 1929 e 1930 - Programa de ensino do Colégio Pedro II}

\section{$4^{0}$ ano}

1. Gramática histórica. Método comparativo. Glotologia, filologia, literatura. Origem da língua portuguesa. As línguas afins.

2. Filiação do português ao latim, revelada pelo léxico, pela morfologia e pela sintaxe. Outros elementos formadores do léxico português. Neologismos, peregrinismos, gíria; arcaização, suas causas. Hibridismos.

3. Leis fonéticas. Metaplasmos.

4. Vocalismo. Vogais átonas, tônicas, pré-tônicas e pós-tônicas. Vogais no hiato. Ditongos.

5. Consonantismo. Grupos consonantais. $\mathrm{O}$ h e o til. 
6. Particularidades fonéticas nas palavras de fonte árabe e germânica.

7. Estudo das formas convergentes e divergentes, suas causas. Formas eruditas, semieruditas e populares.

8. Histórico das flexões. Caso lexiogênico. Criações sintáticas resultantes da obliteração dos casos.

9. Redução das declinações latinas. Desaparecimento do neutro; vestígios. Masculino e feminino. Gênero dos derivados da terceira declinação. Formação do plural.

10. Grau dos substantivos; sufixos especiais. Grau dos adjetivos: vestígios do comparativo sintético. O superlativo sintético.

11. Etimologia dos adjetivos e pronomes; evolução de cada classe.

12. Flexões verbais; histórico das desinências.

13. Morfologia histórica do verbo ser.

14. Idem dos verbos: estar e dar.

15. Idem dos verbos: ter, caber e saber.

16. Idem dos verbos: fazer, dizer e trazer.

17. Idem dos verbos: haver, jazer e morrer.

18. Idem dos verbos: pôr e seus análogos (soer, doer, moer).

19. Idem dos verbos: ver, perder e valer.

20. Idem dos verbos: ir e vir.

21. Idem dos verbos: medir, pedir, impedir e cognatos, mentir, ouvir.

22. Modificações no quadro das conjugações. Futuro e condicional românicos. Expressão da passiva; espécies de passiva. A passiva com se nas línguas românicas. A passiva com o infinito. 23. Etimologia dos advérbios, preposições e conjunções; formas arcaicas.

24. Grafia, morfologia e sintaxe dos cancioneiros (estudo prático dos textos).

25. O português dos quinhentistas (estudo prático nos textos da Antologia Nacional).

26. Idem para os seiscentistas.

27. Idem para os árcades.

28. A construção clássica e a moderna. Estilo direto e indireto. Valor literário das orações reduzidas.

29. Particularidades do português popular no Brasil. Tendências dialetais. Influência indígena e africana.

1931 - Programa de ensino do Ministério da Educação e Saúde Pública (Reforma Francisco Campos)

\section{QUARTA SÉRIE}

- Origem da lingua portuguesa; seu domínio; constituição do léxico português; as línguas românicas. O português do Brasil.

- Estudo elementar de fonetica histórica.

- Formas divergentes; suas causas.

- As três declinações do latim popular. O caso lexicogênico. O desaparecimento do neutro.

- Fatos devidos á analogia.

- Justificação das regras referentes ás flexões de gênero e número e á graduação sintatica.

- As tres conjugações do latim popular, perdas sofridas pelo latim literário; creações romanicas, fatos devidos á analogia. Explicação das formas verbais mais características, consideradas irregulares pela gramática expositiva. 
- Observações sôbre a ortografia apoiadas nos conhecimentos de fonetica historica.

1942 - Programa de ensino do Ministério da Educação e Saúde (Reforma Gustavo Capanema)

\section{QUARTA ANO}

II - GRAMÁTICA - Sempre aproveitando o material linguístico encontrado nos textos de aula, tratar-se-á do seguinte:

$(\ldots)$

Unidade II - 1. Latim vulgar. As três declinações do latim vulgar. Sobrevivência do acusativo. O desaparecimento do neutro. As três conjugações do latim vulgar na Península Ibérica. 2. Idéia da ação da analogia, ministrada por meio de alguns exemplos expressivos. 3. Criações românicas.

Unidade III - 1. Origem das línguas românicas. A língua portuguesa, seu domínio. Constituição do léxico português. 2. Estudo breve e elementaríssimo de fonética-histórica. Formas divergentes e convergentes. 3. O português do Brasil. 


\section{QUADRO 11B - Gramáticas históricas do Português}

\begin{tabular}{|c|c|}
\hline $\begin{array}{c}\text { ABREU, } \\
\text { Modesto de }\end{array}$ & $\begin{array}{l}\text { Coleção antiga }{ }^{412} \text { : } \\
\text { - Idioma pátrio: seleta, gramática, exercícios ( } 4^{\mathrm{a}} \text { série) }(1940) \boldsymbol{\Omega} \\
\text { Coleção nova: } \\
\text { - Idioma pátrio: volume } 3^{413} \text { : gramática expositiva e histórica; noções } \\
\text { de estilística e literatura (1944) } \boldsymbol{\beta}\end{array}$ \\
\hline $\begin{array}{l}\text { ALBUQUERQU } \\
\text { E, Acir }{ }^{414} \text { Tenorio } \\
\text { de }\end{array}$ & $\begin{array}{l}\text { - Curso de Português para ginásios: quarta serie: gramática, } \\
\text { antologia, exercícios (1946) } \mathbf{\Omega}\end{array}$ \\
\hline BRUNO, Aníbal & - Língua portuguesa: para a $4^{\mathrm{a}}$ série ginasial (1940_1 ${ }^{\mathrm{a}}$ ed.) $\boldsymbol{\beta}$ \\
\hline BUENO, Silveira & $\begin{array}{l}\text { - Páginas floridas: gramática histórica, comentários etimológicos, } \\
\text { textos arcaicos e modernos: } 4^{\mathrm{a}} \text { série - curso fundamental (1938) } \boldsymbol{\beta}\end{array}$ \\
\hline $\begin{array}{l}\text { CÂMARA JR., } \\
\text { Joaquim Mattoso }\end{array}$ & - Elementos de língua pátria: volume 4 (1938_2ª ed.) $\mathbf{\Omega}$ \\
\hline $\begin{array}{l}\text { COUTINHO, } \\
\text { Ismael de Lima }\end{array}$ & - Pontos de gramática histórica (1938) $\boldsymbol{\beta}$ \\
\hline $\begin{array}{l}\text { CRETELLA, } \\
\text { JÚNIOR, José }\end{array}$ & - Português para o ginásio: $4^{\mathrm{a}}$ série (1945) $\boldsymbol{\Omega}$ \\
\hline CRUZ, Estêvão & $\begin{array}{l}\text { - Programa de vernáculo: gramática e antologia: contém toda a matéria } \\
\text { exigida para o estudo da } 3^{\text {a }} \text { série (1936) } \boldsymbol{\Omega}\end{array}$ \\
\hline $\begin{array}{l}\text { CRUZ, José } \\
\text { Marques da }\end{array}$ & - Português prático: para a $4^{\mathrm{a}}$ série ginasial $\left(1942 \_2^{\mathrm{a} e d}\right) \boldsymbol{\Omega}$ \\
\hline
\end{tabular}

\footnotetext{
${ }^{412}$ A coleção Idioma pátrio tem duas apresentações: uma relativa ao "antigo programa", composta de 5 volumes, e outra do "novo programa", formada por 3 volumes. Há, obviamente, algumas diferenças que aqui explicitaremos: a coleção de 5 volumes segue a estruturação clássica para os livros didáticos de Português da época, presente em quase todas as coleções didáticas que aqui relacionamos. Dos volumes 1 a 4, conteúdo gramatical, de leitura e de redação e $5^{\circ}$ volume destinado aos estudos da história da Literatura e da estilística, fato, aliás, que nos fez não incluir esses volumes no presente levantamento. Na coleção nova, de 3 volumes, o autor fez a seguinte estruturação: volume 1 , para as $1^{\mathrm{a}}$ e $2^{\mathrm{a}}$ séries do Secundário, seleta literária destinada à leitura e interpretação, volume 2, o mesmo conteúdo, só que para as $3^{\mathrm{a}}$ e $4^{\mathrm{a}}$ séries e o volume 3 , destinado a todos os anos do Secundário, é uma gramática expositiva e histórica, além de conter também "noções de estilística e literatura", conteúdo esse que, na coleção antiga, era apresentado no volume 5 .

${ }^{413}$ Como explicado na nota anterior, os volumes 1 e 2 são seletas literárias, fato que motivou a não inclusão dessas obras no levantamento.

${ }^{414}$ Há registros também de seu primeiro nome grafado como Arcy.
} 


\begin{tabular}{|c|c|}
\hline $\begin{array}{l}\text { GEENEN, } \\
\text { Henrique }\end{array}$ & - Questões de grammatica historica latino-portugueza (1911) $\boldsymbol{\Omega}$ \\
\hline $\begin{array}{l}\text { GONÇALVES, } \\
\text { Maximiano } \\
\text { Augusto }\end{array}$ & - Pontos de grammatica histórica (1932) $\boldsymbol{\Omega}$ \\
\hline $\begin{array}{l}\text { GUÉRIOS, } \\
\text { Rosário Mansur }\end{array}$ & $\begin{array}{l}\text { - Pontos de gramática histórica portuguesa: } 4^{\mathrm{a}} \text { série: de acordo com o } \\
\text { programa oficial (1937) } \boldsymbol{\beta} \\
\text { - Português ginasial: gramática e exercícios para a } 1^{\mathrm{a}}, 2^{\mathrm{a}}, 3^{\mathrm{a}} \text { e } 4^{\mathrm{a}} \text { séries } \\
(1944)^{415} \boldsymbol{\beta}\end{array}$ \\
\hline HORTA, Brant ${ }^{416}$ & - Noções de gramática histórica da língua nacional $(1941)^{417} \boldsymbol{\beta}$ \\
\hline $\begin{array}{l}\text { JUCÁ (filho), } \\
\text { Cândido }\end{array}$ & - Gramática histórica do português contemporâneo (1945) $\beta$ \\
\hline LOBO, Vaz & $\begin{array}{l}\text { - Grammatica historica: programma de Portuguez da } 4^{\mathrm{a}} \text { série } \\
\text { gymnasial (1936) } \boldsymbol{\beta}\end{array}$ \\
\hline $\begin{array}{l}\text { MARTINS, Jaime } \\
\text { de Souza }\end{array}$ & - Elementos de gramática histórica: para a quarta série (1937) $\boldsymbol{\beta}$ \\
\hline $\begin{array}{l}\text { MOTTA, } \\
\text { Othoniel }\end{array}$ & - O meu idioma (1916) $\boldsymbol{\beta}$ \\
\hline $\begin{array}{l}\text { NASCENTES, } \\
\text { Antenor }\end{array}$ & - O idioma nacional: volume 4 (1928) $\boldsymbol{\beta}$ \\
\hline $\begin{array}{l}\text { NUNES, José de } \\
\text { Sá }^{418}\end{array}$ & $\begin{array}{l}\text { - Língua vernácula: grammatica historica e anthologia (4ª série) (1938) } \\
\Sigma\end{array}$ \\
\hline $\begin{array}{l}\text { NOGUEIRA, } \\
\text { Julio }\end{array}$ & $\begin{array}{l}\text { - O exame de portuguez: obra indicada no programma official do } \\
\text { Collegio Pedro II (1918) } \boldsymbol{\beta} \\
\text { - Programa de Português: 4a. série secundária (1941) } \boldsymbol{\beta}\end{array}$ \\
\hline $\begin{array}{l}\text { PEREIRA, } \\
\text { Eduardo Carlos }\end{array}$ & - Grammatica historica (1916) $\boldsymbol{\beta}$ \\
\hline
\end{tabular}

$415 \mathrm{O}$ presente volume é formado por uma gramática tradicional e uma gramática histórica. Em função dessa característica "dois em um", a incluímos tanto aqui como no levantamento das obras do programa gramatical, no grupo das "gramáticas completas" (cf. Tabela 1A - Apêndice A).

416 Francisco Eugenio Brant Horta

${ }^{417}$ Este é o título estampado na capa dura (editorial) do livro, mas na folha de rosto aparece um título ligeiramente modificado: Noções de gramática histórica da Lingua Portugueza.

${ }^{418}$ Professor Catedrático de Português no Ginásio Paranaense, em Curitiba, Paraná. A partir de 1939, passa a ser professor de Filologia Portuguesa, na Faculdade de Filosofia, Ciências e Letras, da Universidade de São Paulo. 


\begin{tabular}{|c|c|}
\hline $\begin{array}{c}\text { P.S } \\
\text { (Pedro Schneider) }\end{array}$ & - Syntaxe e grammatica historica da Lingua Portuguesa $(1909)^{419} \boldsymbol{\beta}$ \\
\hline $\begin{array}{l}\text { RESENDE, A. de } \\
\text { Lara }\end{array}$ & $\begin{array}{l}\text { - Lições de grammatica historica: de acordo com o Programma do } \\
\text { Collegio Pedro II (1918) } \Omega\end{array}$ \\
\hline $\begin{array}{l}\text { SILVA NETO, } \\
\text { Serafim da }\end{array}$ & $\begin{array}{l}\text { - Manual de gramática histórica portuguesa: de acordo com o } \\
\text { Programa Oficial do } 4^{\circ} \text { ano (1942) } \boldsymbol{\beta}\end{array}$ \\
\hline $\begin{array}{l}\text { SILVEIRA, } \\
\text { Sousa da }\end{array}$ & $\begin{array}{l}\text { - Lições de Português: dadas no } 3^{\circ} \text { ano da escola normal: de acordo } \\
\text { com o programa (1921) } \boldsymbol{\beta}\end{array}$ \\
\hline $\begin{array}{l}\text { TORRES, Arthur } \\
\text { de Almeida }\end{array}$ & - Compêndio de língua portuguesa: $4^{\mathrm{a}}$ série ginasial (1937) $\boldsymbol{\Omega}$ \\
\hline $\begin{array}{c}\text { Reunião de } \\
\text { professores (obra } \\
\text { coletiva) }\end{array}$ & $\begin{array}{l}\text { - Novo manual de lingua portuguesa: grammatica historica: Curso } \\
\text { Complementar (1925) } \boldsymbol{\beta}\end{array}$ \\
\hline TOTAL & 30 obras \\
\hline
\end{tabular}

419 O presente volume é formado por uma gramática tradicional e uma gramática histórica. Em função dessa característica "dois em um", a incluímos tanto aqui como no levantamento das obras do programa gramatical, no grupo das "gramáticas completas" (cf. Tabela 1A - Apêndice A). 
QUADRO 12B - Definições de gramática histórica, filologia, glotologia, linguística e demais conceitos correlatos presentes nas Gramáticas Históricas do Português

\section{ABREU, Modesto de. Idioma pátrio: volume 3: gramática expositiva e histórica; noções de estilística e literatura (1944) $\boldsymbol{\beta}$ \\ GRAMÁTICA HISTORICA \\ NOÇÕES PRELIMINARES}

Gramática. - Quanto aos métodos que emprega, a Gramática pode ser: descritiva, prática ou expositiva (programa das 3 primeiras séries) e histórica ou comparada (programa da quarta série).

Gramática Histórica. - Estuda a evolução da Língua desde as suas origens. - Emprega principalmente o método comparativo (comparação das formas atuais com as antigas, na própria língua e nas línguas estrangeiras). - Prestam-lhe concurso vários ramos de conhecimentos, artísticos ou científicos: a lingüística, a filologia, a lexicografia, o folclore, a literatura, a crítica.

Lingüística ou Glotologia. - Estudo da linguagem e suas leis, regras e usos, em cada povo ou raça. - A linguagem pode ser: mímica, falada e gráfica. A linguagem mímica se manifesta por meio de gestos; a falada, por gritos inarticulados e por vocábulos; a gráfica, por desenhos, sinais pictóricos e palavras escritas.

Filologia. - Estudo comparativo e crítico das diversas línguas através de suas literaturas.

Lexicografia. - Estudo das palavras e expressões de uma ou mais línguas, sua catalogação e codificação em dicionários, vocabulários, léxicos ou glossários.

Folclore. - Estudo das tradições e costumes populares, através das canções, lendas e contos transmitidos de geração em geração à memória do povo. - O folclore (do inglês folk, povo + lore, ciência, erudição) corresponde à infância da literatura: é anterior à arte escrita e à disciplina gramatical e estilística.

Literatura. - Estudo das creações artísticas em que se fixa a língua de um ou mais povos. Compreende a arte literária (produção de obras em prosa e verso) e a história literária (conhecimento sistemático das obras produzidas pelos literatos).

Crítica. - Estudo das qualidades artísticas das obras literárias ou científicas, comparadas entre si ou quanto à técnica do estilo, à gramática, ao vocabulário e à arte literária. (p.183184) 
ALI, Said. Grammatica secundária da Lingua Portugueza ${ }^{420}(1923) \boldsymbol{\beta}$

Grammatica historica é aquella que estuda a evolução dos diversos factos da língua desde a sua origem até a epoca presente. (p.5)

BRUNO, Aníbal. Língua portuguesa: para a 4ª série ginasial (1940_1ª ed.) $\boldsymbol{\beta}$

O autor não define gramática histórica.

BUENO, Silveira. Páginas floridas: gramática histórica, comentários etimológicos, textos arcaicos e modernos: $4^{\mathrm{a}}$ série - curso fundamental (1938) $\boldsymbol{\beta}$

\section{DE GRAMATICA HISTORICA}

A Ciência da Linguagem - É aquela que estuda a expressão oral e escrita dos povos em todos os seus aspectos. Divide-se em glotologia e filologia.

Glotologia - É a ciência que estuda a origem, o desenvolvimento e a classificação da linguagem. Faz parte das ciências naturais. O estudo da origem, evolução e classificação das línguas indo-européias constitue a Glotologia indo-européia.

Filologia - É a ciência que estuda a linguagem fixada em documentos de um povo, numa determinada época. O estudo dos documentos deixados pelos gregos e latinos chamase Filologia Clássica. O estudo dos documentos (poesias, contos, romances, teatro, sermões, discursos), portugueses forma a Filologia Portuguesa.

Linguagem - Entendemos por linguagem: o complexo de sinais orais e audíveis de que a humanidade se serve para representar e comunicar idéias. (G. de Gregório - M. da Ciência da Ling., 29).

Língua - ... e por língua: a forma que a linguagem toma nos vários povos e nações (Idem, Ibidem).

A linguagem é geral; a lingua é particular.

Língua viva - É aquela que está em uso nalgum povo ou nação. Línguas portuguesa, espanhola, italiana, etc.

Língua morta - É aquela que só existe escrita e não é mais falada por povo algum. O latim, o grego clássico.

Língua extinta - É aquela que não existe nem siquer em documentos, da qual se faz apenas hipótese. O proto-árico.

$(\ldots)$

Gramática Histórica - É aquela que estuda a origem e a evolução de uma língua através das influências das épocas e dos lugares em que se falou essa língua. Exemplo: a Gramática Histórica do Português estuda a origem da língua portuguesa desde as primeiras transformações do latim popular na península ibérica até o seu estado atual em Portugal e no Brasil. Abrange desde o segundo século antes de Cristo até hoje. Note-se, porém, que o estudo histórico do português se inicia pròpriamente no século IX, depois de Cristo quando começaram a aparecer os primeiros documentos escritos.

Método histórico-comparativo - O estudo evolutivo da nossa língua é feito de acórdo com o confronto das formas históricas não só portuguesas, mas também espanholas, ${ }^{420}$ Said Ali, na Grammatica historica, não define o que vem a ser gramática histórica. Isso só acontece em sua
Grammatica secundaria. 
italianas, francesas, etc., afim de que as conclusões sejam certas e científicas. Assim, a forma atual do futuro (amarei) dizemos que é criação puramente romana, e a esta conclusão chegamos através das comparações históricas que remontam até o tempo de Cícero. (p.1113)

COUTINHO, Ismael de Lima. Pontos de gramática histórica $\boldsymbol{\beta}$ (1938)

\section{Gramática Histórica. Método Comparativo. Glotologia, Filologia e Literatura.}

1. Gramática Histórica é a ciência que estuda os fatos de uma língua, no seu desenvolvimento sucessivo, desde a origem até a época atual.

Da definição logo ressalta que o objeto da Gramática Histórica é muito mais amplo que o da Gramática Expositiva, Descritiva ou Prática.

Com efeito, enquanto esta se ocupa de uma língua no estado atual; aquela, remontando no passado às suas origens, ao seu período de formação, explica-nos as transformações por que essa mesma língua passou, na sua evolução através do espaço e do tempo.

Essas transformações não se deram por acaso, não foram produzidas pela moda ou capricho, mas obedeceram a tendências naturais, a hábitos fonéticos espontâneos. A constância e regularidade, que se observam em tais transformações, permitiram ao gramático formular-lhes os princípios e leis. $\mathrm{O}$ estudo dêstes princípios e leis se faz na Gramática Histórica.

Há relações de natureza íntima entre a Gramática Histórica e a Gramática Expositiva, Descritiva ou Prática. Pode-se afirmar que uma é o complemento da outra. O que à Gramática Expositiva se afigura uma irregularidade ou exceção, não passa, as mais das vezes, de um fato perfeitamente explicável pelas leis da Gramática Histórica.

Nem todas as línguas têm um passado, o que importa dizer, nem todas são suscetíveis de possuir uma Gramática Histórica. Neste caso, estão o volapuque, o ido e o esperanto, criações artificiais, destinadas a servir de instrumento nas comunicações internacionais.

Em situação idêntica, acham-se os idiomas que carecem de documentos escritos. Constituem estes os materiais sôbre que o gramático faz as suas observações.

A Gramática Histórica não é uma ciência inteiramente autônoma, mas está subordinada à Glotologia, em cujas conclusões deve basear os seus princípios; do mesmo modo, o papel do gramático se subordina ao do glotólogo.

Modificação do latim popular, levado pelos legionários romanos para a Península Ibérica, e aí transformado e grandemente enriquecido no seu léxico, o português é um ramo importante do grupo de línguas novi-latinas, possuindo documentos literários apreciáveis, cujo exame nos revela as várias fases da sua evolução.

2. A Gramática Histórica da língua portuguesa estuda a origem e a evolução do idioma português no tempo e no espaço.

Esta evolução processou-se normalmente, de acôrdo com as tendências naturais de que resultaram os hábitos glóticos do povo português.

$\mathrm{Na}$ Gramática Histórica da língua portuguesa, encontram-se, por conseguinte, formulados, os princípios e leis, segundo os quais se operou essa evolução.

3. Divisão. - Divide-se a Gramática Histórica em Lexiologia e Sintaxe. 
4. A Lexiologia estuda a palavra isoladamente. Sob dois aspectos se pode fazer êste estudo: o material e o significativo. Daí a subdivisão da Lexiologia em Fonologia e Morfologia.

5. A Sintaxe ocupa-se das palavras relacionadas umas com as outras, na frase.

6. Método Comparativo. - Consiste o Método Comparativo em relacionar os fatos de uma língua com os análogos de outra ou outras da mesma família, para descobrir-lhes a origem ou procedência.

O Método Comparativo é um auxiliar poderoso e seguro nas pesquisas etimológicas, fornecendo, de pronto, a chave de muitos problemas que, de outro modo, seriam de difícil solução.

Para exemplo, tomemos o verbo ousar.

O latim clássico ministra-nos audere, de idêntico sentido, que, entretanto, não pode justificar a origem de ousar.

Apliquemos ao caso o Método Comparativo.

Em provençal, a palavra correspondente à portuguesa é ausar; em italiano, osare; em espanhol, osar; em francês, oser.

Estas formas paralelas, nas línguas românicas, estão a indicar que o verbo originário, em latim, devia ser da primeira conjugação. A permanência do $s$, em todos os exemplos, é também argumento contra audere.

Conhecidas as leis fonéticas que presidiram à evolução dos vocábulos nas citadas línguas novi-latinas, só uma palavra há que pode justificar plenamente a existência daquelas várias formas, e esta é *ausare, verbo formado, no latim popular, a exemplo de outros, do particípio ausum, de audere.

Não raro, somos obrigados a admitir formas hipotéticas, para explicar a origem de algumas palavras nossas, em virtude da quasi absoluta escassez de documentos do latim popular.

Denominamo-las hipotéticas, não porque nos assalte alguma dúvida sôbre a sua existência, mas porque não temos delas memória documental.

Não basta comparar o vocábulo português, no seu aspecto moderno, com os respectivos representantes nas línguas afins; faz-se mister, às vezes, procurar-lhe uma forma mais antiga ou um dos tipos intermediários, para que a comparação surta o desejado efeito.

É o que sucede com o artigo $o$.

$\mathrm{O}$ francês $l e$, o provençal $l o$, o espanhol $e l, l o$, o romeno $l e, l$, o reto-romano $i l, l$, e o italiano $i l, l o$, modificações do demonstrativo latino illu (acus.) ou ille (nom), à primeira vista parecem não ter comunidade de origem com o nosso artigo. No entanto, a forma lo dêste, no antigo português, não deixa nenhuma dúvida sôbre isso.

É fácil concluir, pois, que o Método Comparativo deve ser auxiliado pelo conhecimento da história da língua, para que as suas conclusões sejam reais.

7. Glotologia é a ciência que estuda a origem e o de desenvolvimento da linguagem. Esta denominação é italiana. Os franceses preferem o têrmo Linguiística. Glótica é criação alemã. Acha Adolfo Coelho que todos estes têrmos estão suficientemente consagrados. psicológico.

8. Estudando a linguagem, a Glotologia a encara sob o aspecto fisiológico e

Assim, é privativo desta ciência o estudo dos sons da voz humana, da origem da linguagem, do seu desenvolvimento sucessivo, dos fenômenos gerais que as línguas apresentam, da classificação das línguas, etc.

A Glotologia estuda uma ou mais línguas, sem outra finalidade que não seja o seu conhecimento. Para ela, tanto monta aplicar-se a um idioma bárbaro, sem monumentos literários, como a outro que tenha rica literatura. 
São auxiliares da ciência da linguagem a Arqueologia, a Mitologia, a História, a Etnologia, etc.

9. Histórico. - No desenvolvimento gradual da ciência da linguagem, descobrem-se, segundo Benfey, quatro fases bem distintas: a Fisiológica, a Filosófica, a Histórica e a Comparativa.

10. A Fisiológica é caracterizada pelos trabalhos dos gramáticos índios, cuja preocupação era analisar minuciosamente os sons do sânscrito. Panini, desde o século IV antes da Era Cristã, traça, com admirável precisão, as principais regras fonéticas e gramaticais dessa língua, servindo o seu trabalho de ponto inicial para toda uma literatura de comentários aos velhos textos indianos.

11. A Filosófica é-nos revelada pela orientação que os pensadores gregos imprimiam aos seus estudos acêrca da linguagem. Todas as suas investigações, nêste assunto, eram de natureza filosófica. Para êles, o que interessava saber era o que é a linguagem em si; qual a sua origem; se a relação existente entre a palavra e a coisa é, ou não, necessária e natural; se o nome é dado ao ser por convenção, etc. O Crátilo de Platão demonstra essa preocupação filosófica.

12. A Histórica denuncia-se pela existência de trabalhos, tendentes a explicar a origem e as transformações sucessivas dos fatos de uma língua, em face dos seus documentos escritos. Só se imobilizam os idiomas mortos ou extintos. Os outros estão em contínuo movimento. Tal é a sorte das línguas faladas. Cada geração contribue, sem que o perceba, com o seu pequeno contingente, para a transformação do próprio idioma. Estas, à proporção que o tempo procede, se vão avolumando e radicando nas gerações posteriores, até que se tornam verdadeiramente sensíveis, depois de alguns séculos.

13. A Comparativa surge com as obras em que se cotejam dois ou mais idiomas afins, com o objetivo de encontrar uma explicação cabal aos seus fatos gramaticais ou lingüísticos. A Histórica e a Comparativa são as fases mais modernas da ciência da linguagem. Para ser completo o conhecimento de uma língua, faz-se mister que à sua suficiente notícia histórica se alie a noção de outros idiomas da mesma família. A semelhança de fenômenos leva-nos a conjecturar sobre a identidade da causa. Assim, a semelhança de inúmeros fenômenos, verificados no sânscrito, persa, grego, latim e línguas germânicas, levou estudiosos a pensarem que estas línguas tinham comunidade de origem. Entretanto, como explicar as diferenças consideráveis que elas apresentam?

De um lado, esta dificuldade foi superada pela comparação das diversas partes do seu mecanismo gramatical; de outro, pela história que, tomando conhecimento das divergências existentes, tratou de estudar-lhes as causas, se eram filhas do acaso ou se obedeciam a leis certas, e de explicar como as divergências se foram acentuando, no correr do tempo.

"Foi na tarefa da resolução dessas questões, diz Adolfo Coelho, que o método da moderna ciência da linguagem se criou com todos os seus característicos".

Podemos dizer que a verdadeira ciência da linguagem, com os processos rigorosos de que atualmente dispõe, é uma das principais conquistas do século XIX.

14. Foi Filippo Sassetti, sábio italiano, que viveu em Goa, de 1581 a 1588, quem primeiro, numa de suas cartas, chamou a atenção dos ocidentais para a existência da língua sânscruta, assinalando, ao mesmo tempo, a grande semelhança que havia entre algumas palavras dêste idioma e o italiano.

Em 1606, o missionário Roberto de Nóbili aporta à Índia e, desde logo, se entrega, anos seguidos, ao estudo das línguas locais, notadamente do sânscrito. Os seus conhecimentos dêsse idioma e de sua literatura foram de tal ordem que êle, para melhor êxito de sua missão apostólica, concebeu o arrojado projeto de se apresentar em público, disfarçado 
em sacerdote bramânico. Acusado de idolatria, nas memórias que então enviou a Roma para sua defesa, traça um quadro completo das religiões, costumes e literatura dos brâmanes.

Ainda no século XVII, o jesuíta Heinrich Roth, que viveu, alguns anos, em Agra, se revela profundamente versado em coisas da Índia, tendo sido ele quem deu a notícia sôbre o alfabeto dessa língua, publicada por Athanasius Kircher, na China illustrata (1667).

A partir do século XVIII, começam finalmente os sábios europeus a voltar as suas vistas para tão extraordinária descoberta. A própria "Academia Francesa" mostra-se interessada e pede aos missionários que lá se acham, em função do seu apostolado, notícias mais circunstanciadas sôbre o sânscrito.

Ao abade Barthélemy, em París, envia de Pondichery, em 1767, o Pe. Coeurdoux, respondendo a uma solicitação que aquele lhe fizera para elaborar uma gramática e dicionário do sânscrito, uma interessantíssima memória, que lhe pede apresentar aos seus colegas de Academia sob o título "Donde de palavras que lhe são comuns com o latim e grego, sobretudo com o latim?". Apesar da novidade e do valor das observações de Coeurdoux, o seu manuscrito não mereceu grande atenção por parte dos estudiosos franceses, até que Bréal reivindicou para o seu autor a glória de ter sido um dos mais notáveis precursores da nova ciência.

Foi o carmelita alemão Johann Philip Wesdin, geralmente conhecido por Paulinus a Santo-Bartholomeo, que viveu na Índia entre os anos de 1776 a 1789, o primeiro que publicou uma gramática do sânscrito (Roma, 1790).

O conhecimento do histórico da filologia indiana pelos europeus, entretanto, só se inicia definitivamente com a fundação da "Sociedade Asiática de Calcutá", em 1784, destinada a traduzir e interpretar os principais monumentos literários da Índia. Entre os seus membros mais distinguidos, contam-se William Jones, Carey, Wilkins, Forster e Colebrooke. Dizia o primeiro: "Nenhum filólogo saberia examinar o sânscrito, grego e latim, sem pensar que saíram de uma fonte comum, que talvez não mais exista. Razão idêntica, embora menos evidente, há para a suposição de que o gótico e céltico tiveram a mesma origem que o sânscrito. Podemos também compreender o antigo persa nesta família."

No desenvolvimento da Glotologia convém ainda ressaltar o papel importante que desempenhou o poeta alemão Frederico Schlegel, com a sua obra Sôbre a lingua e a sabedoria dos Indianos, publicada em 1808, não própriamente pelo seu valor científico, mas, sobretudo, pela influência que ela teve e interêsse que despertou.

15. A glória da criação da nova ciência, porém, estava reservada a outro alemão ilustre, Francisco Bopp. O sábio lingüísta teuto, com o seu Sistema de Conjugação, dado a lume em 1816, em que pôs em confronto o sânscrito, o grego, o latim, o persa e o germânico, instituiu o verdadeiro método a ser observado no estudo da ciência da linguagem. A esta obra, seguiu-se a Gramática comparativa das linguas indoeuropéias, em que ampliou o plano dos estudos anteriores, arrolando outros idiomas. A publicação deste trabalho que começou em 1833, só ficou terminada em 1852.

Constituída a ciência da linguagem, logo uma plêiade de estudiosos se consagra ao conhecimento de idiomas menos explorados, aplicando-lhes os novos métodos científicos. O celta, o persa, o lituânio, os dialetos itálicos, o eslavo, etc., tornam-se objeto de curiosas e importantes pesquisas.

Os processos então descobertos são aplicados pelo orientalista Renan na sua Gramática comparativa das linguas semíticas (1858); por Zeuss na das célticas (1853); por Grimm na das germânicas (1827); por Miklosich na das eslavas (1857); por Diez na das românicas ou novi-latinas (1868).

Modernamente conta a ciência da linguagem cultores desvelados, em todas as nações civilizadas. 
16. A História da Glotologia Portuguesa pode ser dividida, segundo Leite de Vasconcelos, em 4 períodos: o $1^{\circ}$ compreende os quatro primeiros séculos da monarquia lusitana; o $2^{\circ}$ estende-se do princípio do século XVI ao ano de 1779, em que se funda, em Lisboa, a Academia Real de Ciências; o $3^{\circ}$ vai de 1779 a 1868, em que Adolfo Coelho inaugura, em Portugal, os novos métodos científicos; o $4^{\circ}$ começa em 1868 e chega até os nossos dias.

17. Filologia é a ciência que estuda a literatura de um povo ou de uma época, e a língua que lhe serviu de instrumento.

No conceito dos filólogos alemães, abrange o estudo da Filologia: 1) a Glotologia; 2) a Métrica; 3) a História da Literatura.

É uma ciência muito velha.

Nasceu da necessidade, que sentiram os antigos povos, de explicar os textos arcaicos dos seus monumentos literários ou religiosos.

$\mathrm{Na}$ Índia, ela aparece com os trabalhos destinados a interpretar os Vedas, que são os mais antigos poemas bramânicos.

Entre os gregos, no século III antes da Era Cristã, já são notáveis, os estudos dos autores alexandrinos sôbre as obras de Homero e dos velhos poetas líricos. Aristarco é o grande vulto que domina toda essa época.

Qualquer estudo feito no sentido de reconstituir textos antigos de uma lingua, corrigílos quando errados, restituí-los sua genuinidade quando interpolados, constitue trabalho de Filologia.

Rollin denomina filólogos "os que trabalham sôbre os autores antigos, corrigindo-os, explicando-os e editando-lhes as obras".

Quando a Filologia tem por objeto o estudo de duas ou mais línguas, toma o nome de Filologia Comparada. Assim, há uma Filologia Comparada das linguas clássicas, grega e latina; outra das germânicas; ainda outra das novi-latinas ou românicas.

É freqüente encontrar-se empregada a palavra Filologia por Glotologia, e vice-versa. Esta confusão desaparece, quando se considera que o objeto e fim destas duas ciências são diferentes.

18. Distinção entre a Filologia e a Glotologia. - A Filologia visa à parte artística da linguagem; esta preocupação escapa ao domínio da Glotologia. Com efeito, a primeira tem por objeto a literatura de um povo ou de uma época; o objeto da segunda é constituído pela língua. Aquela, se estuda um idioma, é para conhecer-lhe a literatura; esta encontra a sua finalidade no próprio estudo do idioma.

Schleicher, numa feliz comparação, deixou bem patente a diferença que vai do filólogo ao glotólogo. Aquele, estudando com exclusividade as línguas que possuem literatura, é o jardineiro, cuja atenção se volta sòmente para as espécies belas; êste, aplicando-se ao conhecimento de qualquer língua, tenha ou não monumentos literários, é o naturalista, que analisa a flor, pouco se lhe dando da sua beleza.

19. Literatura. - Em dois sentidos, pode-se tomar a palavra Literatura, segundo o seu objeto é mais ou menos extenso.

20. Literatura, em sentido lato, é o conjunto de obras produzidas pelo espírito humano, por meio da palavra.

Nesta definição, estão compreendidas todas as espécies de composição, em prosa ou em verso, literárias ou científicas; em suma, todas as produções do espírito humano, veiculadas pela palavra, que não visem ùnicamente ao interesse individual.

Os telegramas, os recibos, os bilhetes, as cartas particulares, não fazem parte da literatura, porque a utilidade pessoal é o seu objetivo imediato. 
21. Literatura, em sentido restrito, é o complexo de manifestações verbais, destinadas a despertar em nós o sentimento do belo. Isto pode conseguir a obra literária de duas maneiras: pela beleza da forma ou excelência das idéias.

À luz desta definição, só se considera obra literária a que nos impressiona agradàvelmente, despertando em nós sentimentos de entusiasmo e de admiração.

22. Divisão. - A Literatura pode ser culta e popular ou folclórica.

23. Diz-se Literatura Culta a que se acomoda ao sentido da definição.

24. Literatura Popular ou Folclórica é o conjunto de pequenas composições do povo, em que a simplicidade e a principal nota característica.

Nelas se extravasa a alma ingênua da nacionalidade, impregnando-as de suas alegrias e dôres, esperanças e desalentos. Não é difícil descobrir aí os traços de uma filosofia profunda, que só o contacto direto com a natureza fornece ao homem.

A êste ramo de Literatura pertencem as canções, os adágios, as novelas, os romances, as quadras, etc., enfim, todas essas composições, na maioria anônimas, que as gerações guardam cuidadosamente na memória. (p.13-22)

GUÉRIOS, Rosário Mansur. Pontos de gramática histórica portuguesa: $4^{\mathrm{a}}$ série: de acordo com o programa oficial (1937) $\boldsymbol{\beta}$

1. A ciência que trata da linguagem humana em todos os seus aspectos (oral, escrito; científico e artístico) chama-se Ciência da Linguagem. Divide-se em três grandes partes: Filologia, Glotologia e Lingüística.

2. Filologia é a ciência dos fatos literários e eruditos que se referem sòmente a uma determinada língua. "É o estudo científico, histórico e comparado da lingua nacional em toda a sua amplitude, não só quanto à gramática (fonética, morfologia e sintaxe) e quanto à etimologia, semasiologia, etc., mas também como órgão da literatura e como manifestação do espírito nacional" (Carolina M. de Vasconcelos).

3. Glotologia é a ciência das línguas estudadas comparativamente através do tempo e do espaço.

OBS.: 1) Através do tempo gramática histórica ou histórico-comparativa; através do espaço dialetologia (geografia lingüística).

2) Há filologia portuguesa, italiana, clássica (grego e latim), etc., mas não há glotologia portuguesa, italiana, etc., senão glotologia românica, indo-européia, semítica, etc.

4. Linguiística é a ciência da origem e do desenvolvimento da linguagem humana.

OBS.: 1) Pode receber o nome particular de Paleolingüística ou Paleontologia lingüística, quando estuda a linguagem do homem fóssil ou prehistórico.

2) A Filologia está para a Glotologia e a Linguística como, p. ex., a Floricultura (que é arte) está para a Botânica (que é ciência).

5. Linguagem é, no sentido amplo, todo sistema de sinais suscetível de servir de comunicação entre os indivíduos.

6. Linguagem é, no sentido restrito, o complexo de sinais orais de que a humanidade se serve para manifestar as suas idéias.

7. Quando êsse complexo de sinais orais é servido pelo conjunto de um determinado povo, diz-se língua. Esta pode ser viva, morta, ou extinta.

8. Língua viva é a que se fala presentemente; é a que satisfaz às necessidades atuais. Exs.: o português, o francês, o árabe, o chinês, etc. 
9. Língua morta é a que já não é falada por nenhum povo; apenas sobrevive em documentos escritos. Ex.: o latim, o egipcio das piràmides, o assàrio-babilónico, etc.

10. Língua extinta é a lingua morta de que não restou nenhum documento próprio ou direto, e é apenas conhecida em traços gerais, hipotéticos, deduzidos do método comparativo. Exs.: o proto-indo-europeu ou indo-europeu comum, o itálico ou proto-itálico, o ibérico, o ligure, etc.

OBS.: A comparação ou método comparativo é um método, prineipalmente indutivo, que consiste em explicar a uniformidade ou a dissemelhança de processos e de fatos em duas ou mais línguas, para dai tirar conclusões (v. § 81 e obs.).

11. O estudo sistemático dos elementos constitutivos de uma lingua (fonética, morfologia e sintaxe) chama-se gramática. Divide-se esta em expositiva, histórica, comparativa e geral.

12. Gramática expositiva ou descritiva é a que expõe ou descreve o estado atual ou não de uma língua determinada.

OBS.: Não descreve o estado atual de uma língua, quando, p. ex., trata do português do século XVI, ou de um autor, ou da linguagem de uma obra literária (gramática dos "Lusíadas", p. ex.).

13. Gramática histórica é a que estuda origem e o desenvolvimento de uma lingua. A gramática histórica explica os fatos da gramática expositiva atual em estudando o passado; remonta ao curso da lingua em observando as mutações que têm sofrido os sons, as palavras (forma e sentido) e as construções.

14. Gramática comparativa ou comparada é a que estuda os fatos de uma lingua em comparação com os de outra ou outras línguas.

A gramática comparativa trata das correspondências que permitem concluir parentescos e definir grupos, ramos e famílias de línguas.

OBS.: Uma gramática não pode ser verdadeiramente histórica, sem ser ao mesmo tempo comparada. Na gramática histórica, compara-se principalmente o estado da língua de um tempo a outro, e na gramática comparativa historiam-se os estados de duas ou mais línguas provenientes de uma fonte comum.

15. Gramática geral é a que estuda os fatos e as leis da linguagem humana em geral. Trata dos princípios comuns a todas as linguas.

OBS.: São problemas da gramática geral, ou, melhor, da lingüística, entre muitos: a questão de línguas sintéticas e analíticas; línguas isolantes, aglutinantes e flexivas; os elementos principais da oração; enfim as leis gerais, comuns a todas as línguas, à linguagem (leis fonéticas, psicológicas, sociológicas, geográficas, etc.). V. J. Marouzeau, "La Linguistique ou Science du Langage", Paris, 1921; M. Bartoli e G. Bertoni, "Breviario di Neolinguistica ”, Módena, 1925. 


\section{ESQUEMAS}

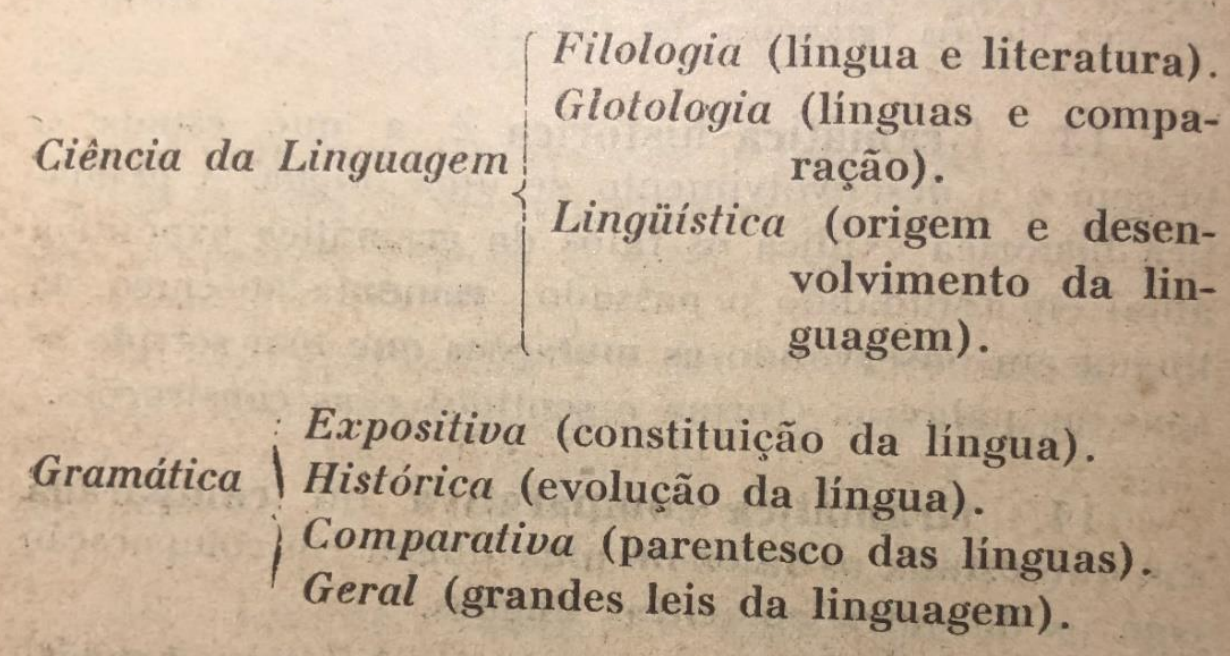

(p. 15-18)

GUÉRIOS, Rosário Mansur. Português ginasial: gramática e exercícios para a $1^{\mathrm{a}}, 2^{\mathrm{a}}, 3^{\mathrm{a}} \mathrm{e}$ $4^{\mathrm{a}}$ séries (1944) $\boldsymbol{\beta}$

Gramática Histórica é a que estuda a origem e o desenvolvimento de uma lingua.

A gramática histórica explica metòdicamente os fatos da gramática expositiva atual em estudando o passado; remonta ao curso da lingua em observando as mutações que têm sofrido os sons, as palavras e as frases.

Gramática Comparativa ou Comparada é a que estuda os fatos de uma lingua em comparação com os de outra ou outras linguas.

A gramática comparatiya trata das correspondências que permitem concluir parentescos e definir grupos, ramos ou familias de línguas. (p.250)

\section{HORTA, Brant. Noções de gramática histórica da língua nacional (1941) $\beta$}

Gramática Histórica estuda a origem e as leis de formação e evolução de uma língua de sorte que a gramática histórica da língua portuguêsa estuda a origem e as leis de formação e evolução do português.

O método a seguir é o comparativo que consiste em estudar uma língua, comparando as suas formas com as formas gramaticais das línguas afins e também com as transformações sucessivas que a própria língua sofreu.

As línguas afins são as que se originam de um mesmo tronco comum.

As línguas afins do português são as que se originam, como ele, do latim popular. o dalmático.

São élas o francês, o italiano, o espanhol, o provençal, o rético, o rumeno, o sardo e

Glotologia também chamada glossologia ou linguistica, é a ciência que estuda a linguagem, sob o aspeto fisiológico e psicológico, em sua formação, desenvolvimento e classificação.

Filologia é a ciência que estuda as linguas não só sob o aspeto glotológico, como também literário e métrico.

Literatura estuda as línguas sob o aspecto literário isto é, estuda a importância dos seus escritores e o valor das obras sob o ponto de vista estético. 


\begin{tabular}{|} 
Não se deve confundir linguagem com língua. \\
Linguagem é o meio pelo qual exprimimos nossas idéas e sentimentos. \\
Língua é o sistema de palavras usado por um grupo de homens para se entenderem. \\
A linguagem pode ser glótica ou falada, gráfica ou escríta, gesticulada ou mímíca. \\
Glótica é a linguagem que se exprime por meio de sons articulados que se chamam \\
- fonemas. \\
Gráfica é a linguagem que se exprime por meio de sinais que se chamam - letras. \\
Mímica é a linguagem que se exprime por meio de movimentos expressivos que se \\
chamam gestos, como a linguagem dos surdos-mudos. (p.13-14) \\
JUCÁ (filho), Cândido. Gramática histórica do português contemporâneo (1945) $\boldsymbol{\beta}$ \\
O autor não define gramática histórica. \\
O autor não define gramática histórica.
\end{tabular}

MARTINS, Jaime de Souza. Elementos de gramática histórica: para a quarta série (1937) $\boldsymbol{\beta}$

TODOS os povos evolucionam no meio ambiente em que se encontram.

A linguagem, como vínculo social que é, deve, forçosamente, acompanhar as variações sociais, por outras palavras, modificar-se.

A Gramática histórica ou comparativa abrange precisamente o estudo dessas modificações, confrontando-as ou comparando-as nas diversas épocas de uma mesma língua, ou nas diversas línguas de um mesmo grupo, afim de verificar quais as leis que as regem.

A gramática histórica é dirigida, nessa investigação, pela Glotologia, Glossologia ou Glótica também chamada Lingüística.

O objeto da glotologia é o estudo das línguas em si próprias, considerando: $1^{\circ}$ ) sua classificação; $2^{\circ}$ ) os agentes exteriores que a modificam; $3^{\circ}$ ) sua gramática comparativa.

A ciência glotológica está estabelecida desde os fins do século XVIII. A Francisco Bopp deve-se a sua descoberta.

A Filologia é o estudo da literatura de um povo ou de uma época e da língua que lhe serviu de veículo. É, portanto, o estudo da arte da linguagem, da sua parte estética.

Do meado do século XIX, parte a distinção que hoje estabelecemos entre a Glotologia e a Filologia.

Pela definição de ambas, observamos que qualquer língua, ainda bárbara, será objeto da Glotologia; ao passo que tão só das línguas que apresentam documentos literários se pode ocupar a Filologia.

Sendo a linguagem uma criação social, o estudo da Filologia e da Glotologia são históricos.

A Literatura, por sua vez, é o conjunto de documentos, que determinam o valor artístico de uma língua. (p.13-14) 
MOTTA, Othoniel. O meu idioma (1916) $\beta$

O autor não define gramática histórica.

\section{NASCENTES, Antenor. O idioma nacional: volume 4 (1942 [1928]) $\beta$}

Gramática histórica - Classificação da lingua portuguesa no quadro geral das línguas

O estudo de uma lingua em seu estado atual se faz na gramática chamada expositiva.

Foi o que tivemos nos três volumes anteriores.

O estudo de uma lingua no passado pertence à gramática denominada histórica.

É o que vamos fazer no presente volume.

À primeira vista pareceria que só fosse necessario conhecer a gramática expositiva.

Considerando melhor, veremos que só o estudo da gramática histórica dará perfeita segurança aos conhecimentos hauridos na expositiva: alem disso, a gramática histórica permite melhor compreensão de fenômenos que, para a expositiva, representam verdadeiras anormalidades.

Assim, por exemplo, os dois futuros partem-se ao meio para receber pronomes obliquos, fato que não se observa em nenhum outro tempo.

A formação histórica destes dois tempos é que vem mostrar a razão pela qual tal fenômeno pode dar-se.

Para suas investigações, a gramática histórica lança mão do método chamado histórico- comparativo porque, ao mesmo tempo que estuda o fenômeno em todas as suas transformações no passado, desde a lingua mãe, recorre muitas vezes para corroborar suas afirmações, a linguas oriundas do mesmo tronco.

Assim, por exemplo, a palavra portuguesa nau vem certamente do latim nave (de acordo com a praxe moderna as palavras latinas são dadas no acusativo sem a desinencia $\mathrm{m}$ : nave $(\mathrm{m})$ ), que deu nave. A presença anormal daquele $u$ só nos pode ser explicada por meio do catalão, lingua em que normalmente desaparece a final vocálica latina, com alterações da consoante precedente ou sem ela: nave> nav > nau.

O complexo de observações sistemáticas sobre a origem e o desenvolvimento da linguagem constitue a ciencia chamada por uns linguística (Hovelacque, de Saussure), por outros, ciencia da linguagem (Max Müller), por outros filologia comparada (Sayce), por outros glotologia (di Gregorio, Pacheco Junior, Trombetti).

A linguística classifica as numerosas linguas existentes no globo terrestre, levando em conta o parentesco que as liga.

De acordo com o parentesco, numerosas são as familias de linguas; citemos algumas das principais: a indo-européia, a semítica, a uralo-altaica, a camítica, a dravídica, a malaiopolinesia, a indo-chinesa, a bantu, etc.

O português, por sua lingua mãe, o latim, pertence à familia indo-européia que compreende: o sánscrito (India), o velho persa, o grego, as linguas itálicas (latim, osco, umbrio), as célticas (Grã Bretanha, Galias), as bálticas, as eslavas, as germânicas, o albanês, o armenio, e o tocariano (Asia Central), hoitita (Asia Menor).

Esta é a classificação de Meillet, uma das maiores autoridades atuais em materia de lingua indo-européias. (p.13-15)

NOGUEIRA, Julio. Programa de Português: 4a. série secundária (1941) $\mathbf{\Omega}$ 


\section{O autor não define gramática histórica.}

NOGUEIRA, Julio. O exame de portuguez: obra indicada no programma official do Collegio Pedro II (1918) $\boldsymbol{\beta}$

\section{Grammatica historica. Methodo comparativo. Glottologia, philologia, literatura.}

A grammatica historica é o estudo documental das linguas. Não se atém aos factos actuaes: para o seu conhecimento perfeito investiga os phenomenos que se passaram neste ou naquelle campo linguistico. Quanto á fórma, ella aprecia os sons que compõem as palavras e a maneira de graphal-os; evidencia as differenças de pronuncia que porventura se hajam operado; separa os vocabulos, quando constituidos de varios elementos, que vae encontrar isolados no mesmo momento historico ou em periodo linguistico anterior; examina as modalidades intermediarias, cuja estructura é mais suggestiva para attestar o etymo verdadeiro; e, quando essas modalidades não se encontram nos documentos antigos, imagina typos hypotheticos, theoricos, desde que obedeçam aos moldes de formação da lingua. Além dessas indagações que dizem respeito á fórma, a grammatica historica estuda a significação das palavras (semantica) observando os ligeiros matizes ou differenças profundas de sentido que se hajam manifestado, apurando a causa desses phenomenos de ordem psychologica, seja ella meramente espontanea, pela imprecisão ou indecisão de emprego, seja ligada a uma circumstancia occasional.

Depois de apreciar as palavras insuladamente, por esses differentes prismas, a grammatica historica estuda-as no seu conjunto, nas suas relações reciprocas: na sentença. Compara a estructura oracional da lingua com a dos seus antigos cultores; annota as locuções e modismos já desapparecidos. Sómente um conhecimento perfeito dos varios estádios das linguas, da chronologia das suas formas, das suas tendencias, póde ministrar elementos para julgar dos seus documentos literarios. Ante o criterio da esthetica actual as mais bellas paginas, a fina flôr do engenho literario, as obras primas dos autores antigos podem parecer detestaveis, insipidas, rancidas.

A grammatica historica é, por assim dizer, a biographia das linguas, o registro dos factos capitaes, dos differentes aspectos que ellas vão apresentando, nessa evolução perenne a que estão sujeitas.

$\mathrm{Na}$ technica do ensino desrespeitam-se por vezes as verdadeiras lições da grammatica historica. Adoptam-se processos praticos, artificios didacticos accessiveis á mentalidade dos discentes, mas em desaccordo com a boa doutrina que ainda não estão preparados para comprehender. Está neste caso a classe dos verbos chamados irregulares. Se tomarmos para exemplo a forma pôde, preterito perfeito do indicativo de poder, vemos que ella provem naturalmente de potuit, com alterações phoneticas vulgares. Imaginando, porem, um thema artificial de infinitivo portuguez pod e as terminações do tempo verbal alludido ( $i$, este, eu etc.) nas conjugações ditas regulares, declara-se que pôde é irregular, porque regular seria podeu. O mesmo se diria, mutatis mutandis, de posso, faço etc., em vez de podo, fazo, quando aquellas formas decorrem normalmente de possum, facio.

$\mathrm{Na}$ exposição da doutrina concernente ás flexões nominaes igualmente entram em conflicto a grammatica historica e a expositiva ou pratica. Esta reconhece, por exemplo, varios suffixos para a formação dos superlativos syntheticos: issimo, errimo, ilimo; aquella nos ensina que tal divergencia não existe, pois todas essas modalidades se reduzem a imo, variando o superlativo portuguez de accordo com o thema da palavra latina. Assim: grandissimo (lat. grandis), acerrimo (lat. acer), facilimo (lat. facilis). 
É ainda na grammatica historica que vamos encontrar a causa da divergencia de plural dos nomes terminados em ão, como veremos noutro logar.

\section{Methodo comparativo}

Nas investigações de ordem glottologica não é possivel, muitas vezes, chegar a conclusões seguras dentro das fronteiras de um idioma. Muito cedo, ainda antes de constituida a philologia como sciencia independente, já haviam sido observadas as affinidades mais ou menos estreitas que as linguas apresentavam entre si. Era natural que se applicassem ao seu estudo os mesmos processos que orientaram o homem na acquisição dos seus conhecimentos geraes, fôssem de ordem scientifica ou pratica, tanto mais quanto a linguagem se mostrava campo favoravel a taes confrontos. Assim, surgiu o chamado methodo comparativo, que é o complemento natural dos estudos historicos. Alguns autores até reunem as duas orientações numa só denominação: - methodo historico-comparativo.

Devemos obedecer na linguagem aos mesmos principios geraes da comparação. No mundo physico, como no moral, não se estabelecem comparações entre idéas dissemelhantes, que não apresentem caracteres communs. Se quizermos comparar os factos da lingua portugueza com os de outra devemos recorrer ás demais linguas romanicas, que tiveram origem commum - o baixo latim. Isto não importa dizer que certos factos de linguas de familias diversas não se possam comparar até determinado limite. $\mathrm{O}$ allemão e o latim, pertencendo a grupos differentes, apresentam varios pontos de affinidade, como sejam as declinações, a regencia dos casos, algumas regras de syntaxe etc. Ainda neste caso existe uma communidade de origem, se bem que mais remota, tendo-se em vista o indo-europeu, o mais conhecido dos grupos de linguas até aqui estudadas ${ }^{421}$. Até sobre typos de linguas de todo estranhas ha principios e leis geraes em que o estudo comparativo se pode exercer efficazmente. Mas a verdadeira comparação de que resultam observações seguras, evidentes, conclusões inelutaveis, é a que se faz entre linguas congeneres.

Examinando a transformação do grupo latino $p l$ em algumas palavras de linguas romanicas, nós vemos:

$\begin{array}{lllll}\text { latim } & \text { portuguez }(\mathrm{ch}) & \text { franc. }(\mathrm{pl}) & \text { esp. }(1 \mathrm{l}) & \text { ital. }(\mathrm{pi}) \\ \text { plenus } & \text { cheio } & \text { plein } & \text { lleno } & \text { pieno } \\ \text { plaga } & \text { chaga } & \text { plaie } & \text { llaga } & \text { piaga } \\ \text { pluvia } & \text { chuva } & \text { pluie } & \text { lluvia } & \text { pioggia } \\ \text { planus } & \text { chão } & \text { plain } & \text { llano } & \text { piano } \\ \text { etc. } & \text { etc. } & \text { etc. } & \text { etc. } & \text { etc. }\end{array}$

Se, dos dominios da phonologia historica passamos ás formações integraes de palavras, a mesma uniformidade se evidencia. As palavras oriundas dos accusativos nominaes em atem reapparecem com o aspecto peculiar ao genio de cada uma das linguas indicadas.

421 "Il existe un groupe très vaste de langues où l'on observe des formes semblables, d'autant plus semblables que les formes considérées dans chaque langue sont plus anciennes. Ces langues sont: en Europe, les langues italiques (Osco-ombrien et latin, ancêtre des langues romanes), celtiques, germaniques, baltiques (vieux prussien, lituanien, lette) et slaves (polonais, tchèque, serbo-croate, bulgare, russe), le grec, l'albanais, l'arménien; en Asie, les langues de l'Inde (védique et sanskrit classique) et de l'Iran (vieux-perse, zend ou avestique, persan, afghan, etc.) ainsi que le tokharien (langue dont des textes trouvés naguère en Asie centrale ont fourni des spécimens).

On nomme indo-européen commun la langue dont tout ce vaste groupe représente les transformations".

(A. Meillet et J. Vendryes: “Traité de Grammaire Comparée des langues classiques”. 1924, p. 4). 


\begin{tabular}{llcll} 
latim & portuguez & francez & esp. & italiano \\
veritatem & verdade & vérité & verdad & verità \\
varietatem & variedade & variété & variedad & varietà \\
qualitatem & qualidade & qualité & calidad & qualità \\
vanitatem & vaidade & vanité & vanidad & vanità \\
equitatem & equidade & équité & equidad & equità \\
bonitatem & bondade & bonté & bondad & bontà \\
\multicolumn{1}{c}{ etc. } & etc. & etc. & etc. & etc.
\end{tabular}

Nos vastos dominios da semantica preciosas são as indicações que o estudo comparativo pode trazer. As formas romanicas nem sempre seguem direcção uniforme de sentido; ellas, porém, se comprovam, as mais das vezes, subsistindo uma idea vaga da origem commum.

A significação altera-se da mesma maneira que a forma dos vocabulos. D'ahi a conveniencia da applicação simultanea do methodo historico-comparativo, em que as tradições semanticas e as modificações phoneticas se auxiliam efficazmente para verificação dos phenomenos linguisticos.

\section{Glottologia, philologia}

Não existe ainda perfeito accordo entre os autores sobre a maneira de nomear as sciencias que tém seus dominios na linguagem. Glottologia, philologia, linguistica são nomes propostos e empregados arbitrariamente e assim permanecerão decerto. Em alguns tratados essa divergencia de nomenclatura constitue assumpto de vastos capitulos.

Hovelacque $^{422}$ estabelece distincção entre a linguistica e a philologia. Para elle a linguistica é uma sciencia natural; a philologia, uma sciencia historica. Assim a linguistica estuda a linguagem como faculdade peculiar ao homem, apreciando-a quer do ponto de vista physiologico, quer do psychologico, acompanhando a sua evolução e estabelecendo comparações entre as linguas, ao passo que a philologia só considera a lingua como vehiculo de uma literatura e em relação ao uso que della fizeram os escriptores, cujos trechos interpreta, critica ou corrige. O papel dos philologos será o mesmo que desempenharam os chamados philologos da Renascença, em opposição aos humanistas. De uma forma geral: a linguistica tem por objecto o estudo da linguagem em si mesma; a philologia considera particularmente a literatura das linguas.

Giacomo de Gregorio ${ }^{423}$ e Ad. Coelho ${ }^{424}$ estabeleceram mais ou menos a mesma distincção entre a glottologia e a philologia.

De tudo isto o que se pode concluir é que os limites entre a philologia e a linguistica (ou glottologia) não são muito nitidos e, se por uma rigorosa classificação das sciencias cumpre distinguil-as, não é menos certo que ellas, pela sua esphera de acção, constantemente se auxiliam. Dahi as denominações intermediarias de philologia comparada, grammaticageral, etc.

O estudo completo da linguagem não se poderá fazer sem uma documentação abundante, sob pena de tornar-se metaphysico, arido, incomprehensivel. Essa documentação, de accordo com as distincções rigorosas dos mestres, pertence já aos dominios da philologia. Assim, as duas sciencias andarão sempre conjugadas, soccorrendo-se mutuamente, como

${ }^{422}$ La Linguistique, Chapitre I.

${ }^{423}$ Manual da Sciencia da Linguagem. Trad. de C. de Fig., § 1.

${ }^{424}$ Curso de Lit. Nac. A Lingua Portugueza, $§ 1$. 
acontece ás demais, cujos limites se tocam e cujos prolongamentos se confundem em terreno commum.

A philologia é mais velha e de mais amplos dominios. Segundo os autores allemães ella comprehende a glottologia, a metrica e a historia da literatura. Platão já lhe chamava o amor da sciencia, a cultura literaria ou scientifica. Salomon Reinach e Ferdinand Wolf entendem que ella comprehende todas as manifestações do espirito humano, no tempo e no espaço. Virtualmente envolvia a linguistica, que só nos tempos modernos conquistou a sua independencia, constituindo uma sciencia propriamente dita. Até então o estudo da linguagem se fazia subsidiariamente, ao serviço das investigações philologicas. As linguas eram estudadas como vehiculo das literaturas. Póde-se dizer que somente ao alvorecer do seculo XIX foi que o estudo da linguagem começou a ser feito seriamente, com os trabalhos de F. Bopp, Schleicher, Grimm, G. Humboldt, os irmãos Schlegel e outros. Com a fundação da glottologia vieram os naturaes exageros de doutrina, o exclusivismo intolerante, de maneira que se estabeleceram divergencias profundas. Mas é certo que com essa phase combatente dissiparam-se os absurdos de outrora e a nova sciencia foi-se constituindo e firmando de forma definitiva. A Bopp deve-se, sobretudo, a applicação do methodo comparativo á analyse das linguas, que elle considerava como organismos vivos, sujeitos a leis proprias. Schleicher creou a divisão morphologica das linguas, reduzindo-as aos tres grupos: isolante, agglutinante e flexional; Jacob Grimm descobriu a lei de rotação dos sons, que tomou o seu nome, e, assim, cada um dos fundadores da novél sciencia foi encarando um aspecto particular della e contribuindo poderosamente para a sua organização. Um dos mais importantes concursos foi o do sabio professor Michel Bréal, com suas investigações superiores nos dominios da semantica, estudo inteiramente novo e ainda não systematizado.

\section{Literatura}

O vocabulo literatura ja existia em latim e com varias accepções. Era formado de litera ou littera.

Ainda que a etymologia fosse sempre guia seguro, indeclinavel da significação, literatura não seria sómente a sciencia ou a arte da letra, isto é: o symbolo do alfabeto.

Literatura exprimia em latim a escripta, o alphabeto, a grammatica, etc.

Desta succinta exposição conclue-se que a etymologia é de importancia pouco apreciavel quanto á significação do vocabulo literatura, sobretudo nas accepções modernas, que variam conforme o ponto de vista de onde o termo é observado ${ }^{425}$.

A vasta estensão e a multiplicidade de applicações que lhe são dadas, segundo os varios criterios, augmentam as difficuldades de ordem geral inherentes a qualquer definição, e, assim, definir literatura seria verdadeira impossibilidade sem a prefixação de um conceito determinado. Adoptando o criterio historico, tem-se dito: "Literatura é o conjunto das producções intellectuaes dos differentes povos". Esta definição, apesar do seu caracter geral, está sujeita a distincções. Cumpre saber se no cabedal dessas producções intellectuaes entram todos os documentos escriptos, se apenas os que apresentam intenção artistica, pela fórma,

\footnotetext{
${ }^{425}$ A literatura tem tido a mesma fortuna da philologia, da sociologia e de outras sciencias a que ora se dá uma esphera de acção amplissima, ora se recusa existencia propria. Para uns ella comprehende todos os ramos do saber, tudo que se ha produzido nos dominios da sciencia e da arte; para outros não passa de uma provincia da arte e resume-se nas bellas letras.
} 
imaginação, etc. No primeiro caso as bases historicas da literatura assentam na epigraphia ${ }^{426}$, entrando ella em conflicto com a philologia a que pertence, segundo alguns, a sciencia das inscripções.

Alguns autores tém, por uma definição irreflectida, limitado o cabedal da literatura aos documentos escriptos. Fica, assim, fóra do quadro, a chamada literatura de tradição, que se transmitte oralmente, taes sejam os cantos, os contos e as fabulas populares, as lendas, anecdotas, proverbios, ditos de espirito e toda a contribuição anonyma, que constitue o saber do povo, o folk-lore. Essa collaboração popular ás vezes se perpetúa nos cancioneiros, collectaneas e monographias.

A literatura tem sido confundida com a bibliographia, significando o conjunto de trabalhos escriptos sobre determinado assumpto. É o que se vê nas expressões: - a literatura da mathematica, do occultismo, etc.

Para que as primeiras producções literarias se manifestem no seio de um povo é condição precipua haver o mesmo chegado a certo grau de cultura e possuir uma lingua que seja um docil instrumento de communicação. Os povos em estado selvagem não tém literatura, a menos que consideremos como tal as suas lendas obscuras e não raro construidas por ficção nos centros civilizados ${ }^{427}$. (p.7-17)

$(\ldots)$

\section{PEREIRA, Eduardo Carlos. Grammatica historica (1916) $\boldsymbol{\beta}$}

A Grammatica tem intima relação com a Glottologia e com a Philologia, e todas com a Linguagem. Convem preliminarmente determinar essas relações, estudando, em succinto esboço, a natureza da Linguagem, o dominio e a historia da Glottologia e da Philologia.

Linguagem (lingua + agem) é o conjuncto dos signaes de que intencionalmente nos servimos para a communicação de nossas idéas e pensamentos. A linguagem propriamente dicta é, no sentir de Whitney e outros glottologos, exclusiva do homem, é o seu apanagio, a

426 Deveriam, pois, ser estudados todos os documentos escriptos desde a mais remota antiguidade. Mas a escripta, por sua vez, teve a sua evolução. De registro da idea pela sua representação directa, isto é, pelo desenho mais ou menos grosseiro (pictographia) ella chegou a servir-se dos alphabetos modernos, cujos elementos representam expoentes de sons que podem ser fielmente reproduzidos.

Alguns povos, entre os quaes os indigenas da America do Norte, usaram da escripta pictographica. Ha innumeros typos de escripta, como sejam: os hieroglyphos dos egypcios, hittitas, mexicanos, etc.; os cuneiformes usados no occidente da Asia, os calculiformes da America, etc. Além destes signaes houve tambem rudimentos de escripta em varios processos mnemonicos de alguns povos, que davam significação convencional a signaes feitos com seixos, cordas a que faziam nodulos etc. A todos esses systemas primitivos de escripta pode dar-se, de maneira geral o qualificativo de escripta ideographica, em opposição á escripta alphabetica ou literal. Esta usa de letras; aquella, de ideogrammas.

O nome hieroglypho (escripta sagrada) foi dado pelos gregos aos desenhos e signaes que encontravam nos monumentos egypcios; eram figuras de homens, aves, insectos, crescentes, discos, etc. A escripta hieroglyphica constituia verdadeiros enigmas. Em 1822, porém, foi descoberta a chave dos hieroglyphos por Champollion, le Jeune, o que facultou o estudo comprehensão das inscripções, esclarecendo-se grandemente a historia do antigo Egypto.

Os hieroglyphos de outros povos ainda não foram decifrados.

Os cuneiformes (cuneus e forma) tinham a forma de cunha, como a sua etymologia o indica, e serviam de signaes de escripta a varios povos da antiguidade. Foram encontrados nas ruinas dos monumentos da Persia, na Assyria, na Chaldea e em grande quantidade de tijollos extrahidos dos tumulos da Mesopotamia, constituindo verdadeiras bibliothecas. As mais antigas inscripções deste genero datam de cerca de 4.000 annos antes de Christo. 427 Os trabalhos dos nossos indianistas, entre os quaes avultam José de Alencar, na prosa, e Gonçalves Dias, no verso, devem ser apreciados mais pelo ardor da imaginação e belleza do estilo do que pela verdade historica. 
sua faculdade entre todos os animaes. É apenas por uma extensão analogica que se fala na linguagem dos animaes, das flores, etc.

$(\ldots)$

\section{GLOTTOLOGIA}

Discute-se ainda o nome desta nova sciencia. Chamam-lhe alguns - sciencia da linguagem, outros linguistica, philologia comparada, glossologia e glottologia. Com MaxMüller damos preferencia a esta ultima designação.

Glottolosia (gr. glôtta ou glossa = língua) é a sciencia que tem por objecto a origem, desenvolvimento e classificação da linguagem, quer considerada em abstracto, quer em concreto.

(...)

Philologia (gr. philos = amante, $\operatorname{logos}+$ ia = discurso, palavra) é a sciencia que tem por objecto o estudo critico da literatura de um povo, ou da literatura de uma época, e da lingua que lhes serviu de instrumento. Dahi dois aspectos principaes da Philologia - o literario e o linguistico.

O fim desta sciencia é a analyse e a synthese dos documentos literarios, que ella estuda systematicamente em todos os seus aspectos. O estudo da respectiva língua, se bem que de visceral importancia para a critica dos documentos literarios, não é o fím da sciencia, mas apenas o meio indispensável. Além desse meio, recorre a Philologia a outras sciencias subsidiarias, taes como a historia, a archeologia, a ethnologia, a mythologia, etc.

Quando a Philologia tem por objecto o estudo comparativo das literaturas de dois ou mais povos, chama-se Philologia comparada, como, por ex., o estudo comparativo das literaturas classicas do grego e do latim, das literaturas germanicas. romanicas ou neo-latinas.

O estudo practico, mais largo e profundo, dos idiomas antigos e modernos, já provocado por Leibnitz, e modernamente desenvolvido, fez com que a Glottologia se desaggregasse da Philologia, especializando-se em sciencia propria, no primeiro quartel do seculo passado.

\section{COMO A GLOTTOLOGIA SE SEPAROU DA PHILOLOGIA.}

Damos em seguida rapido esboço historico do facto declarado no paragrapho antecedente. Vasco da Gama, o heroe dos Lusiadas, navegante portuguez, abriu, ao findar do sec. XV: o desejado caminho das Indias, e patenteou ao commercio europeu as riquezas do Oriente.

Já em 1585, Filippo Sassetti, nobre mercador florentino, havia notado, em uma carta datada de 17 de janeiro desse mesmo anno, semelhanças entre nomes da lingua italiana e certos nomes da lingua fallada na India. No começo do seculo seguinte, um outro italiano, Roberto de Nobili da Montepulciano, missionario jesuita, estudou profundamente a literatura e a língua sagrada da India, o sânskrito (lingua sábia), lingua admiravel pela sua estructura regular, idioma dos livros sagrados, os Vedas, "da poesia lyrico-religiosa, da epopéa e da philosophia indiana". Em 1664, um missionario allemão, Heinrich Roth, tornou-se tão versado em sânskrito, que podia entrar em controversia com os brahmanes. Um missionario jesuita, que permaneceu na India de 1699 a 1792, foi o primeiro europeu que escreveu uma grammatica do sânskrito e compoz um dicionário malabar-sânskrito-portuguez. Outros, allemães e francezes, notaram analogias entre o sânskrito e outras linguas congeneres, e forneceram preciosas informações sobre a lingua, a literatura, a religião e a philosophia da India. 
Finalmente, o Padre Coeurdoux, encarregado pelo sábio Barthélemy de redigir uma grammatica e um diccionario do sânskrito, em uma memoria lida em 1768, e só publicada quarenta annos depois, expõe a affinidade entre o sânskrito, o grego e o latim, e conclue pelo parentesco original dos indios, dos gregos e dos latinos. Em 1783. chegou á India o inglez Mr. William Jones, é perante a "Sociedade Asiatica de Calcuttá", por elle fundada, declarou, em 1786, que a lingua sânskrita era admiravel em sua estructura; mais perfeita que o grego, mais rica que o latim, mais melodiosa que ambas, e que a ellas se relacionava por uma tão grande analogia, tanto nas raizes dos verbos como nas fórmas grammaticaes, que nenhum philologo podia examinar essas trez linguas sem concluir que eram oriundas de uma fonte commum.

Deante desse novo mundo descoberto, na expressão de um illustre pensador, surgiu uma pleiade de illustres allemães, taes como Frederico e Guilherme Schlegel, Guilherme Humbolt, Jacob Grimm, Pott, Schleicher, Curtius e Benfey, que se applicaram aos estudos linguisticos e forneceram importantes subsidios para a explicação do phenomeno assignalado por Coeurdoux e W. Jones.

A Francisco Bopp (1791-1867) porém, eminente philologo allemão, cabe a gloria de fundador da sciencia glottologica pela demonstração da unidade das linguas aryanas ou indoeuropéas, effectuada em seu Systema de Comparação (1816), e em sua Grammatica comparativa (1833-1852).

A eschola boppiana dá a agglutinação como a origem das flexões. As linguas não se formam por um processo de germinação, mas por juxtaposição dos elementos.

Uma nova eschola de linguistas, porém, iniciada pelo prof. Leskien, de Leipsic, e seguida por Brugmann, Osthoff, Paulo e outros, e por alguns dos chamados neogrammaticos, ergue-se em opposição a muitas theorias da eschola de Bopp, dando proeminencia á alteração phonetica e á analogia na formação das línguas.

Evolvida dos estudos philologicos das literaturas classicas, a Glottologia tem de commum com a sua irmã primogenita, a Philologia, o estudo das linguas; mas ao passo que esse estudo é um meio para a Philologia, é um fim para a Glottologia.

Estabelecendo Schleicher, neste ponto, a differença entre uma e outra, compara a Glottologia com o botanico e a Philologia com o jardineiro. Applicam ambos a sua actividade ao mesmo jardim; porém o botanico tem um fim scientifico em vista, e o jardineiro um fim artistico e utilitario. Assim a Glottologia estuda as linguas com um mero fim scientifico, e toda lingua, tenha ou não documentos escriptos, cae dentro de suas pesquisas; emquanto a Philologia estuda as linguas com o fim practico de explanar e caracterizar os seus documentos literarios, e, portanto, só as linguas que possuem esses documentos podem ter philologia.

\section{GRAMMATICA}

A Grammatica (gr. grammatikê, de gramma = letra) é um ramo importante da Glottologia e um subsidio indispensavel da Philologia. Em sua accepção generica, é ella a sciencia da palavra, que estuda em seus multiplos aspectos - em sua origem, formação, metamorphoses, sentido e relações.

Quatro são os aspectos fundamentaes da Grammatica em relação a extensão e ao tempo: grammatica geral e particular, grammatica historica e expositiva.

Grammatica geral é a grammatica comparada que estuda os factos linguisticos communs a todas as linguas ou a um grupo de linguas congeneres. Por isso, a Grammatica pode ser geral em sentido amplo e em sentido restricto.

A Grammatica geral em sentido amplo é a que tracta de questões pertinentes a todas as linguas. "Uma grammatica universal --- escreve Giacomo di Gregorio, prof. da Universidade 
de Palermo é tão inadmissivel como uma forma universal das constituições dos Estados, ou uma forma geral de plantas e animaes". Entretanto, ha certas questões geraes, communs a todas as formas da linguagem, que podem ser objecto de uma grammatica geral no sentido amplo, taes as formuladas por A. Coelho: "Ha artigos em todas as linguas? Ha verbos em todas as linguas? São as palavras formadas em todas as linguas por meio de raizes e suffixos?"

A Grammatica geral em sentido restricto é a grammatica comparativa que estuda factos linguisticos communs a um grupo de linguas congeneres, tal como a "Grammatica das linguas românicas" de Frederico Diez, a "Grammatica comparada" das linguas aryanas de F. Bopp.

Grammatica particular é a que tem por objecto de seu estudo os factos de uma lingua em particular, ou em uma dada época, ou no decurso de sua historia.

Grammatica historica é a que estuda a origem e evolução de uma lingua no tempo e no espaço. O seu methodo é sempre o methodo historico-comparativo, versando a comparação das formas grammaticaes, não só com as transformações parallelas das linguas affins, mas ainda com as transformações successivas da mesma lingua.

Grammatica expositiva, descriptiva ou practica é a que se limita a expor ou a descrever, para fins practicos, os factos da lingua na época actual.

\section{CORRENTES E METHODOS HISTORICOS NO ESTUDO DA GRAMMATICA.}

Trez correntes teem, em geral, caracterizado o estudo da Grammatica, no decurso dos seculos: - a physiologica, a philosophica e a historica.

$1^{a}$ A corrente physiologica transparece na India em antiquissimos tempos. Ahi os velhos grammaticos do sânskrito deram attenção á physiologia dos sons, e deixaram sensatas observações sobre a formação dos phonemas.

$2^{\mathrm{a}}$ A corrente phylosophica apparece entre os gramrnaticos gregos, latinos e medievaes. Tal orientação dominou exclusiva até o seculo passado, dando origem ás grarnrnaticas philosophicas do sec XVII e do sec XVIII. Nesta corrente as theorias grammaticaes eram, em regra, subordinadas a concepções à priori, e de leis arbitrarias desciam os grammaticos a factos violentados ou imaginarios. Em vez de subirem da observação dos factos linguisticos á inducção das leis glotticas, faziam da lingua apenas uma exteriorização da psychologia e da logica, desconhecendo, por completo, o genio da linguagem e a autonomia da grammatica. Devido ao predominio secular desta corrente e á intima relação que ha realmente entre a linguagem e o pensamento, ainda hoje vae larga a confusão da logica com a grammatica. "A linguagem tem a sua lógica, escreve M. Bréal; mas é uma logica especial, de alguma sorte profissional, que não se confunde com aquella a que damos ordinariamente este nome".

$3^{\mathrm{a}}$ A corrente historica surgiu na primeira parte do seculo passado com os glottologos allemães. Bacon e Descartes (sec.XVII) haviam aberto á sciencia uma nova éra, com a observação e experimentação do methodo inductivo. A Grammatica seguiu a nova rota. Já Leibnitz havia indicado esse caminho novo no estudo da linguagem. A necessidade de irem os glottologos buscar nos factos reaes das linguas os elementos da nova sciencia, veio abrir aos estudos grammaticaes uma orientação mais racional e fecunda. Deixou então a Grammatica de ser o leito de Procusto da língua, para ser o repositorio dos factos observados e systematizados; e o grammatico deixou de ser o alchimista, que extrahia das retortas da Logica os factos da linguagem, para seguir a rota fecunda das sciencias naturaes, patenteada pelo methodo inductivo da moderna orientação scientifica. Em vez de partir do pensamento para os factos glotticos, segue hoje caminho mais racional, partindo destes para aquelle. A introducção da corrente historica nos estudos grammaticaes, levou os grammaticographos á observação e comparação dos factos da lingua em todos os seus aspectos, restaurando-se 
dest'arte os estudos dos antigos grammaticos da India sobre o mechanismo physiologico da linguagem.

A Grammatica hoje deve conter a synthese das trez correntes.

Grammatica historica da lingua portugueza é o estudo da origem e evolução do portuguez no tempo e no espaço.

E como a lingua portugueza não é mais que a lingua latina transportada para a faixa occidental da Hispania pelos soldados e colonos romanos, e transformada no decorrer dos seculos, a Grammatica historica nos explanas as circumstancias historicas e as leis dessa transformação lenta do latim na lingua vernacula.

O seu estudo divide-se naturalmente em trez partes, chamadas - Phonologia, Morphologia e Syntaxe.

Estas trez partes da Grammatica encerram os trez aspectos fundamentaes em que a palavra pode ser estudada na expressão completa do pensamento.

Cada um desses aspectos pode ser encarado em uma época determinada ou na successão das épocas. Dahi a distincção entre grammatica expositiva e grammatica historica. Esta estuda a lingua no tempo, isto é, nas épocas successivas de sua vida historica; aquella no espaço, na região ou regiões em que ella é actualmente fallada.

A Grammatica historica baseia-se no facto de jamais se estacionar a lingua viva na bocca do povo, mas de soffrer continuamente alterações em todos os seus elementos, quer lexeologicos, quer syntacticos. A esta transformação lenta e continua das linguas vivas dá-se o nome de evolução historica ou metamorphismo da linguagem.

A evolução de uma lingua não se opera arbitrariamente, a capricho das multidões, mas sob o imperio de leis glotticas, que, na inconsciencia popular, regem o destino das linguas.

A Grammatica historica do portuguez é a chave da Grammatica expositiva, pois naquella tem esta a razão de ser de suas regras. A Grammatica expositiva deve ser o registro fiel dos habitos da lingua e de sua boa tradição, a depositaria dos ultimos resultados de sua evolução espontanea, a expressão actual de sua vida secular e de seu genio historico. (p.116)

\section{P.S. Syntaxe e grammatica histórica da Lingua Portuguesa (1909) $\beta$}

\section{Grammatica historica e seu methodo}

A grammatica historica indaga os factos que apresenta a lingua e as leis a que está sujeita, desde a origem até a epoca presente.

O methodo a seguir é o historico comparativo i. é estudamos as diversas phases, valendo-nos das analogias ou differenças que nos subministram as outras linguas da mesma familia.

Este methodo, primeiramente adoptado pelos fins do seculo 18 no estudo das linguas aryanas, foi no seculo 19 applicado por Diez á investigação dos idiomas que descendem do tronco latino.

Modernamente empregam, sobretudo nas indagações phonicas, o subsidio da physiologia dos sons i. é uma divisão mais exacta e a facilidade ou difficuldade, com que em certa lingua se proferem e associam os phonemas. (p.215)

$(\ldots)$

Estudo historico-comparativo das linguas 
No fim do seculo $18^{\circ}$ surgiu o estudo historico comparativo das linguas, remontando ao tronco commum, donde se derivam.

Foram ao principio as linguas aryanas que desafiaram o fervor de indagação.

Os resultados lisonjeiros convidaram, meio seculo mais tarde, a se applicarem os mesmos processos ao estudo das linguas derivadas do latim. Foi o allemão Frederico Diez que, em 1838, publicou a obra classica: Grammatica das linguas romanicas, contribuindo poderosamente não só para a generalização destes conhecimentos, mas tambem para o desenvolvimento desta novel disciplina.

Modernamente tem tomado impulso vigoroso com a applicação da theoria da psychologia dos sons (vide introducção ao III anno) e o estudo aprofundado dos dialectos.

De conformidade com este methodo moderno escreveu sua obra monumental Meyer Lübke, editando em Jena, 1889, a "Grammatica das linguas românicas".

Novo e importante progresso marca o diccionario latino-romanico de Gustavo Körting Paderborna - 1901.

Em Portugal foram introduzidos estes estudos por Adolpho Coelho e contam hoje abalizados cultivadores de nomeada europea, taes como: Gonçalves Vianna, José Leite de Vasconcellos, D. Carolina Michaëlis, etc.

\section{Linguas romanicas}

Do latim derivaram-se as seguintes linguas: o rumeno, rhetico, italiano, francez, hespanhol, portuguez e o antigo provençal.

1) O rumeno é fallado na Romania, Siebenbuergen, Serbia e Bessarabia; é o tronco latino mesclado com o slavo.

2) O rhetico hoje se falla em territorio bastante restricto do cantão dos Grisões na Suissa, mas outrora abrangia territorio muito mais vasto, como provam os nomes geographicos daquellas regiões.

Ex.: Mumma, cara mumma, jeu haiel fum (mamãe ... eu tenho fome).

Nomes geographicos: Gallina, Valduna, Montafon.

3) O provençal antigo abrangia o sul da França. Foi a primeira lingua romanica que se fixou litterariamente. Depois da conquista pelos francezes do norte decahiu muito, até que os neo-provençaes no seculo passado tornaram a cultival-a.

Ex.: Las! mos cors no dorm ni pauza

Ni poc en un loc estar.

4) O italiano é o resultado do cultivo litterario do dialecto toscano.

D'entre os dialectos tem valor excepcional o sardico, pois apresenta a phase mais antiga de decomposição do latim.

5) O francez é o dialecto de Isle de France o qual chegou a triumphar sobre o loreno, picardo etc. graças á litteratura e influencia politica daquella região.

6) O portuguez apresenta o desenvolvimento ulterior do gallego, com que ao principio coincidia.

7) O hespanhol é o dialecto de Castella que adquiriu a supremacia sobre o catalão e gallego pela preponderancia politica e consequente cultivo das lettras. Tanto o catalão como 
gallego tiveram litteratura muito anterior, mas ficaram estacionarios. O catalão era um dialecto provençal transportado para a Hespanha. (p.218-220)

SILVA NETO, Serafim da. Manual de gramática histórica portuguesa: de acordo com o Programa Oficial do $4^{\circ}$ ano (1942) $\boldsymbol{\beta}$

\section{Gramática histórica. Definição e divisão}

Até aquí temos estudado a gramática expositiva, isto é, a exposição dos princípios da linguagem literária em determinada época.

De fato, podemos compará-la a uma fotografia que reproduz a língua literária em dada fase de evolução.

Está claro que, assim sendo, a gramática varía e evolve com os tempos. Certamente a primeira que se escreveu sobre a nossa língua, a de Fernão d'Oliveira, em 1536, apresentava uma fotografia diversa da atual.

Agora, no quarto ano, cabe-nos o estudo da gramática histórica, a qual se ocupa com a origem e evolução da lingua.

Portanto, gramática histórica portuguesa é o estudo da língua desde a origem latina até a fase atual. Ela semelha um filme, ou seja uma série de fotografias que se desenrolam sucessivamente.

Podemos dizer, pois, que durante este ano, aprendendo a gramática histórica, desenvolver-se-á deante de nossos olhos a história da lingua.

Vamos dividi-la em história externa e história interna: a primeira ocupa-se com a origem e a expansão do idioma, enquanto a segunda traça a evolução do material linguístico latino até o português.

Por material lingùístico entendemos os fonemas, as palavras e as frases de uma língua.

A história interna divide-se, portanto, em fonética histórica, morfologia histórica e sintaxe histórica.

O estudo da gramática histórica é indispensável ao conhecimento da língua. Ela ensina-nos de tudo: tocado pela sua varinha mágica, cada vocábulo nos conta a própria história, cada forma repassa por todas as metamorfoses - e, aos poucos, surgem na sua constância e regularidade as normas que presidiram à evolução do latim.

Falando-se no Vocabulário, é preciso esclarecer um fato importante.

Nem todas as palavras da nossa língua continuam, através de elos intermediários, as formas latinas. Ao lado desses elementos hereditários, que constituem a mais antiga camada, existem os empréstimos e as novas formações.

Empréstimos são vocábulos tomados a quaisquer línguas, inclusive ao latim. Distinguem-se dos hereditários por se terem incorporado em várias épocas, já prontos, sem evolução progressiva.

Por exemplo, ao francês tomamos chapéu, charrúa, boné, jardim; ao espanhol pedimos hediondo, colcha, trecho, vislumbrar; do italiano recebemos soneto, arpejo, piano, sonata, barcarola; do inglês vieram-nos iate, pudim, clube, futebol...

Os empréstimos ao latim são as chamadas palavras eruditas: saltam do latim escrito para a nossa língua. Os ingleses chamam-lhes bookish words.

Exemplos: plaga [lat. plaga], nitido [lat. nítǐdu], pleno [lat. plenu], mácula [lat. macǔla], que não passaram pelas leis que regularam as transformações dos fonemas latinos, mas apenas adaptaram-se à nossa língua. 
Por novas formações entendemos as criações do idioma, a prata de casa. Podemos referir, como tais: milagroso (de milagre + oso) adoçar $($ de a + doce + ar), enovelar $(\mathrm{en}+$ novelo + ar), etc.

A gramática histórica ocupa-se especialmente com as palavras hereditárias.

Em suma: a gramática histórica estuda a língua portuguesa em suas várias fases, desde o latim até o século vinte. seguintes:

Esses vários períodos, pontes entre o latim de Cícero e o português de hoje, são os 1. latim lusitânico (falado na Lusitânia) - vai até o séc. V;

2. romanço lusitânico (falado na Lusitânia) - vai do V. ${ }^{\circ}$ ao IX. ${ }^{\circ}$ séc.;

3. português proto-histórico - vai do IX. ${ }^{\circ}$ ao XII. ${ }^{\circ}$ séc.;

4. português arcaico - vai do XII. ${ }^{\circ}$ ao XVI. ${ }^{\circ}$ século;

5. português moderno - vai do séc. XVI ao XX. ${ }^{\circ}$.

Vemos portanto que a transformação do latim no português se realizou muito lentamente, passando por várias fases intermédias. (p.11-13, itálicos do autor)

SILVEIRA, Sousa da. Lições de Português: dadas no $3^{\circ}$ ano da escola normal: de acordo com o programa (1921) $\boldsymbol{\beta}$

\section{O autor não define gramática histórica.}

Reunião de professores (obra coletiva). Novo manual de lingua portuguesa: grammatica historica: Curso Complementar (1925) $\boldsymbol{\beta}$

Filologia. Chama-se filologia, $($ do grego filos $=$ amigo $+\operatorname{logos}=$ discurso $)$, ou linguistica, ao estudo geral das linguas. Atende mais, porém, á sua estructura historica do que ás suas manifestações artisticas. A estas reserva-se o nome de literatura.

[Os autores, a partir daqui, citam outros autores com o objetivo de se posicionarem a respeito das questões relativas à disciplina histórica.]

(...)

II. A Philologia é o estudo scientifico, historico e comparado da lingua nacional em toda a sua amplitude, não só quanto á grammatica (phonetica, morphologia e syntaxe) e quanto á etymologia, semasiologia, etc., mas tambem como orgam da literatura e como manifestação do espirito nacional. CAROLINA MICHAELIS DE VASCONCELLOS.

III. - METHODO DA FILOLOGIA. - O unico methodo que se póde adoptar para o estudo dos phenomenos linguisticos repousa sobre a observação e a comparação. O scientista não tem a possibilidade de modificar as condições naturaes dos phenomenos linguisticos e fazer experimentalmente, como em biologia, verificação da sua doutrina. J. L. CAMPOS.

IV. - Glottologia, sinonimo de linguistica. Sendo a linguagem um phenomeno puramente natural, provocado por uma necessidade natural, e regulado por leis naturaes, logico será que não tenhamos rebuço algum em encorporar a GLOTTOLOGIA na categoria das sciencias da natureza, a par da biologia, da psychologia e de outras. RODRIGO DE SÁ NOGUEIRA. (...) 
VIII. - A linguistica é uma sciencia natural; a philologia uma sciencia historica; a etymologia não é uma sciencia. HOVELACQUE.

IX. - Existe por exemplo uma philologia latina, independente da philologia grega; uma philologia hebraica inteiramente independente da philologia arabe ou assyria. Mas não pode haver uma linguistica puramente latina ou uma linguistica puramente hebraica. SCHLEICHER. (p.35-36)

TOTAL DE GRAMÁTICAS HISTÓRICAS CONSULTADAS: 20 


\section{QUADRO 13B - Definições de dialeto presentes nas gramáticas históricas do Português}

PEREIRA, Eduardo Carlos. Grammatica histórica (1916) $\boldsymbol{\beta}$

\section{O dialecto.}

Em geral chama-se dialecto a differenciação regional de uma lingua, e ao processo lento dessa differenciação dá-se o nome de dialectação. Assim no decurso de 2.000 annos operou-se, na região occidental da peninsula Iberica, a dialectação do latim em portuguez. O portuguez, pois, como o hespanhol, o francez e o italiano, são dialectos do latim. No seio, porém, do portuguez, tanto em Portugal como no Brasil, operam-se differenciações dialectaes, que são tanto mais rapidas, quanto menos intensa fôr a acção conservadora da literatura.

O conceito, porém, do dialecto é vago, pois difficil, senão impossivel, é determinarse o quantum satis dessas differenciações lexicas e grammaticaes para se constituir o dialecto. Qualquer desvio do typo normal da lingua, por insignificante que seja, ensina Whitney, é uma differenciação dialectal. Nesta linha geral, lançada por este illustre glottologo, ha uma concepção ampla e mais definida de dialecto, que consiste em chamarse dialecto qualquer differenciação de linguagem no falar de uma região ou de uma classe social. Deste ponto de vista, temos não só os dialectos continental, insulano e ultramarino, no seio do portuguez, mas ainda o dialecto literario, o dialecto popular, etc.

Seja, porém, qual fôr o modo por que encaremos o conceito de dialecto, o movimento dialectal apresenta-se como a actividade ingenita da lingua, e o dialecto como o ponto de confluencia da extrema mobilidade do lexico e das fórmas grammaticaes.

O latim, transportado para a faixa occidental da Peninsula, no $2 .^{\circ}$ sec. antes da éra christã, separa-se paulatinamente do hispano-romano, no dialecto portugalense, que com a nacionalidade portugueza, constituida em 1143, adquiriu os fóros de lingua, sem perder por isso o caracter de dialecto latino.

$\mathrm{Na}$ Galliza, situada ao norte do Minho, mas cujos limites variaveis na edade-média, se extenderam, no sec. XI, até as margens septentrionaes do Tejo, cobrindo a região portugalense, desenvolveu-se anteriormente o dialecto galleziano, denominado romanço ou rymance, paladino ou ladino, que attingira notavel preeminencia entre os dialectos hispanoromanos nos tempos medievicos.

Ao sul dessa faixa occidental da Peninsula, onde predominava o elemento neo-arabe, julgam alguns que um outro dialecto se constituira com o nome de aravio. F. M. Pacheco Junior chega mesmo a conjecturar que o portuguez nasceu da fusão do dialecto gallego com o aravio (Introd. Gr. Hist., 44). O que, porém, é mais provavel, é que o aravio fosse o proprio arabe das populações mourescas do sul, e que o gallego fosse identico ou quasi identico ao dialecto portugalense, que daquelle se desaggregou para se constituir em lingua com a creação do reino de Portugal, ao passo que o gallego se immobilizou pela falta de estimulo de nacionalidade. Além do elemento politico para a ascendencia do dialecto portugalense, havia, como observa Theophilo Braga, um elemento ethnico. Os suevos, povo barbaro, rechassados pelos visigodos, a quem tinham precedido na invasão da Peninsula, vieram estabelecer-se na Lusitania no sec. V, e, de mistura com as populações celticas, lançaram os germens da resistencia ethnico-politica, que deviam mais tarde desabrochar na nacionalidade e na lingua. 
282. CODIALECTOS. Quatro codialectos existem do portuguez, segundo o eminente romanista Dr. J. Leite de Vasconcellos, os quaes, por circumstancias historicas, se estacionaram em seus apertados territorios, emquanto o portuguez se elevou e desenvolveu como lingua de um povo independente; são elles: o gallego ou galleziano, o mirandez, o riodonorez, e o guadramilez. Todos estes, com excepção do primeiro, são fallados em pequenas regiões da provincia de Traz-os-Montes, na fronteira da Hespanha (Esquisse d'une Dialectologie Portugaise).

283. DIALECTOS. O movimento dialectal continúa, no seio do portuguez, e de seus actuaes dialectos, dá-nos o mesmo abalisado auctor acima referido, a seguinte classificação, a saber: a) o continental, b) o insulano, e c) o ultra-marino.

a) O continental abrange quatro dialectos do continente: o interamnense, o transmontano, o beirão e o meridional.

b) $\mathrm{O}$ insulano comprehende dois dialectos: o açoriano e o madeirense.

c) O ultramarino consiste do dialecto brasileiro e do creolo da Asia e da Africa, etc.

\section{O portuguez no Brasil e em Portugal}

284. A lingua, como a corrente dos grandes rios, vive em perpetuo movimento. De seculo para seculo, de região para região, de individuo para individuo, e, até no mesmo individuo, nas diversas épocas de sua edade, e, mesmo, nos differentes momentos de sua existencia, ha uma continua variação, por vezes infinitesimal, na expressão de Whitney que constitue a dialectação das linguas vivas. Quer, pois, a consideremos no tempo, quer no espaço, é do genio da lingua o diversificar-se constantemente. A acção conservadora da literatura torna mais lenta, porém não annulla essa impulsão genial, essa dialectação incessante.

Ha quatrocentos annos que o portuguez do Brasil se segregou do de Portugal. Foi na época de maior esplendor da lingua, no periodo aureo do quinhentismo, que delle se transplantou para aqui uma vergontea forte e vigorosa, pelos donatarios e colonos, que vieram povoar nossas costas. Bifurcou-se o portuguez, e, sob o influxo de novos factores mesologicos, proseguiu elle aqui a sua evolução genial.

Quatro seculos são passados de uma dupla evolução, e, a esta hora, apresenta a lingua, na historia de sua dialectação divergente, o aspecto de um amplo triangulo cujo apice attinge o sec. XVI, e a cujos pontos extremos da base correspondem já apreciaveis differenciações dialectaes. Deste ponto de vista, apresentam-se o fallar brasileiro e o lusitano como um duplo aspecto da evolução divergente do portuguez quinhentista, e, não raro, se descobrem, como adeante mostraremos, em nossos habitos prosodicos, vestigios quinhentistas, que em Portugal se perderam.

No lexico, na prosodia e na syntaxe vão se accentuando as linhas divisorias entre o portuguez do Brasil e o de Portugal.

I. LEXICO. [seguem os estudos da PROSODIA (II) e da SYNTAXE (III).] (p. 189-192, itálicos do autor)

COUTINHO, Ismael de Lima. Pontos de gramática histórica (1938) $\beta$

48. Dialeto é a modificação regional de uma língua. 
Não se deve admitir a falsa idéia de que o dialeto seja a corrupção de uma língua. $O$ povo, quando modifica o idioma, obedecendo às suas tendências naturais, não o corrompe. A língua, como tudo na natureza, está sujeita a transforma- ções inevitáveis.

Para a formação de um dialeto, concorrem causas de várias ordens: étnica, social, climática ou mixta.

Uma língua só conserva o seu aspecto uniforme, enquanto é falada por um pequeno agrupamento humano. É que, nêste caso, as influências são as mesmas; as comunicações entre as pessoas, mais íntimas e constantes; os interesses idênticos, etc..

Desde, porém, que a família humana se multiplica, desdobrando-se por várias regiões, a unidade lingüística se torna insustentável, a menos que haja uma ação enérgica do poder central, mantendo as diversas regiões vinculadas espiritual e materialmente à metrópole. Esta ação, que se exerce, sobretudo, pela influência da literatura, do jornalismo, das escolas, está condicionada ao grau de dependência política, à distância e aos meios de comunicação. Assim, quanto mais dependente politicamente estiver a região, menos distante se achar da capital ou sede do poder central, mais facilidade houver de comunicações com ela, tanto maior será a resistência da língua em manter a sua unidade.

Quebrados os laços políticos ou enfraquecida a ação da metrópole, começam logo a surgir diferenças locais, que darão em resultado, no correr dos anos, a formação de dialetos.

É o que, por outras palavras, afirma Dauzat: "desde que a ação do poder central se enfraquece ou desaparece, desde que o laço social se relaxa, os grupos se deslocam e cada um deles, retomando a sua autonomia, chega rápida e inconcientemente a se constituir em linguagem independente: foi o que aconteceu, por exemplo, depois da queda do império romano".

Não se pode ignorar presentemente a importância do conhecimento dos dialetos, porque são eles que nos dão a chave de muitos problemas de linguagem. "Não é possível, declara o já citado Dauzat, que se trate de uma questão qualquer de linguagem, com abstração dos documentos dialetológicos."

A dialetologia científica só apareceu no século XIX, com os trabalhos de Cornu e de Áscoli.

Os estudos dialetológicos, aperfeiçoados com os modernos processos da fonética experimental, assumem hoje caráter definitivo, graças à contribuição que the veio trazer uma ciência nova, de origem francesa - a Geografia lingüística.

Em sua origem, toda língua é um dialeto, que, por circunstâncias várias, consegue predominar. Assim, o italiano foi, a princípio, o dialeto da Toscana; o espanhol, o de Castela; ofrancês, o da Ilha de França, etc..

Língua e dialeto são, pois, têrmos relativos. O italiano, francês, o espanhol, o português, etc., que, tomados separadamente, constituem verdadeiras línguas, com relação ao latim, não passam de simples dialetos. (p.30-31, itálicos do autor)

ABREU, Modesto de. Idioma pátrio: volume 3: gramática expositiva e histórica; noções de estilística e literatura (1944) $\boldsymbol{\beta}$

Dialetos. - São variedades regionais de uma mesma língua, tendente a formar novas línguas, à proporção que vão constituindo uma literatura e uma disciplina gramatical próprias. -- São causas de dialetação: diversidades do meio gráfico e do clima; influência do linguajar da plebe e dos estrangeiros; afastamento de frações dos mesmos grupos sociais para regiões diversas; progressiva diferenciação prosódica e sintática resultante dessas causas. Formam-se ainda subdialetos, derivados dos dialetos iniciais. Dois dialetos divergentes da mesma língua, constituindo-se progressivamente em línguas novas, sobretudo por efeito da 
distinção de fronteiras, têm o nome de codialetos. - O português luso e o português do Brasil, diferenciados da língua portuguesa do século XVI, constituem, um para o outro, codialetos, como o galego é codialeto daquele. (p.185, itálicos do autor)

\section{SILVEIRA, Sousa da. Lições de Português (1934) $\beta$}

\section{A língua portuguesa no Brasil (1)}

A língua portuguesa foi trazida para o Brasil pelos portugueses, seus descobridores e colonizadores. Aquí encontrou um forte rival no tupí, (2) que, tornado língua geral, houve tempo em que esteve para o português na razão de 3:1.

Para essa notável expansão daquele idioma indígena em território brasileiro concorreram o próprio elemento europeu e os seus descendentes cruzados. Os padres, empenhados na catequese, falavam o tupí, escreviam-lhe a gramática e organizavam-lhe o dicionário, e o ensinavam nos seminários a par do português. Falavam-no as levas que partiam do litoral para a conquista do sertão - as bandeiras - e era com vocábulos dessa procedência que batizavam os acidentes geográficos que descobriam e os povoados que fundavam, os quais ficavam constituindo núcleos de disseminação do tupí. Os mesmos portugueses usaram denominar-se com apelidos tupís, uso renovado mais tarde, na época da independência.

O português venceu finalmente e tornou-se o nosso idioma nacional, recebendo, porém, do tupí grosso cabedal de vocábulos e expressões. Grande parte dêsses termos legados figuram como denominações geográficas em quasi todo o mapa do país: Aracajú, Baependí, Botucatú, Itaboraí, Jaguaribe, etc. Outros são nomes de pessoas, como Iracema. Muitos insinuam-se na linguagem falada ou mesmo literária, como elementos já pertencentes aos recursos naturais do idioma. Se vemos alguém triste, calado, fechado em si, dizemo-lo jururú; à galinha pedrês não hesitamos em chamar carijó, e i quem para indicar um estado de míngua pecuniária não terá empregado a frase estar na pindaíba? ¿E quantos não estão na pindaíba por serem caiporas? Basta uma simples evocação, e logo nos adejará aos lábios um enxame de vozes tupis: mocotó, xará, mingau, catapora, pereba, arapuca, capim, cipó, mandioca, manacá, combuca, perereca, urubú, motuca, pipoca, siri, peteca, pirão, sapecar... Expressões são estas naturalissimas entre nós. Tanto, que aparecem em textos dos autores nossos que mais se esmeravam em escrever com pureza vernácula. E não só essas, mas também expressões de outras fontes indígenas, ou provenientes do elemento africano, ou já de pura criação brasileira.

Enriqueceu-se, pois, a língua portuguesa no Brasil de têrmos e locuções novas, e, além disso, adquiriu pronúncia diferente e foi sofrendo algumas alterações sintáticas.

¿Falamos então um dialeto?

Não, se interpretarmos dialeto como sinónimo de falar inculto, pois que tal não é o nosso, instrumento de uma literatura já importante e promissora de mais viçosa e abundante florescência. Sim, dando ao vocábulo a definição com que o apresenta o mestre da filologia portuguesa, o Dr. José Leite de Vasconcelos, que a toma de Bluteau:

"Dialeto: modo de falar próprio e particular de uma língua nas diferentes partes do mesmo reino: o que consiste no acento, ou na pronunciação, ou em certas palavras, ou no modo de declinar e conjugar". (3)

Disso conclue-se: uma língua de grande extensão geográfica é uma entidade abstrata; logo que a consideramos falada, vemo-la algo diversificada segundo as regiões na 
fonética, na morfologia, na sintaxe e no léxico, e a cada região corresponde um dialeto. Assim o dialeto transmontano, o beirão, etc., e o brasileiro. Éste, por sua vez, difundido por larga superfície territorial, se concretiza em dialetos que, ponderados em relação à língua principal, passam à categoria de sub-dialetos.

Isto pôsto, vejamos algumas particularidades do nosso falar; mas o que digo a respeito de pronúncia entenda-se que se refere à do Rio-de-Janeiro, que é a que conheço melhor. E não se esqueça que uma pronúncia apresentada não nega a existência de outra, na mesma região.

[A partir daqui o autor apresenta diferenças entre o Português falado no Brasil e em Portugal.]

(1) De proveitosa leitura é o magnífico trabalho do professor Clóvis Monteiro: Português da Europa e Português da América.

(2) O que digo a respeito do tupi, haurí no interessante trabalho "O tupí na geografia nacional" de TEODORO SAMPAIO, 2. edição, 1914; mas creio que ainda está por fazerse um estudo rigoroso acerca desse idioma e da sua influência na língua nacional.

(3) Dr. J. LEITE DE VASCONCELOS, Esquisse d'une dialectologie portugaise, 1901, pág. 16.

(p. 340-342, itálicos do autor e sublinhados nossos)

MARTINS, Jaime de Souza. Elementos de gramática histórica: para a quarta série (1937) $\boldsymbol{\beta}$

Dialeto é a diferenciação sensível que uma língua apresenta na área em que é falada.

Não se deve admitir a falsa idéia de que o dialeto seja uma corrupção.

O povo, quando modifica uma língua, obedecendo ás suas tendências naturais, não a corrompe. O idioma, como tudo mais, está sujeito a transformações inevitáveis.

Em sua origem, tôda língua é dialeto, que, por circunstâncias várias consegue predominar.

Assim, o italiano é o dialeto da Toscana; o espanhol, o de Castela; o francês, o da Ilha de França, etc.

Língua e dialeto são, pois, termos relativos. O italiano, o francês, o espanhol, o português, etc., que, tomados separadamente, constituem verdadeiras línguas, com relação ao latim não passam de dialetos.

Leite de Vasconcelos classifica os dialetos portugueses em: continentais (interamnense, transmontano, beirão e meridional); insulares (açoriano e madeirense); ultramarinos (brasileiro e crioulos).

\section{O português do Brasil}

A língua portuguesa, para aquí trazida pelos reinóis, que vieram colonizar o Brasil, entrou desde cedo em contacto com o idioma dos naturais da terra e com os dialetos africanos dos escravos.

Várias causas contribuiram para que ela aqui se modificasse, apresentando diferenças minimas a principio, mas que se foram acentuando com o tempo, até que deram em resultado a formação do dialeto brasileiro.

Acham, todavia, alguns autores nacionais que essas diferenças não são bastante apreciáveis, para que se considere o falar brasileiro um dialeto do português. 
Como quer que seja, essas diferenças existem:
a) no léxico;
b) na prosódia;
c) na morfologia;
d) na sintaxe;
e) na semântica.

(p. 18-19, itálicos do autor)

\section{P.S. Syntaxe e grammatica historica da Lingua Portuguesa (1909) $\beta$}

Dialecto é a linguagem (cf. Roquete synonymos) particular a uma porção do territorio que occupa uma língua.

Requer-se tal somma de differenças que constituam linguagem propria.

Ficam aquem deste limite os chamados provincialismos, nome com que se designam particularidades avulsas duma certa região, V. g. a pronuncia surda do o fechado no Pará (сапиа).

Requer-se outrosim que as differenças não sejam tantas e tão profundas que cheguem a formar lingua nova. Estão nesta condição o catalão e o portuguez.

$\mathrm{Na}$ historia das linguas chamam dialectos ou com termo technico codialectos as diversas formas do idioma que coexistiam com aquella, que depois constituiu lingua litteraria. O gallego v. g. i codialecto do portuguez, bem como o mirandez etc. fallado em Traz-os-Montes.

Exemplo de gallego. Mendes dos Remedios. Introducção, pag. 82.

Cando morreu Xan Pereira,
vecino de Santa Comba,
chorando detras da tomba
iban catro pranxideiras (carpideiras)
- Berrade mais - dilles Xan
E unha (uma), mala cara pondo,
contesta: - Berro d'abondo (bastante)
Pra dés cartos que me dan.

Os dialectos portuguezes são divididos por J. Leite de Vasconcellos em tres grupos: continental, abrangendo o interamnense, beirão e meridional; o insulano formado pelo açoreano e madeirense e o ultramarino que comprehende o creoulo das possessões africanas e asiaticas e o brazileiro.

\section{O Portuguez fallado no Brazil}

Nota preliminar. Neste capitulo não se estabelece confronto com o portuguez dialectal, mas sim com o portuguez litterario moderno. Quanto á pronuncia serviu de base de comparação o livro de Gonçalves Vianna: „Pronuncia normal portuguesa”.

O portuguez fallado no Brazil distingue-se do reinol (litterario) principalmente pela pronuncia, collocação dos pronomes encliticos e um vocabulario africano, guarany e hespanhol colonial. 
A pronuncia brazileira apresenta uma enunciação e delimitação mais clara das syllabas que forma contraste frisante com a rapidez e ensurdecimento da loquela (sic) portugueza.

Exemplos. O brazileiro não conhece $o$ som surdo de $\boldsymbol{e}, \boldsymbol{a}$ - a prolação apressada das vogaes pretonicas - nem tão pouco o som chiante brando dado ao $s$ final antes de consoante ou em grupo consonantal, etc., etc.

A collocação dos pronomes encliticos baseia-se, se não completamente, ao menos em grande parte na pronuncia.

(p. 290-292, itálicos e negritos do autor)

\section{SILVA NETO, Serafim da. Manual de gramática histórica portuguesa: de acordo com o Programa Oficial do $4^{\circ}$ ano (1942) $\boldsymbol{\beta}$}

Em 1500 as afortunadas velas de Pedro Álvares Cabral chegam às maravilhosas plagas da Terra de Santa Cruz.

Ora, as línguas, fieis companheiras, seguem o destino dos homens que as falam. Porisso o conceituado filólogo Schuchardt escrevia com razão: "A história dos descobrimentos e conquistas portuguesas é também, em geral, a história da expansão da língua portuguesa."

Por todo o mundo se fez ouvir o maravilhoso idioma de Camões.

Na índia esteve com Afonso d'Alboquerque, na África foi companheiro de Diogo Cão, ao Brasil chegou com Cabral e seus marinheiros.

Por toda a parte onde esteve criou raízes. É verdade que, adotado pelos mais diversos povos do ultramar, se transformava e alterava. Constituía, assim, variantes denominadas dialetos.

Quando essas variantes se formam na bôca de seres rudes e socialmente inferiores chamam-se dialetos criolos.

Tais linguajares criolos se criaram principalmente com fins práticos: a necessidade em que se viam as nações submetidas de comunicar-se com os vencedores.

No Brasil isso não se deu porque a nossa população é, na maioria, de origem europeia.

O grande filólogo português Leite de Vasconcelos desta maneira dividiu os dialetos da nossa língua:

1) continentais (existentes em Portugal): a) interamnense; b) trasmontano; c) beirão; d) meridional.

2) insulanos (falados nas ilhas europeias): a) açoriano; b) madeirense.

3) ultramarinos: a) dialeto brasileiro; b) indo-português (criolo de Diu; criolo de Damão; dialeto norteiro; português de Gôa; criolo de Mangalor; criolo de Cananor; criolo de Cochim; criolo de Maé; português da costa de Coromandel); c) criolo de Ceilão; d) criolo de Macau; e) malaio-português (criolo de Java; criolo de Malaca e Singapura); f) português de Timor (pequena ilha na Oceânia, próximo à Austrália); g) criolo do arquipélago de Cabo Verde; h) criolo da Guiné; i) criolo das ilhas de S. Tomé, Príncipe e Ano-Bom; j) português das Costas da África (Angola, Moçambique, Zanzibar, Mombaça, Melinde).

(p. 30-31, itálicos do autor e sublinhados nossos) 
NASCENTES, Antenor. O idioma nacional: volume 4 (1942 [1928]) $\boldsymbol{\beta}$

\section{O português do Brasil}

Uma lingua não se espalha através de uma região sem alterar-se aquí e alí.

Assim aconteceu ao latim quando foi introduzido nas diversas provincias do imperio romano.

Outro tanto se deu com o português na sua expansão da margem esquerda do Minho à direita do Guadiana e mais tarde pela Asia, Oceania, Africa e América.

Com o tempo formou-se, porem, no centro do país, entre Coimbra e Lisboa, uma lingua-padrão que dominou os falares das demais regiões, os quais dela procuram aproximar-se.

Segundo Leite de Vasconcelos, a maior autoridade em dialetologia portuguesa, o português ao lado de um co-dialeto apresenta dialetos continentais, insulares e ultramarinos.

Co-dialeto é idioma especial que, hoje não sendo propriamente português, com ele mantem estreitas relações.

Trata-se do galego, que é falado na Galiza, provincia espanhola, e vizinhanças.

Ao lado do codialeto galego há três falares raianos, o rionorês, o guadramilês e o mirandês, falados em regiões portuguesas que desde remotas eras tiveram uma vida mais ou menos apartada.

Os dialetos continentais são quatro: o interamnense, falado entre o Douro e o Minho; o transmontano, em Trás-os-Montes; o beirão, na Beira; o meridional, na Estremadura, no Alentejo e no Algarve.

Os insulares são dois: o açoriano e o madeirense.

Os ultramarinos compreendem: o brasileiro, o indo-português, o dialeto crioulo de Ceilão, o macaista, o malaio- Português, o português de Timor, o dialeto crioulo caboverdiano, o dialeto crioulo guineense, os dialetos crioulos das ilhas do golfo da Guiné e o português das costas da África (Angola e Moçambique).

Como se vê, a lingua do Brasil, em que pese ao orgulho nacional, não passa de um dialeto ultramarino do português e a Europa assim o considera. Nas Universidades, nas escolas de linguas vivas, quem quer aprender português não recorre a um brasileiro, como quem quer aprender inglês não procura um norte-americano. É verdade que a importancia comercial de um mercado de quarenta milhões de compradores já faz que em Hamburgo, por exemplo, se dê maior atenção ao português do Brasil.

O proprio Leite de Vasconcelos reconheceu que a denominação de dialeto, dada ao português do Brasil, ia ferir os nossos melindres patrióticos.

Mas, diz ele, se eu chamo dialeto, por exemplo, ao português de Trás-os-Montes, com mais forte razão devo dar este nome ao português do Brasil.

O estudo das particularidades, principalmente dos dialetos continentais, dos insulares e dos ultramarinos da África, da Asia e da Oceania, não nos interessa a nós brasileiros senão pelo que de comum encontramos com o nosso dialeto.

A colonização do Brasil começou depois do primeiro quartel do século XVI. Desde então, colonos portugueses, indios e africanos escravizados os seus descendentes puros ou mestiços começaram, cada qual a seu jeito, a introduzir na lingua portuguesa modificações que determinaram com o andar do tempo a constituição de uma variante.

A propria lingua literaria tomou algumas feições particulares (Leite de Vasconcelos, Opúsculos, I, 281). 
A enorme extensão territorial do nosso país, sem faceis comunicações interiores, as diferenças de povoamento e outras causas quebraram a unidade do dialeto, fragmentandoo em dois subdialetos cada qual com suas variantes (1).

(1) O estudo do português popular do Brasil é uma especialidade que cabe aos que investigam a dialectologia. Numa classe seria elemento altamente perturbador. Da variante falada no Rio de Janeiro tratamos em nosso trabalho intitulado $O$ Linguajar carioca em 1922; alem desta, as únicas variantes cientificamente estudadas são a lingua dos caipiras paulistas com a qual se ocupou Amadeu Amaral em $O$ Dialeto Caipira, a linguagem do Nordeste de que tratavam Clovis Monteiro e Mario Marroquim e a do Triângulo Mineiro, estudada por José A. Teixeira.

De um modo geral se pode reconhecer uma grande divisão: o norte, do Amazonas e do Pará até a Baía, e o sul, da Baía ao Rio Grande do Sul.

É palpavel a diferença entre o falar cantado do nortista e o descansado do sulista.

À parte diferenças do léxico, existem na fonética importantes caraterísticos dos quais o principal é a inexistencia de protônicas abertas no sul, salvo tratando-se de diminutivos de oxítonos (xaràzinho, cafèzinho, paletòzinho) e adverbios de modo: belamente, fortemente.

Os traços caraterísticos da pronuncia brasileira são uma frouxidão e uma suavidade, que não se notam na portuguesa.

"La pronontiation brésilienne, comparée à la nôtre, diz Leite de Vasconcelos na Esquisse d'une Dialectologie Portugaise, a quelque chose de traînant".

Há uma expressão bem caraterística da suavidade da nossa pronuncia: a lingua do Brasil é denominada o português com açucar.

O falar português é enérgico e áspero.

Na Exposição da Pronuncia Normal Portuguesa, diz Gonçalves Viana que o carater preguiçoso e lento da nossa dicção arrastada contrasta singularmente com a energia do falar português e denuncia imediatamente o brasileiro.

A rudeza é atestada por autoridade insuspeita como o ilustre foneticista Frederico Wulf, da Universidade de Upsala, citado pelo proprio Gonçalves Viana.

(p. 181-183, itálicos do autor e sublinhados nossos)

BUENO, Silveira. Páginas floridas: gramática histórica, comentários etimológicos, textos arcaicos e modernos: $4^{\mathrm{a}}$ série - curso fundamental (1938) $\boldsymbol{\beta}$

\section{DE GRAMÁTICA HISTÓRICA}

\section{DIFERENCIAÇOES DIALETAIS DO BRASIL}

Seria produto de pura imaginação o trabalho de quem quisesse determinar, no Brasil, regiões distintas, áreas dialetais, porque tudo ainda está por fazer. Renato Mendonça, em seu livro "O Português do Brasil", apresenta nada menos do que nove áreas dialetais, portanto, nove dialetos em formação. São as seguintes: 1) Amazônica: Acre - Amazonas, Pará. 2) Cearense: Ceará e parte oriental de Piauí. 3) Nordestina: R. G. do Norte, Paraíba, Pernambuco e Alagoas. 4) Baiana: Baía até S. Francisco, Sergipe. 5) Fluminense: Estado do Rio, Distr. Federal, Esp. Santo. 6) Caipira: S. Paulo e zona fronteira de Minas. 7) 
Mineira: zona do capiau em Minas e Baía além S. Francisco. 8) Gaúcha: R. G. do Sul e sul de S. Catarina. 9) Sertaneja: Goiaz e Mato Grosso.

Tudo isto é muito arbitrário e incerto porque as pequeninas diferenças de pronúncia e significação existentes entre uma zona dialetal e outra não permitem que haja, de fato, dialetos. Não há paulista que não possa conversar com um gaúcho ou com um cearense sem entendê-los. Um ou outro têrmo local escapa, mas, isto é muito pouco para servir de base a dialetos.

Por curiosidade vamos transcrever alguns trechos por ele chamados dialetais e verá o leitor que, à parte os têrmos locais, isto é, nomes de peixes, de plantas, o geral é fàcilmente compreensível a todos.

(...)

(p. 50-51, itálicos do autor)

GUÉRIOS, Rosário Mansur. Pontos de gramática histórica portuguesa: $4^{\mathrm{a}}$ série: de acordo com o programa oficial (1937) $\boldsymbol{\beta}$

Glotologia é a ciência das línguas estudadas comparativamente através do tempo e do espaço.

OBS.: 1) Através do tempo - gramática histórica ou comparativa; através do espaço dialetologia (geografia lingüística).

(p. 15, negrito do autor e sublinhado nosso) 


\title{
QUADRO 14B - Definições e considerações sobre dialeto presentes nas obras dialetológicas
}

\section{do Português}

\begin{abstract}
AMARAL, Amadeu. O dialecto caipira: gramática, vocabulário (1955 [1920]) $\boldsymbol{\beta}$
Tivemos, até cerca de vinte e cinco a trinta anos atrás, um dialeto bem pronunciado, no território da antiga província de S. Paulo. É de todos sabido que o nosso falar caipira bastante característico para ser notado pelos mais desprevenidos como um sistema distinto e inconfundível - dominava em absoluto a grande maioria da população e estendia a sua influência à própria minoria culta. As mesmas pessoas educadas e bem falantes não se podiam esquivar a essa influência.

(...)

O processo dialetal iria longe, se as condições do meio não houvessem sofrido uma série de abalos, que partiram os fios à continuidade da sua evolução.

Ao tempo em que o célebre falar paulista reinava sem contraste sensível, o caipirismo não existia apenas na linguagem, mas em todas as manifestações da nossa vida provinciana. De algumas décadas para cá tudo entrou a transformar-se. A substituição do braço escravo pelo assalariado afastou da convivência cotidiana dos brancos grande parte da população negra, modificando assim um dos fatores da nossa diferenciação dialetal. Os genuínos caipiras, os roceiros ignorantes e atrasados, começaram também a ser postos de banda, a ser atirados à margem da vida coletiva, a ter uma interferência cada vez menor nos costumes e na organização da nova ordem de coisas. A população cresceu e mesclou-se de novos elementos. Construíram-se vias de comunicação por toda a parte, intensificou-se o comércio, os pequenos centros populosos que viviam isolados passaram a trocar entre si relações de toda a espécie, e a província entrou por sua vez em contato permanente com a civilização exterior. A instrução, limitadíssima, tomou extraordinário incremento. Era impossível que o dialeto caipira deixasse de sofrer com tão grandes alterações do meio social.
\end{abstract}

(p. 41-42, itálicos do autor e sublinhados nossos)

MARROQUIM, Mário. A lingua do nordeste: Alagôas e Pernambuco (1934) $\boldsymbol{\beta}$

\section{DIALETO}

1. Não está ainda feito o estudo do dialeto brasileiro. A enorme extensão geografica em que o português é falado no Brasil, dá a cada região peculiaridades e modismos desconhecidos nas outras, e exige, antes da obra integral que fixe e defina nossa diferenciação dialetal, trabalhos parcelados, feitos com criterio e honestidade, sobre cada zona do país. Esses trabalhos serão o material de que lançará mão o estudioso de amanhã para uma obra de conjunto, completa e definitiva, sobre o dialeto brasileiro.

É extranhavel mesmo que, um assunto tão importante qual seja esse das modificações sofridas pelo português na America, tenha sido tratado até hoje com tanto indiferentismo pelos nossos linguistas e filologos. Somos, no entanto, quarenta milhões de pessôas que falamos uma lingua transplantada ha quatro seculos para um novo meio, onde tem estado exposta aos influxos modificadores de clima diferente, de ambiente diverso, sofrendo ainda o contacto intimo de dois grupos etnicos e gloticos extranhos. Nossa língua ter-se-á 
transformado, da mesma forma que o português falado em Portugal no seculo XVI se alterou apenas pelo impulso genial da evolução das línguas, apesar de não ter estado em contacto com fatores externos de modificação.

2. O português do seculo XVI é o ponto de partida de uma evolução divergente. Enquanto em Portugal se modificava num sentido, no Brasil, envolvido por fatores mesologicos étnicos e geograficos radicalmente diversos, orientou diferentemente a sua evolução.

É o que Eduardo Carlos Pereira chama um amplo triangulo cujo apice é o seculo XVI e os lados o falar brasileiro e português. Os lados, partindo do apice, cada vez mais se afastarão.

Contra a opinião dos que negam o dialeto brasileiro, opinião que vai de encontro a tudo o que está estabelecido em relação á evolução das linguas, se opõe a realidade que não exige demonstrações. Nem o dialeto brasileiro nos envergonha.

É um fenomeno cuja espontaneidade não podemos deter nem governar, é uma força viva

que surge das massas populares ao impulso de tendencias logicas e naturais e cuja expansão devemos estudar e observar, mas que não está em nós orientar, porque ela se dirige de acordo com leis gloticas certas e imutaveis.

A essa preocupação de repudiar e negar o dialeto brasileiro, é que cabe a culpa de não termos até hoje um estudo sistematizado de nossas tendencias dialetais.

Amadeu Amaral, em 1920, com o seu "Dialeto caipira" abriu resolutamente o caminho, dando um exemplo que deve ser imitado.

Antenôr Nascentes seguiu-lhe os passos com "O linguajar carioca em 1922".

Depois destes, teem surgido pequenas contribuições em revistas e jornais, além de vários glossarios regionais, demonstrando que o problema começa a apaixonar os estudiosos de nossas coisas e de nossa lingua.

Contra a opinião de Ribeiro de Vasconcelos, Teofilo Braga, Adolfo Coelho, Gonçalves

Viana e Leite de Vasconcelos, que em Portugal afirmam a existencia do nosso dialeto, ha no Brasil ilustres filologos que o negam.

O povo, porem, que ignora ser objeto dessa controversia, continúa na obra inconsciente da diferenciação linguística cada vez mais acentuada. falado

E a despeito da repugnancia dos nossos letrados em considerar dialeto o português no Brasil, a despeito da classificação de simples "brasileirismos" dada aos nossos modismos dialetais, a língua portuguesa tal como é falada pelo povo, e tal como tambem é falada na intimidade, despreocupadamente, pelas pessôas cultas, vai impondo suas formas especiais, já forçou as portas da literatura, e está obrigando os gramaticos a tomarem conhecimento de sua presença. Já conquistou, emfim, o seu logar ao sol.

(p. 5-8, sublinhados nossos)

\section{NASCENTES, Antenor. O linguajar carioca (1953 [1922]) ß}

Querem uns que as variedades só constituam dialeto quando houver dificuldade de compreensão mutua entre os que a falam e os que os falam a língua mãe; dão outros, como o insigne Leite de Vasconcelos, a maior autoridade em dialectologia portuguesa, o nome de dialeto às diferenciações locais de uma língua, admitindo dentro dos dialetos os subdialetos e dentro destes as variedades. 
Haja ou não haja dialeto brasileiro, questão que se discute desde a celebre polemica entre Alencar e Castilho, o que não se pode contestar é a existencia de variação entre a língua do Brasil e a de sua antiga metropole e é isso principalmente o que nos interessa e o que nos cumpre estudar.

Leite de Vasconcelos, na "Esquisse d'une dialectologie portugaise" mostra nosso dever de estudar o português do Brasil.

O grande Meyer-Lübke, na "Introdução ao estudo da filologia romanica", só se refere ao chileno porque o castelhano do Chile é a unica variante romanica que até hoje recebeu um estudo cientifico e lamenta a escassez do material no tocante à evolução do romaniço nas colonias.

São do mais alto valor cientifico os casos de patologia linguística apresentados pelos dialetos; tem mais importancia do que as questiunculas futeis sobre colocações de pronomes e outros assuntos. (p.12, sublinhados nossos)

PAES, Elpidio Ferreira. Alguns aspectos da fonética sul-riograndense: contribuição ao "Congresso de língua nacional cantada" (1938) $\boldsymbol{\beta}$

Verdade é que numerosos fatos surgidos em nosso linguajar não decorrem de fonte lusitana, pelo menos não são de carater essencialmente português. $\mathrm{O}$ africano e o indígena, como bem acentúam Renato Mendonça e Mário Marroquim, muito contribuiram para a nossa formação linguística. Mas isso em nada nos desdoura, nem tira o caráter distinti ao nosso modo de falar. Também foram os bárbaros da Lusitania que deturparam o latim para formar a língua portuguesa. E nem porisso tão formoso idioma deixou de ser um dos mais poderosos veículos da civilização. A origem do nosso "brasileiro" é humilde como a do "luso". Porque não se poderá tornar grande como êle?

Devemos ainda apontar a influência dos povos de origem espanhola, nossos colindantes, bem como a contribuïção que nos vem trazendo, há algum tempo, os povos europeus que tem vindo colaborar conosco e conosco convivem, especialmente o italiano e o alemão.

Aliás, só nós vivemos nesta obsessão dos "crimes de lingüicídio". Os nossos vizinhos argentinos vão construindo serenamente o seu castelhano sem consultarem a antiga Metrópole; e os yankees sorriem displicentes e divertidos ante os arreganhos filológicos da boa Albion. Ao passo que nos continuamos a tremer diante da sínclise e da regência, como crianças de colo ao avistarem o papão... Felizmente, parece que já vamos atingindo a maioridade... (p.7-8)

\section{TEIXEIRA, José de Aparecida. O falar mineiro (1938) $\boldsymbol{\beta}$}

Dialeto é a variedade regional de uma lingua.

Instrumento de comunicação, a lingua não é estatica. Como nada da natureza.

Transportando para o cenário americano, diverso do de Portugal, instrumento de uma população mestiça de processos de expressão diferentes, o português quinhentista tinha de alterar-se, de modificar-se. E assim não é nada extraordinario que depois de quatrocentos anos apresente caracteres diversos do português ultramarino. Se até este diverge bastante do quinhentista. E somente pra espiritos fossilizados é preciso que filologos portugueses, como Adolfo Coelho, Gonçalves Viana, Leite de Vasconcelos e outros, venham dar-lhes a nova desagradavel da existencia do dialeto.

O processo de dialetação é um facto normal em linguistica. Como é o da diferenciação na natureza. 
E suas causas parte pertencem ao dominio geral, parte ao particular a cada país e a cada povo, que é o que imprime feição nacional ás linguas.

A tendencia de economizar esforço, a analogia, a necessidade de clareza de expressão, são fatores gerais.

O clima, o solo, o habitat, são agentes modificadores sobretudo do lexico. Não que o meio fisico intervenha ativamente. Mas como material da ação do grupo humano, que o povoa. $\underline{O}$ lexico português por exemplo se enriqueceu na designação das novas coisas da America.

O meio fisico frequentemente ainda concorre para a fragmentação da lingua, pela dificuldade de intercomunição dos individuos.

É o que sucedeu ao dialeto brasileiro, que disseminado pelo vasto territorio, se fragmentou em sub-dialetos, que dominam cada zona de unidade geografica, etnica, e de identica formação historica.

O meio social é outra fonte abundante de fenomenos linguisticos especificos, principalmente morfologicos e sintaticos.

Sob essa denominação se classificam - as influencias oriundas da constituição etnica da população, as da formação historica e politica e as provenientes da divisão da sociedade em classes.

A particularidade de uma pronúncia, de uma sintaxe, acusam frequentemente a incapacidade indigena ou africana de pronunciar tal consoante ou qual grupo vocalico, ou ainda o processo de expressão das linguas destes povos primitivos transportado para o português.

O terceiro fator social talvez o mais importante, e a que bem pouco relevo tem sido dado no papel da dialetação, é o da divisão de classes da sociedade. Existe um falar proprio das altas classes e medias superiores, como existe uma falar das classes medias inferiores e das classes infimas, que principalmente constituem o povo. Já na antiguidade, no latim sermo urbanus e sermo plebeius designavam a diferença entre a lingua das altas classes e a do povo.

As classes são fronteiras dentro da sociedade.

Elas delimitam a esfera de convivio social e portanto concorrem pra formação de falares proprios só do meio social que caracteriza a classe.

As relações diretas com a natureza pela produção, por exemplo, criam nas classes operarias do campo e da cidade, um vocabulario e um sistema de imagens proprias do meio, um processo de associação diferente e rico.

Assim o trabalhador do campo diz: campear uma pessoa por procurar; passarinhar por assustar (em relação aos animais). A ausencia absoluta da disciplina gramatical, permite a ação livre dos fatores de diferenciação latentes: vezada, discutição, etc., são formas produto da analogia. Assim cada classe, segundo o papel que desempenha no processo de produção social da existencia, e segundo o grau nulo, maior ou menor de instrução, cria um vocabulario peculiar e um sistema de imagens caracteristico, bem como processos sintaticos e factos morfologicos diferentes. $\mathrm{O}$ falar mineiro, como o brasileiro, apresenta a este respeito pelo menos tres tipos de linguagem:

a) - a linguagem popular, das grandes massas analfabetas e semi-alfabetas, operarias e camponesas, com seu vocabulario distinto e ininteligivel muitas vezes ás outras classes, imagens diversas e processos sintáticos proprios.

b) - a linguagem das classes medias. A gama social e cultural delas oferece dificuldades na classificação exata dos fenomenos linguisticos. 
Nas escalas inferiores, pelo contacto com as grandes massas e menor instrução, a lingua apresenta caracteristicas numerosas comuns com a lingua popular.

Nas superiores, as das profissões liberais, do alto comercio e industria, por efeito da instrução, o vocabulario apresenta caracteristicas de seu meio; a sintaxe e a morfologia modificadas pela instrução. Oferecem ainda os "brasileirismos" tão anatematizados pelos gramaticos. É a lingua de Macunaima e Belazarte, Menino de Engenho e de toda a literatura nova. A lingua da imprensa em geral.

c) - a linguagem oficial, que é a portuguesa, a lingua das escolas, dos atos públicos, e de reduzidissimo número de individuos da pequena aristocracia social e cultural.

Mesmo aqui nas mais altas esferas, a verdadeira lingua portuguesa é ideal de muitos e apanagio de poucos.

Seguindo este criterio, procuramos aqui, embora com grande imperfeição, classificar os factos de acordo com o meio social de origem, e assim nas denominações - popular, inculta, designamos a lingua da primeira classe, a do povo.

$\mathrm{Na}$ de - linguagem semi-culta, a das classes medias inferiores. E na de - linguagem culta as das classes medias superiores.

4 - O falar mineiro é uma variedade do dialeto brasileiro. Na discriminação sub-dialetal de Rodolfo Garcia, ele forma um bloco com o falar goiano e mato-grossense, constituindo a zona-

Alti-plana-central. (2)

Já Antenor Nascentes, distribuiu as zonas mineiras entre varios sub-dialetos: no fluminense - O sul de Minas e a zona da mata: no sertanejo, o norte de Minas e o sertão do Nordeste: no sulista, o Triangulo Mineiro.

Não estando ainda estudadas as variantes dialetais das regiões que formam os subdialetos mencionados, não entramos na consideração de-se o falar mineiro se prende ao falar deste ou

daquele estado visinho. O que constitue objeto deste insignificante trabalho são as caracteristicas gerais, morfologicas e sintaticas, constatadas em diversas regiões do Estado, representadas no triangulo, e zonas centralizadas pelos municipios da Capital, de Alfenas, S. João Del-Rey, Pouso Alegre, Teofilo Otoni, Manhuassú.

Temos ainda que observar, antes de entrarmos na exposição dos factos, que o linguajar mineiro, pela insignificancia da imigração estrangeira, não tende a modificar atualmente suas caracteristicas essenciais.

(2) - R. Garcia, Dicionario de Brasileirismos, 651.

(p. 8-11, itálicos do autor e sublinhados nossos) 


\title{
QUADRO 15B - Posições nacionalistas nas obras dialetológicas lexicográficas
}

\author{
D’ALBUQUERQUE, A. Tenório. Falsos brasileirismos: argentinismos e americanismos \\ erradamente apontados como brasileirismos (1942) $\boldsymbol{\beta}$
}

\section{BRASILEIRISMO - O seu conceito}

"Os brasileiros têm o seu modo característico de falar, algo diferente do falar dos lusitanos, mas êsse modo é tão legítimo como o é qualquer fato da linguagem portuguesa, tanto aqui como além mar."

(José de Sá Nunes - “A Lingua Vernácula”, 4.a série, pág. 210).

Não sem tempo, já se modificou o conceito dos fenômenos de linguagem ocorridos no Brasil.

BRASILEIRISMO: Não são deslizes de linguagem cometidos no Brasil.

BRASILEIRISMO: é a classificação de um fenômeno lingüístico e não apenas de dislates de linguagem.

Por uma questão de tradição, ainda os brasileirismos são, nas gramáticas, incluídos entre os "vícios de linguagem". É incoerência, que também cometemos, em nosso livro "Pontos de Português", já na 5.a edição, e da qual nos penitenciamos.

Para nós, "BRASILEIRISMOS são vocábulos, pronúncias e construções de uso no Brasil e mais ou menos desconhecidos em Portugal porque lá nunca usaram ou porque se arcaizaram. (p.37-38)

\section{RIBEIRO, João. A língua nacional (1933). $\beta$}

\section{A LINGUA NACIONAL}

Por vezes temos meditado nas atribulações que soffre o nosso homem de letras no uso da sua propria lingua.

É por simples vaidade, e talvez por snobismo, que um que outro mais ousado affecta desdem e indifferença pelas questões de grammatica.

Não ha inteira sinceridade n'esse menosprezo. A pecha de incorrecção é um precalço terrivel.

D'ahi, o exito relativo d'essas secções jornalísticas que nos instruem nas fantasias do bem falar ou do bem escrever, e nos dizem como se fala e escreve em... Coimbra ou em Lisboa.

Os conselhos não são lidos com interesse; mas sempre se passa a vista por essas impertinencias.

Enfim, convém inteirar-se do que contêm os cartapacios do bom tom, com agrado ou com desplicencia.

Parece todavia incrivel que a nossa Independencia ainda conserve essa algema nos pulsos, e que a personalidade de americanos pague tributo á submissão das palavras. $(\ldots)$

A nossa grammatica não póde ser inteiramente a mesma dos portuguezes. As differenciações regionaes reclamam estylo e methodo diversos.

A verdade é que, corrigindo-nos, estamos de facto a mutilar idéas e sentimentos que não são pessoaes. 
Já não é a lingua que apuramos, é o nosso espirito que sujeitamos a servilismo inexplicavel.

Falar differentemente não é falar errado. A physiognomia dos filhos não é a aberração teratologica da physiognomia paterna.

(...)

Trocar um vocabulo, uma inflexão nossa, por outra de Coimbra, é alterar o valor de ambos a preço de uniformidades artificiosas e enganadoras.

(p. 7-8, sublinhados nossos)

OLIVEIRA, Sebastião Almeida. Expressões do populário sertanejo: vocabulário e superstições (1940) $\boldsymbol{\beta}$

O nosso idioma, que é o depositário e o transmissor do pensamento brasileiro em seus diferentes e múltiplos aspectos, podendo refletir também sob diversas formas o índice da civilização, exige por isso mesmo seja ele próprio coordenado em vários estudos para maior facilidade de seu conhecimento. É claro que, podendo assim compreender melhor as idéias e os sentimentos de nossos compatrícios, melhor possamos organizar e dirigir o plano educacional para as nossas escolas.

Por esse motivo cumpre-nos acolher com simpatia, e às vezes com entusiasmo, as contribuiçõoes que surgirem sôbre o estudo do idioma nacional. Quem se dedica a essas locubrações é porque sente real interêsse pelas coisas brasílicas.

Além de tudo, a comunidade da lingua, bem sabemos, é liame fortissimo de cooperação e solidariedade, sem as quais impossível se torna levar avante as legitimas aspirações de progresso. A lingua pátria, qual deve ser usada, como poderoso meio educativo, vale tanto quanto o território para formar a nacionalidade.

Eu quisera ver no organismo administrativo uma repartição dedicada ao serviço do idioma nacional. Ha um grande programa que realizar nesse sentido, garantidor de coisas essenciais à vida do Brasil.

A lingua encontra-se ligada ao patriotismo do mesmo modo por que êste se acha unido ao território nacional. Aquela é como que a alma dêste esplêndido corpo, ambos confiados a todos nós que somos brasileiros.

(p. 7-8, sublinhados nosso)

MORAES, Raymundo. O meu diccionario da Amazonia (2 volumes) (1931) $\boldsymbol{\beta}$

É, pois, curial que O MEU DICCIONARIO DE COUSAS DA AMAZONIA, filho das aguas, irmão das lagunas, primo das fontes, aflore tambem do aranhol hydrographico. Epitome informativo do que vae por alli, elle reflecte toalha prateada do Guajará, o lençol maravilhoso do estuario, a corda pardo-vermelho do Amazonas, a colcha escura do Negro, o azul, o verde, o laranja, o branco desses affluentes e confluentes que humedecem, fertilizam e alteiam a gleba da Planicie.

Suas paginas agitadas, confusas, contraditorias, serenas, harmoniosas, placidas, narrando vida do homem, o costume da gente, a crença do selvicola, a dôr do vencido, e o avanço do civilizado, lembram o borborinho fluvio, o rodopio das espumas, as angusturas goro golejantes, os mananciaes silvestres, os paues escuros, as fontes crystallinas e constituem, emfim, o cyclo maravilhoso da Amazonia, que marca, pela fuga das aguas, uma época assistida por esta geração, vista miraculosamente pelos nossos olhos privilegiados de homens do seculo. A obra toda, abrangente de mytho, de tradição, de folk-lore, de lenda, de costumes, synthetiza o apocalyptico 
Amazonas, na figura de genio ou de deus, transportando no dorso pardo, colhidos no cimo dos montes, na aba das cordilheiras, no regaço das planicies, ao cortat vertiginosamente o continente - semestes, troncos, balsas, gramineas, aves, passaros, cadaveres, dectritos e areia de ouro.

(p.29-31, volume 1, sublinhado nosso)

\section{TESCHAUER, Carlos. Apostillas ao "Diccionario de vocabulos brasileiros" (I Serie) (1912) $\boldsymbol{\beta}$}

Entre os motivos, que determinaram este trabalho, não foi o ultimo ponto de vista historico, assentando com muitos ethnologos e historiadores que a lingua de um povo é o unico distinctivo infalsificavel do seu caracter nacional. Nella se espelham os grandes factos, as instituições, suas propriedades, suas guerras, suas victorias como derrotar, as transições no progresso ou deste á decadencia, e tudo isso tão indelevelmente é gravado num vocabulo como numa moeda o seu valor; porque espontanea e naturalmente, sem legisladores nem deputados, assembleas e decretos, formam-se as palavras que retratam inequivocamente o pensar e o sentir do povo, as suas leis, seus costumes, as suas aspirações e idéas.

Reflectem-se no nosso meio as tres raças india, europea e africana e o gráo do seu respectivo influxo, reflectem o ambiente proprio como o contacto com os povos visinhos. (p. 3, sublinhados nossos)

\section{DAISSON, Augusto. Á margem de alguns brasileirismos (1925) $\boldsymbol{\beta}$}

Em outro artigo, diz o sr. Affonso de E. Taunay que a experiencia lhe convenceu de que deve haver, pelo menos, uns cem mil brasileirismos, que os grandes lexicos da lingua não contemplaram ainda.

Pouco tenho viajado escreve -- nas diversas zonas do paiz a não ser quanto a $S$. Paulo, Rio de Janeiro e Minas, mas sempre me succedeu descobrir regionalismos, por vezes numerosos, ao percorrer novas directrizes, sobretudo, pondo-me em contacto com pessoas do povo, caipiras e caboclos.

É essa uma historia a que já estamos acostumados e, por isso, não nos admiramos. A's vezes, parece mesmo que o olhar do escriptor carioca não vae além de S. Paulo e de Minas. Alcança a Europa e outros continentes, mas o sul do Brasil é, não raramente, para elle, como se não existisse. Os Estados do Paraná, de Santa Catharina e do Rio Grande do Sul ficam quasi sempre esquecidos.

Pois é pena que o sr. Affonso de E. Taunay não tenha ainda viajado pelo Rio Grande do $\underline{\text { Sul, }}$ porque encontraria aqui, não sem sorpreza, uma fonte inexgottavel de termos, em muitos dos quaes nunca ouviu falar, e outros que figuram nos diccionarios, mas com significação differente, ou, melhor ainda, com applicação differente. Então, com o seu estylo claro, corrente e bellissimo, s. ex. poderia escrever um livro precioso, que os estudiosos da lingua muito lhe agradeceriam e apreciariam.

Sobretudo, o que mais extranhamos, e mesmo o que mais sentimos, no meio de todo esse barulho de vocabulos, é que não se diga uma só palavra de applauso, ou de simples lembrança, ao magnifico trabalho que fez o nosso saudoso amigo e professor Apollinario Porto Alegre, trabalho esse que muito se avantaja a todos os que, nesse sentido, até hoje, temos conhecido, como opportunamente demonstraremos. (p. 9-10, sublinhados nossos) 
TAUNAY, Affonso D'Escragnolle. Reparos ao novo diccionario de Candido de Figueiredo (1926) $\boldsymbol{\beta}$

Mas, ars longa. Infelizmente está o Novo Diccionario muito e muito longe, ainda, de ser o lexico exigido pelo estado cultural presente da lingua portugueza, hoje patrimonio de uns quarenta milhões de individuos. E isto por muitos motivos serios.

Primeiro pela sua deficiencia em materia de brasileirismos e neologismos de todo o genero nascidos da plastificação litteraria e jornalistica do portuguez no Brasil e em Portugal, do colossal avolumamento da technologia industrial e da scientifica, da creação de enormes nomenclaturas derivadas de inventos modernos, etc.

Ha cem mil palavras vulgares, correntes no Brasil que o Snr. Candido de Figueiredo desconhece. O Rev.Pe. Carlos Teschauer nos seus lexicos e eu nos tres que publiquei em 1909, 1914 e 1924: Lexico de termos technicos e scientificos, Lexico de lacunas e Vocabulario de omissões, arrolámos uns vinte mil vocabulos, lacunas do Novo Diccionario. Algum esforço mais teriamos dobrado a colheita.

Desafiado por um sceptico, certa vez, a descobrir tres lacunas nas edições de tres grandes jornaes brasileiros publicados num mesmo dia, demonstrei em publico que as tiragens de dous jornaes paulistas e um carioca, de 17 de fevereiro de 1924, me davam 106 lacunas do diccionario do Snr. Candido de Figueiredo!

(...)

Além dos numerosissimos brasileirismos deturpados, falhos, insufficientes e até disparatados, ha no léxico figueiredeano numerosas heresias scientificas.

(p. 2-3, sublinhados nossos)

[Consultamos outras obras de Taunay e lá encontramos observações semelhantes, motivo que nos fez não incluí-las aqui.]

\section{LESSA, Claudo Ribeiro de. Vocabulário de caça (1944) $\beta$}

Constitui, pois, o opúsculo ora apresentado um embrião de enciclopédia venatória (do Brasil, em particular), em ordem alfabética, e para cujo desenvolvimento e correção solicito e espero a ajuda de todos os cultores da brasilidade, aos quais antecipadamente agradeço as contribuições que me enviarem, e que serão devidamente aproveitadas em futuras edições. (p. 8-9, sublinhados nossos)

MAGALHÃES, Raimundo. Vocabulario popular: augmentado com grande numero de locuções populares brasileiras (1911) $\boldsymbol{\beta}$

A titulo de modesta contribuição para o estudo das transformações por que vae passando a lingua portugueza no Brazil, ha cerca de quatro annos, iniciámos a compilação deste nosso VOCABULARIO.

Todos os vocabulos que aqui figuram, muitos dos quaes completamente desconhecidos no sul, são de uso corrente nos Estados do norte e especialmente no Ceará, onde os colhemos das 
nossas relações directas com o povo, cuja pittoresca linguagem, eriçada de barbarismos, não foi ainda desfigurada pela macaqueação do extrangeiro.

Ninguem, mais do que nós, está convencido de que é este trabalho superior ás nossas forças, e quando o tomamos sobre os hombros não nos movia o desejo de ostentar envergadura de heroe. Bem sabiamos que a tarefa de expurgar a lingua dos plebeismos e barbarismos que a affeiam, ou - se quizerem por outro modo - o patriotico labor de colleccionar esses vocabulos que hão de servir de base á sonhada LINGUA BRAZILICA, compete aos homens de sciencia, aos doutos e eruditos, a todos quantos, pelo seu saber, se acham obrigados a trabalhar pelo progresso e engrandecimento das lettras. (p. 7, maiúscula do autor e sublinhados nossos) 
QUADRO 16B - Obras dialetológicas lexicográficas: descrição de dialetos regionais e sociais

\begin{tabular}{|c|c|}
\hline CALLAGE, Roque & $\begin{array}{l}\text { - Vocabulario gaúcho: contendo mais de } 2 \text { mil termos usados } \\
\text { no linguajar rio-grandense (1926) } \Sigma\end{array}$ \\
\hline CARVALHO, Elysio de & - Giria dos gatunos cariocas (1913) $\boldsymbol{\beta}$ \\
\hline $\begin{array}{l}\text { CORRÊA, José } \\
\text { Romaguera }\end{array}$ & - Vocabulario sul rio-grandense (1898) $\Sigma$ \\
\hline $\begin{array}{l}\text { COSTA, Francisco } \\
\text { Augusto Pereira da }\end{array}$ & - Vocabulário pernambucano $(1916)^{428} \boldsymbol{\Sigma}$ \\
\hline $\begin{array}{l}\text { GARCIA, Rodolfo } \\
\text { Augusto de Amorim }\end{array}$ & $\begin{array}{l}\text { - Diccionario de brasileirismos: peculiaridades } \\
\text { pernambucanas (1915) } \boldsymbol{\beta}\end{array}$ \\
\hline LAYTANO, Dante de & $\begin{array}{l}\text { - Os africanismos do dialeto gaúcho (1936) } \boldsymbol{\beta} \\
\text { - Vocabulário dos pescadores do Rio-Grande-Sul: } \\
\text { etimologia dos têrmos praieiros usados na costa nordeste } \\
\text { (1937) } \boldsymbol{\beta}\end{array}$ \\
\hline $\begin{array}{l}\text { LESSA, Claudo Ribeiro } \\
\text { de }\end{array}$ & - Vocabulário de caça (1944) $\beta$ \\
\hline $\begin{array}{l}\text { MAGALHÃES, } \\
\text { Raimundo }\end{array}$ & $\begin{array}{l}\text { - Vocabulario popular: augmentado com grande numero de } \\
\text { locuções populares brasileiras (1911) } \boldsymbol{\beta}\end{array}$ \\
\hline $\begin{array}{l}\text { MATTA, Alfredo } \\
\text { Augusto da }\end{array}$ & $\begin{array}{l}\text { - Contribuição ao estudo do vocabulario amazonense } \\
(1938)^{429} \Sigma\end{array}$ \\
\hline MENDES, José Amando & - Vocabulário amazônico: estudos (1942) $\boldsymbol{\Omega}$ \\
\hline $\begin{array}{l}\text { MIRANDA, Vicente } \\
\text { Chermont de }\end{array}$ & $\begin{array}{l}\text { - Glossario paraense: ou collecção de vocabulos peculiares á } \\
\text { Amazonia e especialmente á ilha do Marajó (1905) } \Sigma\end{array}$ \\
\hline $\begin{array}{l}\text { MORAES, Luiz Carlos } \\
\text { de }\end{array}$ & - Vocabulário sul-rio-grandense (1935) $\Sigma$ \\
\hline
\end{tabular}

428 Publicação póstuma. "'Separata do vol. XXXIV da Revista do Instituto Archeológico, Histórico e Geográphico Pernambucano'. Em 1916, a Revista do Instituto Arqueológico, Histórico e Geográfico Pernambucano iniciou a publicação do interessantíssimo trabalho de Pereira da Costa, modestamente intitulado Apontamentos para um vocabulario pernambucano. Não pôde, entretanto, ir além da letra B." (UNIVERSIDADE DE SÃO PAULO, 2019).

429 Em 1939, a obra sai com o título alterado para Vocabulario amazonense: contribuição para o seu estudo. 


\begin{tabular}{|c|c|}
\hline MORAES, Raimundo & - O meu diccionario da Amazonia (2 volumes) (1931) $\boldsymbol{\beta}$ \\
\hline $\begin{array}{l}\text { OLIVEIRA, Sebastião } \\
\text { Almeida }\end{array}$ & $\begin{array}{l}\text { - Expressões do populário sertanejo: vocabulário e } \\
\text { superstições (1940) } \boldsymbol{\beta}\end{array}$ \\
\hline PEDERNEIRAS, Raul & $\begin{array}{l}\text { - Geringonça carioca: verbetes para um diccionario da gíria } \\
\text { (1922) } \boldsymbol{\beta}\end{array}$ \\
\hline PERDIGÃO, Edmylson & - Linguajar da malandragem (1940) $\boldsymbol{\beta}$ \\
\hline PINTO, P. A. ${ }^{430}$ & $\begin{array}{l}\text { - Dicionário de termos médicos (1926) } \boldsymbol{\beta} \\
\text { - Os sertões de Euclides da Cunha: vocabulário e notas } \\
\text { lexicográficas (1930) } \\
\text { - Brasileirismos e supostos brasileirismos de Os sertões de } \\
\text { Euclides da Cunha (1931) } \boldsymbol{\beta}\end{array}$ \\
\hline SÃO PAULO, Fernando & - Linguagem médica popular no Brasil $(1936)^{431} \Sigma$ \\
\hline $\begin{array}{l}\text { TAUNAY, Affonso } \\
\text { D'Escragnolle }\end{array}$ & $\begin{array}{l}\text { - Lexico de termos technicos e scientificos ainda nao } \\
\text { apontados nos diccionarios da lingua portugueza (1909) } \beta \\
\text { - Insufficiencia e deficiencia dos grandes diccionarios } \\
\text { portuguezes (1928) } \boldsymbol{\beta}\end{array}$ \\
\hline TERÊNCIO, Paulo ${ }^{432}$ & $\begin{array}{l}\text { - Estudos euclidianos: notas para o vocabulario de "Os } \\
\text { sertões" [de Euclydes da Cunha] (1929) } \boldsymbol{\Sigma}\end{array}$ \\
\hline VIOTTI, Manuel & - Dicionário da gíria brasileira (1945) $\beta$ \\
\hline TOTAL & 25 obras \\
\hline
\end{tabular}

\footnotetext{
${ }^{430} \mathrm{O}$ autor assina suas obras desta forma, usando iniciais. Seu nome completo é Pedro Augusto Pinto.

${ }^{431}$ Obra em 2 volumes.

${ }^{432}$ Paulo Terêncio é o pseudônimo de P.A. Pinto.
} 
QUADRO 17B - Obras dialetológicas não-lexicográficas: descrição de dialetos regionais e sociais

\begin{tabular}{|c|c|}
\hline AMARAL, Amadeu & - O dialeto caipira (1920) $\boldsymbol{\beta}$ \\
\hline $\begin{array}{l}\text { MACHADO FILHO, } \\
\text { Aires da Mata }\end{array}$ & - O negro e o garimpo em Minas Gerais (1943) $\beta$ \\
\hline MARROQUIM, Mário & - A lingua do nordeste (Alagôas e Pernambuco) (1934) $\boldsymbol{\beta}$ \\
\hline MOTTA, Leonardo & $\begin{array}{l}\text { - Cantadores: poesia e linguagem do sertão cearense (1921) } \boldsymbol{\beta} \\
\text { - Violeiros do norte: poesia e linguagem do sertão nordestino } \\
\text { (1925) } \boldsymbol{\beta} \\
\text { - Sertão alegre: poesia e linguagem do sertão nordestino (1928) } \\
\boldsymbol{\beta}\end{array}$ \\
\hline NASCENTES, Antenor & - O linguajar carioca em 1922 (1922) $\beta$ \\
\hline PAES, Elpidio Ferreira & $\begin{array}{l}\text { - Alguns aspectos da fonética sul-riograndense: contribuição } \\
\text { ao "Congresso de língua nacional cantada" (1938) } \boldsymbol{\beta}\end{array}$ \\
\hline RIBEIRO, Joaquim & - Folklore dos bandeirantes $(1946)^{433} \boldsymbol{\beta}$ \\
\hline $\begin{array}{l}\text { TEIXEIRA, José de } \\
\text { Aparecida }\end{array}$ & $\begin{array}{l}\text { - O falar mineiro (1938) } \boldsymbol{\beta} \\
\text { - Estudos de dialetologia portuguesa }(1944)^{434} \boldsymbol{\beta}\end{array}$ \\
\hline TESCHAUER, Carlos & $\begin{array}{l}\text { - Poranduba rio-grandense: investigações sobre o idioma } \\
\text { fallado no Brasil e particularmente no Rio Grande do Sul }{ }^{435} \\
\left(1921 \_2^{\mathrm{a}} \mathrm{ed} .\right)^{436} \Sigma\end{array}$ \\
\hline TOTAL & 12 obras \\
\hline
\end{tabular}

\footnotetext{
${ }^{433}$ Neste livro, há três capítulos, um deles é chamado "Dialetologia bandeirante", característica que nos fez incluir esta obra no presente levantamento.

${ }^{434}$ Aborda o falar goiano.

${ }^{435}$ Esta obra aborda apenas aspectos linguístico e tem 81 páginas. Localizamos outra, publicada em 1929, de 468 páginas, em que o subtítulo é extraído, ficando apenas Poranduba riograndense. Nessa, não só aspectos dialetológicos são tratados, mas também outros aspectos culturais do Rio Grande do Sul. Na obra mais ampla, um dos capítulos tem exatamente o mesmo nome que foi atribuído ao subtítulo da obra de 1921.

436 Quando não conseguimos acesso à data da $1^{\text {a }}$ edição, registramos a data/edição mais antiga a que tivermos acesso.
} 
QUADRO 18B - Obras dialetológicas lexicográficas: descrição dialetológica do Português do Brasil

\begin{tabular}{|c|c|}
\hline $\begin{array}{l}\text { ALBUQUERQUE, } \\
\text { Acir }{ }^{437} \text { Tenorio de }\end{array}$ & $\begin{array}{l}\text { - Falsos brasileirismos: argentinismos e americanismos } \\
\text { erradamente apontados como brasileirismos (1942) } \boldsymbol{\beta}\end{array}$ \\
\hline DAISSON, Augusto & - À margem de alguns brasileirismos (1925) $\beta$ \\
\hline $\begin{array}{l}\text { NASCENTES, } \\
\text { Antenor }\end{array}$ & - Tesouro da fraseologia brasileira (1945) $\boldsymbol{\beta}$ \\
\hline SENNA, Nelson de & - A influência do índio na linguagem brasileira $(1947)^{438} \boldsymbol{\beta}$ \\
\hline PEIXOTO, Afrânio & - Brasileirismos (s/d) $[1924]^{439} \boldsymbol{\beta}$ \\
\hline RAIMUNDO, Jacques & $\begin{array}{l}\text { - Vocabulários indígenas de Venezuela: da importância dos } \\
\text { idiomas ameríndios nas relações com o português-brasileiro } \\
\text { (1934) } \boldsymbol{\beta}\end{array}$ \\
\hline RIBEIRO, João & $\begin{array}{l}\text { - Frazes feitas: estudo conjectural de locuções, ditados e } \\
\text { proverbios (1908) } \boldsymbol{\beta} \\
\text { - A lingua nacional (1921) } \boldsymbol{\beta}\end{array}$ \\
\hline SOARES, Macedo ${ }^{440}$ & - Estudos lexicográficos do dialeto brasileiro $(1943)^{441} \boldsymbol{\beta}$ \\
\hline $\begin{array}{c}\text { SOUZA, Bernardino } \\
\text { José de }\end{array}$ & - Dicionário da terra e da gente do Brasil $(1910)^{442} \boldsymbol{\beta}$ \\
\hline
\end{tabular}

\footnotetext{
${ }^{437}$ Há registros também de seu primeiro nome grafado como Arcy.

438 “Conferência proferida pelo professor Nelson de Senna (da Universidade de Minas), a convite do exmo. sr. general Rondon, na sessão de encerramento da "celebração da terceira semana do indio do Brasil", a 30 de abril de 1946, na sede do Conselho Nacional de Proteção aos Índios, na capital federal."; "Separata da publicação ${ }^{\circ}$ 101. Impresso pelo CNPI".

439 Não consta na obra o ano de publicação, mas há a informação de que ela é uma separata da Revista de Filologia Portuguesa, $n^{\circ}$ s 6, 7, 8 e 9. Tais números desta revista foram publicados em 1924.

${ }^{440}$ Antonio Joaquim Macedo Soares.

${ }^{441}$ Nesta obra póstuma, reúnem-se vários textos avulsos publicados pelo autor, no final do século XIX, em diferentes veículos. Como a publicação em livro se deu em 1943, optamos por inclui-la em nosso levantamento. ${ }^{442}$ Este é o título da $4^{\mathrm{a}}$ edição, publicada em 1939 e que permaneceu até edições mais recentes, como a de 2006. Nomenclatura geografica peculiar ao Brasil foi a título dado à $1^{a}$ e à $2^{a}$ edições, respectivamente, de $1910 \mathrm{e}$ 1917. Onomastica geral da geografia brasileira foi o título da $3^{\text {a }}$ edição, em 1927. Como o autor esclarece na Advertencia preliminar, da $4^{\mathrm{a}}$ edição, são “tres nomes diferentes para o mesmo trabalho".
} 


\begin{tabular}{|c|c|}
\hline $\begin{array}{l}\text { TAUNAY, Affonso } \\
\text { D'Escragnolle }\end{array}$ & $\begin{array}{l}\text { - Léxico de lacunas: subsídios para os dicionarios da Lingua } \\
\text { Portugueza (1914) }{ }^{443} \boldsymbol{\beta} \\
\text { - Vocabulario de omissões: collectanea de milheiro e meio de } \\
\text { palavras correntes no Brasil, e em Portugal, não registadas [sic] } \\
\text { na terceira ed. do Novo diccionario da lingua portuguesa do Sr. } \\
\text { Candido de Figueiredo (1924) } \boldsymbol{\Omega} \\
\text { - Reparos ao novo diccionario de Candido de Figueiredo } \\
\text { (1926) } \boldsymbol{\beta} \\
\text { - Inopia scientifica e vocabular dos grandes diccionarios } \\
\text { portuguezes (1932) } \boldsymbol{\beta}\end{array}$ \\
\hline TESCHAUER, Carlos & $\begin{array}{l}\text { - Apostillas ao "Diccionario de vocabulos brasileiros" (I } \\
\text { Serie) (1912) } \boldsymbol{\beta} \\
\text { - Novo vocabulario brasileiro: II'. serie das apostillas ao } \\
\text { diccionario de vocabulos brasileiros (1918) } \boldsymbol{\beta} \\
\text { - Novo vocabulário nacional: III serie (1923) } \boldsymbol{\Omega} \\
\text { - Novo diccionario nacional }(1923)^{444} \boldsymbol{\Sigma}\end{array}$ \\
\hline TOTAL & 18 obras \\
\hline
\end{tabular}

${ }^{443}$ Depois da folha de rosto, aparece o seguinte texto: "LÉXICO DE termos vulgares, correntes no Brazil, sobretudo no Estado de São Paulo, e de accepções de numerosos vocábulos, ainda: não apontados nos grandes diccionarios da língua portugueza".

444 “[em 1928 sai a] 2. ed. (das tres series de vocabulos brasileiros) muito augm. por Carlos Teschauer, S.J”. 
QUADRO 19B - Obras dialetológicas não-lexicográficas: descrição dialetológica do Português do Brasil

\begin{tabular}{|c|c|}
\hline CASTRO, Eugenio de & - Geographia linguística e cultura brasileira (1937) $\beta$ \\
\hline ELIA, Sílvio & - O problema da língua brasileira (1940) $\boldsymbol{\beta}$ \\
\hline JUCÁ (filho), Cândido & $\begin{array}{l}\text { - Língua nacional: as diferenciações entre o português de } \\
\text { Portugal e o do Brasil autorizam a existência de um ramo } \\
\text { dialetal do português peninsular? (1937) } \beta \\
\text { - A pronúncia brasileira (1939) } \boldsymbol{\beta}\end{array}$ \\
\hline LEDA, João & - A chimera da língua brasileira (1939) $\beta$ \\
\hline LEITE, Solidônio & - A Lingua Portuguesa no Brasil (1922) $\boldsymbol{\beta}$ \\
\hline LEMOS, Virgilio de & - A Lingua Portuguesa no Brasil (1916) $\beta$ \\
\hline $\begin{array}{l}\text { LOPES, Domingos de } \\
\text { Castro }^{445}\end{array}$ & - A língua brazileira $(1935)^{446} \boldsymbol{\beta}$ \\
\hline MARQUES, Xavier & - Cultura da lingua nacional (1933) $\beta$ \\
\hline $\begin{array}{l}\text { MARTINS, Maria de } \\
\text { Lourdes de Paula }\end{array}$ & $\begin{array}{l}\text { - A influência indígena no Português do Brasil: estudo do } \\
\text { vocabulário (1944) (T) } \boldsymbol{\beta}\end{array}$ \\
\hline $\begin{array}{l}\text { MELO, Gladstone } \\
\text { Chaves de }\end{array}$ & - Língua do Brasil $(1946)^{447} \boldsymbol{\beta}$ \\
\hline MENDONÇA, Renato & $\begin{array}{l}\text { - A influência africana no Português do Brasil (1933) } \boldsymbol{\beta} \\
\text { - O Português do Brasil: origens, evoluções, tendências } \\
\text { (1936) } \boldsymbol{\beta}\end{array}$ \\
\hline MONTEIRO, Clóvis & - Da influência do Tupi no Português (1926) $(\mathrm{T})^{448} \boldsymbol{\beta}$ \\
\hline
\end{tabular}

\footnotetext{
445 O autor em questão é filho de Castro Lopes.

446 Publicação póstuma.

447 O ano de edição do livro é 1946, porém destaca o autor - no prefácio à obra datado de 25/1/1945 - que os dois primeiros capítulos foram escritos anteriormente a essas datas: o primeiro, em 1942 e o segundo acabou por não ser publicado na época, o sendo apenas em 1946.

448 Da tendência na evolução de nosso idioma (1926) e Da influência do Tupi no Português (1926) apresentados inicialmente como teses - são reunidos e publicados como livro, em 1931, sob o título Português da Europa e Português da América: aspectos da evolução do nosso idioma.
} 


\begin{tabular}{|c|c|}
\hline MOTTA, João ${ }^{449}$ & - O Portuguez falado no Brazil (1905) $\beta$ \\
\hline NEIVA, Arthur & - Estudos de lingua nacional (1940) $\boldsymbol{\beta}$ \\
\hline PÁDUA, Ciro T. de & $\begin{array}{l}\text { - O dialeto brasileiro: ensaio de filologia e sociologia sobre a } \\
\text { língua falada no Brasil (1942) } \boldsymbol{\beta}\end{array}$ \\
\hline $\begin{array}{l}\text { PEREIRA, Altamirano } \\
\text { Nunes }\end{array}$ & $\begin{array}{l}\text { - Breves considerações a propósito da língua brasileira } \\
\text { (1946) } \boldsymbol{\beta}\end{array}$ \\
\hline RAIMUNDO, Jacques & $\begin{array}{l}\text { - O elemento afro-negro na Lingua Portuguesa (1933) } \boldsymbol{\beta} \\
\text { - O negro brasileiro e outros escritos (1936) } \Sigma \\
\text { - A Lingua Portuguesa no Brasil: expansão, penetração, } \\
\text { unidade e estado atual (1941) } \boldsymbol{\beta} \\
\text { - Guinêanos e sudanenses: etnologia e linguagem (s/d) }{ }^{450} \boldsymbol{\Omega}\end{array}$ \\
\hline RIBEIRO, João & - O elemento negro: historia, folklore, linguística (1939) $\boldsymbol{\beta}$ \\
\hline SANCHES, Edgard & - Lingua brasileira (1940) $\boldsymbol{\beta}$ \\
\hline SENNA, Nelson de & $\begin{array}{l}\text { - Os africanos no Brasil: estudos sobre os negros africanos e } \\
\text { influencias afro-negras sobre a linguagem e costumes do povo } \\
\text { (1938) } \boldsymbol{\beta} \\
\text { - A influência do índio na linguagem brasileira }(1947)^{451} \boldsymbol{\beta}\end{array}$ \\
\hline $\begin{array}{l}\text { SILVA NETO, Serafim } \\
\text { da }\end{array}$ & $\begin{array}{l}\text { - Capítulos de história da Língua Portuguesa no Brasil } \\
\text { (1946) } \boldsymbol{\beta} \\
\text { - Diferenciação e unificação do Português do Brasil (1946) } \\
\boldsymbol{\beta}\end{array}$ \\
\hline VIANNA FILHO, Luiz & - A lingua do Brasil (1936) $\boldsymbol{\beta}$ \\
\hline TOTAL & 29 obras \\
\hline
\end{tabular}

${ }^{449}$ João Nepomuceno Nogueira da Motta.

${ }^{450} \mathrm{Na}$ relação de obras do autor, presente no $\mathbf{O}$ negro brasileiro e outros escritos (1936) há menção à referida obra, sem, no entanto, informar sua data de publicação, dizendo apenas que ela ocorrerá em breve. Nessa mesma obra, o autor afirma que Guinêanos e sudanenses "é um trabalhinho suplementar ao nosso $\mathbf{O}$ elemento afronegro na lingua portuguesa (Rio,1933)" (RAIMUNDO, 1936, p.34)

451 "Conferência proferida pelo professor Nelson de Senna (da Universidade de Minas), a convite do exmo. sr. general Rondon, na sessão de encerramento da "celebração da terceira semana do indio do Brasil", a 30 de abril de 1946, na sede do Conselho Nacional de Proteção aos Índios, na capital federal."; "Separata da publicação no 101. Impresso pelo CNPI". 
ANEXO A

Este anexo contém os programas de ensino de Português entre 1887 e 1942 e está assim estruturado:

ANEXO A1 - Programa de Fausto Barreto - 1887

ANEXO A2 - Programa de ensino do Colégio Pedro II - Português - 1898

ANEXO A3 - Programa de ensino do Colégio Pedro II - Português - 1912

ANEXO A4 - Programa de ensino do Colégio Pedro II - Português - 1915 e 1916

ANEXO A5 - Programa de ensino do Colégio Pedro II - Português - 1917

ANEXO A6 - Programa de ensino do Colégio Pedro II - Português - 1926

ANEXO A7 - Programas de ensino do Colégio Pedro II - Português - 1928, 1929 e 1930

ANEXO A8 - Programa de ensino do Ministério da Educação e Saúde Pública - Português 1931

ANEXO A9 - Programa de ensino do Ministério da Educação e Saúde - Português - 1942 ANEXO A10 - Instruções metodológicas para execução do programa de Português - 1942 
ANEXO A1 - PROGRAMA DE FAUSTO BARRETO - 1887

Organizado de conformidade com as disposições do decreto $\mathrm{n}^{\circ} 9649$ de 2 de Outubro de 1886, e do aviso $\mathrm{n}^{\circ} 974$ de 17 de Março de 1887 baixou um programma para os exames geraes de preparatorios em todo o imperio.

É esta a sua primeira disposição - "O exame de Portuguez precederá a qualquer outro."

\section{Prova escripta}

A prova escripta consistirá em uma composição livre sobre assumpto que a sorte designar dentre os pontos organizados diariamente pela commissão julgadora.

\section{Prova oral}

A prova oral constará: $1^{\circ}$, de analyse phonetica, etymologica e syntaxica de um trecho de extensão razoavel, escolhido pela commissão julgadora em uma pagina sorteada, na forma do regulamento vigente, de um dos livros abaixo indicados; $2^{\circ}$, da exposição de um dos pontos grammaticaes seguintes, tambem sorteados na forma das disposições regulamentares.

Sortear-se-á em cada dia um dos livros marcados no programma, bem como a centena de paginas, da qual se sorteará tambem a pagina em que cada alumno deverá ser examinado, escolhendo nella os examinadores o trecho para esse fim." Art. 39 do decreto n. 6.130 de $1^{\circ}$ de Março de 1876.

\section{Livros de exame}

Camões, Lusiadas, seculo XVI.

Lucena, Historia do padre Francisco Xavier, idem.

Fr. Luiz de Souza, A vida do Arcebispo, seculo XVII.

Gabriel de Castro, A Ulysséa, idem.

Santa Rita Durão, O Caramurú, seculo XVIII.

Padre Theodoro de Almeida, O Feliz Independente, idem.

João Francisco Lisboa, Vida do Padre Antonio Vieira, seculo XIX.

Barão de Paranapiacaba, A Camoneana, idem.

Indicação. - Por occasião da analyse, o examinando tambem deverá ser arguido sobre o sentido preciso de cada palavra do trecho sorteado, e sobre o sentido geral do mesmo trecho. Um dos examinadores se occupará desta parte do exame, e o outro das theorias grammaticaes.

\section{Pontos oraes}

1. - Observações geraes sobre o que se entende por grammatica geral, por grammatica historica ou comparativa e por grammatica descriptiva ou expositiva. 
Objecto da grammatica portugueza e divisão do seu estudo. Phonologia: os sons e as lettras; classificação dos sons e das lettras; vogaes; grupos vocalicos; consoantes; grupos consonantaes; syllaba; grupos syllabicos; vocabulos; notações lexicas.

2. - Da accentuação e da quantidade.

3. - Origem das lettras portuguezas; leis que presidem á permuta das lettras; importancia destas transformações phonicas no processo de derivação das palavras.

4. - Dos Metaplasmas.

5. - Dos systemas de ortographia e das causas de sua irregularidade.

6. - Morphologia: estructura da palavra; raiz; thema; terminação; affixos. Do sentido das palavras deduzido dos elementos morphicos que as constituem; desenvolvimento de sentidos novos nas palavras.

7. - Da classificação das palavras. Do substantivo e suas especies.

8. - Da classificação das palavras. Do adjectivo e suas especies.

9. - Classificação das palavras. Do pronome e suas especies.

10. - Classificação das palavras. Do verbo e suas especies.

11. - Classificação das palavras. Das palavras invariaveis.

12. - Agrupamentos de palavras por familias e por associação de idéias. Dos synonimos, homonymos e paronymos.

13. - Flexão dos nomes: genero; numero; caso. Noções de declinação latina. Desapparecimento do neutro latino em Portuguez; vestigios de neutro em Portuguez; vestigios da declinação em Portuguez. Origem do s do plural.

14. - Flexão dos nomes: grau do substantivo e do adjectivo; comparativos e superlativos syntheticos; comparativos e superlativos analyticos.

15. - Flexão dos nomes; flexão do pronome; declinação dos pronomes pessoaes.

16. - Flexão do verbo; conjugação; fórmas de conjugação.

17. - Formação das palavras em geral: composição por prefixos e por juxtaposição. Estudos dos prefixos.

18. - Formação das palavras em geral: derivação propria (por suffixos); derivação impropria (sem suffixos). Estudos dos suffixos.

19. - Das palavras variaveis formadas no proprio seio da lingua portugueza.

20. - Das palavras invariaveis formadas no proprio seio da lingua portugueza.

21. - Etymologia portugueza; principios em que se baseia a etymologia. Leis que presidiram á formação do lexico portuguez.

22. - Da constituição do lexico portuguez. Linguas que maior contingente forneceram ao vocabulario portuguez.

23. - Caracter differencial entre os vocabulos de origem popular e os de formação erudita; duplas ou formas divergentes. 
24. - Da creação de palavras novas. Hybridismos. nomes.

25. - Etymologia do substantivo e do adjectivo. Influencia dos casos na etymologia dos

26. - Etymologia do artigo e do pronome.

27. - Etymologia das formas verbaes; comparação da conjugação latina com a portugueza.

28. - Etymologia das palavras invariaveis.

29. - Da syntaxe em geral. Breves noções sobre a estructura oracional, do Latim popular e do Latim culto. Typos syntaxicos divergentes na lingua portugueza.

30. - Syntaxe da proposição simples. Especies de proposição simples quanto á fórma e á significação. Dos membros da proposição simples.

31. - Syntaxe da proposição composta ou do periodo composto. Coordenação. Subordinação. Classificação das proposições.

32. - Regras de syntaxe relativas a cada um dos termos ou membros da composição.

33. - Regras de syntaxe relativas ao substantivo e ao adjectivo.

34. Regras de syntaxe relativas ao pronome.

35. - Regras de syntaxe relativas ao verbo. Do emprego dos modos e tempos, correspondencia dos tempos dos verbos nas proposições coordenadas e nas proposições subordinadas.

36. - Regras de syntaxe relativas ás fórmas nominaes do verbo.

37. - Regras de syntaxe relativas ás palavras invariaveis.

38. - Syntaxe do verbo haver e do pronome se.

39. Da construcção: ordens das palavras na proposição simples e das proposições simples no periodo composto.

40. - Da collocação dos pronomes pessoaes.

41. - Das notações syntaxicas; pontuação; emprego de lettras maiusculas.

42. - Figuras de syntaxe. Particulas de realce.

43. - Dos vicios de linguagem.

44. - Das anomalias grammaticaes; idiotismos; provincialismos; brasileirismos e dialecto.

45. - Das alterações lexicas e syntaxicas; archaismo e neologismo.

46. - A syntaxe e o estylo.

[In: RIBEIRO, Julio. Procellarias. São Paulo: Edições Cultura Brasileira, [1935?]. p. 85-92.] 


\section{ANEXO A2 - Programa de ensino do Colégio Pedro II - Português - 1898}

\section{$1^{\circ}$ ANO}

\section{Português [Curso Realista e Curso Clássico]}

- Leitura e recitação de trechos de prosadores e poetas brasileiros e portugueses do século atual; explicação do sentido preciso de cada palavra, de cada oração e de cada período.

- Exercícios ortográficos sob ditado de palavras que designem objetos conhecidos dos alunos; de períodos curtos sobre noções usuais, e de provérbios, máximas, sentenças e pensamentos morais.

- Gramática: explicação pelo processo intuitivo das regras mais elementares, análise léxica e sintática de período simples.

- Composição: exercícios fraseológicos, tendo por fim ensinar o aluno a completar e a construir períodos simples sobre assuntos a seu alcance: breves narrações seguidas de perguntas a que terão os alunos de responder de viva voz e por escrito.

\section{Livros:}

Elementos da gramática portuguesa, por Felisberto de Carvalho, (14 edição) e Exercícios de língua portuguesa, correspondentes à Gramática elementar, ( $4^{\mathrm{a}}$ edição) pelo mesmo autor.

Antologia Nacional, por Fausto Barreto e Carlos de Laet.

Autores Contemporâneos, por João Ribeiro.

\section{$2^{\circ}$ ANO}

\section{Português [Curso Realista e Curso Clássico]}

- Leitura e recitação de trechos de prosadores e poetas brasileiros e portugueses do século atual; explicação do sentido preciso de cada período e de cada parágrafo.

- Exercícios ortográficos sob ditado de trechos de prosa e verso para aplicação das regras dos acentos lexicológicos.

- Gramática: revisão das matérias estudadas do ano anterior com desenvolvimento da fonologia; análise sintática e fonética de períodos compostos.

- Composição: exercícios fraseológicos tendo por fim ensinar o aluno a completar e a construir períodos compostos sobre assuntos a seu alcance; breves narrações e descrições, que terão os alunos de redigir oralmente e por escrito, conforme o subsídio que o lente lhes proporcionar.

Livros:

Gramática portuguesa, pelo Dr. Alfredo Gomes, $7^{a}$ edição. 
Antologia Nacional, por Fausto Barreto e Carlos de Laet.

Autores contemporâneos, por João Ribeiro.

\section{$3^{\circ}$ ANO}

\section{Português [Curso Realista e Curso Clássico]}

- Leitura e recitação de trechos de prosadores e poetas brasileiros e portugueses do século XVIII; explicação do sentido geral de todo o trecho lido ou recitado.

- Exercícios ortográficos sob ditado em que entrem homônimos e parônimos.

- Gramática: revisão das doutrinas aprendidas no ano anterior com desenvolvimento da morfologia; noções de etimologia portuguesa, exercícios de composição e derivação de palavras sobre vocábulos de formação popular e de origem erudita; análise sintática e etimológica.

- Composição: exercícios de redução de prosa literária à linguagem comum, de verso à prosa literária ou vulgar e de mudança de estrutura de orações e períodos, breves narrações, descrição e cartas conforme o subsídio que prestar o lente.

\section{$\underline{\text { Livros: }}$}

Gramática portuguesa, pelo Dr. Alfredo Gomes, $7^{\text {a }}$ edição.

Antologia Nacional, por Fausto Barreto e Carlos de Laet.

Seleta Nacional por Francisco Júlio de Caldas Aulete, $3^{\text {a }}$ parte, edição por Tomáz de Carvalho.

\section{$4^{\circ}$ ANO}

\section{Português [Curso Realista e Curso Clássico]}

- Leitura e recitação de trechos de prosadores e poetas brasileiros e portugueses do século XVII; exposição do conteúdo de cada trecho por outras palavras.

- Exercícios ortográficos sob ditado para aplicação das regras de pontuação.

- Gramática: revisão das doutrinas estudadas no ano anterior, com desenvolvimento da sintaxe. Exercícios de agrupamento de palavras por famílias e de composição e derivação das mesmas; análise sintática e etimológica.

- Composição: exercícios fraseológicos para emprego de expressões no sentido material e figurado; breves narrações, descrições e cartas, bem como escritos de uso comum conforme o auxílio que ministrar o lente.

$\underline{\text { Livros: }}$

Gramática portuguesa, pelo Dr. Alfredo Gomes, $7^{\text {a }}$ edição.

Antologia Nacional, por Fausto Barreto e Carlos de Laet. 
Seleta Nacional, por Francisco Júlio de Caldas Aulete, 1ªparte, edição por Tomáz de Carvalho.

\section{$5^{\circ}$ ANO}

\section{Português [Curso Realista e Curso Clássico]}

- Leitura e recitação de trechos de prosadores e poetas brasileiros e portugueses do século XVI; exposição do conteúdo de cada trecho por outras palavras.

- Exercícios ortográficos sob ditado para aplicação das regras de pontuação.

- Gramática: revisão das matérias aprendidas no ano anterior; particularidades de construção, idiotismos; vícios de linguagem; arcaísmos; hibridismos; neologismos; provincialismos; brasileirismos; exercícios de agrupamento de palavras por família e por associação de ideias, análise sintática e etimológica.

- Composição: exercícios fraseológicos pelos alunos, com pureza, propriedade e precisão de dicção, redação de escritos de uso comum sem subsídio ministrado pelo lente, mas sobre assunto que este indicar, imitação de narrações, descrições e cartas, modelos em seu gênero, à escolha do lente.

Livros:

Gramática Portuguesa, por M. Pacheco da Silva Júnior e Lameira de Andrade (2 edição).

Antologia Nacional, por Fausto Barreto e Carlos de Laet.

Antologia Portuguesa, por Teófilo Braga.

\section{$6^{\circ}$ ANO}

\section{Português [Curso Realista e Curso Clássico]}

- Revisão das matérias aprendidas no ano anterior.

- Breves noções sobre história da língua portuguesa.

- Idades da língua portuguesa. Apreciação dos principais monumentos da língua, clássicos ou contemporâneos.

- O lente exercitará os alunos na conversão de trechos de português antigo em trechos de português moderno.

- Exercícios de composição da lavra própria dos alunos, mas sobre assunto designado pelo respectivo lente; paralelos de escritores de nota; análise do estilo de poetas e prosadores importantes e biografias dos grandes patriotas.

Livros:

Os mesmos do $5^{\mathrm{o}}$ ano.

\section{$7^{\circ}$ ANO}


História da Literatura Geral e da Nacional [só para o Curso Clássico]

[Os tópicos gramaticais eram estudados até o $6^{\circ}$ ano. O conteúdo do $7^{\circ}$ ano é constituído apenas por tópicos literários. Como esse tema foge dos objetivos da presente tese, não apresentaremos aqui os 33 pontos que formam o programa desse ano.]

[In: Programas provisórios do Ginásio Nacional para o ensino no ano letivo de 1898: organizados de acordo com o Regulamento n. 2.858 de 30 de março de 1898. Rio de Janeiro: Imprensa Nacional, 1898 apud RAZZINI, 2000, p. 321-324]. 


\section{ANEXO A3 - Programa de ensino do Colégio Pedro II - Português - 1912}

\section{$1^{a}$ Série (3 horas)}

- Leitura e recitação de trechos de prosadores e poetas brasileiros e portugueses do século XIX, explicação do sentido preciso de cada palavra, de cada oração e de cada período.

- Exercícios ortográficos sob ditado de trechos de prosa e verso para a aplicação das regras dos acentos lexicológicos.

GRAMÁTICA EXPOSITIVA: explicação, pelo processo intuitivo, das regras essenciais; análise léxica e sintática.

- Apreciação de trechos em que entrem provérbios, máximas e sentenças morais.

COMPOSIÇÃO: exercícios fraseológicos tendo por fim ensinar o aluno a completar e construir períodos sobre assuntos a seu alcance; breves narrações e descrições, que terão os alunos de redigir oralmente e por escrito, conforme o subsídio que o lente lhes proporcionar.

\section{$2^{a}$ Série (2 horas)}

Leitura e recitação de trechos de prosadores e poetas brasileiros e portugueses do século XVIII, explicação do geral de todo o trecho lido ou recitado.

Exercícios ortográficos sob ditado em que entrem homônimos e parônimos.

GRAMÁTICA EXPOSITIVA: revisão das doutrinas aprendidas no ano anterior com desenvolvimento da fonologia e da morfologia; exercício de composição e derivação de palavras; análise léxica e sintática.

COMPOSIÇÃO: exercícios de redução de prosa literária a linguagem comum, de verso a prosa literária ou vulgar, e de mudança de estrutura de orações e período; exercícios fraseológicos para emprego de expressões no sentido próprio e no figurado; breves narrações, descrições, bem como escritos de uso comum, conforme o auxílio ministrado pelo lente.

\section{$3^{\text {a }}$ Série (3 horas)}

- Leitura e recitação de trechos de prosadores e poetas dos séculos XVII e XVI: exposição do conteúdo de cada trecho por outras palavras.

- Exercícios ortográficos sob ditado para aplicação das regras de pontuação.

GRAMÁTICA EXPOSITIVA: revisão das matérias aprendidas no ano anterior com desenvolvimento da sintaxe; particularidades de construção; idiotismo; vício de linguagem; arcaísmo; neologismo: provincialismo; brasileirismo; exercícios de agrupamento de palavras por família e por associação de idéias; análise léxica e sintática. 
COMPOSIÇÃO: exercícios fraseológicos, pelos alunos, com pureza, propriedade e precisão da dicção; exercícios de redação de escritos sobre assunto de ordem literária anteriormente explicado pelo lente.

\section{$4^{\mathrm{a}}$ Série (3 horas)}

1 - Revisão das matérias estudadas na $3^{\mathrm{a}}$ série de português.

2 - Observação sobre o que entende por gramática expositiva, gramática histórica, gramática geral, glotologia, filologia e literatura.

3 - Gramática histórica da língua portuguesa e divisão do seu estudo.

4 - Do vocalismo e do consonantismo. Modificações acidentais do sistema fonético.

5 - Apreciação dos sistemas gráficos.

6 - Da estrutura e do sentido das palavras; das mudanças de sentido.

7 - Estudo comparado das categorias gramaticais.

8 - Princípios em que se baseia a etimologia.

9 - Etimologia das palavras variáveis e das invariáveis.

10 - Elementos de composição e de derivação.

11 - Constituição do léxico português. Formas divergentes.

12 - Estudo comparado geral da sintaxe latina e portuguesa.

13 - Sintaxe histórica das palavras variáveis e das invariáveis. Estrutura oracional românica, especialmente da língua portuguesa.

14 - Alterações mórficas e sintáticas.

15 - Anomalias gramaticais. Dialetos.

16 - O português falado no Brasil.

17 - História da língua portuguesa.

18 - Teoria da composição literária.

19 - Apreciação das principais épocas das literaturas portuguesa e brasileira.

\section{PARTE PRÁTICA}

O lente exercitará os alunos na conversão de trechos de português antigo em trechos de português moderno. Noções práticas elementares da declinação e da conjugação latinas. Análise sintática, etimológica e literária de escritores de nota, assim portugueses como brasileiros. Exercícios de composição de lavra própria dos alunos, mas sobre assunto designado pelo professor. Apreciação do estilo de poetas e prosadores importantes e biografia dos grandes patriotas.

[In: Programas de Ensino do Colégio Pedro II: para o ano de 1912. Rio de Janeiro: Empresa Fotomecânica do Brasil, 1912 apud RAZZINI, 2000, p. 325-326]. 


\section{ANEXO A4 - Programa de ensino do Colégio Pedro II - Português - 1915 e 1916}

$\mathbf{1}^{\circ}$ ANO (3 horas) [idem a 1912]

\section{$2^{\circ}$ ANO (3 horas)}

- Leitura e recitação de trechos de prosadores e poetas brasileiros e portugueses do século XVI, XVII e XVIII; explicação do sentido geral de todo o trecho lido ou recitado.

- Exercícios ortográficos sob ditado em que entrem homônimos e parônimos e para aplicação das regras de pontuação.

- GRAMÁTICA EXPOSITIVA: revisão das doutrinas aprendidas no ano anterior com desenvolvimento da fonologia e morfologia; exercício de composição e derivação de palavras; análise léxica e sintática, particularidades de construção; idiotismo; vício de linguagem; arcaísmo, neologismo; provincialismo; exercícios de agrupamento de palavras por família e associação de ideias.

- COMPOSIÇÃO: exercícios de redução de prosa literária a linguagem comum, de verso e prosa literária ou vulgar, e de mudança de estrutura de orações e períodos; exercícios fraseológicos para emprego de expressões no sentido próprio e figurado; breves narrações, descrições, bem como escritos de uso comum, conforme o auxílio ministrado pelo lente; exercícios fraseológicos, pelos alunos, com pureza, propriedade e precisão de dicção; exercícios de redação de escritos sobre assunto de ordem literária anteriormente explicado pelo lente.

\section{$3^{\circ}$ ANO (3 horas)}

$1^{\mathrm{a}}$ lição - Revisão das matérias estudadas na $3^{\mathrm{a}}$ série de português.

$2^{\mathrm{a}}$ lição - Observação sobre o que entende por gramática expositiva, gramática histórica, gramática geral, glotológica, filologia e literatura.

$3^{\mathrm{a}}$ lição - Gramática histórica da língua portuguesa e divisão do seu estudo.

$4^{a}$ lição - Do vocalismo e do consonantismo. Modificações acidentais do sistema fonético.

$5^{\mathrm{a}}$ lição - Apreciação dos sistemas gráficos.

$6^{\text {a }}$ lição - Da estrutura do sentido das palavras; das mudanças de sentido.

$7^{a}$ lição - Estudo comparado das categorias gramaticais.

$8^{a}$ lição - Princípios em que se baseia a etimologia.

$9^{a}$ lição - Etimologia das palavras variáveis e invariáveis.

$10^{\mathrm{a}}$ lição - Elementos de composição e de derivação.

$11^{a}$ lição - Constituição do léxico português. Formas divergentes.

$12^{\mathrm{a}}$ lição - Estudo comparado geral da sintaxe latina e portuguesa.

$13^{a}$ lição - Sintaxe histórica das palavras variáveis e das invariáveis. Estrutura oracional românica, especialmente, da língua portuguesa.

$14^{\mathrm{a}}$ lição - Alterações mórficas e sintáticas.

$15^{\mathrm{a}}$ lição - Anomalias gramaticais. Dialetos.

$16^{\mathrm{a}}$ lição - O português falado no Brasil. 
$17^{a}$ lição - História da língua portuguesa.

$18^{\text {a }}$ lição - Teoria da composição literária.

$19^{a}$ lição - Apreciação das principais épocas das literaturas portuguesa e brasileira.

\section{PARTE PRÁTICA}

O lente exercitará os alunos na conversação de trechos de português antigo em trechos de português moderno. Análise sintática, etimológica e literária de escritores de nota, assim portugueses como brasileiros. Exercícios de composição de lavra própria dos alunos, mas sobre assunto designado pelo professor. Apreciação do estilo de poetas e prosadores importantes e biografia dos grandes patriotas.

1916

$\mathbf{1}^{\circ}$ ANO [idem a 1915]

$\mathbf{2}^{\circ}$ ANO [idem a 1915]

$3^{\circ}$ ANO [idem a 1915]

[In: Programas de Ensino do Colégio Pedro II: para o ano de 1912. Rio de Janeiro: Empresa Fotomecânica do Brasil, 1912 apud RAZZINI, 2000, p. 325-326].

[In: Programas de Ensino do Colégio Pedro II: para o ano de 1916. Rio de Janeiro: Empresa Revista dos Tribunais, 1916 apud RAZZINI, 2000, p. 325-326]. 


\section{ANEXO A5 - Programa de ensino do Colégio Pedro II - Português - 1917}

\section{$\mathbf{1}^{\circ}$ ano (Três horas por semana)}

- Leitura e recitação de trechos de prosadores e poetas contemporâneos, com a explicação do sentido.

- Exercícios ortográficos sob ditado.

- Gramática expositiva: princípios e regras essenciais, que deverão ser ensinados mais sobre trechos escritos e analisados no quadro preto do que pela recitação decorada de algum compêndio.

\section{$2^{\circ}$ ano}

- Leitura e recitações de trechos de prosadores e poetas, preferidamente clássicos. Terá também cabida a notícia biobibliográfica de cada autor.

- Exercícios ortográficos, também versando sobre pontuação.

- Composição: exercícios gradualmente mais complexos e difíceis, sendo preferidas as descrições em que os alunos possam entrar com elementos da sua observação pessoal; e as narrativas, de sucessos históricos e de que se tirem lições morais.

- Gramática expositiva: desenvolvimento das noções ministradas no ano anterior. Exercícios reputados de análise lógica e sintática.

\section{$3^{\circ}$ ano}

- Composição: exercícios em que gradualmente se exijam, não somente correção gramatical, mas algumas qualidades estilísticas.

- Gramática expositiva: revisão geral.

- Gramática histórica:

1. Distinção entre gramática expositiva, histórica, comparada; glotologia, filologia, literatura.

2. História resumida da língua portuguesa.

3. Estudo sumário das leis fonéticas observadas na transição do latim ao português.

4. Alterações morfológicas: - obliteração dos casos; supressão do gênero neutro; graduação dos substantivos e adjetivos; modificações no quadro das conjugações, formação dos futuros e condicionais românicos; voz passiva.

5. Elementos formadores do léxico português.

6. Processos formativos de palavras. Estudo de prefixos e sufixos.

7. Etimologia. Formas convergentes e divergentes.

8. Mudanças que as alterações morfológicas introduziram na sintaxe e no estilo do idioma.

9. Anomalias gramaticais mais em uso no Brasil e em Portugal. Erros pronúncia. Erros morfológicos. Erros sintáticos. Exercícios para a sua devida correção.

10. Noções sobre as principais fases literárias. (Não sendo possível, pela escassez do tempo letivo, fazer um verdadeiro curso de literatura nacional, o professor dirá o essencial sobre alguns dos escritores típicos de cada época literária, tanto em Portugal como no Brasil). 
Observação - O programa de gramática histórica, reduzido ao indispensável, pressupõe noções, ainda que elementares, da língua latina, e deve ser exigido não só nos exames finais do Colégio como nos parcelados.

Rio de Janeiro, 2 de março de 1917.

Carlos M. P. de Laet.

Silva Ramos.

[In: Programas de Ensino do Colégio Pedro II: para o ano de 1917. Rio de Janeiro: Tipografia Rev. dos Tribunais, 1917 apud RAZZINI, 2000, p. 327-328]. 


\section{ANEXO A6 - Programa de ensino do Colégio Pedro II - Português - 1926}

\section{$1^{\circ} \mathrm{ANO}$}

I - Como se exprimem os animais, suas vozes (vocabulário). Como fala o homem: palavras, gestos, sinais. Linguagem e línguas. A língua portuguesa e suas parentas (mostrar no mapa, elementarmente, onde se fala o francês, o provençal, o espanhol, o italiano, o romeno e escrever na lousa palavras e frases em cada uma dessas línguas).

II - Por que falamos o português; distribuição do português (com indicações no mapa). Nossa língua não foi sempre o que é hoje (leitura de versos do Crisfal , explicando a época e o autor; depois uma canção tirada de um cancioneiro).

III - Não basta falar e escrever corretamente; cumpre escrever bem. Que é gramática; o auxílio que nos presta na correção da linguagem. Divisão da Gramática.

IV - Que é escrever bem. Descrever, narrar, dissertar. Espécies de descrição. Qualidades do escritor.

V - Leitura. Requisitos de uma boa leitura. Pronúncia correta. Perfeita emissão das vozes e perfeita articulação das consonâncias. Timbre. Classificação das vogais quanto ao timbre.

VI - Diversos timbres do a, do e e do o. Casos duvidosos. Pronúncia do u depois de g e do q. Ditongos ai, ei, oi. Hiatos ea, eo, ia, io, ua. Mudanças s de timbre nos nomes e nos verbos.

VII - Articulação do b, do c, do d, do $\mathbf{q}$, do $\mathbf{l}$, do $\mathbf{m}$, do $\mathbf{n}$, do $\mathbf{r}$, do $\mathbf{s}$ e do $\mathbf{x}$. Pronúncia de consoantes dobradas. Pronúncia dos grupos consonânticos.

VIII - Ligação de palavras na frase. Vícios de pronúncia e sua correção.

IX - Acentuação. Palavras átonas, monótonas, dítonas, trítonas, oxítonas, paroxítonas e proparoxítonas. Palavras de acentuação duvidosa (exemplos mais comuns). Enclíticas e proclíticas. Mudanças de acentuação nos nomes e nos verbos.

$\mathrm{X}$ - Grafia. Letras; sinais diacríticos.

XI - Taxionomia. Funções lógicas: subjetiva, objetiva, predicativa, adjetiva, adverbial e interjectiva. Partículas acessórias. (Aqui o professor começará os exercícios gradativos muito elementares de análise lógica).

XII - Classificação das palavras segundo suas funções lógicas; o nome, o modificativo, o conectivo, as partículas.

XIII - Classificação de substantivos. Coletivos especiais e numéricos (vocabulário).

XIV - Classificação dos adjetivos, pronomes e advérbios.

XV - Preposição. Estudo prático e reiterado das relações indicadas pelas preposições. Demonstração prática da importância desse estudo para a análise lógica.

XVI - Conjunção. Estudo prático e reiterado de cada classe e de cada conjunção com exercícios. Importância desse estudo na análise lógica.

XVII - Revisão da conjunção regular; tempos compostos, voz passiva.

XVIII - Verbos pronominados (com os pronomes me, te, se, nos, vos, enclíticos; com pronomes $\mathbf{o}, \mathbf{a}, \mathbf{a s}, \mathbf{a s}$, enclíticos).

XIX - Verbos irregulares da la conjugação: dar e estar com os seus compostos e cognatos.

XX - Verbo da $\mathrm{l}^{\mathrm{a}}$ conjugação, cujo tema termina em e (ex.: passear) e em i (ex.: afiar, odiar, premiar).

XXI - Verbos moscar-se, apiedar-se; verbos cujo tema termina em o ou u (ex.: magoar, obliquar). Verbos de conjugação viciada (ex.: vexar, repugnar, endeusar, etc.) 
XXII - Verbos irregulares da $2^{\text {a }}$ conjugação cuja vogal da penúltima sílaba é e ou o (ex.: ceder, correr). O verbo pôr, sua inclusão na $2^{\text {a }}$ conjugação (ao lado de doer, moer, roer, soer); suas irregularidades.

XXIII - Verbos caber e saber; haver e reaver.

XXIV - Verbos ser e ter (com seus compostos).

XXV - Verbo ver e compostos (particularidade de prover).

XXVI - Verbos dizer, fazer, trazer com seus compostos; jazer e aprazer com seus compostos. XXVII - Verbos querer e compostos; crer e ler, valer, poder.

XXVIII - Verbos da $2^{a}$ conjugação vulgarmente errados (precaver-se, etc.)

XXIX - Verbos irregulares da $3^{\text {a }}$ conjugação, cuja vogal da penúltima sílaba é e ou o (duas classes; ex.:ferir, agredir); os de vogal u (ex.: fugir); os de vogal a (ex.: sair).

$\mathrm{XXX}$ - Verbos ir, vir e compostos.

XXXI - Verbos medir, pedir, impedir, expedir, despedir.

XXXII - Verbos abundantes e defectivos. Particípios duplos. Particularidades gráficas de certos verbos.

XXXIII - Campenomia. Noção de flexão. Classificação das flexões.

XXXIV - Formação do feminino: por flexão, significação, acepção, heteronímia. Femininos difíceis. Casos duvidosos. Feminino dos adjetivos.

XXXV - Formação do plural; plurais dos compostos; nomes sem plural; outras particularidades (plurais dos nomes em ão, etc.). Plural dos adjetivos.

XXXVI - Formação dos graus. Aumentativos e diminutivos difíceis. Graus dos adjetivos. Comparativos e superlativos difíceis.

XXXVII - Formação dos tempos.

XXXVIII - Significação dos modos e tempos.

XXXIX - Adjetivos pátrios difíceis. Adjetivos de matéria (vocabulário). Adjetivos referentes a animais (vocabulário).

XL - Adjetivos numerais. Exercícios sobre ordinais.

Constará a parte prática de leitura, vocabulário, noções e regras de estilo, exercícios de redação e correção de textos errados.

\section{Livros Indicados:}

Carlos de Laet: Antologia Nacional.

Antenor Nascentes: Análise gramatical e lógica.

$O$ idioma nacional. $1^{\circ}$ vol.

José Oiticica: Manual de análise.

Otelo Reis: Verbos.

Guia umas dificuldades da análise léxica. e

Textos para corrigir.

Said Ali: Gramática elementar.

\section{$2^{\circ}$ ANO}

(O fim essencial deste ano é consolidar a matéria do $1^{\circ}$ ano e preparar os alunos para o estudo de gramática superior do $3^{\circ}$ ano. Ao critério do professor ficará o número de aulas consagradas à revisão de cada matéria).

I - Revisão dos dois primeiros pontos do programa do $1^{\circ}$ ano. (A revisão se fará por meio de sabatinas orais e escritas). 
II - Estudo completo da fonologia em revisão dos pontos IV e $\mathrm{V}$ do $1^{\circ}$ ano.

III - Estudo completo dos encontros vocálicos e consonantais.

IV - Noções de métrica portuguesa; sua necessidade para aquisição da harmonia do estilo. Estudo de cada espécie de verso e sua aplicação à prosa. Pausas rítmicas.

V - Revisão dos pontos VII, VIII e IX.

VI - Ortoépia. Complemento das noções dadas no $1^{\mathbf{0}}$ ano.

VII - Prosódia. Silaba, sua estrutura. Acento secundário. Palavras de acentuação duvidosa.

VIII - Revisão da taxionomia, especialmente das conjunções.

IX - Estudo minucioso da função subjetiva com exemplos de palavras, expressões e orações subjetivas. Frases sem sujeito.

$\mathrm{X}$ - Estudo da função predicativa. Do adjunto predicativo; seu característico de adjunto do sujeito. Predicativo do objeto.

XI - Estudo da função objetiva direta e indireta. Da oração substantiva.

XII - Estudo da função adjetiva. Do adjunto atributivo. Do adjunto denotativo. Da oração adjetiva. Da aposição.

XIII - Da função adverbial. Do adjunto adverbial. Revisão das relações indicadas pelas preposições (ponto XV do $1^{\circ}$ ano). Da oração adverbial.

XIV - Da função interjectiva. Do vocativo. Do realce.

XV - Do período. Da construção lógica. Concordância. Dos três modos elementares da construção (coordenação, subordinação, correlação).

XVI - Da construção passiva (com verbo ser, com partícula se, com o infinitivo). Passiva de estado e de mudança de estado. Do complemento de causa eficiente.

XVII - Revisão dos verbos irregulares (por meio de sabatinas orais e escritas).

XVIII - Revisão do ponto XXXIII do $1^{\circ}$ ano.

XIX - Revisão da campenomia (pontos XXXIV e XXXVII do $1^{\circ}$ ano).

XX - Prefixos latinos (estudo sistemático; formas e acepções de cada prefixo).

XXI - Sufixos latinos (estudo sistemático; formas e acepções de cada sufixo).

XXII - Parônimos e homônimos.

XXIII - Colocação dos pronomes.

\section{Livros Indicados:}

Os mesmos do 1 ano e mais:

Said Ali - Gramática secundária da língua portuguesa.

\section{$3^{\circ}$ ANO}

I - Filiação do português ao latim, revelada pelo léxico, pela morfologia e pela sintaxe. Outros elementos formadores do léxico português.

II - Revisão dos prefixos latinos (por meio de sabatinas).

III - Prefixos e sufixos gregos (estudo sistemático; formas e acepções de cada um).

IV - Plural das palavras terminadas em $\mathbf{l}, \mathbf{m}, \mathbf{n}, \mathbf{s}$ e do ditongo ão.

V - Classificação morfológica; palavras cognatas; famílias de palavras (exercícios práticos).

VI - Estudo sistemático de radicais verbais latinos que deram famílias de palavras em português.

(Várias lições serão consagradas a esse estudo).

VII - Estudo sucinto das palavras de fonte árabe.

IX - Palavras de fonte germânica.

$\mathrm{X}$ - O elemento tupi. Onomástica e toponímia brasileira de fonte tupi.

XI - Elemento africano no léxico português. 
XII - Concordância nominal.

XII - Concordância verbal.

XIV - Emprego, omissão e repetição de artigo.

XV - Funções do pronome se.

XVI - Variedade e funções de que.

XVII- Significação e emprego dos tempos.

XVIII - Significação e emprego dos modos.

XIX - Emprego do infinito impessoal e pessoal.

$\mathrm{XX}$ - Emprego do gerúndio.

XXI - Figuras de sintaxe.

XXII - Vícios de linguagem.

XXIII - Pontuação.

(O professor completará neste ano a análise lógica tomando por texto os Lusíadas de Camões. Especial cuidado cumpre haver no estudo dos anacolutos).

\section{Livros Indicados:}

Os mesmos e mais:

Otoniel Mota - O meu idioma.

Júlio Nogueira - O exame de português.

\section{$6^{\circ}$ ANO}

[O conteúdo do $6^{\circ}$ ano é constituído apenas por tópicos literários. Como esse tema foge dos objetivos da presente tese, não apresentaremos aqui os pontos que formam o programa desse ano.]

[In: Programas de Ensino do Colégio Pedro II: para o ano de 1926. Rio de Janeiro: Tipografia de Encadernadora, 1926 apud RAZZINI, 2000, p. 328-334]. 
ANEXO A7 - Programas de ensino do Colégio Pedro II - Português - 1928, 1929 e 1930

$\underline{1928}$

$\mathbf{1}^{\circ}$ Ano [idem a 1926, com o acréscimo de mais um livro].

Maximino Maciel - Lições elementares de língua portuguesa.

$\mathbf{2}^{\mathbf{0}}$ Ano [idem a 1926, com acréscimo de dois livros].

Antenor Nascentes: $\mathbf{O}$ idioma nacional $-2^{\circ}$ volume.

José Oiticica: Manual de estilo.

$\mathbf{3}^{\circ}$ ano [idem a 1926, com o acréscimo de mais um livro].

Antenor Nascentes - $\mathbf{O}$ idioma nacional $-3^{\circ}$ volume.

$4^{0}$ ano

1. Gramática histórica. Método comparativo. Glotologia, filologia, literatura. Origem da língua portuguesa. As línguas afins.

2. Filiação do português ao latim, revelada pelo léxico, pela morfologia e pela sintaxe. Outros elementos formadores do léxico português. Neologismos, peregrinismos, gíria; arcaização, suas causas. Hibridismos.

3. Leis fonéticas. Metaplasmos.

4. Vocalismo. Vogais átonas, tônicas, pré-tônicas e pós-tônicas. Vogais no hiato. Ditongos.

5. Consonantismo. Grupos consonantais. $\mathrm{O}$ h e o til.

6. Particularidades fonéticas nas palavras de fonte árabe e germânica.

7. Estudo das formas convergentes e divergentes, suas causas. Formas eruditas, semieruditas e populares.

8. Histórico das flexões. Caso lexiogênico. Criações sintáticas resultantes da obliteração dos casos.

9. Redução das declinações latinas. Desaparecimento do neutro; vestígios. Masculino e feminino. Gênero dos derivados da terceira declinação. Formação do plural.

10. Grau dos substantivos; sufixos especiais. Grau dos adjetivos: vestígios do comparativo sintético. O superlativo sintético.

11. Etimologia dos adjetivos e pronomes; evolução de cada classe.

12. Flexões verbais; histórico das desinências.

13. Morfologia histórica do verbo ser.

14. Idem dos verbos: estar e dar.

15. Idem dos verbos: ter, caber e saber.

16. Idem dos verbos: fazer, dizer e trazer.

17. Idem dos verbos: haver, jazer e morrer.

18. Idem dos verbos: pôr e seus análogos (soer, doer, moer).

19. Idem dos verbos: ver, perder e valer.

20. Idem dos verbos: ir e vir.

21. Idem dos verbos: medir, pedir, impedir e cognatos, mentir, ouvir.

22. Modificações no quadro das conjugações. Futuro e condicional românicos. Expressão da passiva; espécies de passiva. A passiva com se nas línguas românicas. A passiva com o infinito. 
23. Etimologia dos advérbios, preposições e conjunções; formas arcaicas.

24. Grafia, morfologia e sintaxe dos cancioneiros (estudo prático dos textos).

25. O português dos quinhentistas (estudo prático nos textos da Antologia Nacional).

26. Idem para os seiscentistas.

27. Idem para os árcades.

28. A construção clássica e a moderna. Estilo direto e indireto. Valor literário das orações reduzidas.

29. Particularidades do português popular no Brasil. Tendências dialetais. Influência indígena e africana.

Dissertações morais e literárias. Impressões de leituras feitas fora de classe. Cartas. Discursos.

\section{Livros Indicados:}

Antenor Nascentes - Apostilas de português.

Júlio Nogueira - O exame de português.

Said Ali - Lexiologia do português histórico.

$5^{\mathbf{0}}$ ano [No documento que consultamos, não consta o $5^{\circ}$ ano, talvez por lapso de Razzini (2000) na transcrição dos originais.]

\section{$6^{0}$ ano}

[O conteúdo do $6^{\circ}$ ano é constituído apenas por tópicos literários. Como esse tema foge dos objetivos da presente tese, não apresentaremos aqui os pontos que formam o programa desse ano.]

$\underline{1929}$

$\mathbf{1}^{\mathbf{0}}$ ano [idem a 1928].

$\mathbf{2}^{\circ}$ ano [idem a 1928].

$\mathbf{3}^{\mathbf{0}}$ ano [idem a 1928].

$4^{\mathbf{0}}$ ano [idem a 1928, com a troca das Apostilas de português de Antenor Nascentes por] Antenor Nascentes - O idioma nacional - vol. IV.

\section{$5^{\circ}$ e $6^{\circ}$ anos}

[O conteúdo do $5^{\circ}$ e $6^{\circ}$ ano é constituído apenas por tópicos literários. Como esse tema foge dos objetivos da presente tese, não apresentaremos aqui os pontos que formam o programa desses anos.] 
$\underline{1930}$

$\mathbf{1}^{\circ}$ ano [idem a 1929].

$\mathbf{2}^{\mathbf{0}}$ ano [idem a 1929].

$3^{\mathbf{0}}$ ano [idem a 1929].

$4^{0}$ ano [idem a 1929].

$\mathbf{5}^{\circ}$ ano [idem a 1929].

$\mathbf{6}^{\mathbf{0}}$ ano [idem a 1929].

[In: Programas de Ensino do Colégio Pedro II: para o ano de 1928. Rio de Janeiro: Tipografia de Encadernadora, 1928 apud RAZZINI, 2000, p. 334-337].

[In: Programas de Ensino do Colégio Pedro II: para o ano de 1929. Rio de Janeiro: Imprensa Nacional, 1929 apud RAZZINI, 2000, p. 337].

[In: Programas de Ensino do Colégio Pedro II: para o ano de 1930. Rio de Janeiro: Imprensa Nacional, 1930 apud RAZZINI, 2000, p. 338]. 


\section{ANEXO A8 - Programa de ensino do Ministério da Educação e Saúde Pública - Português $-1931$}

\section{Ministério da Educação e Saude Pública}

\section{REPUBLICA DOS ESTADOS UNIDOS DO BRASIL}

O Ministro de Estado da Educação e Saúde Publica, em nome do Governo Provisorio:

Resolve, nos termos do art. 10. do decreto n. 19.800, de 18 de abril de 1931, expedir os programas do curso fundamental do ensino secundario, anexos a esta Portaria, que serão observados, de acôrdo com as respectivas instruções pedagogicas e com o numero de horas semanais neles referido, em cada sério do curso a que forem applicaveis.

Rio de Janeiro, 30 de junho de 1931.

Francisco Campos.

\section{PORTUGUÊS}

O programa desta cadeira tem por objetivo proporcionar ao estudante a aquisição efetiva da lingua portuguesa, habilitando-o a exprimir-se corretamente, comunicando-lhe o gosto da leitura dos bons escritores e ministrando-lhe o cabedal indispensável à formação do seu espírito bem como à sua educação literária.

Nas duas primeiras séries do curso, o ensino será acentuadamente prático, reduzidas ao mínimo possível as lições de gramática e transmitidas por processos indutivos. A conversação bem orientada, as pequenas exposições orais e a reprodução livre de um trecho lido na aula darão ensejo a que o professor corrija a linguagem dos alunos e, assim, prepare os subsídios para a composição escrita, mais aconselhável nas séries superiores Desde o princípio do curso, o professor procurará tirar o máximo proveito da leitura, ponto de partida de todo o ensino, não se esquecendo de que, além de visar a fins educativos, ela oferece um manancial de idéias que fecundam e disciplinam a inteligência, prevenindo maiores dificuldades nas aulas de redação e estilo.

O conhecimento do vocabulário, da ortografia e das formas corretas fimdar-se-á nos textos cuidadosamente escolhidos, e pelo exame destes se notarão, pouco a pouco, os fatos gramaticais mais importantes, cujas leis jamais serão apresentadas a priori, mas derivadas naturalmente das observações feitas pelo próprio aluno

Apesar da preferência que nas duas primeiras séries se deve dar aos exercícios orais, convém se destinem, de quando em quando, uns quinze minutos da aula a breves trabalhos escritos, relacionados com a matéria ensinada. 
Cumpre limitar razoavelmente o uso da análise e não a considerar finalidade, porém simples meio auxiliar que pode às vezes intervir na interpretação de uma frase ou na explicação de um período mais ou menos obscuro. Basta que o estudante se familiarize com as partes essenciais da proposição, desprezados, por inúteis, os pormenores e os subentendidos, que fazem perder tempo e nada adiantam a quem aprende um idioma. Todos os esforços do professor hão de convergir para o ensino da significação e da forma.

A análise lexicológica é inseparável da sintática, pois que as duas se completar e as palavras só têm verdadeira expressão quando combinadas na frase.

A coordenação dos fatos gramaticais observados será feita no início da $3^{\text {a }}$ série, prosseguindo com algum desenvolvimento o estudo da morfologia e da sintaxe, baseado sempre em exemplos tirados de livros ou preparados pelo professor.

Os exercícios orais continuarão como nas duas primeiras séries, reservando-se, entretanto, boa parte do tempo à redação de cartas e ao diálogo, escritos no quadro negro e compostos pela classe, sobre assunto por ela sugerido.

Somente na $4^{\mathrm{a}}$ série começará a redação livre, dando-se-lhe daí por diante, até o termo do curso, maior atenção. Cerca de três quartas partes do tempo letivo deverá ser destinado à correspondência, às descrições e narrações, entremeadas com exercícios de estilo e análise literária de textos.

Os trabalhos de composição escrita serão preparados fora da classe, indicando-se ao aluno, tanto quanto possível, as leituras a que convém recorrer afim de melhor executá-los. Para que a correção seja eficaz, recomenda-se ao professor recolher as provas e, fora da aula, nelas assinalar todos os erros, classificando em lista especial os mais comuns (erros de ortografia, pontuação, concordância, regência, impropriedades, etc.); na aula seguinte, mandando fazer, no quadro negro, as emendas necessárias, com a colaboração na classe, deve verificar se os interessados as transportam para as respectivas provas.

$\mathrm{Na} 4^{a}$ série caberá ainda, pelo estudo elementar da gramática histórica, a justificação dos preceitos hauridos na gramática expositiva. A feição arcaica da lingua será ligeiramente considerada em excertos curtos e característicos, de que se dará a redação atual, seguida de rápidos comentários oportunos.

O ensino propriamente literário, subordinado ao da lingua na $4^{\mathrm{a}}$ série, tornar-se-á preponderante na $5^{\mathrm{a}}$ série, expondo-se então as regras da composição literária e o estudo, ainda que sumário, das melhores obras de escritores nacionais e portugueses. Instituídos pêla leitura dos textos, serão os alunos obrigados a tomar parte ativa na análise dos processos de cada autor, caracterizando-lhe a construção e o estilo, mencionando os já conceitos e as passagens que mais os impressionaram, apontando as formas elegantes e vigentes ou as que, arcaicas, não devem ser imitadas. Após o conhecimento fragmentário de uma obra, receberão sumária notícia das demais partes que a constituem, do plano a que obedece, do fim que se propõe, da individualidade do autor, corrente literaria a que pertenceu e outras obras que produziu. Com respeito ao estudo de um escritor ou a propósito de um pensamento notável, colhido na leitura, desenvolverão temas literários ou assuntos de moral privada e social.

Emquanto não existir uma seleta organizada em harmonia com o programa da 5 série, o critério do mestre regulará a extensão adequada a apreciação de cada autor. É preferível começar pelas obras modernas, porque sómente elas, por mais comunicativas, provocam emoções sinceras e despertam o prazer dos estudos desta natureza. Como o que se pretende é, antes de tudo, educar o gôsto literário, quase todo o ensino, para ser atraente, tem de gravitar em torno do pensamento 
hodierno, em ambiente conhecido, convindo, portanto, a preferência pelas obras modernas e deixando-se a análise das obras clássicas para o momento em que o aluno, dotado de algum senso crítico, estiver apto a assimilar com real proveito os velhos exemplares da boa linguagem.

Finalmente incumbe ao professor fazer a sinopse histórica e a apreciação geral da literatura portuguesa e da brasileira, de sorte que, ao concluir o curso fundamental, tenha o estudante indicações seguras para poder consolidar por si as noções adquiridas na escola.

\section{PRIMEIRA E SEGUNDA SÉRIES}

(4 horas)

- Leitura de trechos de prosadores e poetas contemporâneos, escolhidos de acordo com a capacidade média da classe. Explicação dos textos. Estudo metódico do vocabulário. Reprodução oral do assunto lido.

- Recitação de pequenas poesias, previamente interpretadas.

- Composição oral; pequenas descrições de cenas comuns da vida humana e da natureza; breves narrativas, fábulas, contos populares.

- Estudo gramatical baseado no livro de leitura; flexão nominal; graduação; numerais; emprego frequente das formas verbais mais comuns, especialmente do imperativo; estudo simultâneo e moderado da análise lexicológica e da sintática; substituição de frases por outras de formas diversas e sentido equivalente; conversão de frases compostas em frases simples; transformação de orações coordenadas em subordinadas, e vice-versa; passagem de orações conjuncionais a reduzidas, e vice-versa; exercícios de concordância e regência; colocação dos pronomes obliquos; exercícios ortográficos no quadro negro.

\section{TERCEIRA SÉRIE}

(3 horas)

- Leitura de excertos de prosadores e poetas modernos. Explicações dos textos. Estudo metódico do vocabulário.

- Composição oral: pequenas descrições de cenas da vida humana e da natureza: breves narrativas de episódios da história do Brasil; reprodução livre de assuntos lidos fora da classe.

- Composição escrita; cartas e diálogos redigidos pela classe, em colaboração, e escritos no quadro negro.

- Estudo gramatical; resumo sistemático das observações feitas nos anos precedentes; noções elementares de fonética; formação de palavras, particularidades sintáticas; sintaxe de colocação.

\section{QUARTA SÉRIE}


- Leitura e interpretação de trechos de poetas e prosadores dos dois últimos séculos. Análise literaria elementar.

- Exercicios escritos de composição oficial e narrações sobre assuntos variados; descrição de tipos e cenas.

- Exercicios freqüentes de estilo no quadro negro.

- Origem da lingua portuguesa; seu domínio; constituição do léxico português; as línguas românicas. O português do Brasil.

- Estudo elementar de fonetica histórica.

- Formas divergentes; suas causas.

- As três declinações do latim popular. O caso lexicogênico. O desaparecimento do neutro.

- Fatos devidos á analogia.

- Justificação das regras referentes ás flexões de gênero e número e á graduação sintatica.

- As tres conjugações do latim popular, perdas sofridas pelo latim literário; creações romanicas, fatos devidos á analogia. Explicação das formas verbais mais características, consideradas irregulares pela gramática expositiva.

- Observações sôbre a ortografia apoiadas nos conhecimentos de fonetica historica.

\section{QUINTA SÉRIE}

(2 horas)

\section{Análise literária.}

Estudo literário de obras em prosa e verso de autores pelo professor, predominando as modernas e excluindo-se as do periodo ante-clássico.

\section{Literatura.}

a) Noções preliminares - Literatura. Arte literária. Prosa e verso. Ritmo. Formas de exposição: narração, descrição e dissertação. Generos de composição em prosa e verso. Estudo de versificação.

Estilo: virtudes estilísticas.

b) Sinopse de história literária - Formação e desenvolvimento da literatura portuguesa e da brasileira. Os fatores mais importantes. Divisão em períodos. Influência estrangeira. Escolas: origens, caracteres e principais representantes de cada escola.

III. Composição e estilo.

Dissertações morais. Dissertações literarias a proposito dos autores estudados. Impressões de leitura feitas fora da classe. Exercicios de estilo no quadro negro. 
[In: BRASIL. Ministério da Educação e Saúde Pública. Gabinete do Ministro. Portaria (s/n), de 30 de junho de 1931. Regulamenta o art. 10. do decreto n. 19.800, de 18 de abril de 1931. Diário Oficial da União, Rio de Janeiro, DF, 31 jul. 1931, p. 12405.] 
ANEXO A9 - Programa de ensino do Ministério da Educação e Saúde - Português - 1942

\section{Portaria Ministerial n ${ }^{\circ}$. 170, de 11 de julho de 1942.}

O ministro de Estado da Educação e Saúde resolve expedir e determinar que se executem os programas das disciplinas de línguas e de ciências do curso ginasial secundário, os quais se anexam à presente portaria ministerial.

Rio de Janeiro, 11 de julho de 1942. - Gustavo Capanema.

\section{PRIMEIRA SÉRIE}

I - LEITURA - Far-se-á em trechos, em prosa e em verso, que tenham por assunto principal a família, a escola e a terra natal.

II - GRAMÁTICA - Com apoio nessa leitura, se tratará do seguinte:

Unidade I - 1. Oração. Sujeito e predicado. Oração sem sujeito, oração sem verbo. 2. Substantivo, artigos, adjetivo, numerais. 3. Gênero e número. Idéia de concordância nominal. Exercícios para o bom emprego dos artigos e dos numerais.

Unidade II - 1. Verbo: números, pessoas, tempos e modos. Vozes. 2. Verbos regulares e irregulares.

Exercícios de conjugação, feitos por meio de frases. 3. Exercícios de concordância do verbo com o sujeito.

Unidade III - 1. Pronomes, advérbios. 2. Coordenação. Noção de conjunção coordenativa. 3. Estudo simultâneo e moderado da análise léxica e da sintática, não indo esta além do período composto por coordenação. 4. Exercícios para o bom emprego dos pronomes, sobretudo do relativo cujo e dos demonstrativos.

III - OUTROS EXERCÍCIOS - Além da leitura e dos exercícios próprios de cada umidade de gramática, haverá:

1 - Estudo do vocabulário, acompanhado de exercícios.

2 - Exercícios de ortografia e pontuação, ditado de pequenos trechos de assuntos instrutivo e educativo e de sentenças de conteúdo moral ou patriótico.

3 - Breves exposições orais, reprodução livre de trechos lidos na aula, redação escrita de frases curtas e pequenas descrições à vista de gravuras.

\section{SEGUNDA SÉRIE}

I - LEITURA - Far-se-á em trechos, em prosa e em verso, que tenham por assunto principal a paisagem e a vida em cada uma das regiões naturais do Brasil. 
II - GRAMÁTICA - Com apoio nessa leitura, se tratará do seguinte:

Unidade I - 1. Preposições. Exercícios de regência para aquisição do bom uso das preposições. 2. Substituição de frases por outras diversas, mas equivalentes pelo sentido. 3. Primeiras noções de subordinação. 4. Estudo de análise léxica e sintática, um tanto mais desenvolvido que na primeira série.

Unidade II - 1. Predicado verbal, predicado nominal. O predicativo. 2. Aposição. O aposto. 3. Exercícios de conjugação dada especial ao imperativo, ao mais-que-perfeito simples do indicativo e ao futuro do subjuntivo. A forma mais-que-perfeito simples do indicativo com o valor de condicional e de imperfeito do subjuntivo. Exercícios. 4. Exercícios sobre verbos conjugados reflexamente e sobre verbos com o pronome lo ou $o$ enclítico.

Unidade III - 1. O vocativo. Interjeições e locuções interjetivas. 2. Formação de palavras: composição, derivação. Prefixos e sufixos: exercícios. Formação parassintética. 3. Graus de significação do substantivo, do adjetivo e do advérbio: exercícios. 4. Comparação. Exercícios práticos sobre comparação.

III - OUTROS EXERCICIOS - Além da leitura e dos exercícios próprios de cada unidade de gramática, haverá:

1 - Estudo do vocabulário, acompanhado de exercícios.

2 - Exercícios de ortografia e pontuação.

3 - Exercícios de exposição oral e de redação.

4 - Estudo elementar da versificação a propósito das poesias lidas na aula.

\section{TERCEIRA SÉRIE}

I - LEITURA - Far-se-á em trechos, em prosa e em verso, que, sempre subordinados à idéia geral de amor ao Brasil, tenham por assinto principal a conquista da terra, o melhoramento dela e a atualidade brasileira.

II - GRAMÁTICA - Com apoio nessa leitura, se tratará do seguinte:

Unidade I - 1. Conjunções coordenativas. Exercícios sobre conjunções coordenativas. Estudo, mais minucioso e desenvolvido, do período composto por coordenação. 2. Exercícios de análise léxica e sintática. 3. Idéia da sintaxe ideológica e afetiva: alguns exemplos expressivos. Unidade II - 1. Conjunções subordinativas. Exercícios sobre conjunções subordinativas. 2. Exercícios para o correto emprego do verbo haver e da partícula se em função passivadora, e para o bom uso do infinito pessoal e impessoal. 3. Exercícios de concordância do predicativo do sujeito e do predicativo do objeto direto.

Unidade III - 1. O período composto por subordinação. 2. Exercícios de emprêgo de modos e tempos na oração subordinada 3. Exercícios de análise léxica e sintática. 4. Exercícios sôbre a colocação das palavras na frase, principalmente sôbre a dos pronomes átonos.

III - OUTROS EXERCÍCIOS - Além da leitura e dos exercícios próprios de cada unidade de gramática, haverá:

1 - Estudo do vocabulário, acompanhado de exercícios. 
2 - Exercícios de exposição oral, de redação e composição.

3 - Estudo elementar da versificação a propósito das poesias lidas na aula.

\section{QUARTA SÉRIE}

I - LEITURA - Far-se-á, por já aspirar a constituir una iniciação literária, em excertos da literatura brasileira e portuguesa, distribuídos em três classes: cartas, prosa literária e poesia.

II - GRAMÁTICA - Sempre aproveitando o material linguístico encontrado nos textos de aula, tratar-se-á do seguinte:

Unidade I - 1. Vocabulário, sílaba, número de sílabas dos vocabulários, acento tônico, a situação do acento tônico. 2. Constituição das sílabas. Qualidades físicas do som. Vogais e consoantes. Ditongos. Tritongos. 3. Noção da ênclise e da próclise. Ação da ênclise e da prótese: alguns exemplos. 4. Exercícios de verificação e aplicação da matéria estudada.

Unidade II - 1. Latim vulgar. As três declinações do latim vulgar. Sobrevivência do acusativo. O desaparecimento do neutro. As três conjugações do latim vulgar na Península Ibérica. 2. Idéia da ação da analogia, ministrada por meio de alguns exemplos expressivos. 3. Criações românicas.

Unidade III - 1. Origem das línguas românicas. A língua portuguesa, seu domínio. Constituição do léxico português. 2. Estudo breve e elementaríssimo de fonética-histórica. Formas divergentes e convergentes. 3. O português do Brasil.

III - OUTROS EXERCÍCIOS - Além da leitura e dos exercícios próprios de cada unidade de gramática, haverá:

1 - Estudo do vocabulário, acompanhado de exercícios.

2 - Redação de cartas, bilhetes e telegramas, e de documentos oficiais.

3 - Exercícios de composição.

4 - Estudo elementar da versificação a propósito das poesias lidas na aula.

5 - Análise de períodos compostos por subordinação.

[In: CRUZ, JOSÉ Marques da. Português prático: gramática para as 4 séries do Curso Ginasial. São Paulo: Edições Melhoramentos, 1947. p. 13-15.] 
ANEXO A10 - Instruções metodológicas para execução do programa de Português - 1942

\section{Portaria Ministerial $\mathrm{n}^{\circ}$. 172, de 15 de julho de 1942.}

\section{Instruções metodológicas para execução do programa de Português}

O Ministro de Estado da Educação e Saúde resolve expedir, e de terminar que se observem, no curso ginasial do ensino secundário, as instruções metodológicas para execução do programa de português, anexas à presente portaria ministerial.

Rio de Janeiro, 15 de julho de 1942. - Gustavo Capanema.

\section{Finalidades do estudo da língua portuguêsa}

O programa de português no curso ginasial procura:

a) proporcionar ao estudante a aquisição efetiva da língua portuguêsa, de maneira que ele possa exprimir-se corretamente;

b) comunicar-lhe o gosto da leitura dos bons escritores;

c) ministrar-lhe apreciável parte do cabedal indispensável à for- mação do seu espírito e do seu caráter, bem como base à sua educação literária, se quiser ingressar no segundo ciclo ou fazê-la por si, autodidàticamente;

d) mostrar-lhe a origem românica da nossa língua e, portanto, a nossa integração na civilização ocidental, o que o ajudará a compreender melhor o papel do Brasil na comunhão americana e fora dela.

\section{Estrutura do curso de português}

1. Buscar-se-á alcançar essas finalidades mediante um ensino pronunciadamente prático, que compreenderá três partes paralelas: gramática, leitura explicada e outros exercícios.

2. A leitura se fará em todo o curso; a matéria gramatical, com os respectivos exercícios, vai repartida, em cada série, por três unidades, cada uma das quais se lecionará dentro de um trimestre; os trabalhos indicados no programa sob a denominação de "outros exercícios" se distribuirão por todo o ano letivo pelo modo que o professor julgar mais conveniente.

\section{O papel da leitura}

1. O professor se empenhará em obter o máximo proveito da leitura, não se esquecendo de que ela oferece, quando bem escolhida e orientada, um manancial de idéias que fecundam e disciplinam a inteligência e concorrem para acentuar e elevar, no espírito dos adolescentes, a consciência patriótica e a consciência humanística. Na leitura, explicada minuciosamente de todos os pontos de vista educativos, é que os alunos encontrarão boa parte da base necessária à 
formação da sua personalidade integral, bem como aquelas generalidades fundamentais de onde eles poderão subir a estudos mais elevados de caráter especial.

2. O conhecimento do vocabulário, da ortografia, da pontuação e das formas e construções corretas será sobretudo adquirido mediante considerações expendidas a propósito dos textos de leitura; e dos fatos nêles observados deduzirão os próprios alunos, auxiliados pelo professor, as regras da boa linguagem consignadas na gramática expositiva.

3. Qualquer exemplificação da matéria com que se procure enriquecer ou completar a que fôr tirada dos textos, será mais provei- tosa ao intento da educação secundária, se não se fizer só com frases da linguagem quotidiana, mas também com máximas morais e patrióticas e provérbios de conselhos atinentes à vida prática.

4. Recomenda-se que, no comentário da leitura, ou mesmo noutras ocasiões, o professor conduza suas considerações de maneira que ache meio de falar, embora muito sumàriamente, não só dos grandes vultos da civilização brasileira, principalmente os escritores, mas também das figuras mais eminentes das literaturas portuguêsa e estrangeiras. Isto para que o aluno não deixe o seu aprendizado ginasial, sem saber, por exemplo, quem foi Homero, Demóstenes, Dante, Petrarca, Cervantes, Goethe, Schiller, Tolstoi, Ibsen, Camões, Gil Vicente, Garrett, Herculano, . Antero de Quental, João de Deus, etc. Ocasional- mente o professor poderá referir-se aos grandes nomes da literatura latina, da francesa e da inglêsa (e norte-americana), mas não há necessidade de buscar ensejo para isso, visto que eles soarão suficientemente aos ouvidos dos alunos nas aulas de latim, francês e inglês.

\section{O ensino na primeira série}

1. O professor dará as primeiras noções gramaticais partindo da oração, concebida como "a menor unidade do discurso dotada de sentido completo".

2. Assim, tomará um objeto que tenha ao seu alcance, e perguntará a vários alunos o que pensam, o que querem dizer ou saber, a respeito desse objeto. Obterá respostas diferentes. Destas, escolherá as mais simples e que melhor se prestem ao seu fito didático em relação a alunos que mal deixaram a escola primária. Por exemplo:

O giz é branco.

$\mathrm{O}$ giz quebra-se fàcilmente.

Como se fabrica o giz?

3. Dirá então aos alunos que as palavras, com que declaramos ou perguntamos alguma cousa, formam uma "oração". E, pois, uma oração: "O giz é branco"; é outra oração: "Como se fabrica o giz?".

4. Depois, fará que os alunos, com a colaboração dêle, vão apontando as orações, curtas e simples, que o texto de leitura contiver.

5. Realizado durante algumas lições êsse exercício, passará o professor a mostrar que também formam oração as palavras com que exprimimos um desejo, como quando dizemos, no padre nosso: 
"Venha a nós o vosso reino."

6. Dirá que ainda há oração, quando se faz um pedido, se dá uma ordem ou uma incumbência:

Entregue este livro à sua irmã.

Faça direito o seu trabalho.

7. Durante alguns dias auxiliará os alunos a descobrirem, nos textos, todos esses tipos de oração; e quando vir que eles já têm adquirido certa prática de tais pesquisas, entrará a ministrar as noções de sujeito e de predicado, tudo, porém, de modo muito simples e adequado à tenra mentalidade de crianças de onze anos.

8. Assimiladas pelos alunos as noções rudimentares de oração, sujeito e predicado, o professor lhes mostrará, com exemplos, que pode haver oração sem sujeito e, mesmo, sem verbo, embora este se possa subentender. (O professor já pode falar em «verbo » graças ao preparo que os alunos trazem da escola primária).

9. Vencida essa primeira dificuldade, prosseguirá o professor nas suas lições de gramática, tendo o cuidado de reduzi-las ao mínimo possível, transmiti-las por processos indutivos e diligenciar extraí-las dos próprios textos de leitura.

10. Atenderá a que a matéria de cada unidade de gramática deve ser estudada num trimestre, mas que depois (e isto é um preceito que se aplicará a todo o curso), sempre que houver ocasião, serão recordadas as generalidades principais, não só para fixá-las na memória dos alunos, mas também para que estes as compreendam melhor à proporção que a sua inteligência se fôr desenvolvendo e educando.

11. Não se esquecendo de que a correção e propriedade no emprêgo da língua deve constituir preocupação constante, o professor encaminhará os alunos a toda a sorte de atividade que lhe permita oportunidade de corrigir a linguagem dos mesmos e suprir as inevitáveis lacunas que deixaria um ensino teórico, por mais completo que fosse.

São trabalhos dêste gênero adequados a esta série: breves exposições orais, reprodução livre de trechos lidos na aula, pequenos ditados e exercícios elementares de redação.

12. O estudo do vocabulário consistirá em procurarem os alunos no dicionário, que o professor lhes ensinará a manejar, as palavras cujos significados ignorem ou não conheçam com precisão. Os exercícios consistirão em construirem os alunos frases em que apareçam bem empregadas aquelas palavras.

13. Os exercícios de ortografia e pontuação terão por base o texto de leitura; mas, feitas pelo professor as considerações que ele julgar oportuno expender a propósito do texto, poderão ser preparadas, por ele e pelos alunos, frases em que entrem vocábulos cuja correta grafia e prosódia exijam alguma atenção.

\section{O ensino na segunda série}

1. O estudo gramatical inicia-se pelo capítulo das preposições. 
2. O professor transmitirá a noção de preposição por meio do exame de frases lidas na aula, nas quais figurem preposições.

3. Depois, ajudará os alunos a descobrirem preposições nas páginas de leitura. Alcançado certo desembaraço nesse trabalho, o professor iniciará os exercícios de regência para a aquisição do bom uso das preposições. Estes exercícios devem ocupar boa parte do trimestre reservado à unidade I de gramática, mas serão retomados, sempre que possível, em todo o resto do curso, por serem dos mais importantes à vernaculidade da expressão.

4. Na substituição de frases por outras diversas, mas equivalentes pelo sentido, assinalará o professor que a equivalência perfeita nem sempre se verifica. Pode à nova frase vir juntar-se um novo matiz. Entre as orações "levaram o menino à escola" e "o menino foi levado à escola", uma ou outra pessoa sentirá alguma diferença, embora sutil. Na segunda há, talvez, maior relèvo dado à idéia de menino. Já se vê que tais reflexões só as fará o professor verificando que a classe, em sua grande maioria, já pode compreendê-las.

5. É ainda neste trimestre que vêm as primeiras noções de subordinação: subordinação de um têrmo a outro por meio de uma preposição, subordinação de uma oração a outra por meio de uma conjunção de outra espécie de conetivo, como, por exemplo, o pronome relativo. Daí por diante, tôdas as vezes que, nesta segunda série e no primeiro trimestre da terceira, tiver de tratar de análise léxica e sintática, irá o professor conduzindo os alunos ao conhecimento prático de orações subordinadas, para, no segundo trimestre da terceira série, enfrentar o estudo sistemático das conjunções subordinativas e no trimestre seguinte aprofundar e esmiuçar a análise do período composto por subordinação.

6. No segundo trimestre, o professor, que, nos estudos anteriores de análise léxica e sintática, já terá tratado, mas um tanto por alto, do predicado verbal, do predicado nominal, do predicativo e do apôsto de qualquer substantivo, deter-se-á agora um pouco mais no exame dêsses elementos da oração, procurando ampliar e sistematizar as noções que a respeito dos mesmos vinham sendo ministradas esparsamente.

7. No mesmo trimestre fará os exercícios, de óbvia utilidade, indicados na unidade II de gramática sob os números 3 e 4 .

8. No trimestre seguinte tratará logo do vocativo, e, para evitar que os alunos o confundam com o apôsto, lhes recordará que em latim há, até, um caso especial para o vocativo, ao passo que nessa língua o apôsto, em regra geral, vai para o mesmo caso que o substantivo a que se refere.

9. Do vocativo passará o professor a um assunto que tem com a natureza do vocativo alguma afinidade: as interjeições.

10. A seguir versará a formação de palavras, os graus de significação e a comparação.

11. Nos exercícios de comparação, salientará aos alunos um fato comum, a respeito do qual devem estar atentos: a frequente omissão de parte da oração comparativa ou mesmo de toda ela, que então apenas fica denunciada pela presença da conjunção (êle é mais valente do que o irmão; ele contou-me o caso como se eu fosse seu amigo). 
12. Também lhes fará ver que não se diz: "Este quarto é mais grande do que o nosso"; mas que, se a comparação se fizer entre duas qualidades referidas à mesma pessoa ou cousa, há de se dizer: "Ele é mais grande do que pequeno".

13. A aquisição do vocabulário será feita como na primeira série, acrescentando-se aqui o estudo de sinônimos e antônimos; os exercícios de ortografia e pontuação seguirão os mesmos processos adotados na série anterior.

14. Continuarão os exercícios de exposição oral e começarão os exercícios francos de redação, e, a propósito das poesias lidas na classe, se darão noções elementares de versificação.

\section{O ensino na terceira série}

1. O professor iniciará o ensino relativo à unidade I de gramática tratando das conjunções coordenativas. Como anteriormente já se ocupou do assunto de modo prático, aqui lhe caberá ordenar os conhecimentos adquiridos e desenvolvê-los, de modo que possa levar os alunos a um estudo, mais minucioso, do período composto por coordenação.

2. Da sintaxe ideológica e afetiva dará idéia mediante exemplos, que explicará convenientemente: o verbo pôsto no plural por se referir a um coletivo; a silepse de gênero e de pessoa; o complemento de interesse: "Digam-me a esse homem que eu já vou"; uma frase como esta de Garrett: "Sim, eu agora ando bom... E tu, meu Luís, como vamos de saúde?”; etc., etc.

3. Entrando no ensino pertinente à unidade II de gramática, terá o professor de recapitular noções já ministradas pràticamente (v. Programa, segunda série, unidades de gramática I, números 3 e 4, e III número 4, e estas Instruções metodológicas, V, 5), e consolidá-las no espírito dos alunos por meio de exercícios adequados.

4. Recorrendo a exemplos numerosos, mostrará como se emprega corretamente o verbo haver nas suas várias acepções e a partícula se em função passivadora e quando se deve adotar o infinito impessoal, quando pessoal e quando, do ponto de vista gramatical, é indiferente o uso de um ou de outro, dependendo a preferência de fatores de outra ordem, como a clareza, a ênfase, a harmonia do estilo.

5. Em complemento ao estudo do número 3 da unidade I de gramática da primeira série, fará exercícios de concordância do predicativo do sujeito e do predicativo do objeto direto.

6. Entrando na matéria relativa à unidade III de gramática, terá de desenvolver e aprofundar um pouco um estudo que foi iniciado na unidade I da segunda série: o do período composto por subordinação.

7. A seguir fará, satisfazendo a uma necessidade da boa linguagem, exercícios de emprêgo de modos e tempos na oração subordinada.

8. Continuam os exercícios de análise léxica e sintática, e vêm como últimos exercícios da unidade III de gramática os de colocação das palavras na frase. Aqui terá apropriado lugar a transcrição de numerosos exemplos de bons autores para serem acrescidos á lista dos que os alunos, por si, mas a pedido do professor, tiverem colhido no livro de leitura. 
9. A respeito da colocação dos pronomes pessoais átonos evite-se estreiteza de visão. Recomende-se que, na língua pròpriamente literária, não se comece o período por variação pronominal átona, mas tolere-se o fato no diálogo familiar e na correspondência íntima; aconselhe-se o uso da próclise nas orações negativas, mas admita-se a ênclise quando ela produza apreciável efeito estilístico, como sucede por exemplo, no final do poema Pedro Ivo de Alvares de Azevedo:

- Lava-se o poluir de um leito impuro,

Lava-se a palidez do vício escuro;

Mas não lava-se um crime!

O verso, como está, tem muito mais força de expressão do que teria com a próclise:

Mas não se lava um crime!

10. Também se aconselhe a próclise nas orações subordinadas, bem como nas exclamativas e optativas de verbo no subjuntivo e sujeito anteposto ao verbo (Deus te guarde, a terra lhe seja leve). Mas tudo sem rigor, e submetido mais ao gosto de quem escreve do que ao preceito gramatical.

11. Não se pense, porém, em liberdade absoluta de colocação do pronome átono em relação ao verbo. Há tendências respeitáveis, que a leitura dos bons autores ensinará, e, além disso, há colocações que o ouvido repele. Quem preferirá, por exemplo. "É impossível $a$ compreender" a "É impossível compreendê-la?".

12. Das regras relativas à situação do pronome átono em relação ao verbo só uma tomemos como mais ou menos imperiosa: não usar nem próclise nem ênclise com os particípios passados.

13. Assinale-se a colocação invariável de um pronome em relação ao outro nas combinações usuais: mo, to, lho, no-lo, vo-lo, se me (em próclise), -se-me (em ênclise), e, semelhantemente se te, se-te, se lhe, -se-lhe, se nos, -se-nos, se vos, se-vos, se lhes, -se-lhes.

14. Para a aquisição do vocabulário, haverá exercícios semelhantes aos da segunda série, a que se acrescentarão os de agrupamentos de palavras designativas de idéias sugeridas por uma palavra que se tome para base. Por exemplo: sendo mar a palavra-base, quais as idéias que ela irá sugerindo aos alunos? Vastidão, amplidão, imensidade, in- finito; horizonte; mobilidade; planície, campo, azul, campina, cerúleo, campo; arar, mares nunca arados; friso, listão, esteiras, tremulina; ondas, vagas, marouços, escarcéus, mar encapelado, empolado, agitado, alterado, revôlto, crêspo, carneirada; baixos, baixios, bancos de areia, sirtes, vaus, marachões; fragas, penhascos, rochedos, penedos, rochas; penhas, cachopos, arrolhos, recifes, parcéis, maré, preamar, vazante, baixa-mar, ressacas, mecaréus, pororocas; cachões, cachoeira; velas, panos, brins, grandes lenços, asas; embarcação, navio, lenho, madeiro, pau, pinho, faia; árvores, arvoredo, nau desarvorada; balançar ou balouçar, arfar, zimbrar, adernar, varar...

15. Haverá exercícios de exposição oral e de redação e composição e estudo elementar da versificação a propósito das poesias lidas. 


\section{O ensino na quarta série}

1. Na unidade I de gramática ministram-se noções de fonética necessárias à consecução de uma finalidade cultural que é objeto dos estudos nas unidades II e III desta série: o mostrarse a origem românica da nossa língua e, portanto, a nossa integração na civilização ocidental.

2. Ainda aqui os textos de leitura é que fornecerão ao professor o ponto de partida das suas explicações, ou, melhor, das suas conversas com os alunos a respeito da matéria do programa. Com efeito, ser-lhe-á facil, tomando uma palavra do texto, separar as sílabas, contálas, recordar a denominação dos vocábulos segundo o número de suas sílabas, assinalar a situação do acento tônico, recapitular a classificação dos vocábulos em oxítonos, paroxítonos e proparoxítonos, e mostrar e caracterizar as várias espécies de fonemas componentes das sílabas, e, uma vez apreendidas pelos alunos as novas noções, aplicá-las ou verificá-las a propósito de outros vocábulos. O estudo da próclise habilitará o aluno a compreender formas vernáculas como san, depois são, de santo, bel, de belo, em bel-prazer, e como o demonstrativo latino illum, acentuado na primeira sílaba, pôde perdê-la quando em próclise, originando o nosso artigo lo, depois $o$. A ênclise lhe ex- plicará fenômenos fonéticos como mostrá-lo por mostrar-lo, di-lo por diz-lo, fáze-lo, por fazes-lo, temei-lo, por temeis-lo e outros mais.

3. O sonêto de Bilac em que o poeta chama à língua portuguêsa "última flor do Lácio", aquele trecho de Garrett sôbre a utilidade do conhecimento do grego e do latim, qualquer excerto em que haja alusão à origem romana do nosso idioma, abrirão ensejo ao estudo da- quela parte do programa referente à diferenciação do latim vulgar nas línguas românicas e à constituição da língua portuguêsa.

4. Termina a unidade de gramática com o ponto sobre o português do Brasil. Aqui mostrará o professor que a língua portuguêsa importada encontrou forte rival no tupi. Venceu-o, mas enriqueceu-se com êle, bem como com elementos lingüísticos africanos e outros de criação ou adoção puramente brasileiras. Tem pronúncia diferente da do português europeu atual, em parte graças a algumas inovações, em parte por conservar pronúncias arcaicas da mãe pátria. Leves são as diferenças sintáticas na língua literária. E se há uma corrente que procura afastar a nossa língua literária da de Portugal, há outra que se empenha em fazê-la conservar com a de Portugal a possível aproximação.

5. As páginas da literatura lusa contidas no livro de leitura permitirão aos alunos, pela facilidade com que eles as compreenderão, verificarem por si uma realidade: a unidade linguística entre Portugal e Brasil; e um exame comparativo daquelas páginas com as dos autores nossos talvez proporcione ao professor ocasião de surpreender, e então apontá-las aos discípulos, algumas das peculiaridades que caracterizam a modalidade brasileira do idioma comum. Se o resultado da pesquisa fôr nulo, o professor aproveitará o fato para sublinhar, no espírito dos estudantes, o quanto é verdadeira a afirmação da referida unidade linguística luso-brasileira.

6. Haverá nesta série: estudo e exercícios de vocabulário semelhantes aos da terceira, e mais os de agrupamento de palavras enlaçadas pela comunidade da raiz; redação de cartas, bilhetes, telegramas e documentos oficiais; composição; estudo elementar de versificação sôbre os textos de classe, e exercícios de análise de períodos compostos por subordinação para consolidar no espírito do aluno conhecimentos ministrados anteriormente. 


\section{Observações gerais}

1. Em todo este curso de português o professor se esforçará por incutir nos alunos o amor da língua, o zelo traduzido no desejo de manejá-la bem e de protegê-la das forças dissolventes que estão continuamente a assaltá-la.

2. Sobretudo os fará respeitosos da sua modalidade mais nobre - a língua literária, visto ser esta a de mais importante papel social e político e, ao mesmo tempo, um dos mais fortes fatores do progresso, por constituir, através das idades, um fio de transmissão de geração para geração e, no espaço, um laço de aproximação dos contemporâneos, evitando, de um e outro modo, o estéril isolamento do homem.

3. Avivar-lhes-á, no espírito e no coração, o reconhecimento da necessidade de preservála, como instrumento de união e como patrimônio sagrado da coletividade nacional, num país, como o nosso, de amplo território e aberto à imigração de estrangeiros das mais variadas procedências.

4. Ressaltar-lhes-á que zelar a língua literária é, para o Brasil, um dever de própria defesa e que seria condenável o menosprezá-la depois de ela ter atingido tão alta perfeição como a atual, graças ao lento, longo e laborioso processo de apuração das fórmulas de expressão.

5. Entretanto, que não se descambe para o terreno das minúcias gramaticais e do purismo exagerado.

6. Fale-se e escreva-se sem afetação. Haja naturalidade no falar, e naturalidade no escrever. Mas tenha-se na lembrança que a naturalidade do falar nem sempre se admite no escrever, e que a naturalidade do escrever, transportada ao falar, pode converter-se em afetação ou pedantismo.

7. Olhem-se os fenômenos da língua com espírito alto, largo e generoso, e façam-se concessões ao pensamento, que às vêzes reclama expressões de valor estilístico, mas afastadas das regras habituais da gramática.

8. Procure-se a correção e a propriedade, mas sem rigidez, e a par com a clareza, a expressividade e o bom gosto.

\section{Observações finais}

1. Para a realização do curso, além dos livros da biblioteca escolar, de que os alunos se devem utilizar para leituras e consultas, deverão eles ter consigo os seguintes compêndios:

a) livro de leitura, num volume para a primeira e segunda séries e noutro volume para a terceira e quarta;

b) gramática, em um volume, para as quatro séries:

c) dicionário portátil, em um volume, também para as quatro séries.

2. O livro de leitura, nos seus dois volumes, deve conter - além das páginas que satisfazem, de um modo geral, à prescrição do programa para cada série - matéria de leitura 
orientada em dois sentidos: um, que interesse mais às meninas, e o outro, aos rapazes. Os textos destinados de preferência à atenção das meninas devem encarecer as virtudes próprias da mulher, a sua missão de espôsa, de mãe, de filha, de irmã, de educadora, o seu reinado no lar e o seu papel na escola, a sua ação nas obras sociais de caridade, o cultivo daquelas qualidades com que ela deve cooperar com o outro sexo na construção da pátria e na ligação harmônica do sentimento da pátria com o sentimento da fraternidade universal. Os excertos que visarem principalmente à educação dos alunos do sexo masculino procurarão enaltecer aquela têmpera de caráter, a força de vontade, a coragem, a compreensão do dever, que fazem os grandes homens de ação, os heróis da vida civil e militar e esses outros elementos, não menos úteis à sociedade e à nação, que são os bons chefes de família e os homens de trabalho, justos e de bem.

NOTA - Os textos de orientação metodológica para execução dos demais programas irão sendo publicados à medida que forem sendo expedidos em portarias ministeriais.

[In: CRUZ, JOSÉ Marques da. Português prático: gramática para as 4 séries do Curso Ginasial. São Paulo: Edições Melhoramentos, 1947. p. 16-24.] 
ANEXO B

Este anexo contém dois anexos preparados a partir de dados retirados de Polachini (2018) e por nós adaptados para uso nesta tese. São eles:

ANEXO B1 - Gramáticas presumidas como de referência: não acessíveis à análise física e/ou sem pistas no título/subtítulo que são escolares - Século XIX (1853 - 1900)

ANEXO B2 - Gramáticas presumidas como escolares: principalmente pelo não acesso físico às obras - Século XIX (1853 - 1900) 
ANEXO B1 - Gramáticas presumidas como de referência: não acessíveis à análise física e/ou sem pistas no título/subtítulo que são escolares - Século XIX (1853 - 1900) ${ }^{452}$

\section{0}

[1]. 1853. CRUZ, Policarpo José Dias. Compendio de grammatica portugueza. (1853_Edição mais antiga conhecida).

[2]. 1856. ANDRADE, Joao Nunes de (1800 Beira (Portugal) - 1861 Rio de Janeiro - Foi para RJ em 1843). Novo compêndio de eloquiência grammatical da lingua portugueza por systema philosophico. (1856_Única edição conhecida).

[3]. 1858. ALBERTO JUNIOR, Philippe Jose. Grammatica ecletico-rudimentaria da lingua portuguesa. (1858_5 $5^{\mathrm{a}}$ ed._Edição mais antiga conhecida).

[4]. 1858. ALBUQUERQUE, Salvador Henrique. Compendio da grammatica portugueza. (1858_Edição mais antiga).

[5]. 1859. ALBERTO JUNIOR, Philippe Jose. Grammatica da lingua portugueza. (1859_Única edição conhecida).

[6]. 1859. CRUZ, Policarpo José Dias. Postillas de grammatica portugueza. [1859_Única edição conhecida]

[7]. 1860. BARKER, Antonio Maria (1792 Porto - 1853 Brasil [veio ao Brasil em 1810]). Grammatica da lingua portugueza em forma de dialogo, que para intelligencia da orthographia contem o que é absolutamente indipensavel, etc. (1860_8 ${ }^{\mathrm{a}}$ ed._Única edição conhecida).

[8]. 1862. BITHENCOURT, Raimundo Câmara. Epitome da grammatica philosophica da lingua portugueza. (1862_1 ${ }^{\mathrm{a}}$ ed._Única edição conhecida).

452 Este levantamento é de Polachini (2018) e foi por nós ligeiramente adaptado para os objetivos desta tese. Agradeço à autora pela disponibilidade em conversar a respeito destes materiais e de outros aspectos de seu trabalho. 
[9]. 1862. RIBEIRO, Joaquim Sabino Pinto. Compendio de grammatica portugueza. (1862_Única edição conhecida).

[10]. 1862. SOTERO DOS REIS, Francisco. Postillas da grammatica geral applicada á lingua portugueza: pela analyse dos classicos, ou guia para a construcção portuguesa. (1862_1 $1^{\text {a }}$ ed.). $\boldsymbol{\beta}^{453}$

[11]. 1864. MURICI, João da Veiga. Grammatica geral... (1864_Única edição conhecida).

[12]. 1865. GRIVET, Charles Adrian. Grammatica analytica da lingua portugueza. $\left(1865 \_1^{\mathrm{a}} \mathrm{ed}\right)$.

[13]. 1866. SOTERO DOS REIS, Francisco. Grammatica portugueza, accommodada aos principios geraes da palavra, seguidos de immediata applicação pratica, dedicada ao sr. Dr. Pedro Nunes de Leal. (1866_1 ${ }^{\mathrm{a}}$ ed.). $\beta$

[14]. 1869. RABELlO, Laurindo José da Silva. Compendio de grammatica da lingua portugueza. $\left(1869 \_1^{\mathrm{a}} \mathrm{ed}.\right)$.

\section{0}

[15]. 1870. PINHEIRO, Joaquim Caetano Fernandes. Grammatica theorica e pratica da lingua portugueza. (1870_Única edição conhecida).

[16]. 1871. ORTIZ, José; PARDAL, Candido Matheus de Faria. Grammatica analytica e explicativa da lingua portugueza. $\left(1871 \_1^{a}\right.$ ed.).

[17]. 1873. ALBUQUERQUE, Salvador Henrique. Rudimentos da grammatica portugueza. (1873_Única edição conhecida).

[18]. 1874. FRAZÃO, Manuel José Pereira. Postillas de grammatica portugueza. (1874_Única edição conhecida).

[19]. 1875. FREIRE DA SILVA, Augusto. Compendio da grammatica portugueza. $\left(1875 \_2^{a} \text { ed._edição mais antiga conhecida }\right)^{454} \boldsymbol{\beta}$

[20]. 1875. MARQUES, Filipe Pinto. Grammatica elementar da lingua portugueza extrahida dos melhores auctores e coordenada por... (1875_2 $2^{\mathrm{a}}$ ed._Edição mais antiga conhecida).

\footnotetext{
${ }^{453} \boldsymbol{\beta}$ : Marcamos assim as obras que pudemos consultar.

${ }^{454} \mathrm{Nas} 3^{\mathrm{a}}, 4^{\mathrm{a}}, 5^{\mathrm{a}}$ edições, a obra passa a apresentar o seguinte subtítulo: "para uso de alunos de humanidades, que frequentam a aula de português"
} 
[21]. 1877. BEZERRA, Manuel Soares da Silva. Compendio de grammatica da lingua nacional. (1877_Única edição conhecida).

[22]. 1877. CARNEIRO RIBEIRO, Ernesto. Grammatica portugueza philosophica. (1877_1 ${ }^{\text {a }}$ ed.) $\boldsymbol{\beta}$

[23]. 1878. PACHECO da Silva Junior, Manuel. Grammatica historica da Lingua Portugueza. (1878_1 ${ }^{\mathrm{a}}$ ed.). $\boldsymbol{\beta}$

[24]. 1879. CARVALHO, Joaquim José de. Postillas de grammatica portugueza. (1879_Única edição conhecida].

[25]. 1879. SOUZA, José Martiniano de. Tratado de analyse phonetica grammatical, syntaxica e lógica com seus desenvolvimentos e applicações, seguido de um catalogo de palavras diversificaveis em significação, para complemento do mesmo assumpto. (1879_Única edição conhecida).

\section{0}

[26]. 1881. GRIVET, Charles Adrian. Nova grammatica de lingua portugueza. $\left(18811^{\mathrm{a}}\right.$ ed). $\boldsymbol{\beta}$

[27]. 1881. NOGUEIRA, Baptista Caetano de Almeida. Rascunhos sobre a grammatica da lingua portugueza. (1881_Edição mais antiga conhecida). $\boldsymbol{\beta}$

[28]. 1881. RIBEIRO, Julio Cesar Vaughan. Grammatica portugueza. (1881_1 ${ }^{\mathrm{a}}$ ed.). $\boldsymbol{\beta}$

[29]. 1882. MELLO, Silvino Soares de. Grammatica portugueza. (1882_Única edição conhecida).

[30]. 1883. COSTA E CUNHA, Antonio Estevão da. Principios de Grammatica Historica e Comparada. (1883_1 ${ }^{\mathrm{a}}$ ed._Única edição conhecida).

[31]. 1885. CARNEIRO RIBEIRO, Ernesto. Elementos de grammatica portugueza ${ }^{455}$. $\beta$

[32]. 1885. CARVALHO, Joaquim José de. Methodo de grammatica analytica. (1885_Única edição conhecida).

\footnotetext{
${ }^{455}$ No "Prologo da $2^{\mathrm{a}}$ edição", o autor diz que sua gramática vai impressa em dois tamanhos de tipo: o maior, destinado aos alunos do Primário, e, logo abaixo dos maiores, os tipos menores contendo a matéria gramatical destinada aos alunos do Secundário. A análise física que realizamos da gramática nos mostrou que essa é a única referência ao universo escolar, além do fato, principal, ao nosso ver, de o nível de aprofundamento da obra ser grande, muitíssimo longe daquilo que se praticava nas classes primárias e secundárias, como se pode verificar em outros materiais destinados a esses níveis de ensino. Tal fato nos fez incluir essa gramática no rol das "não escolares", pois julgamos que as menções aos níveis de ensino que acima apontamos funcionavam apenas como retórica do autor (Murray, 1994).
} 
[33]. 1885. RABELO, Laurindo José da Silva. Elementos de grammatica portugueza. (1885_Única edição conhecida).

[34]. 1885. RIBEIRO, Julio Cesar Vaughan. A grammatica analytica. (1885_Única edição conhecida).

[35]. 1887. BOSCOLI, José Ventura; PAIO, João Zeferino Rangel de S. Grammatica portugueza. (1887_Única edição conhecida).

[36]. 1887. RIBEIRO Fernandes, João. Grammatica portugueza. Curso superior. $3 .^{\circ}$ anno de $\underline{\text { Portuguez }}^{456}$. Com um complemento de anotações no texto. $\left(1887 \_1^{\mathrm{a}}\right.$ ed.). $\boldsymbol{\beta}$

[37]. 1887. MACIEL, Maximino de Araújo. Grammatica analytica baseada nas doutrinas modernas satisfazendo às condič̃es do actual programma ${ }^{457} \cdot\left(1887{ }_{-} 1^{\mathrm{a}} \mathrm{ed}\right.$.).

[38]. 1887. PACHECO DA SILVA JR, Manuel; DE ANDRADE, Lameira. Noções da grammatica portugueza de accordo com o programma official para os exames geraes de preparatorios do corrente anno. $\left(1887 \_1^{\mathrm{a}}\right.$ ed.). $\boldsymbol{\beta}$

[39]. 1888. MASSA, José de Noronha Nápoles. Grammatica analytica da lingua portugueza, composta e offerecida aos brazileiros... (1888_ $1^{\text {a }}$ ed.)

[40]. 1889. CARDOSO, Domiciano H. Perdigão. Compendio de grammatica portugueza. (1889_Única edição conhecida).

\section{0}

[41]. 1890. CARNEIRO RIBEIRO, Ernesto. Seroes grammaticaes ou nova grammatica portugueza $^{458} \cdot \boldsymbol{\beta}$

\footnotetext{
456 Apesar de no título haver "curso superior" e " $3^{\circ}$ ano" (esta referência não mais aparece em edições futuras, ficando apenas a menção ao "curso superior"), ao examinarmos fisicamente a obra, notamos que ela atende aos critérios que definimos para as gramáticas de referência da século XIX, ou seja, há significativo aprofundamento da matéria linguística, referência a outras obras teóricas nacionais/estrangeiras e ausência de exercícios, questionários ou qualquer outra estratégia didática para uso deste material no contexto escolar. Essa observação nos leva a um fato que parece ocorrer com outras gramáticas do final do século XIX, neste ambiente de recente valorização da disciplina "Português" no Secundário, ou seja, as menções à escola, séries, programas de ensino aparecem nos subtítulos, frontispícios, prólogos ou até mesmo em atender os tópicos gramaticais solicitados por algum programa oficial, mas como essas gramáticas são desenvolvidas parecem representar muito mais um projeto pessoal de reflexão linguística do autor do que um material didático elaborado com vistas ao jovem secundarista. Marcamos essas referências, nos títulos, com um sublinhado.

${ }^{457} \mathrm{Em} 1894, \mathrm{~m} 2^{\mathrm{a}}$ edição, a obra passa a se chamar Grammatica descriptiva: baseada nas doutrinas modernas ( $\left.\boldsymbol{\beta}\right)$, título que se manteve até sua última edição, em 1931.

${ }^{458} \mathrm{Na} 1^{\mathrm{a}}$ edição, no frontispício da obra, depois do nome e qualificações do autor, aparece a seguinte observação: "obra adaptada ao curso secundario da lingua portugueza e adaptada ao novo programma de exames". A partir da $2^{\mathrm{a}}$ edição, tal observação é retirada e não retorna mais à obra. A análise física da gramática nos mostrou ser esta a única referência à escola, não bastando, evidentemente, para classificá-la como uma gramática escolar. Mesmo restrita apenas à $1^{a}$ edição, nos parece que a intenção de tal observação era mais comercial do que efetivamente pedagógica.
} 
[42]. 1892. REIS, Luiz Augusto dos. Grammatica portugueza. (1892_Única edição conhecida).

[43]. 1893-4. BOSCOLI, José Ventura. Grammatica portugueza: estudo raciocinado segundo os principaes hodiernos da sciencia da linguagem (1893-4_ Edição mais antiga conhecida).

[44]. 1899. MAIA, Zillah do Paço Mattoso. Grammatica da lingua portugueza. (1899_Edição mais antiga). 
ANEXO B2 - Gramáticas presumidas como escolares: principalmente pelo não acesso físico às obras - Século XIX $\left(1853\right.$ - 1900) ${ }^{459}$

I - Gramáticas em que a relação com a escola é explícita no título e/ou subtítulo

\section{0}

[45]. 1854. CAJA, Jose Ferreira Santos. Compendio da grammatica portugueza, resumido para uso das escolas de primeiras ${ }^{460}$ lettras, extraido dos autores de melhor nota e mais seguidos neste imperio do Brazil e reino de Portugal. (1854_2a ed._Única edição conhecida).

[46]. 1855. PASSOS, José Alexandre. Resumo da grammatica portugueza para uso das escolas de primeiras lettras. (1855_2 $2^{a}$ ed._Edição mais antiga conhecida).

[47]. 1855. SILVEIRA, Cyrillo Dillermando da. Compendio de grammatica da lingua portugueza: obra adoptada pelo conselho de instrucção publica. (1855_Edição mais antiga conhecida).

[48]. 1857. GRAÇA, Manoel Fernandes da Cunha. (1824 Portugal - ? Brasil). Elementos de grammatica portugueza, colligidos para uso de seus alumnos. (1857_Única edição conhecida).

\section{0}

[49]. 1860. RUBIM, Joaquim Frederico Kiappe da Costa (1831 Porto - 1866 Corrientes (Argentina), naturalizado brasileiro). Novo methodo da grammatica portugueza composto em verso rimado, approvado e adoptado para as aulas da provincia do Ceará e pelo Conselho director da instruccão publica da mesma província. (1860_Edição mais antiga conhecida).

[50]. 1861. PERTENCE, Francisco Praxedes de Andrade; VERGUEIRO. Compendio de grammatica portugueza, accommodado ao uso das escolas. (1861_Única edição conhecida).

[51]. 1861. BEZERRA, Manuel Soares da Silva. Compendio da grammatica philosophica do lyceu provincial. (1861_Única edição conhecida).

\footnotetext{
${ }^{459}$ Este levantamento é de Polachini (2018) e foi por nós ligeiramente adaptado para os objetivos desta tese.

${ }^{460}$ Marcamos com um sublinhado as referências ao universo escolar.
} 
[52]. 1862. SENNA, José Bernardino de Senna. Lições de grammatica portugueza, destinadas ao uso dos alumnos de ambos os sexos que frequntam as aulas de primeiras letras. (1862_Única edição conhecida).

[53]. 1862. TILBAULT, José Vicente. Grammatica elementar, methodica do Brazil para uso das aulas de ensino primario. (1862_Única edição conhecida).

[54]. 1863. CARVALHO, Manoel Domingos. Elementos de grammatica portugueza para uso dos alumnos do mesmo estabelecimento. (1863_Única edição conhecida).

[55]. 1863. KOEFFER, Frederico Adão Carlos (1822 Prússia - ?). Resumo da grammatica nacional, adequado ao ensino methodico dos principiantes. (1863_Única edição conhecida).

[56]. 1864. PINHEIRO, Joaquim Caetano Fernandes. Grammatica da infância, dedicada aos senhores professores de instruccão primaria. (1864_Única edição conhecida).

[57]. 1865. BEZERRA, Manuel Soares da Silva. Compendio de grammatica portugueza para uso do atheneu cearense e das escolas primarias. (1865_Única edição conhecida).

[58]. 1865. IBIRAPITANGA, Antonio Gentil. Compendio grammatical, reduzido a dialogo, para uso dos principiantes do ensino das primeiras lettras. (1865_única edição conhecida).

[59]. 1866. MARTAGÃO, Bernadino Affonso. Compendio da grammatica da lingua portugueza para uso das aulas de primeiras lettras, mais correcto, recopilado e extrahido das melhores grammaticas, até o presente conhecidas, posto em ordem e offerecidos a mocidade brazileira etc. (1866_8a ed._Única edição conhecida).

[60]. 1868. SOARES, Vicente Rodrigues da Costa (? Portugal - 1884 Rio de Janeiro). Curso elementar e theorico-pratico da grammatica nacional, approvado pelo conselho director da instrucção publica. (1868_Única edição conhecida).

[61]. [s.d. (mas) pós-1862]. LEAL, Pedro Nunes Noções grammaticaes para uso da infância que freqüenta as escolas do primeiro gráo, extrahidas da grammatica portugueza de Sotero. (pós-1862_Única edição conhecida) ${ }^{461}$.

\footnotetext{
${ }^{461}$ Se a gramática de Sotero dos Reis é de 1862, esta gramática tem de ser de época posterior a esse ano.
} 
[62]. 1870. VILLEROY, Frederico Ernesto Estrella. Compendio da grammatica portugueza adoptado para uso das escolas da provincia do Rio Grande do Sul pelo respectivo Conselho Director da Instrucção Publica. (1870_Única edição conhecida). $\beta$

[63]. 1871. FREIRE DA SILVA, Augusto; LEAL, Pedro Nunes. Noções de prosódia e orthographia para uso da infancia que frequenta as aulas do primeiro grau do instituto santista, intercaladas de um resumo da etymologia e syntaxe, extrahido da Grammatica portugueza de Francisco Sotero dos Reis pelo doutor Pedro Nunes Leal. (1871_1 $1^{\mathrm{a}}$ ed.).

[64]. 1871. TAYLOR, H. C. Grammatica da lingua nacional. Compendio adaptado ao ensino nas aulas de instrucção primaria. (1871_Única edição conhecida).

[65]. 1872. SOUZA, Julio Cesar Ribeiro. Grammatica portugueza para as escolas primarias, adoptada e premiada pelo conselho da instrucção publica da provincia do Pará. (1872_Única edição conhecida).

[66]. 1875. PIMENTEL, Francisco da Silveira da Ávila. Explicador de portuguez de conformidade com o programma do $1^{\circ}$ anno do imperial collegio de Pedro II. (1875_Única edição conhecida).

[67]. 1876. CANECA, Frei Joaquim do Amor Divino. Breve compêndio de grammatica portugueza, organisado em fôrma systematica, com adaptação á capacidade dos alumnos. In: Obras políticas e litterarias de Frei Joaquim do Amor Divino Caneca, colleccionadas pelo Commendados Antonio Joaquim de Mello, em virtude da lei provincial n. ${ }^{\circ} 900$ de 25 de junho de 1869 mandadas publicar pelo exm. Sr. Commendados Presidente da Provincia - Desembargador Henrique Pereira de Lucena Tomo II. (1876_1 ${ }^{\mathrm{a}}$ ed.). $\boldsymbol{\beta}$

[68]. 1876. COSTA, Manuel Olimpio Rodrigues da. Grammatica portugueza destinada ao curso do $1 .^{\circ}$ anno do Imperial Collegio Pedro Segundo. (1876_Edição mais antiga conhecida).

[69]. 1877. VIEIRA, Joaquim José de Menezes. Primeiras noções de grammatica portugueza. $\left(1877 \_1^{\mathrm{a}}\right.$ ed.). ${ }^{462}$

[70]. 1879. SANTOS, Hemetério José dos. Grammatica elementar da lingua portugueza extrahida dos melhores auctores e... (1913_3 $\left.3^{\mathrm{a} e d .}\right) .{ }^{463} \boldsymbol{\beta}$

[71]. 1879. FREIRE DA SILVA, Augusto. Rudimentos da grammatica portugueza para uso dos alumnos de primeiras lettras. (1879_1 ${ }^{\mathrm{a}}$ ed.).

\footnotetext{
462 "Este livro e os que o seguem pertencem à 'Bibliotheca da infância', collecção de livrinhos compilados especialmente para uso do Collegio Menezes Vieira."

${ }^{463}$ Tivemos acesso apenas à $3^{\mathrm{a}}$ edição, de 1913, e, ao examinarmos a obra, pudemos ver que se trata de gramática escolar. Não nos parece que tenha havido mudança de orientação relativamente à $1^{\mathrm{a}}$ edição.
} 


\section{0}

[72]. 1880. CARVALHO, Felisberto Rodrigues Pereira de. Elementos de grammatica portugueza para uso dos alumnos da instruccão primaria. (1880_Edição mais antiga conhecida).

[73]. 1880. COSTA E CUNHA, Antonio Estevão da. Grammatica elementar portugueza, adaptada ao ensino das escolas da instrucção primaria, quer dos menores, quer dos adultos, e bem assim dos collegios, lycêos, escolas normaes e aulas preparatórias. (1880_Edição mais antiga conhecida).

[74]. 1880. ALMEIDA, Bibiano Francisco. Compêndio de grammatica da lingua portugueza: dedicado aos estudantes rio-grandenses. (1880_1 ${ }^{\mathrm{a}} \mathrm{ed}$.). $\boldsymbol{\beta}$

[75]. 1882. BRANDÃO, Thomaz da Silva. Grammatica infantil da lingua portugueza, composta, etc. e adoptada pela Inspeciona geral da instruccão publica de MinasGeraes para uso das escolas primarias. (1882_2 $2^{\mathrm{a}}$ ed._Única edição conhecida).

[76]. 1882. FEITOSA, Miguel Alves. Grammatica das escolas, dedicada à provincia de S. Paulo sobre o plano de Pierre Larousse. (1882_Edição mais antiga conhecida).

[77]. 1887. RIBEIRO, Julio Cesar Vaughan. Holmer brazileiro ou grammatica da puericia. Tradução da "Introduction to English Grammar" de G. F. Holmer. (1887_Única edição conhecida). $\boldsymbol{\beta}$

[78]. 1887. GOMES, Alfredo. Grammatica portugueza. $\left(1887 \_1^{\mathrm{a}}\right.$ ed.) $\boldsymbol{\beta}$

[79]. 1888. LAPAGESSE, Leon Eugenio (1852 França - ? [casou-se em 1874 no Brasil, Santa Catarina]). Grammatica portugueza. Compêndio mandado adoptar pelo governo para uso das escolas publicas de Santa Catharina por acto de 26 de outubro de 1888, em virtude do parecer do Conselho de Instrucção publica. (1888_2a ed._Única edição conhecida).

[80]. 1888. RIBEIRO Fernandes, João. Grammatica portugueza elementar. (1888_Única edição conhecida).

[81]. 1888. RIBEIRO Fernandes, João. Grammatica portugueza. Curso médio. $2 .^{\circ}$ anno de Portuguez. (1888_Única edição conhecida). $\boldsymbol{\beta}$

[82]. 1889. VIEIRA, Verissimo Ricardo. Grammatica elementar da lingua portugueza, dedicada á instruccão primaria e organisada de accordo com o programma vigente da instrucção primaria. (1889_Única edição conhecida). 
[83]. 188?. LACERDA, Joaquim Maria de. Pequena grammatica da infancia composta para uso das escolas primarias. "Nova edição" (188?_Única edição conhecida).

\section{0}

[84]. 1894. RIBEIRO Fernandes, João. Grammatica portugueza: curso primário, $1^{\circ}$ anno de portuguez. ("nova edição"). $\boldsymbol{\beta}$

[85]. 1895. ALVES, Francisco Ferreira de Vilhena. Grammatica portugueza... (Curso Superior). (1895_Única edição conhecida).

[86]. 1895. BOSCOLI, José Ventura. Grammatica da Puericia (lingua vernácula). (1895_1 ${ }^{\mathrm{a}}$ ed.). $\boldsymbol{\beta}$

[87]. 1895. COSTA E CUNHA, José Estevão da. Grammatica Pratica do $1^{\circ}$ Gráo contendo muito e variados exercicios praticos de linguagem, lexiologia, syntaxe e recitação, regras de composição etc. Organisada de acordo com o novo plano de ensino primario do $1^{\circ}$ gráo. (1895_4 $4^{\mathrm{a}}$ ed._Única edição conhecida).

[88]. 1896. ALVES, Francisco Ferreira de Vilhena. Primeira grammatica da infância. (1896_Edição mais antiga conhecida).

[89]. 1896. LUZ, Sabino da. Elementos de grammatica para uso das escolas primarias pelo professor. (1896_Única edição conhecida).

[90]. 1897. ALVES, Francisco Ferreira de Vilhena. Primeira grammatica da infancia e Segunda grammatica da infância. (1897_única edição conhecida).

[91]. 1897. P.S (Pedro Schneider). Livro de exercicios para apprender os elementos da grammatica portugueza. (1897_3 $3^{\mathrm{a} e d}$. Edição mais antiga conhecida). $\boldsymbol{\beta}$

[92]. 1898. VIEIRA, Verissimo Ricardo. Grammatica portugueza: curso elementar (Instrucção primaria). (Única edição conhecida).

[93]. 1899. BRITO, Paulino de Almeida. Grammatica primaria. (1899_Única edição conhecida). II - Gramáticas em que a relação com a escola é menos explícita nos títulos e/ou
subtítulos 
[94]. 1860. BORGES, Abílio César. Epitome da grammatica portugueza. (1860_1a ed). ${ }^{464}$

[95]. 1864. CASTILHO, Francisco Alves da Silva. Preliminares de grammatica, dispostos em leitura apropriada para exercitar a intelligencia dos principiantes e preparal-os para o estudo desta doutrina em obras de maior desenvolvimento, representando o systema grammatical figurado por meio da arvore da sciencia. (1864_Única edição conhecida).

[96]. 1866. d'ALMEIDA, F. M. Rapozo. Elementos de grammatica portugueza segundo um systema mnemônico. (1866_2 $2^{\mathrm{a}}$ ed._Única edição conhecida).

[97]. 1869. MORAIS, Alexandre José de Melo. Grammatica analytica da lingua portugueza, ensinada por meio de quadros analyticos, methodo facilimo para aprender a língua. (1869_Única edição conhecida).

\section{0}

[98]. 1879. WALTER, Luiz Kraemer. Segundo livro de grammatica, composto segundo o methodo Marcet. (1879_Única edição conhecida).

[99]. 1879. WALTER, Luiz Kraemer. Terceiro livro de grammatica, composto segundo o methodo Marcet. (1879_2a ed._Única edição conhecida).

\section{0}

[100]. 1881. WALTER, Luiz Kraemer. Primeiro livro de grammatica, composto segundo o methodo Marcet. (1881_4ª ed._Única edição conhecida).

[101]. 1882. ANDRADE E SILVA, Hilario Ribeiro de. Grammatica elementar e liç̃es progressivas de composição, adoptada nas províncias do Rio Grande do Sul, Santa Catharina, Paraná, S. Paulo, Rio de Janeiro e município neutro. Terceira edição, melhorada e consideravelmente augmentada com novos exercicios de lexicologia, orthographia e linguagem; exercicios de invenção, estylo e sobre synonymos. (1882_3 $3^{\mathrm{a}}$ ed._Edição mais antiga conhecida).

[102]. 1883. COSTA E CUNHA, Antonio Estevão da. Manual do examinando de portuguez: repertorio philologico grammatical e litterario da lingua materna. (1883_1 ${ }^{\mathrm{a}} \mathrm{ed}$.).

\footnotetext{
${ }^{464}$ Segundo informações presentes em Alves (1942), todos os livros do autor são "compêndios para uso nas escolas (ALVES, Isaías, Vida e obra do Barão de Macahubas. São Paulo, Nacional, 1942.).
} 
[103]. [1887. RIBEIRO Fernandes, João. Exames de portuguez. Lições de grammatica portugueza, coordenadas segundo o programma de 1887. $\left(1887 \_1^{\mathrm{a}} \mathrm{ed}.\right)$.

[104]. 1888. LIMA, João Fernandes de. Resumo da grammatica portugueza. Pontos de portuguez, segundo o novo programma de exames. (1888_Única edição conhecida).

[105]. 1888. BOSCOLI, José Ventura; PACHECO da Silva Junior, Manoel. Noções de analyse grammatical, phonetica, etymologica e syntaxica. (1888_Única edição conhecida). ${ }^{465}$ $\boldsymbol{\beta}$

[106]. 1897. BANDEIRA, Adelia Ennes. Grammatica portugueza practica. (1897_1 ${ }^{\mathrm{a}}$ ed.) $\boldsymbol{\beta}$

${ }^{465}$ No prefácio, há a informação de que o livro foi escrito para atender aos exames preparatórios. 